rir

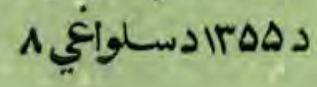

$$
\text { داطلاعاتواونكتودوزارتاجرآت }
$$

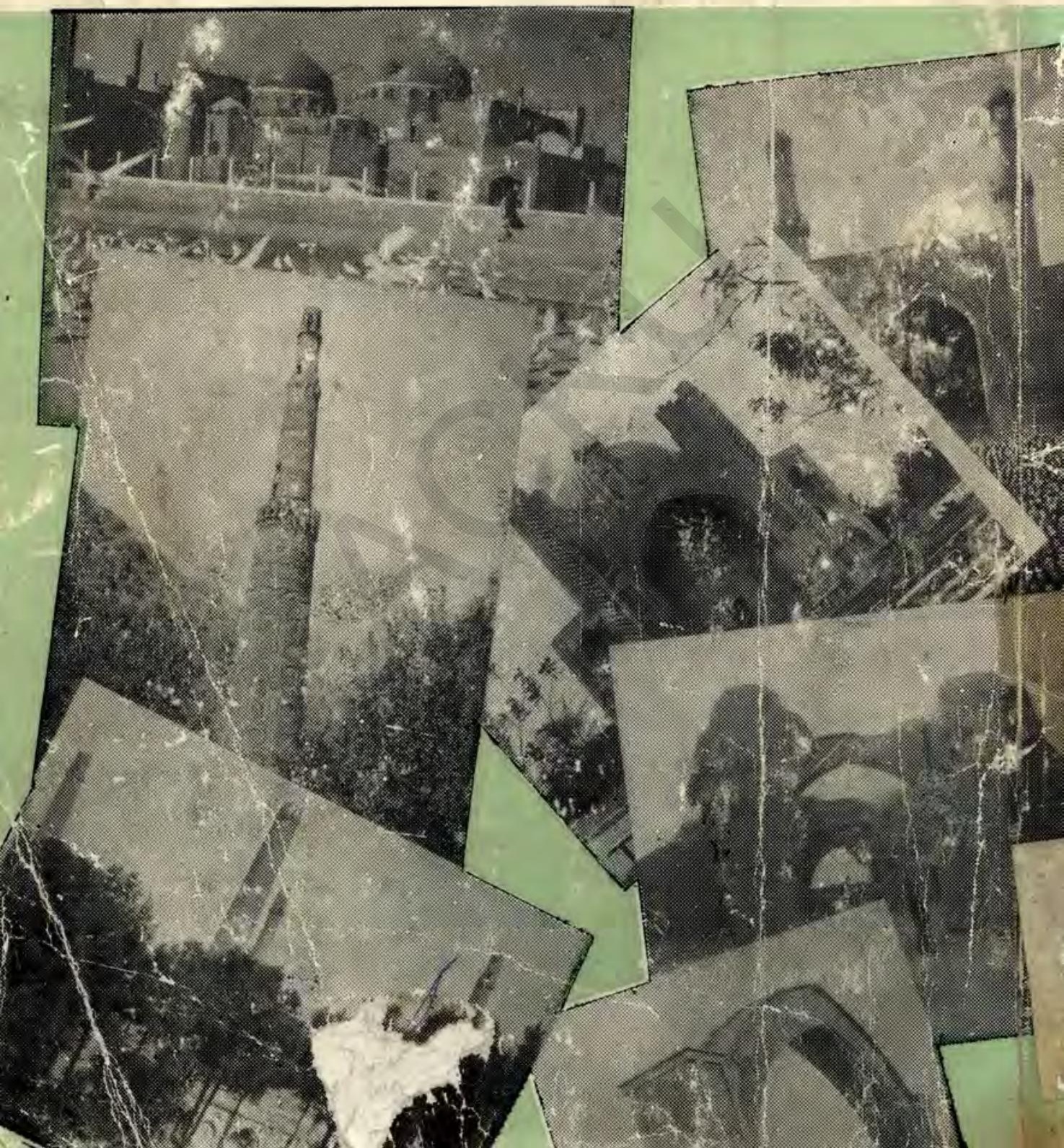


خصو صى 'نمبر (IIA)

عهومى نمبر (10.)

$$
\begin{aligned}
& \text { ومندر جاتو فهر ست } \\
& \text { - يادونه : } \\
& \text { (lor }-1) \text { (بنيتو: } \\
& \text { دوs: (ran -lor) } \\
& \text { - اطلا عاتو او كلتور وزارت } \\
& \text { (خلود كلن اجرآت) } \\
& \text { - - داطلاعاتواوكلتور دوزارت تشكبل }
\end{aligned}
$$

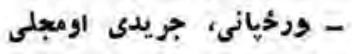

$$
\begin{aligned}
& \text { : } \\
& \text { - كتابونه او دسالى (الف - }
\end{aligned}
$$

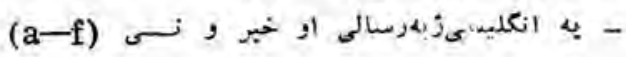




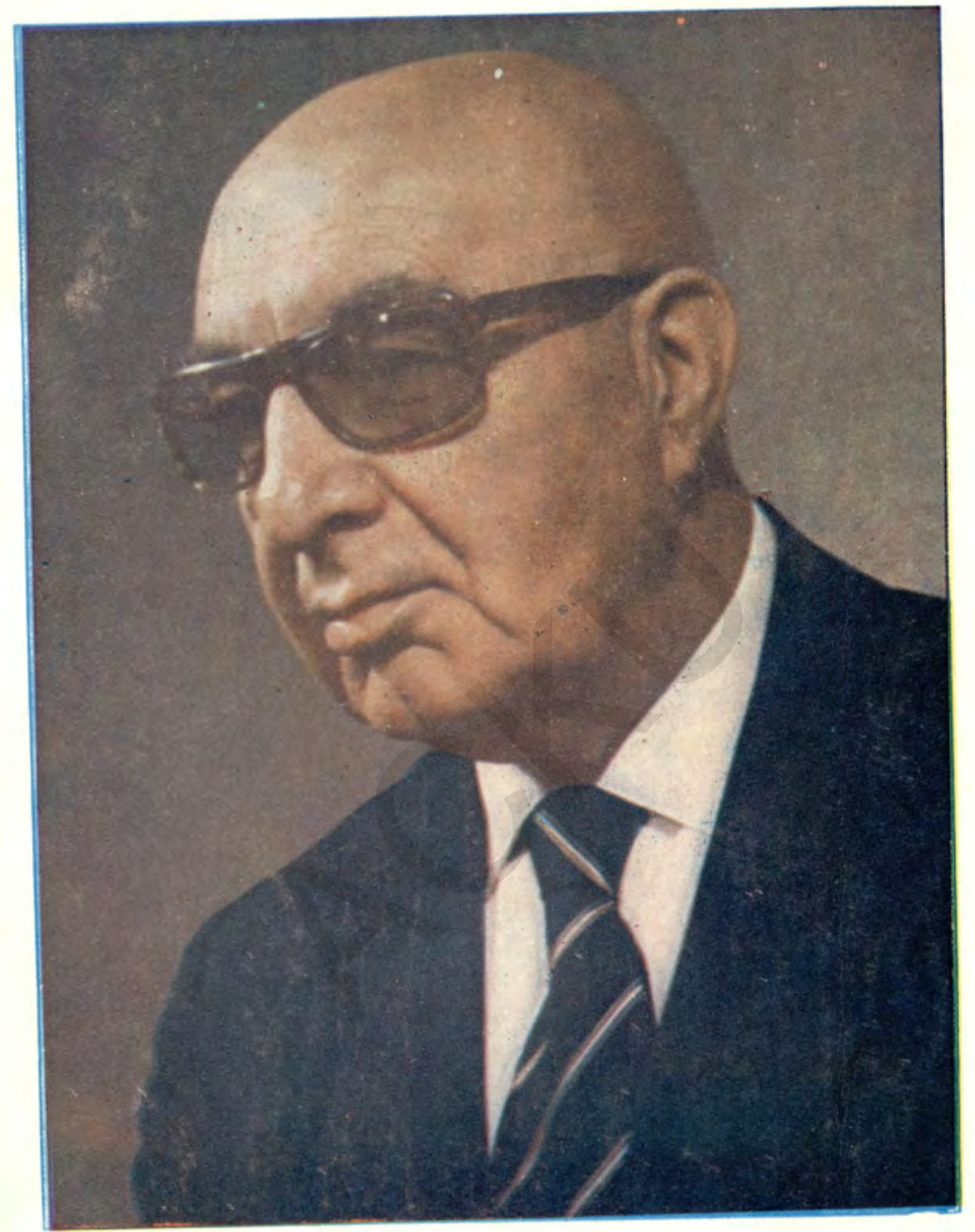

رهبر انقلاب بنباغلى محمدداؤد رئيس دولت وصدراغظم

وزارت اطلاعات وكلتود كمال افتخار دارد كه دريرتو هدايات ورهنمايى هاى مدبرانه رهبرانقلاب ومؤسس جمهوريت بنماغلى متحمد داؤد اجسرآت وخـدمسات

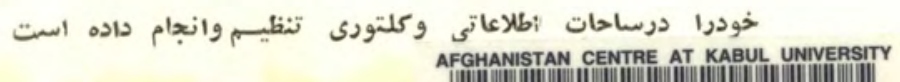

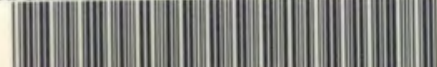
3 ACKU 000061183 


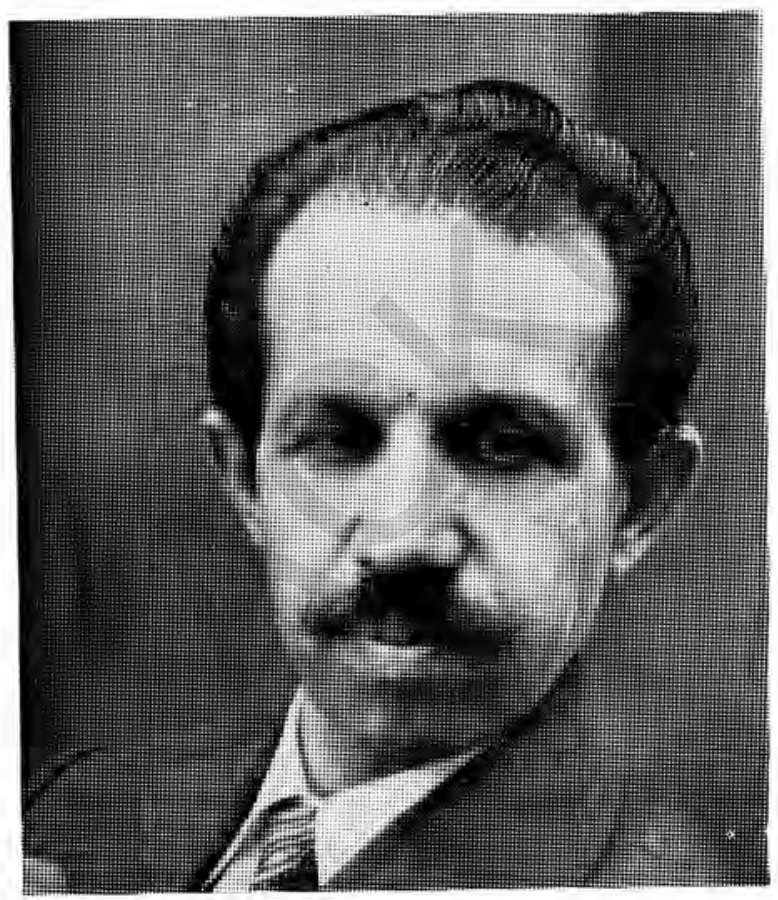

يوهاند دكتور نوين وزير اطلاعاتوكلتود 
( جمهودى دولت به دخلكـــــودبيدارى يه مقعد دديمو كراتيـك

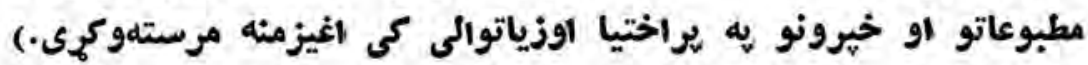
(دافغانستان خلكــو ته دخطابخخه )

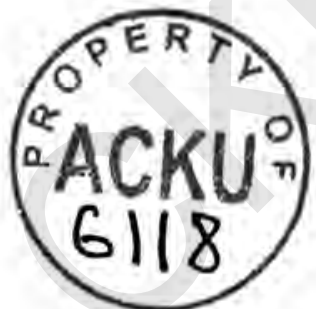

يادورنه:

جمهودى دولت الكه حنكه جيديوهملى اومترقى نظام يهتوكه نوى آولنيز

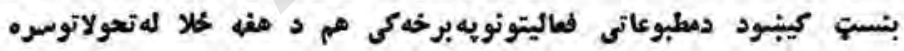

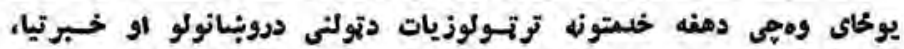

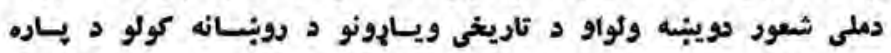

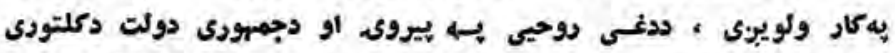

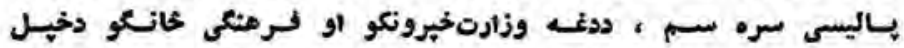

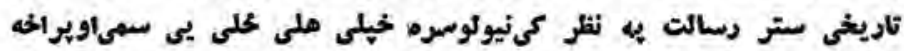

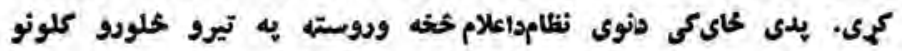

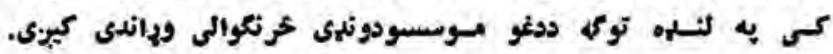


دأطلاعاتو او كلمور دوزارت

خلور كلن اجرآت

IPAD - IPAT

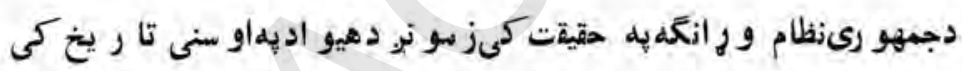

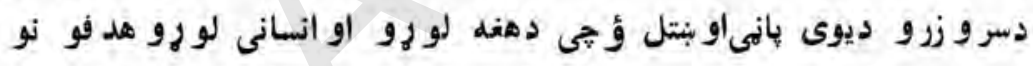

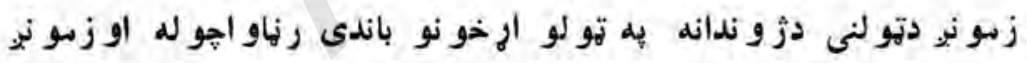

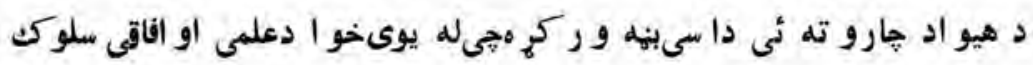

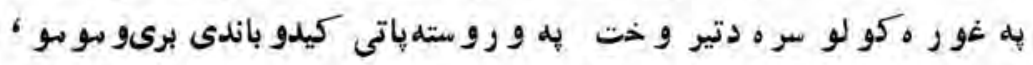

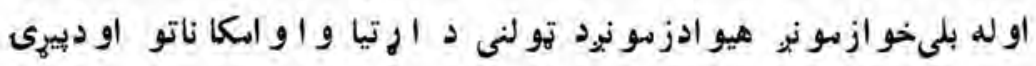

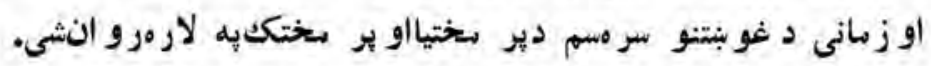

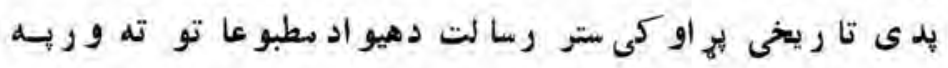

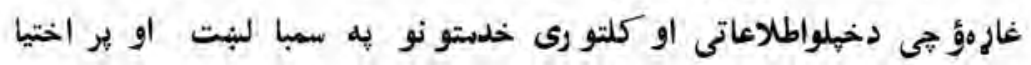
سره

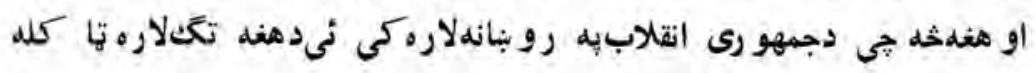




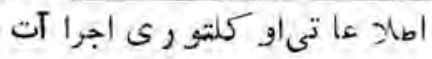

هه خهله ثار يخى و يناكى دانقلابدسشر بناغلى متحد داو دكتيو رهو يناده

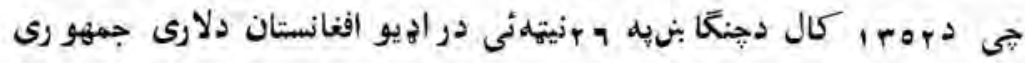

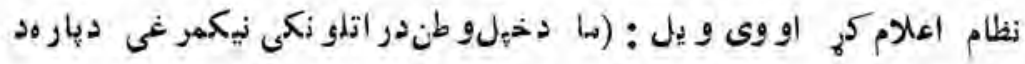

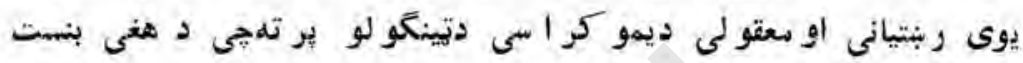
دافغانستان دخلكو د اكثر يت يهخدمت ايببو دلشوىوى بلهلاره نلهدرلو ده،

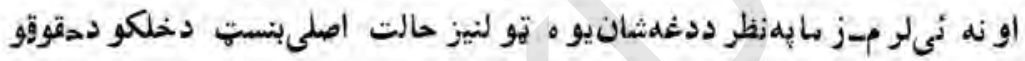

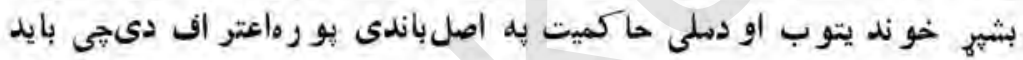

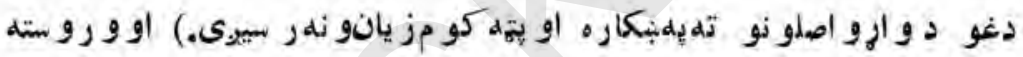

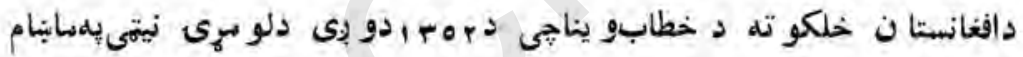

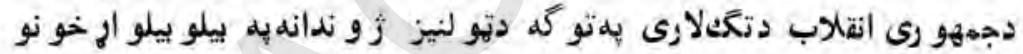

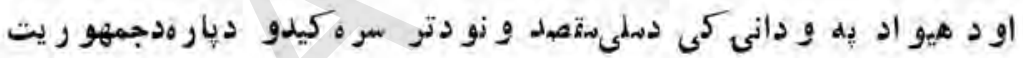

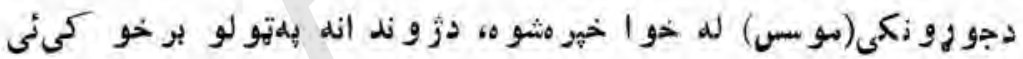

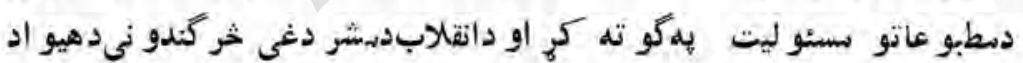

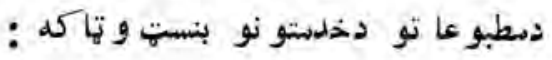

(جهمور ى دولت به دمطبوعـاتواوديموكراتيك خير ونو ديراختيا دياره

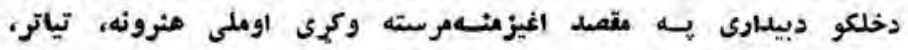

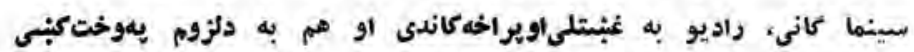

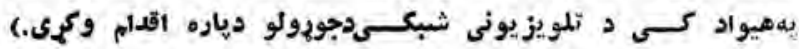

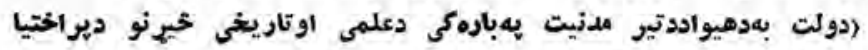

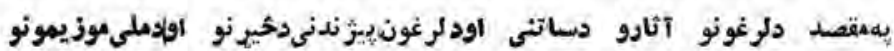
دجويولو دياره لاذم اقدام وكاندي..) 


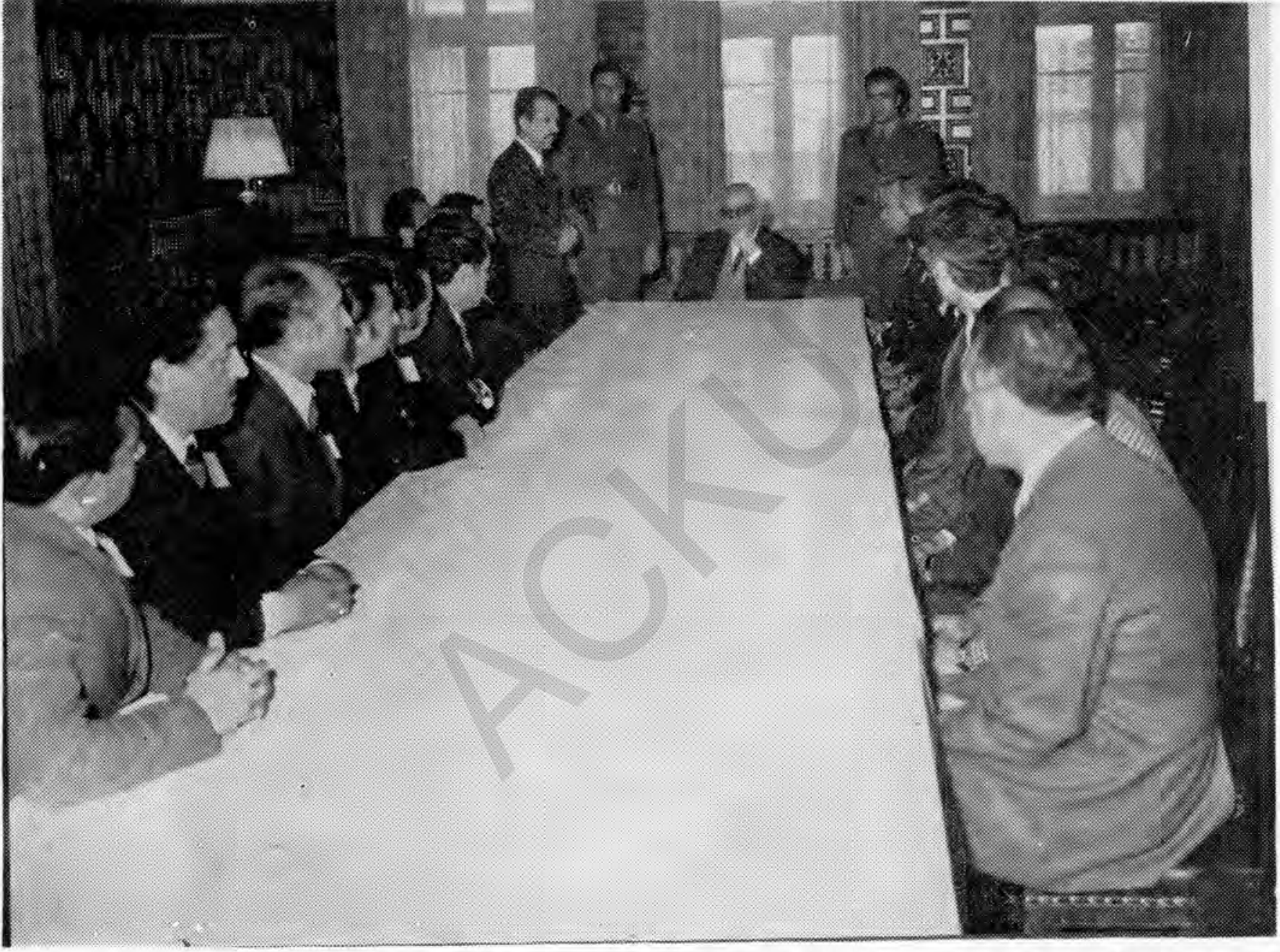

ديولت بناغلى دئيس او صدراعظمداطلن عاتواوكلتور دآمرانودسيميناردتشكيل يه وخت كى دو اطلا عاتواو

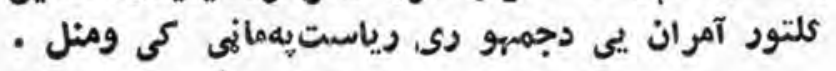




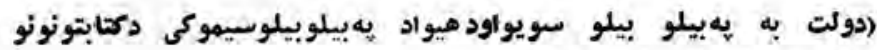

$$
\text { دجوجولو يهبرخه كى زيار وباسى. }
$$

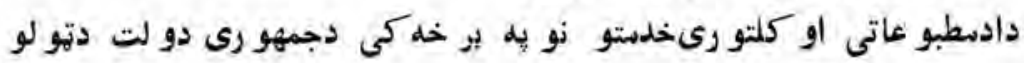

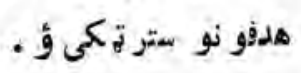

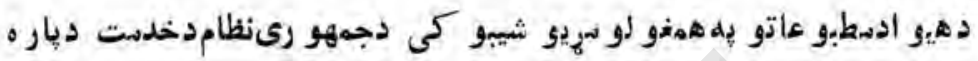

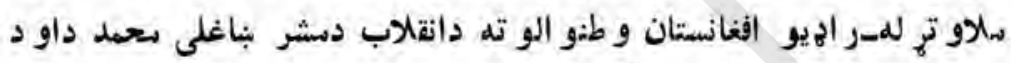

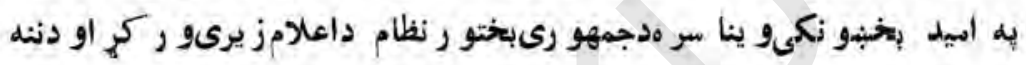

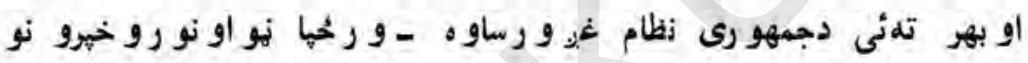

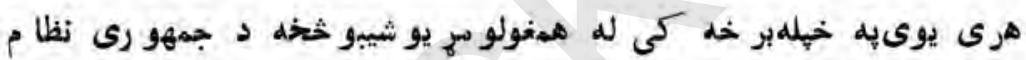

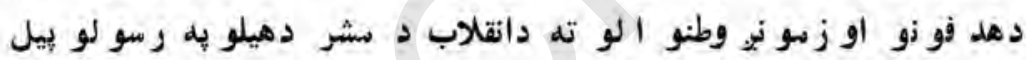

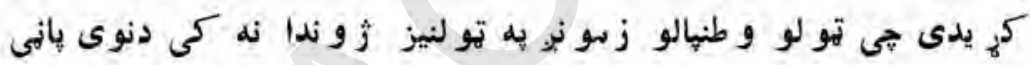

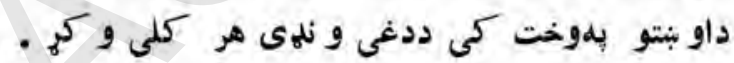

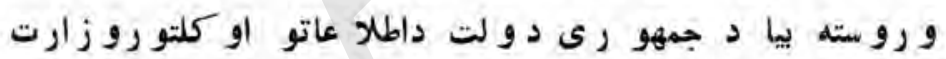

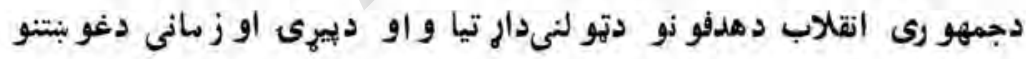

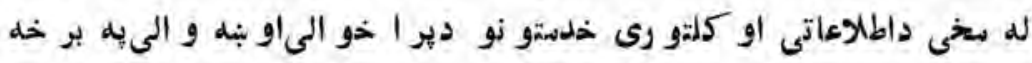

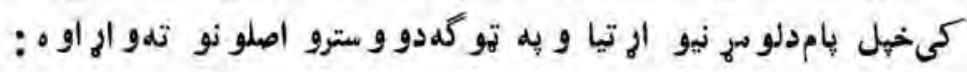

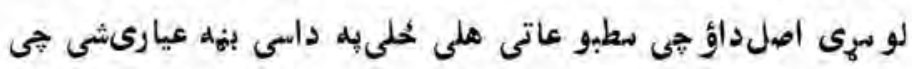

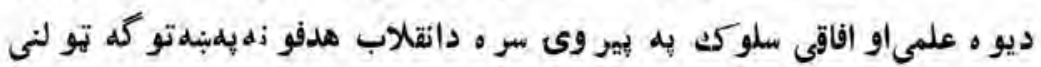

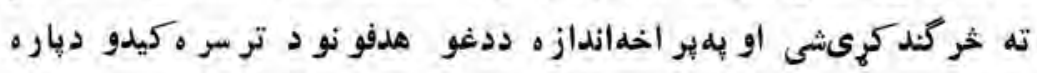

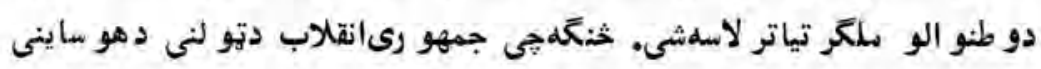

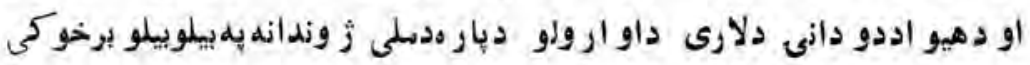




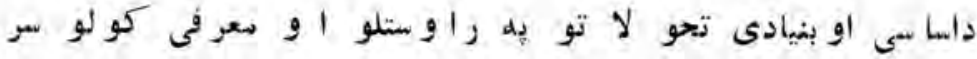

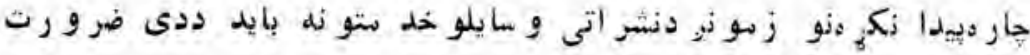

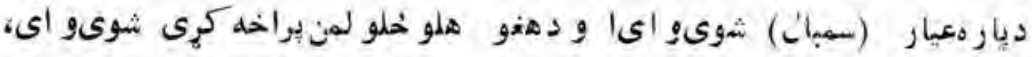

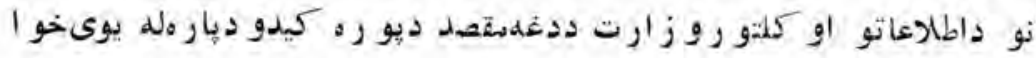

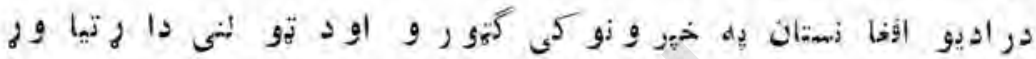

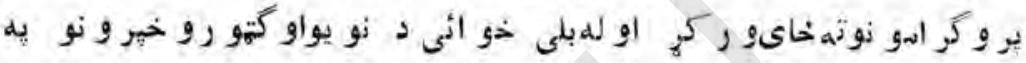

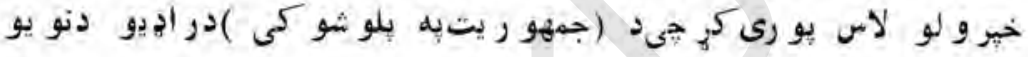

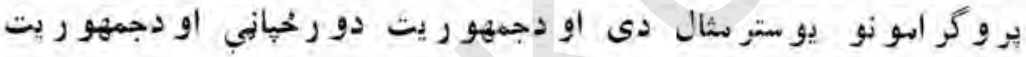

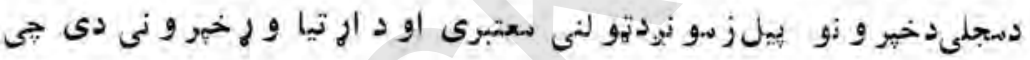

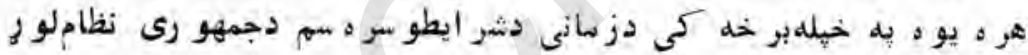

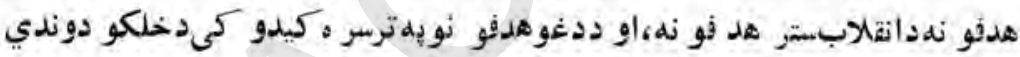

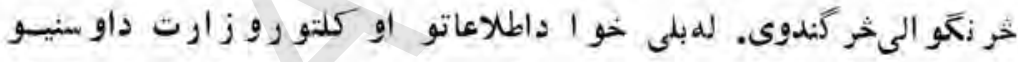

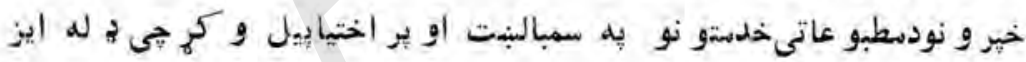

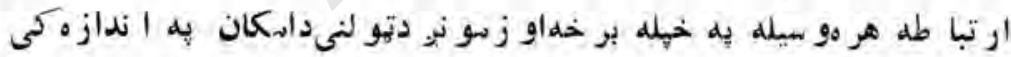

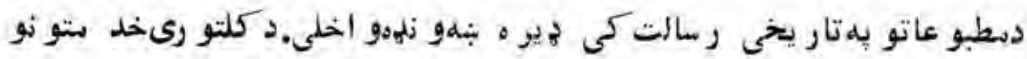

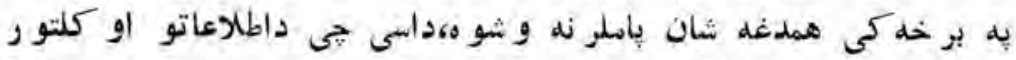

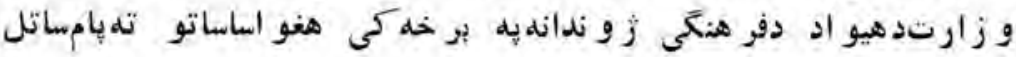

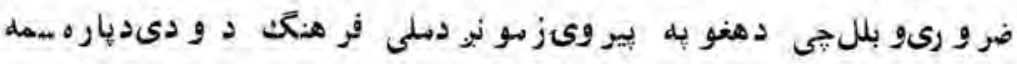

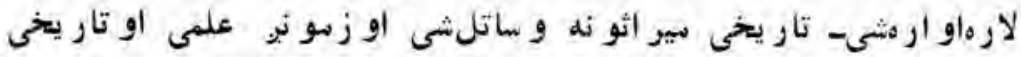

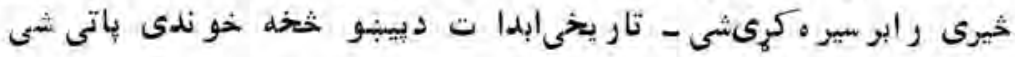

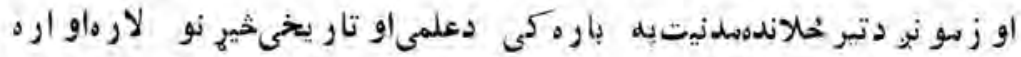




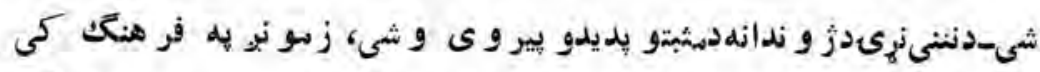

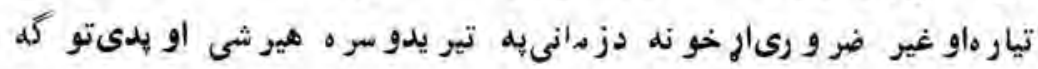

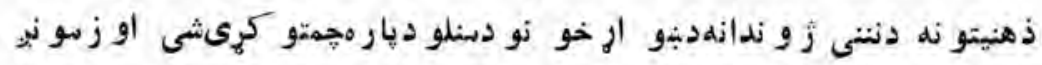

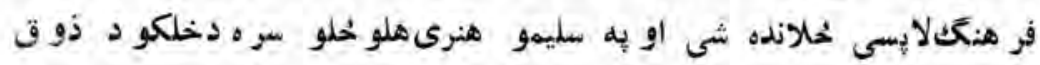

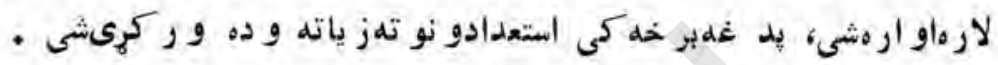
نو ددىديارهِي نشر اتى اوفر هنكى مو سسى دجمهو رى انقلابدتكثلارى

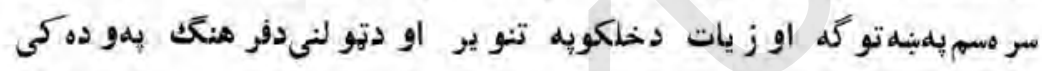

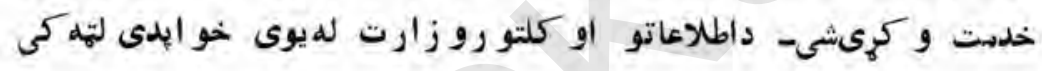
شو جيددغه وز ارتمر كزى دايرى اونشر اتى سوسى ده سر هسمبا لى

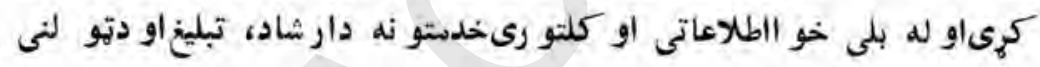

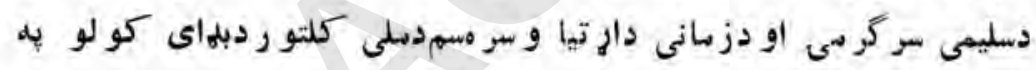

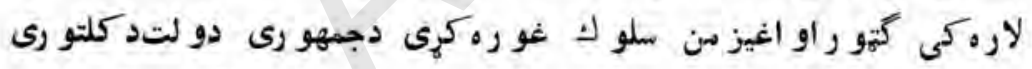

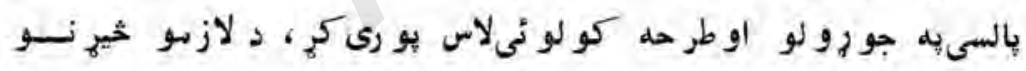
و رو سته ئى اطلاعاتو اوكلتو رد و ز ارتتشكيل دجمهو رىدو لتدسيما احل

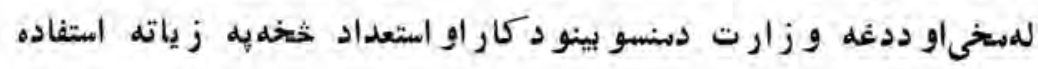

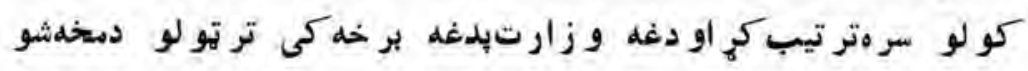

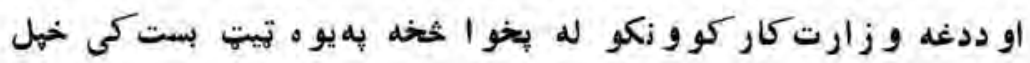

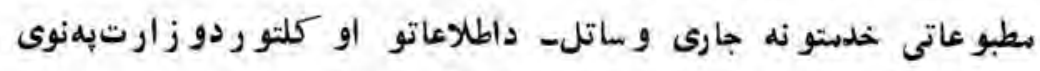

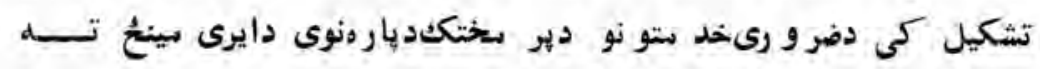

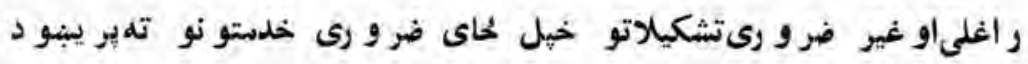


الطاكعاتى اه كاتتورى اجرا آت

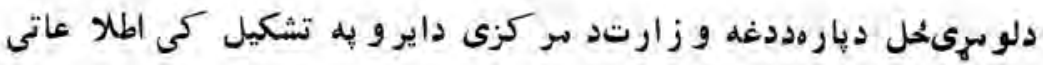

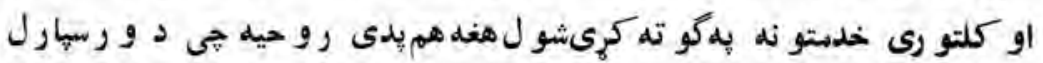

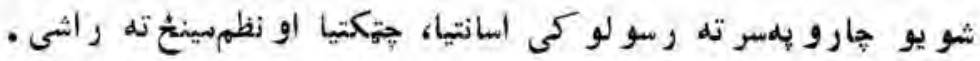

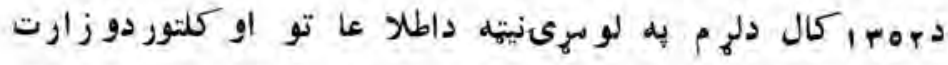

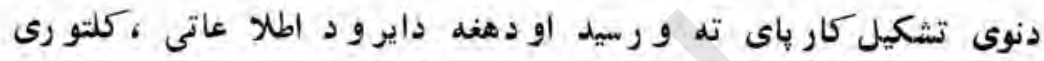

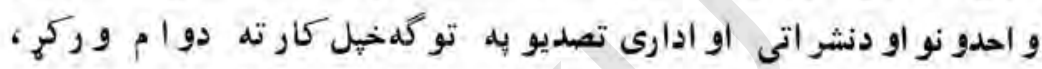

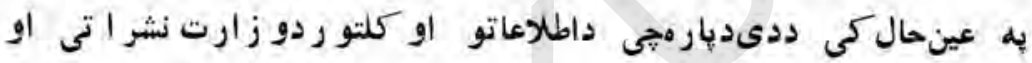

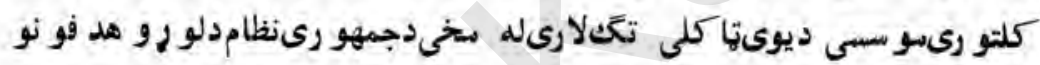

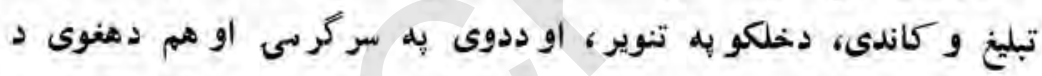

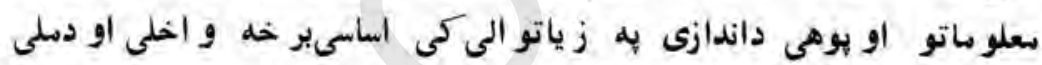

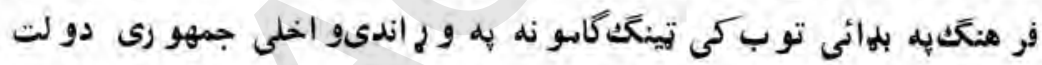

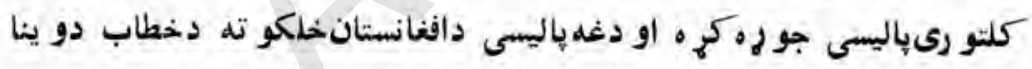

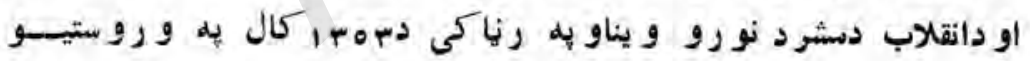

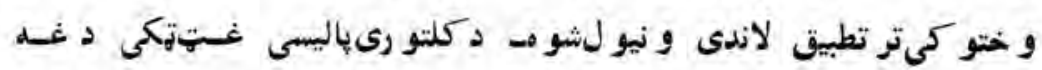
مطالبدى:

دتولنى دفر منكى ميراث باتنهاوخوندى كول،كلتورىمثبتو ادزبتهونو

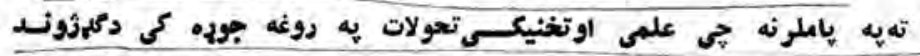

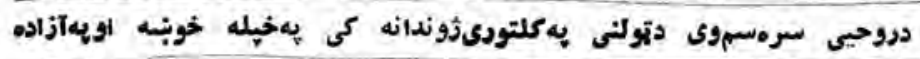

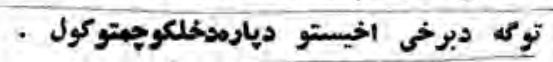

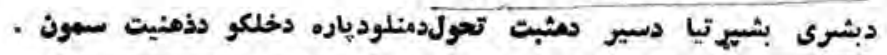

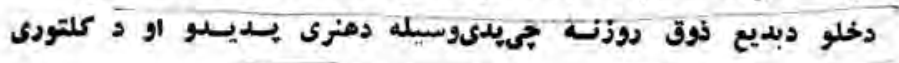




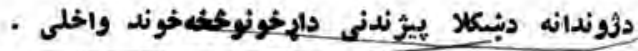

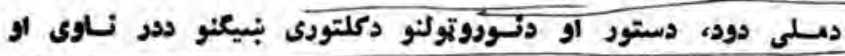

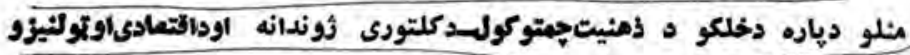

شرايطو ترمثئ د مستقيمو اجيكوييداكول. يهملى كلتودى مدفونو اولفاليتونو

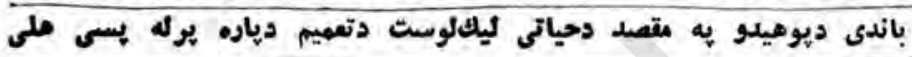

خلى

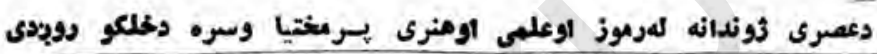

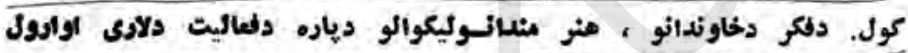

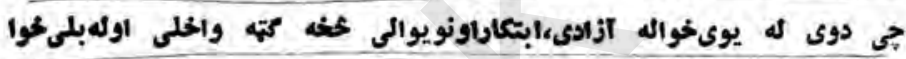

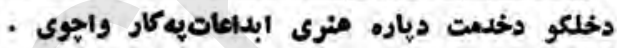

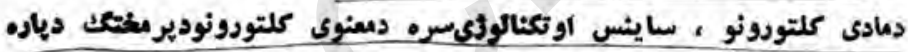

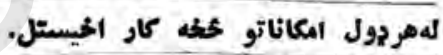

دكموهدلونو اودملى يووالى دروحيىيدرناكى دميواد دبيلو بيلو قومونوه

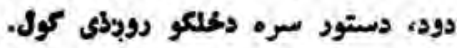

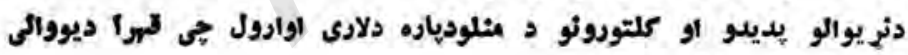

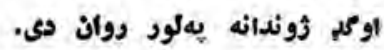

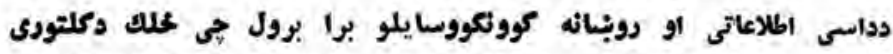

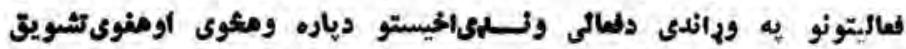
- كاندى

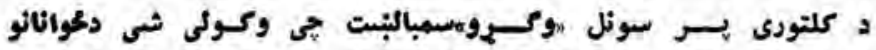

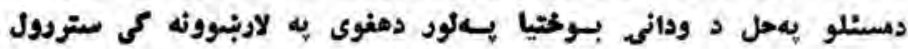

• ولوبولى شعى

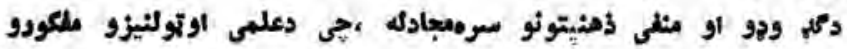

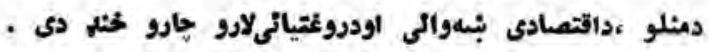

دنشراتى او تعليمى وسايلو دلاوىيبتو أودرى دُبو اونود وسيهه ايؤو 


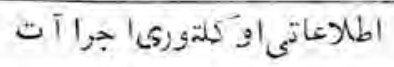

ذبوديرمختيا او رواجولو دياره دلادى آوادول ،دفرهنعى ميراثداميلوايخونو

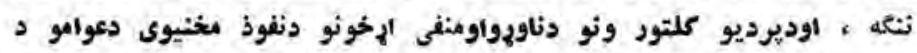

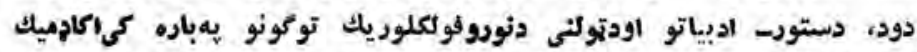

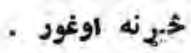
دآولو تاريخى آبداتو اوهرمنئميراثساتنه .

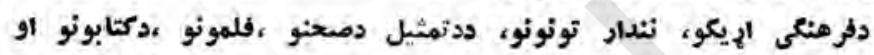

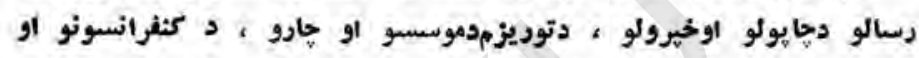

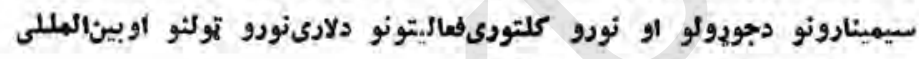
هوسسوته دافنانى كلتور ورييز ندنه.

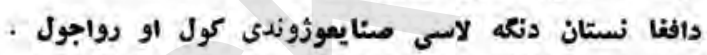

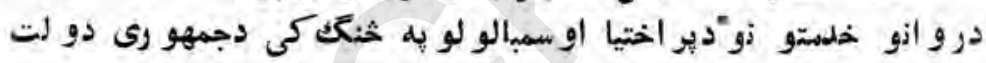

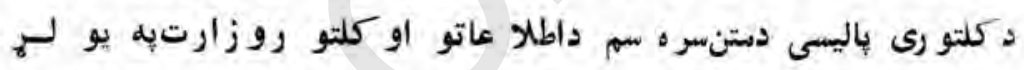

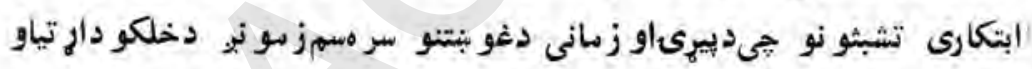

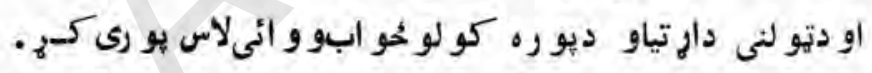

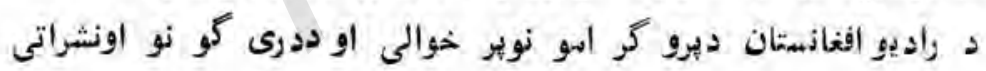

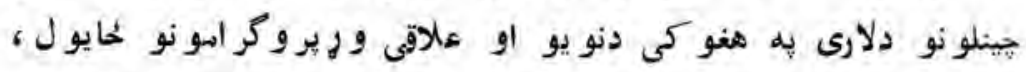

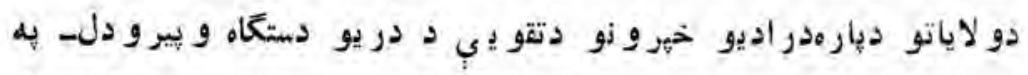

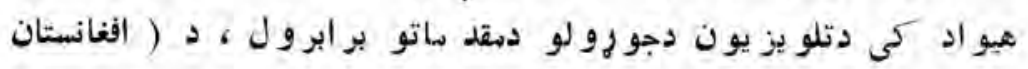

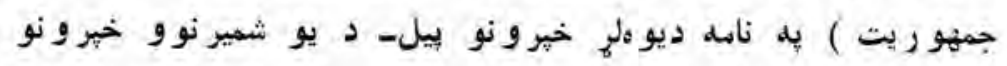

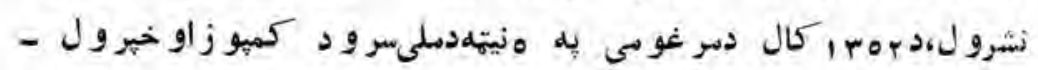

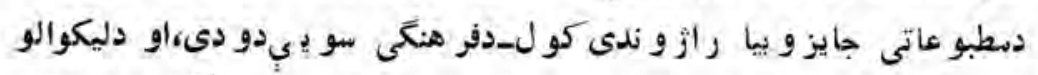

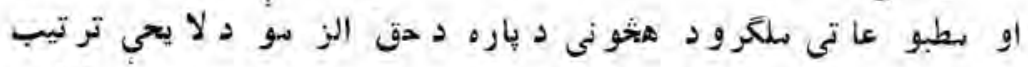

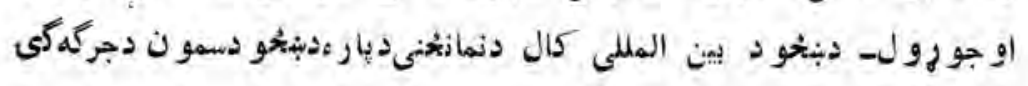




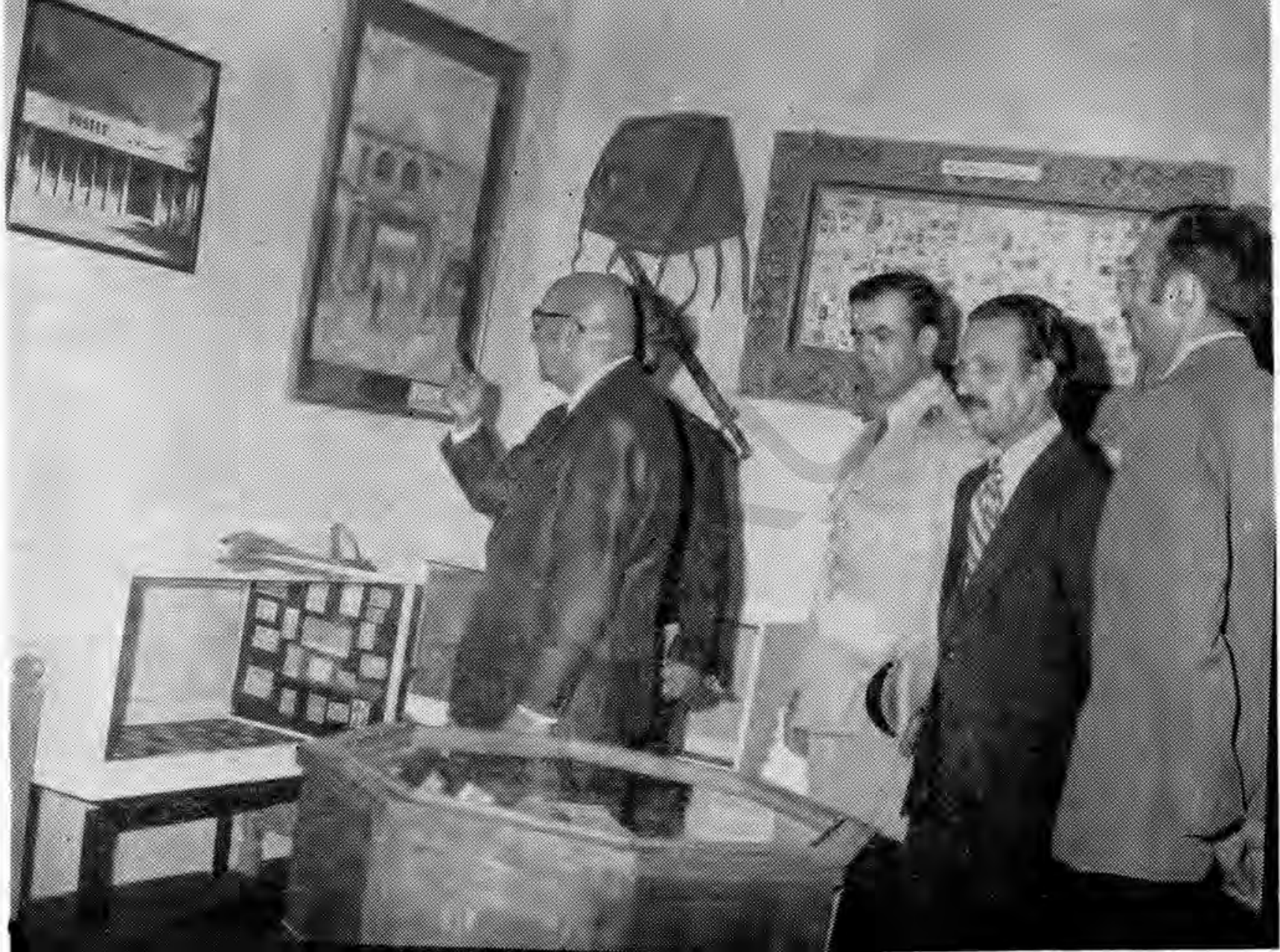

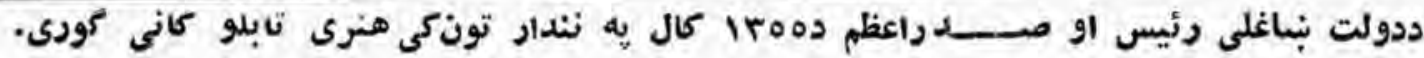


دجو رو لو دلارىدبنيخو دنهضتدسر بوطو خد متونو به بر اختيا كى

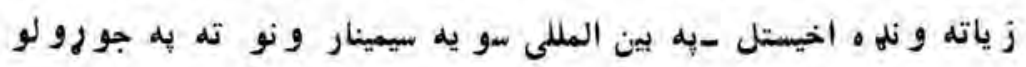

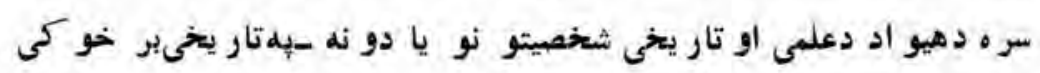

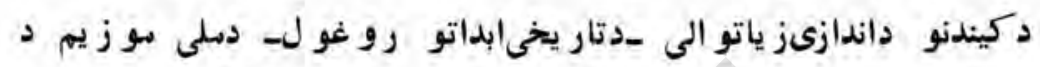

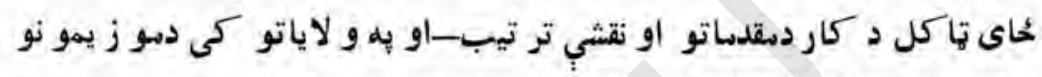

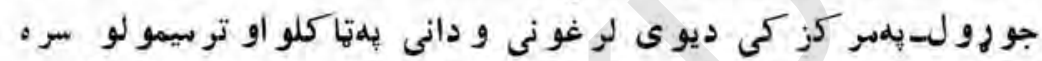

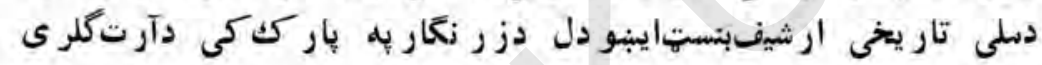

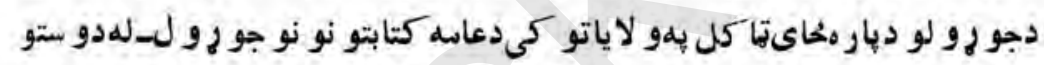

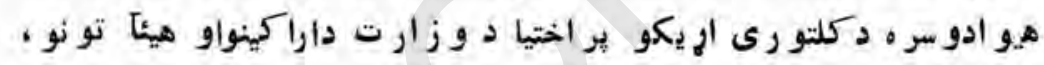

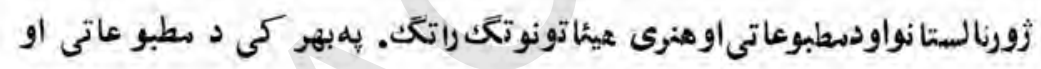

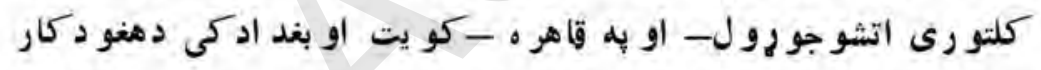

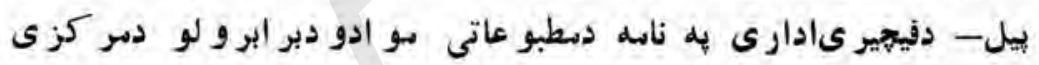

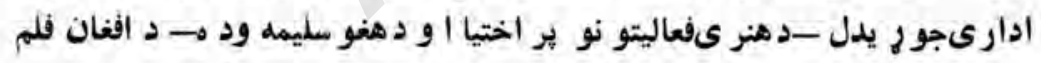

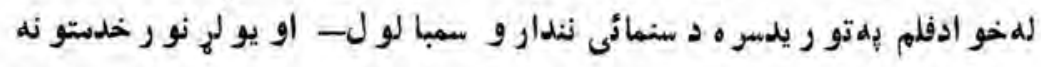

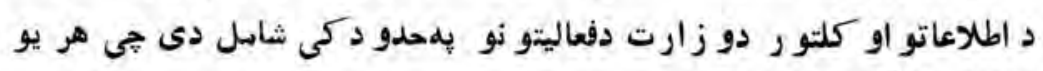

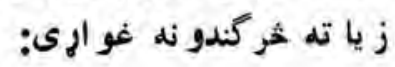

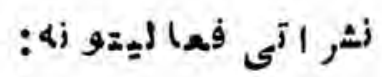

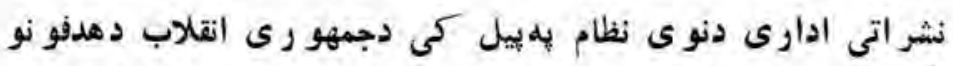

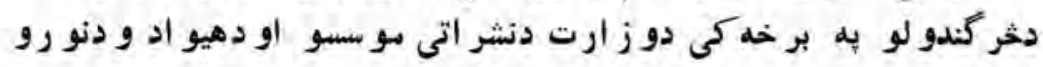

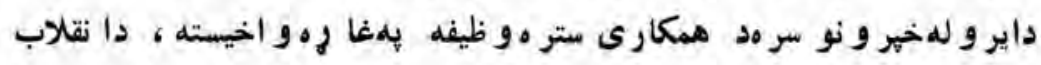




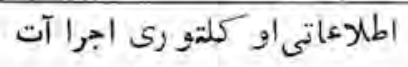

دنشرلمو ينا.دجمهو رى ارزز بنتو نواو دتولنى دار تياو سر مسمئى دكيو رو اوسسليمو

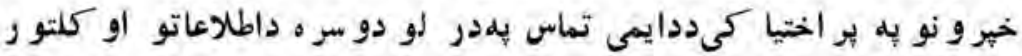

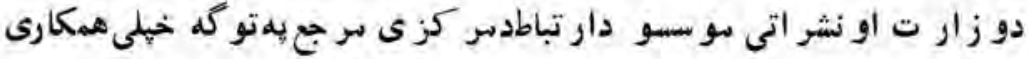

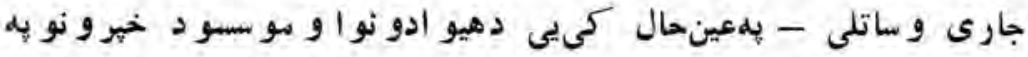

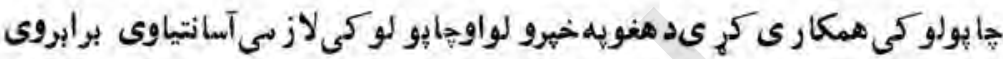

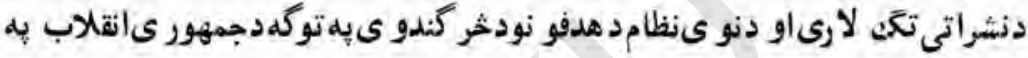

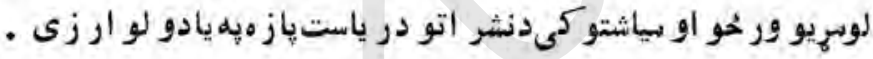

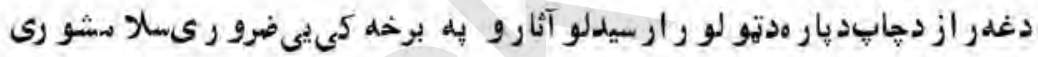

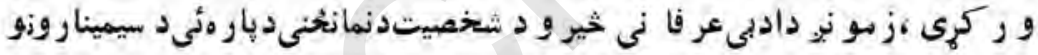

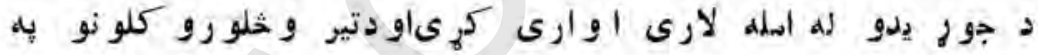

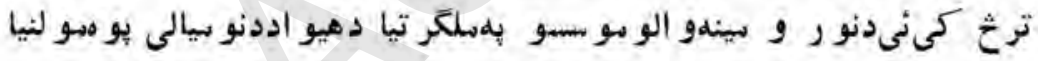

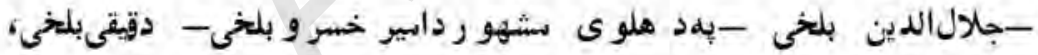

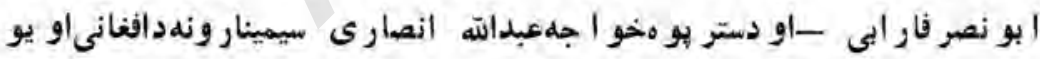

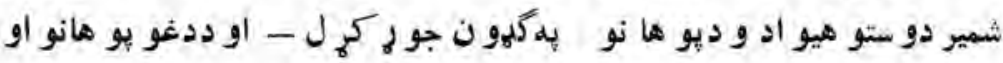

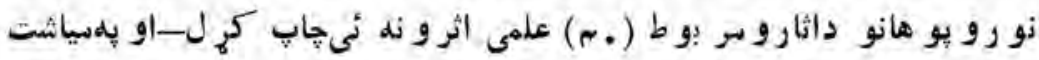

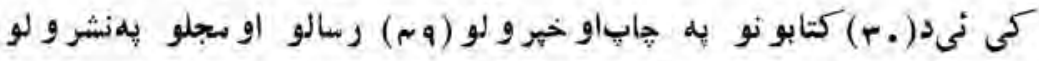

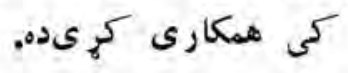

يه عين حال كمى به تير و د ر يو كلو نو كسي د نو ر و خهبر و نو (9...)

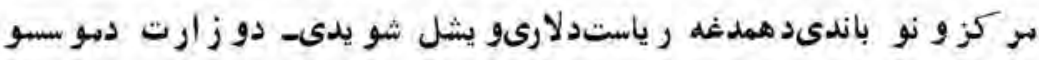



(11)
نشراتى فعا ليتو نيه

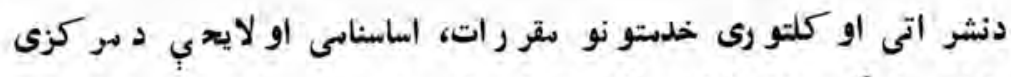

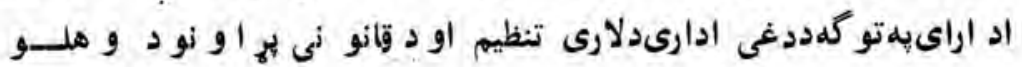
وروسته تو تطبيق لاندى نيول ثو يدى. يه عين حال كحى و زارت د

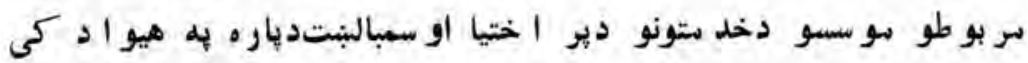

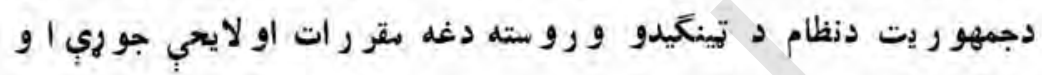
ترتطبيقلاندى نيولثنو يدى . ا-هيه خلو رو فصلو نو او اتلسو سا دو كمى دطباعتى، تنو يرى او هنرى سو سسو دجو هر يدو مقر ر ات . r-بها (r)فحلو نو او (v) مادو كمى دتيا تر و نو سركسو نو او كنسر تونو دجو ر يدو نقر ر ات.

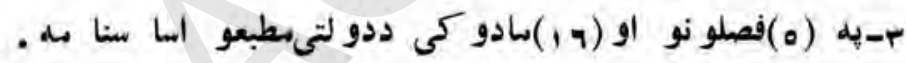

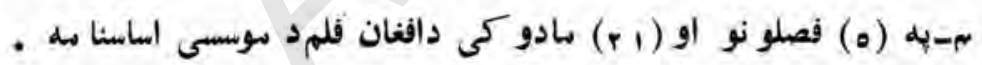

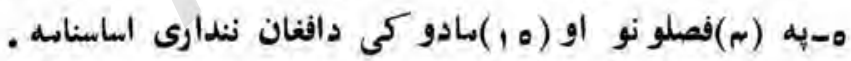
צ-يه(0) فصلو نو او (v)سادو كى دافغان اعلاناتو اساسنامه. دغه راز دجمهو رى نظامدنيني ته ر اتلو و رو سته دهنرى فلمو نو د بر ابر و لو

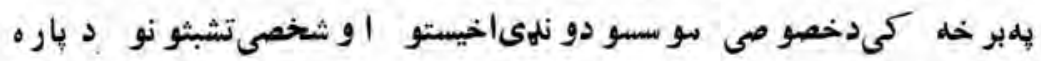

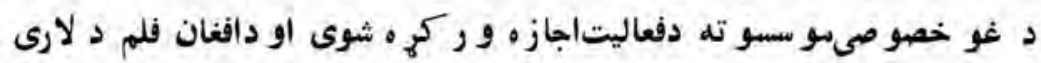
له هغوى سر ه دهنرى فلمونو دبو ابو ولو دياره فنى او بر له بسى هدكار ى شو يدى. ا-ددنذير فلم دياره ددهنى فعاليتونو دايتيازصادريدل . 
جاددآر ياناقلم دِار هدهنرىقعاليتو نو اودفلم دتوليد داستياز صادر يدل .

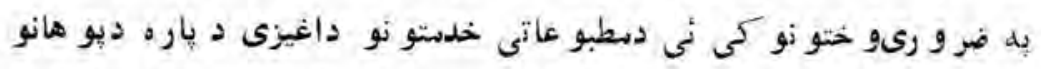

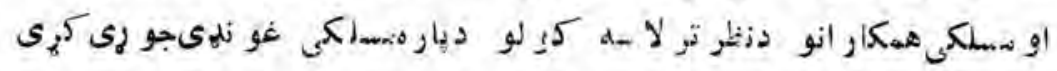

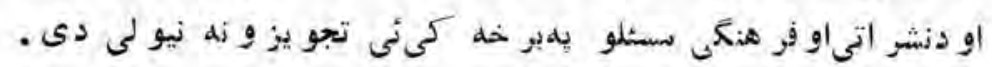

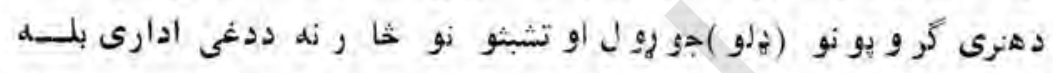

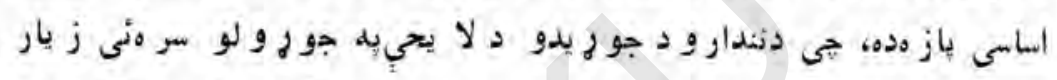

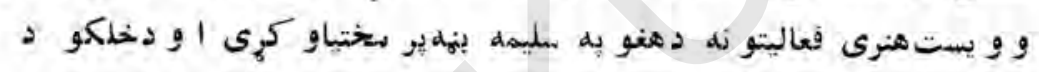
خدنست ديار مو كمار لشیى.

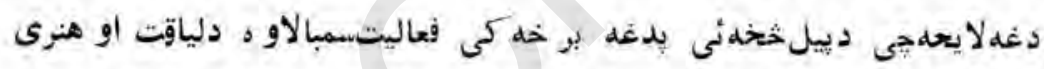

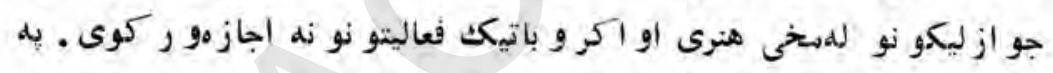

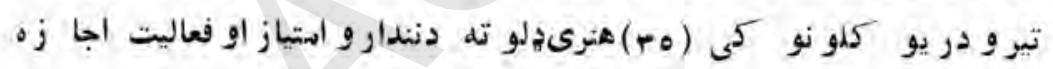

$$
\text { . } 0 \text {. }
$$

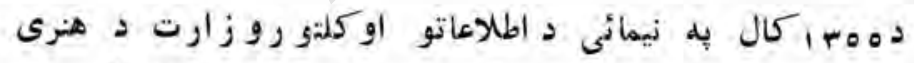

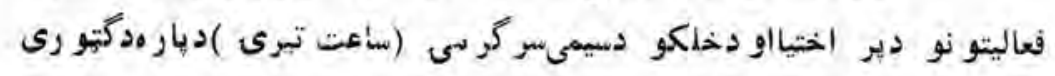

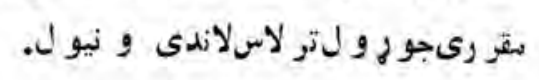

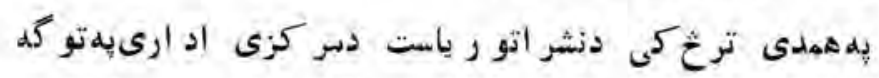

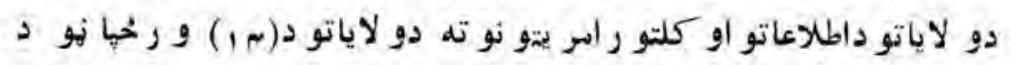

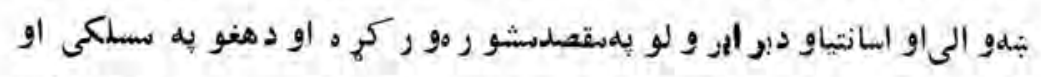

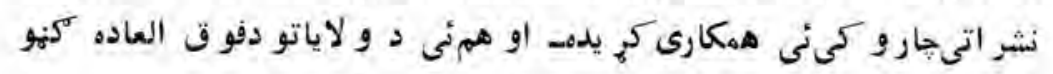

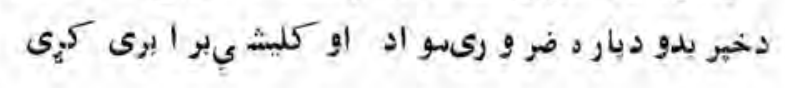




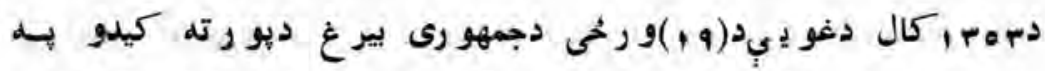

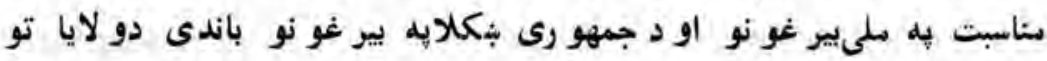

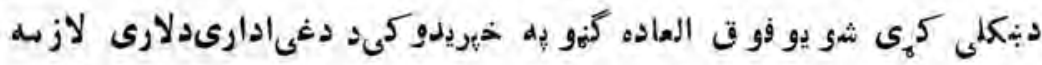

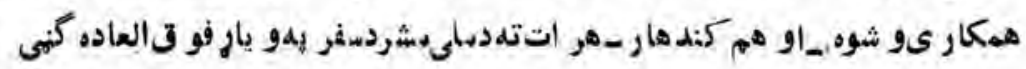
خيرى او و و يشل شوى.

دخارجى كتابو نو اوخيرو نو دو يشهر بوطى اسانتياوىد خار جى نشر اتو دادارى دلارى بر ابرىشوى-داسى جى يه تير و دريو 15 لو اوشير بيا ثتو

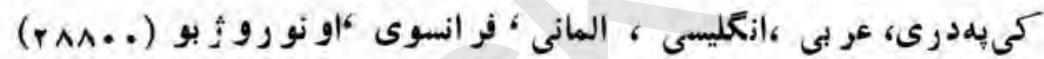

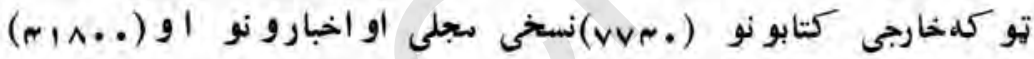
ر يكاردو نو او فيتو دو يثاجازه و ركم هشوى افغانستان ته دد و ستو هيو ادو دسشر انو اوستر و كسانو دسفر بهوخت كى به بين المللى سو يسه تو لمسطبو عاتى السانتياوى دنشر اتو در ياستدلارى بر ابوى شوى او هملـه تو لو خارجى نطبو عاتى هياتونو اوز و رنالستانو سر مدهر كو بهترتيب، دهيو اد به و ر بيزث ندنه،و لاياتوته بهسفر او دمطبو عاتى سو ادو به برابر ولو لو كى همكارىشوى مده

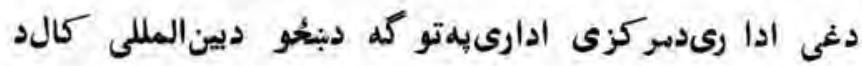

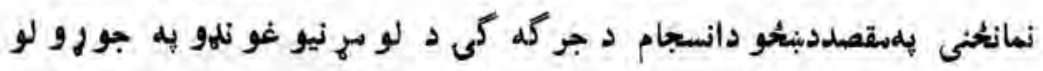

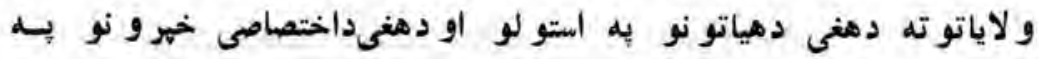

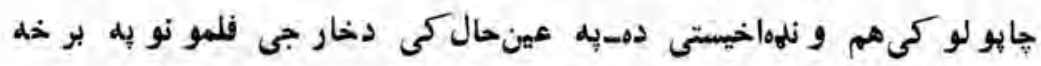

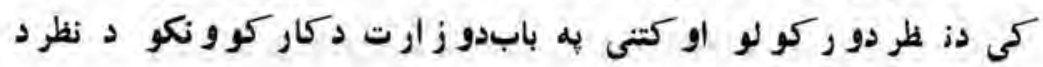




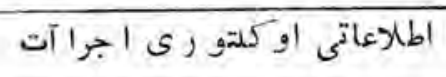

خاو نداتو همكارى ترلاسه شو يده او همئى د هنو خبرى او مستيندو فلمونو

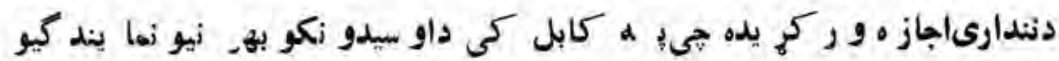
خخه و رسيدلىدى .

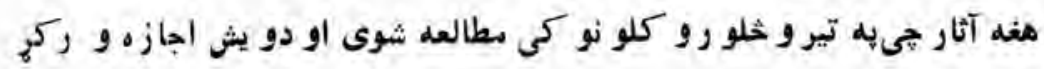
شوى بدى دول دى. أستخى (1.r.)

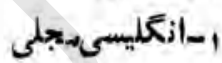

$$
\begin{aligned}
& \text { " }(1+9) \\
& \text { ז- الهانى دجلى } \\
& \text { " ( } \mathrm{N}) \\
& \text { r- اردو سجلى المان } \\
& \text { "( ( 9v) } \\
& \text { م- فر انسوى مجلى اردو ملى } \\
& \text { a }(r \cdot v) \\
& \text { 0- - روسى نمجلى } \\
& \text { " (trav) } \\
& \text { ه- فار سىمجلى ا:كتابو نه } \\
& \text { a } \\
& \text { v- عر بي كتابو نه } \\
& \text { a (or.er) } \\
& \text { ي- روسى كتابونه } \\
& \text { "( (To1r) } \\
& \text { ه- انزليسى كتابو نه } \\
& \text { a (irOA) } \\
& \text { • } 1 \text { - الهانى كتابو نه } \\
& \text { a }(r, q)
\end{aligned}
$$

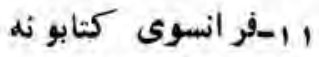

$$
\begin{aligned}
& \text { * }(1+q) \\
& \text { " ا- إنانى كتابو نه } \\
& \text { " (vr) } \\
& \text { rا-يو لنهى كتابو نه } \\
& \text { ما-المانى شجلى }
\end{aligned}
$$




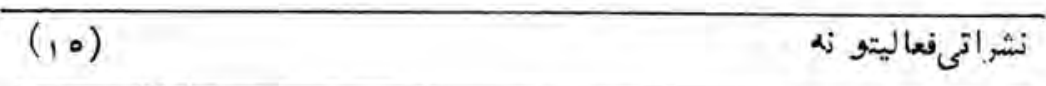

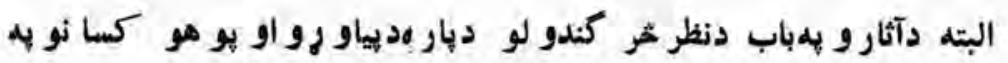

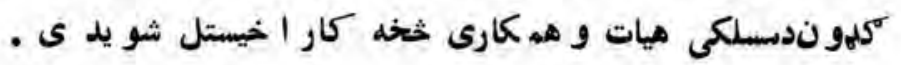
دغه رازدتو لو خلكو داستفادى دبار ملو برىحل (اطلا عات او

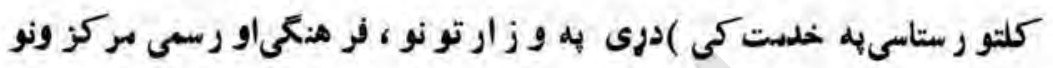

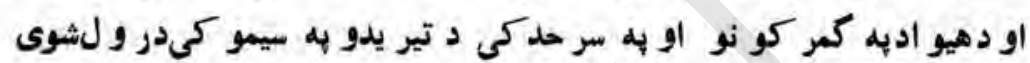
او دجمهو ر يتو رخحيانهيرى نببلول شوى نوده .

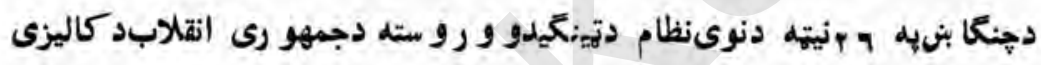
دنمانجلو به و يار دافغانستان كالنى هر كالهاب شو يده. دافغانستان كالنى

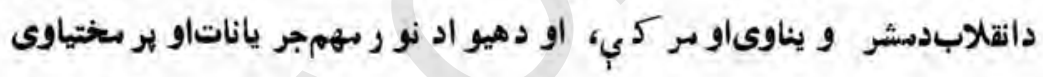

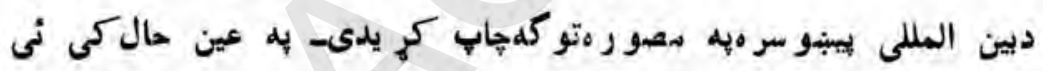

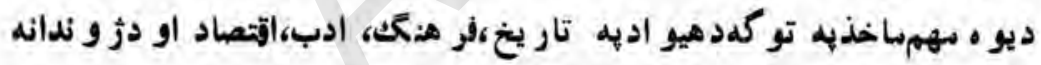

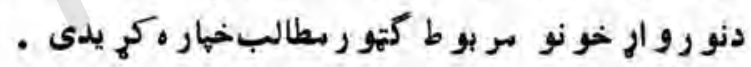

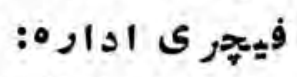

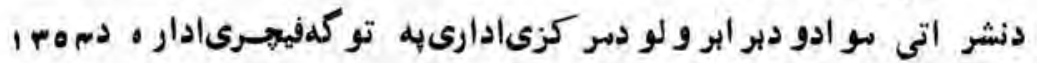
كال دله مبه مياشت كى داطلاعا تو او كلتو ربه وز ارتكى جور مشوه

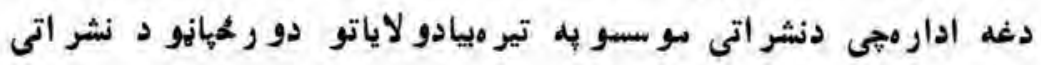

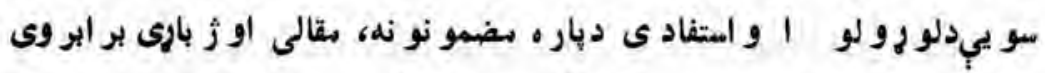

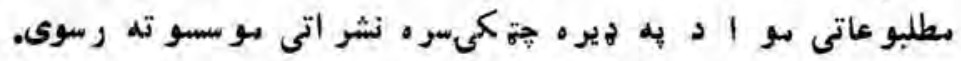

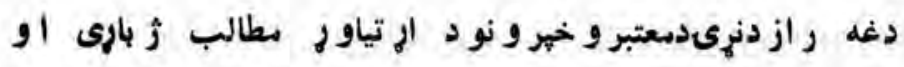


نشو اتحى مو سسو تهئى و ركوى-او دز بارى اودمطالبو د بر ابر و لو بهبر خه

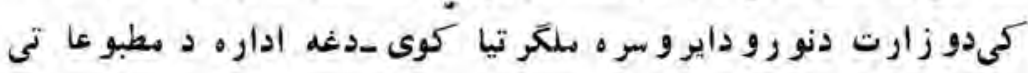

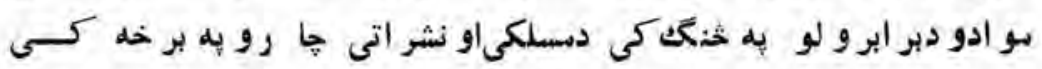

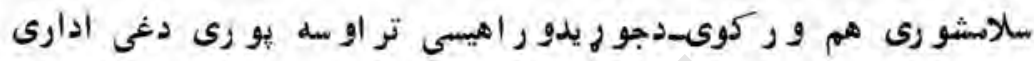

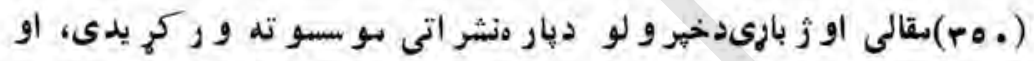

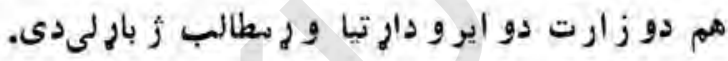

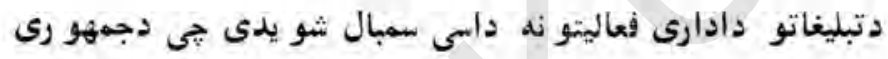
انقلاب دارزبنتو نو او زمونبو دخلكو دمعنوى إي تياوسر ه سم خهلىخير ونى عيازى كا ندى .

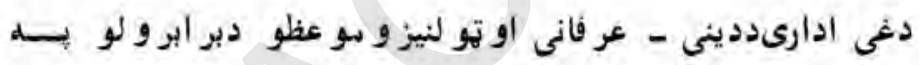

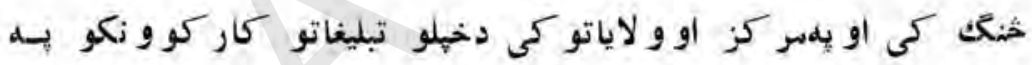

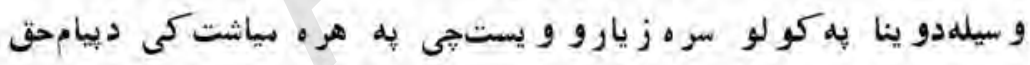

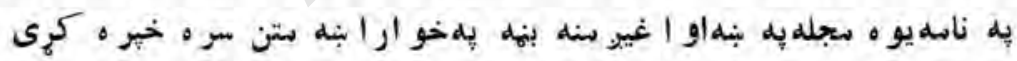
يحى وطنو ال ترىاستفادىوكرى .

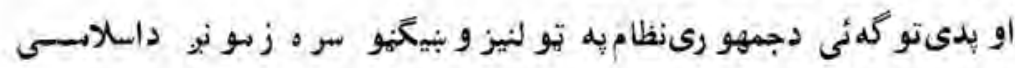

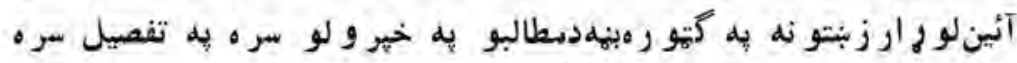

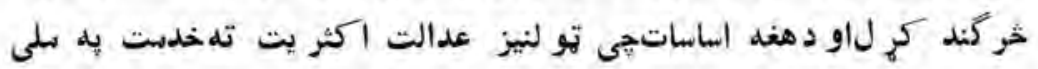

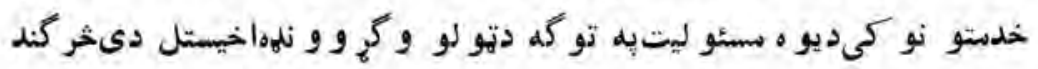
- $\sqrt{5}$

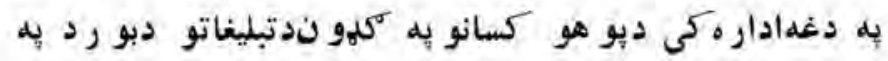


و سيله ارزنبتناكت كار ير مختكثو كر -دكار بر مختكك هغه تفسير شر يف

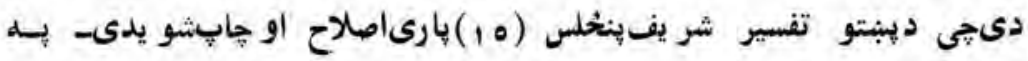

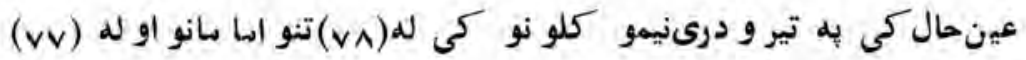

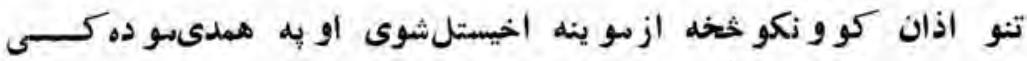
دتبليغا تو دبو رداو كابل نبارو الى كمه و نهايندكانو (0م)جو سا تونو تهد

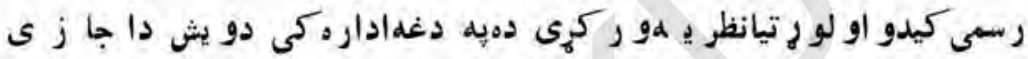

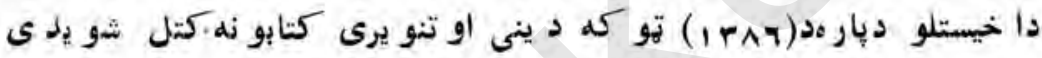

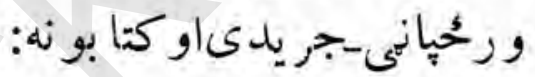

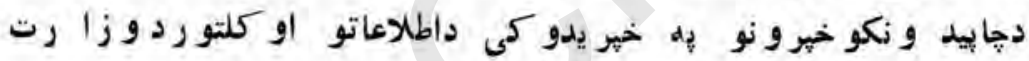
زياريه دريو اصلونو ولاهؤو 1- دنو يو خهرونو بيل ب- داو سنيو خهر و نو بنه و المي.

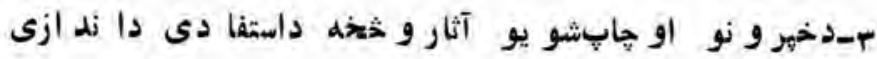

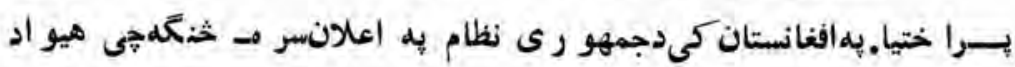
يو مر و بنانه تار يخىيم او ته و ردننهشو ، او دجمهو رى هدفو نو دورها ند ي

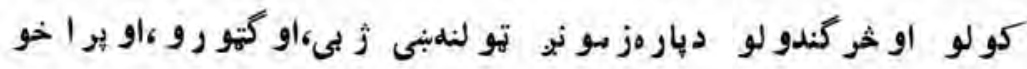
خهر و نو تله الرهو م6نو ددغه ملمىهدفاو دخلكو دخبر تيا او رو بنا نتيا او

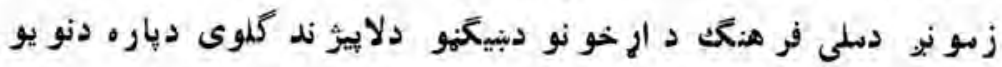
خير و نو يبل ترلاسلاندى و نيولثنو 


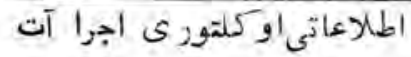

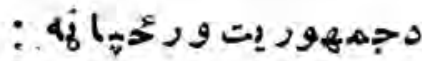

د جمهو رى انقلاب دهدفو نواو ارمانو نو ثركندو لو به مقصه مددغه نظام

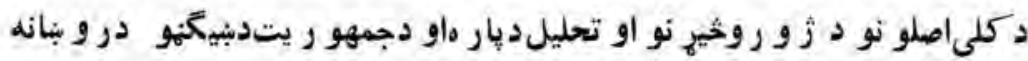

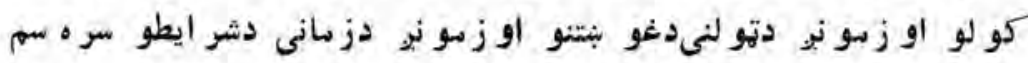

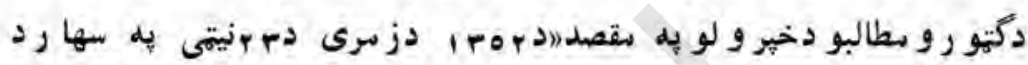

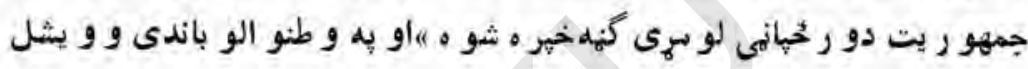
- شو

دغى و رخهانيهى دجمهو رىدو لت دنشر اتى ا و ركان حيثيت لرىله يوى

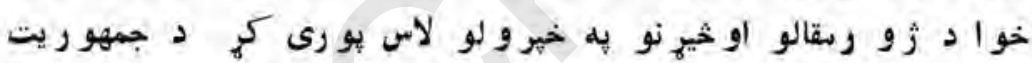

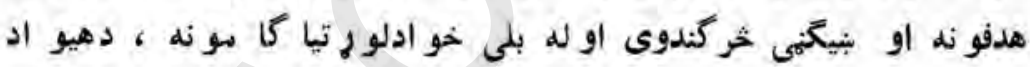

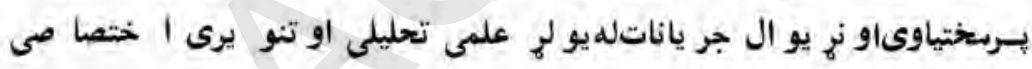
مطالبو سو ه يوحاى خهر وى .

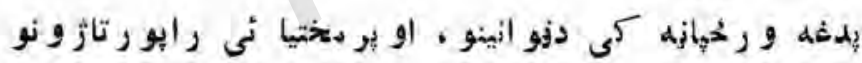

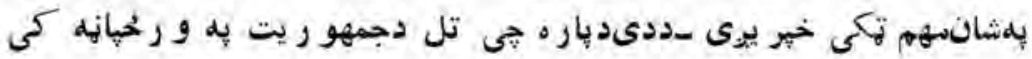

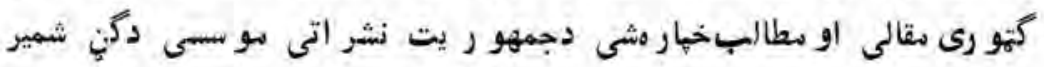
بو هانو اوليكو الو هماكاري نى لئب كري يده .

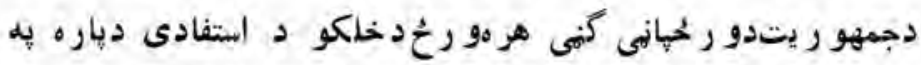

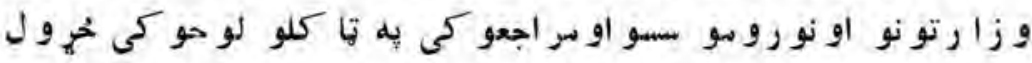

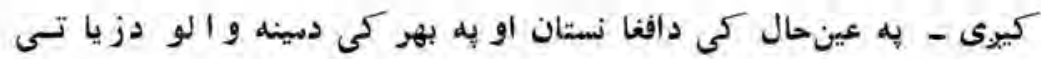

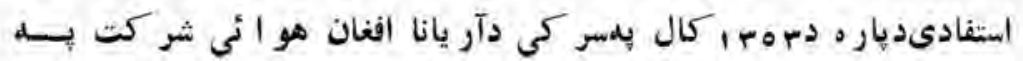




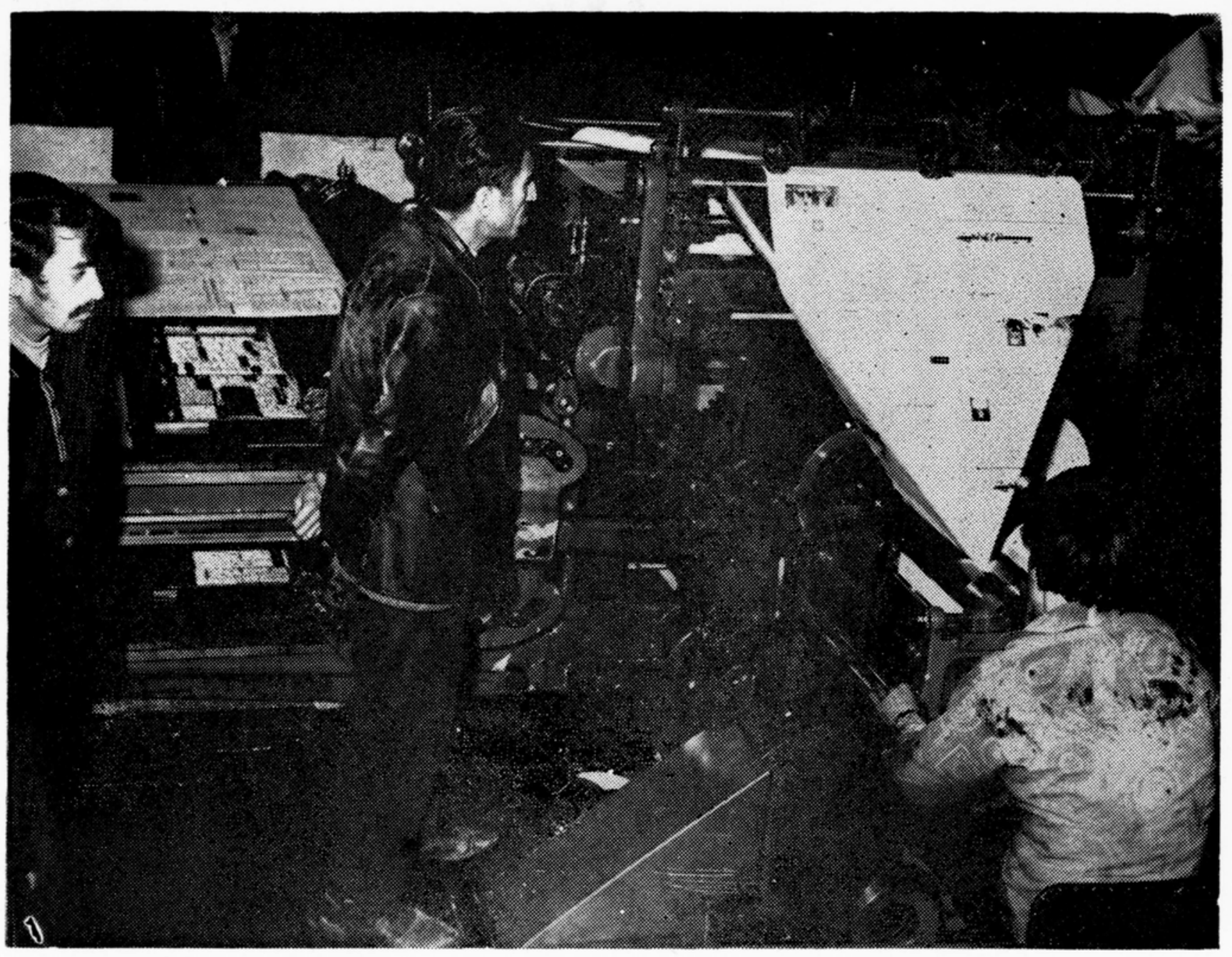

دجمهوديت ورحيا نه دكاكسو تايي یهماشين كى دهاي ضه حال كى. 


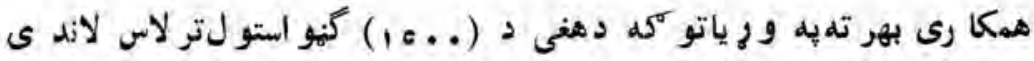
و نيول ثول.

دجمهو ر يتو رحخيانه دسقالو ، تبصر و ، رابو ر تا ثو نو، در كو او كور نيو

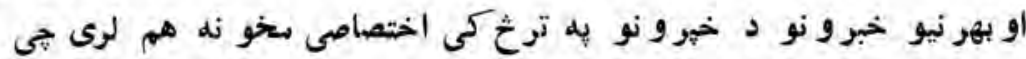

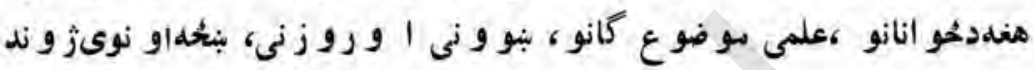

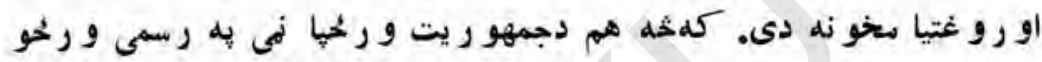

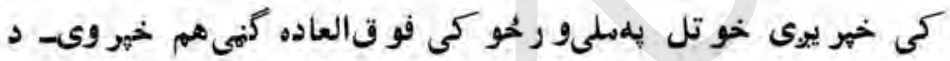

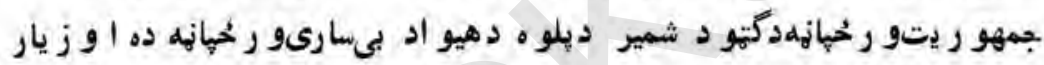

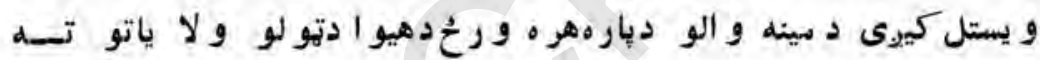
و روسيوى

د جمهو ريت نشر اتى سو سسى دجمهو رى ندفو نو او دهغله د ملسى

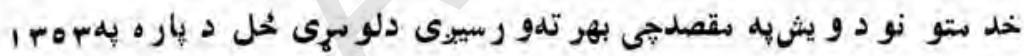

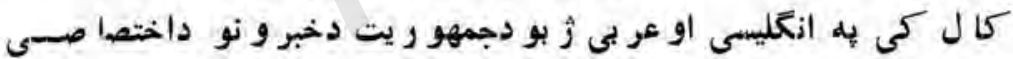

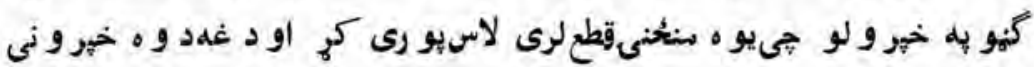
دجمهو رى انقلاب دلو رو هدفو نو هيه رناكى د هيو اد اود هغ دير ديختيا دجر يان دز ياتى بيز ند كلوىديار ه دبهر نيو هيو ادو به فر هنكى او دطبو عاتى مر كزونو باندى و يشل كيو

\section{: :}

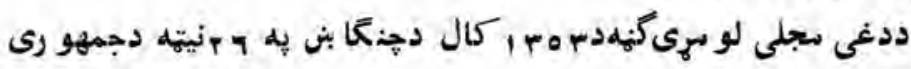

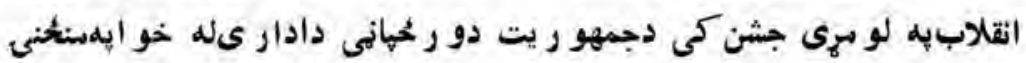




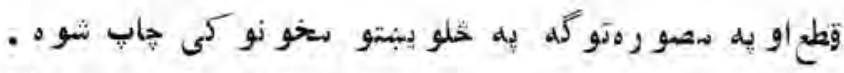

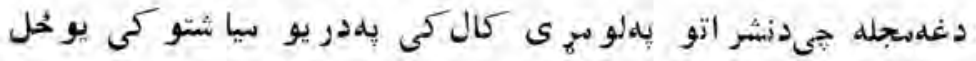

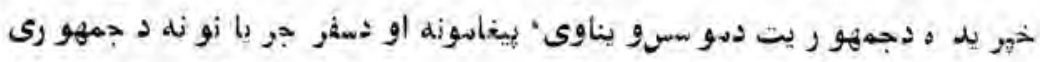

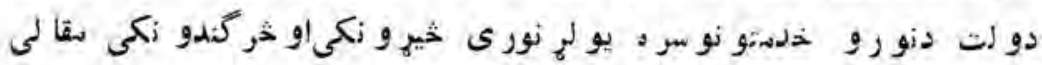

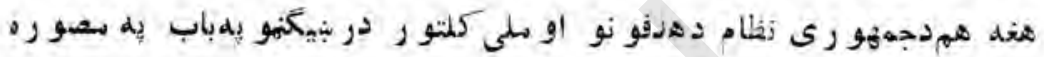
- نو

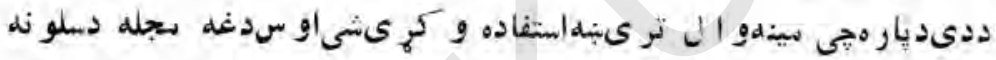

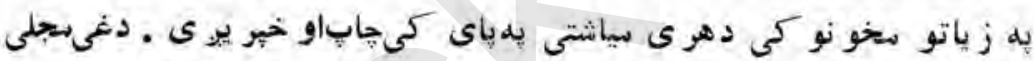

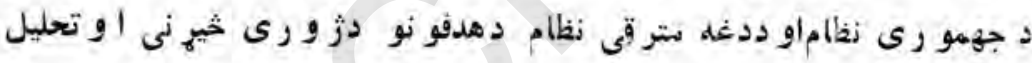

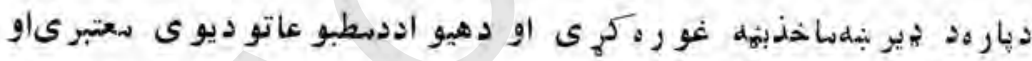

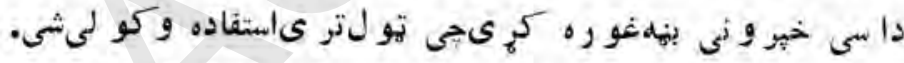

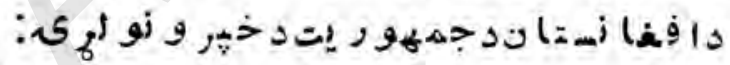

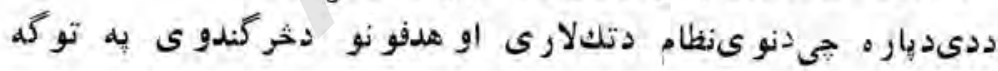

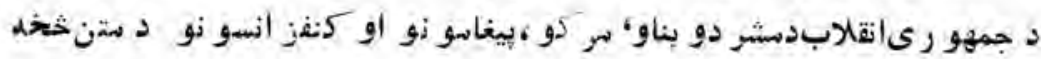
وير ثر رو طنو ال استفاده و كولىثى او همددهيو ادداطلاعاتى ، او تار يخى

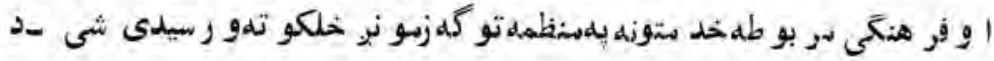

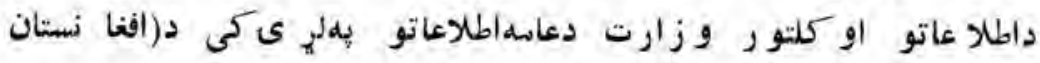

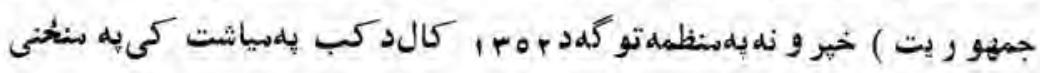

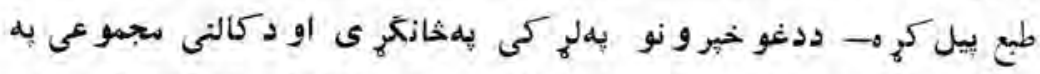

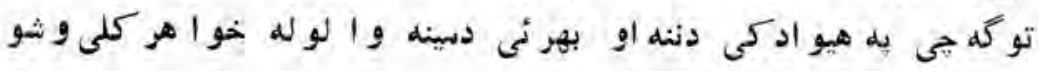


دجمهو و يتد سو سس و يناوى' يِناسو نه او مطبو عاتى سر كي، او هم دحياتى

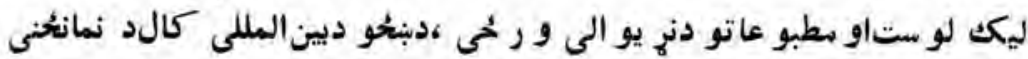

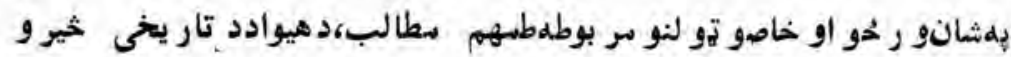
نها نحلو دسيمينار ونو او يين المللمجيو كو مو بو طه نطالب ، او دهيو اددو يارنه

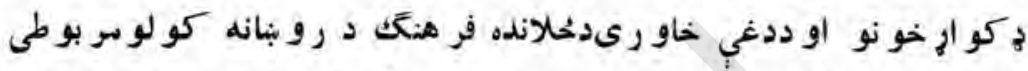

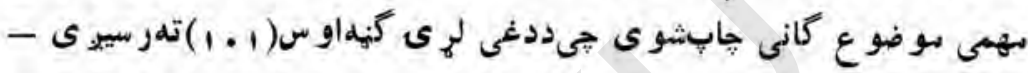

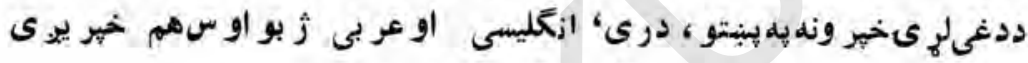

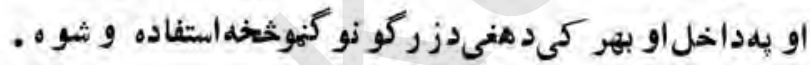

$$
\text { : }
$$

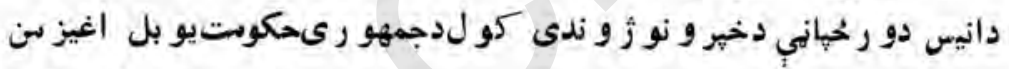

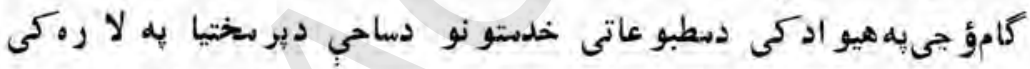
و اخيستن شو.دانيسدو رخهيانبي خير و نى جلهد هغى خهير يد ل دز مانى دعو ا ملو

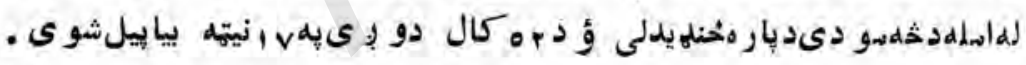

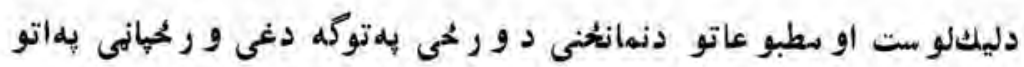

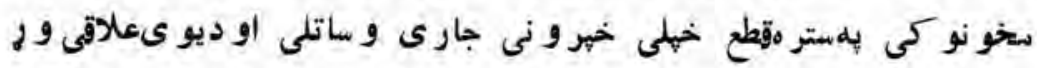

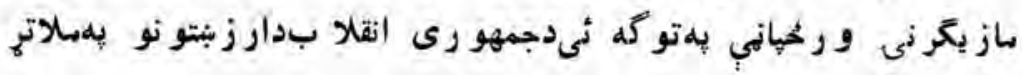

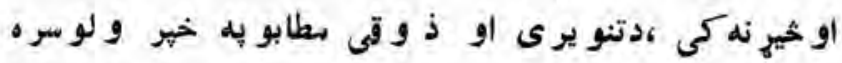

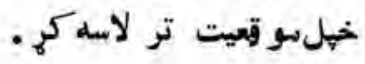

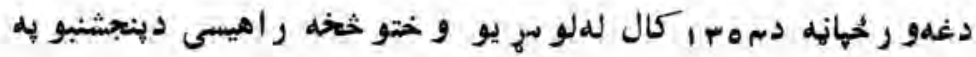

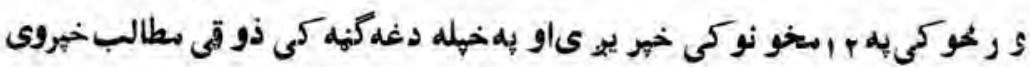


اطاواتى اوكلةو رىاجر آت آت

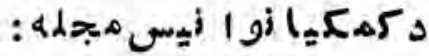

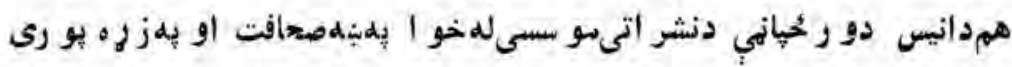
او سعلو ساتى خبير و نوسر ه دماشو شانو دفو هنكى او ذو قى سو يب دو دى او

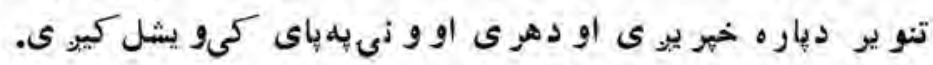

\section{: درونه}

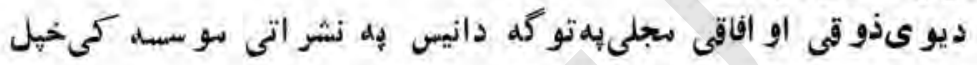

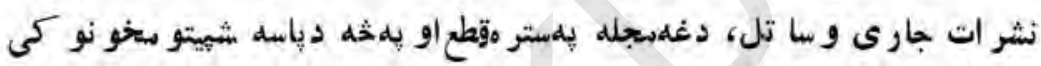

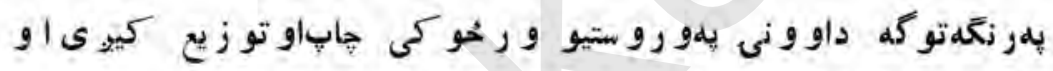
دلو ستو نكو ذو قى او معلو ساتى اله تياو ى يهنظز كى نيسى .

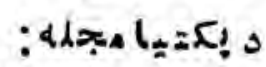

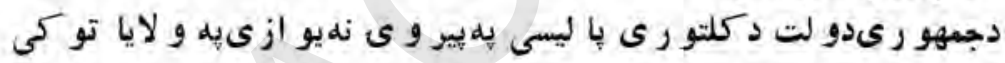

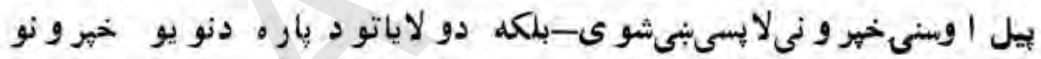
همترلاسلاندىونيولشو-دجمهورىانقلابد هدفونودثركندولو " دهيو ادد إيونتختياو

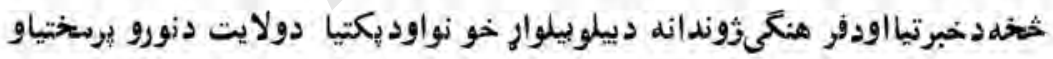

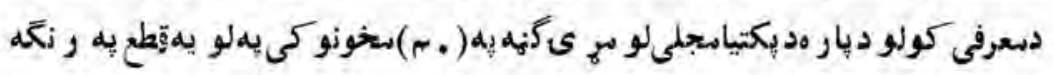

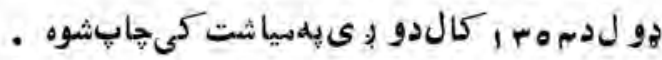

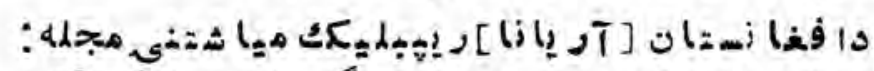

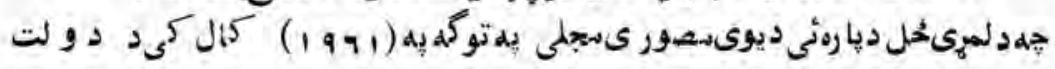

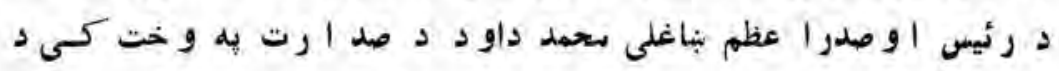

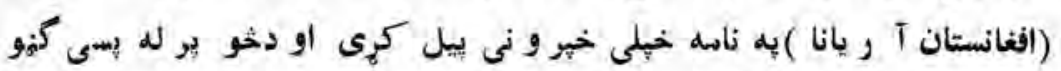
دخير يدو و رو سته دهغىخير و نى بندىشوىوى-يو خلم بيانى دكابل تبايهز 


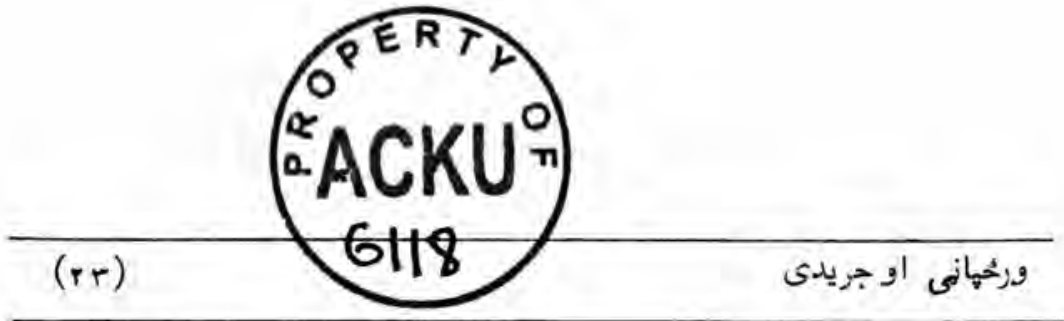

د نشر اتى سو سسىلارىيه انكليسى به خهلى سنظمى خهر و نى بيل كهى ،

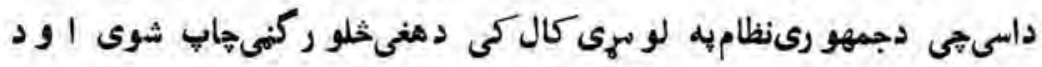

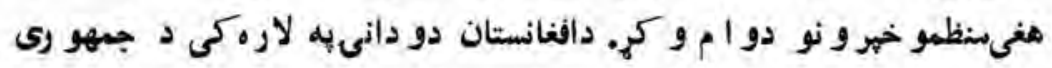

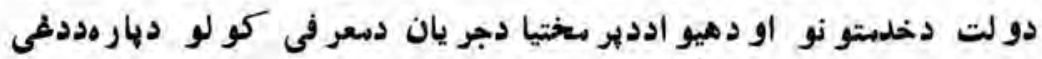

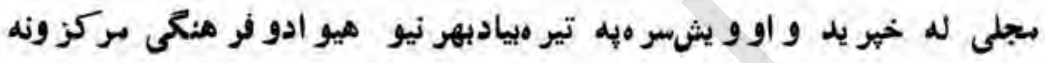

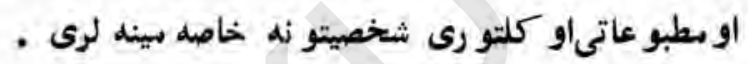

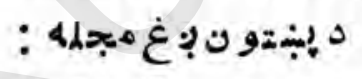

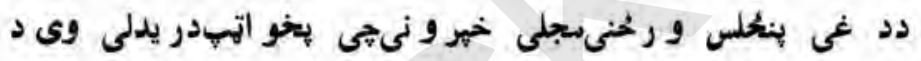

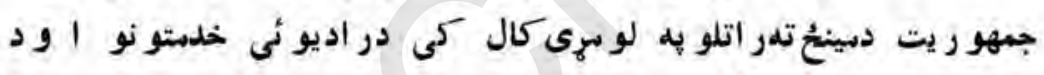

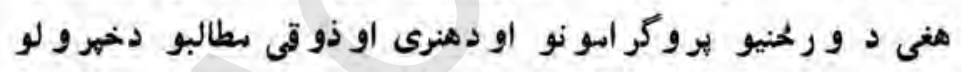

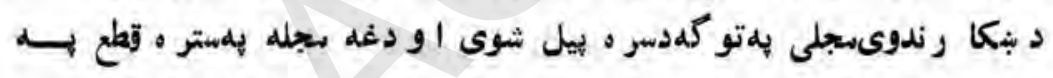

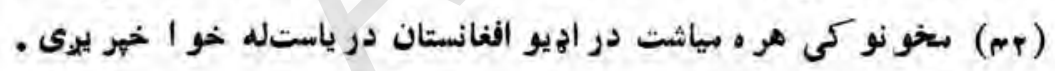

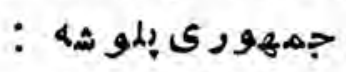

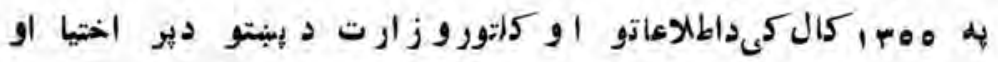

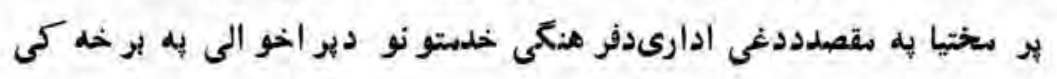

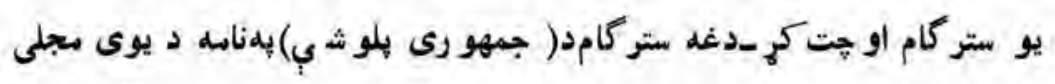

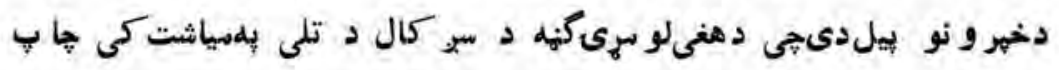

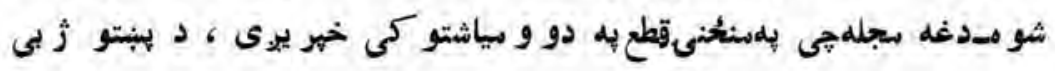

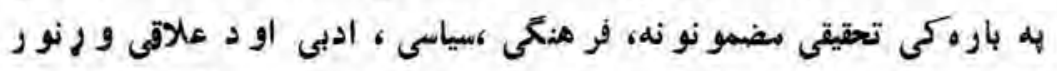

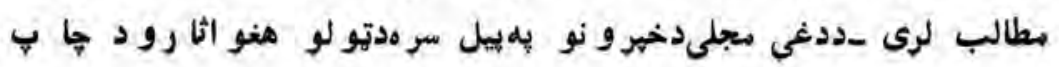




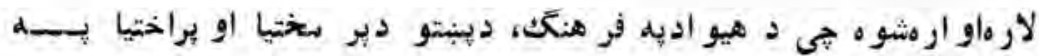

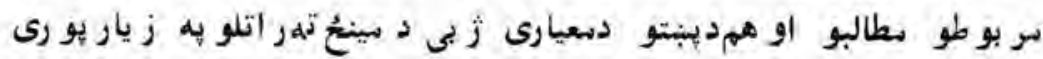
الره زيدا كوى

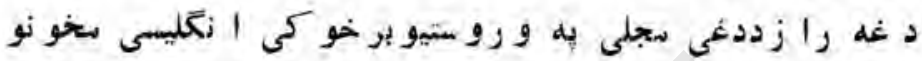

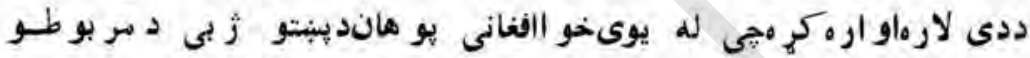

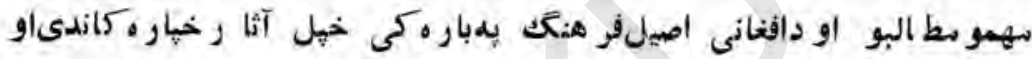

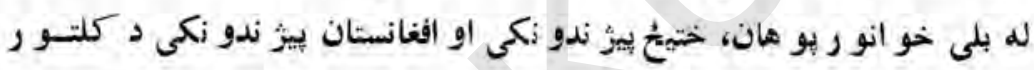

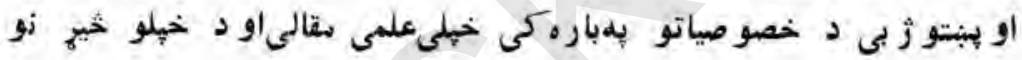
نتيجى نشر ثله و سهارى.

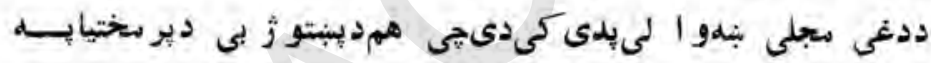

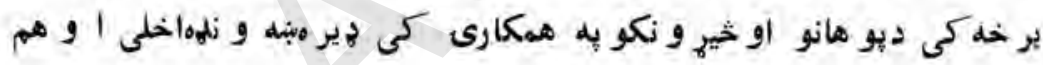

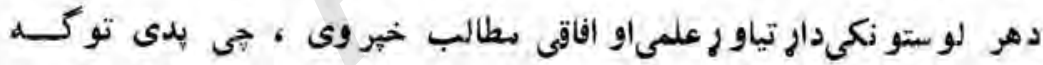

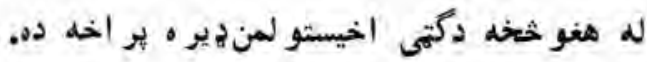
: 4d?0. Jges,

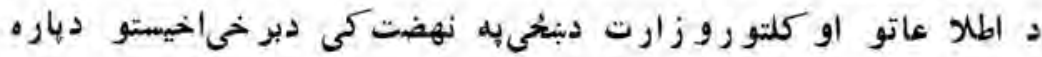

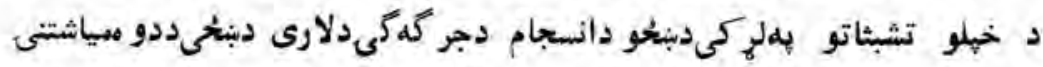

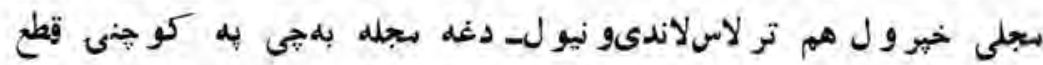

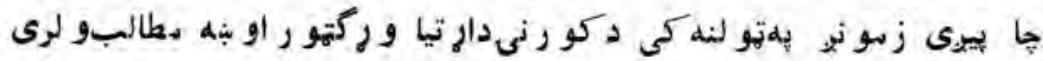

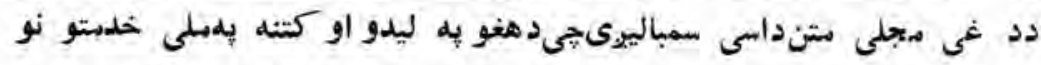

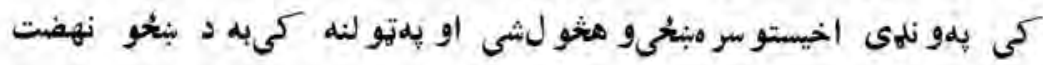




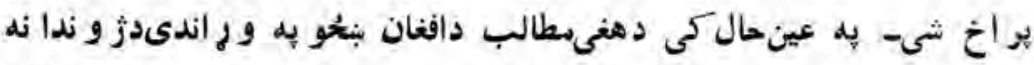
را تلو نكى اقق رو بنائه و بنئى كددوىيه ثروندانهكى د داسىاساساتو أو

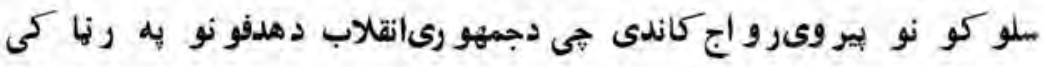

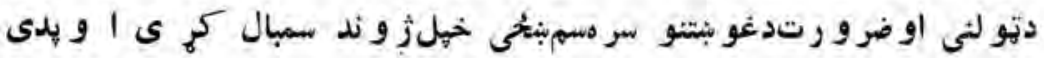

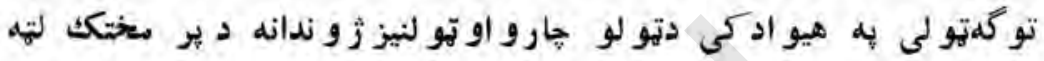

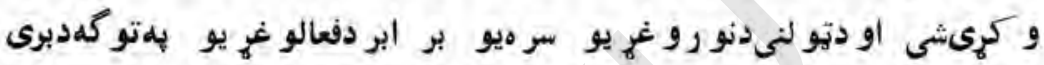

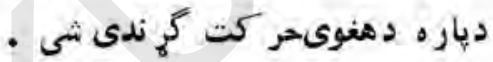

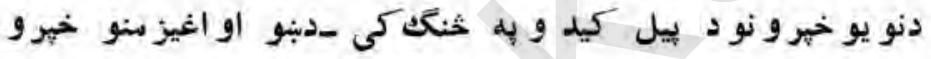

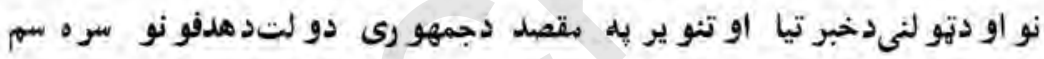
داوسنيو خهرونو نشر اتبنهوى اودهيو دخدهتو نولمن بر اخه شوه -

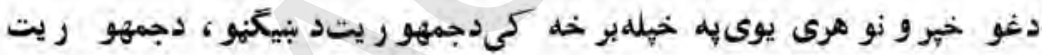
دانقلابدهدفونو د سلىسشر توبدهيلو لهيه ثركندونو، او دتو لنى د ارٍ تيا

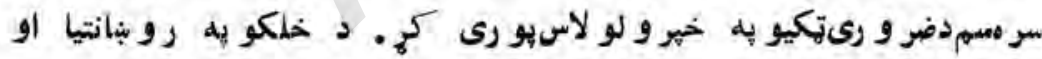

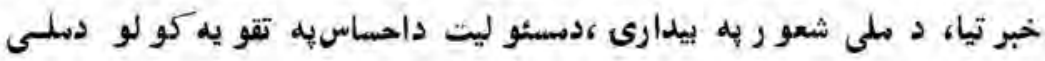
خدمتو نو به بو ميختكك كى دتو لهىيه ونلهه ، دمثبتى او فعالى ييطرفى د روحيى

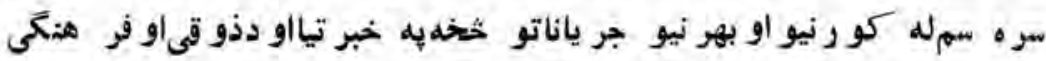

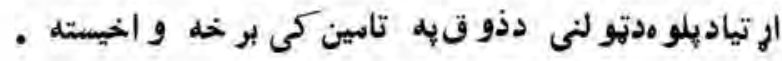

$$
\text { دهيو ادور }
$$

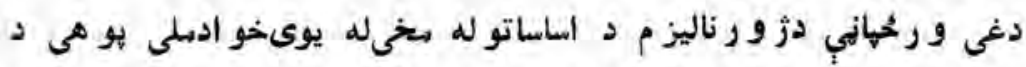

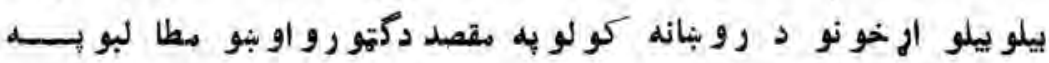


اطلاعاتى إوكلتو رىاجرا آت

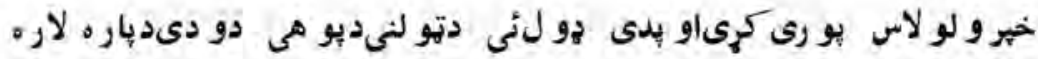

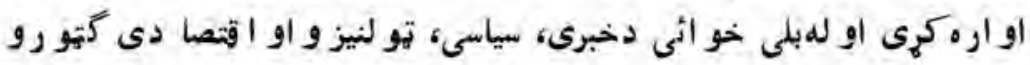

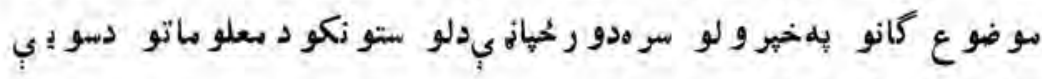

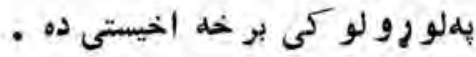

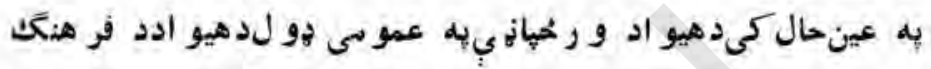

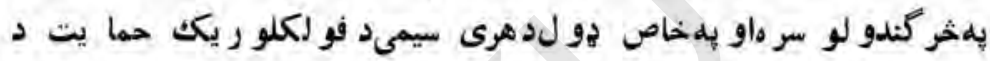

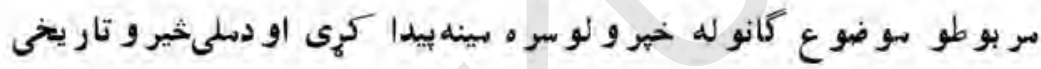

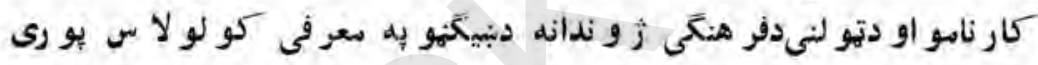
- 5

همدغلشان سياسى تبصرى، او دعلمىبديدو سو ه دهيو اد ا 1 ونزى ورخنى يو مختياوىخهر وى.

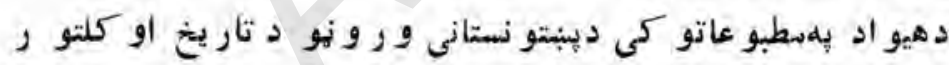

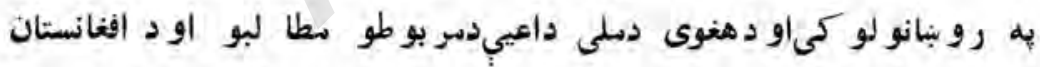

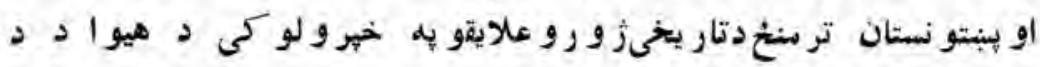

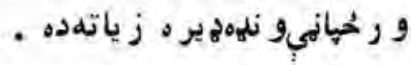

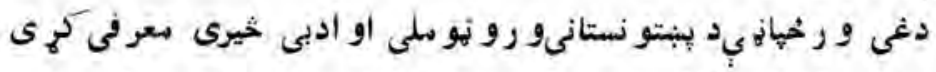

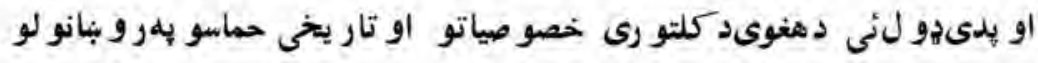

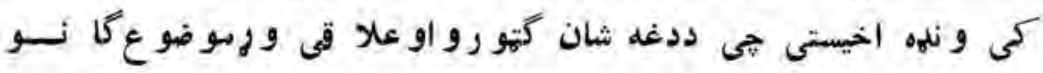

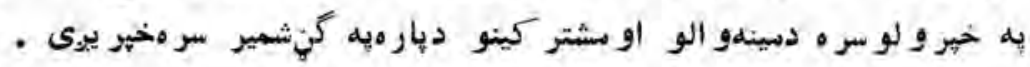

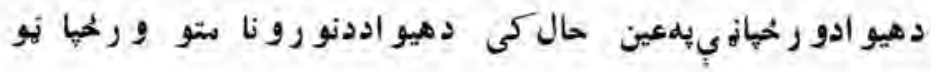


(rv) ورخانى|وجريدى

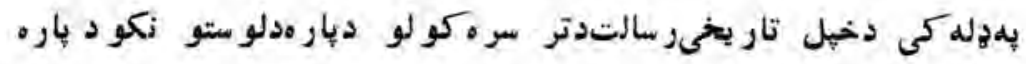

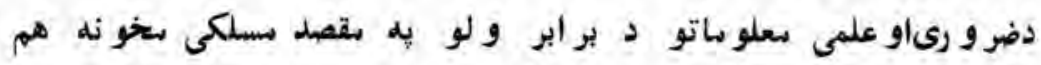

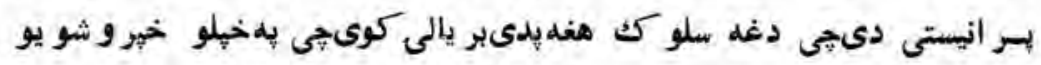
سطالبو كىدتنوع بير وى كرىى. دمينه و الودز ياتى استفادى دياره دنوى

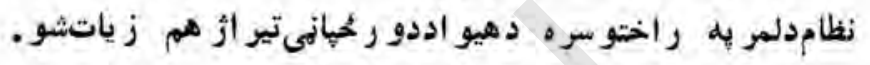

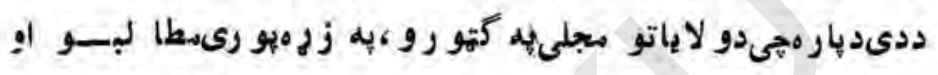
بنكليو سخو نو سو ه خيرىاو دو طنو الو او بهتير هيبابه سر بو طو و لاياتو كى

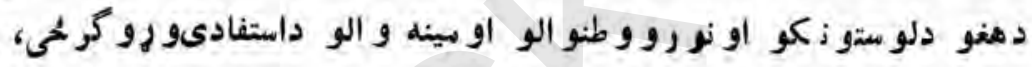
داطلاعاتو او كلتو روزارت داسىو بتيلهيى دننكو هار او كندهار هجلي

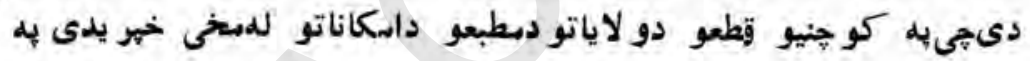

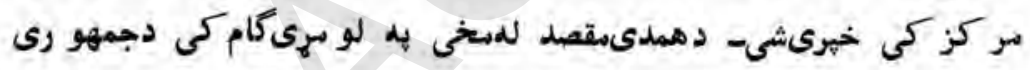

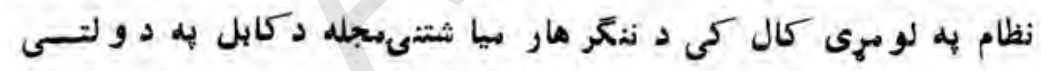

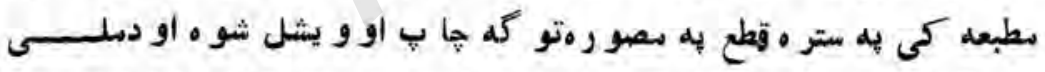

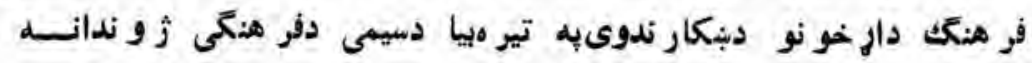

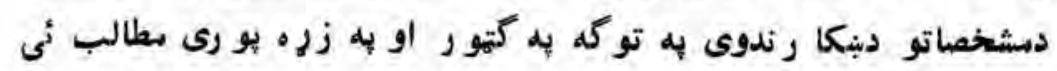
خهار ه كم ل ـالبته هه بر كز كى دهنى ادارى اسانتياوى دهيو اد دنشر اتى

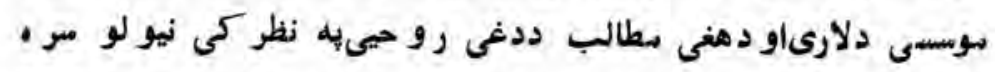

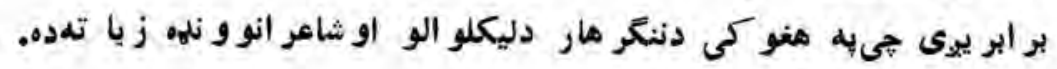
:4l

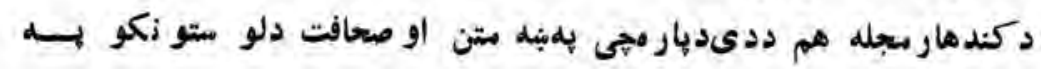




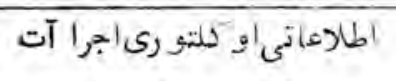

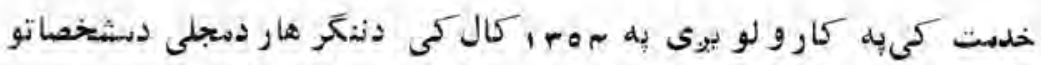

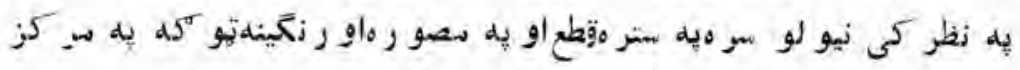

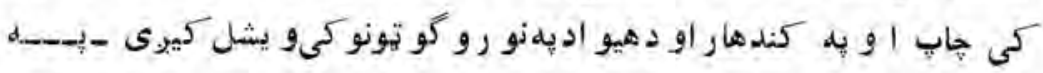

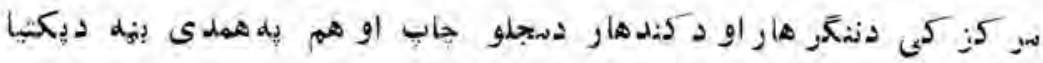

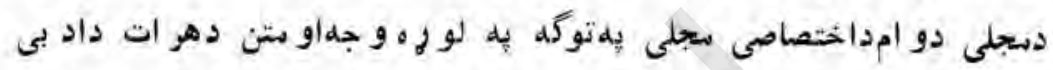

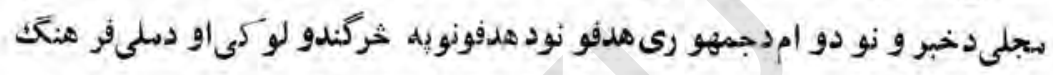

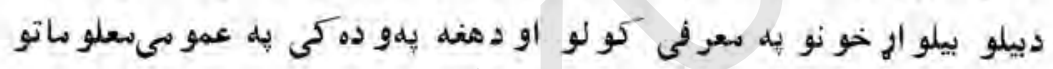

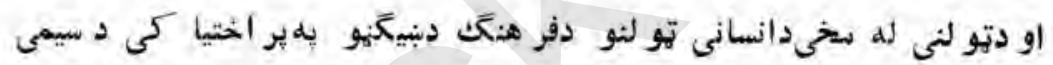

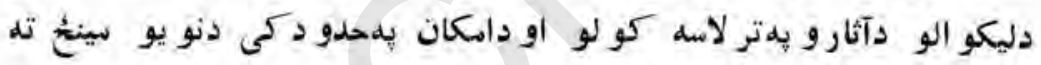

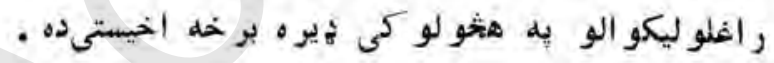

$$
\text { : }
$$

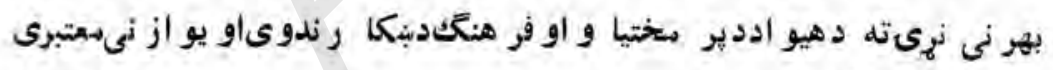

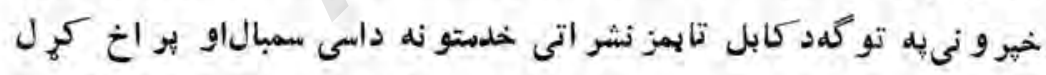

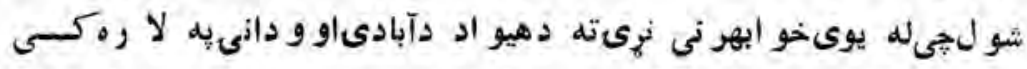

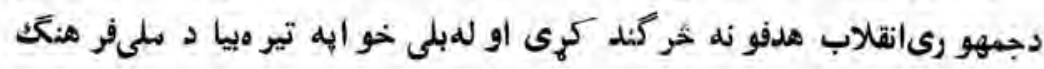

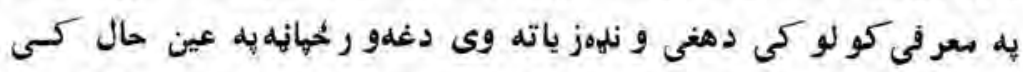

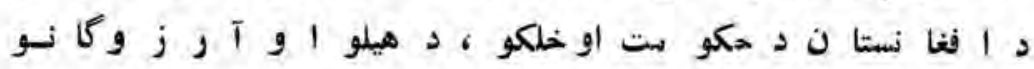

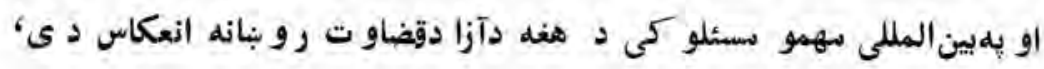

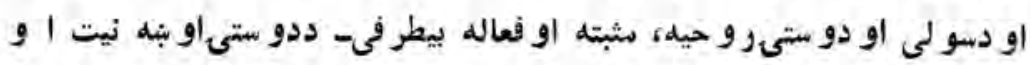

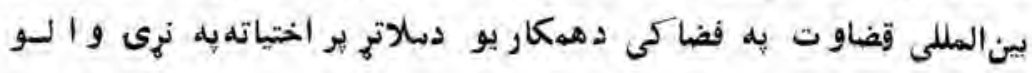




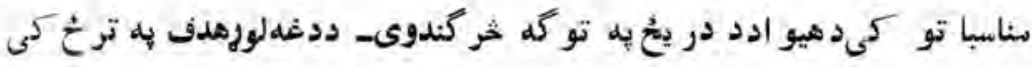

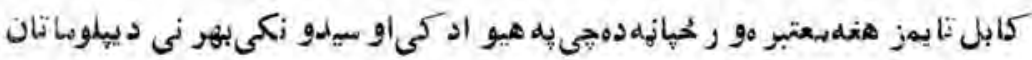

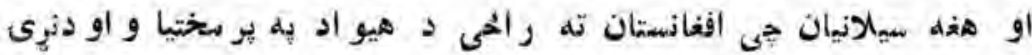

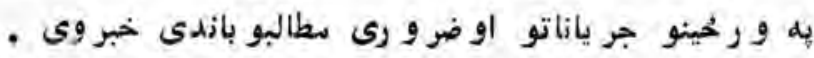

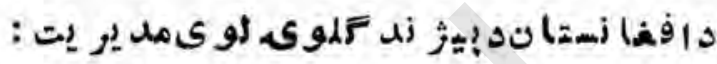

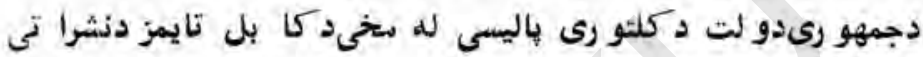

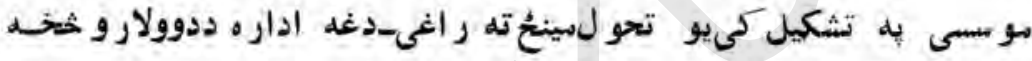

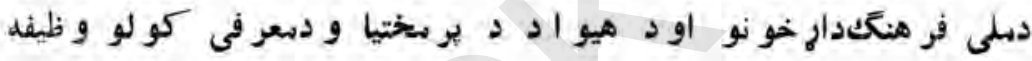

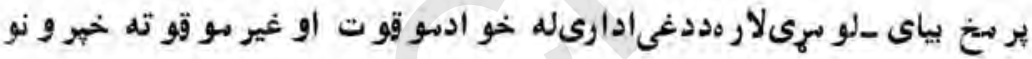

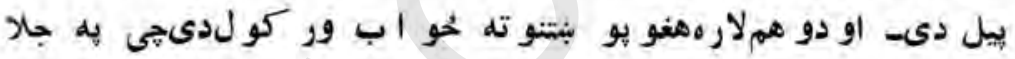

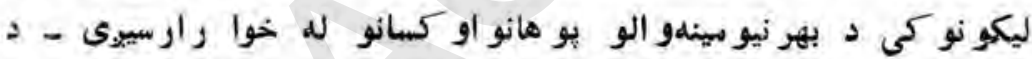

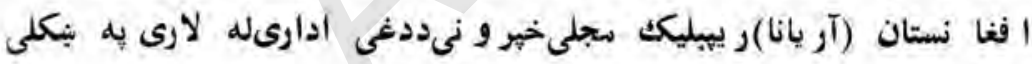

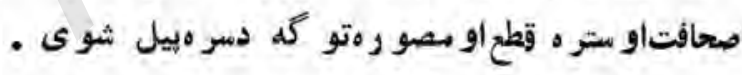

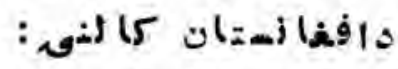

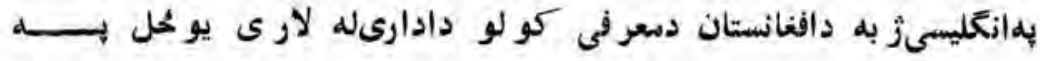

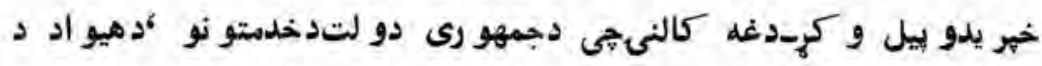

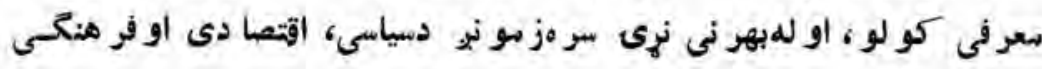
علايقو به باب ضرو ورىمو اداو مطالبلرى دجمهو رىنظامدتهيزيد و و رو سته

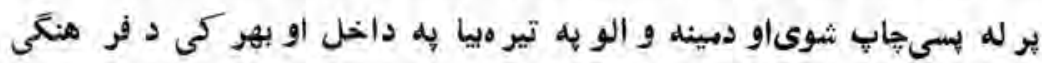

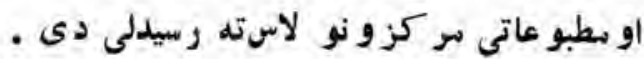


الطاوعاتى اوكلثو رى اجرا آت

(r.)

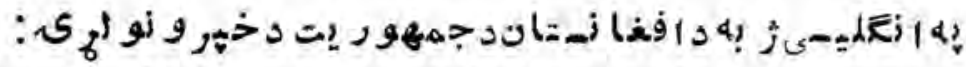

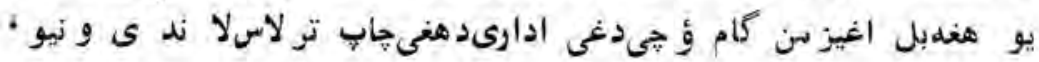

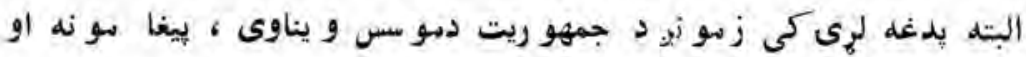

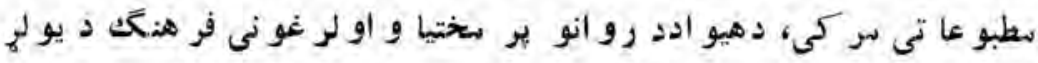

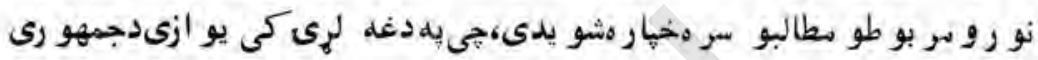

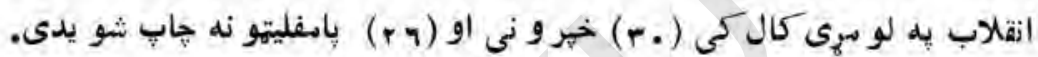

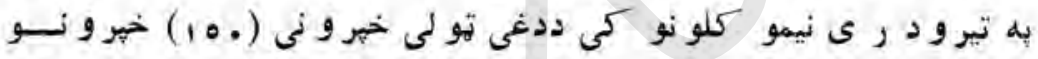

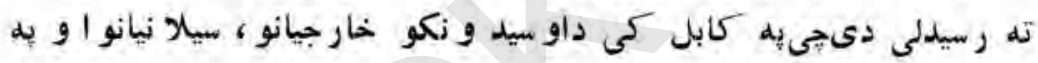

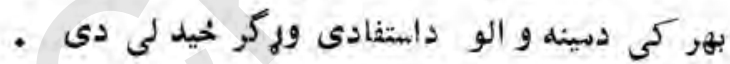

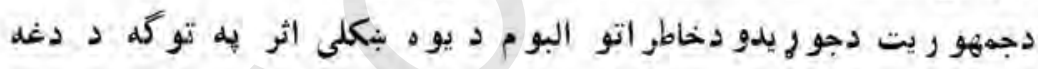

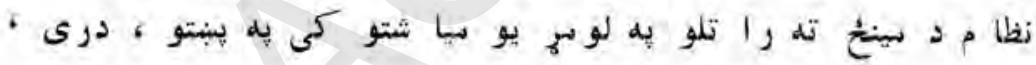

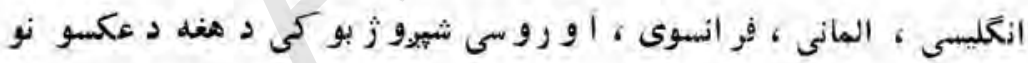

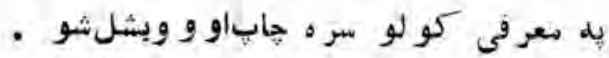

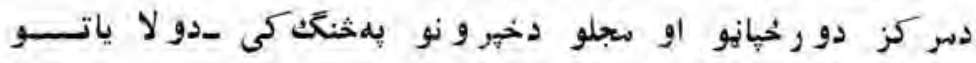

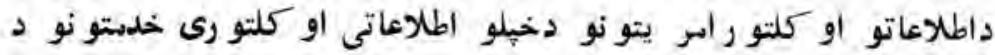

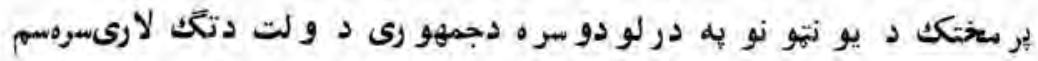

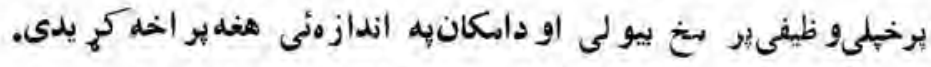

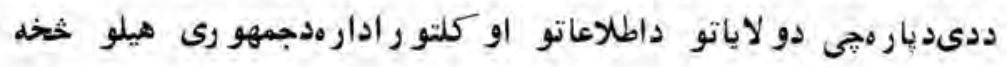

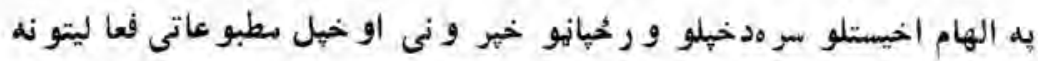

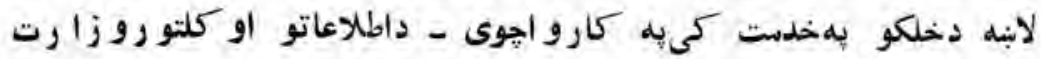




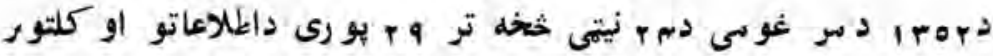

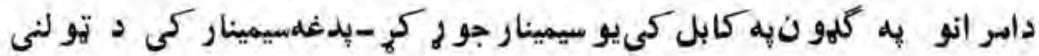

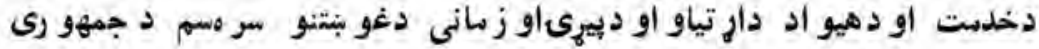
لو إو هدفو نو يه رناكى د مطبو عاتو سمثوليت، و نلهاو در يُحو خيرلشو'

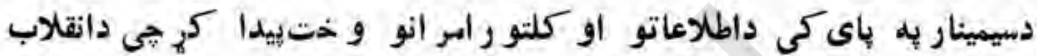

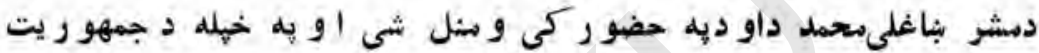
دموسسله خو اد خلكو به تنو يو اود تولنىدلابنه و الىىبه بر خلهى فعالسى و نلهىاخيستو به بر خه كىخيلو و ظيفو او مكلفيتو نو ته هلتفت كري شى -

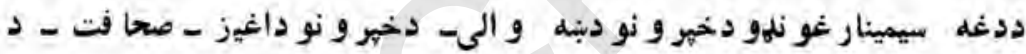
و رحيانو دتير أز او دهمكار انو يه جلبو لو كى ستر هبر خهدر لو دهـ او دددى

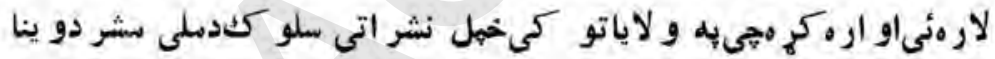

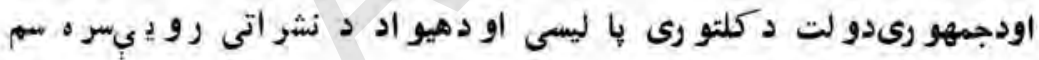

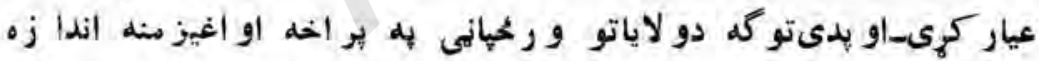

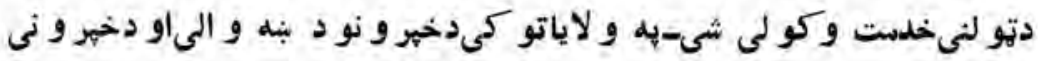

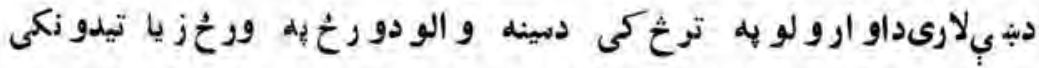

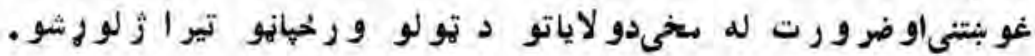

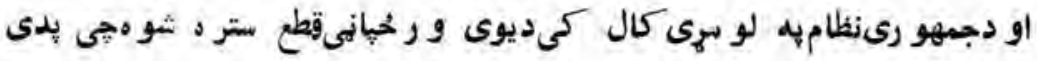

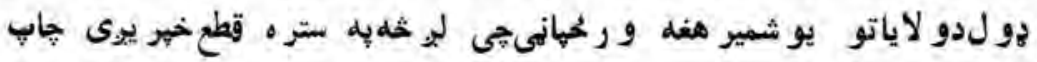
- شو הو

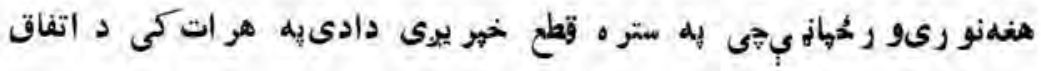




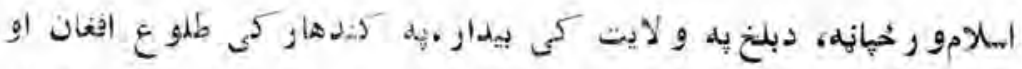

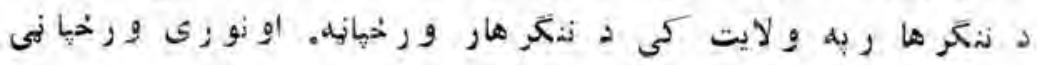

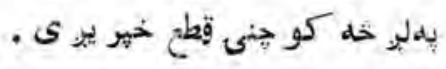

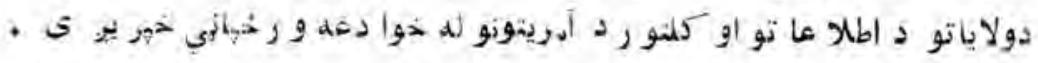

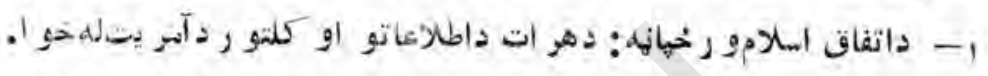

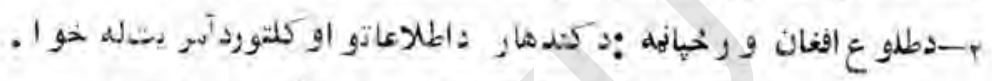

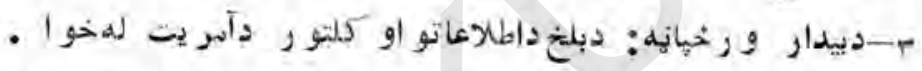

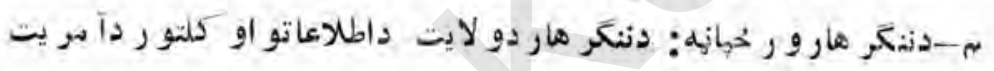
. لd

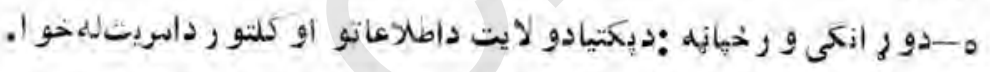

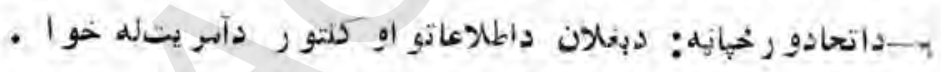

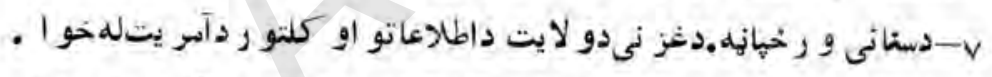

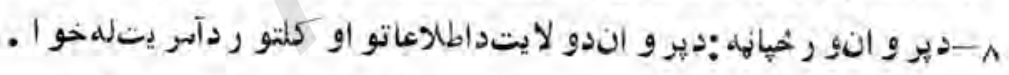

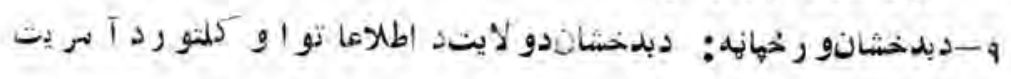
. ل

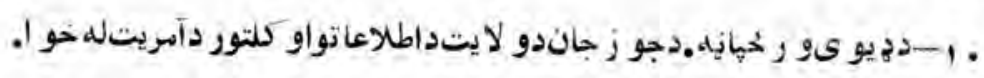

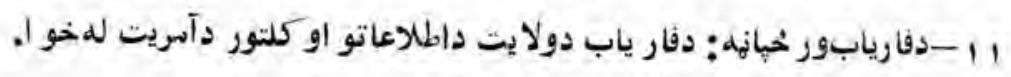

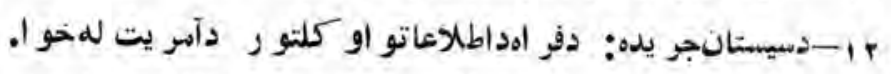

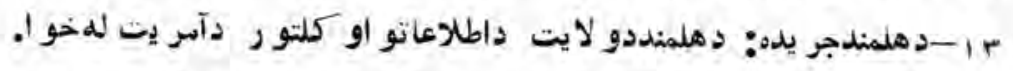

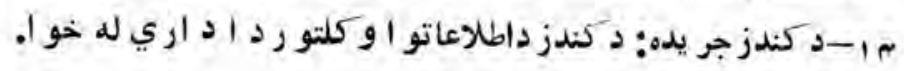




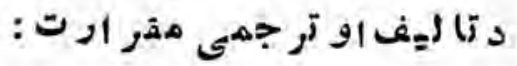

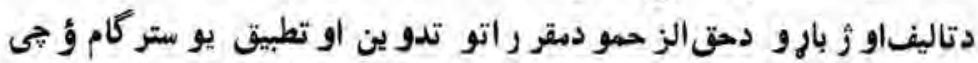

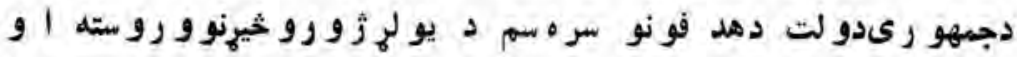

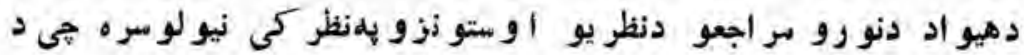

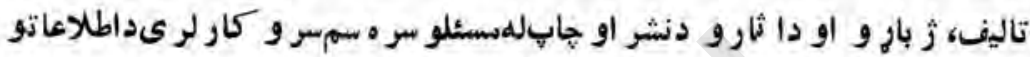

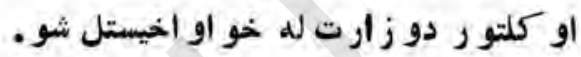

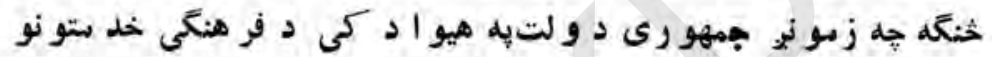

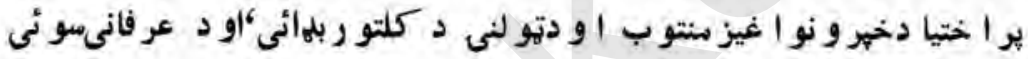

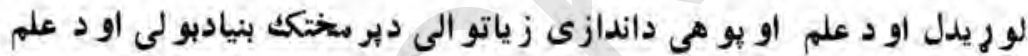

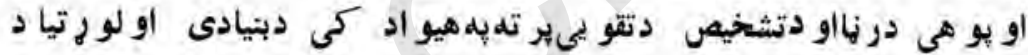

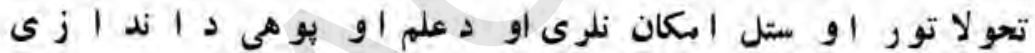

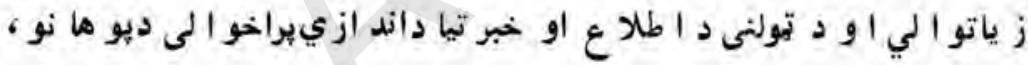

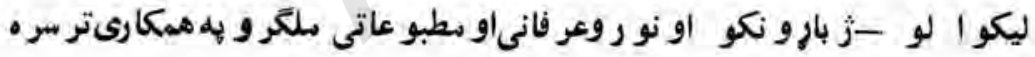

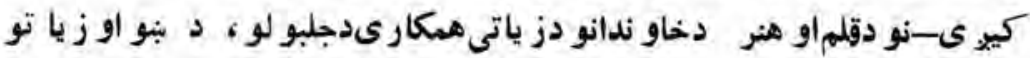

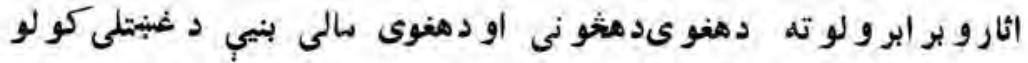

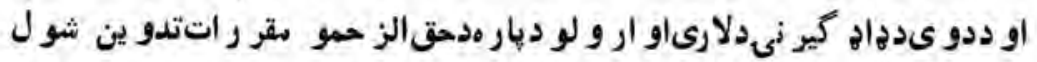

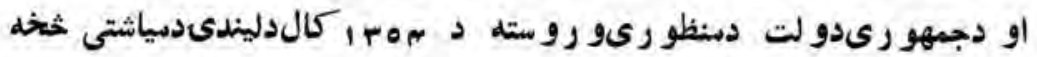
را هيسى ترطتبيق لاندى و نيول شول.

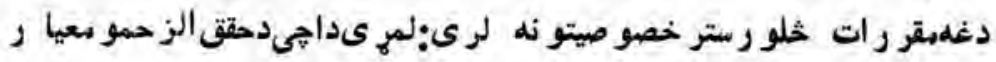

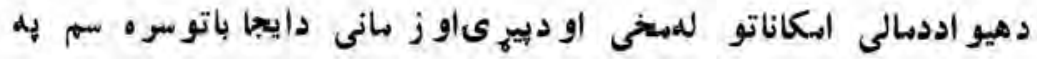


اطإعاتى اوكلتورى اجرا آت

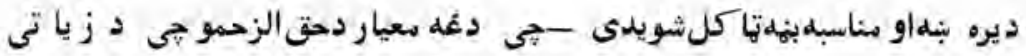

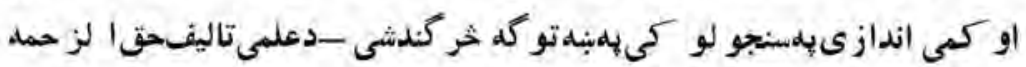

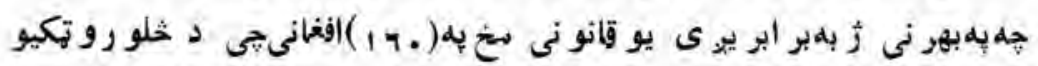

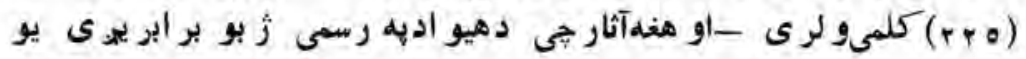

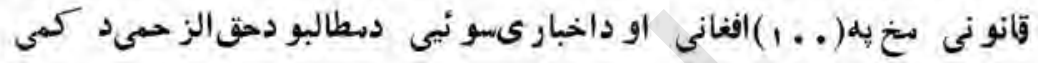
اندازى

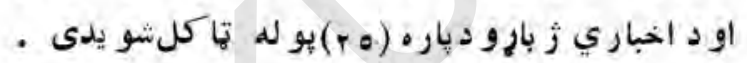

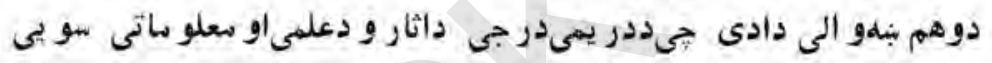

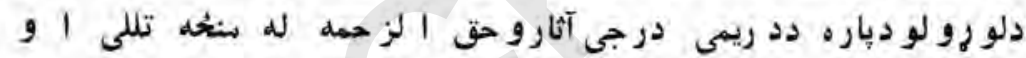

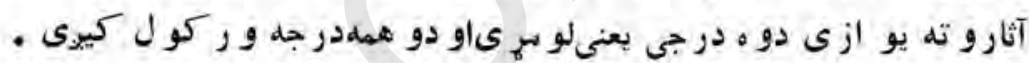

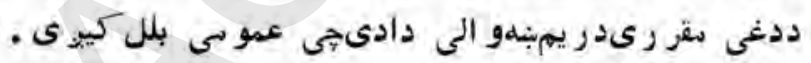

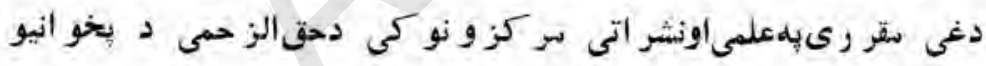

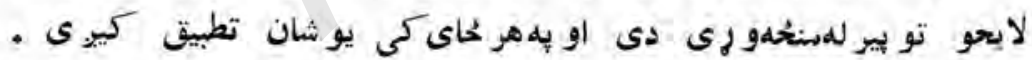

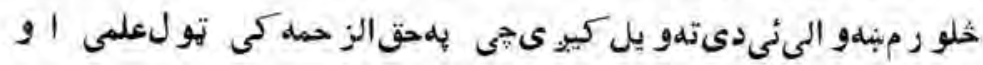

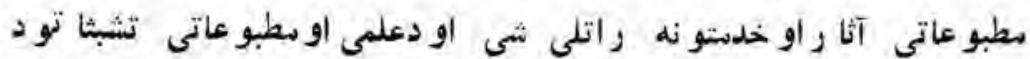
سو بوطو آثارو هيثخ يو الرخاو هغه خدستونه خى ددغى سا حى سر ستثدوى

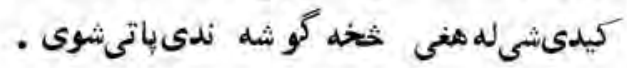

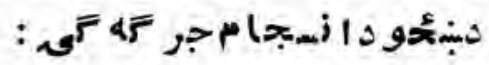

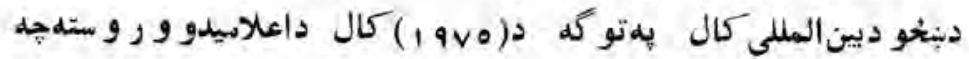

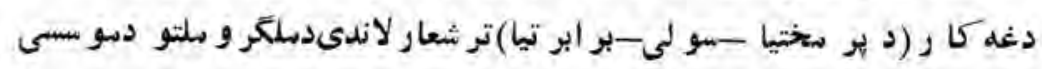




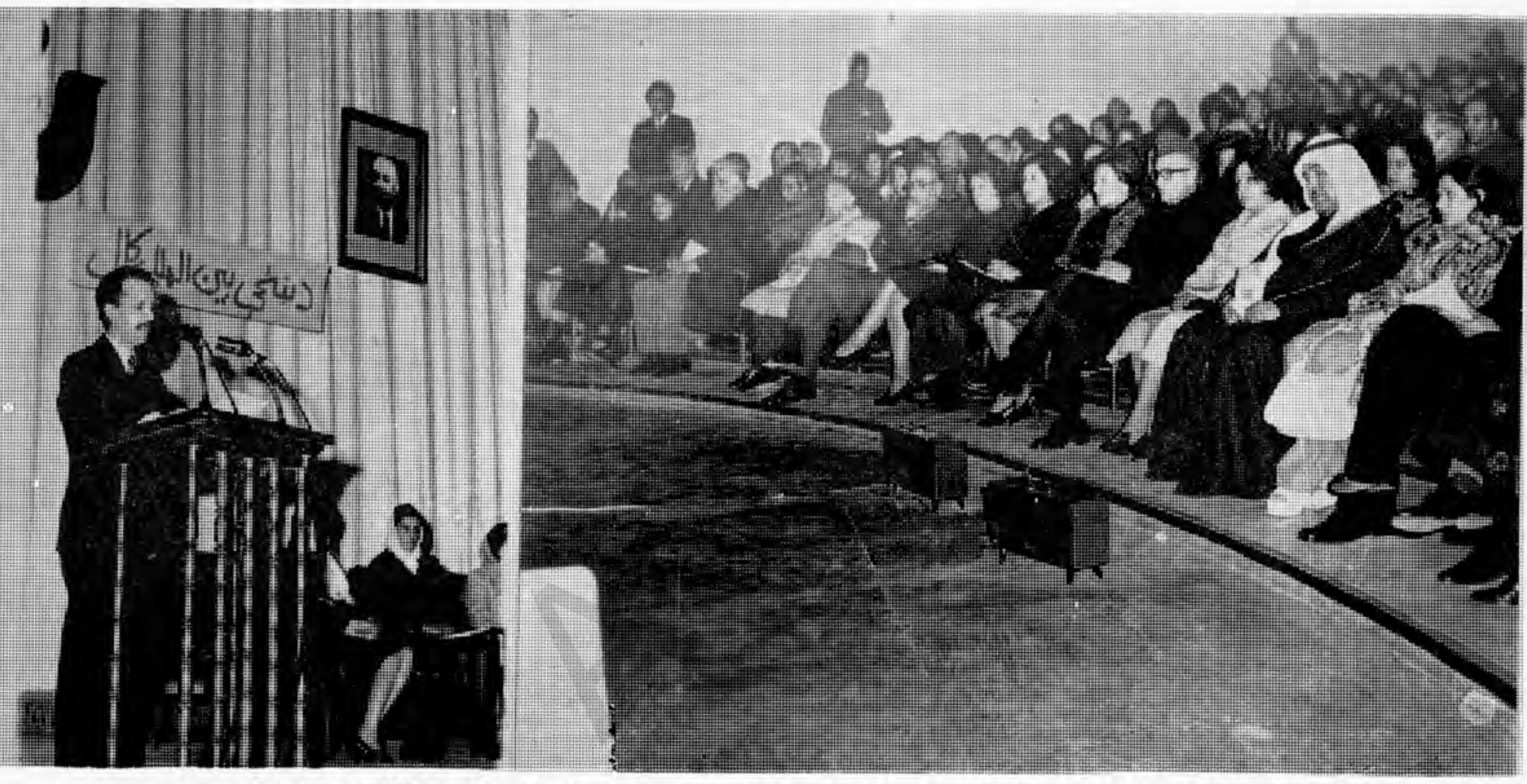

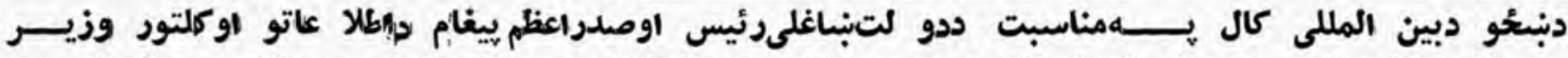

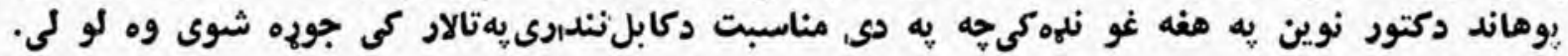


لهخو او شو داطلاعاتو اوكلتو رو ز ارتبهابتكار لاسبو رى كرىدى دلمي نيو

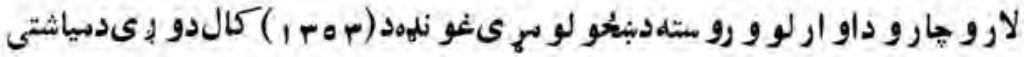

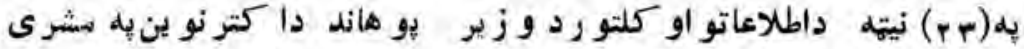

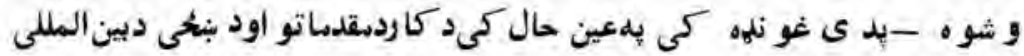

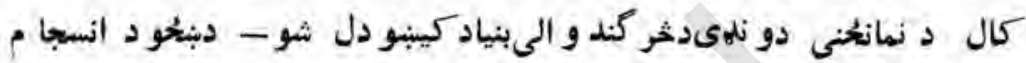

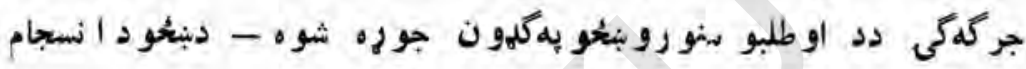

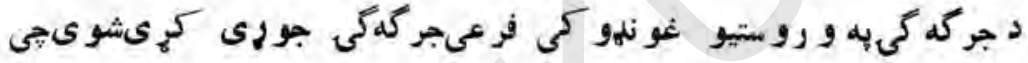

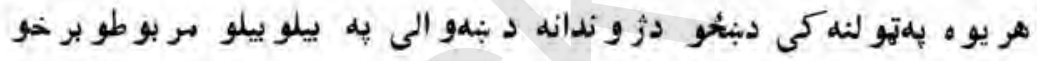
كى او دهغوى مقام اودر يفي تهداحتر ام اوهم دجمهو رى دود لتد انقلجيى

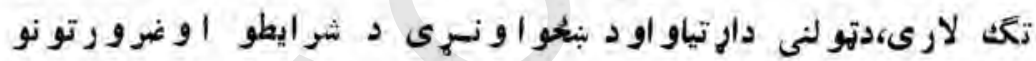

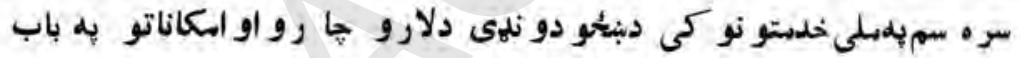

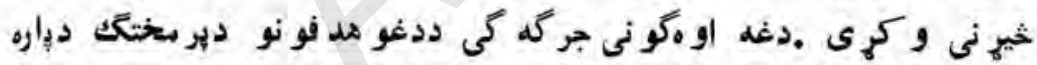

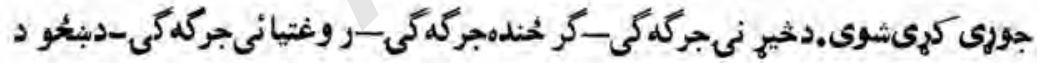

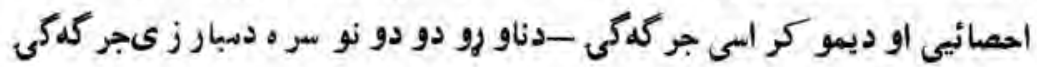

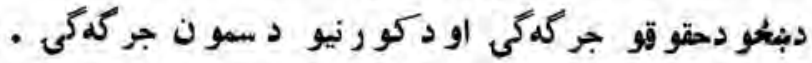

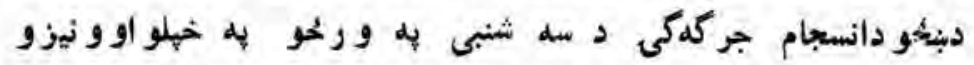

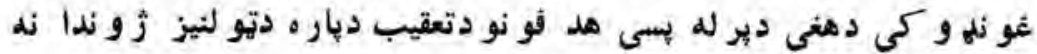

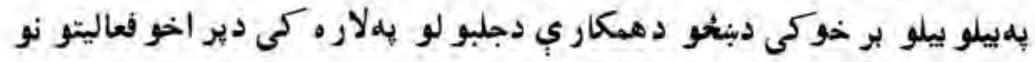

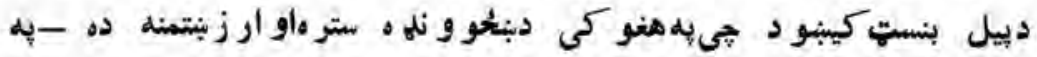

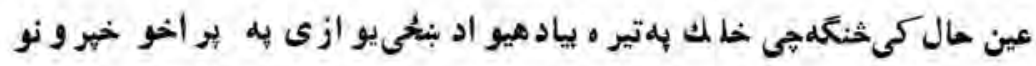


الطاءعاتى اوكلمتو رىاجر آت

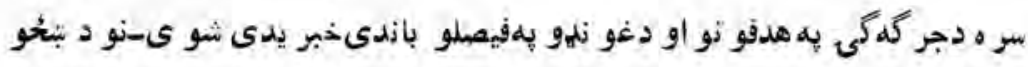

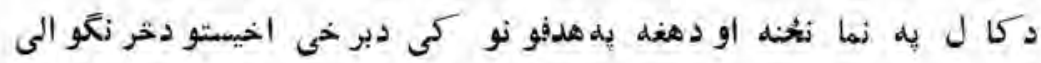

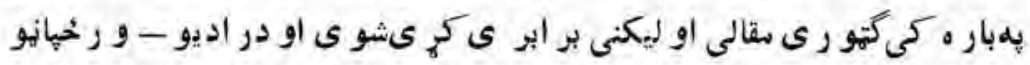

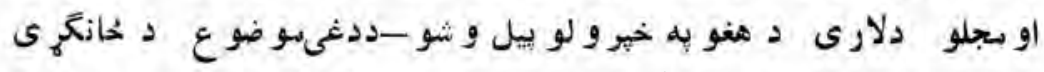

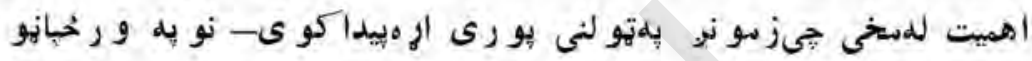

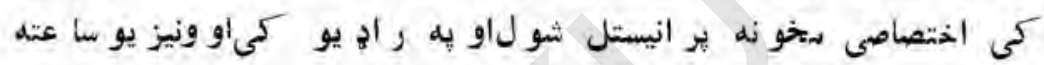

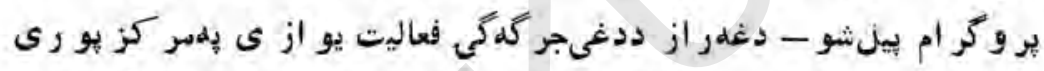

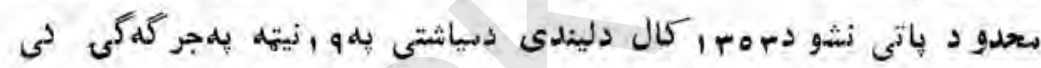

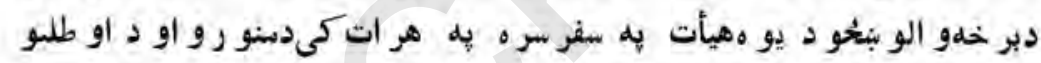

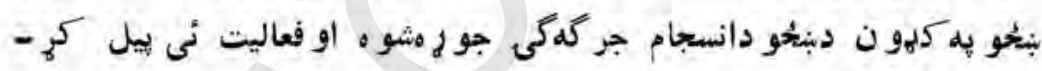

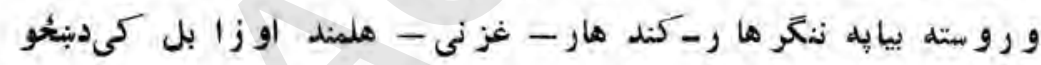

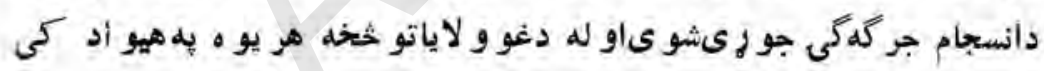

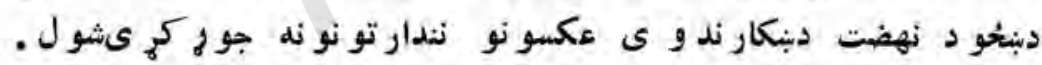

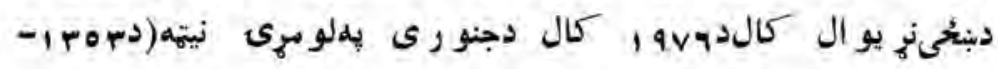

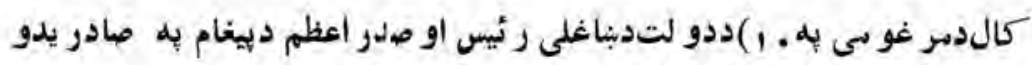

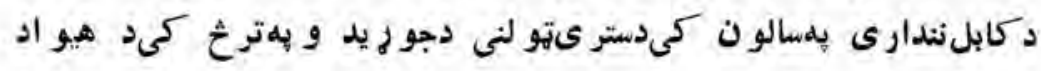

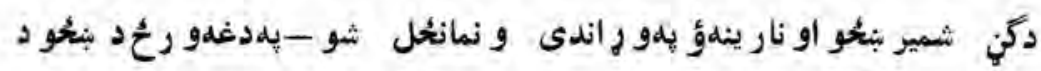

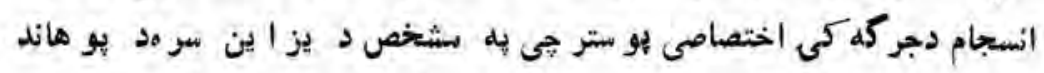

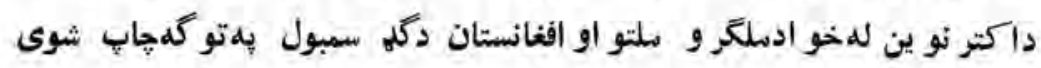

ؤ دهيو اد دمر كز او و لاياتو بهتو لو عامو حايو نو كى نصب او وو يشلشو. 

$(r v)$

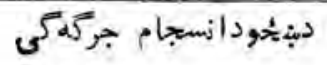

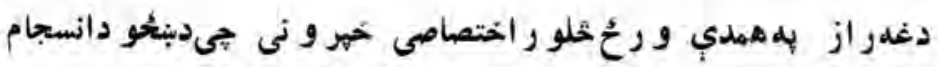

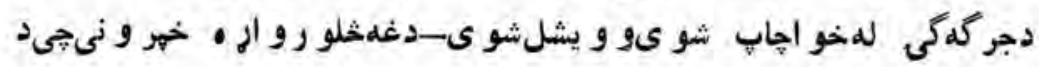

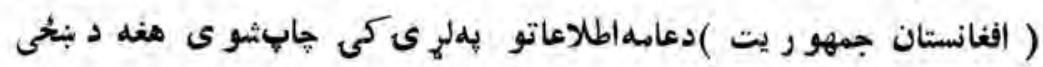

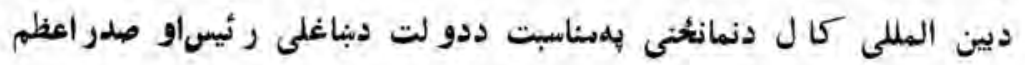

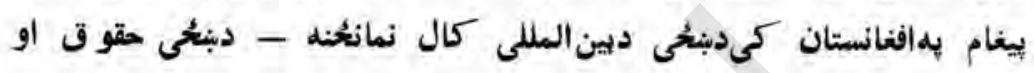
مقام او دبنئحى در بئ.

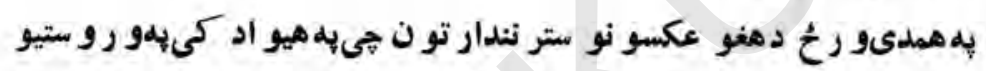

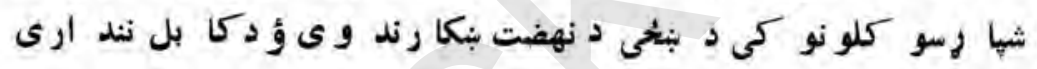

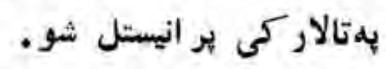

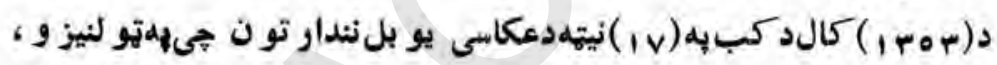

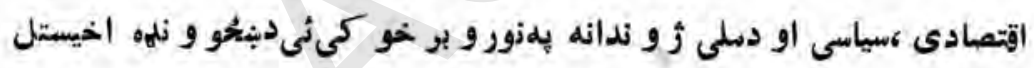

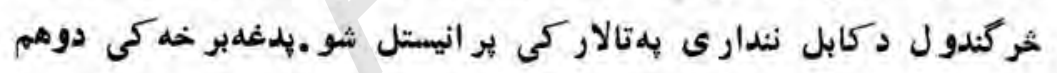
بو ستر خيى دملى خدمتو نو به بيلو بيلو برخو كمى نى افغانى بير منىديوه ستر

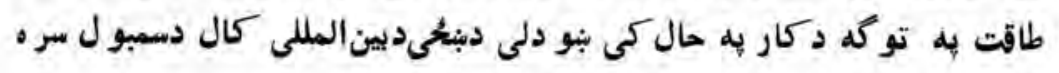

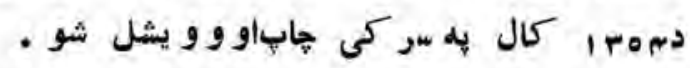

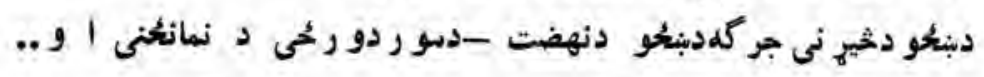

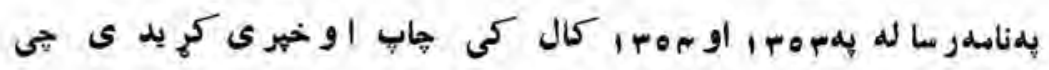
سلسلهئى دو ام كو

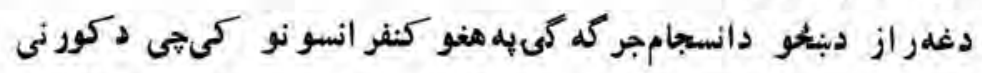
دلار بنوودنى دتولنى به ممكار ىدسلو اغى به ( ه ) نيتهدر اديوافغانستانيه تالاركى 


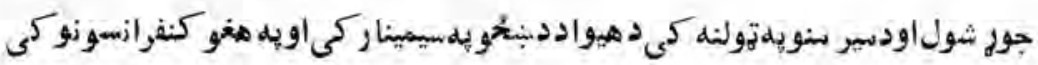

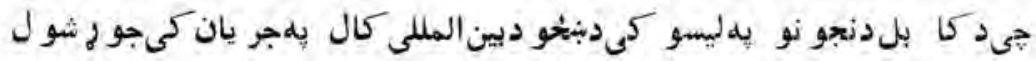

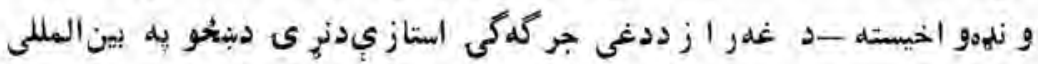

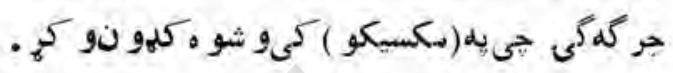

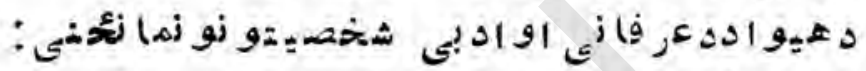

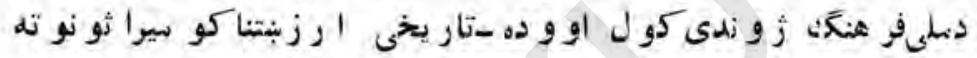

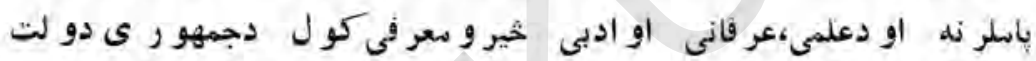

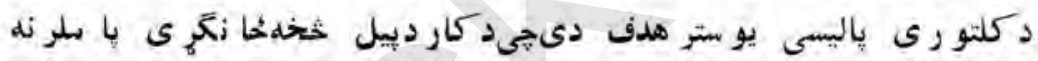
و رته شو يده.

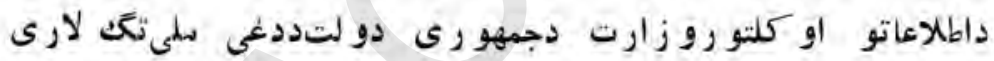

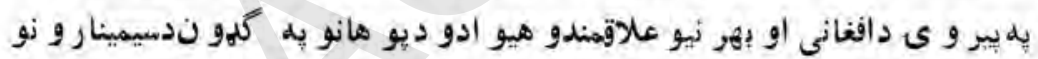

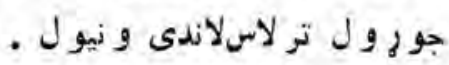

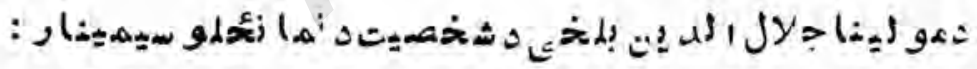

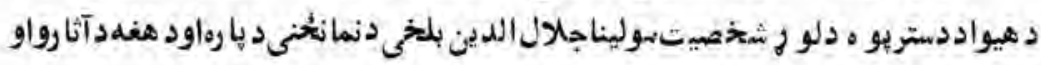

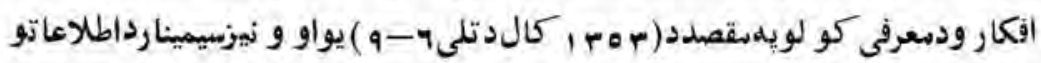

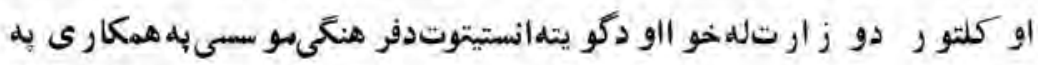

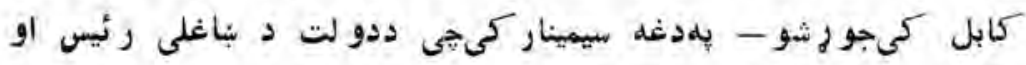

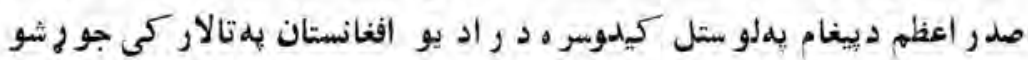

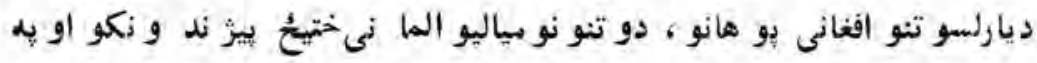

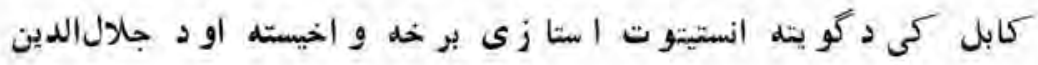




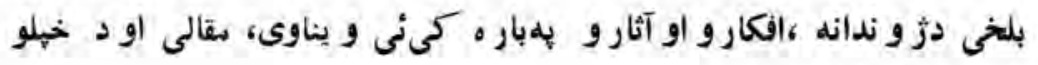

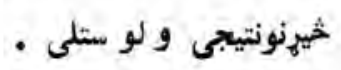

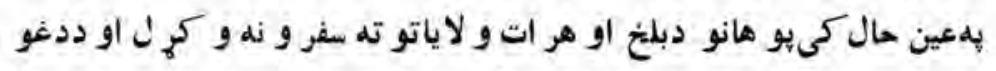

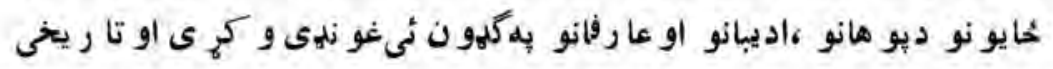

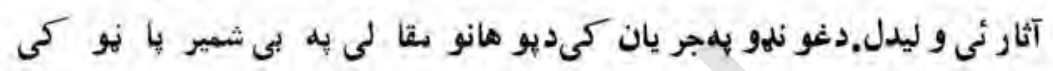

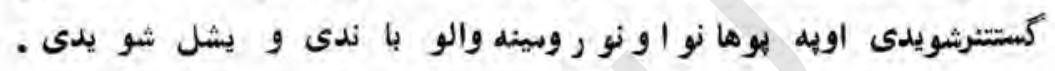

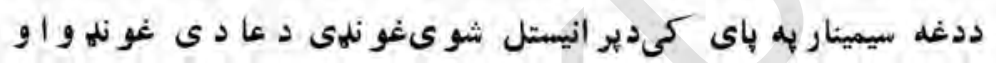

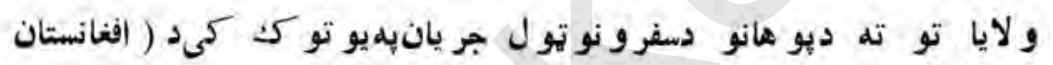

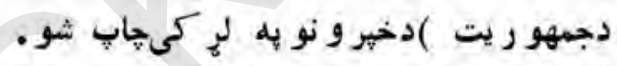

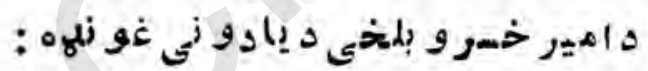

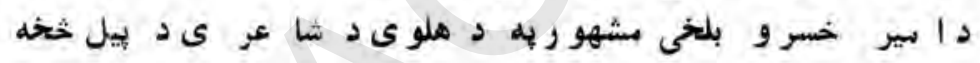

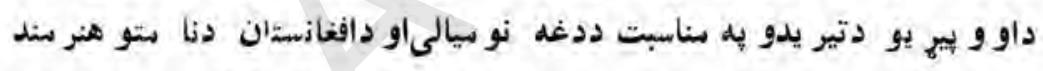

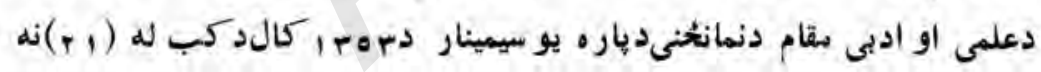

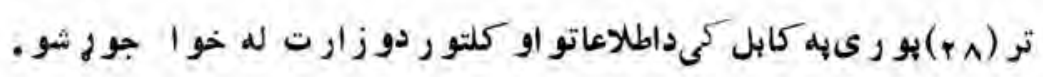

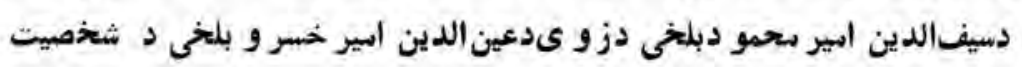

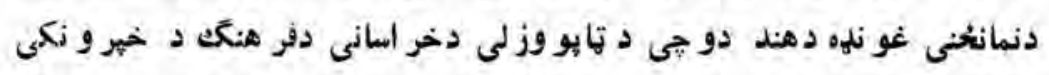

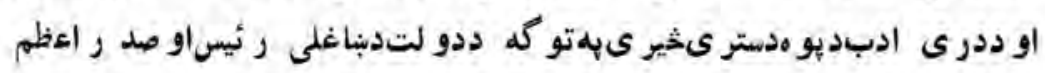

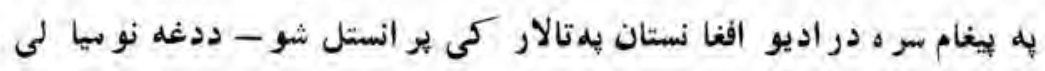

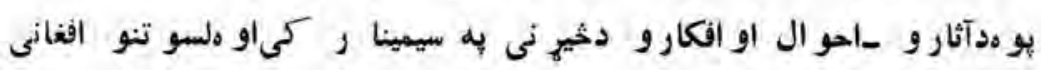

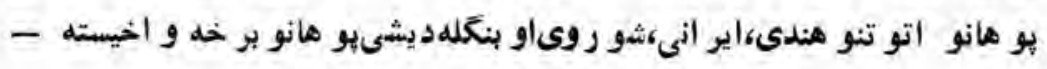




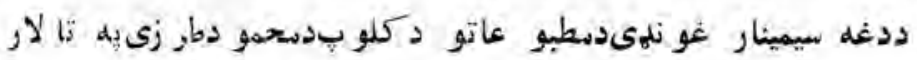

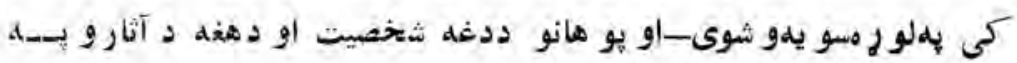

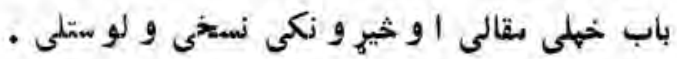

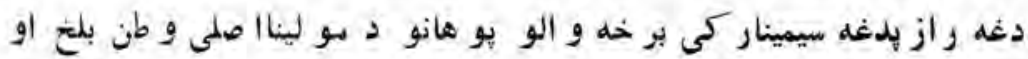

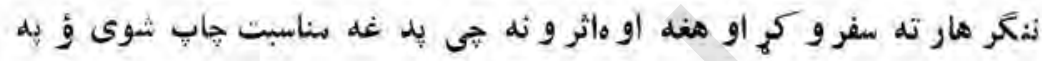

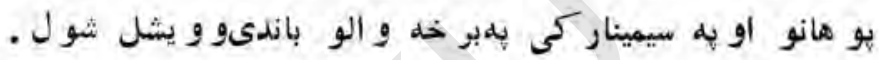

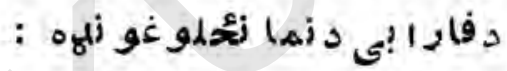

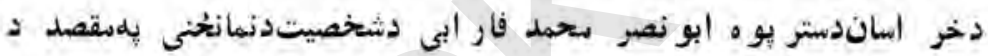

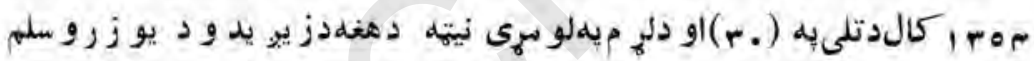

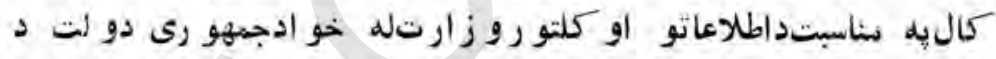

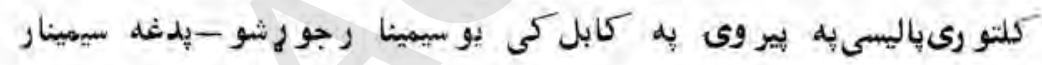

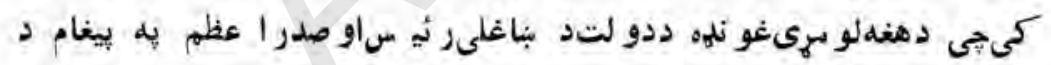

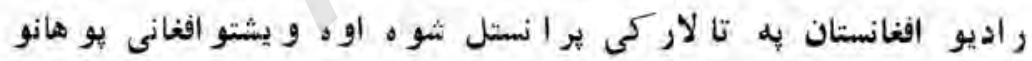

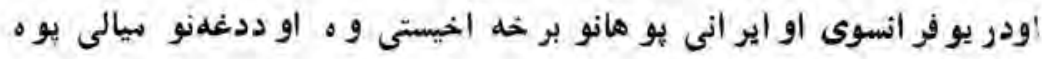

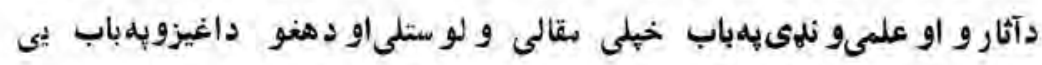

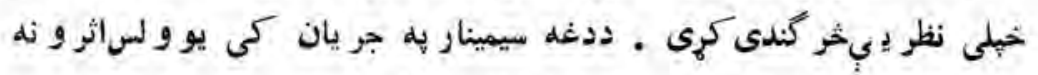

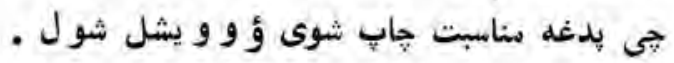

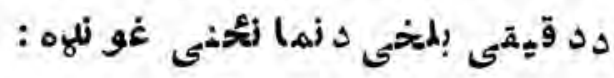

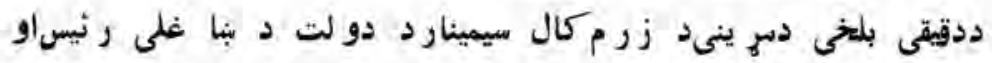

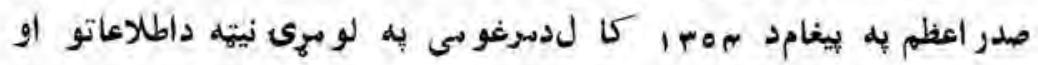




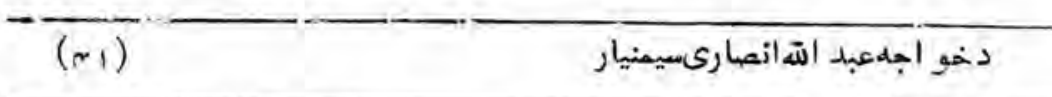

كلتورد و زار تله خو ادر اديو افغا نستان به تالاركى بر انستل شو- او

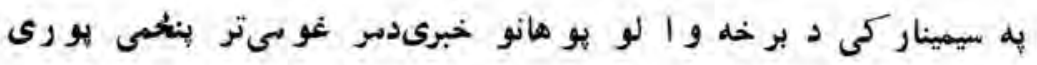

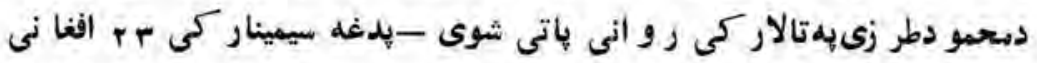

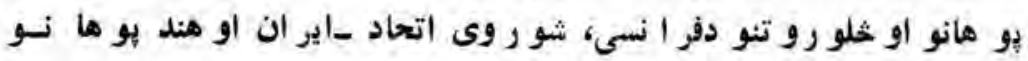

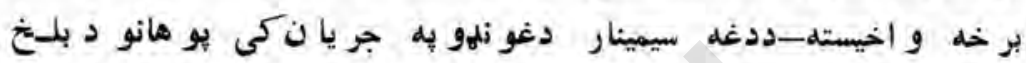

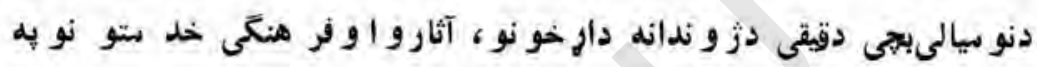

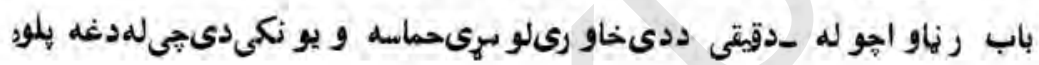

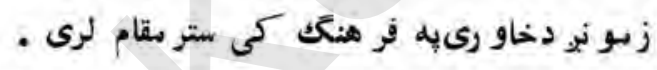

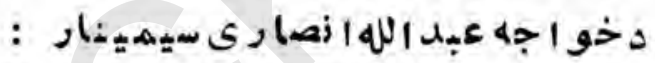

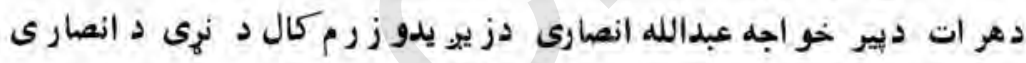
بيثز ندو نكو بو هانو او افغا نى اديبانو يه گثهو نيه يو منهله و رحنى سيمينار

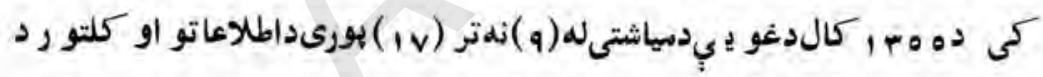
وز ارتله خو ايه كابل او هو اتكى و نمانثحل شو - ددغه سيمينار غو نله

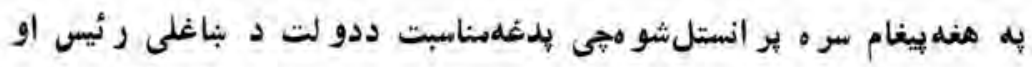

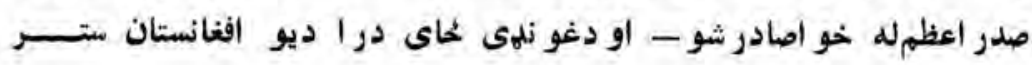

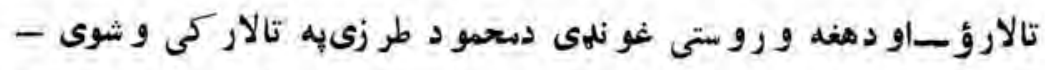

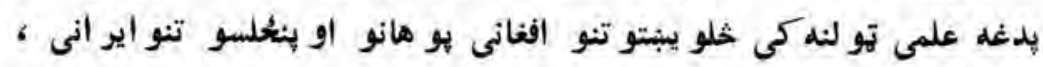

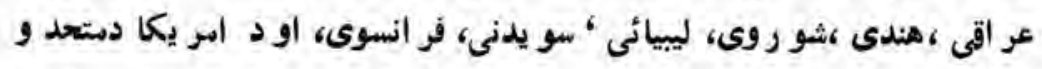

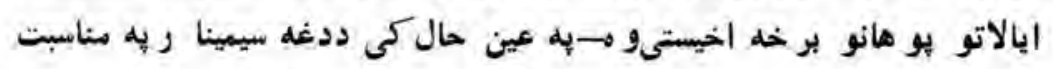
دخو اجه عبدالله انصارى دخطى (به لاسليكل شو يو ) آثارو نندارتون ديه 
اطلxعاتى اوكلتو رىاجرا آت

الطلاعاتو اوكلتو ردو زا رت دخطى نسخو به كتا بتو ن كى بر انستـل

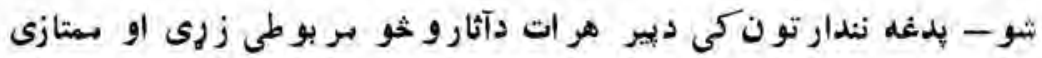

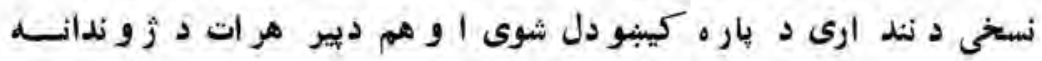

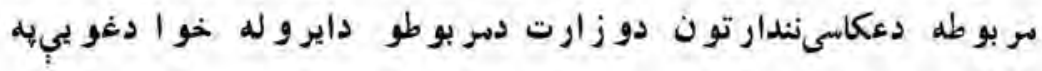
( ) نيته جور شمو.

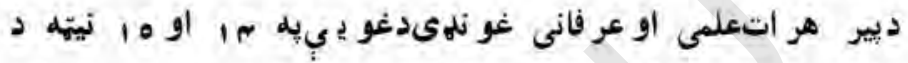

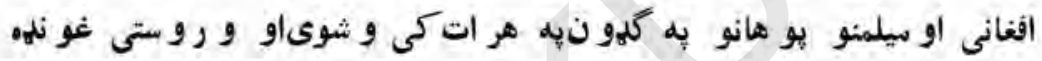

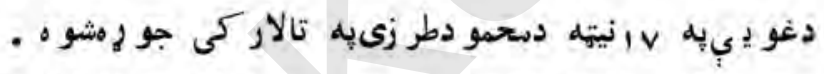
دافغانستان د علمى شخصيثو نو د نمنا نُخنى د دغو سيمينا رونو رنو

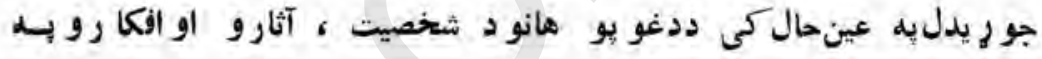

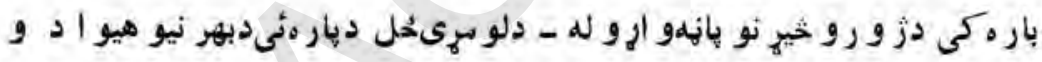

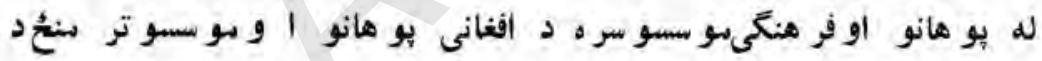

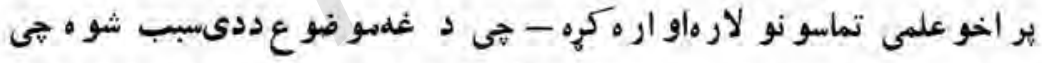

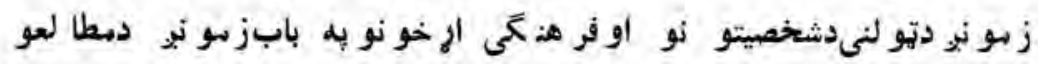

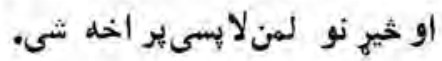

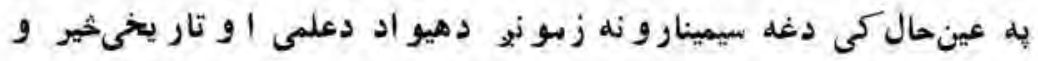

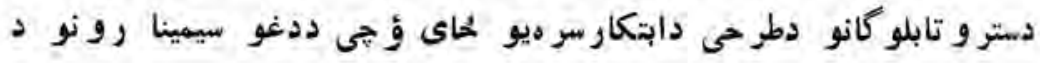

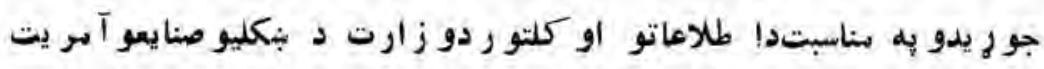

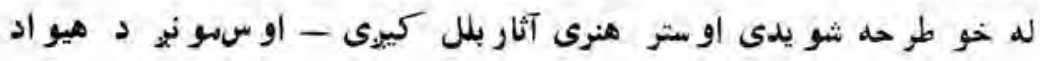

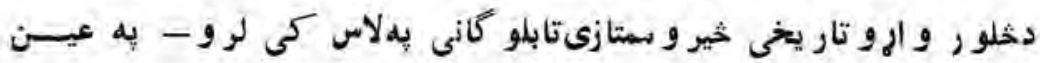




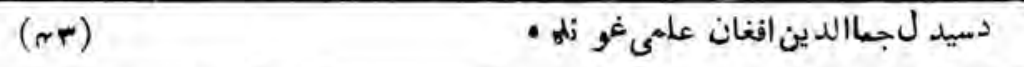

حال كى ددغوسيمينا رونو دبر انستو دغو نلو ديار هيى تولو بو ها نو فاضلانو اوددولت اراكينو دكو رد ييلو ما تيكو سر بره هغو كلى بوخه

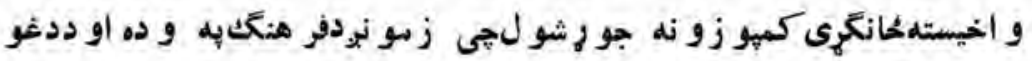

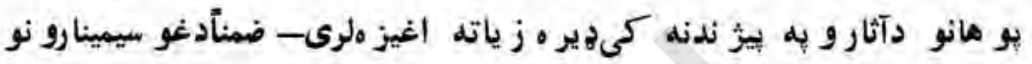

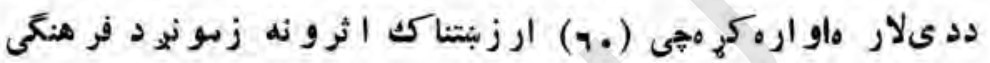

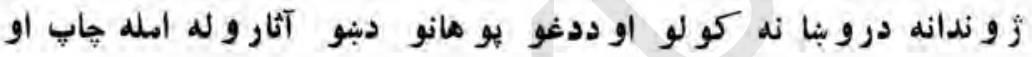

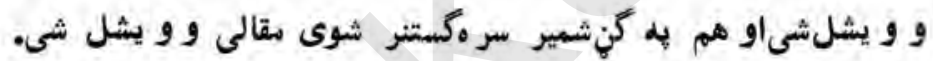

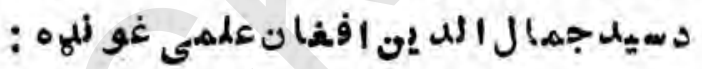

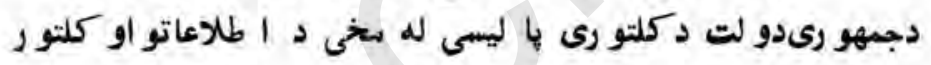
وزارتفيصلهو كر مجى د سيد جمال الدين افغان دمر ينى د اتيايم(.یم) كال

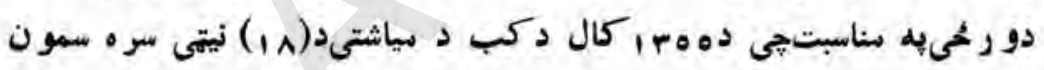

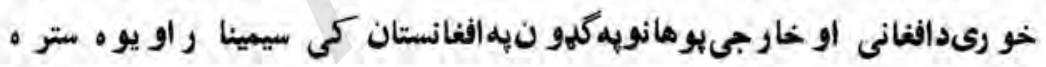

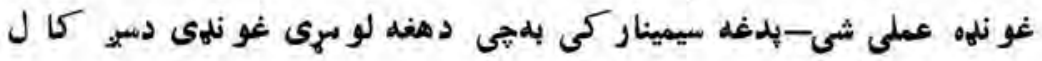

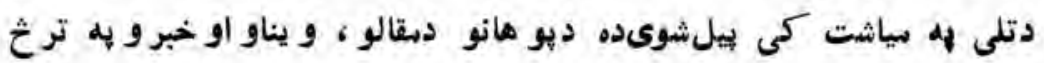

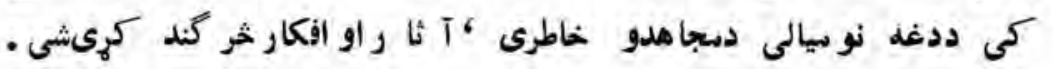

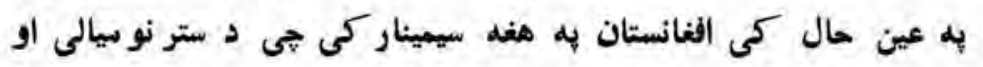
فيلسوف سيد جعال الدين افغان دو ر تكفدلم كال به منا سبت زمونب دو رور

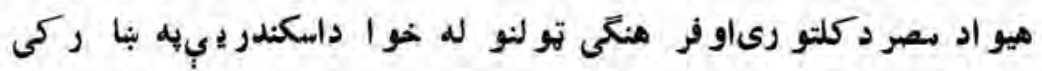

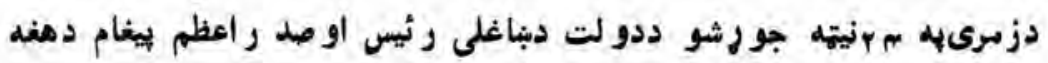

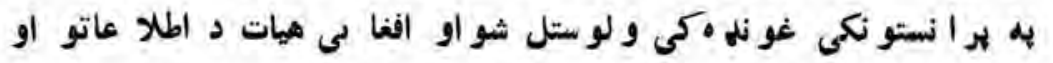


كلتو ردو زير بو هاند داكتر نو ين به سشرى به هغنه كمى برخه و اخيسته

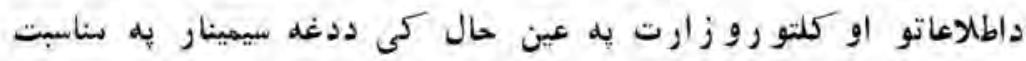

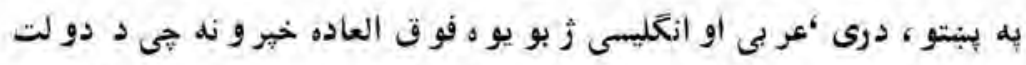

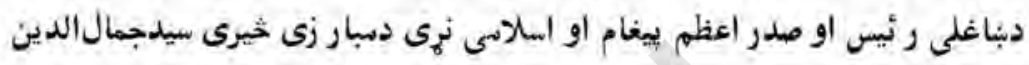
افغان دشخصيت به بارِكى داطلا عاتو او كلتو ردو ز ير بوهاندداكترنو ين

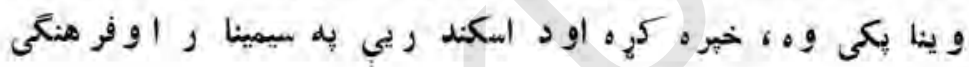
تو لنو كى ويشل شو هـ

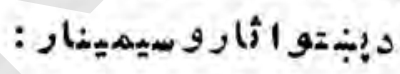

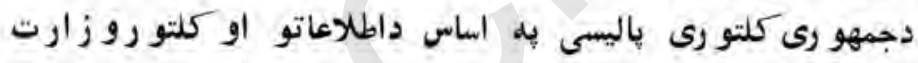

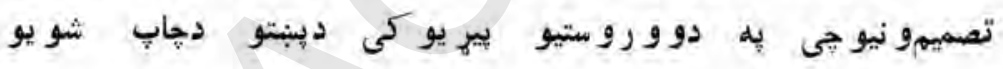

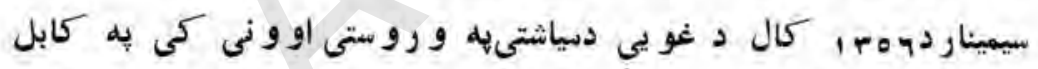

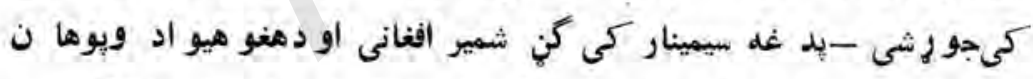

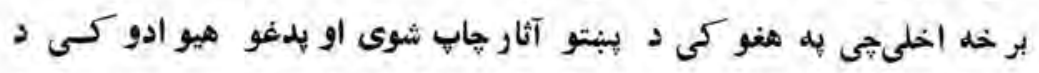

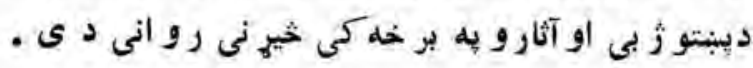

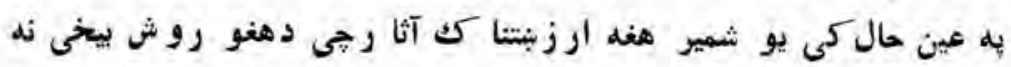

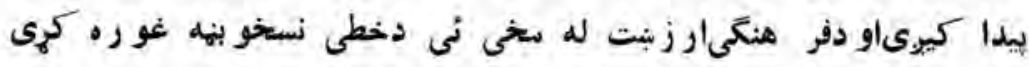

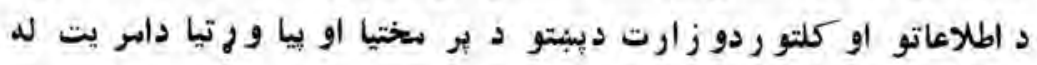

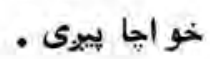

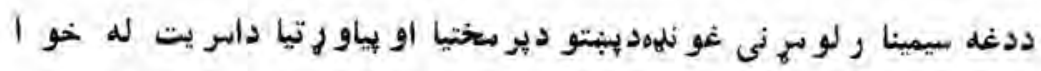
داطلا عا تو ا و كلتو ردو زارت او دهيو ادد نو رو فر هنكى سر كز و نو 

(ro)
2

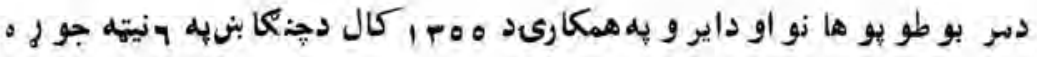

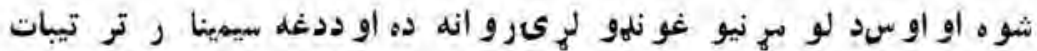

$$
\text { نيول كيبرى }
$$

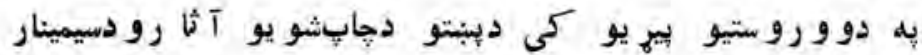

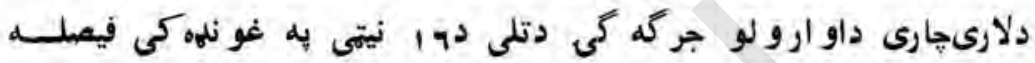

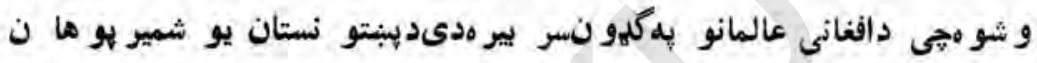

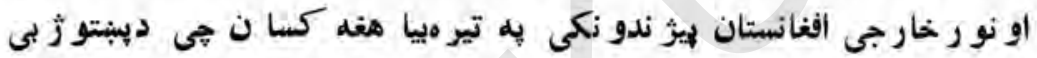
به بارهمى سابقهاو زو رىثيرنى لرىدمر بوطو دايو و اومقا ماتو د لارى

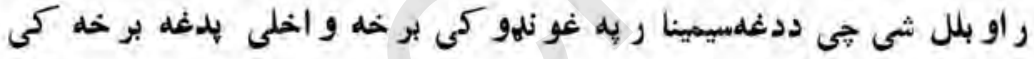

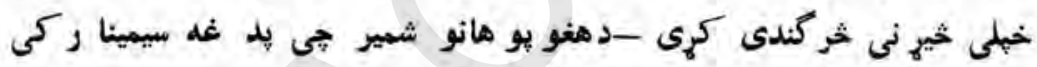

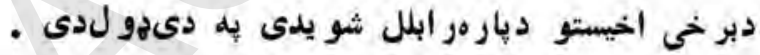

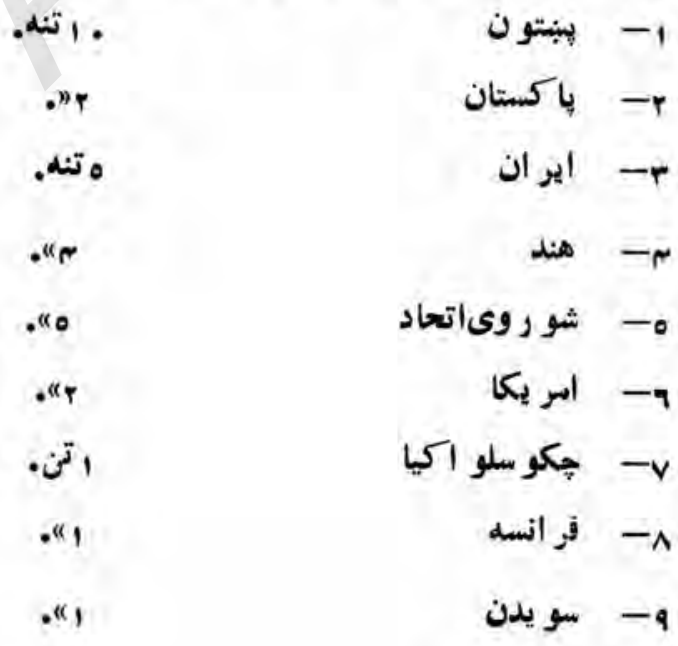




$$
\text { اطاناعاتى اوكلتورى اجرآ آت }
$$

$$
\begin{aligned}
& \text { r } \\
& \text { ا } \\
& \text { " } \\
& \text { داهين و لسىجهو ريت } \\
& \text { " "र } \\
& \text { - 1\% } \\
& .4 \\
& \text { rا }
\end{aligned}
$$

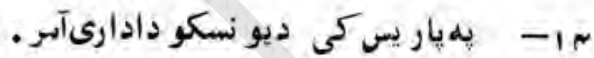

البته ددغو هيو ادوله مقاساتو موه مكا تبه رو انه دهخى د خهلو بو ها نو

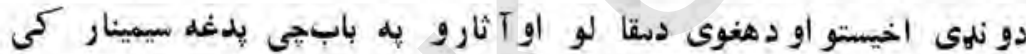

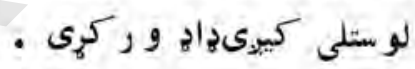

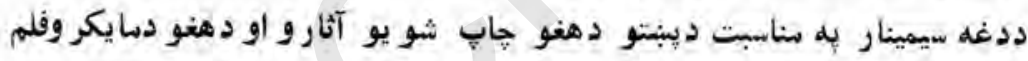

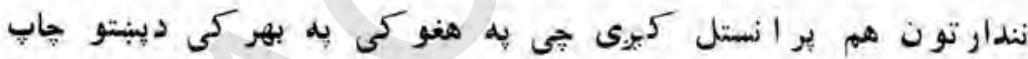

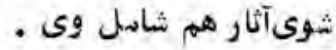

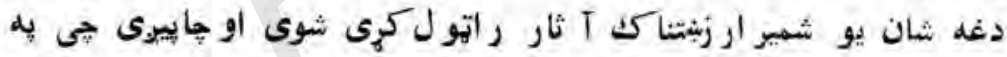

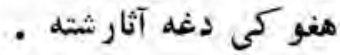

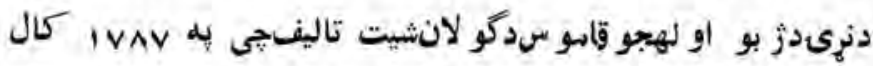

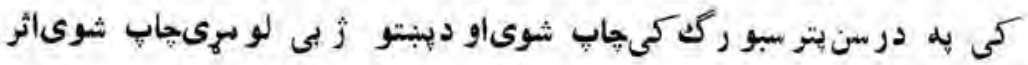
نبل كيوى

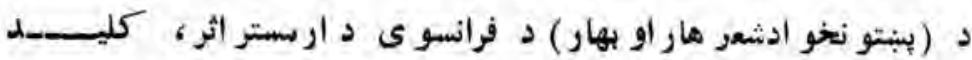

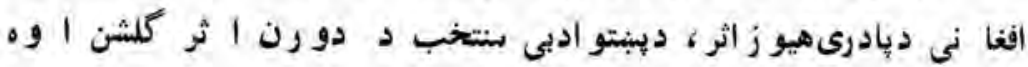

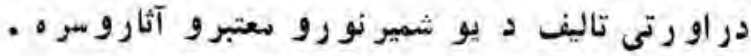
دغه رازداطلاعاتو او كلتو ردوز ارت دو ايرو اوار اكينو 


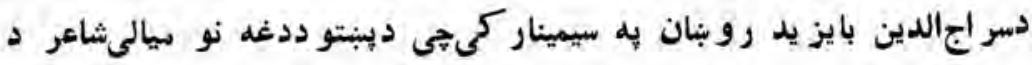

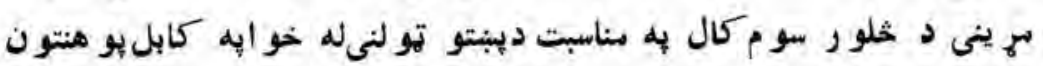

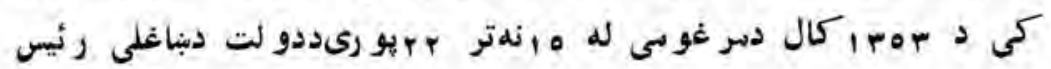

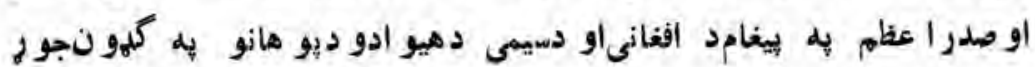

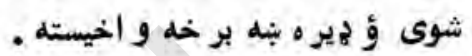

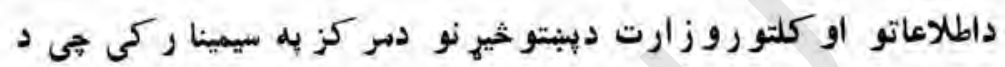

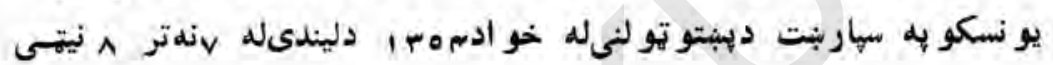

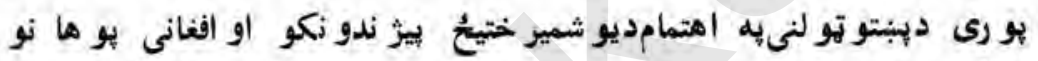

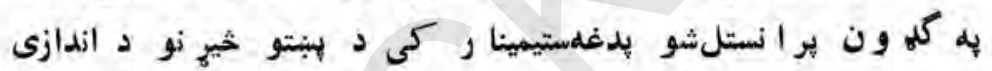

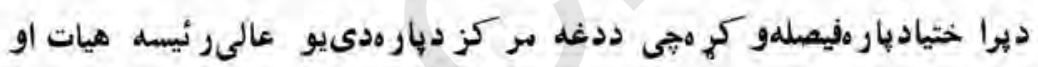

$$
\begin{aligned}
& \text { يوه او ياكسيزه علىجركة كى جور هشى. } \\
& \text { راديوا افولهانان: }
\end{aligned}
$$

د خبر تيا ، رو بنانو لو اوساعت اونيرى ديوىسترى وسيلىيه توكندر اديسو

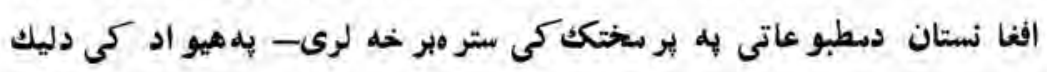

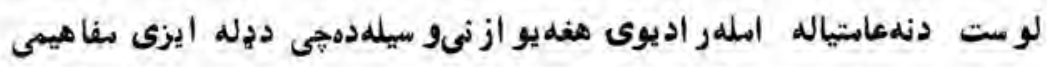

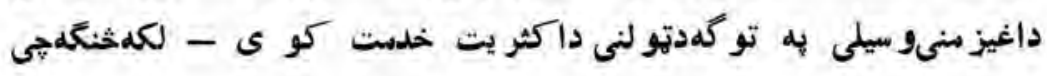

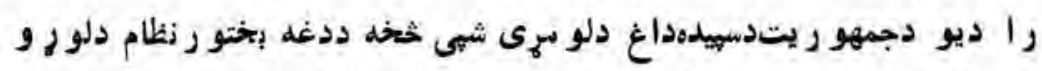

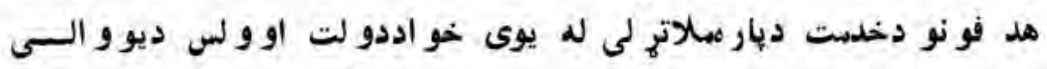

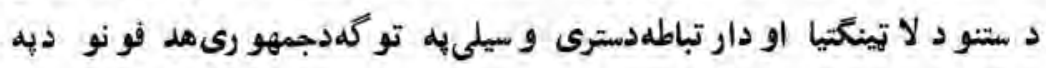

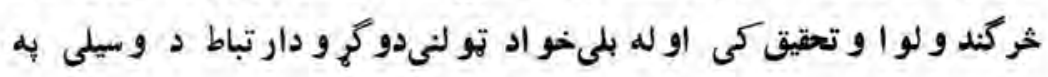




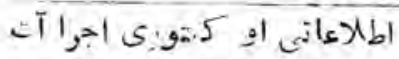

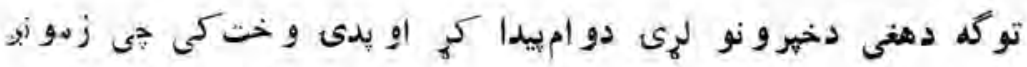

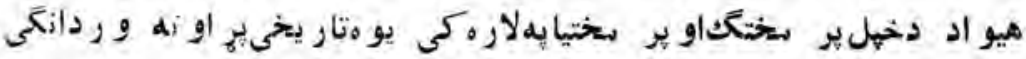

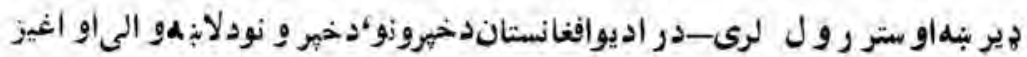

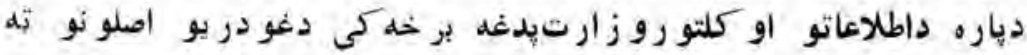

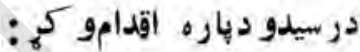

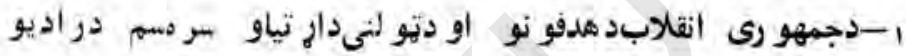
افغانستان برو وكر امونو كمى دنو يو خبر ونو نيل.

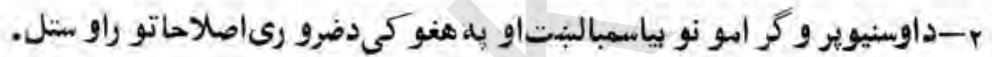

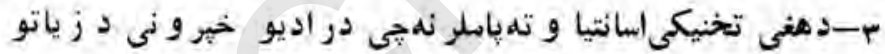

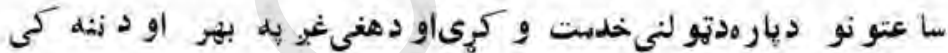

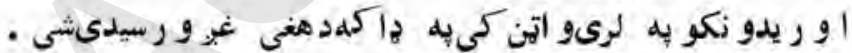

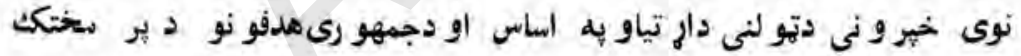

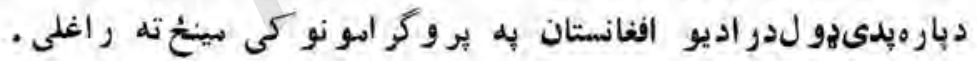
:

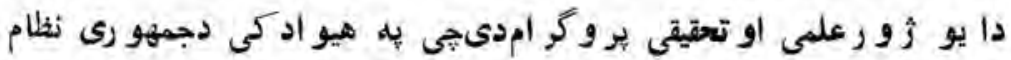

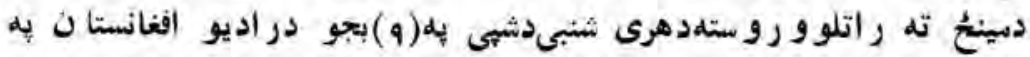

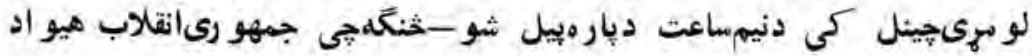
يوه زوى تاريتخى بهاوته وز ساوه نو دثهازقلاب ديوه بنه ثوندانه دياره ز مبو ني د

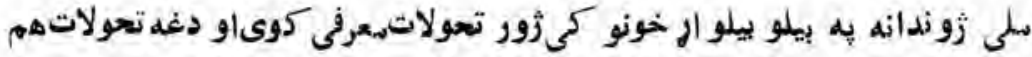

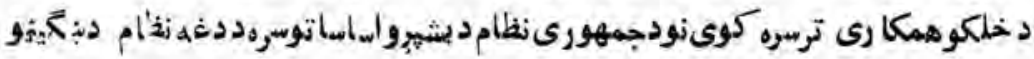




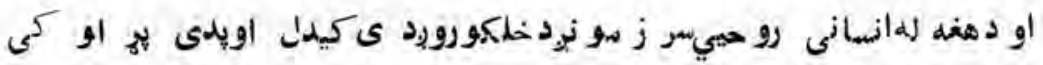
دانقلابد إنيادى هدفو نوبه تطبيق كى يوو الى او دخلكو همكارىيهتير ه بيالو مزى الوى ضرو رتبلل كيرىجى بهعمو سىهو لتو لنشر اتىو سايل او يهخاصدول ر اديو يهدغه برخه كى و نلهاخلى . دهمدى ضر و رتله مشخى راديو افغانستان

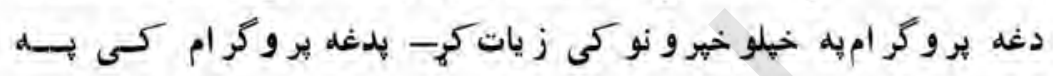
جمنو ريتاو دجمهو رىأنقلابهه هدفونو اودهيو اد دو دانى اود خلكو

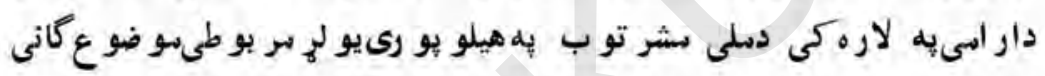

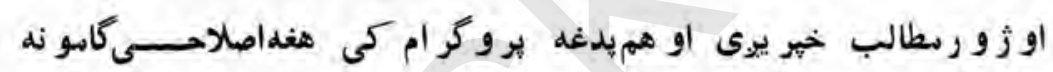

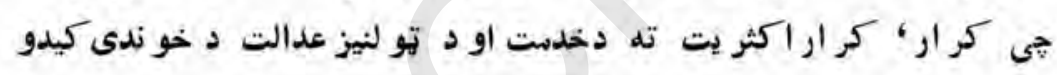
دياره او هتييوى يو يو تحليل اوخير ل كيبوى او دخلكو د احو البه بنهو الىى

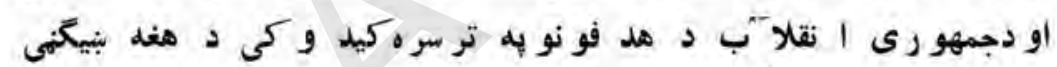

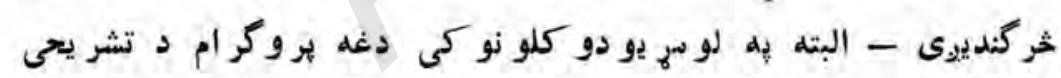

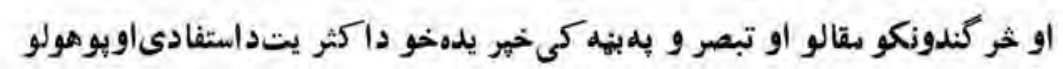

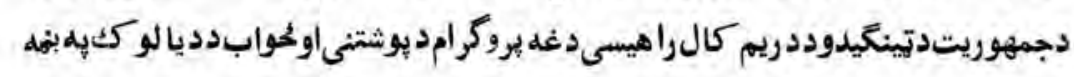

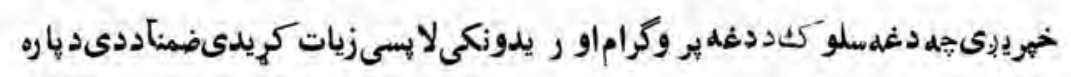

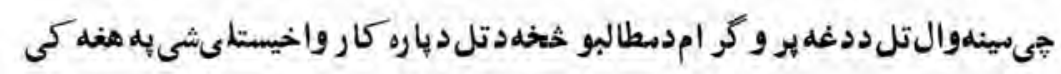

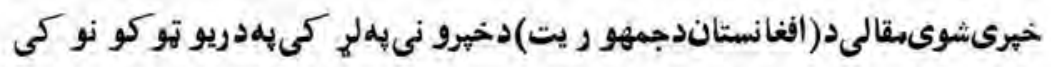

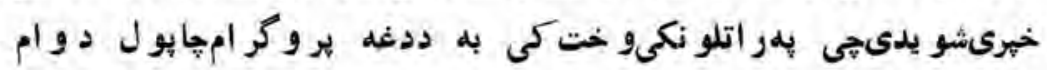


اطلا عاتى او كلتورى اجرآ آت

$(0$.

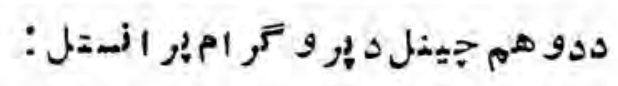

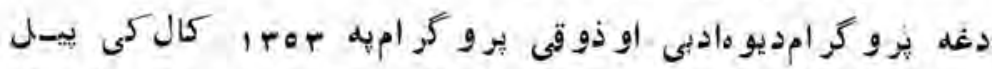

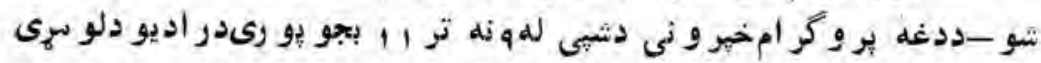

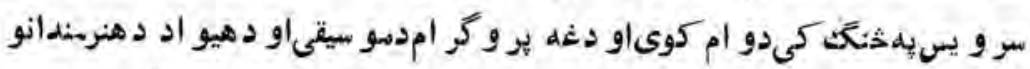

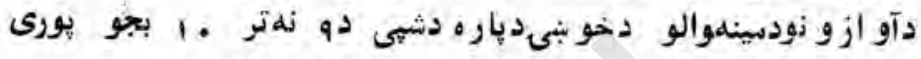

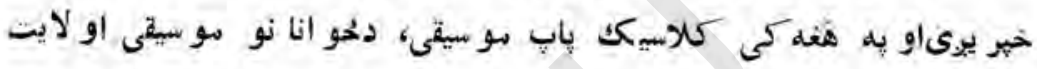

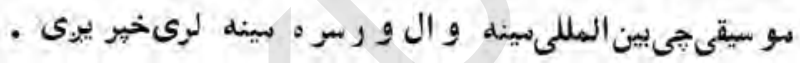

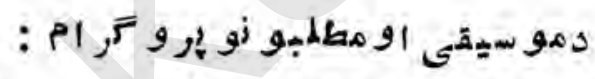

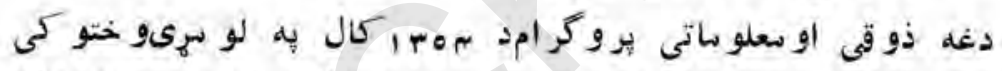

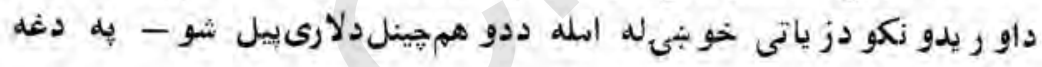

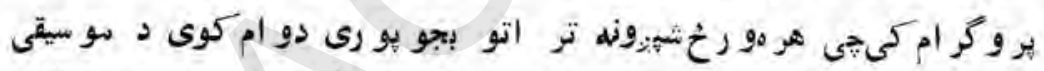

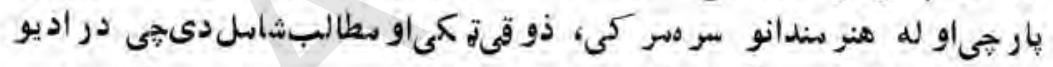

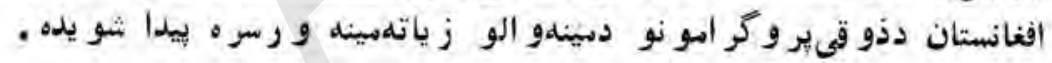

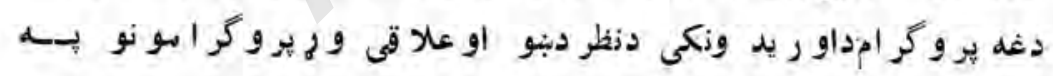

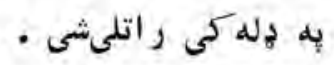
زمونز

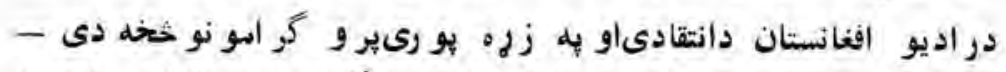

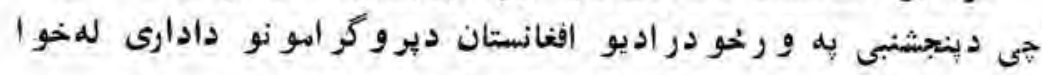

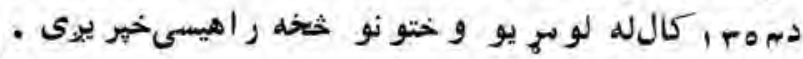

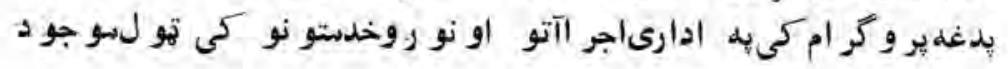

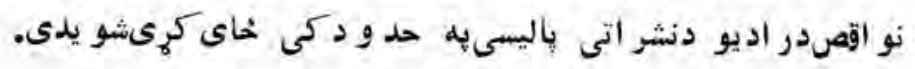


راديو افغانستان

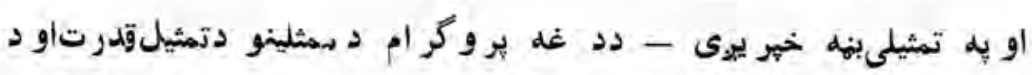

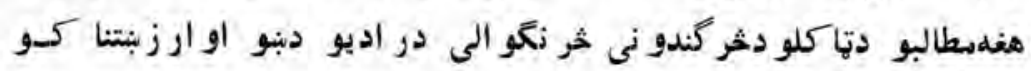

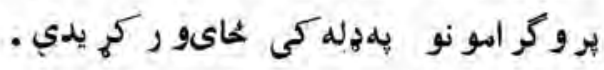

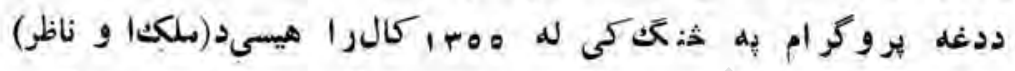

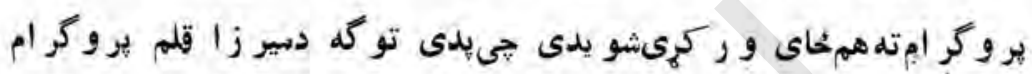

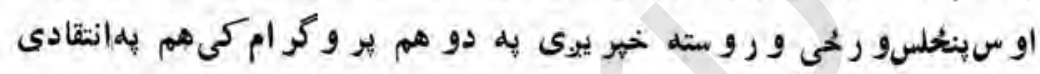

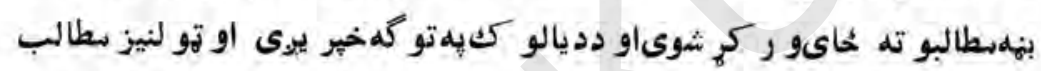

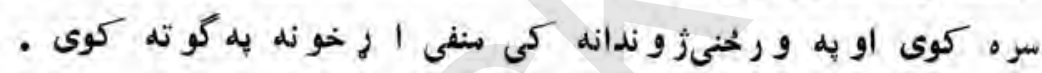

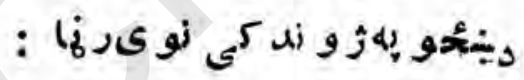

دغفه بيروكر امدر اديو افغائستان لهنو يو خهرو نو او بو بل بهمه

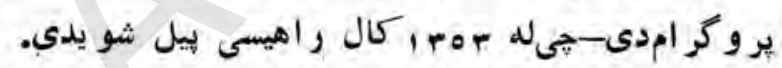

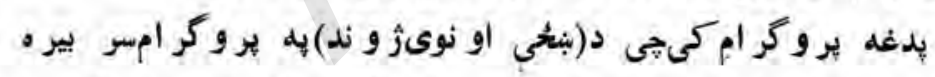

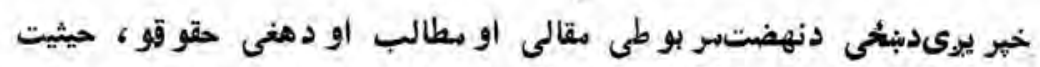

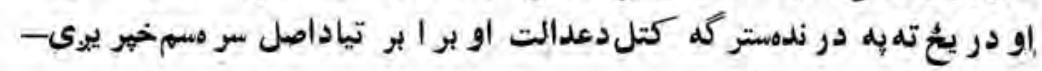

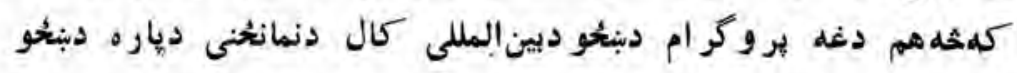

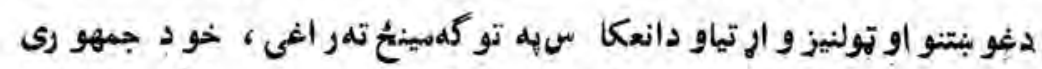

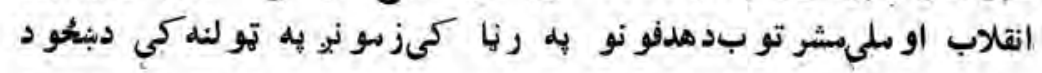

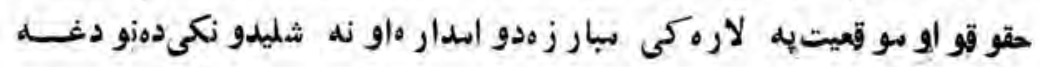

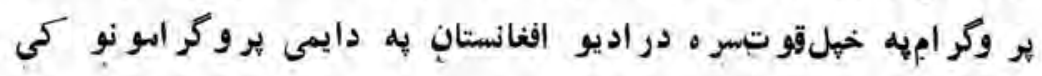
شامل كرى شو. 
الطانعاتى او كلنورى اجرا آت

$$
:{ }^{l}
$$

ددغلير وكر ام خبر و نه دنرىديا يدو نكو خير و ،نابغانو او ستر و كسانو

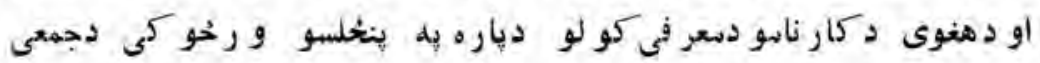

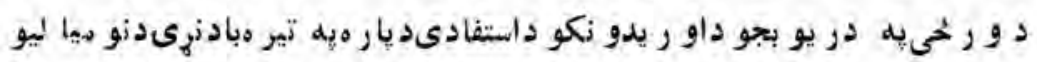

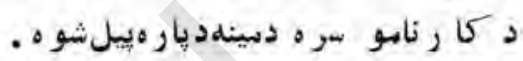

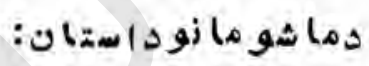

تر اتهكلنىيو رى دهاشونانو دساعت تيوىاوخو شحالى دياره او هم

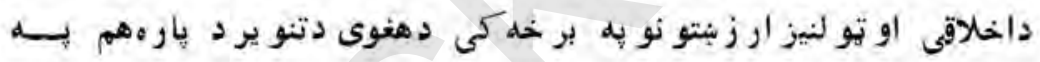

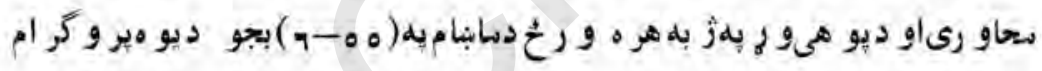
خير و نه بيلشو ماند دهذر باز ار : 20

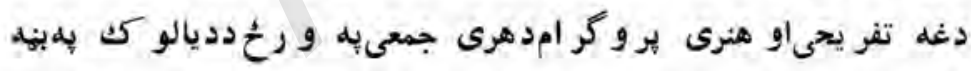

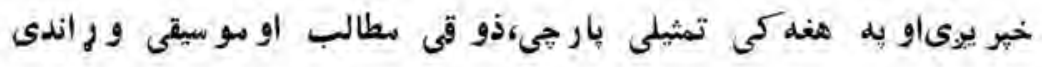
كي.رى.

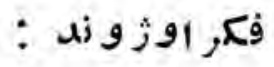

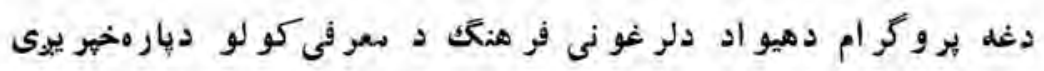

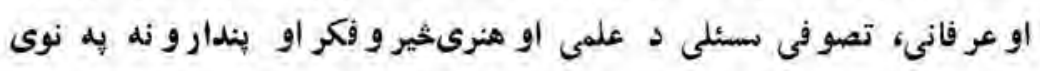

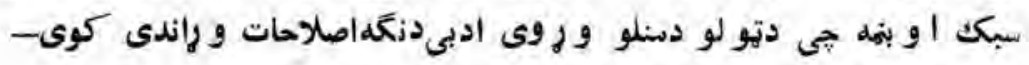

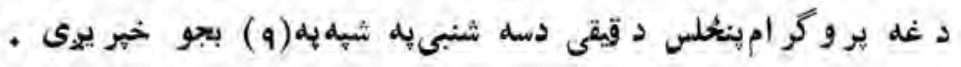




$$
\text { راد يو يإبياتياتر: }
$$

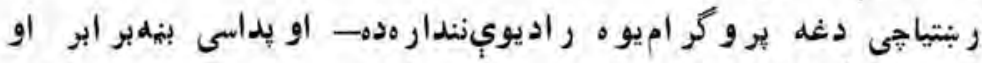

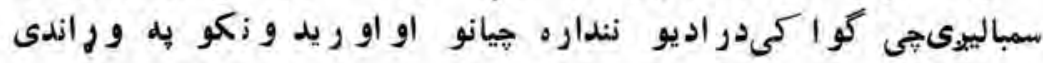

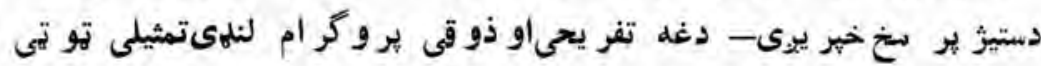

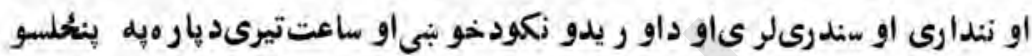
و رحمو كى دجمعو يه و روحو خيو يونى. :

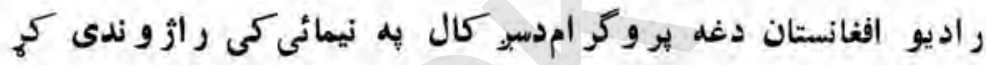

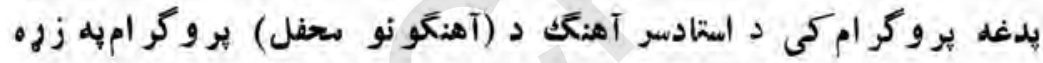

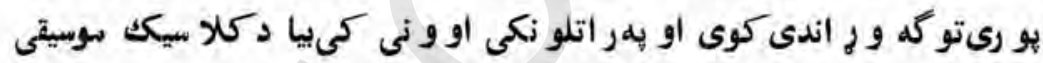

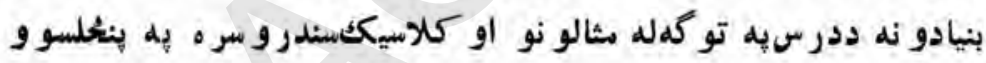

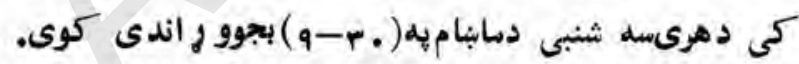

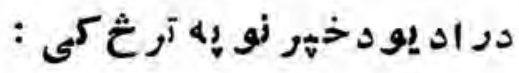

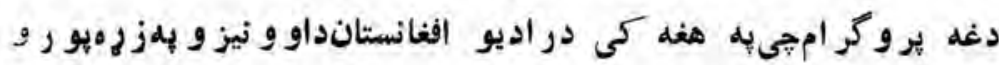

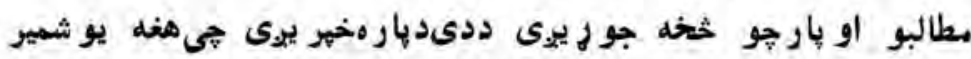

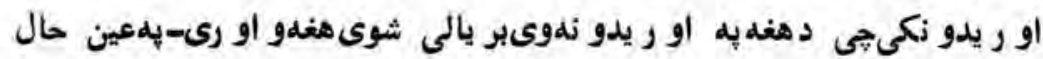

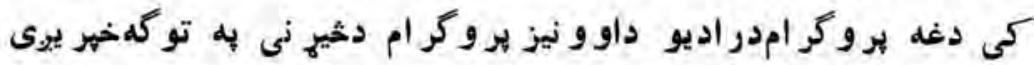

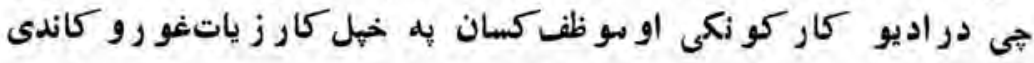

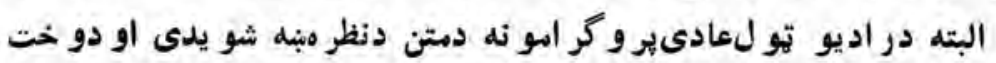

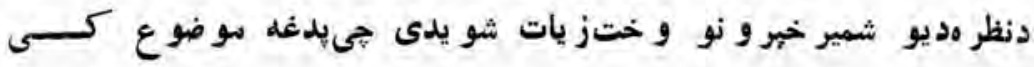




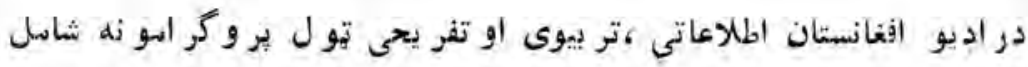
دى.

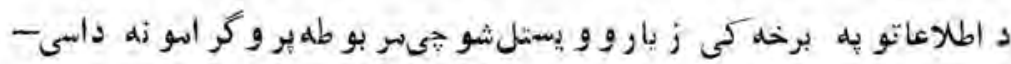

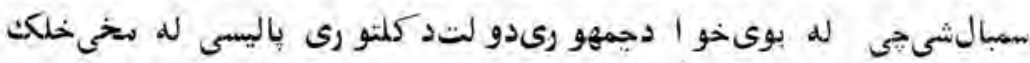

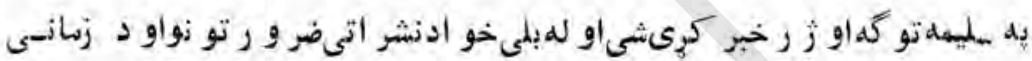

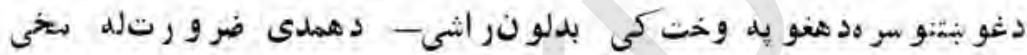

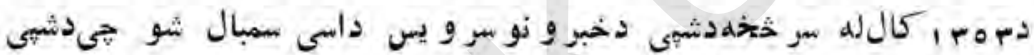

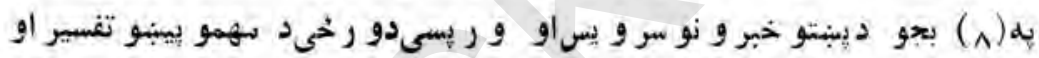

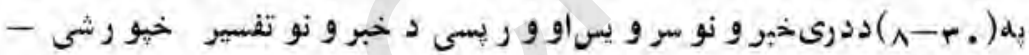

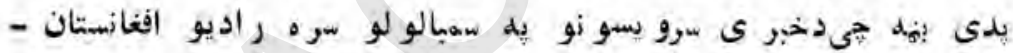

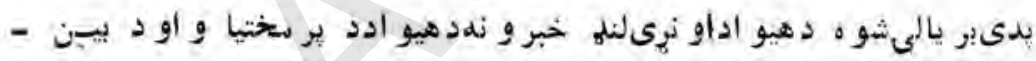

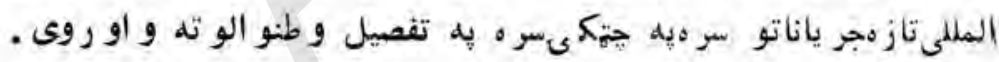

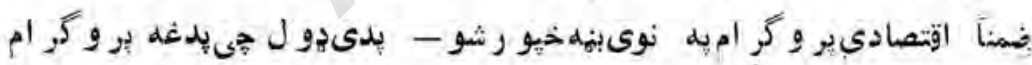

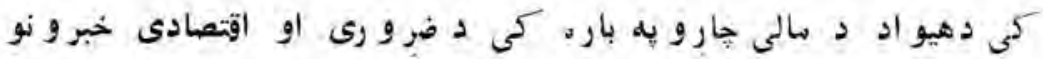

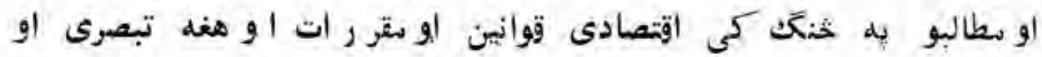

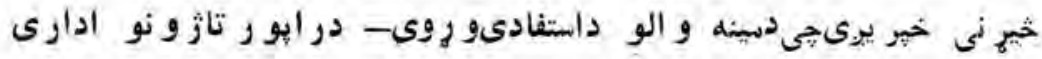

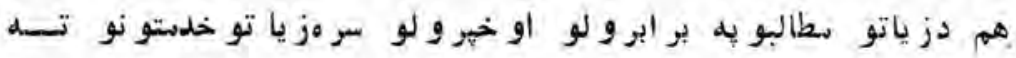

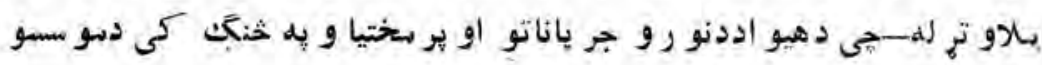

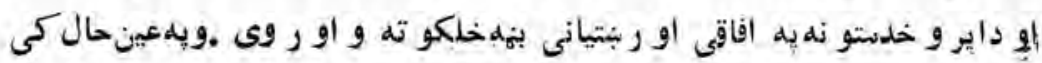

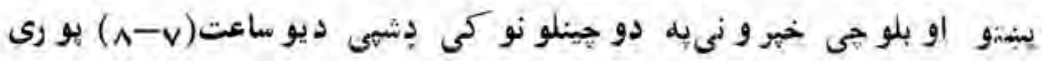




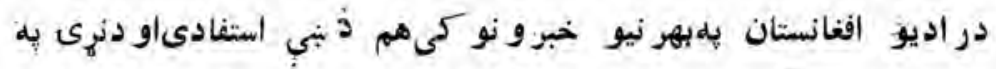

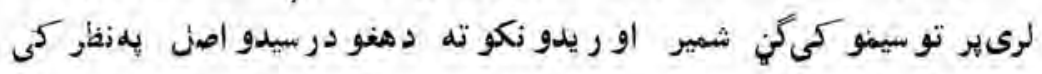
نيول ثيو يدى

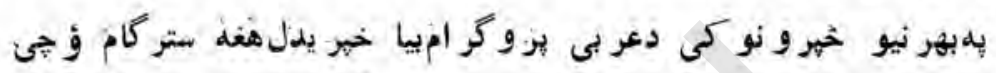

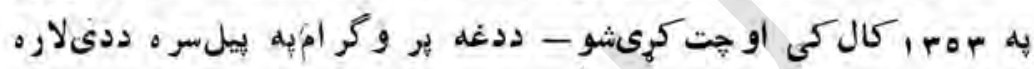

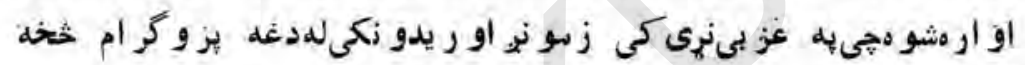

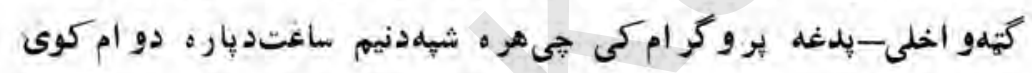

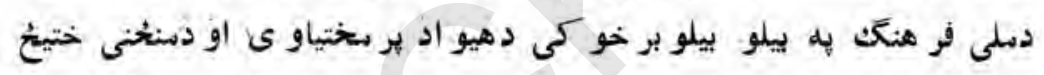

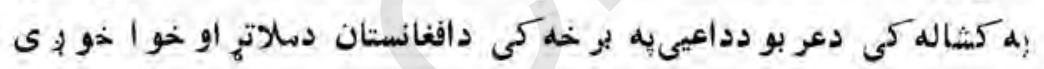
. ز ياروو يستيل شو جهيه بهو كى داو سيد و نكو اوغا نا نو او دبهر نيو

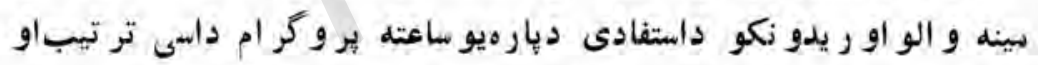

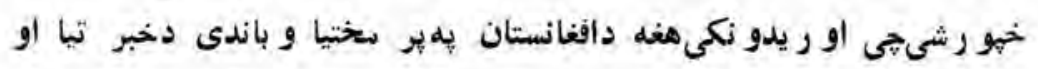

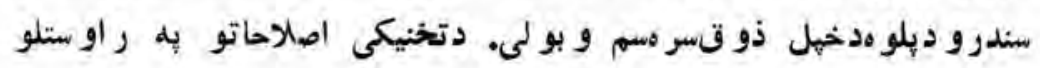

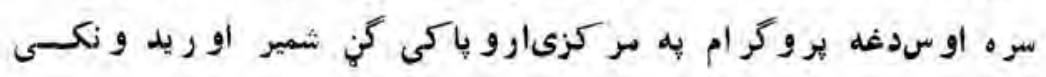
لرى

دغهز ازدتخنيكى اسانتيا و بهبر ابرو لو سوردر اديو افغانستان د بهر نيو

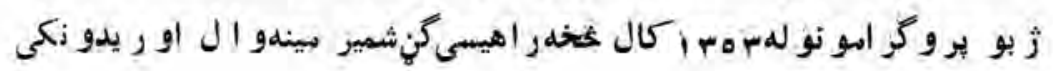




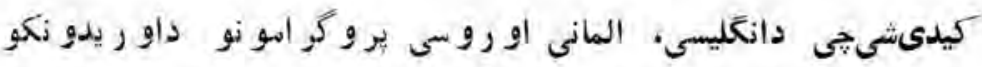

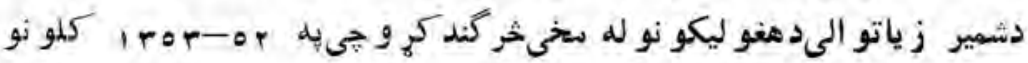

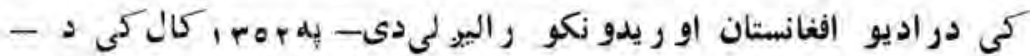

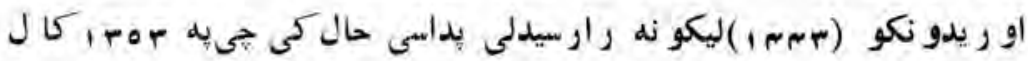

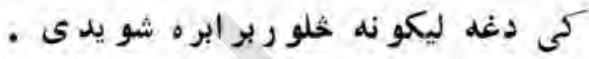

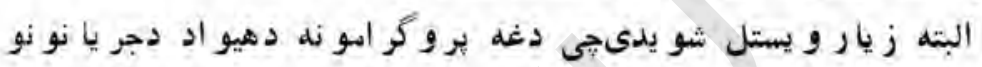

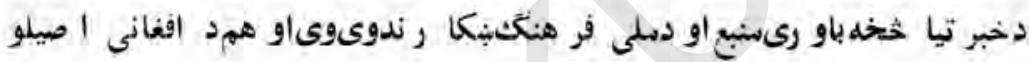

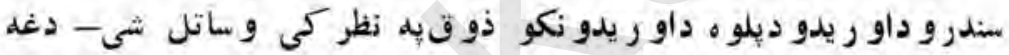

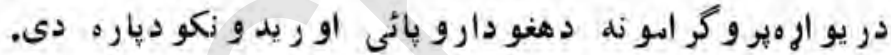
داردو سرو يس او دانكليسى دو هم بر وكر ام دسيمى دهيو اد و دد بارن

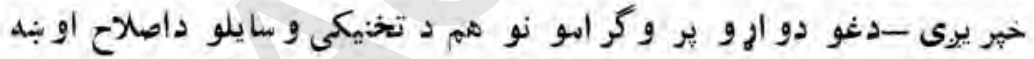

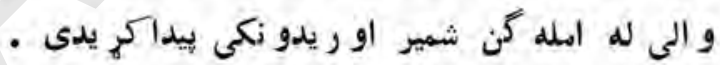

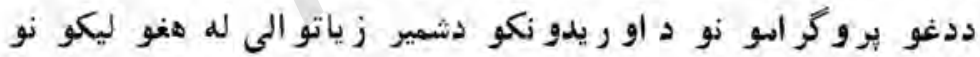

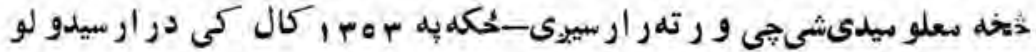

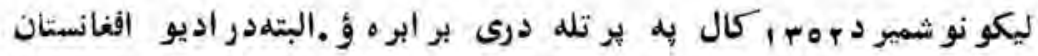

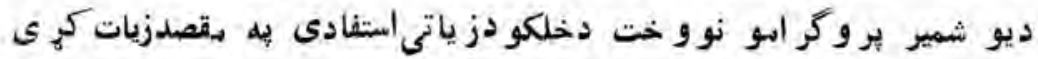

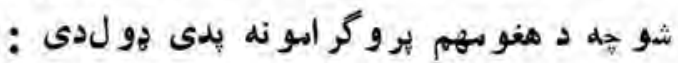

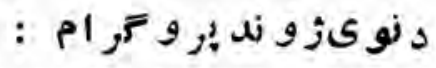

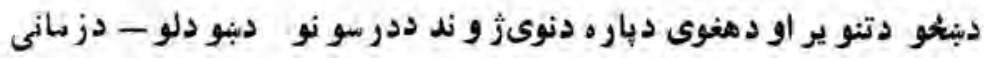

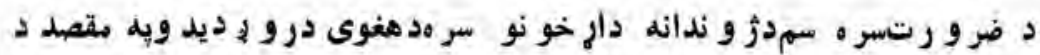




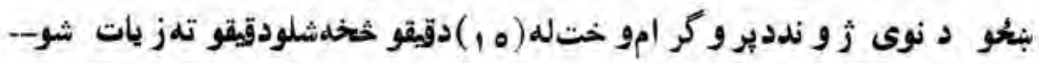

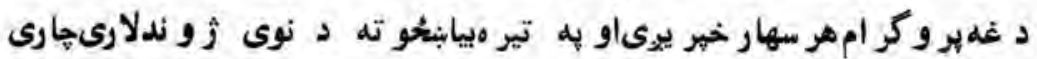

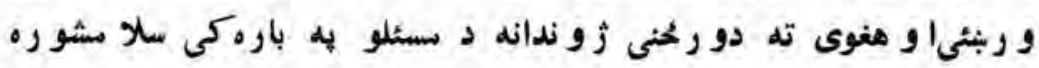
وركوى .

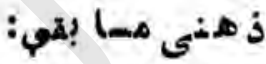

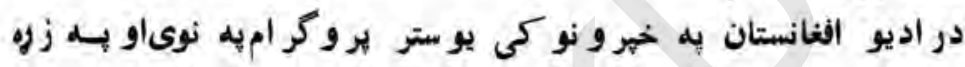

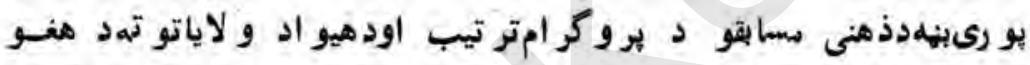

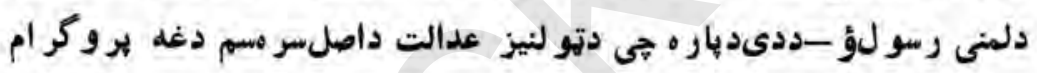

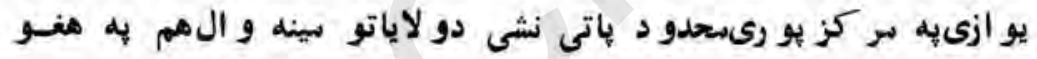

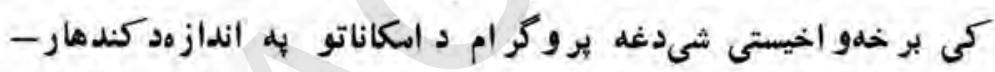

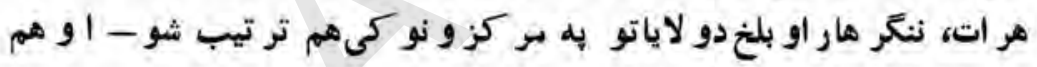

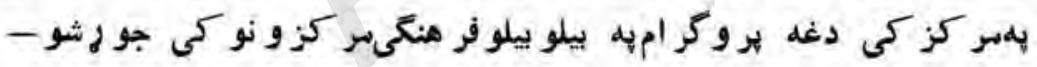

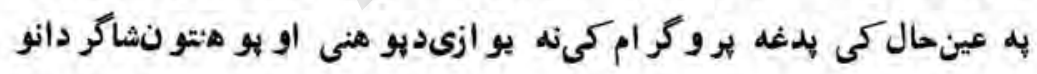

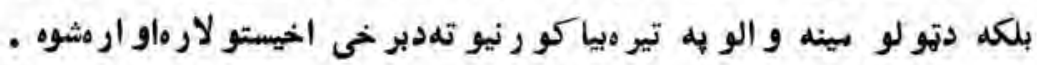

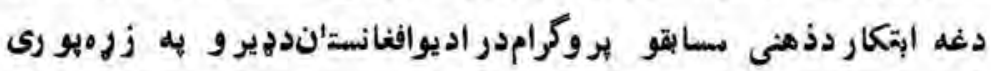

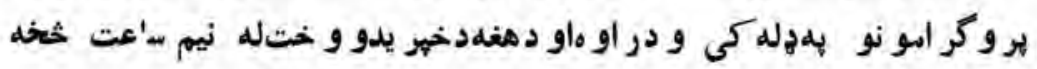

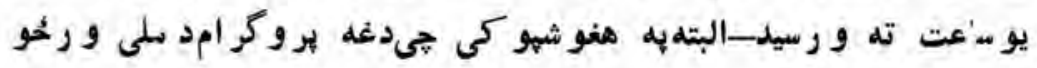

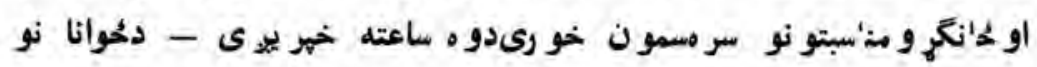

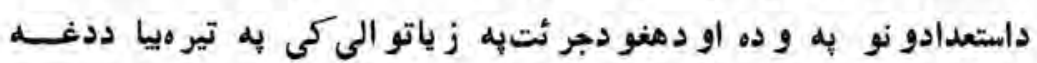

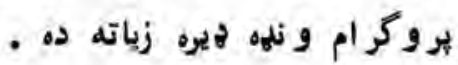




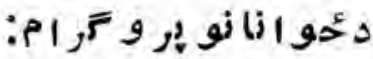

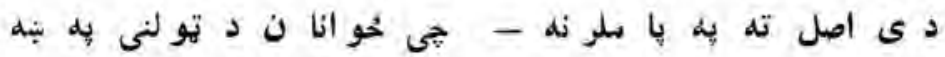

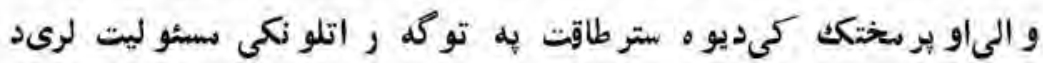

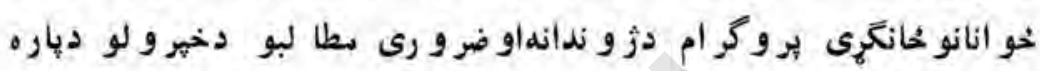

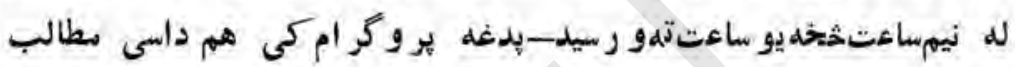
خير يوىخى للهيوىخو ا ددوى دجايير يال يه بارنمى دخوانانو معلو مات

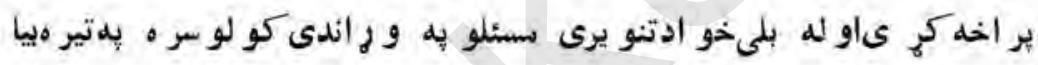

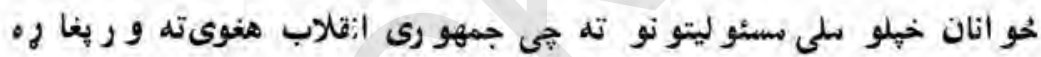

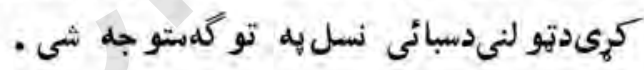

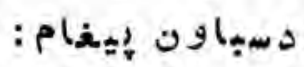

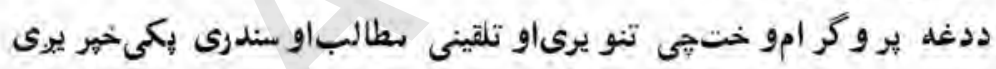

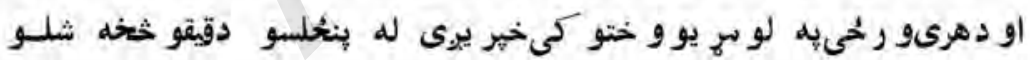

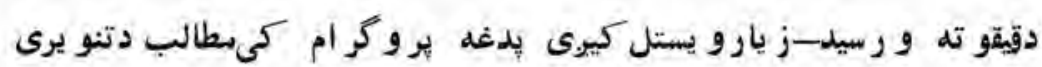

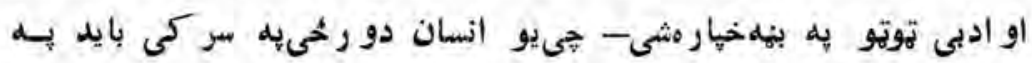

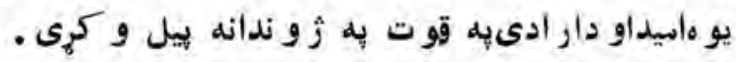

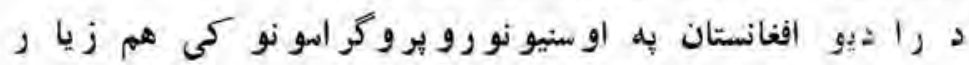

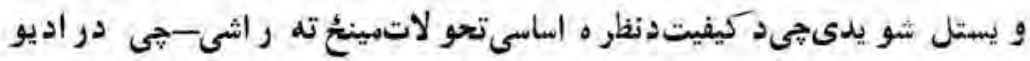

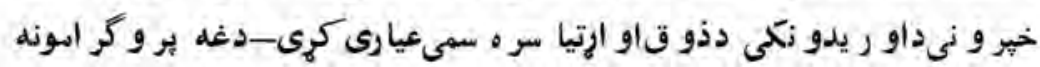
: ज小 دسندرو او سو سيقى دخهير ولو او برابر و لو يهبر خه كى در اديو خدنتو نم 


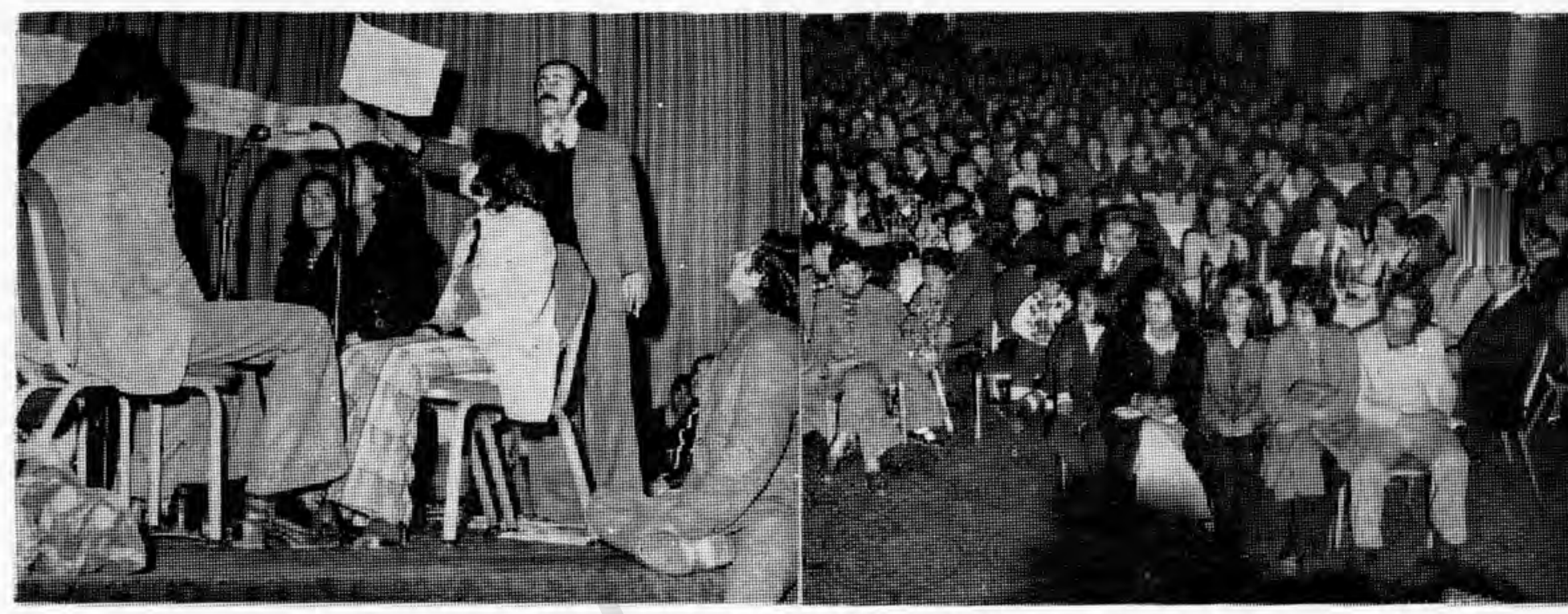

دانتر كا ثتينتتال هه سالون كىدراديو الفغانستان دذهنمسابقا تويوه صحنه . 
يه دو اصلو نو ولاردى-لومئاصل دوختاود د اديو د يروكرام لسهـ نظر مداو ر يدو نكو دغو بنتنى او ذو قسو ه سم دسندر و او مو سيقىخير و ل-

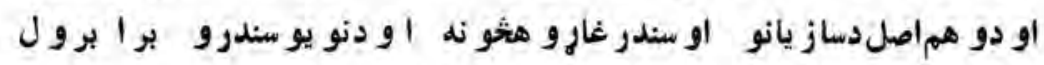

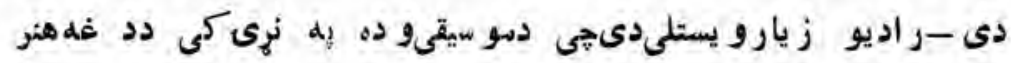

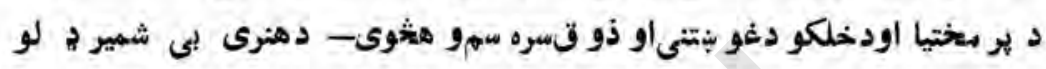

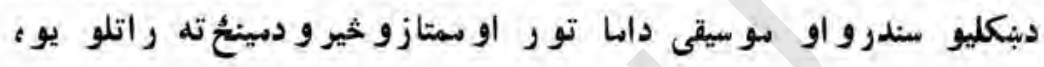

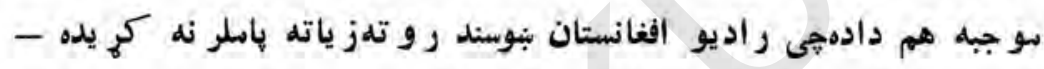

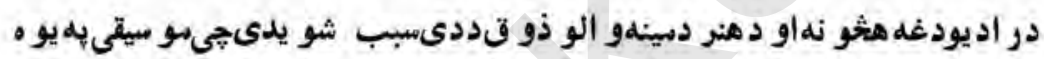

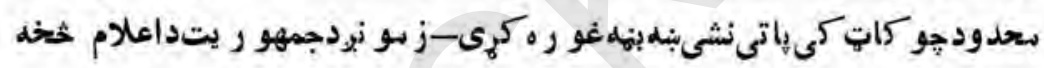

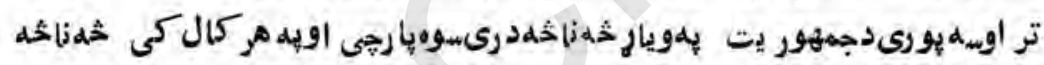

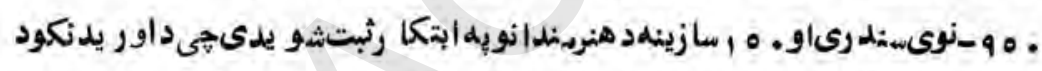

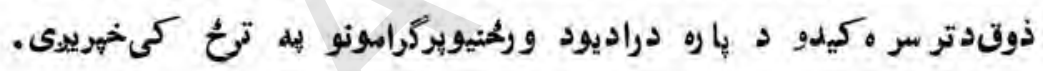

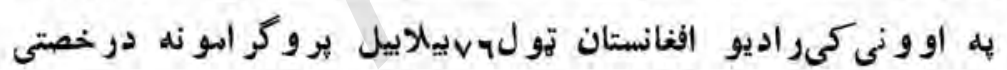

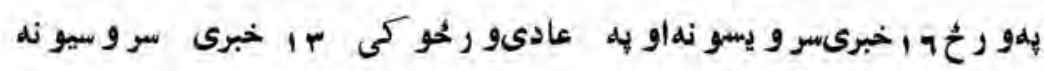
خهر وى

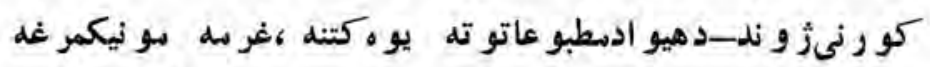

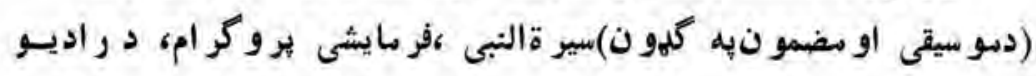

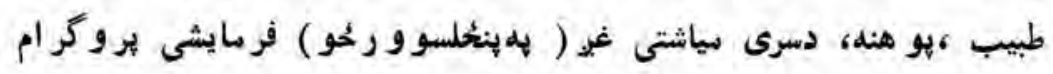

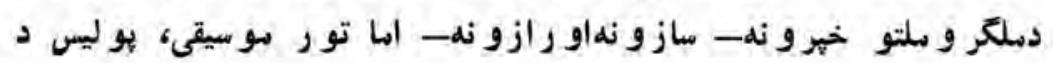

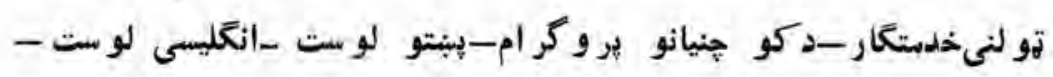


فر انسوى لو ست-روسى لو ست_المانى لوست-ستحلى نوى آهنغو نه - كر مكتنه

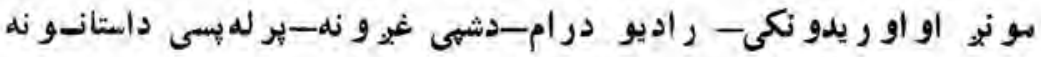
دسهو رتنزى-نوى ثبت شوى سندرى - ددو ستا نو مر كه ر راديو نُمجلهله

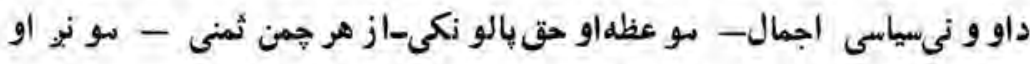

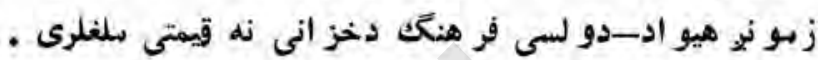

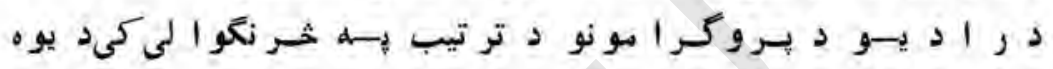

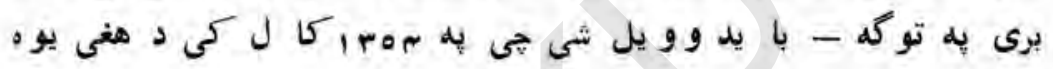

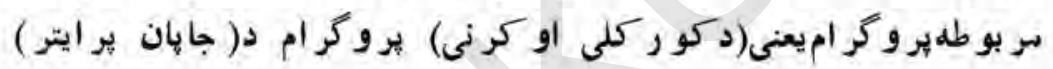

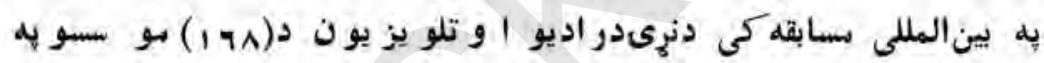

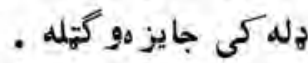

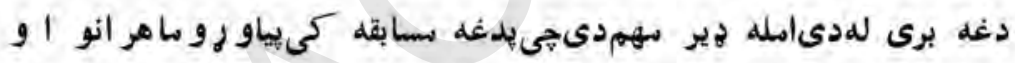

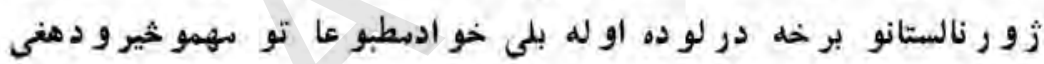

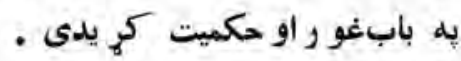

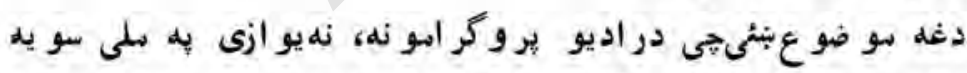

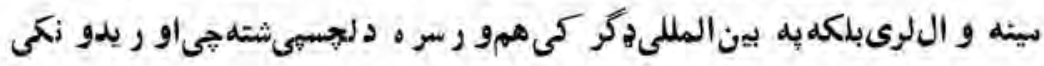
نى لحانته راكبنلى دى .

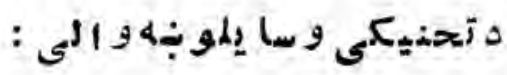

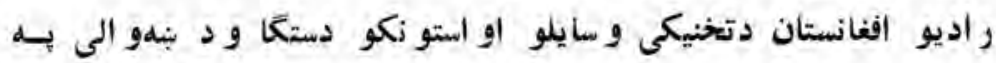

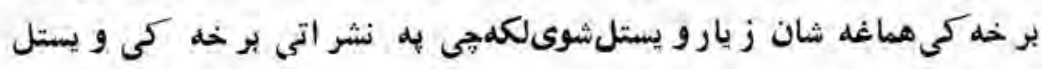

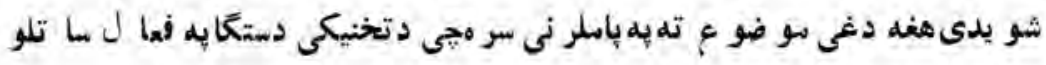




\section{راد الد يو افغا نستان}

او به كار كى يلبنهو الىاو زياتى غبنتلياسو مر اديو دوطنو الو او او ريدو نكو

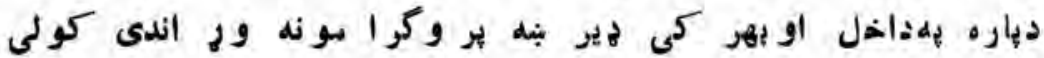

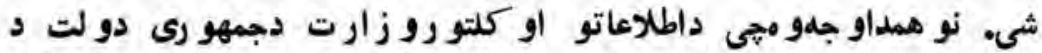

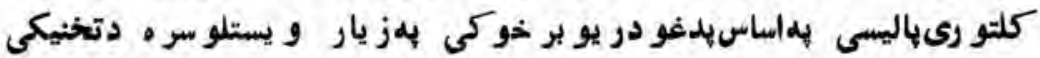
اسانتياو دكار بنه و الى تولاسلاندى و نيو -

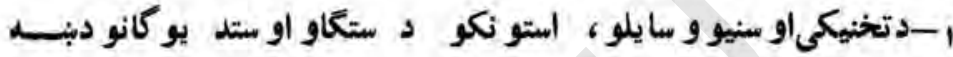

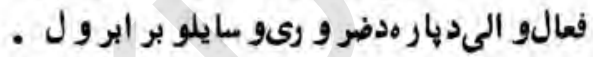

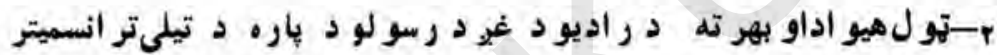
دنو يو دستغاو به كا راهول

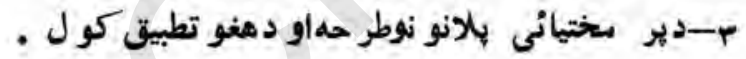

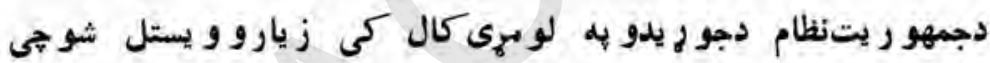

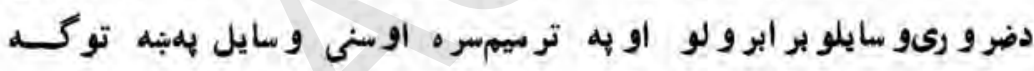

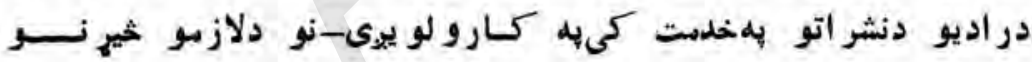

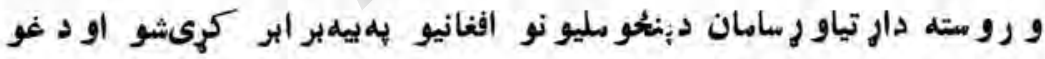

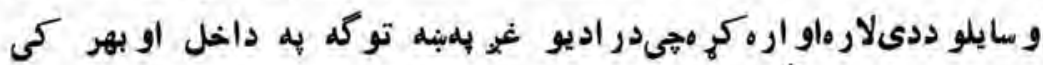
ماو ر يدو نكوغو حو و نو تلهو رسييزى

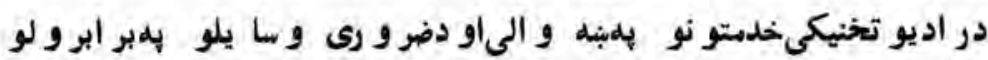

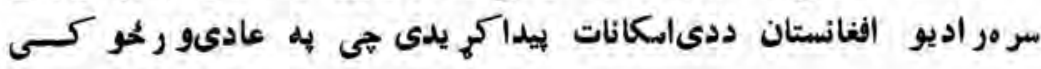

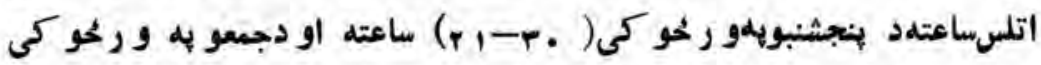

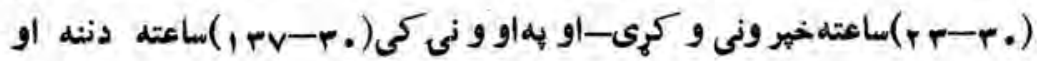
بهر كى داو ر يدو نكو خدست و كرى . 
إطل) اعاتى او كلتهو رىاجرا آت

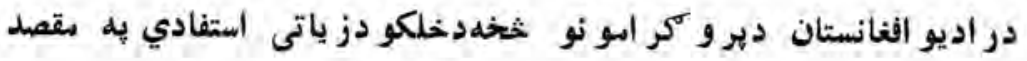

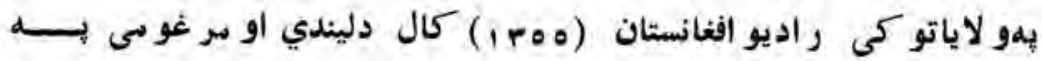

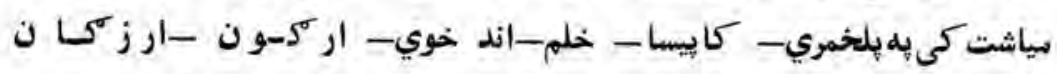
لشكر مَاه- لغمان - لو مَ او سقر كىلس نوي اخيستو نكى دستخاوي به كار و اجو لحى

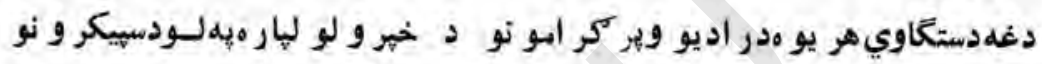
باند ي سببالى دي.

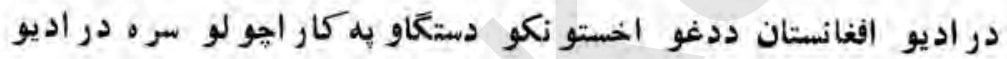
افغانستان د دستخاو شميردو دير شو ته رسيري.

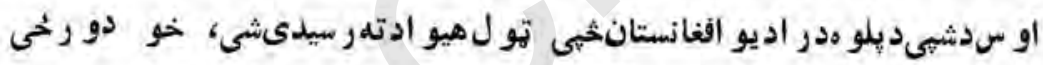

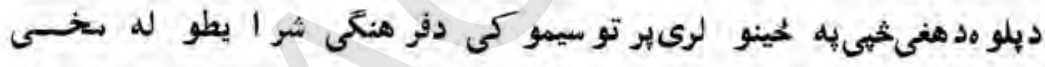

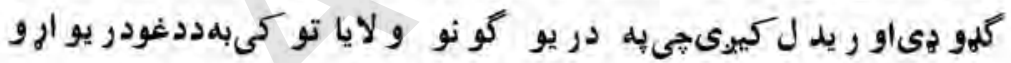

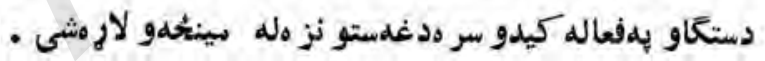

در اديو افغانستان بهر نى خير و نىتولى ارو با - دسميى اولى لوى ختيخ

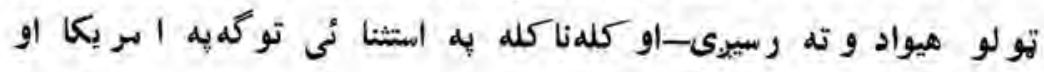
آسترا ليا كى هم او ريدل كيدى نهى.

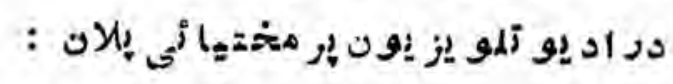

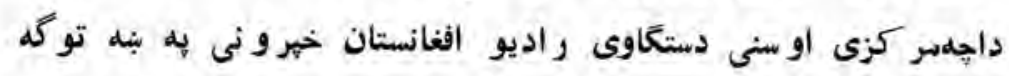

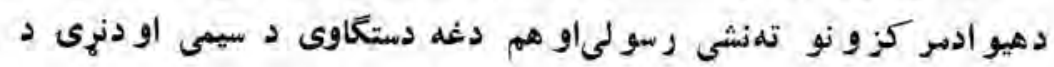

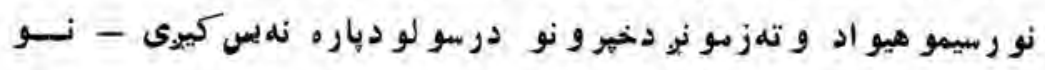



(Tr)
راديو افغانستان

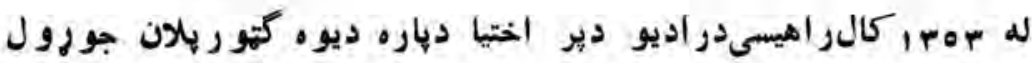
تولاسلاندى نيولشو يدى او يدىفيصلهو شو ه جى كر اركى ار دغه بها ن ن

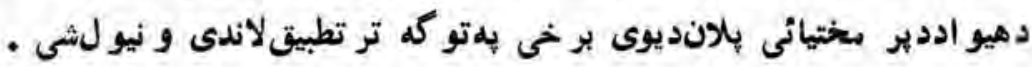

$$
\text { : و }
$$

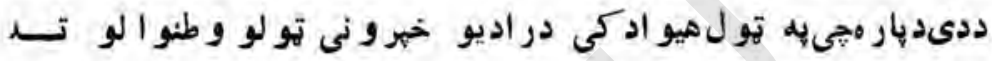

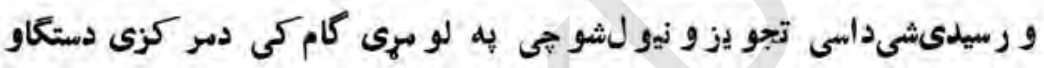

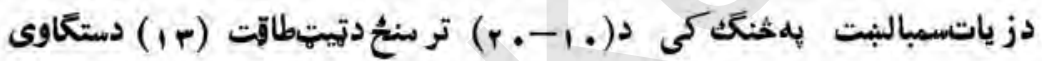

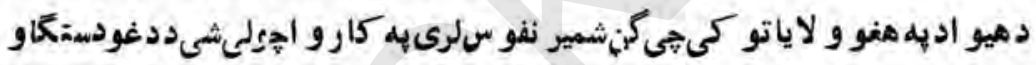

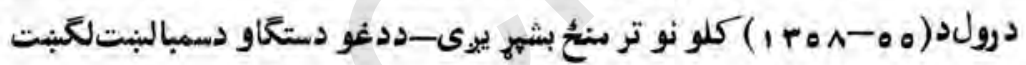

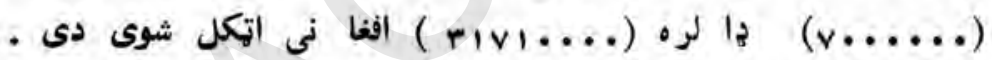

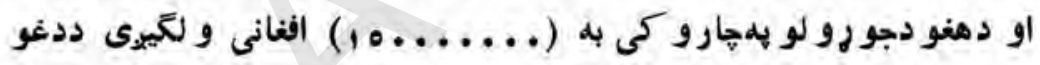

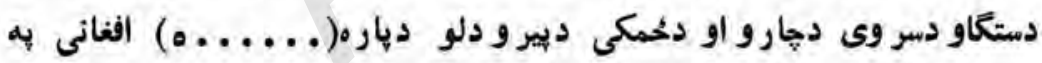

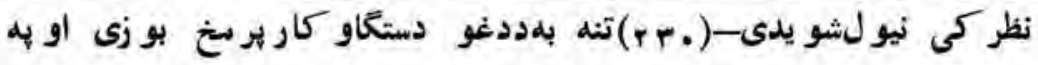

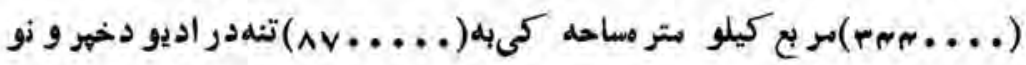
- خخخ استفاده و كرى كثى

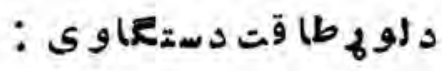

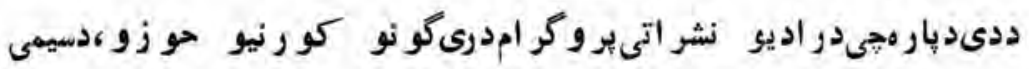

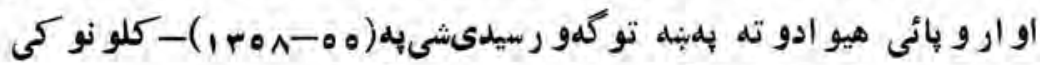

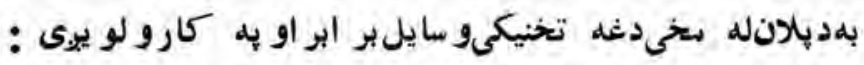

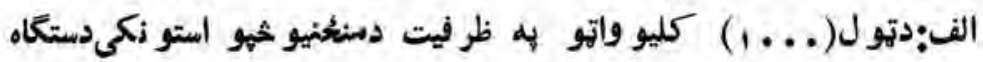




$$
\text { - مو احده-هو و احد(. م. ) كليو واته. }
$$

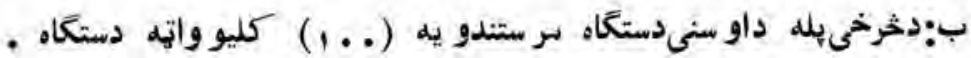

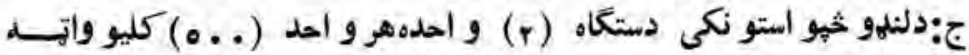

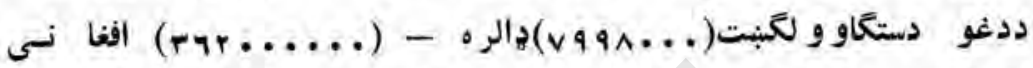

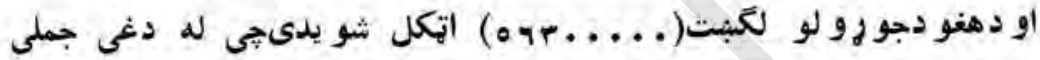

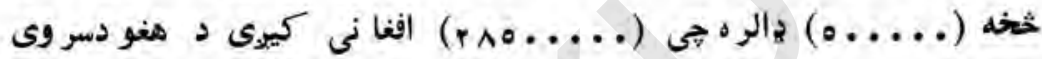

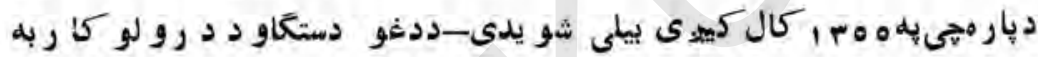

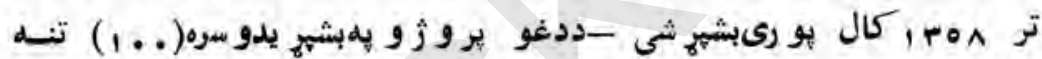

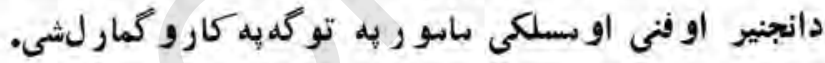

$$
\text { : }
$$

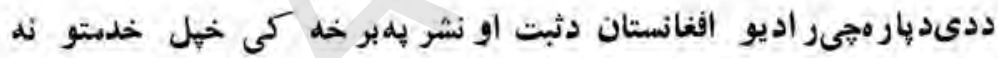

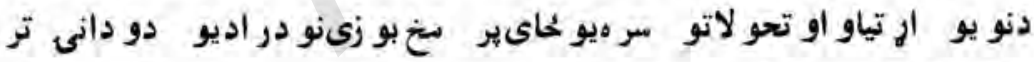

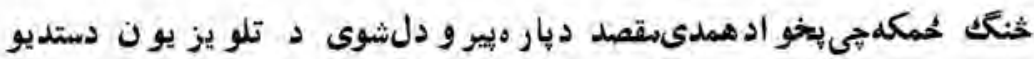

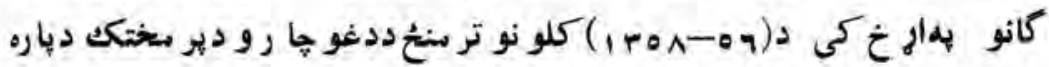
در اديو افغانستان نوى ستديو كانىو دانيزي

$$
\begin{aligned}
& \text { م بواحده. } \\
& \text { ـدغبر دثبتستديو كانى } \\
& \text { بو احده. }
\end{aligned}
$$

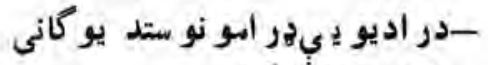

$$
\begin{aligned}
& \text {. " } r \\
& \text { - مدابىستديو كانى } \\
& \text {. " } r \\
& \text {-ددو ز يكثستديو كانى } \\
& \text {." } \\
& \text {-دفترو نه، تحو يلخخانى أو نور }
\end{aligned}
$$




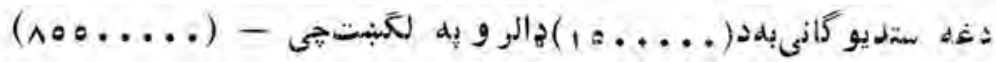

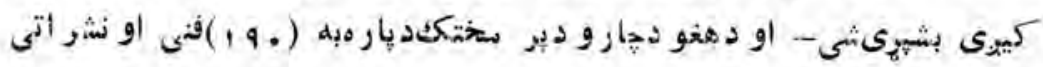

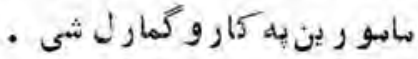

$$
\text { i }
$$

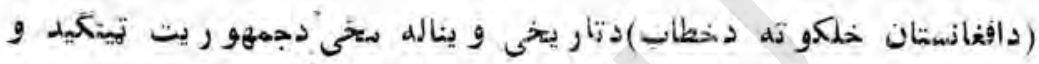

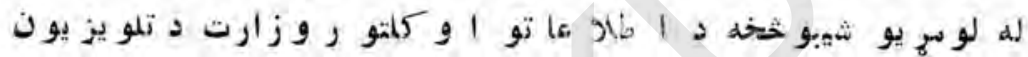

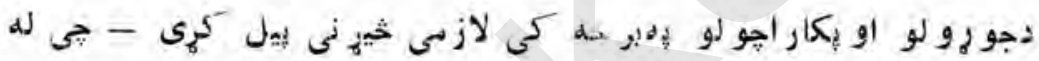

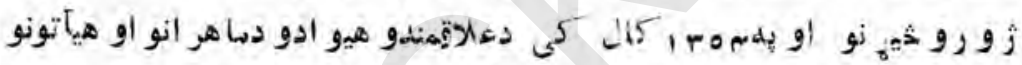

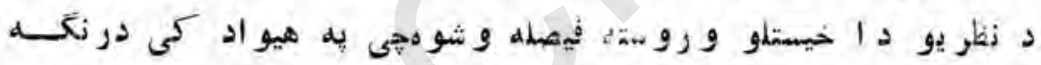

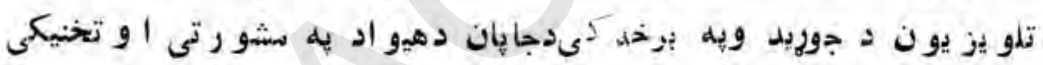

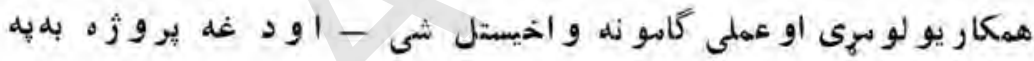

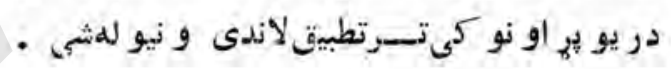

$$
\text { : }
$$

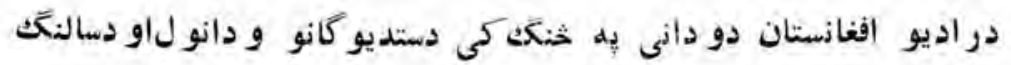

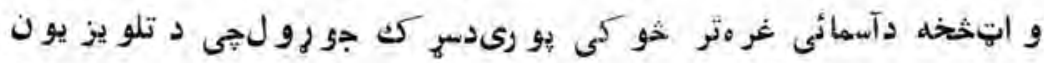

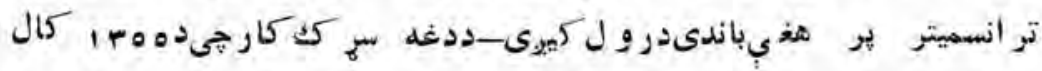

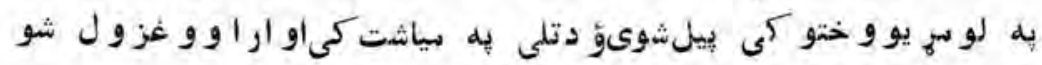

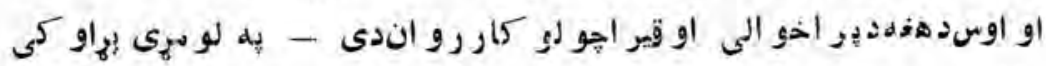

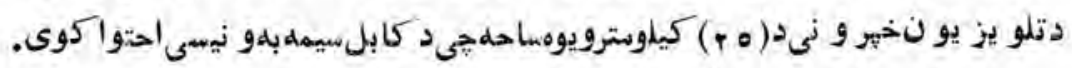

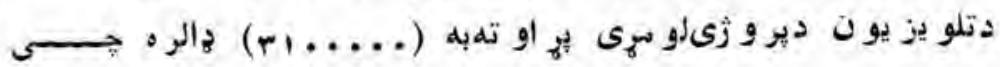




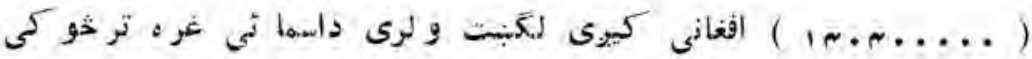

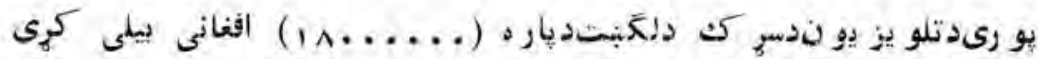

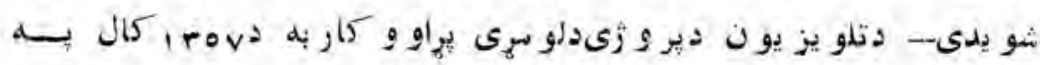

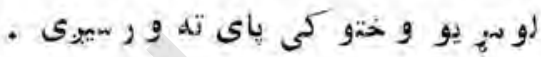

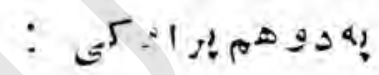

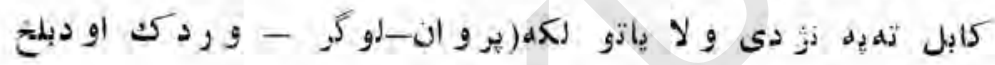

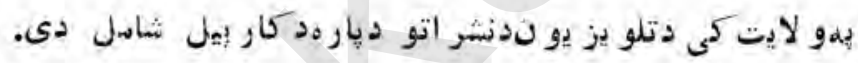

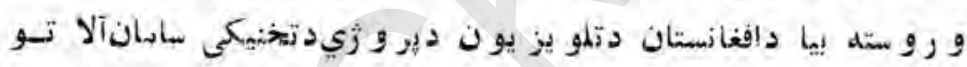

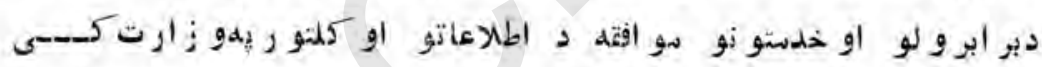

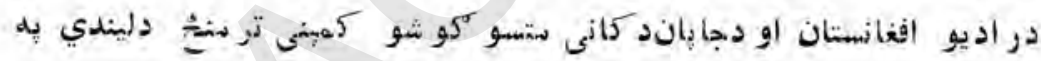

$$
\begin{aligned}
& \text {. } \\
& \therefore
\end{aligned}
$$

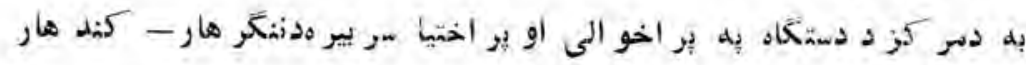

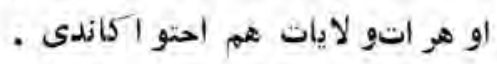

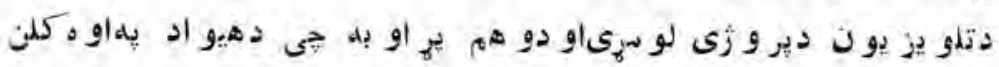

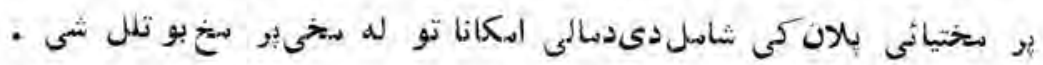

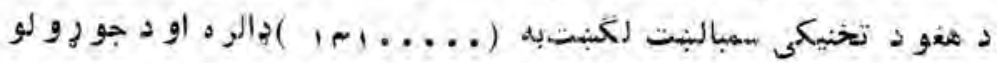

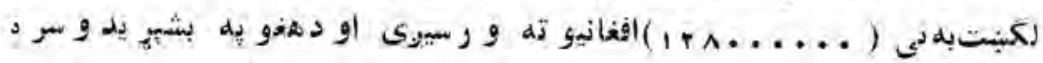

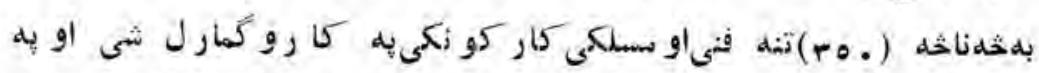

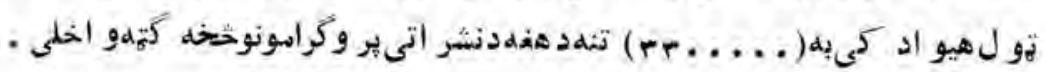




$$
\text { ! آن: }
$$

باختر آ ث انس خيل فعاليتو نهدجمهو رىدو لتد كلتو رى تَكَلارى او د

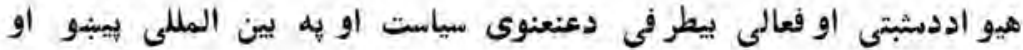

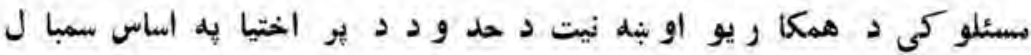
ك 2

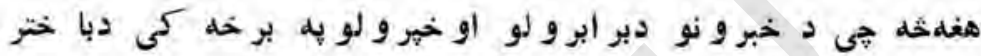

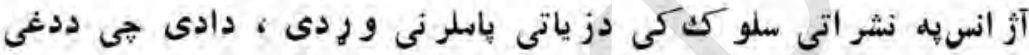
سو سسى خيه خبر و نو كى زيارو و يستل شو هي افاقى او دو اقع بينى روحيه

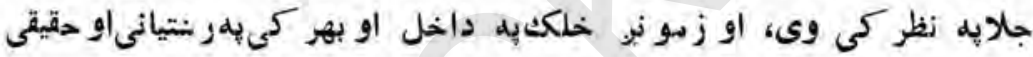

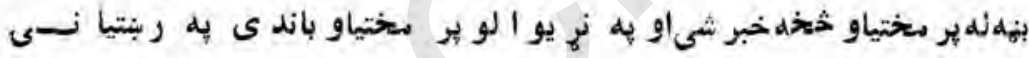

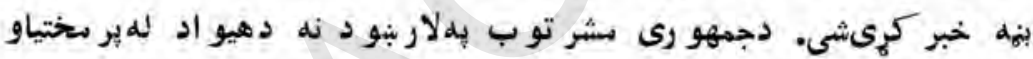

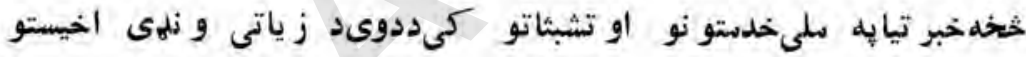

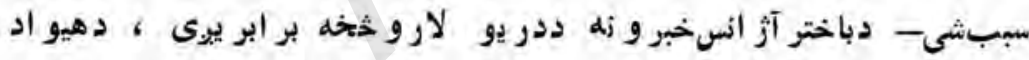

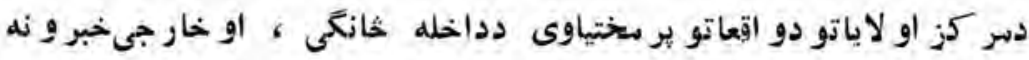

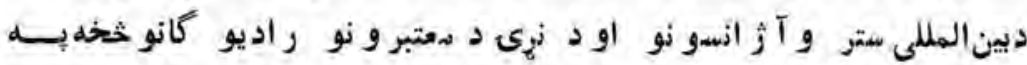
استفادهو لو سر ه دتيلى تايب أو راديو كأ نو به و سيله .

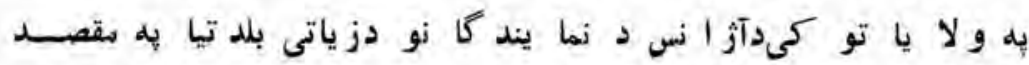

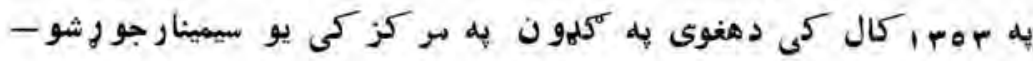

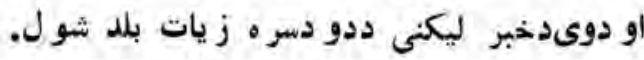
دغه رازددىدياره جي دهيو اد و زياتو جر ياناتو او بر بختيا و او هم 


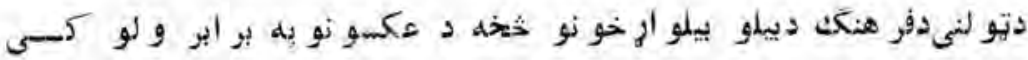

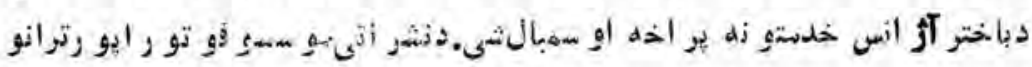

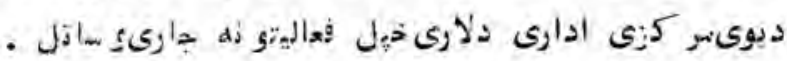

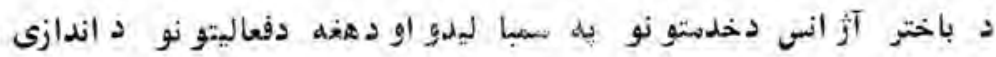

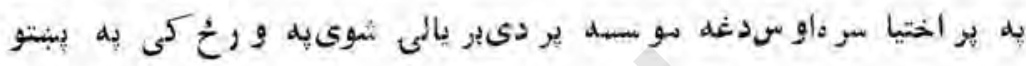

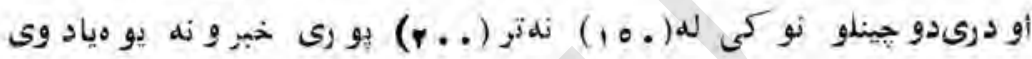

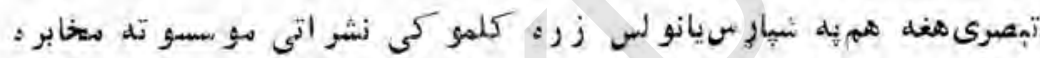

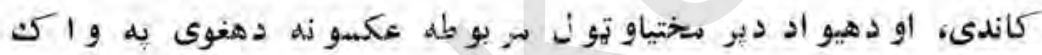

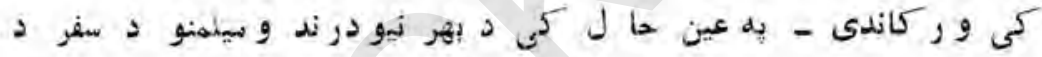

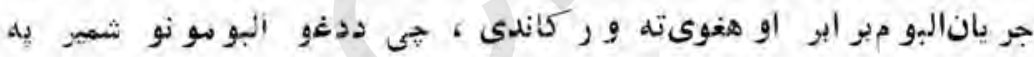
.

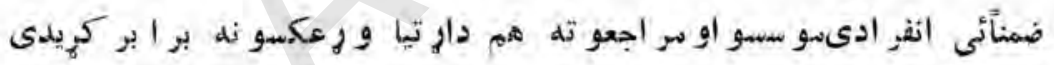

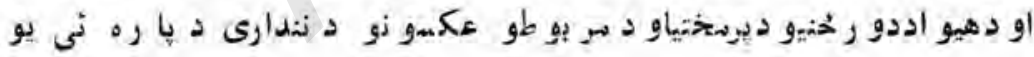

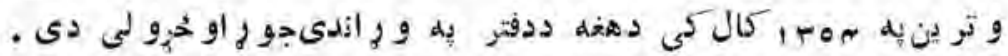

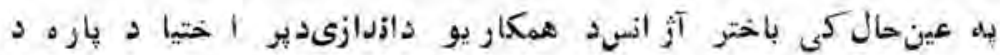

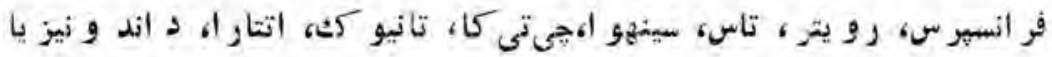

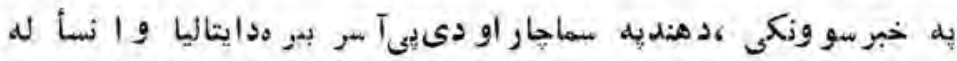

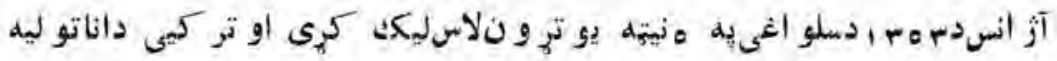

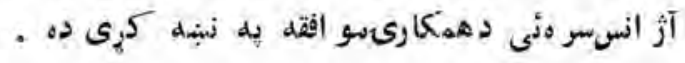

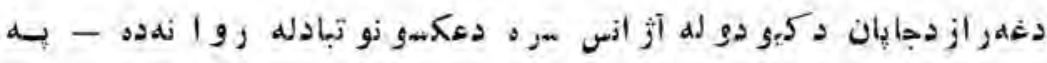




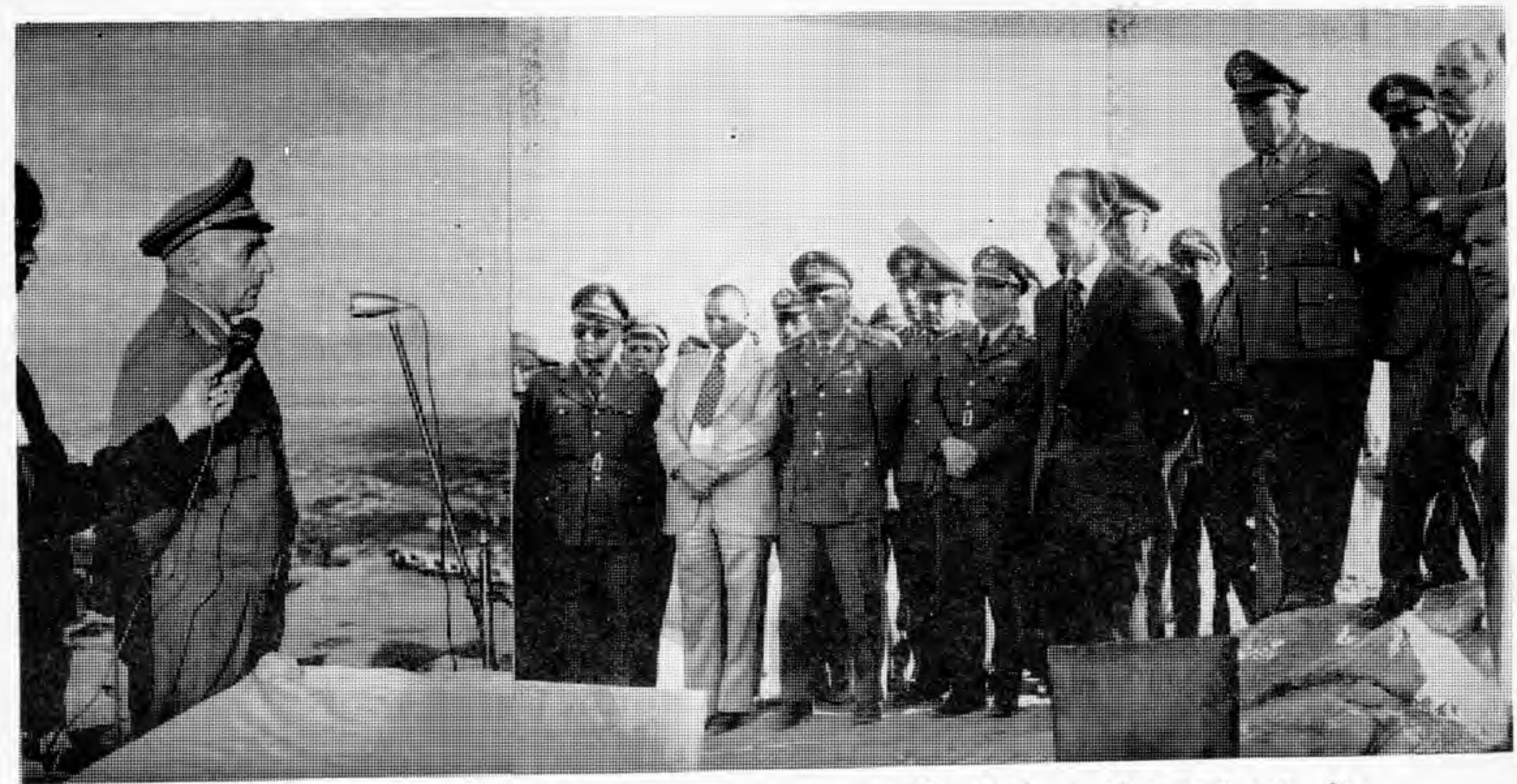

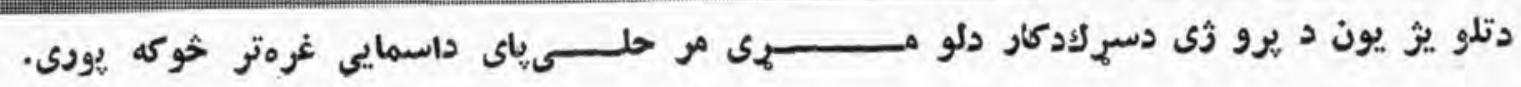


عينحال كَى بيه هيو ادكى ديبن المللى آث انسو نو دنمايثد كانو هِه فعا ليت كى

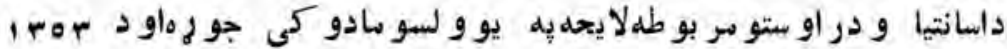

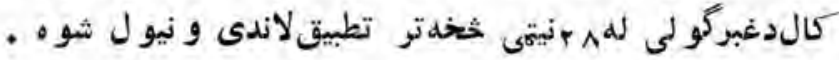

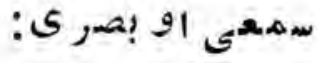

داجيىزمونبودنو لنى اكثر يت لاتو اوسهيو رىدليكك لو ستدنعهت خخه بى برخىدى-نو جهو رىدو كتدسمعى او بصرىخدنتونو دلارى دخلكو

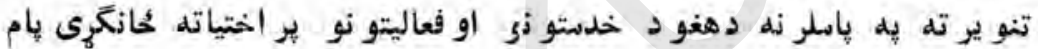
سا تلى دىدهمدىضرو رتله سخىداطلاعاتو او كلتوروز اروت كر ار

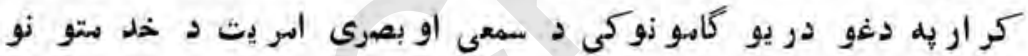
بر اخو الى تر لاس لاندى و نيو:

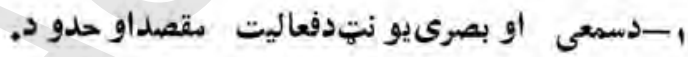

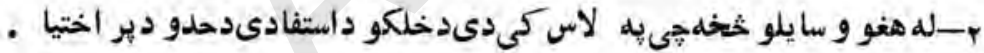

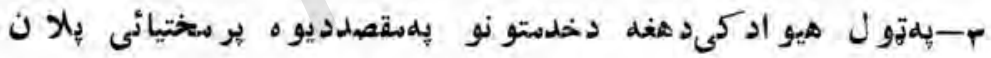
جو هول البته ددغه يونت سقصد وطنو الو تلهيه تير هياد لوىيو توبنارو نو

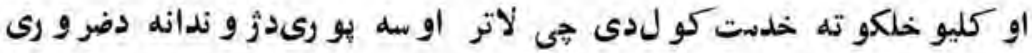

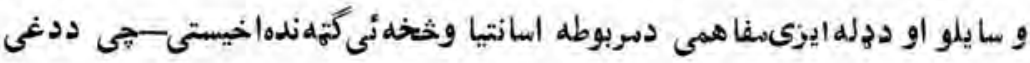

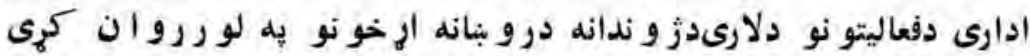

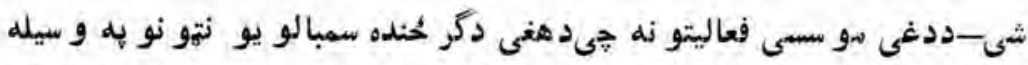

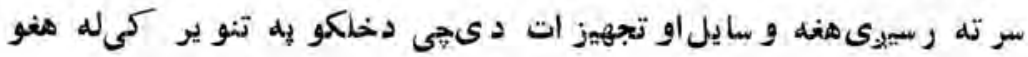
خخه كار الخيستل كيرى. ددى.قصدديارِز يارو ووستل شو شيى دد و لتى 


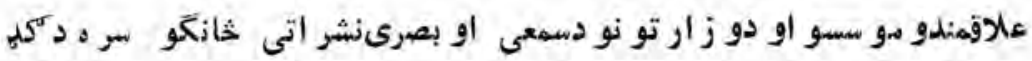

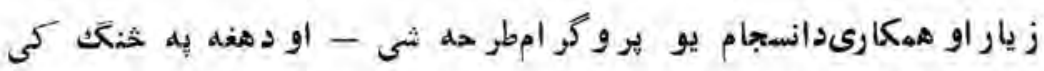

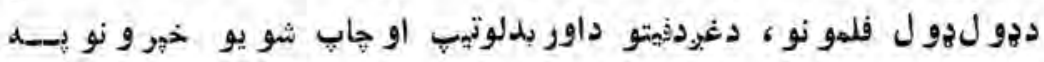

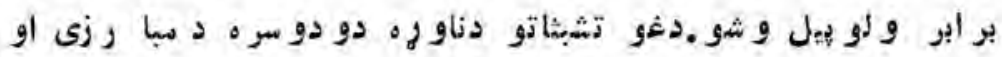

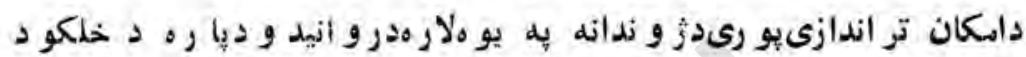

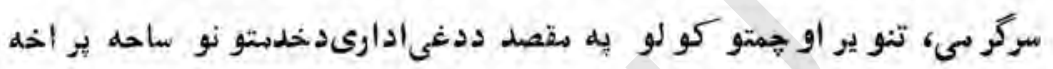
كر.

دجمهو رى نظلام دلمر در اختو به لو سئيو خلو رو كلمو نو كمدسمعى او بصرىخدنتو نو لنهيز بدى بهدول دى : بهري

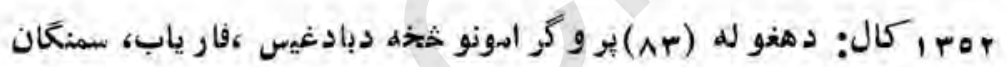

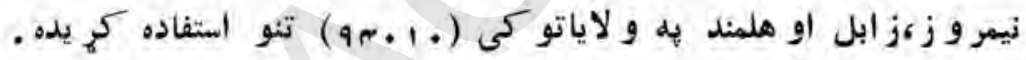

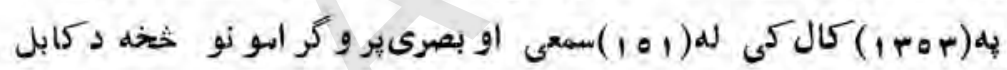

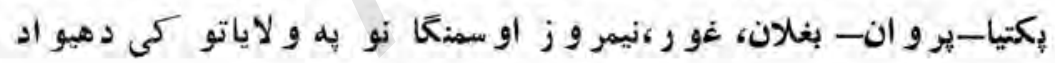

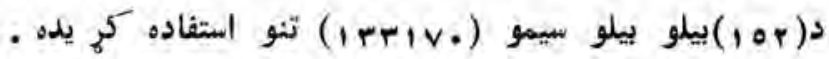

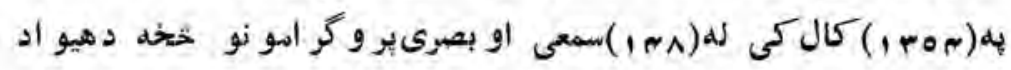

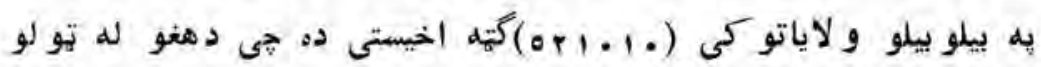

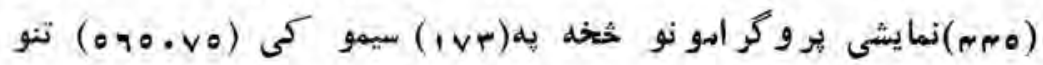

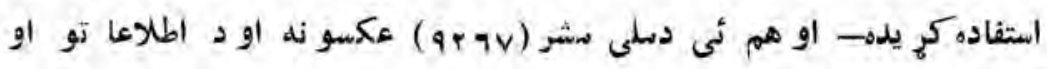

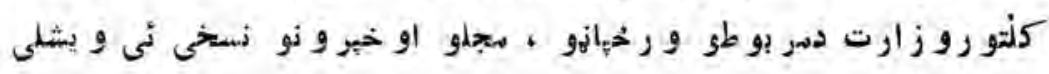




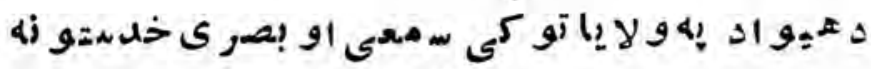

\section{J15irap}

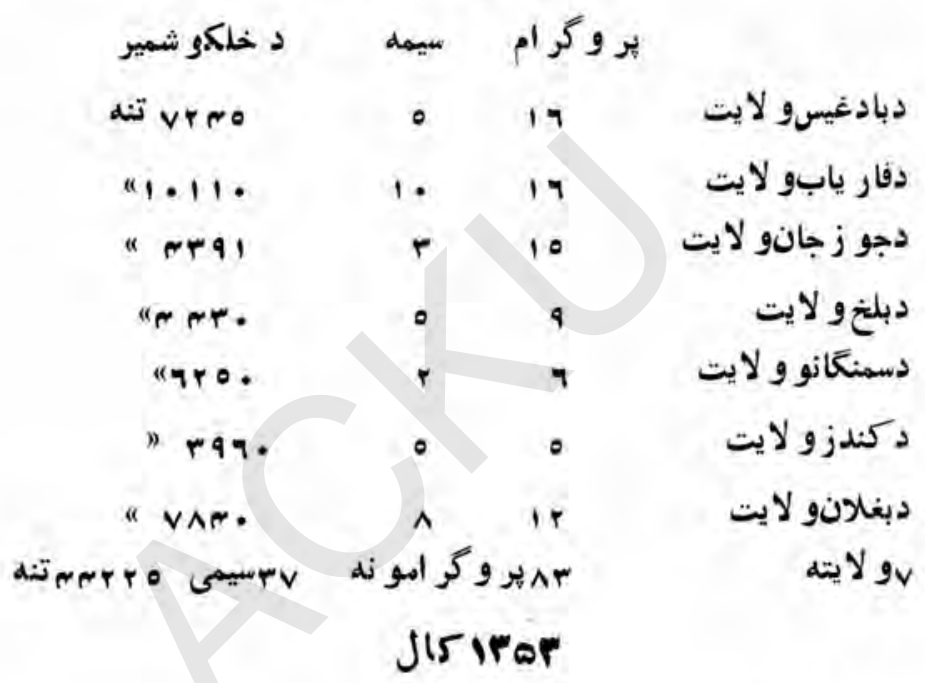

نيمر وز زولايت

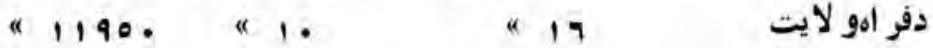

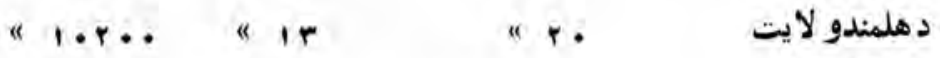

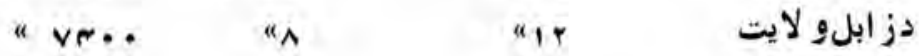

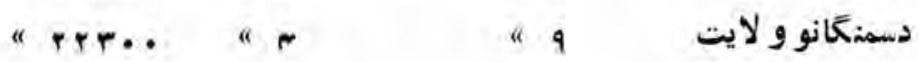

" " ل "

" دير و انولايت

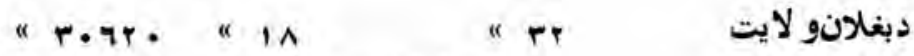

يو لايته 


\section{J15 IPAF}

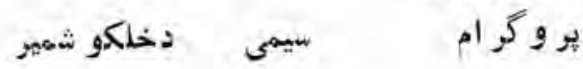

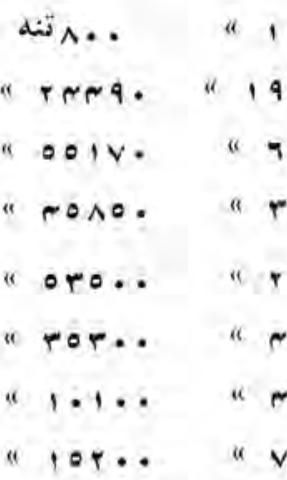

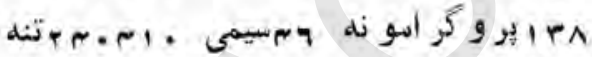

\section{J15 IFDQ}

"ror..

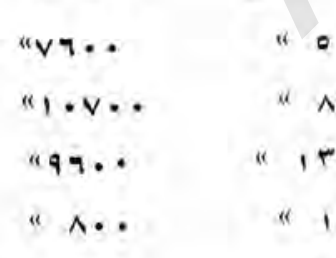

"rvr. *

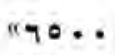

"r. * .

".. $9 .$.

$" v \ldots$

hijo $7 .+$ a i) $\%$

u $\%$

")

$18 \%$

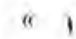

111

(1) 9

1 17

is $\%$

i 11

*

i1 17

a 9

40

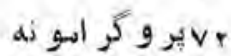

دزيمر هار و لايت ديكتياو لإيت دغو رو لاديت دابل

دمنانمانو و لايت دنيمر و زو لاليت دبدخشانو لايت دتخار و لاديت هو لايتة

دكابل

دنَّكر هار و لاليت خز ابلى لايت دغز ني لا لايت

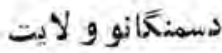
دغو ر ولاليت 2i دارز كانو لا لا يت

. لو كو و لإيت , 
بلهينحال كى دسمعى او بصر ىخدمتو نو دير اختيا انكشافى بلان جو رشو

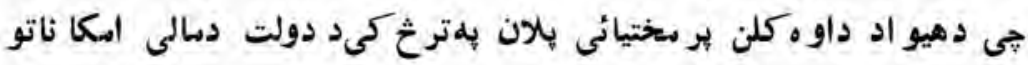

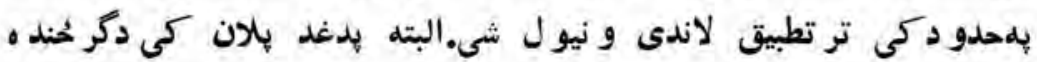

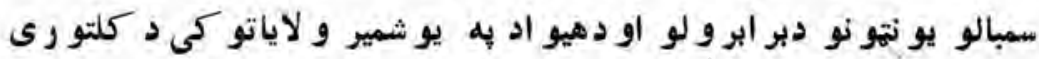

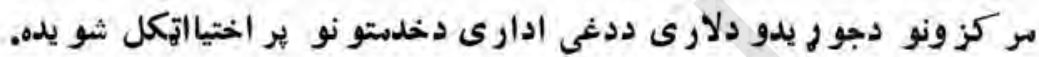

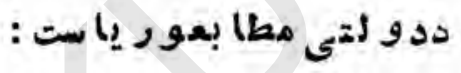

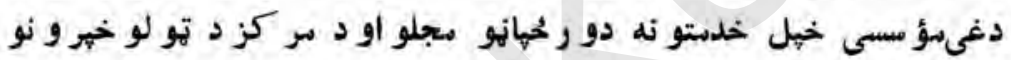

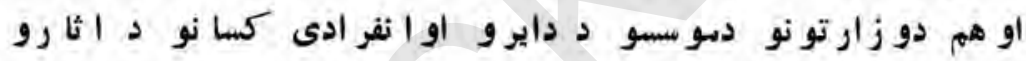

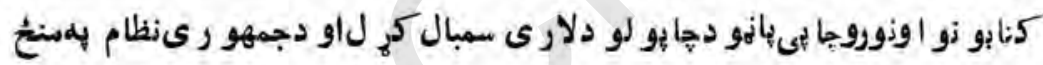

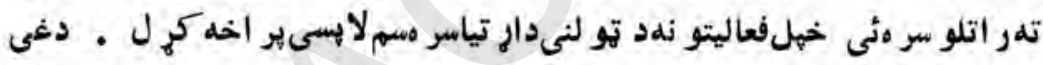

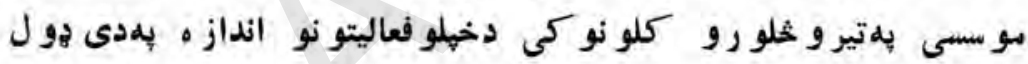

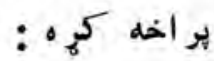
: Jisirar

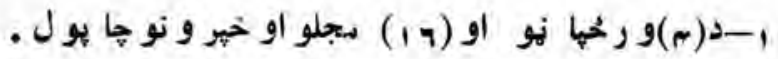

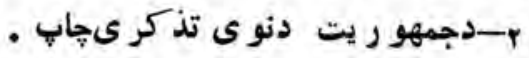

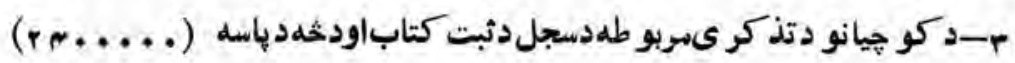
متفر قهبانو حايول .

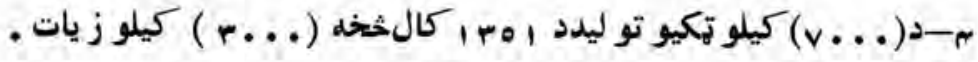

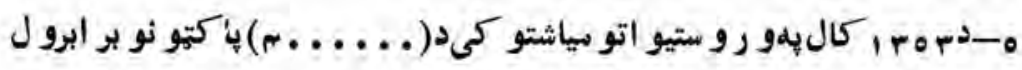

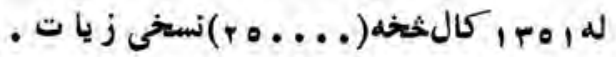




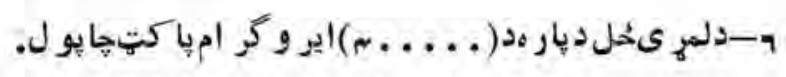

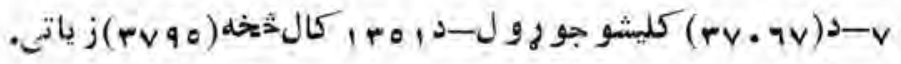

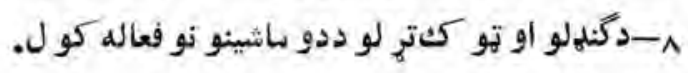

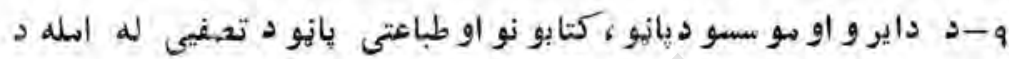

$$
\text { (1 (1.....) }
$$

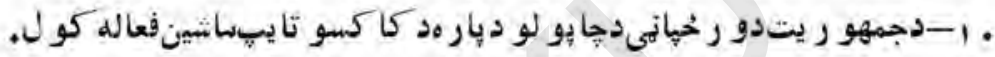

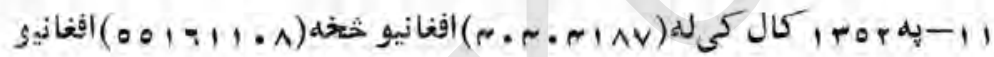

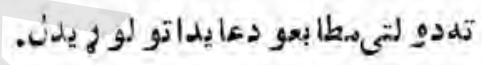

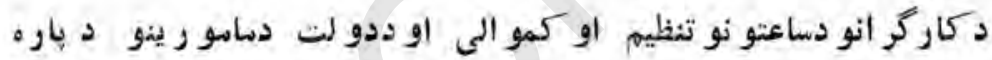

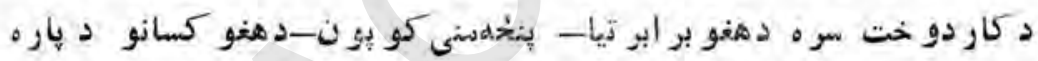

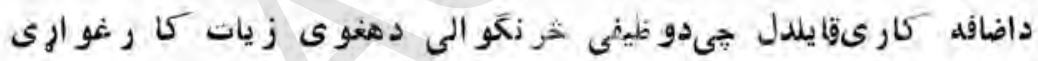

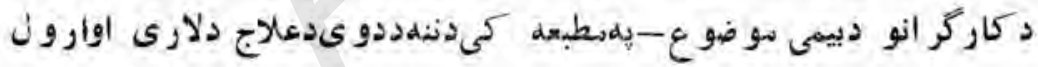

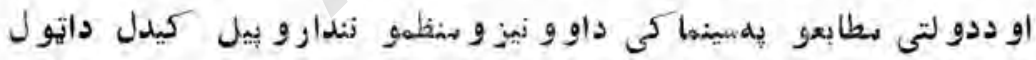

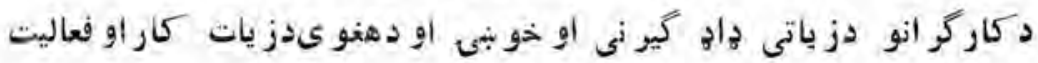

$$
\text { سبب شو يدى . }
$$

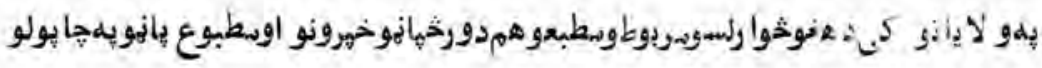

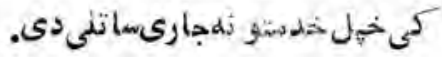

$$
\begin{aligned}
& 5 \text { J15 I Far? }
\end{aligned}
$$

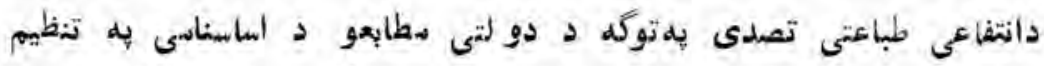

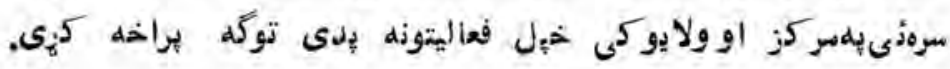




\begin{tabular}{|c|c|}
\hline$\left(v_{0}\right)$ & دو لتى نطابِ \\
\hline
\end{tabular}

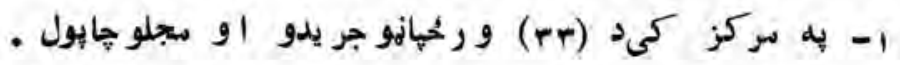

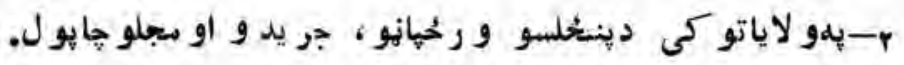

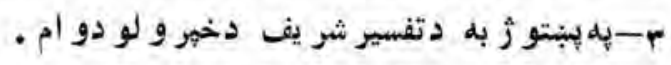

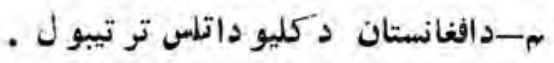

$$
\text { ه-د تيلفو نلاربيو د. }
$$

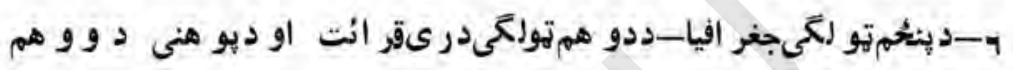

$$
\text { تو الخى حساب إيو ل. }
$$

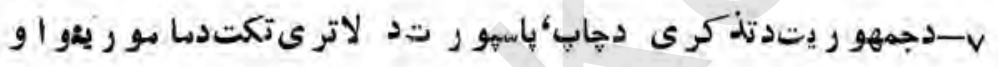
كاركر انود كو إيون ، د دول هول كاليز واو دو اير و او نو سسو دمهر و نو دجآ دو ام.

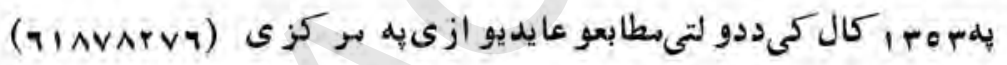

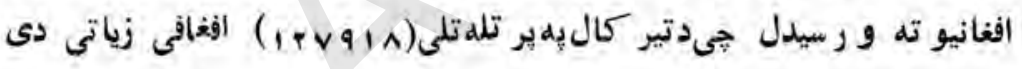

$$
\text { : } 515 \text { IFAfs? }
$$

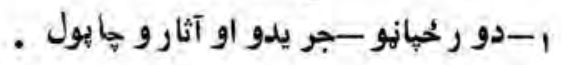

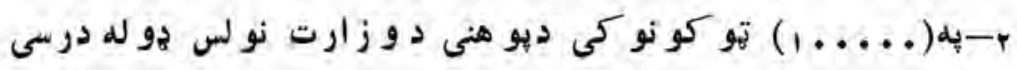
كتا بو نه

ب- د( rr) اثر و نو خا بو لد بيهقى دكتابخايو لو دمو سسى لهخو ادتار يخى - خير و دسيمينار و نو دجو هريد و بلهمناسبب

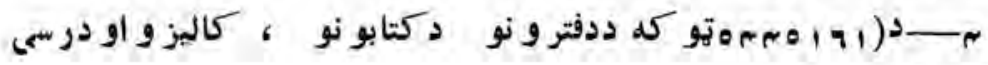
كتابو نو جابول ل 
الطاعاتى او كلتو )ى اجر آتى

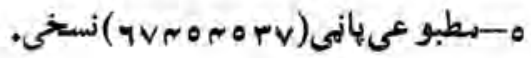
- كليشى (rtava)-

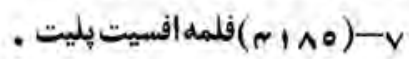

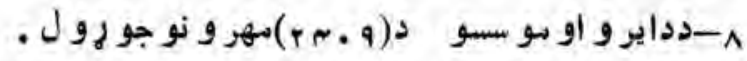

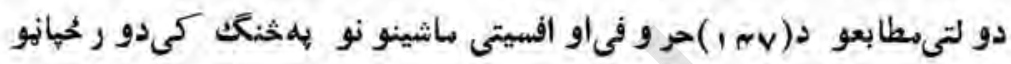

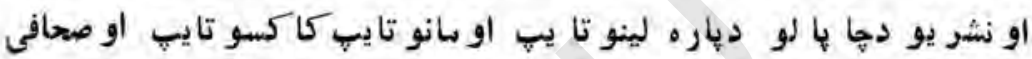

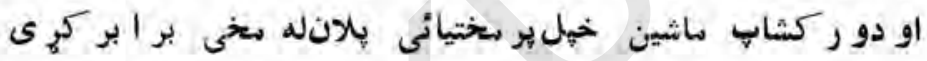

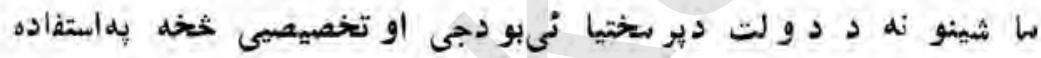

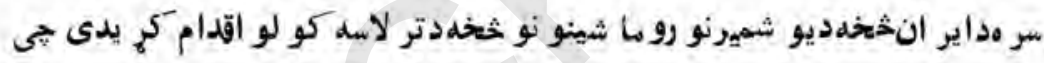

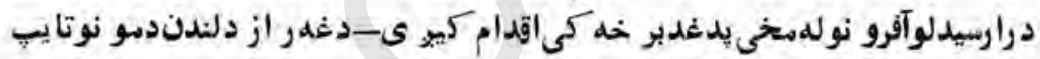

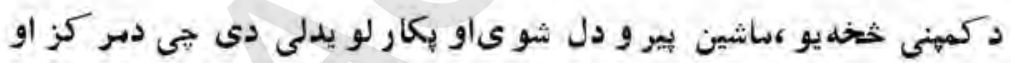

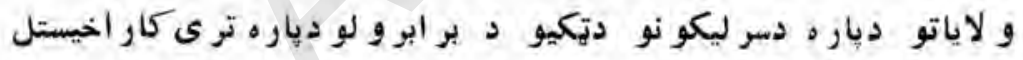
كيبر ى.

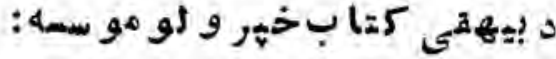

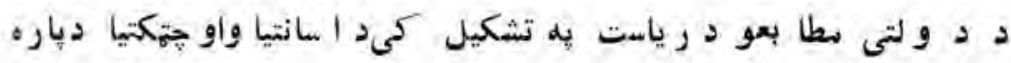

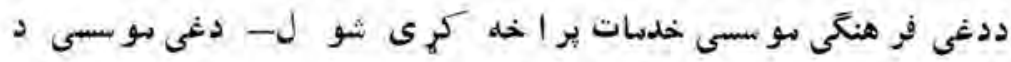

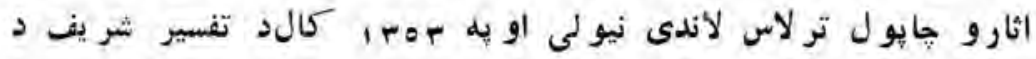

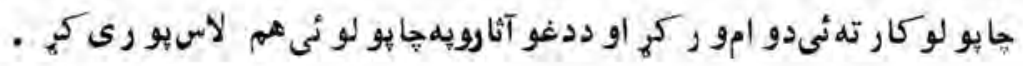

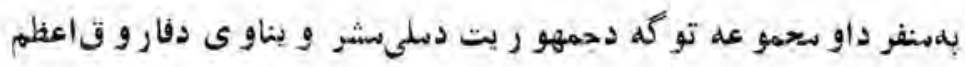


(رض)د كتابدو همتو كت د افغانستان (ييشليكت) د(جمهو ر يتيهيلوشو كى) (عقابز رين) دمو لينا جلال الدين بلخى دسيمينار دمقالو اوو يناو مجمو عه

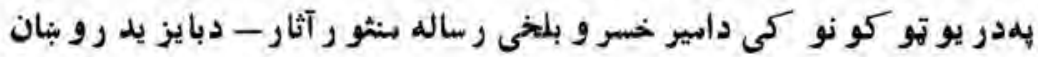
روبان رساله-دسو اد او بطبو عاتولسر سالى - دبنحو دبين المللى كالى لمال

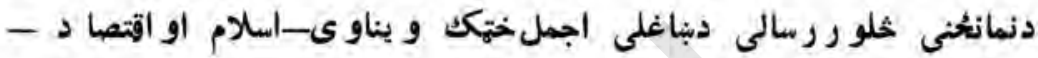
دجمهو ريتدلوبي ىجشن لسالبو بو نه -خنكه بنهر ايو ركيدى شو كتاب

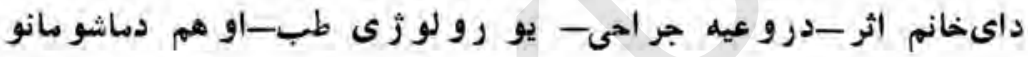

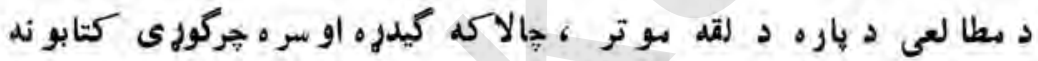

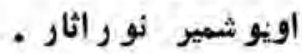

\section{افضان اعلازات}

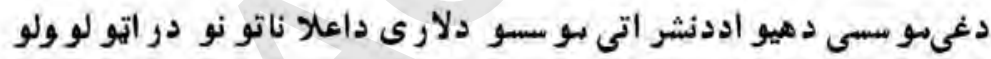

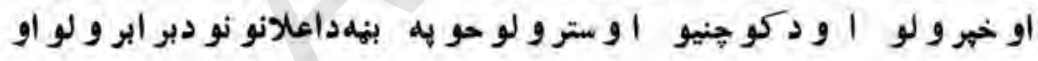

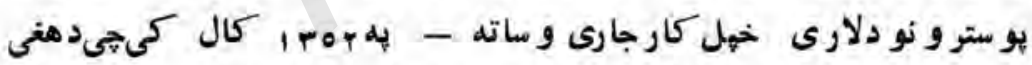

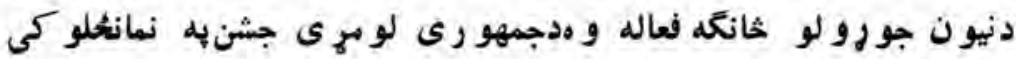

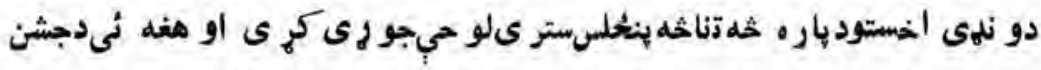

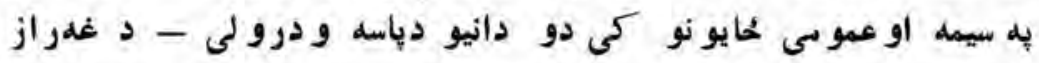

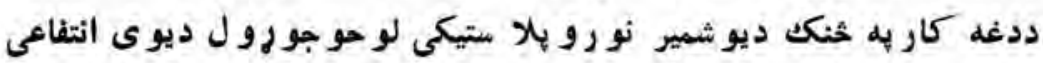

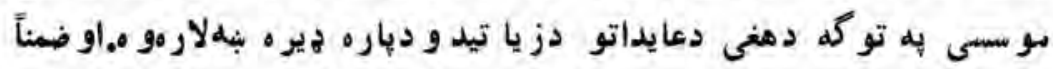

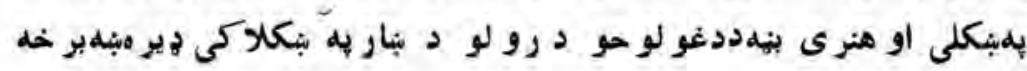




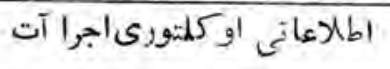

$(\vee \wedge)$

دورخيانو اوراديو افغانستان دلارى اوهم ديار كونو اوواتونو

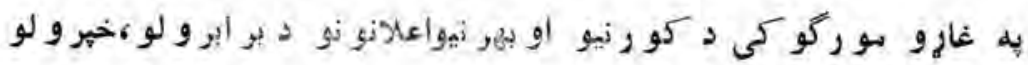

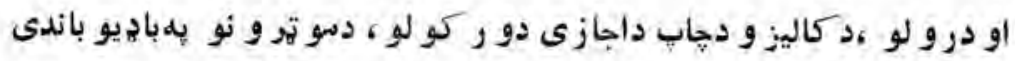

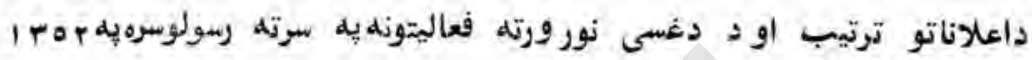

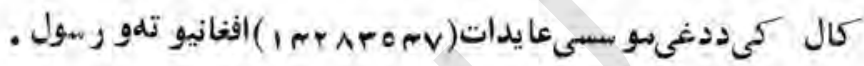

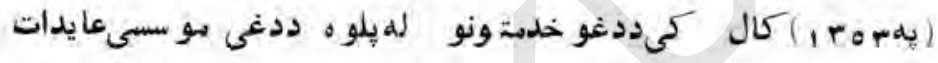

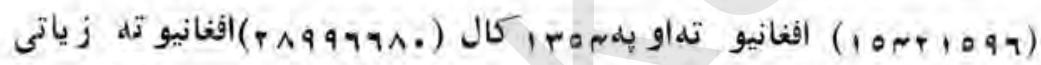

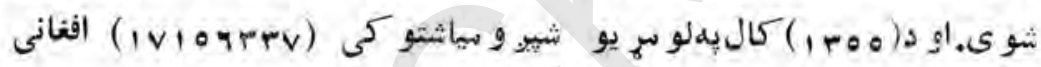

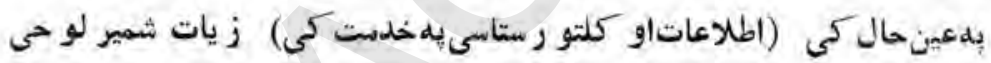

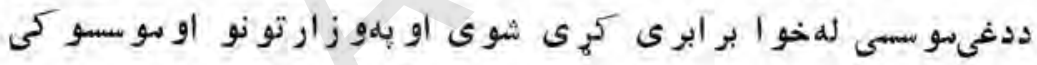

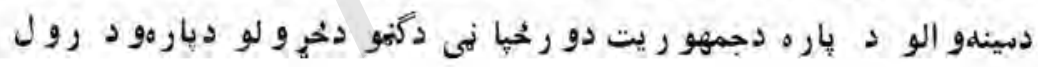
- شوىى

افغاناعلانات دخيلى لايحىسر ه سم كلمو رنيو او بهونيو هر اجعوخخه اعلانو نهاخلى اوديوىثيا كلمىفيصدى اخبيتلو سره هغd نشر اتى موستو

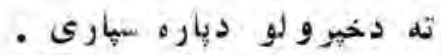

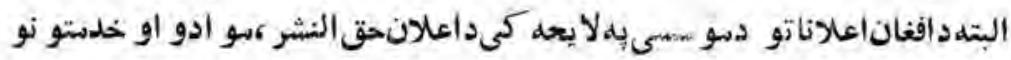
او دهيو اد دصنايعو او معصو لاتو تشثو يق رو حيه يهنظر كىده. 


\section{كلم=ورى فعاليتو نه:}

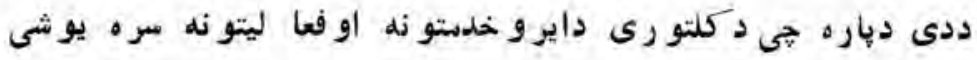

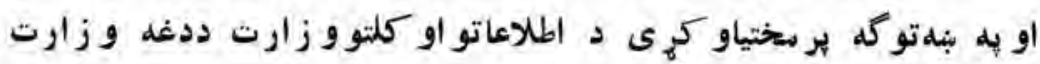

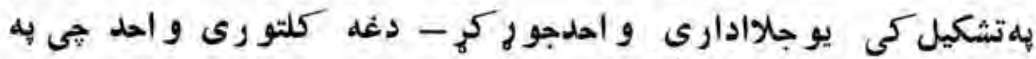

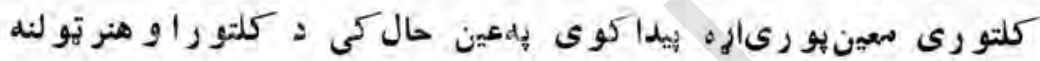

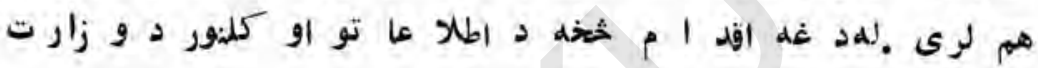

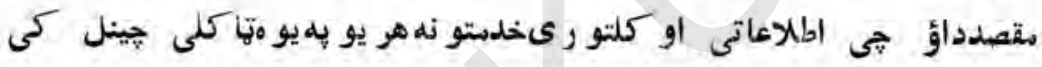

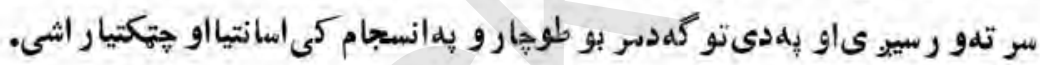

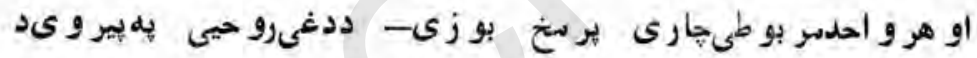

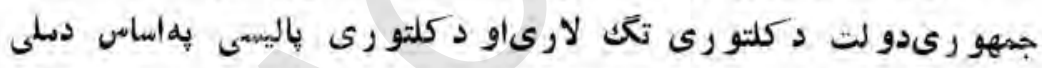

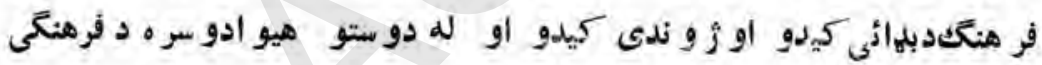

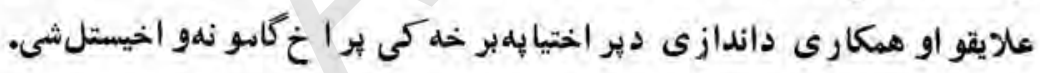

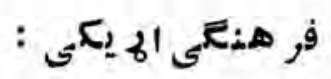

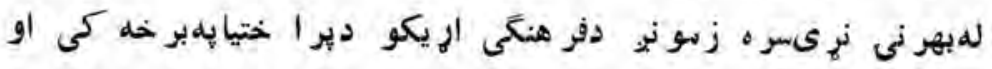

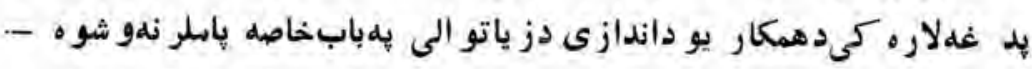

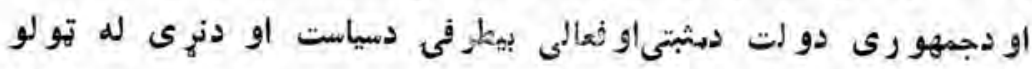

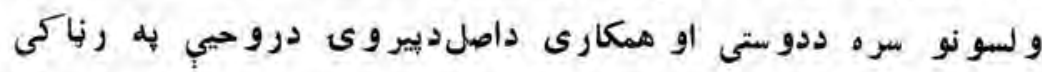

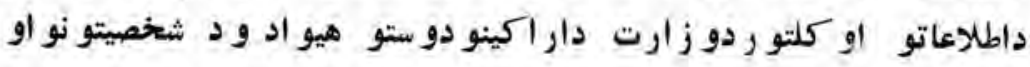

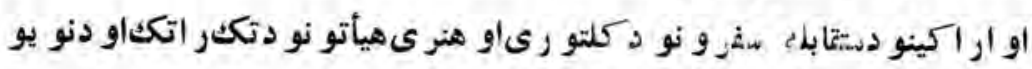

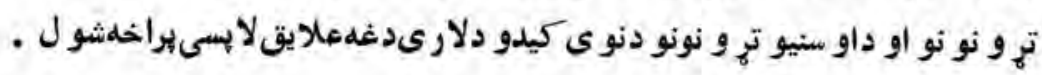


الطاءعاتى اوكلمتو رى جاجر آت

دنوىنظامدلمو در آختو ر اهيسىلهدغو هيو ادوسره كنتورى تئو نونه لاسليكك شو يدى . - الم

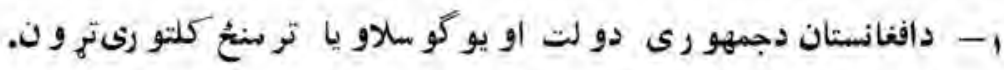

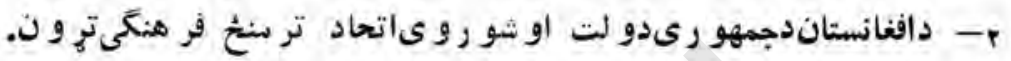

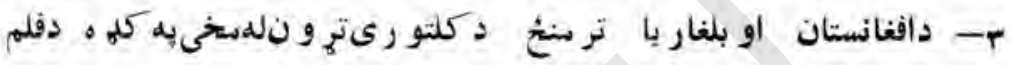
جو هولوقر ارداد .

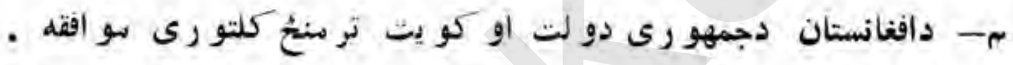
•- دافغانستاندجمهو رىدولت او دهند دجمهو ريت تر سنعُد تا ر يخى ابداتو دتر ميمتر ون .

و- دافغانستاندجمهو رىدو لت اوايتاليا دحكومت ترسنغ دتار يتخى آيداتو دتريم ترون.

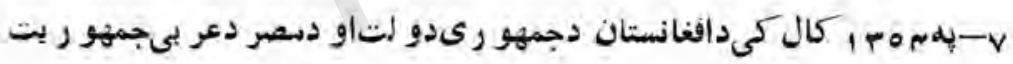
تونئ كلثو رعى القه.

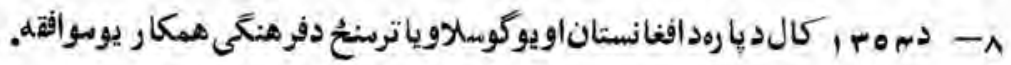

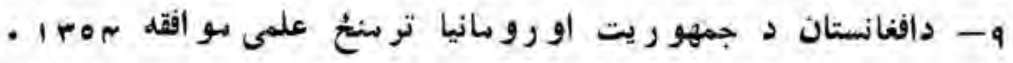

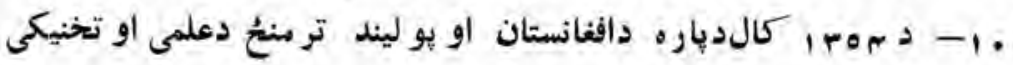
همكار يو سو افقه .

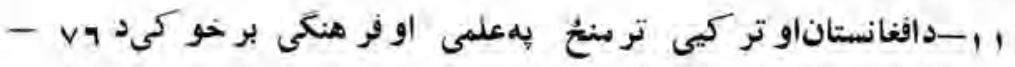
- AVV 

$(\wedge$,
فرهن في الهيكى

(1, (1)

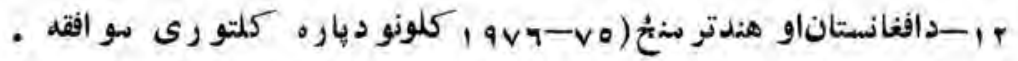

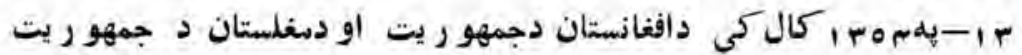
تر سنئ همكارى مسو افقله.

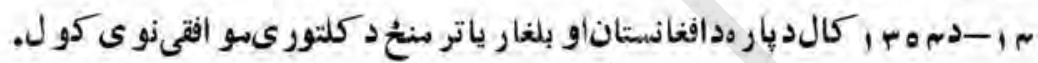

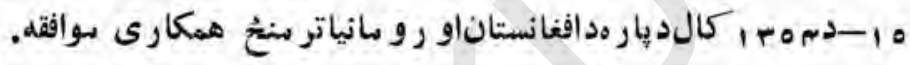

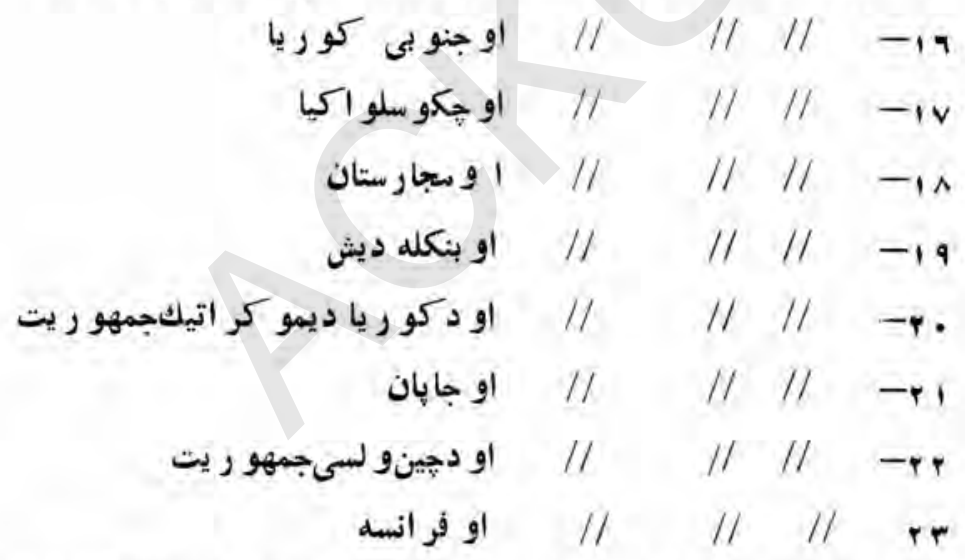

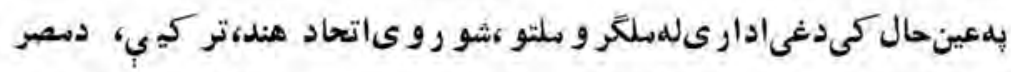

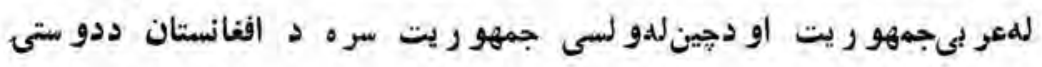

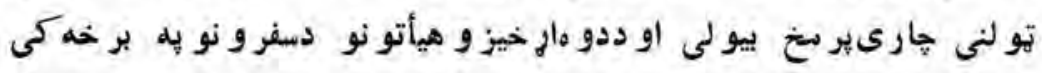

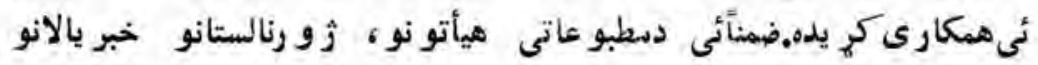
او عكساخيستو نكو دسفر ونولارواو اره كرى او ددغه وزارت له نو رو له مو سسو سو مدفو هنكى الريكو دلارى ديونسكو خدنتو نه توسوه كييرى 


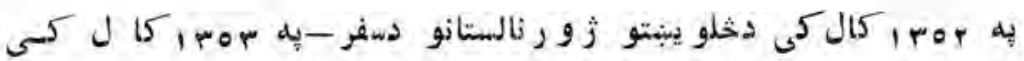

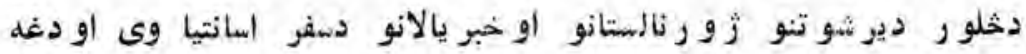

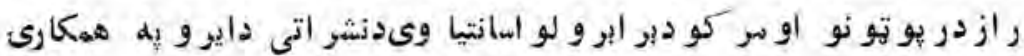

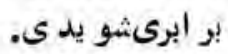

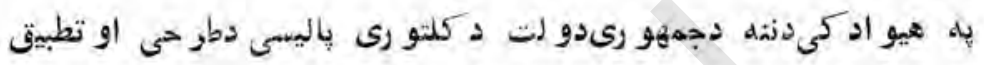

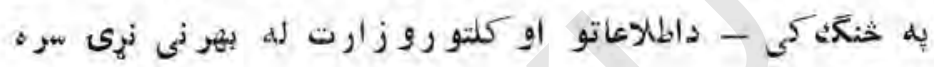

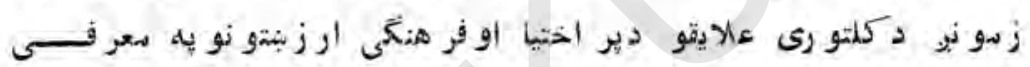

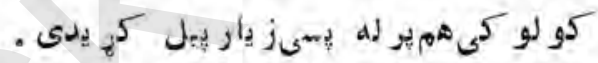

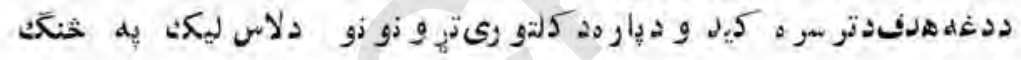

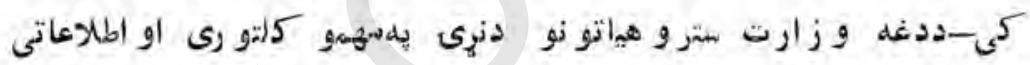

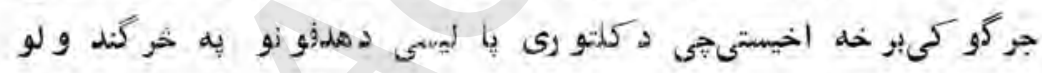

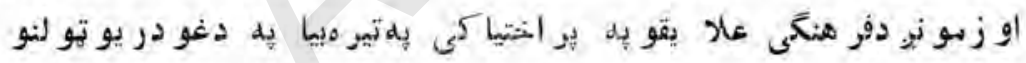

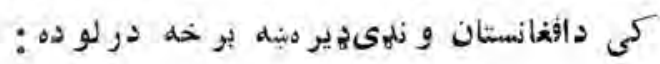

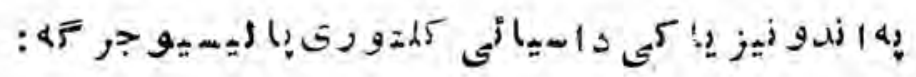

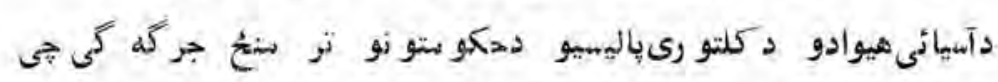

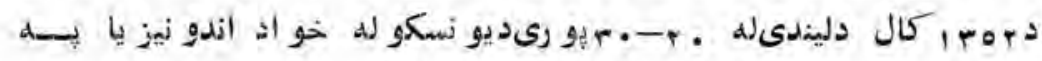

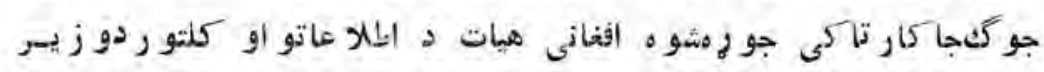

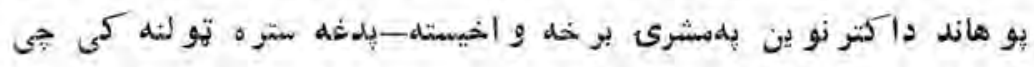

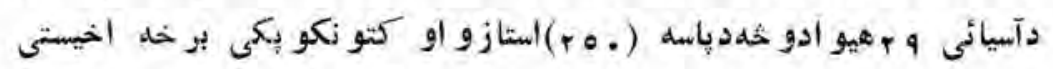

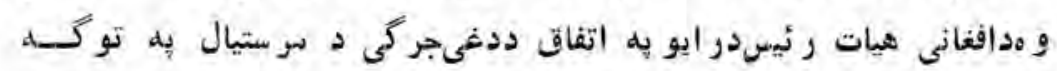



$(\wedge r)$
فر هن كائيكى

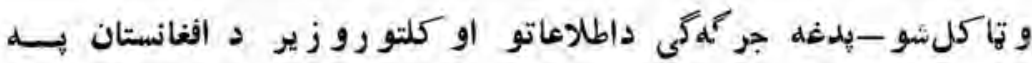

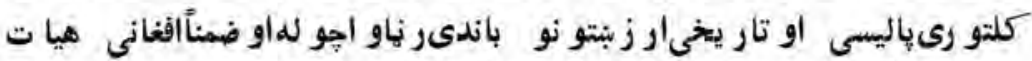

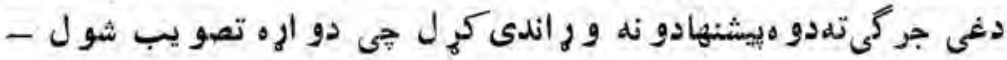

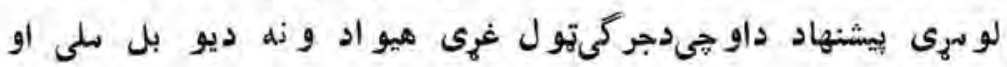

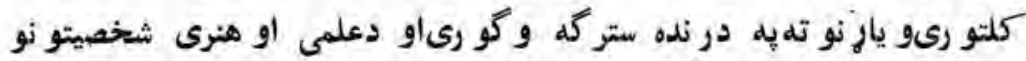

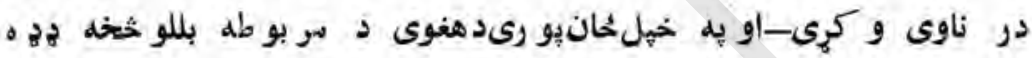

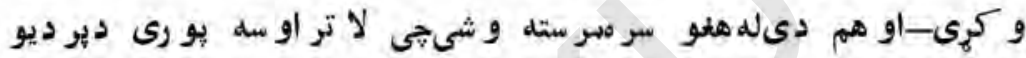

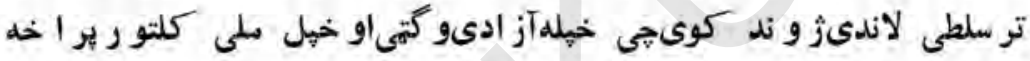

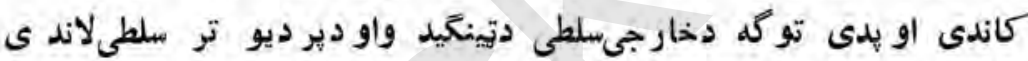

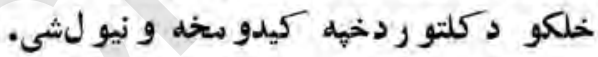

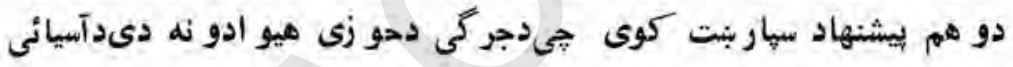

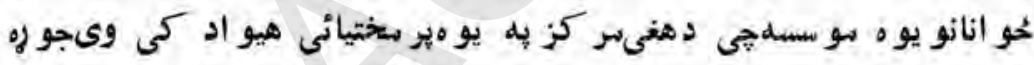

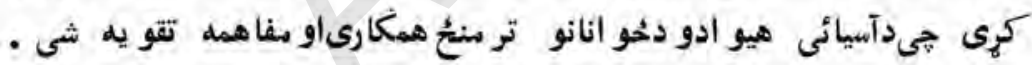

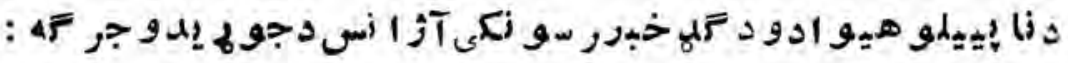

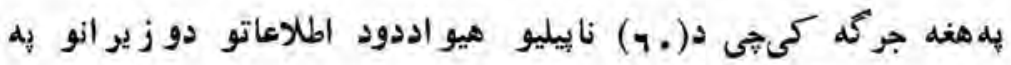

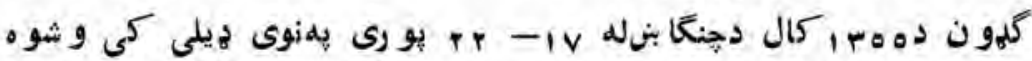

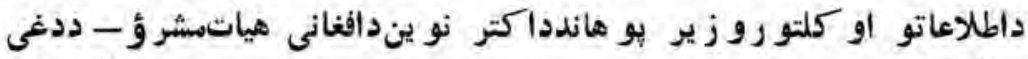

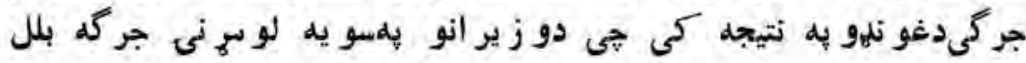

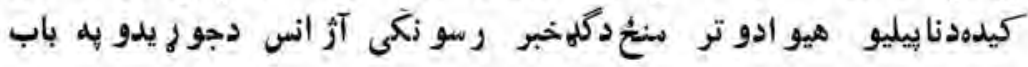

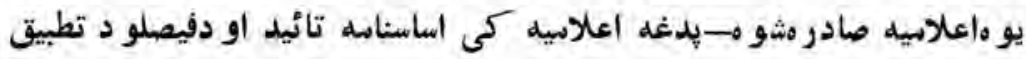




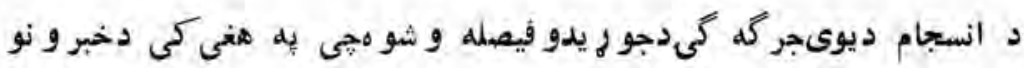

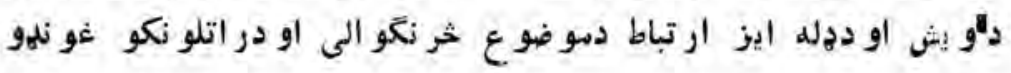

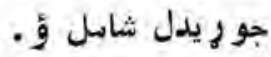

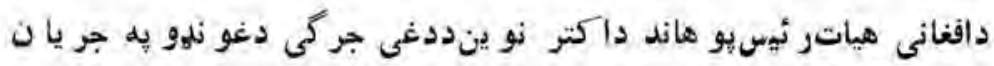

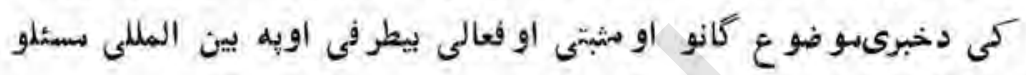

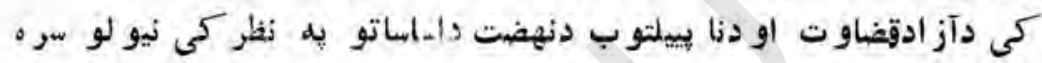

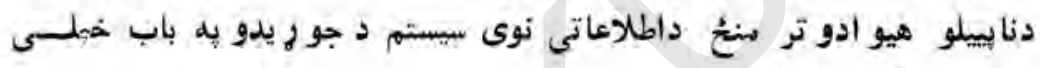

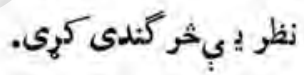

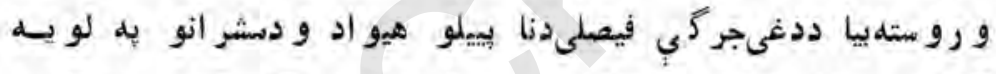

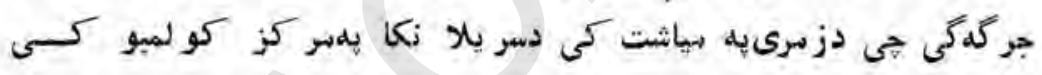
جوري شوه تصو يب ثوى .

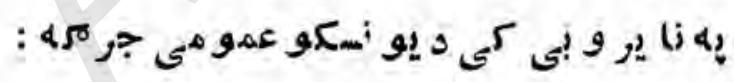

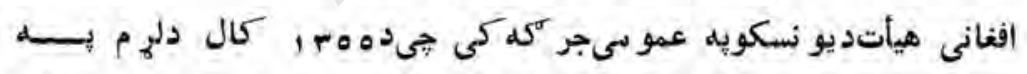

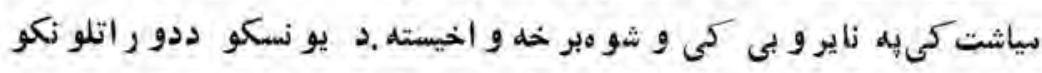

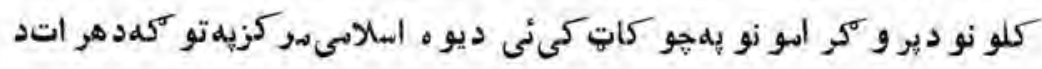

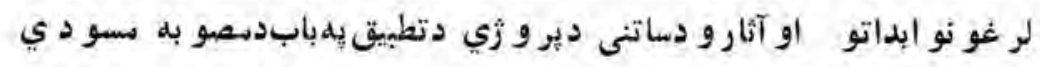

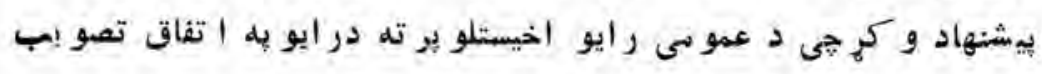

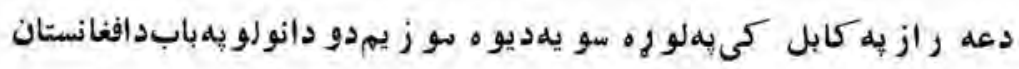



(^०)
زورهنى اريكى

دحكو ست ييشنهاد ديو نسكويه عمو بىغو نده كى داكثر يت لهخو اتصو يب

شو

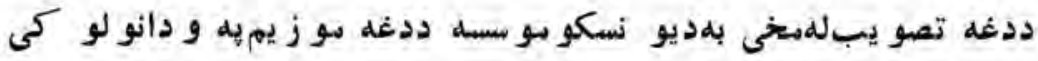

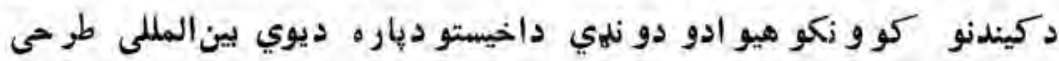

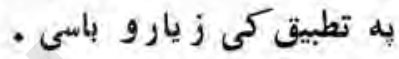

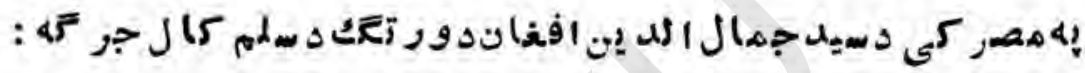

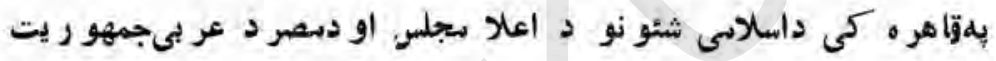

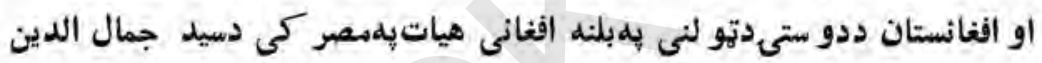

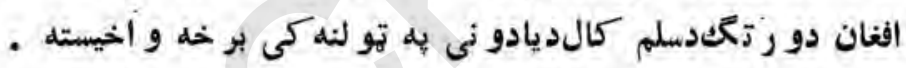

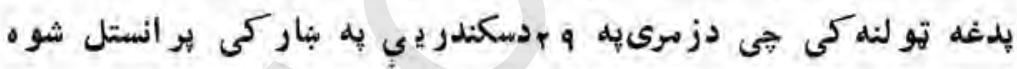

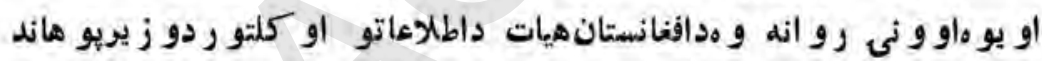

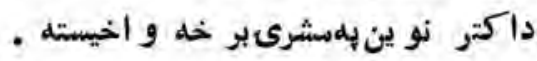

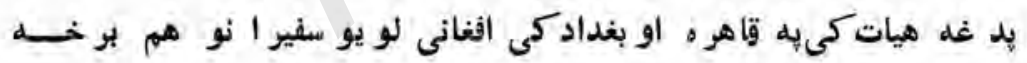
درلو ده. دسكندر بِيه تو لنه كى ددولت دبناغلى رئيس اوصدر اعظم بيغا م جيى

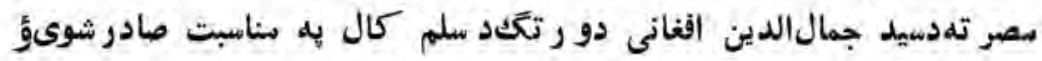

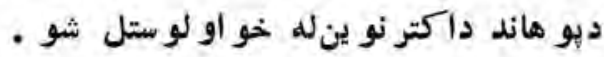

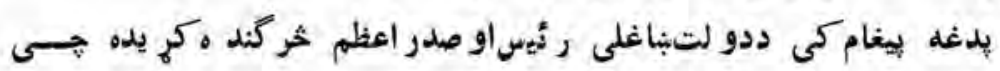

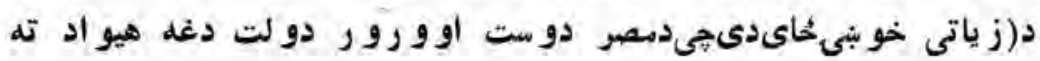

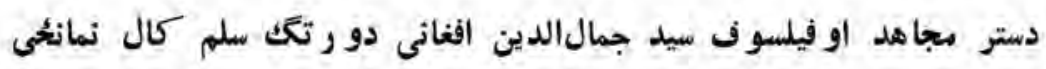




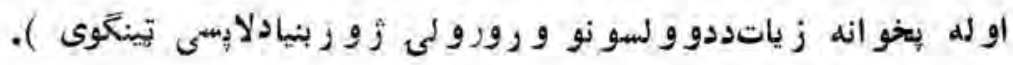

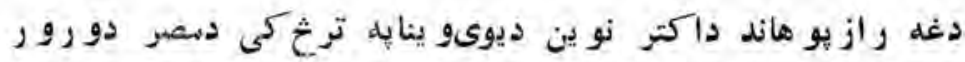

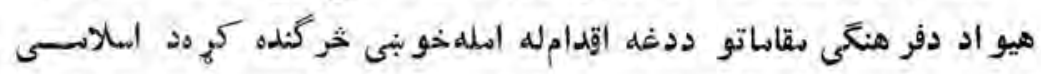

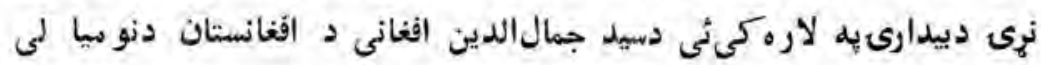

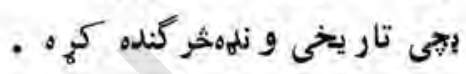

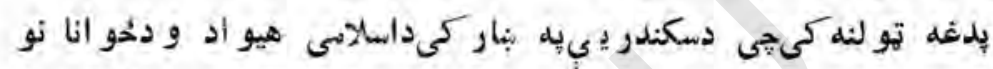

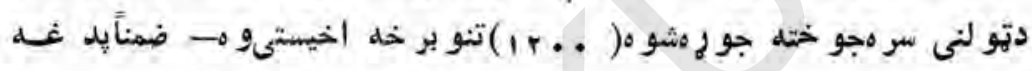

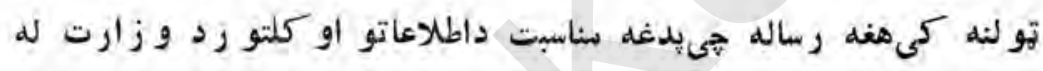

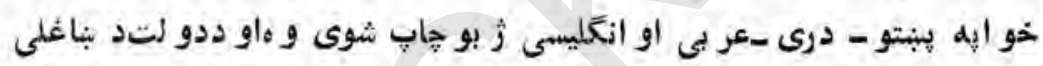

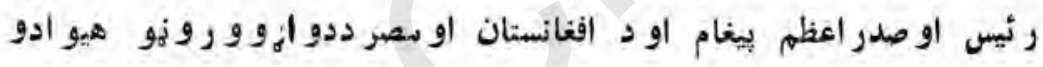

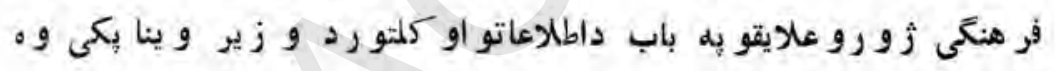
و و يشل شوه .

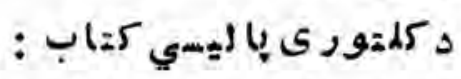

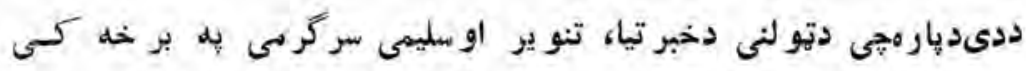

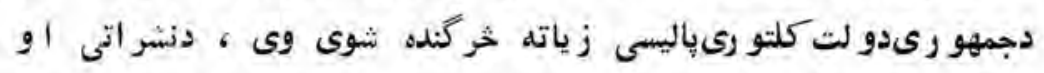

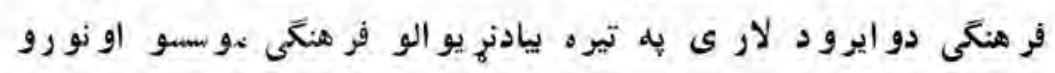

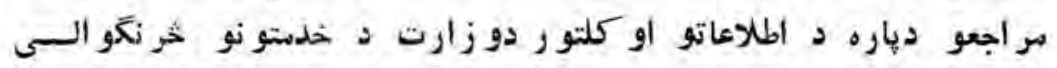

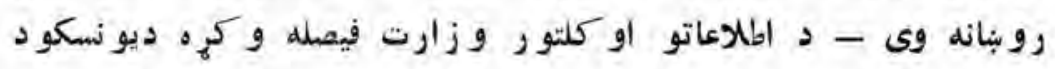

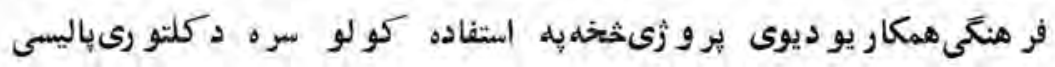

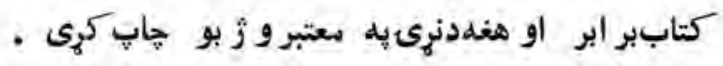


شو هغه كلتو رى با ليسى جي ددغله و زا ر ت له خوا به انغليسى ز به بر ابره

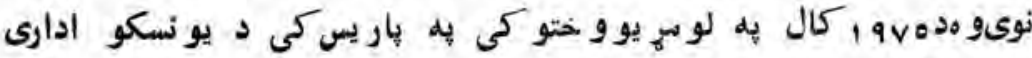

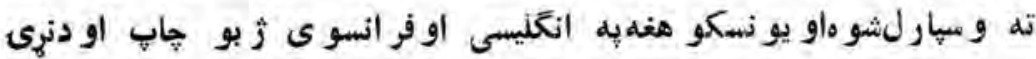

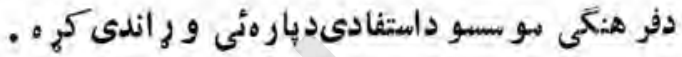

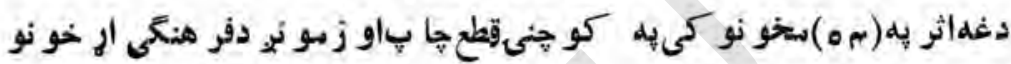

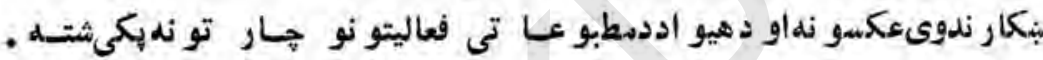
بهر تهد أفانى كلتورى او هنر ىهينتونو سفر:

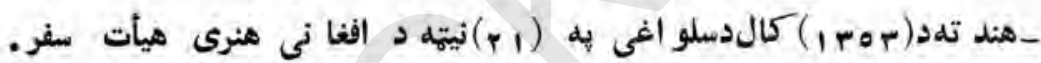

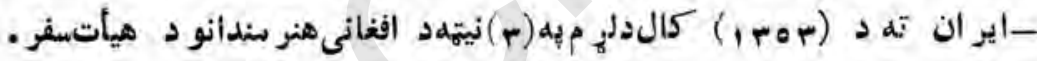

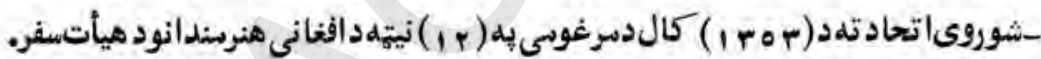

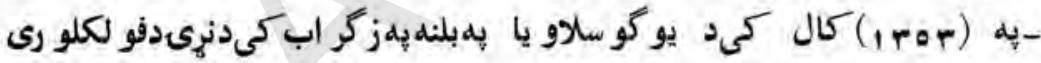

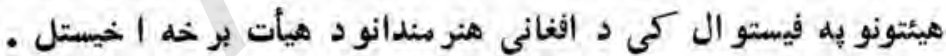

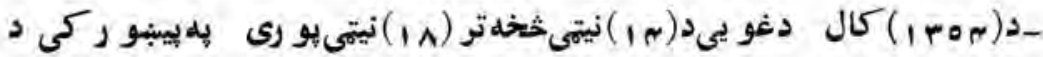

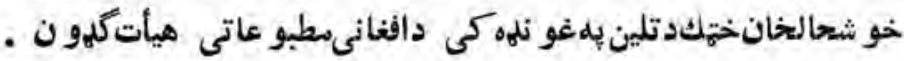

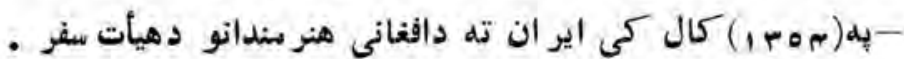

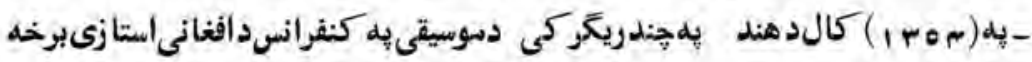

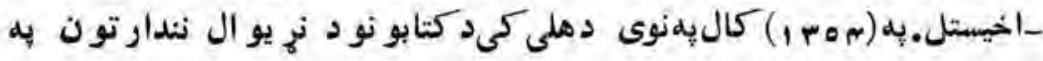
تر تيبولو كى دافغانى هيأت برخه ا خيستل .

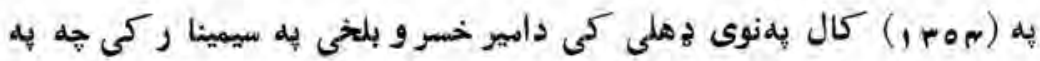




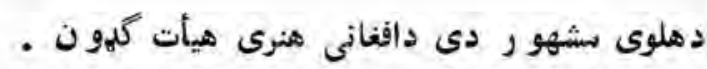

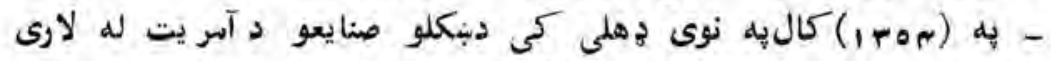

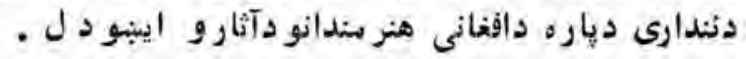

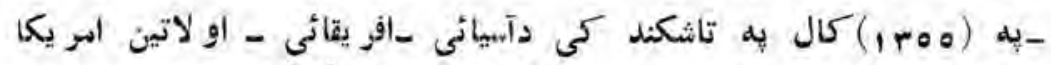

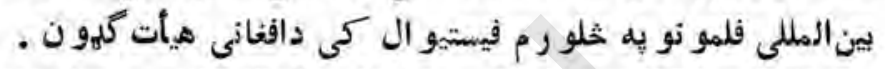

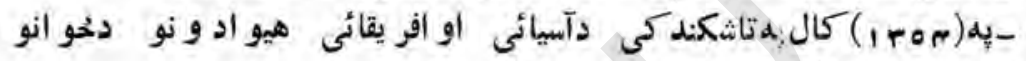

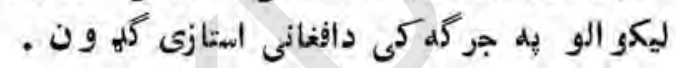

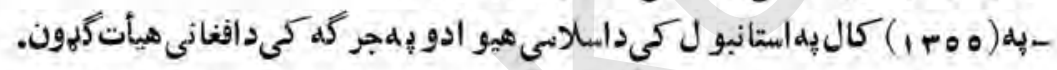

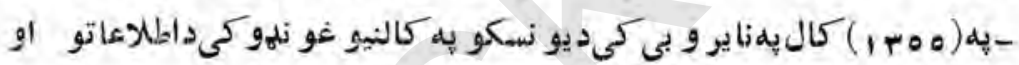

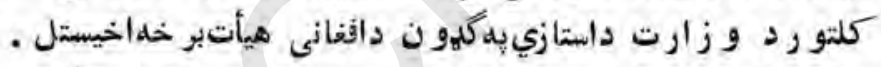

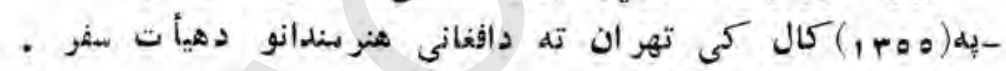

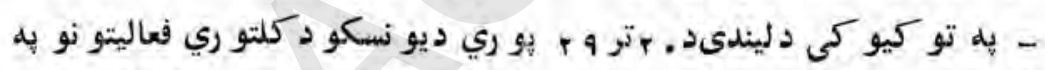

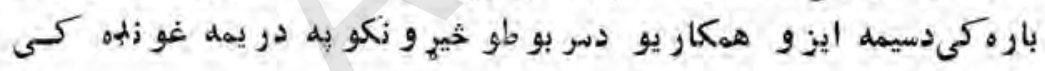
دافغانى استازي بر خله اخيستل.

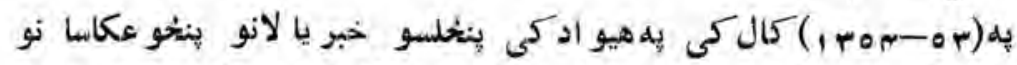

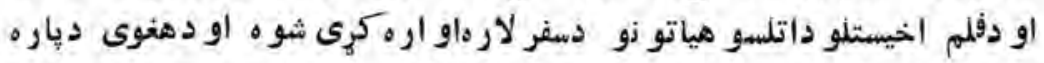

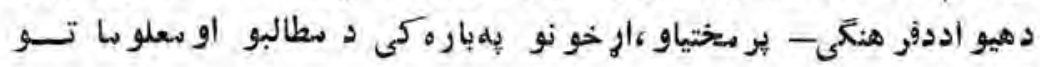

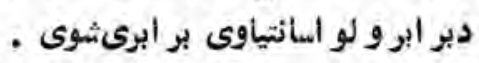

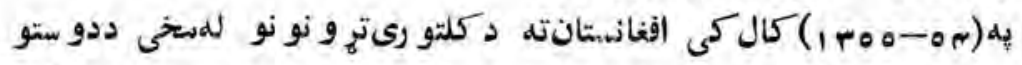

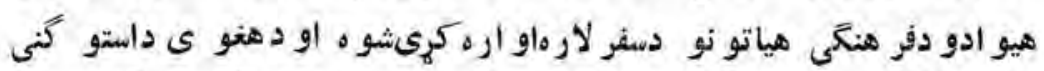

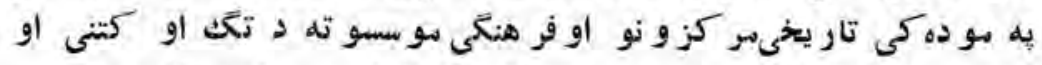

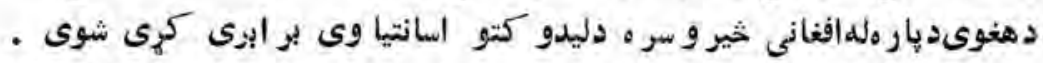

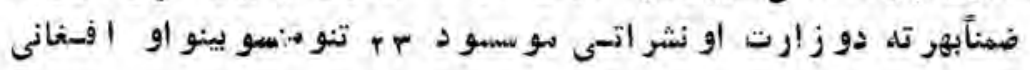




\section{$(\wedge 9)$

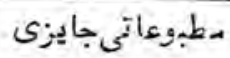

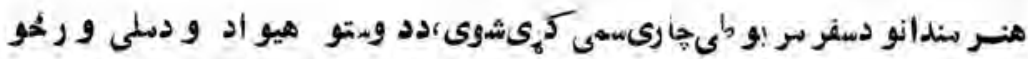

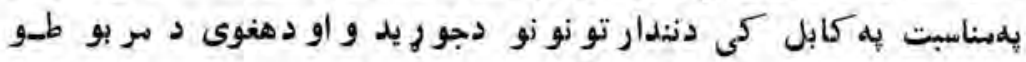

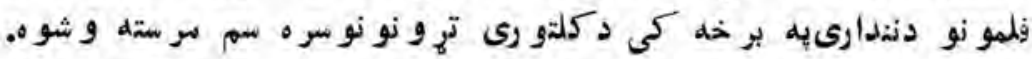

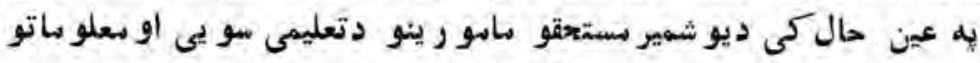

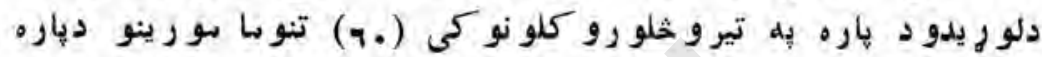

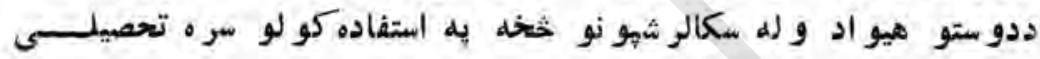

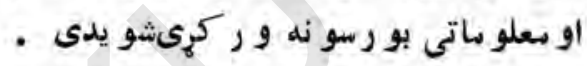

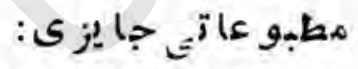

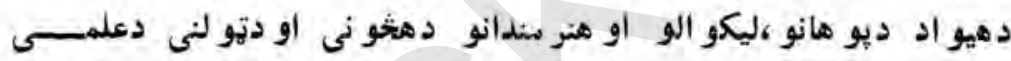

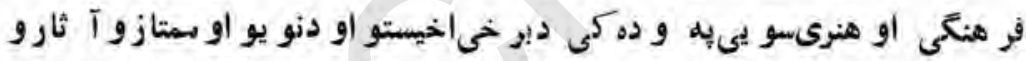

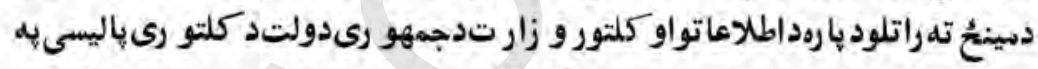

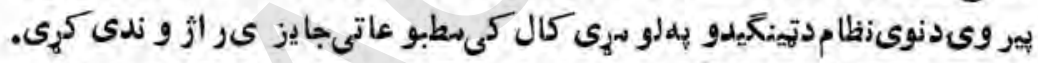

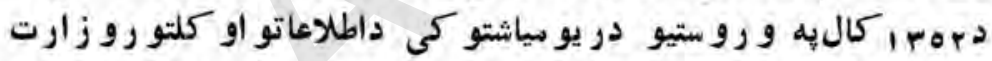

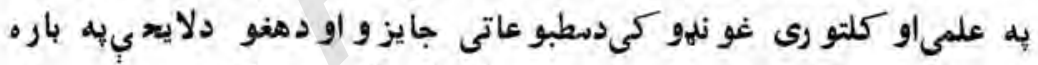

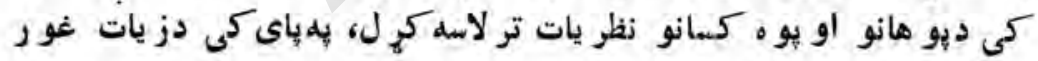

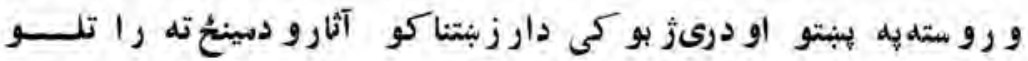

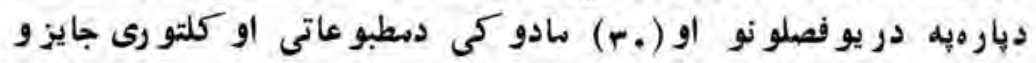

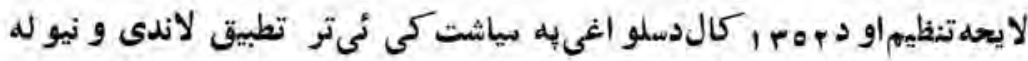

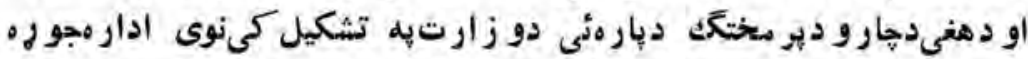

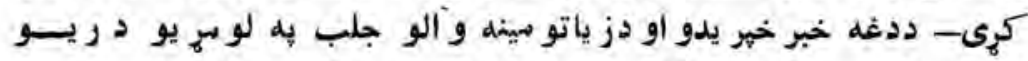

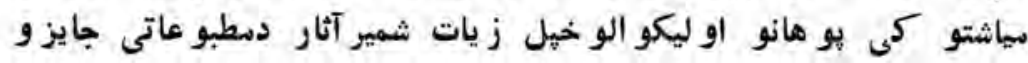
دكانديدديار مدغى ادارىته و سهارل .

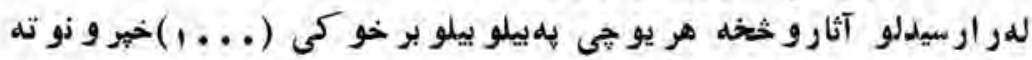




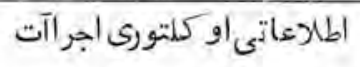

رسيدلدنظر دخاو ندانو ددر يو تنو كله خو او كتل شو ل او بدغلبر خله كسى

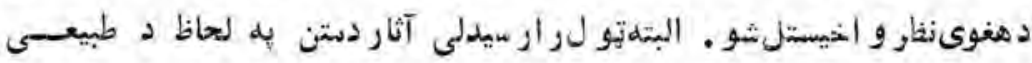

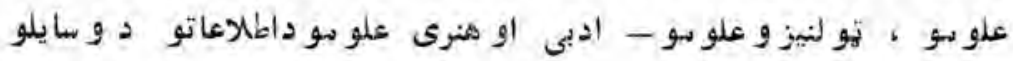

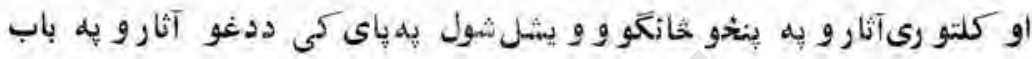

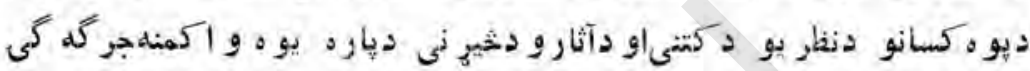

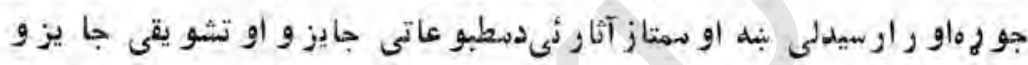

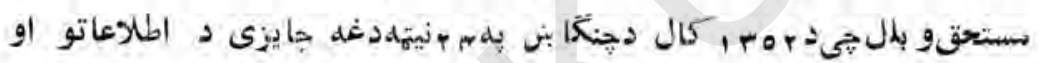

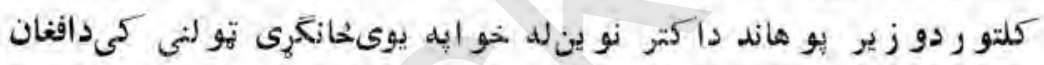

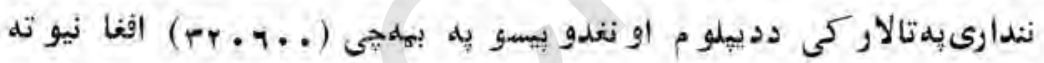

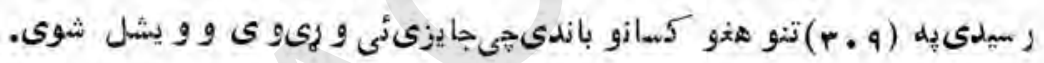

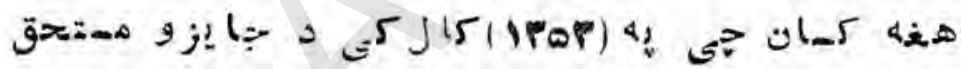
و ?!لز شول هغه

متند

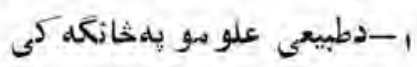
"r

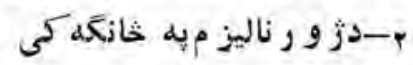

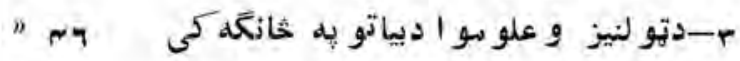

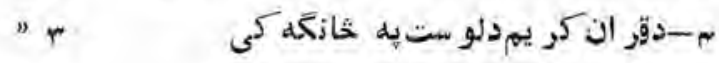
م جايزى

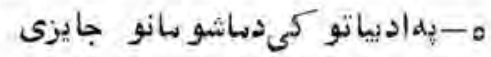

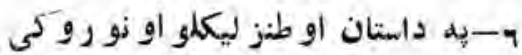




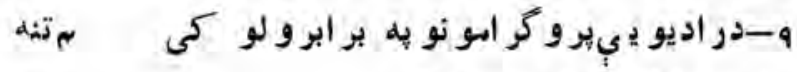

$$
\begin{aligned}
& \text { (1) } \\
& \text { • . } \\
& \text { "9 }
\end{aligned}
$$

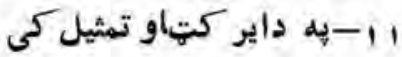

$$
\begin{aligned}
& \text { " }
\end{aligned}
$$

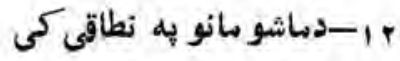

$$
\begin{aligned}
& \text { - }
\end{aligned}
$$

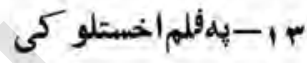

$$
\begin{aligned}
& \text { di } 19 \\
& \text { ك }
\end{aligned}
$$

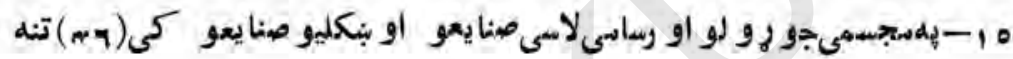
I 9 كى 19 :

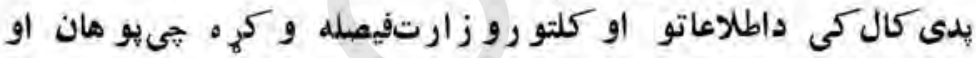
دقلم خاو ندان دداسىآثارو ليكلو او بو ابو و لو ته وهثوى يو اوكىدهيو اددير مختيا و او اساسى تحولاتو يه برخو كى د جمهو رى انقلاب دهدفو نو اودهغو دثبوتمر ستندوى وى-نود يو هانو يه همكارى ديو و و اكهن كميسيو ندجو ريدو يه نتيجلكمى به خلو رو فصلو نو او (10)

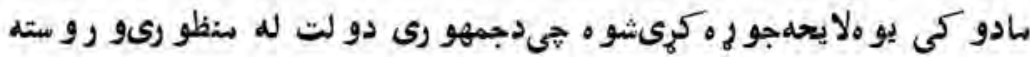

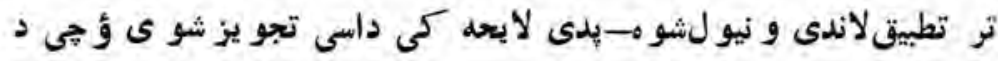

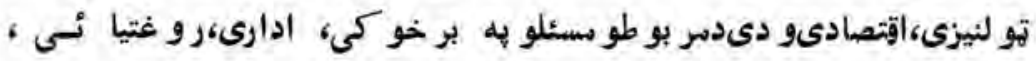
بنارو الى سو ضو عانو دوف هنكى او سياسىو د بى، تار يخى، جغر افيا ئىخير نو اود افغانستان دفر هنغك، دافغانستان د تار يخىى تحول لاو معاصر ادب او

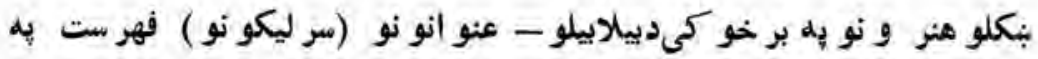




$$
\text { اطالوعاتى اوكلتو رىاجرا آت }
$$

او و فصلو نو كى ثرتيباو دنشر اتىهنابعو دلارى يو هان او بينه و الل إوى

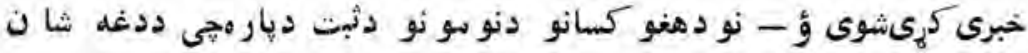

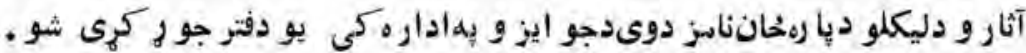

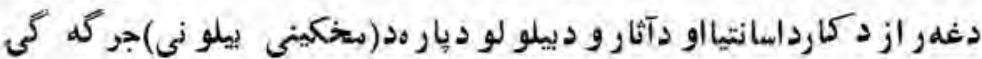
داطلاعاتو او كلتو ردو زارتله خو اجو رمثوه- جي آثار دثيمنى هياتته

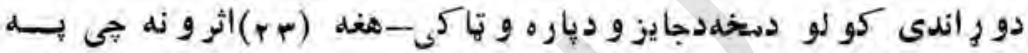

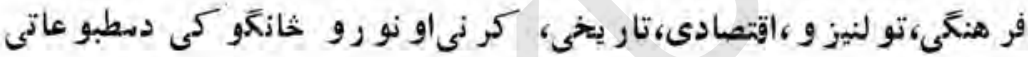

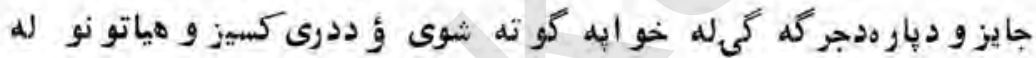

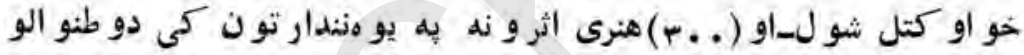

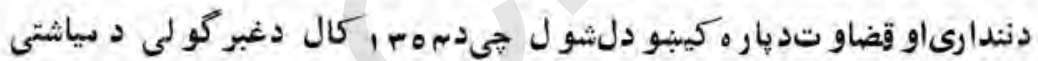

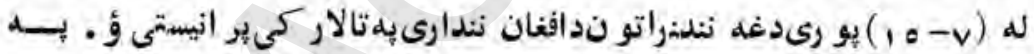

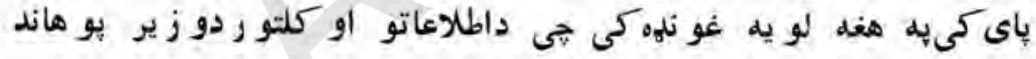

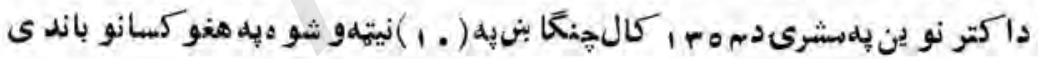

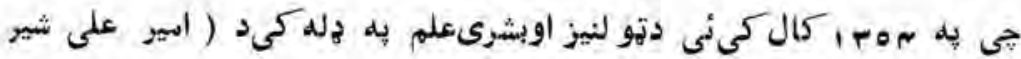

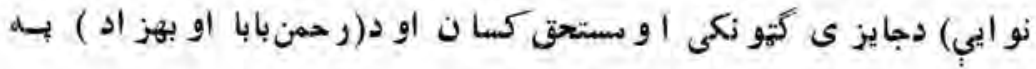
نامه د بنكليو هنر و نو جايزى و تياكل كلشوى.

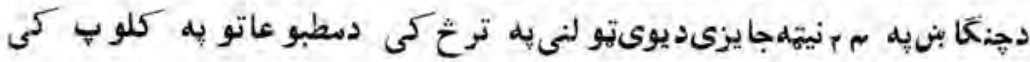

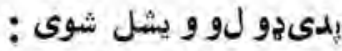

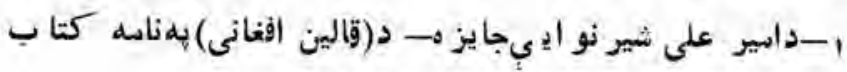
ب-دررحمن بابا او كمال الدين بهز اد جايزى : 


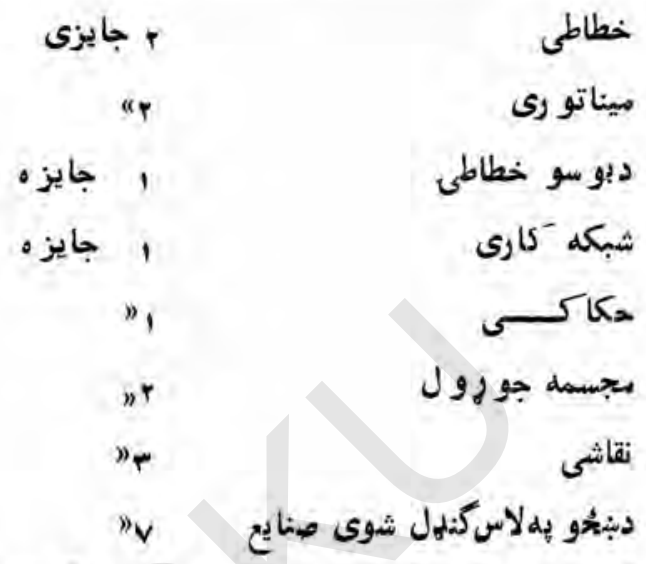

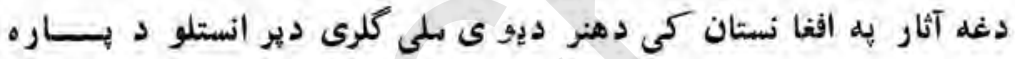

و ساتل شول

:

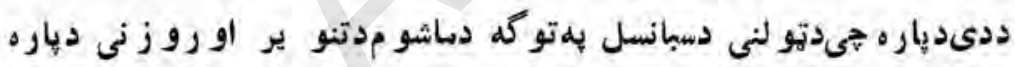

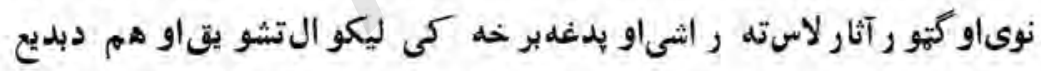

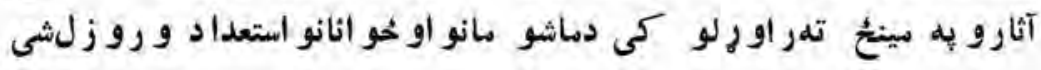

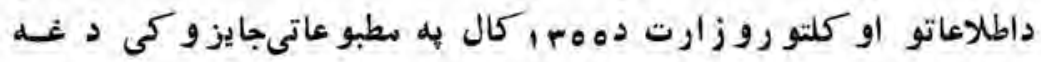

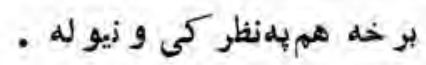

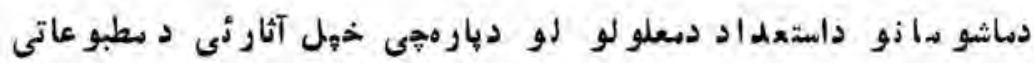

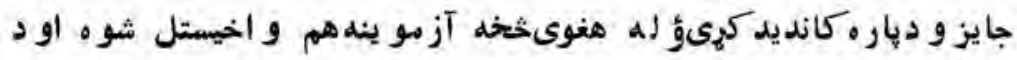

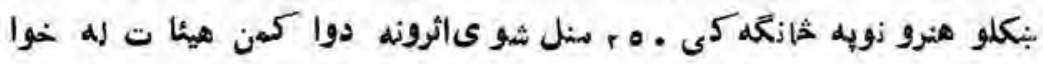

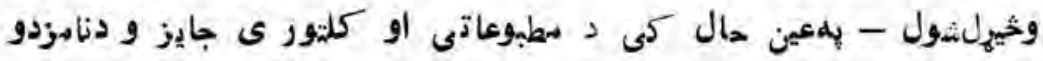




$$
\text { اطارعاتى او كلةو رى'جر آت }
$$

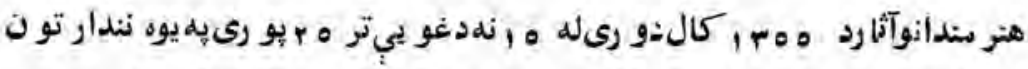

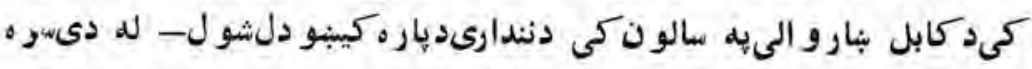

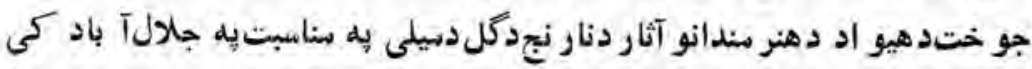
• بهيوه بل نندارتون كىد نندارىدياره كينبو دل شول ل د(تاليف او زبازى) (.r) اثرو ثله دجايز و دكانديد و دياره و سنل

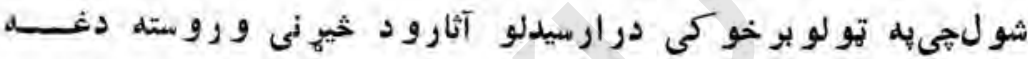

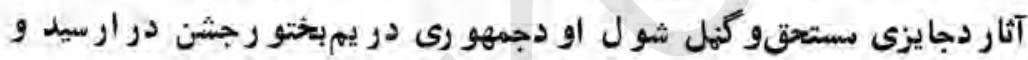
لهابله دجايز و دُّو نكو جايزى ديوىتو لنى يلتوشكى و و يشلشوى : الف- دليكل شوو آثا روريهثانته
أl

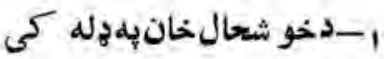
$n \rightarrow$

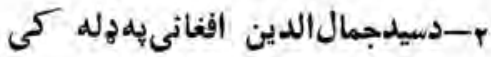
$n-r$

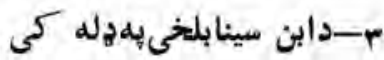 $n-1$

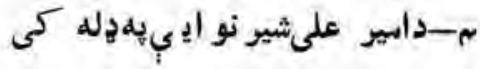

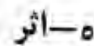

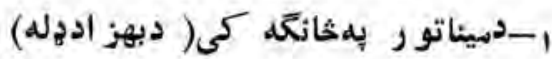 $n \rightarrow$

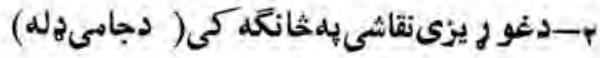 $n-r$

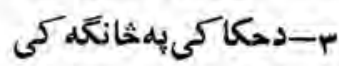 $n-1$

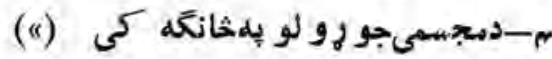 $n-1$

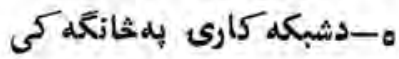
بــدنبكليو هنر و نو بهثانكه كى: 
ج:دماثو مانو دبارههنرىجايزى .

I I

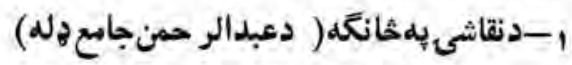

${ }^{n} r$ ب-دخطاطى بهخانَّه كى (درحمن بابادله ) "Y

(a) n

(a)

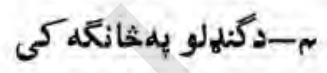

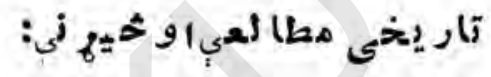

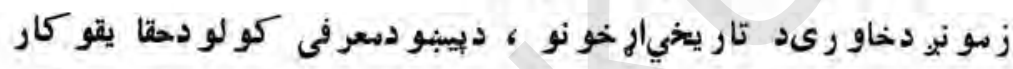

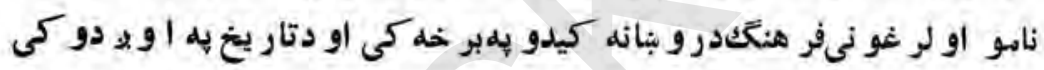

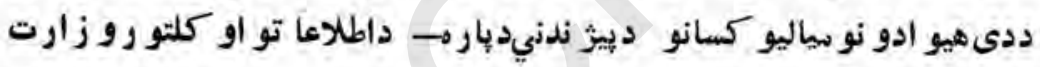

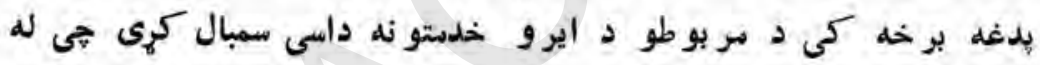

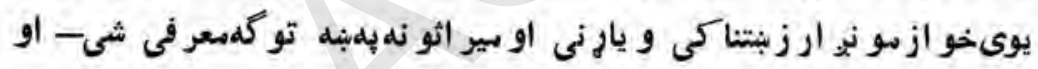

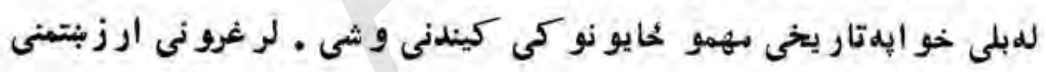

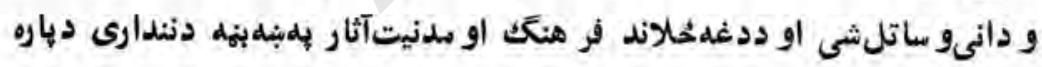

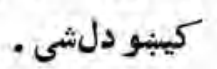

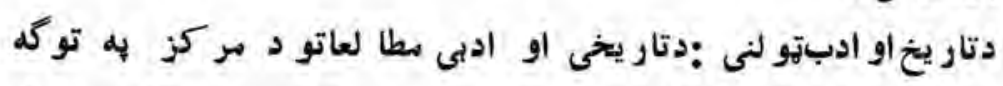
دمؤ ر رخانو او اديبانو د همكارى يهجلبو لو او دمعتبر و آثارو بهنبير و لو سر مخهل

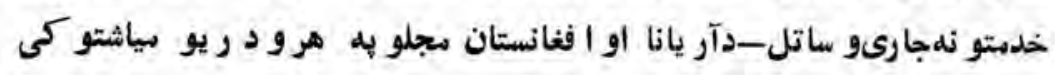

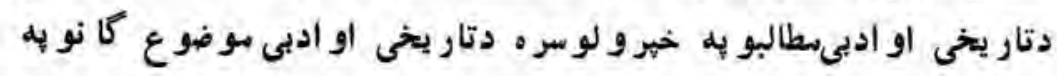

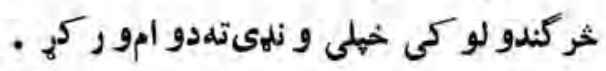

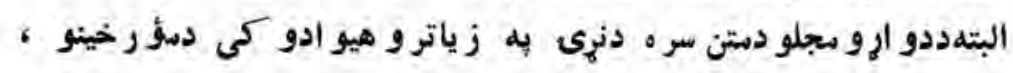




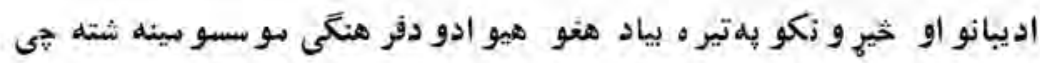

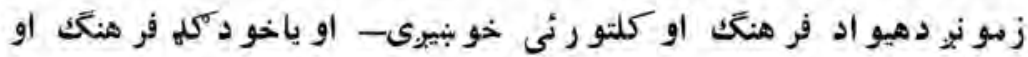

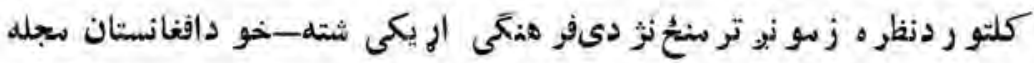

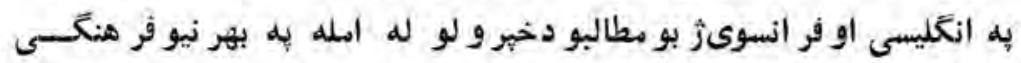

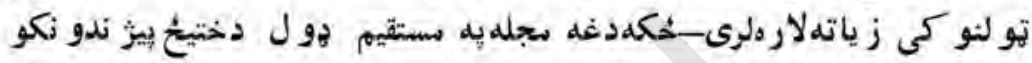

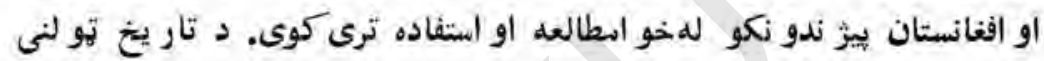

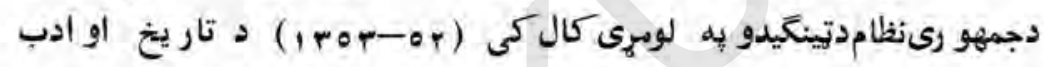

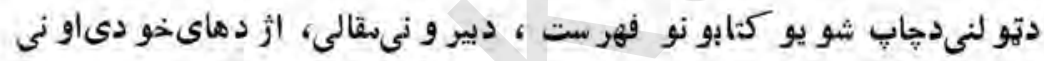

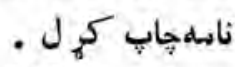

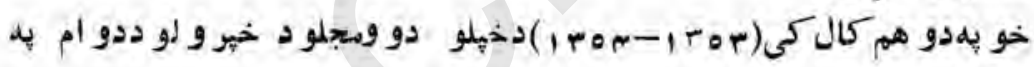

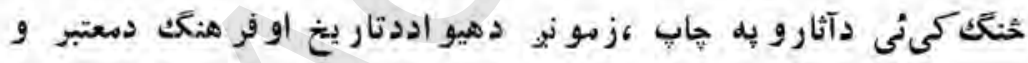

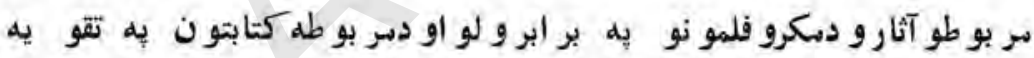

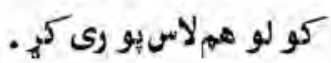

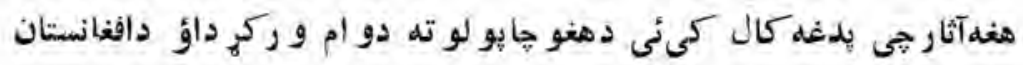

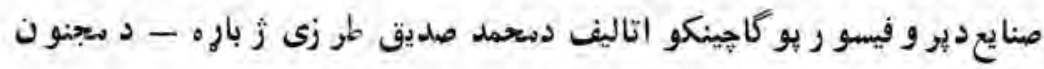

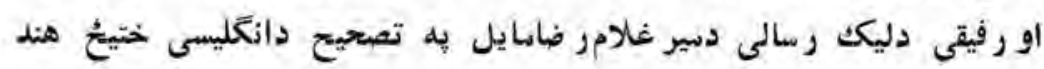

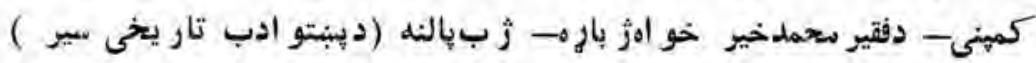
تير يادو نهاو دحبيب اللئرففي د اشعار و مجمو عله.

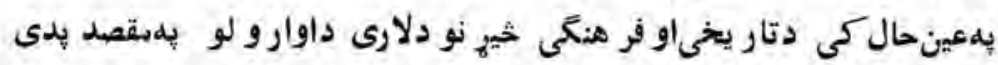
هو لد كلتو ردبهكار ندو يو هعتبر و كتابونو او آثارود نكرو فلم اوفو تو 


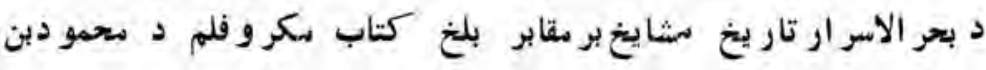

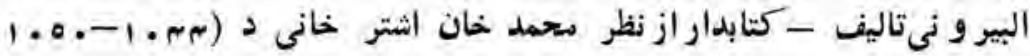
تاليف)دهند- لندندديو ان كتابتون . ـدديو ان هند - ملندن له كتابتو ن خخه د ابن يمين فو يو مدى دبشير ديو ان دسعتبرىخطى نسخى مكر و فلم .

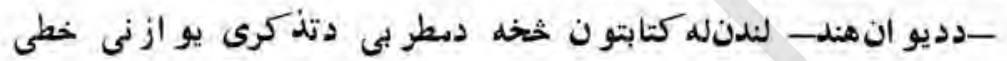
- نسيخى هـكر و فلم

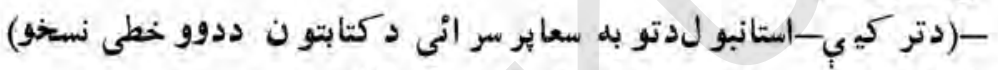

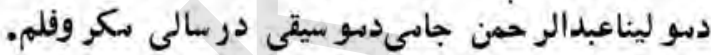

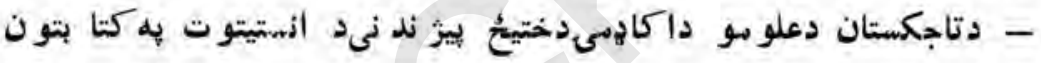
كى 2 مو جو دو (يه ينينتو اودوى ز بو ) دتيمو رشاه درانى دخطى ديو ان - ملمر و فلم

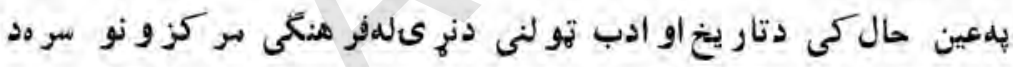
رو دمبادلى به زياتو الى لاس يو رى كي او دهغى د اختصاصى كتا بتو ن

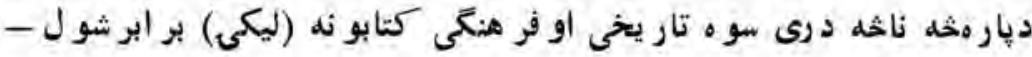

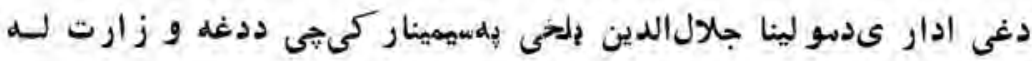
خو ا جو هر هم بو خله و اخيسته .

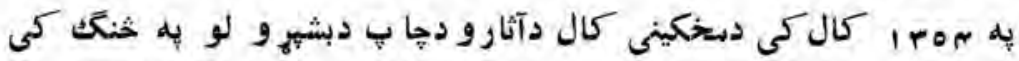

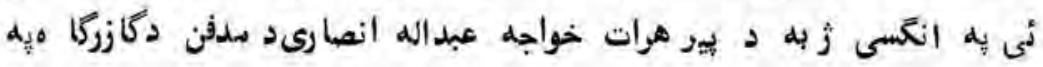

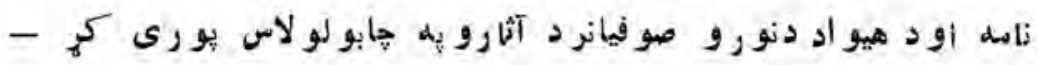




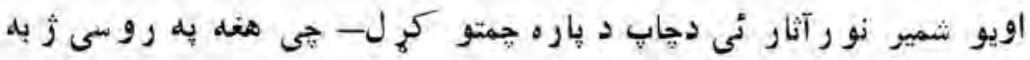

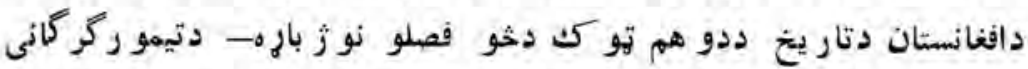

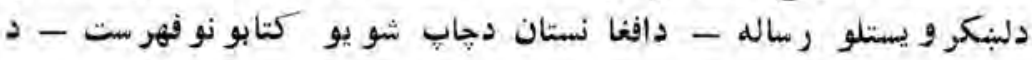
افغانستان دكو شا نيانو ددو رى دجشتيه اوثير نو رسالهده - بهعين حال

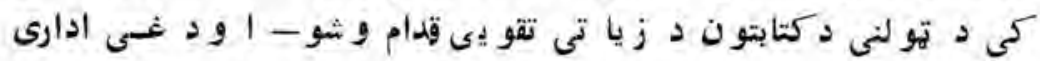
دابو نصر فار ابىى دقيقى بلنخىاو - خو اجه عبدالله انصارى هر وى دشخصيتو

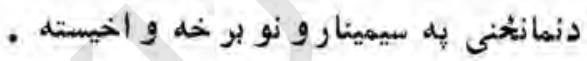

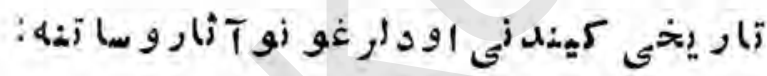

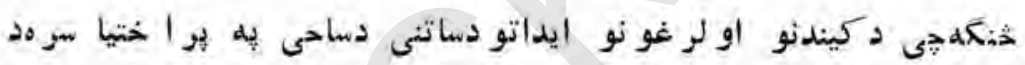

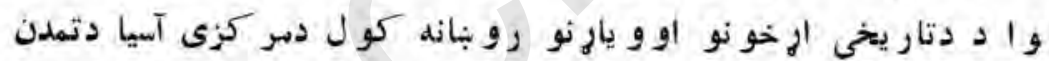

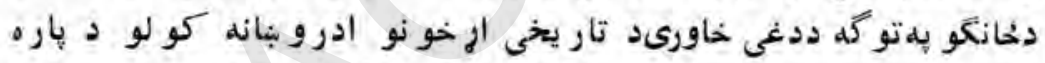

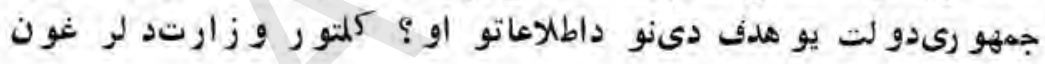

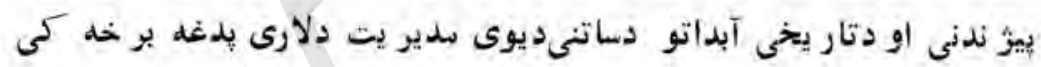

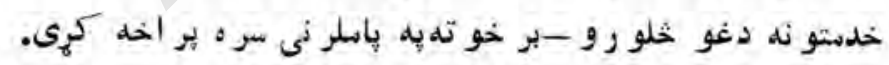

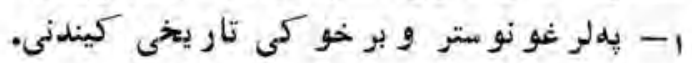

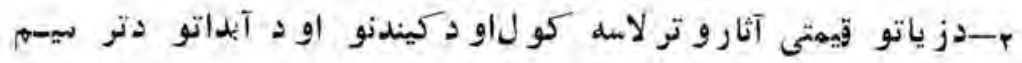

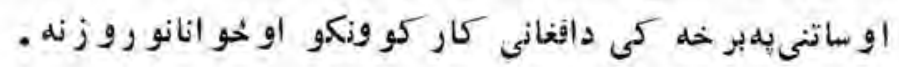

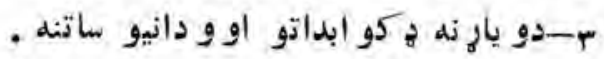

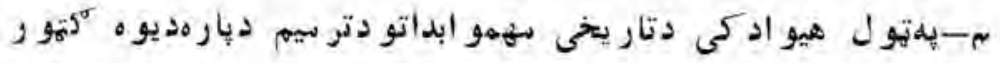
. 
بله تاريخى مهمو سيهو او خايو نو كى تار يخى كيند نو ته دو ام او

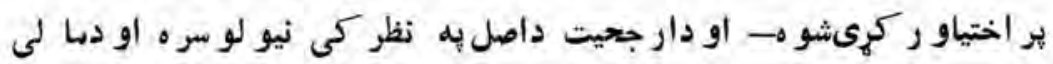

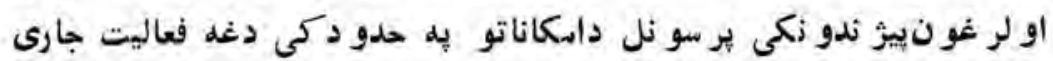
• و نساتل شو

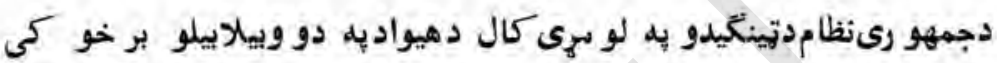

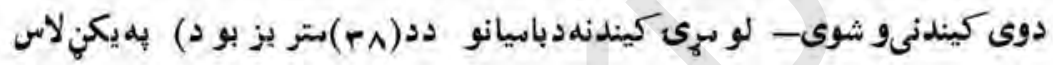

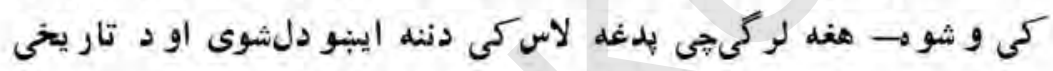

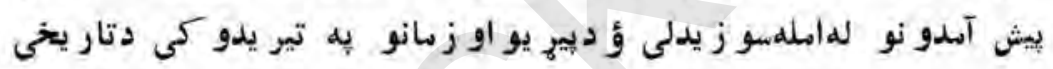

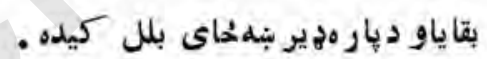

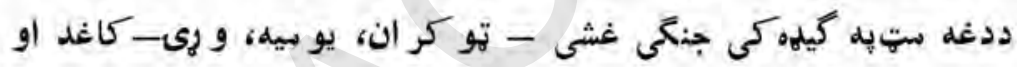

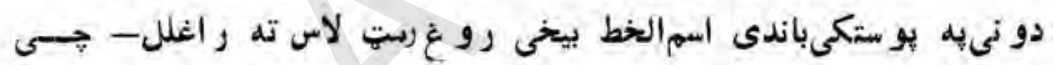

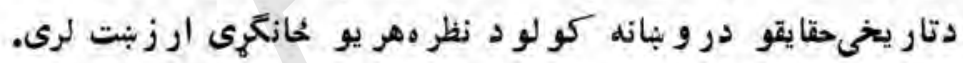

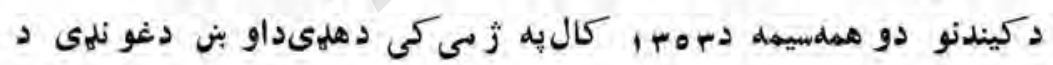

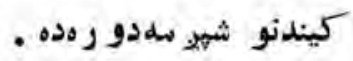

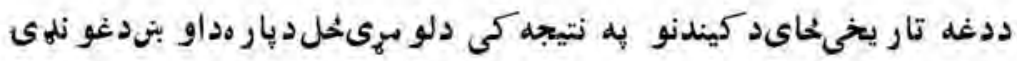

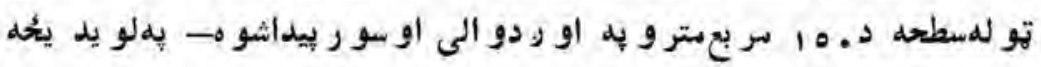

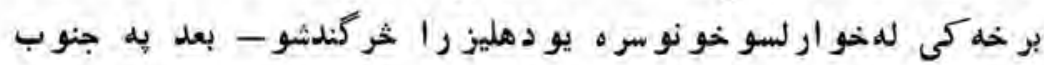

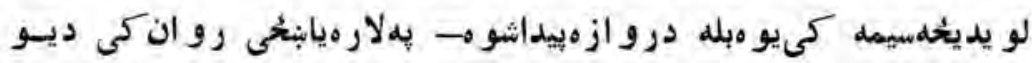

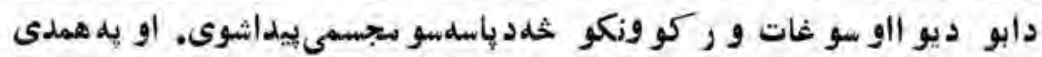


ألج عاتى او كلتو رى اجرا آت أل

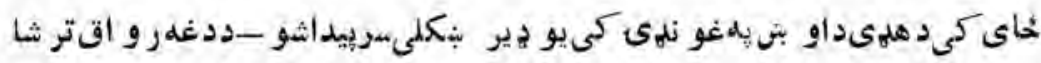
و ساختمانددرى

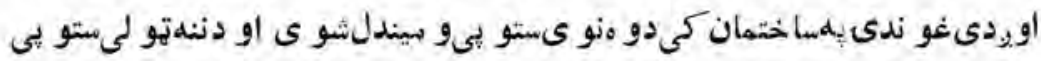

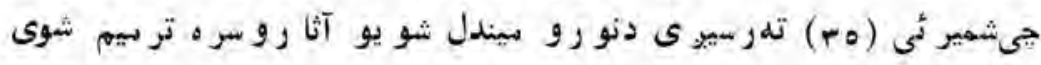

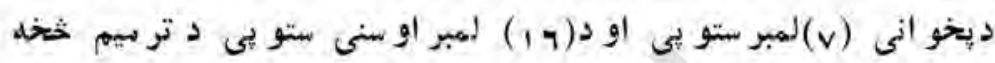

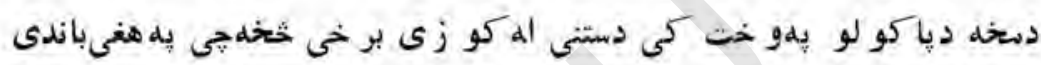

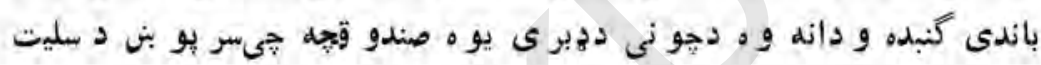

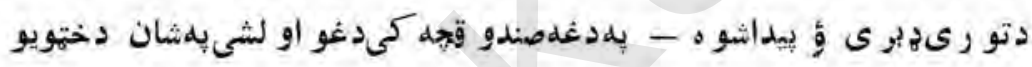

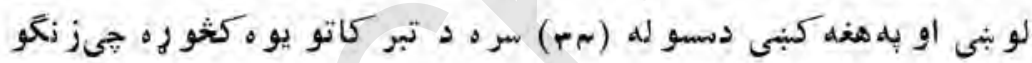

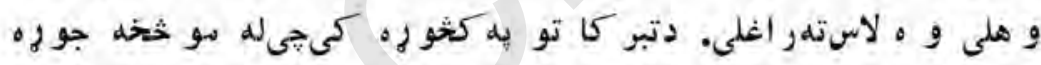

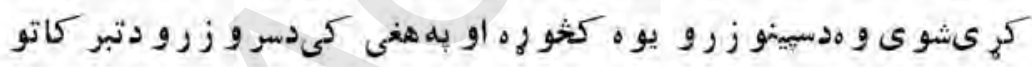

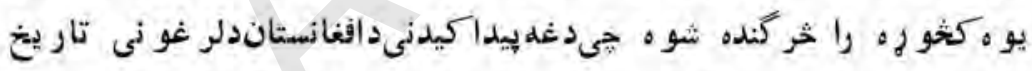

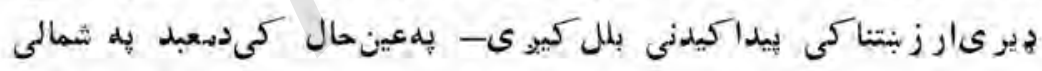

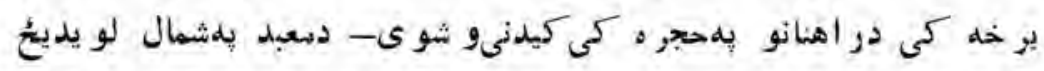

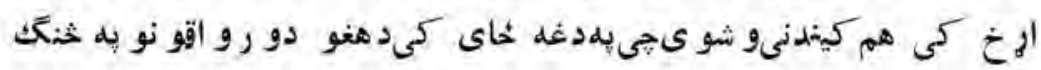

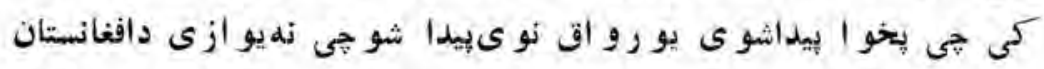

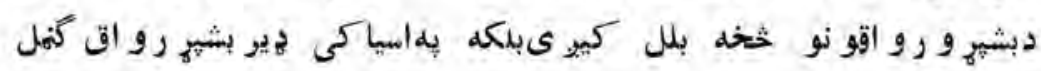

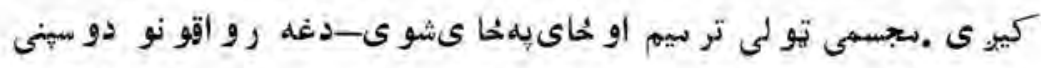

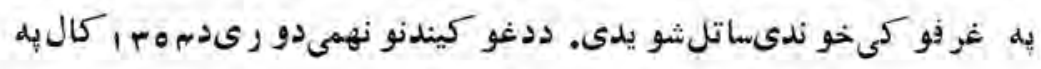

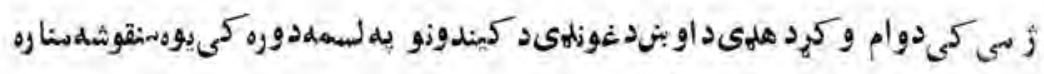



$(1,1)$

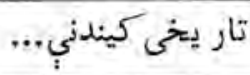

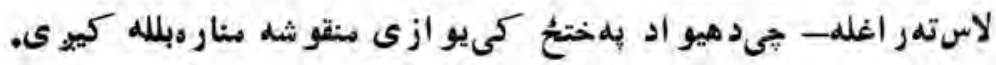

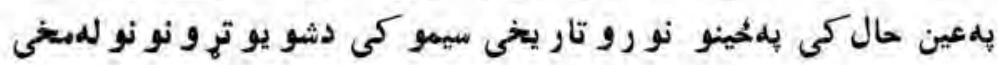

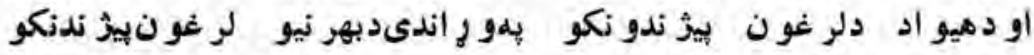

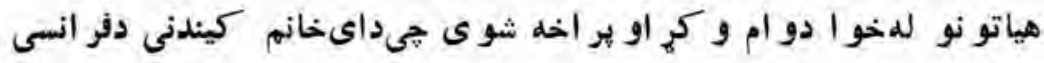

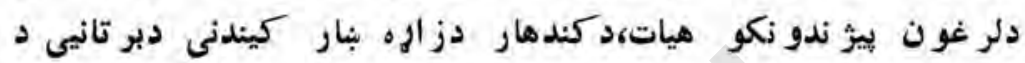

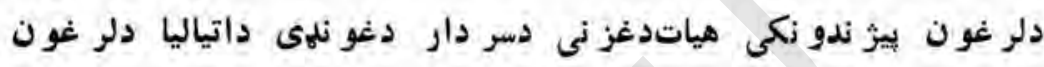
بيثز ندو نكمى هياتاو دنيمر و زدتارو سارد بنارو نو او دغلغلى دبنار كيندنى

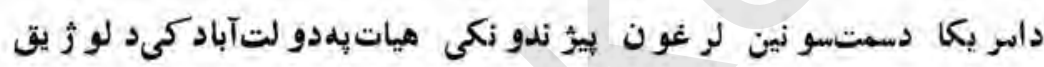

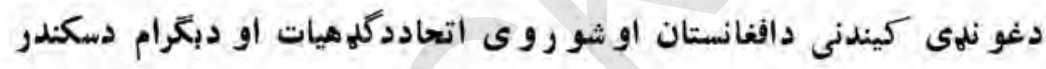

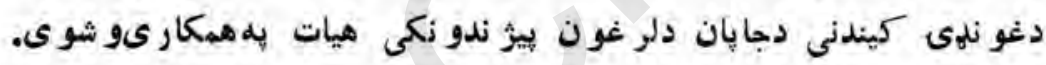
دوهم:--دغه آبداتدافغانى هياتاو دافغانى او هندى كمهياتلهخو اتر ميهمول-

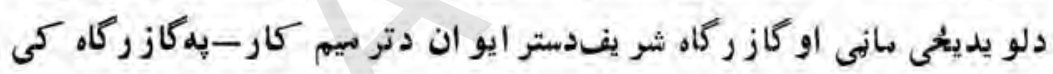

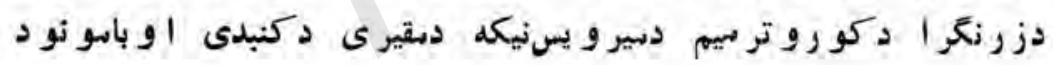

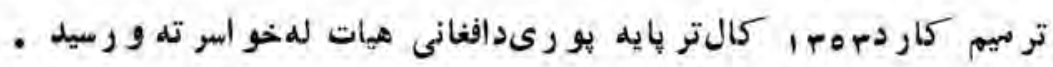

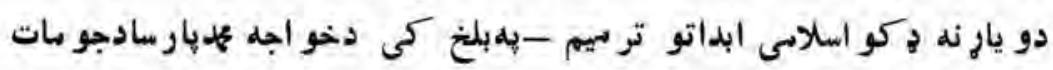
دتو ميم كاربهمبهر

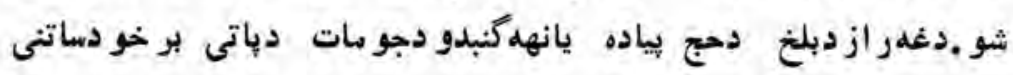

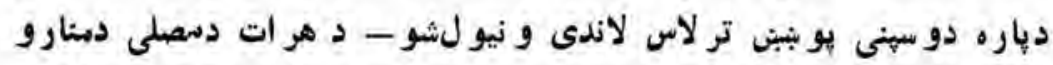

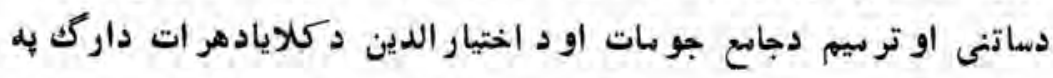

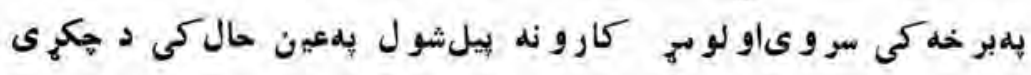


دمناردتو ميم كار بيلشو.دغهر از داطلاعاتو او كلتوردوزارت او

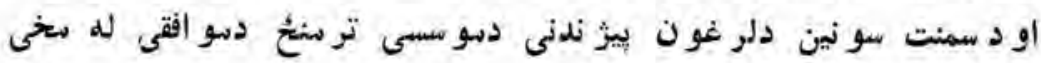

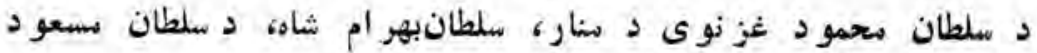
لقبوىى، دشر يفشاه دمقبر ى يلشاندغز نىدمشهو رو ابداتود لو سه نى كار

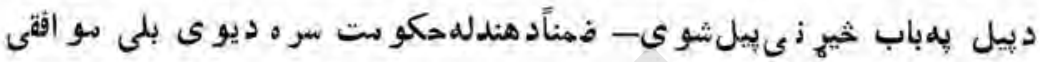

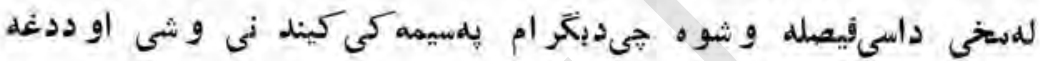

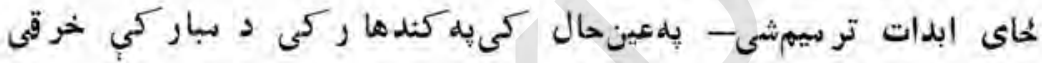

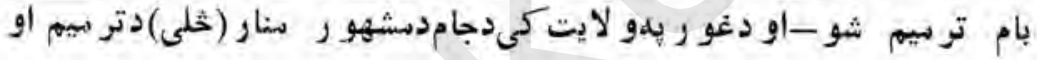

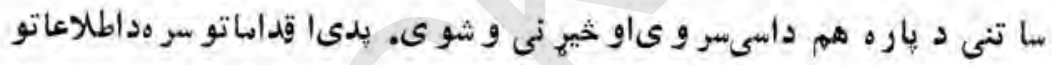

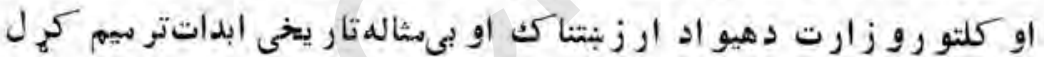

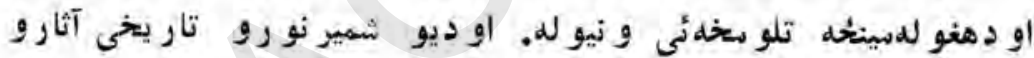

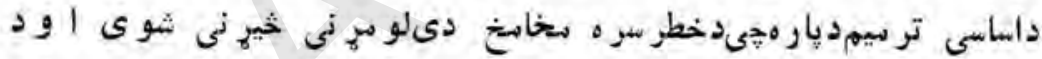

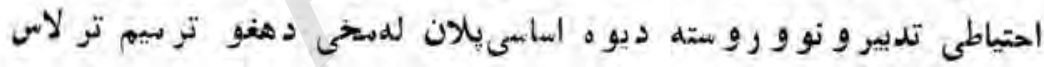
- لاندى لو

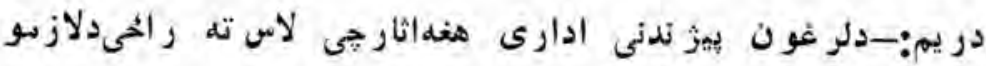

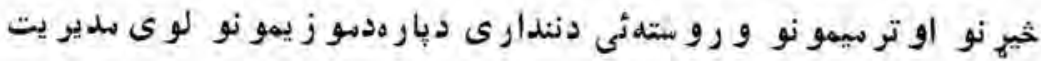

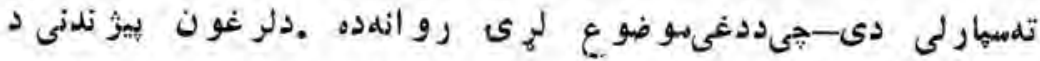

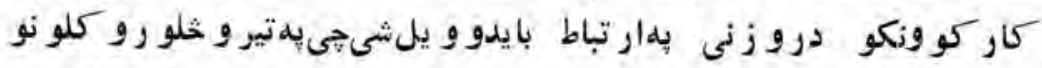
كى دلى ثون بيز ندنى اودتار يخى ابداتو دساتنىدادارى كاركو ونكو او

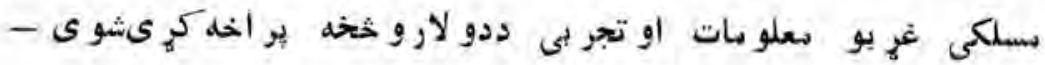




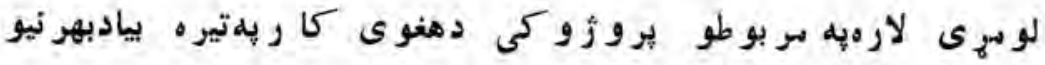

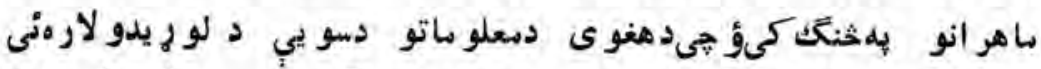

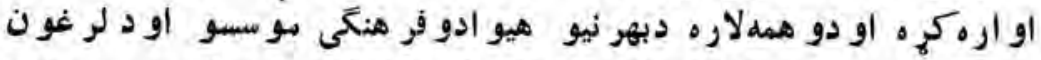

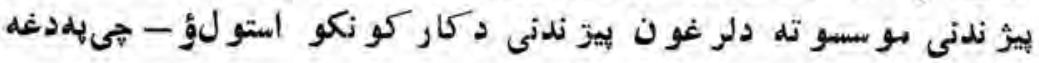

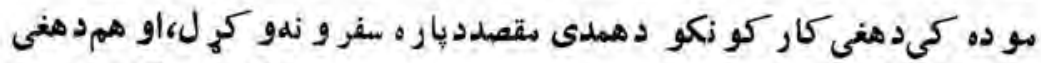

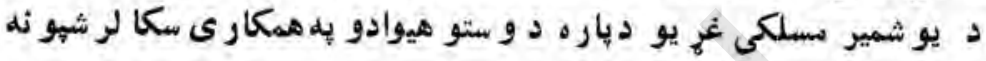

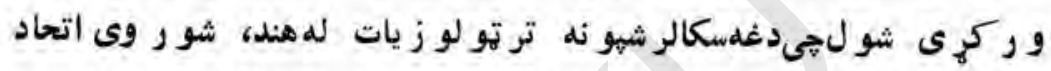

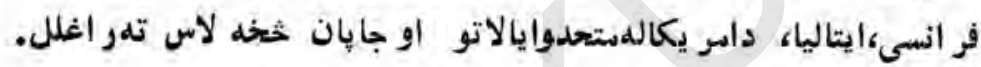

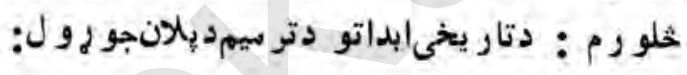
داطلاعاتو او كلتور و زارت دمهمو تار يخى و دانيو د ساتنى دباره

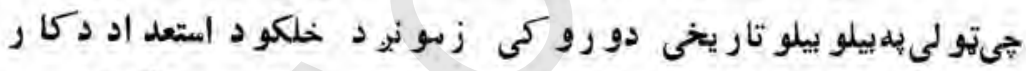

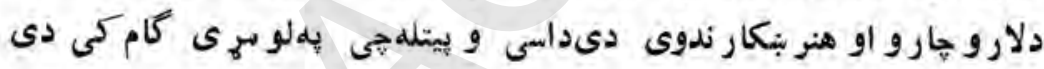

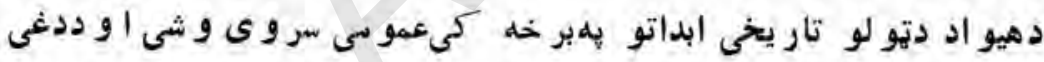

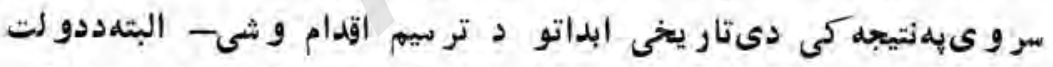

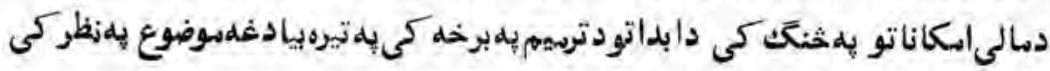

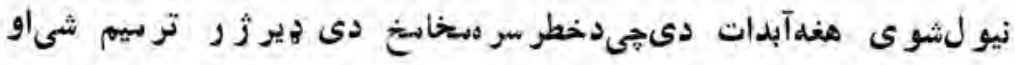

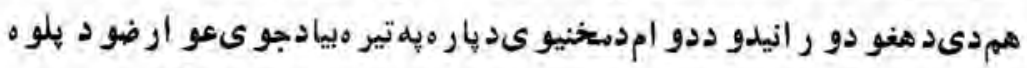

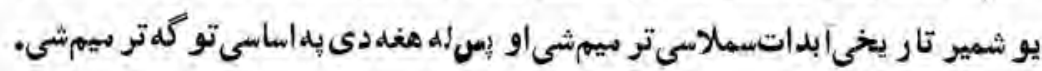

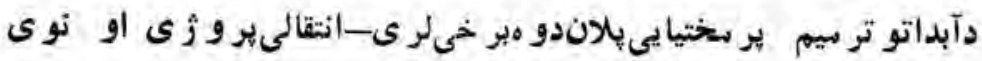

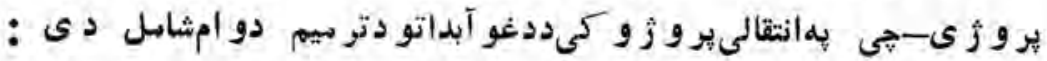


اطلح عاتى او كلتو رى اجرآ آت

$(1 \cdot \%)$

دكاز ركاهر يفتر بيم -ددغىتار يخى آبدي سملاسى تر ميم جيى تيهو رىى

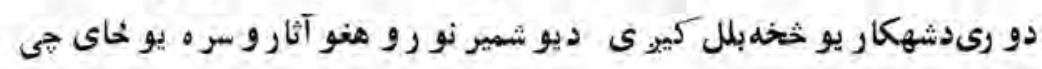

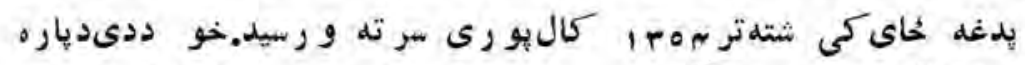

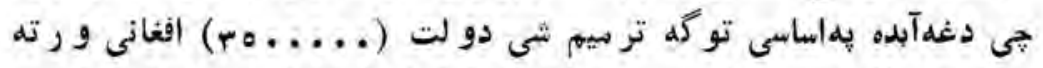

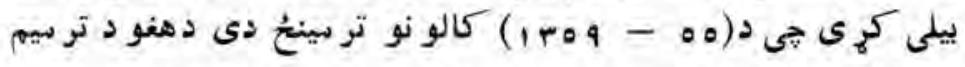

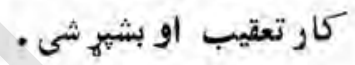

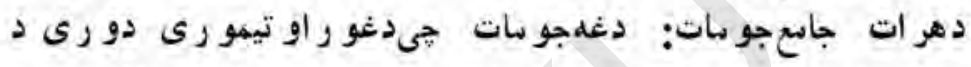

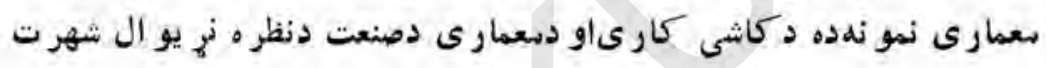

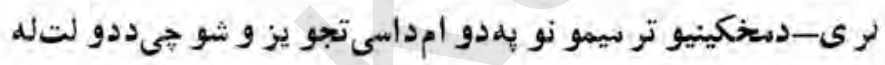

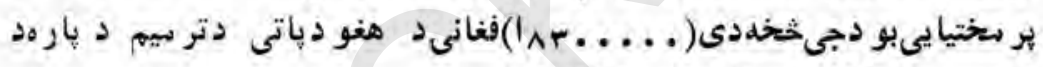

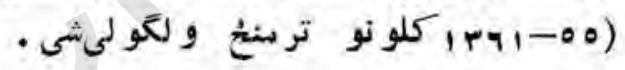

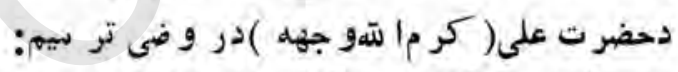

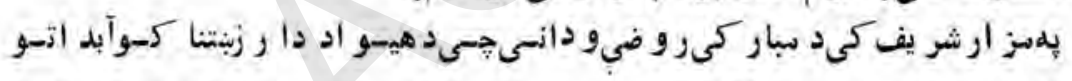

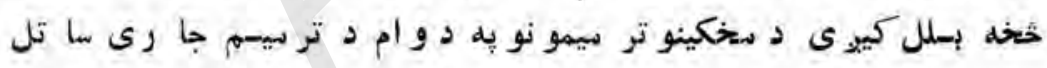

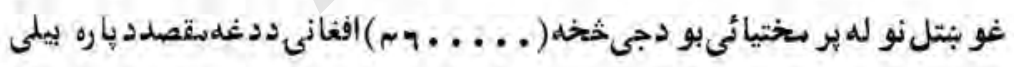

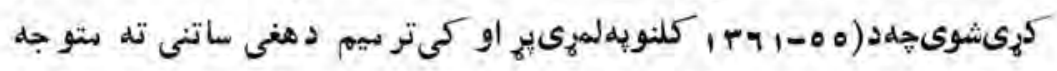

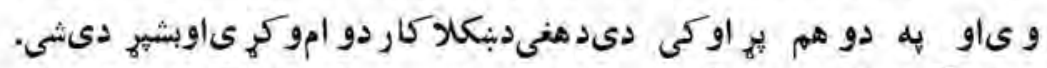

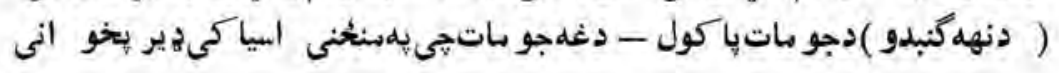

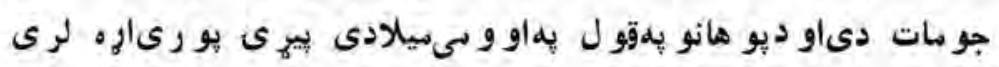

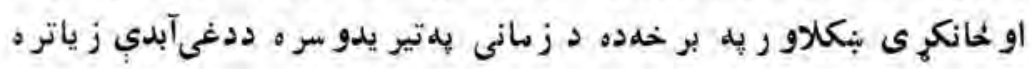

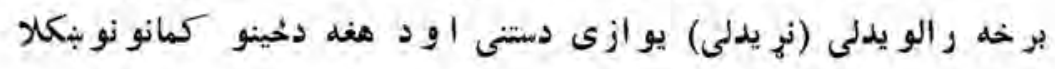



: I:

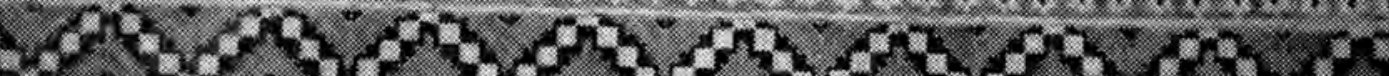
T.

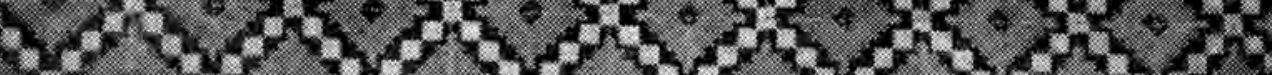

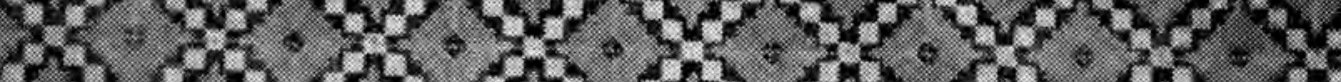
(1.7. يهمزاد شيريف كى ثقاه ولايتماب دروفى وختيز هلخل دكاشى كارىنهونه. 


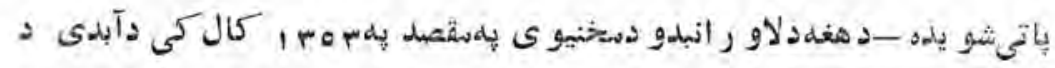

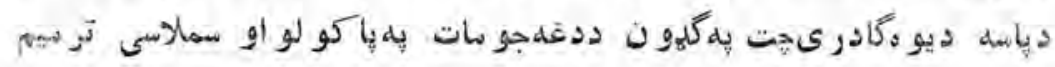

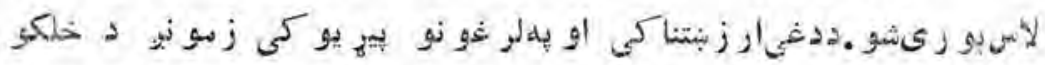

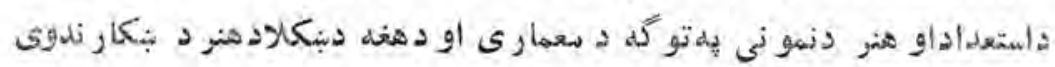

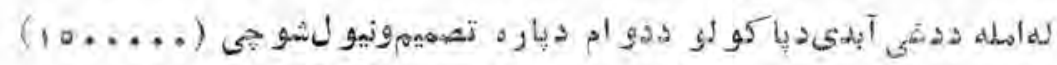

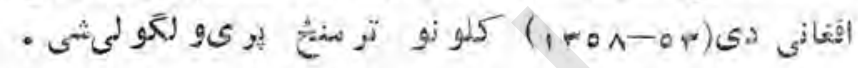
و

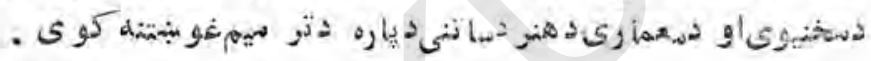
:

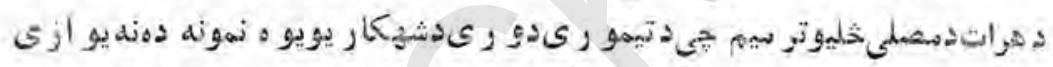

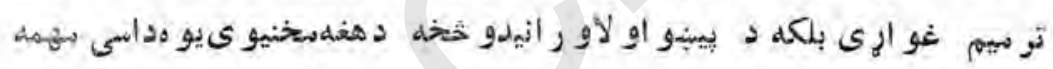

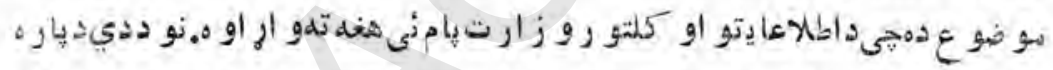

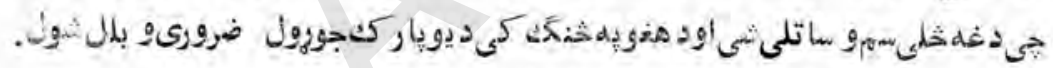

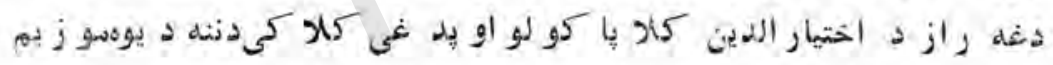

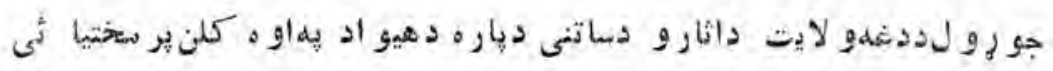

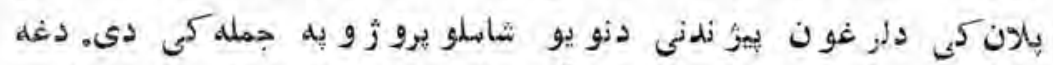

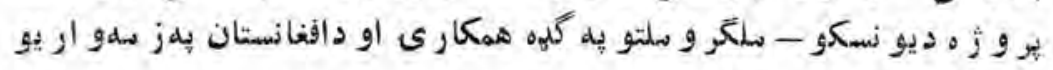

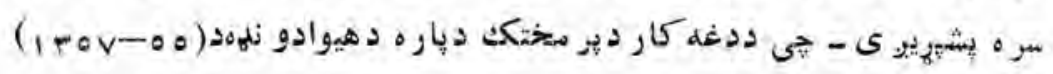

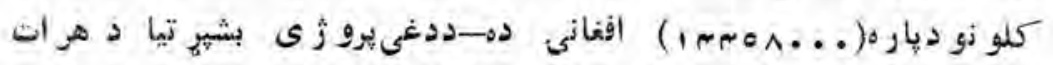

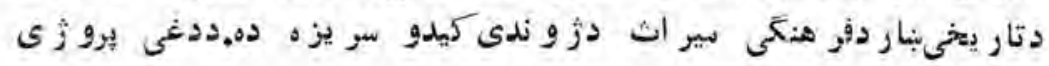

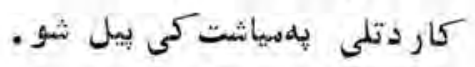




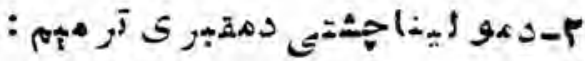

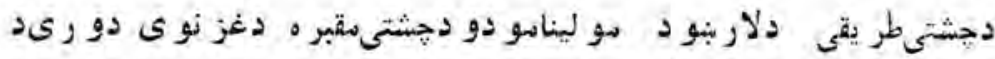

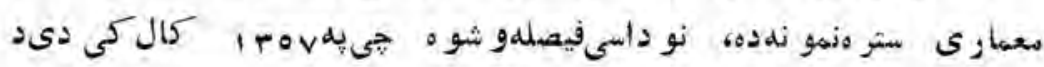

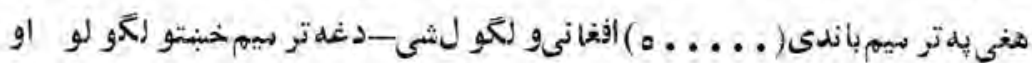

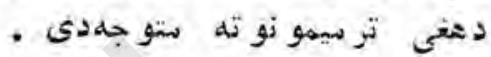

$$
\text { : }
$$

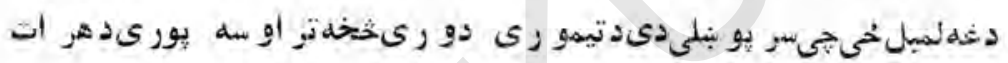

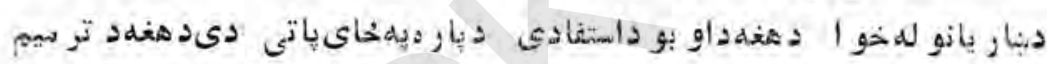

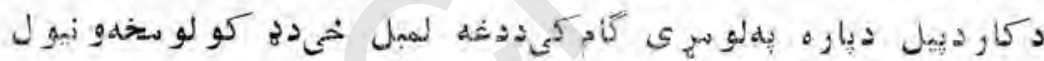
شو

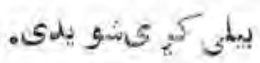

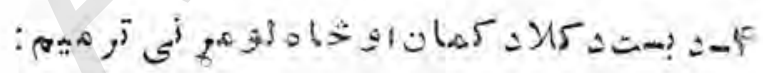

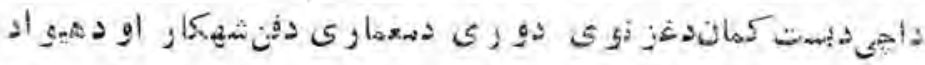

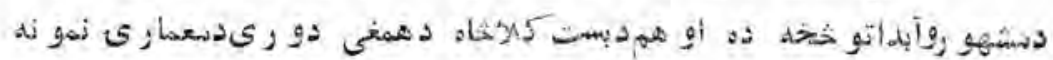

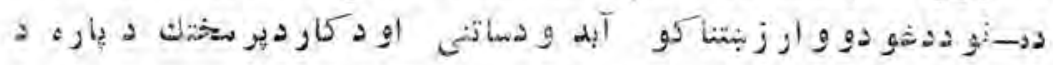

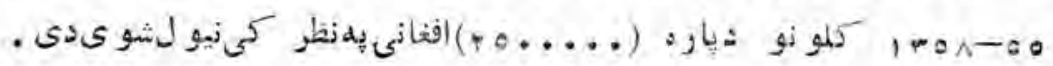

$$
\text { : } 0
$$

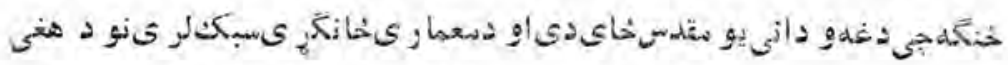

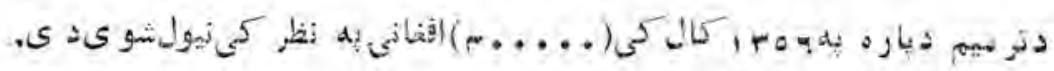




$$
\text { : } 0
$$

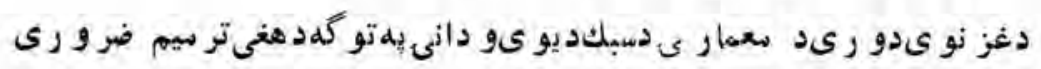

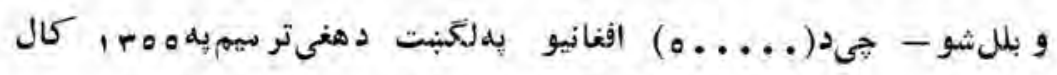

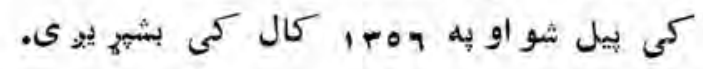

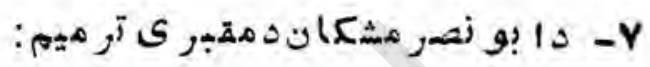

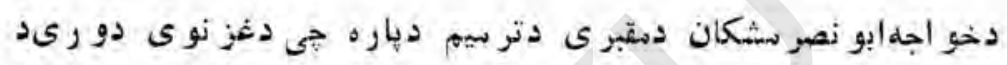

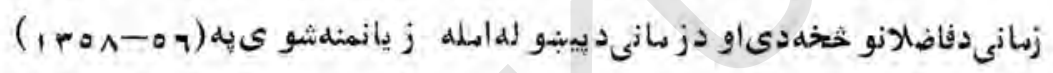

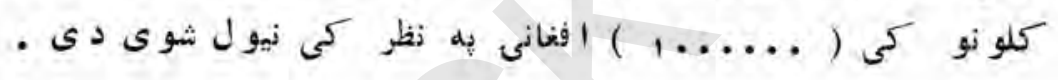

$$
\text { : A }
$$

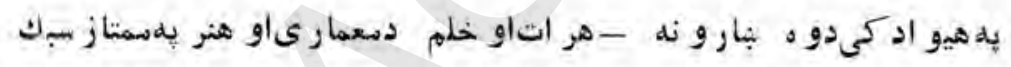

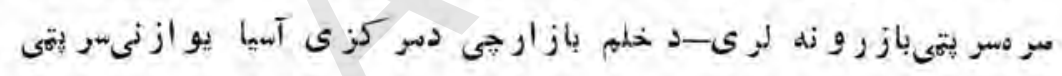

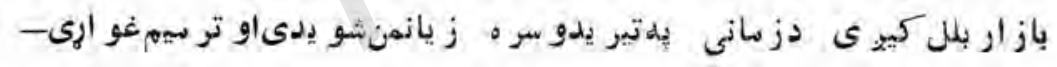

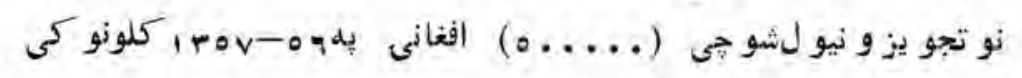

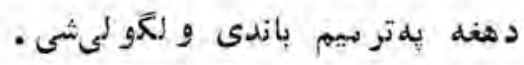

$$
\begin{aligned}
& \text { : }
\end{aligned}
$$

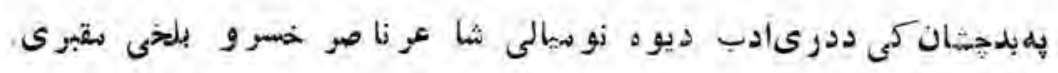

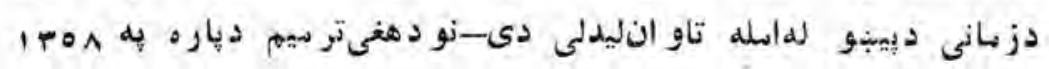

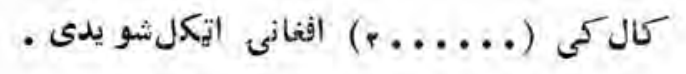




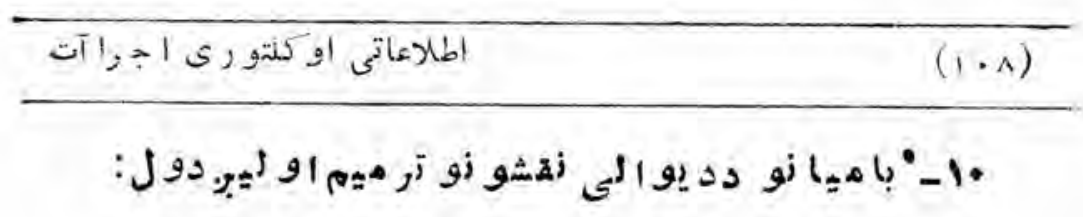

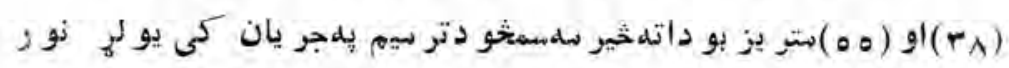

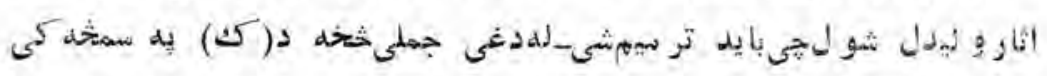

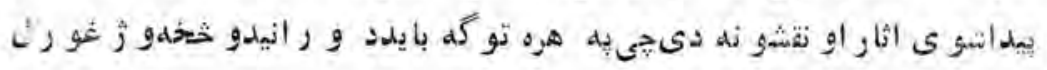

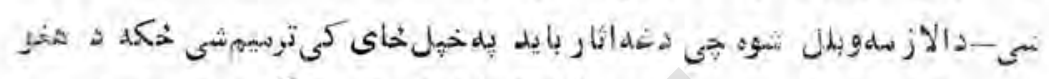

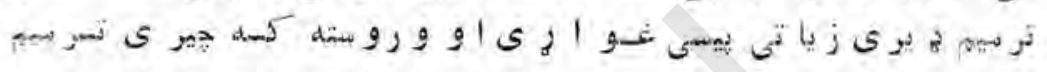

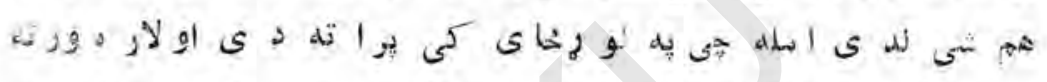

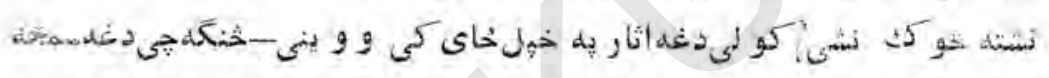

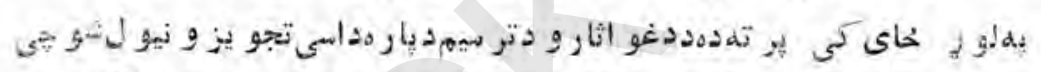

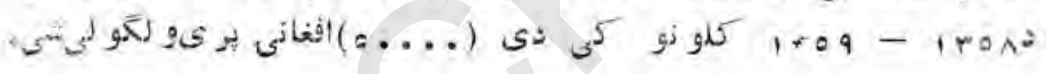

$$
: 000 \text { : }
$$

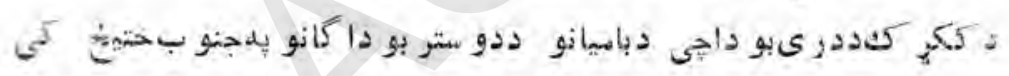

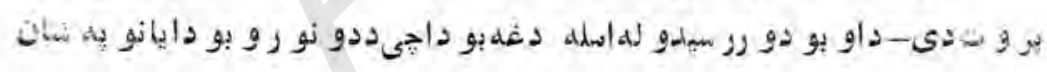

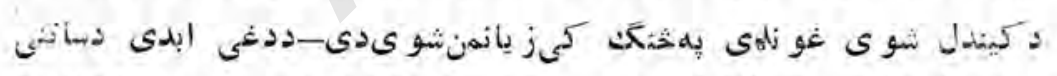

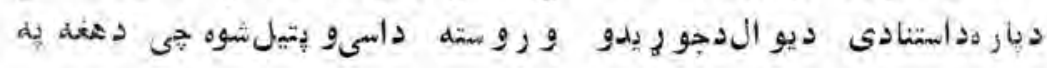

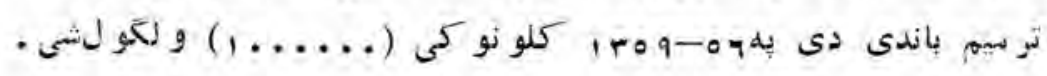

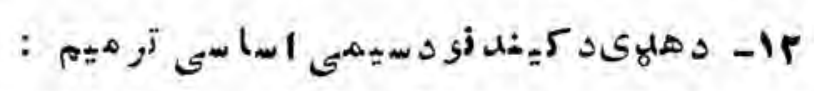

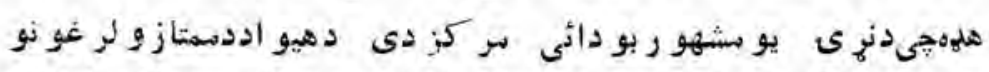

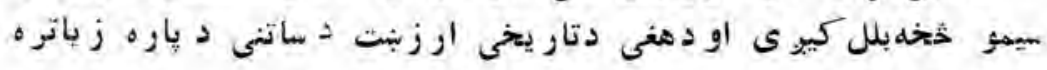

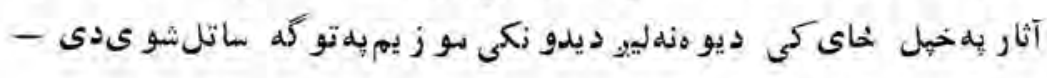




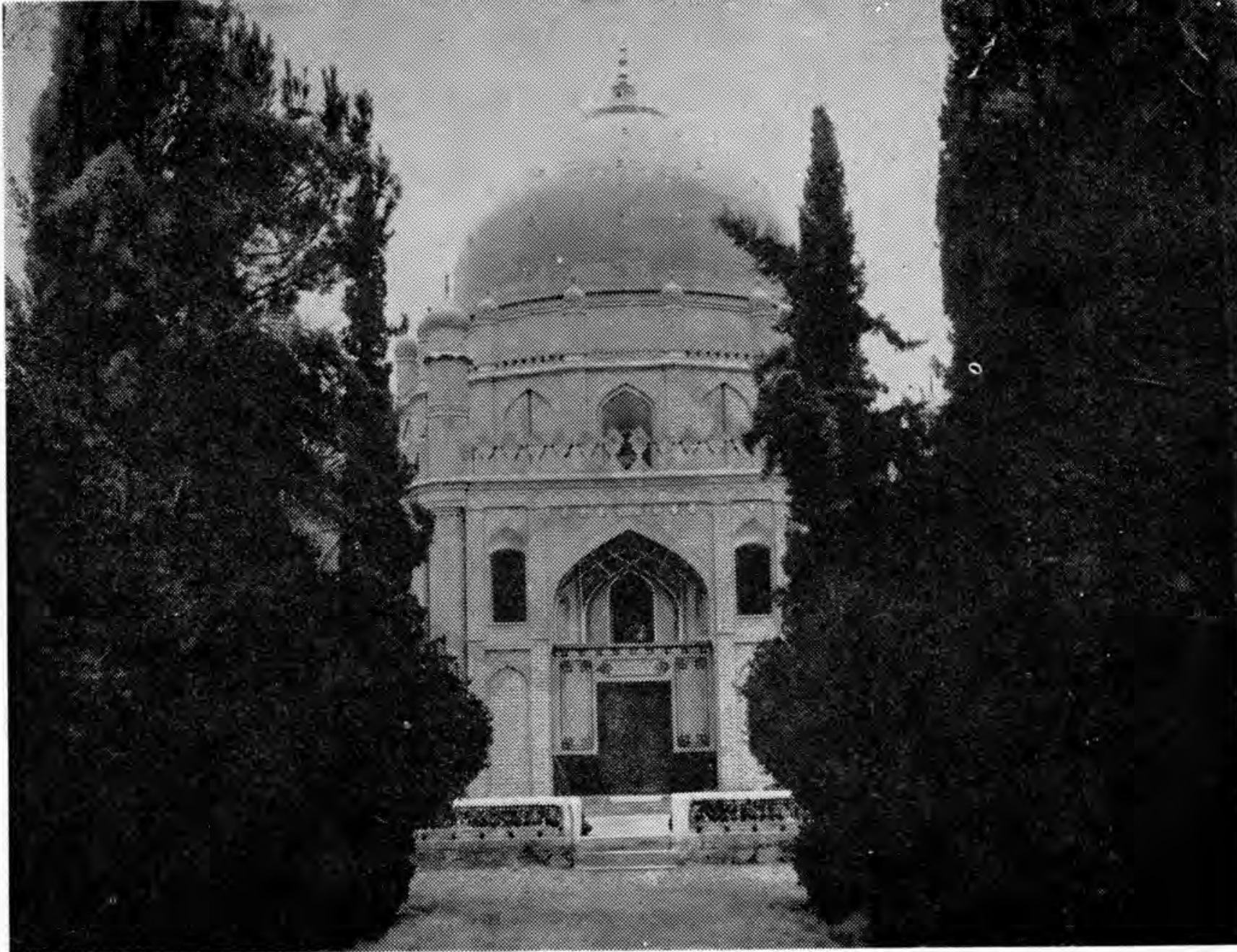

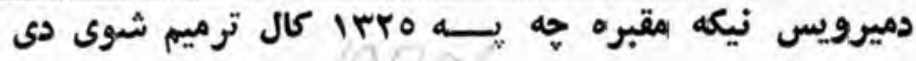




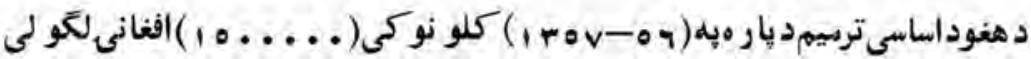

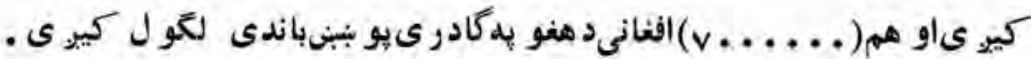

$$
\text { : }
$$

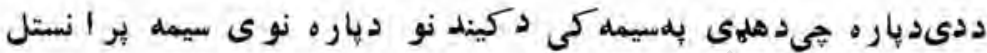

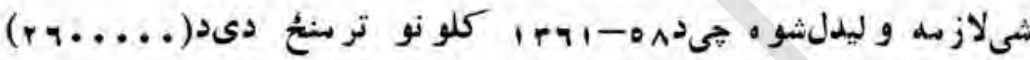

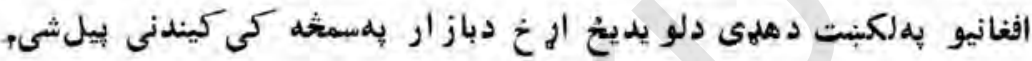

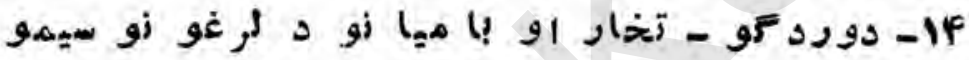
:

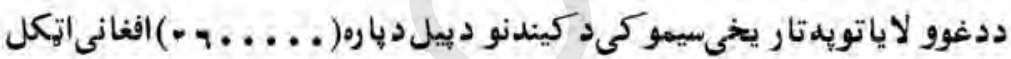

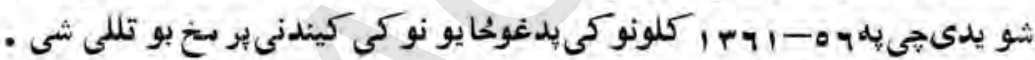

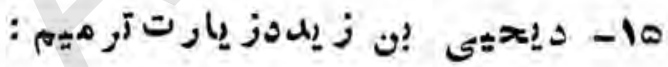

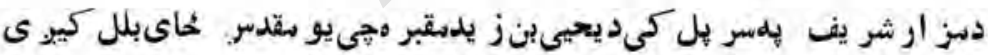

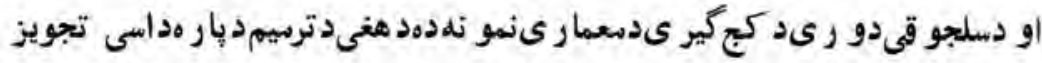

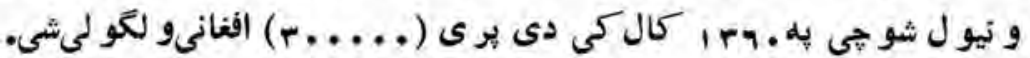

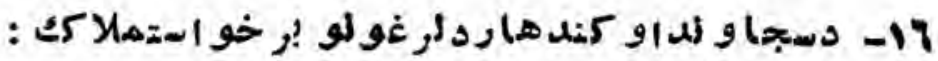

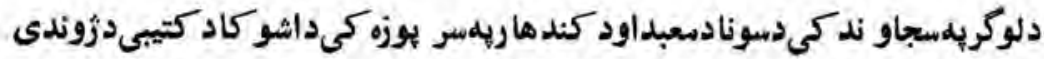

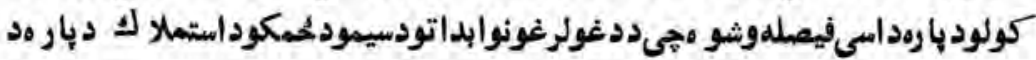

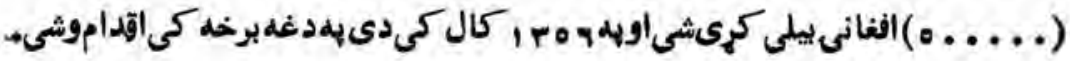




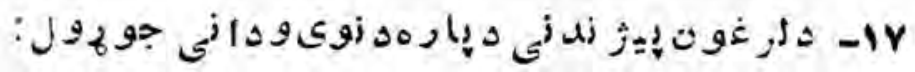

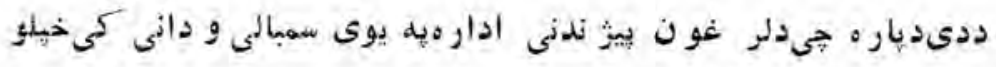

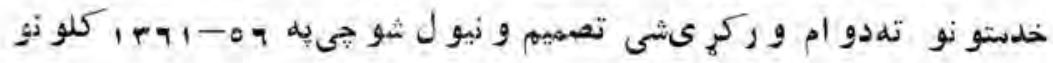

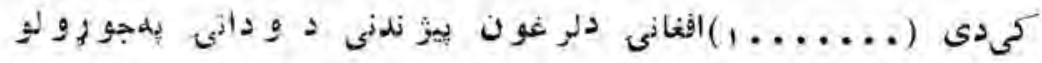

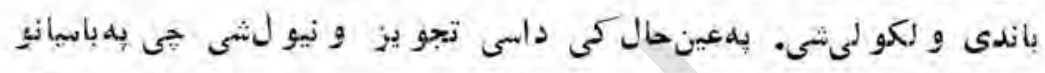

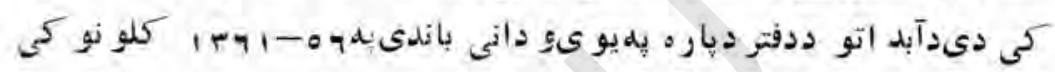

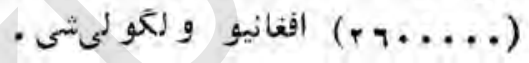

$$
\begin{aligned}
& \text { : IA }
\end{aligned}
$$

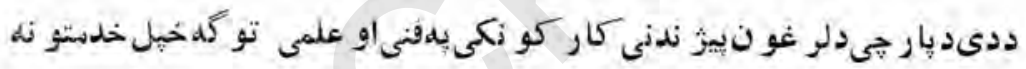

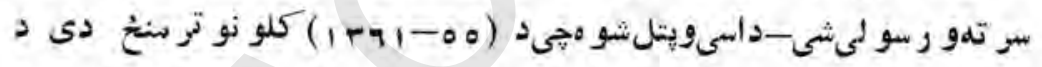

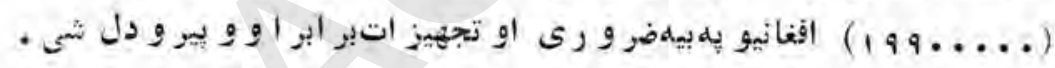

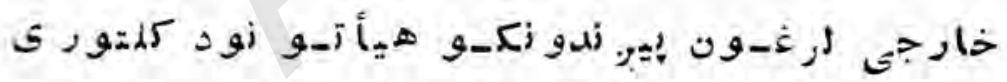

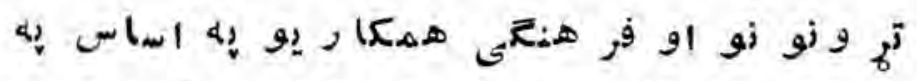$$
\text { : }
$$

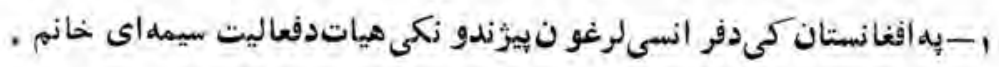

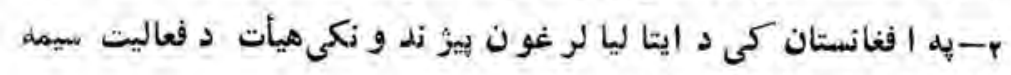

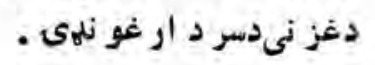

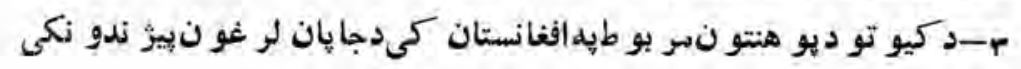

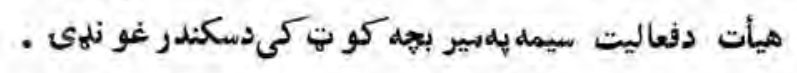




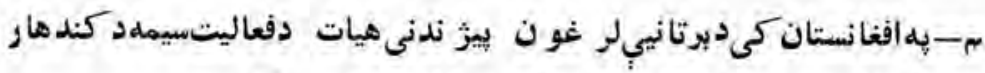

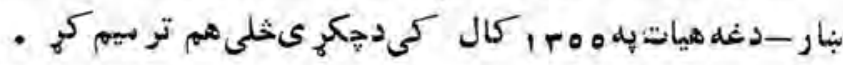

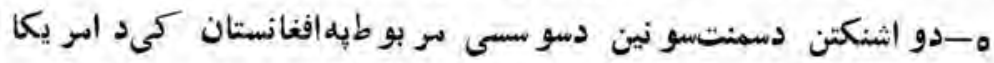
لر غو ن بيمث ندو نكى هياتدفعاليت سيمهدنيمر و ز دو لاليتسر بو طهدغلغلىنبار -

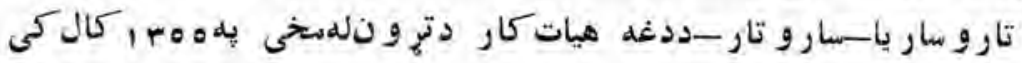

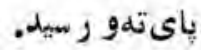

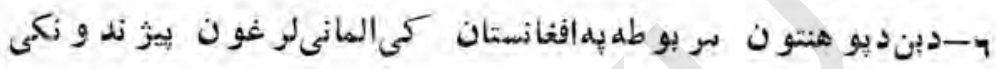

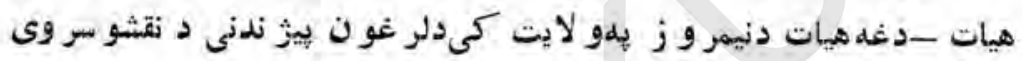

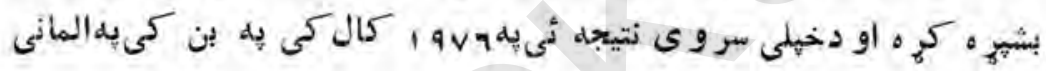

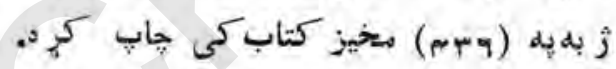

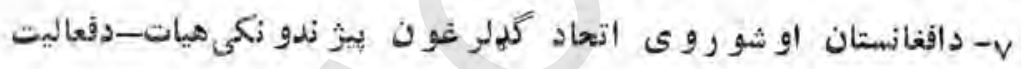

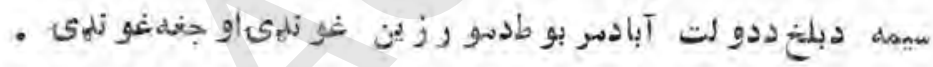

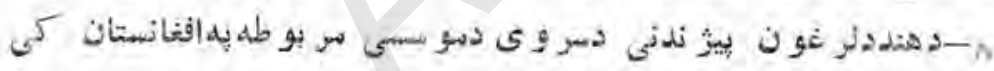

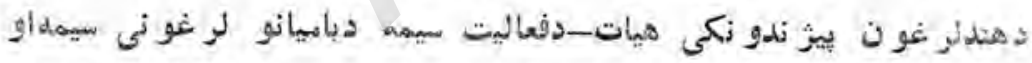

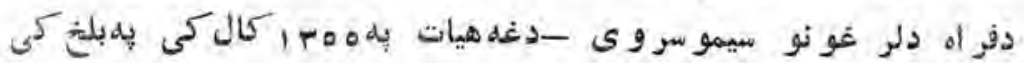

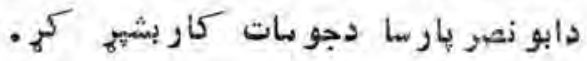

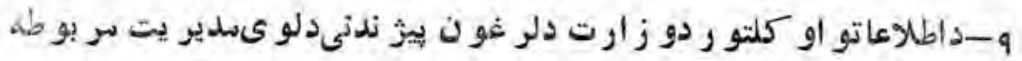

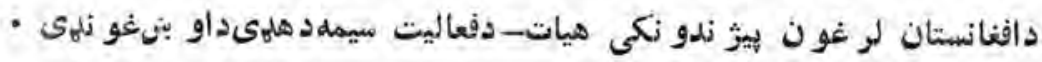

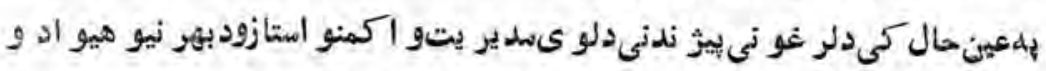
لهتولوهيأتونوبرود هغوى دفعاليت بهجريان كى به تاريختى كيندنوكى همكارى كريلهث. 


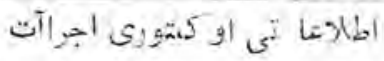

\section{4j $9.0 ! j 9.0$}

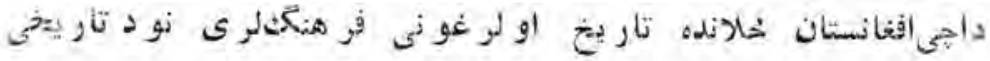

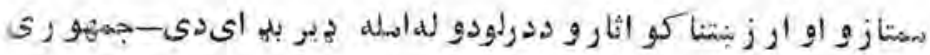

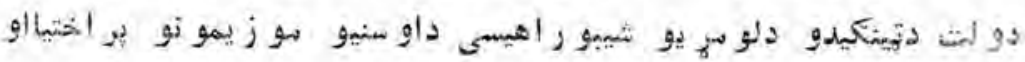

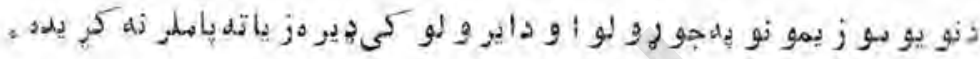

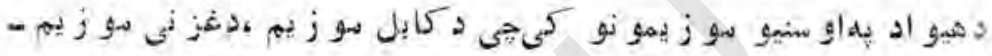

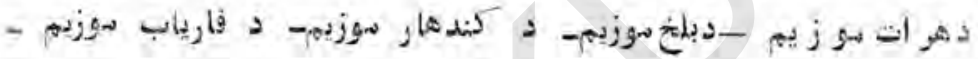

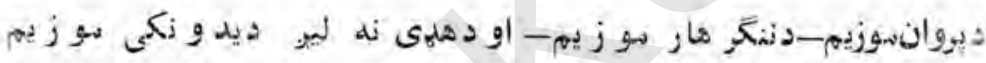

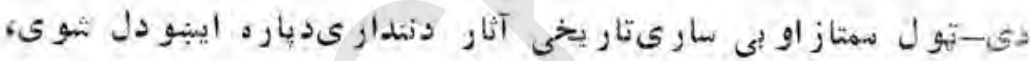

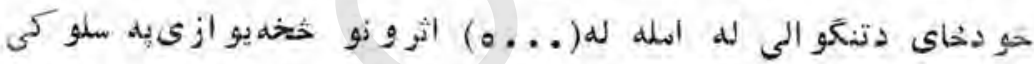

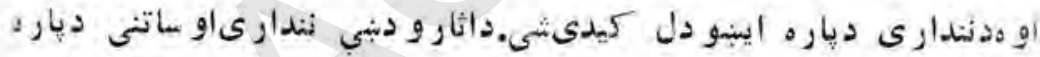

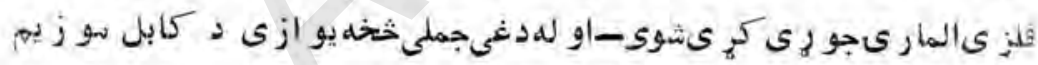

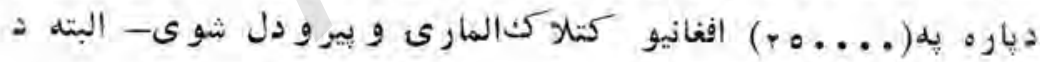

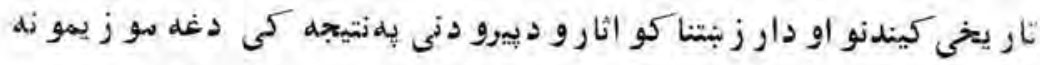

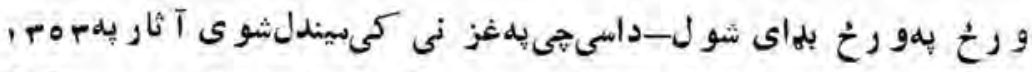

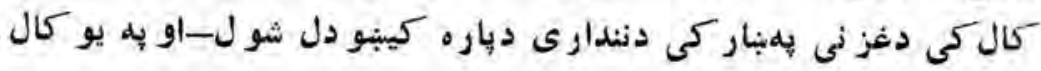

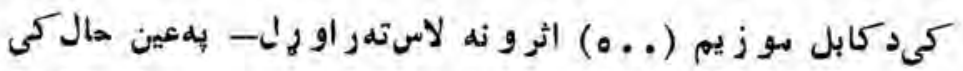

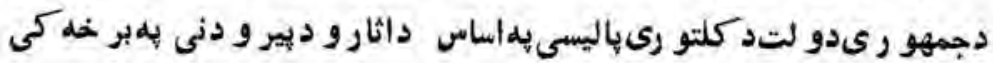

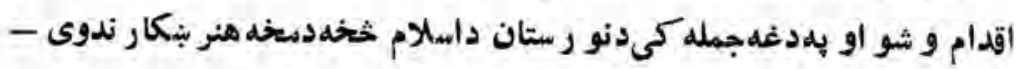




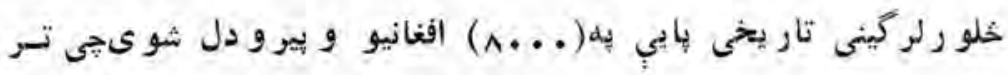

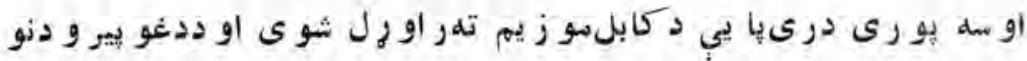

$$
\begin{aligned}
& \text { له }
\end{aligned}
$$

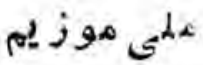

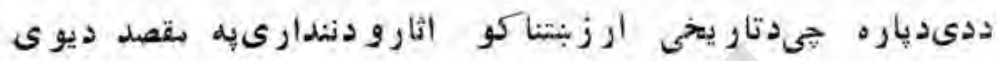
ير اخحى ساحب سهباله و دانى و لرو دجمهو رىىدو لت دكلتو رىى باليسى

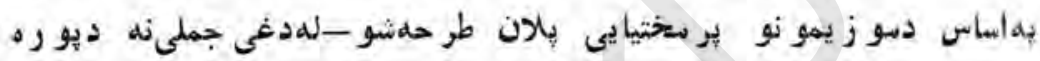

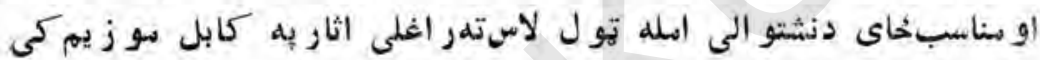

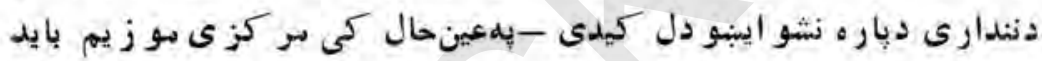
يلهيو مناسب خاى بر ووت و ىجمهو رىدولت دغلضر و رت تلمتو جلشو

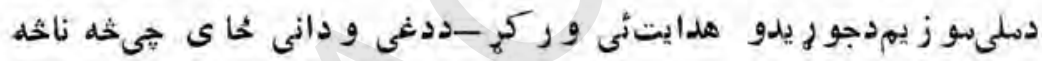

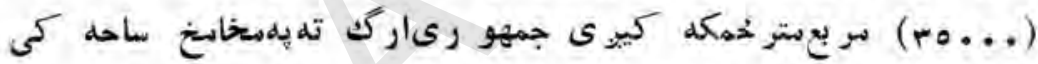

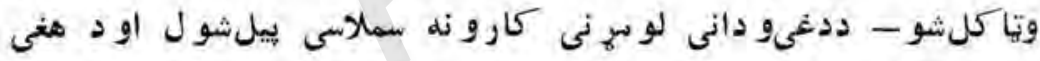

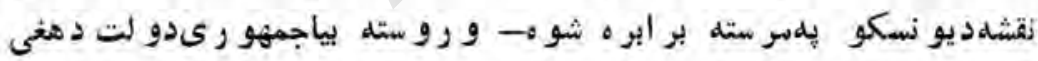

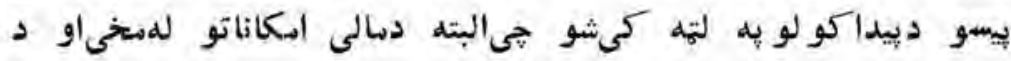

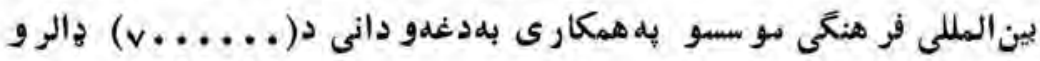

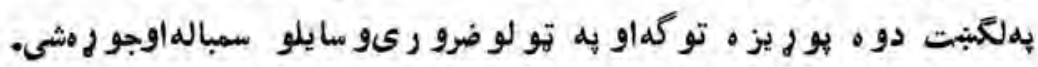

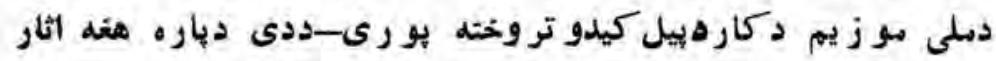

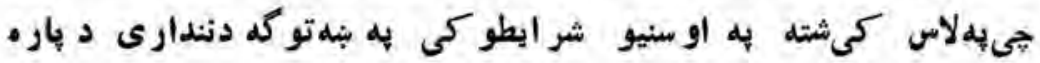
كيبيو دل شىداطلاعاتو او كلتو روزارت دكابل موز يمداو سنىودانى 


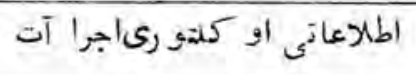

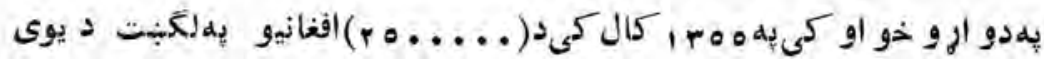

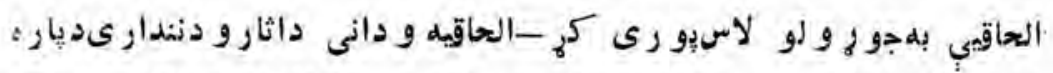

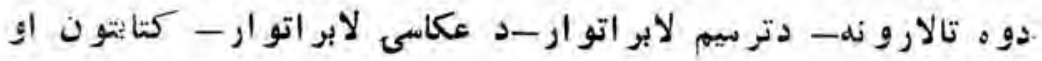

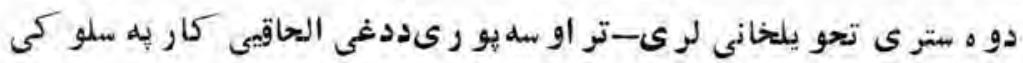

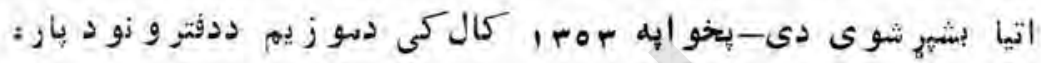

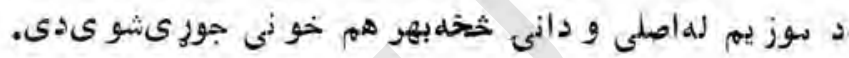

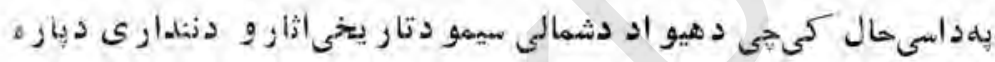

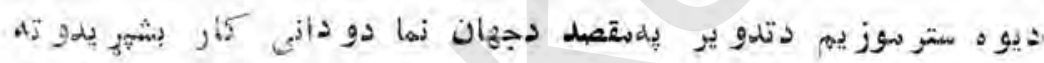

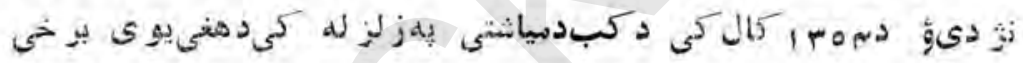

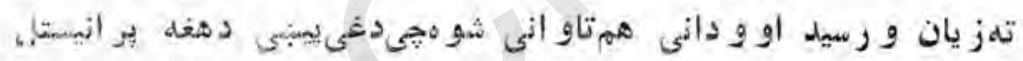

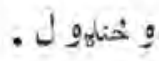

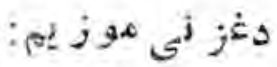

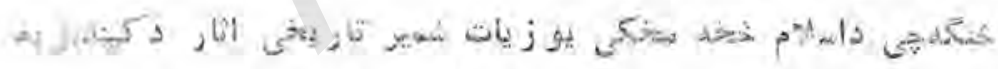

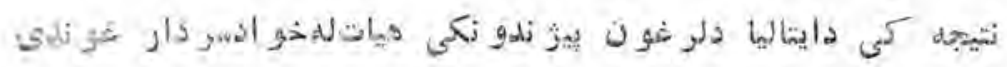

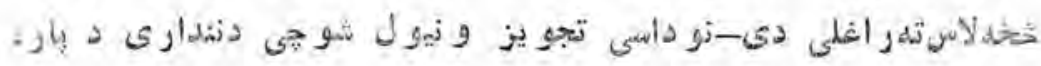

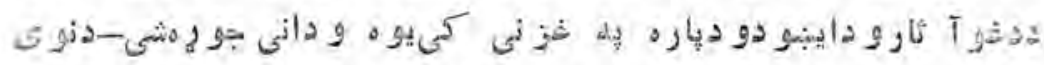

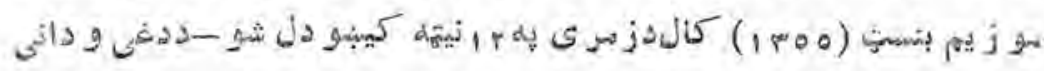

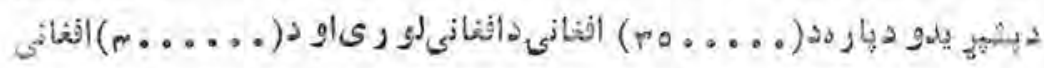

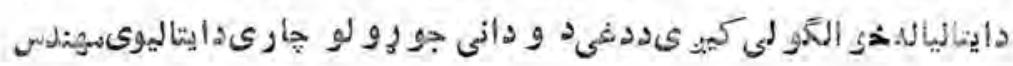

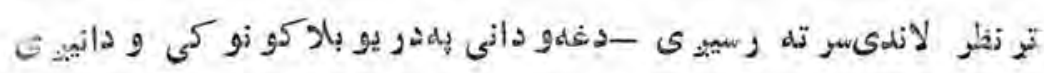




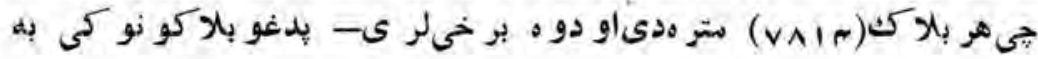

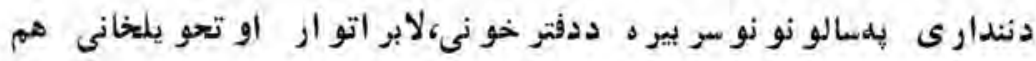

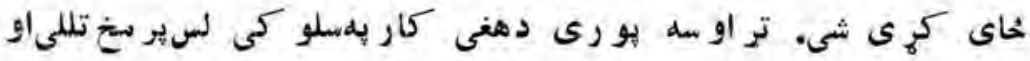

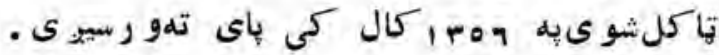
ددفى و دانى يله إيشتهيه يدو سر ه سم بهدغز نى تار يخخى بنار دو ه مو ز يمو نه

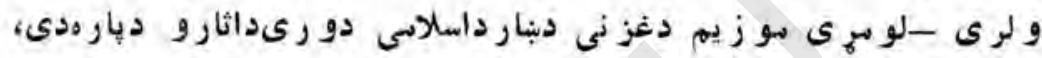

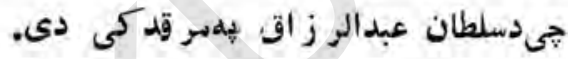

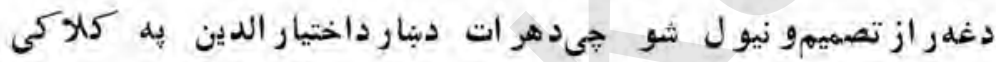

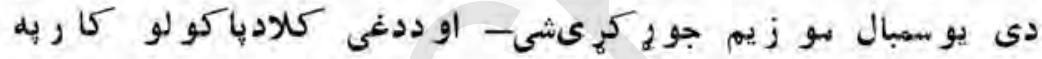

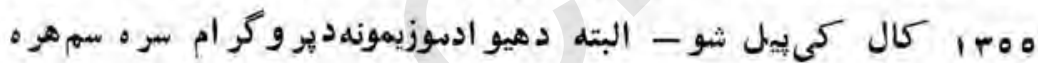

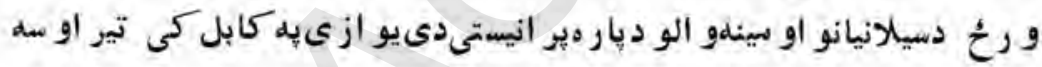

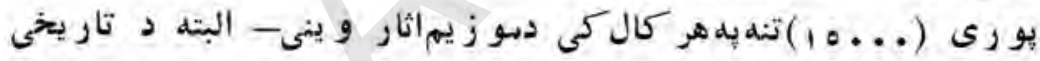

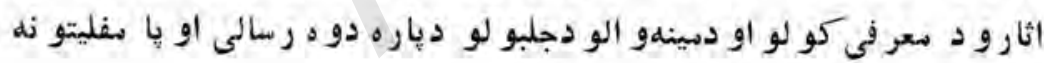

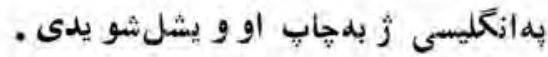
داطلاعاتو او كلتو رو زارت دتار يخحىاثار و دو تلو ديار هتديير و نه تو لاس

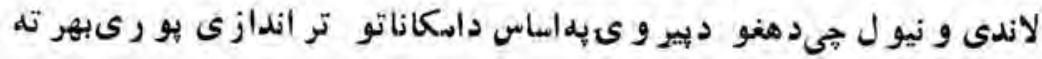

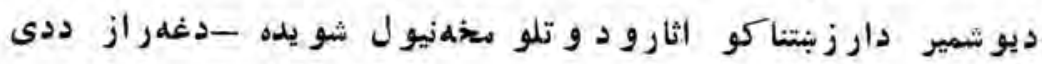

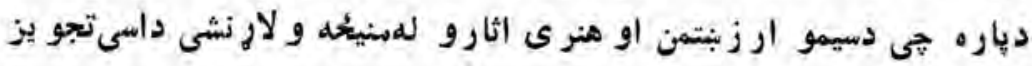

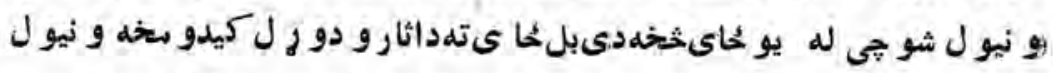

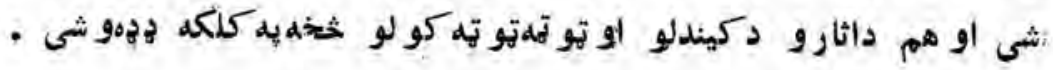


الطاجعاتى او كلمتورى اجرآت

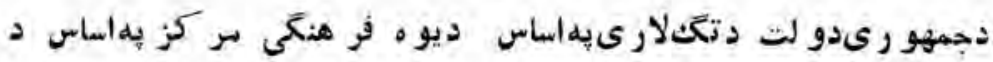

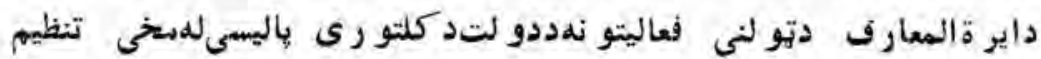

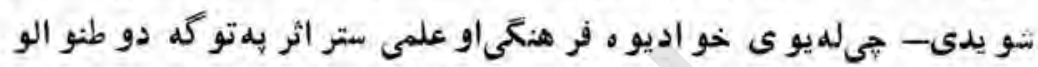

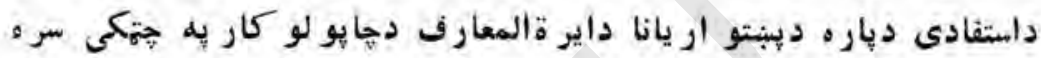

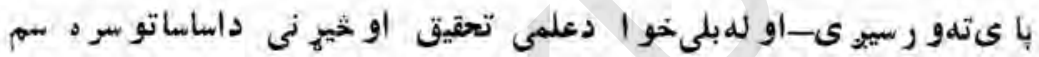

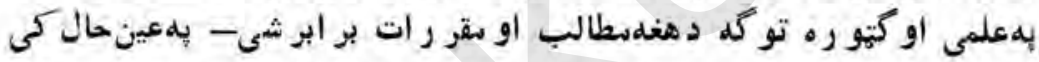

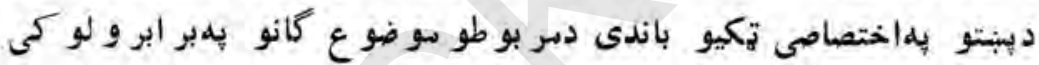

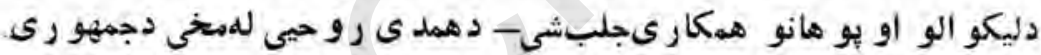

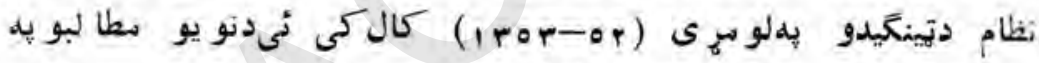

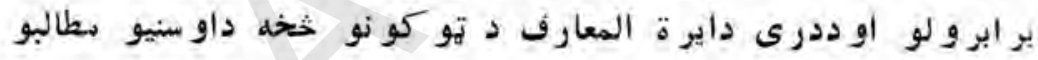

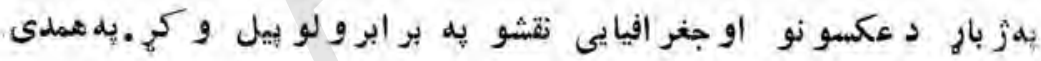

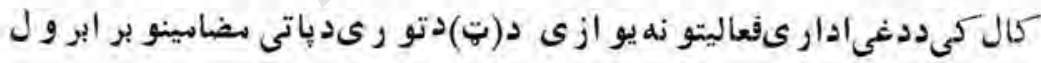

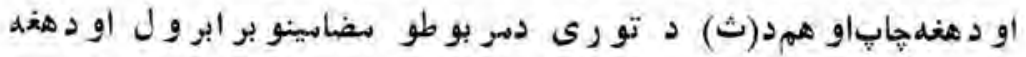

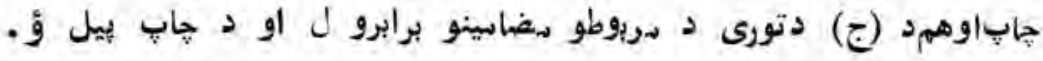

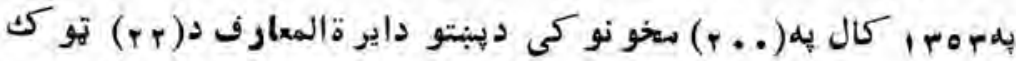

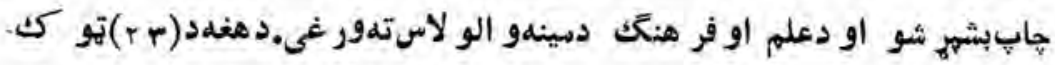

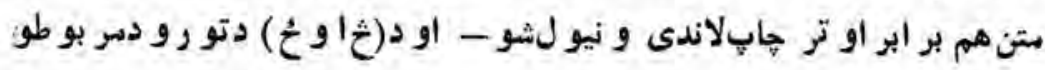

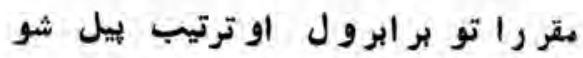

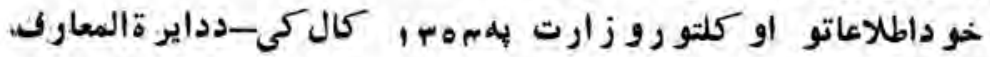




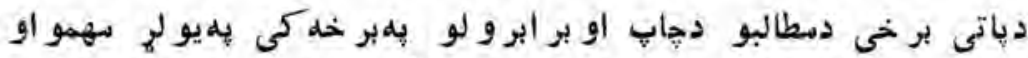

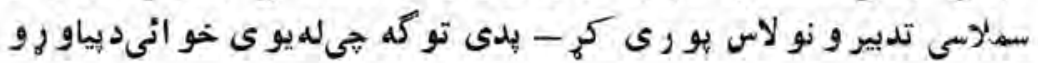

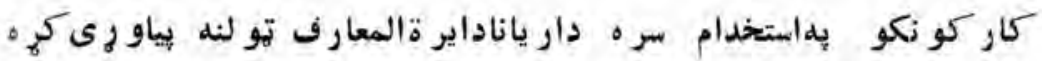

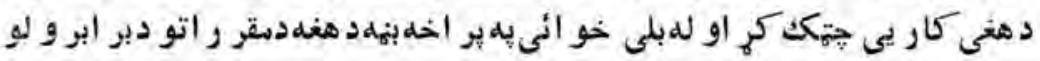

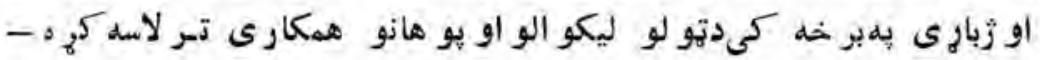

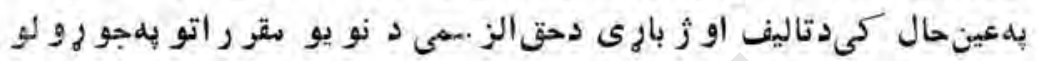

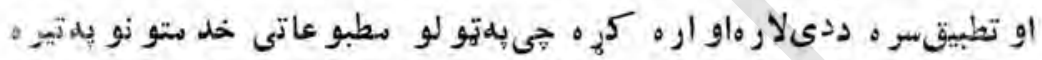

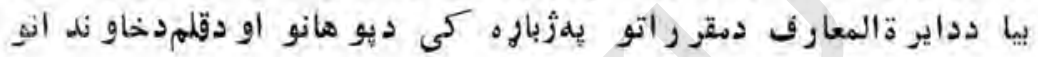

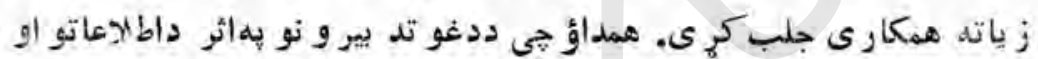

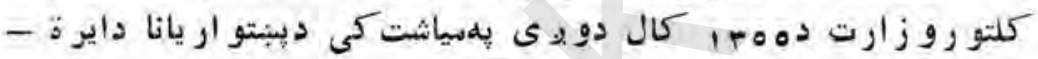

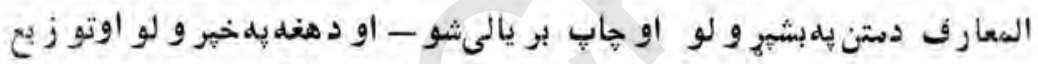

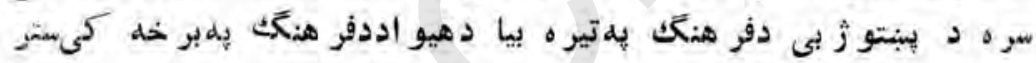

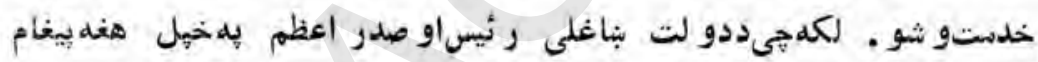

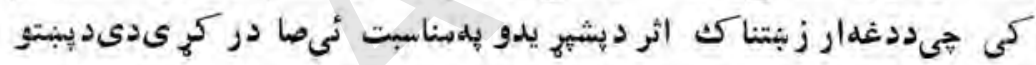

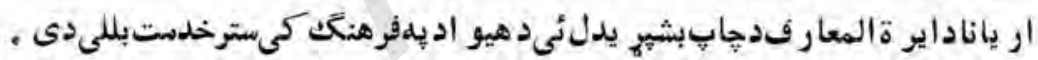

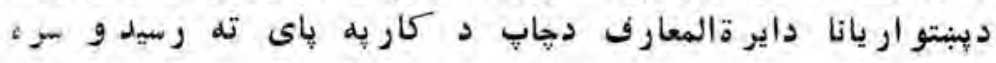

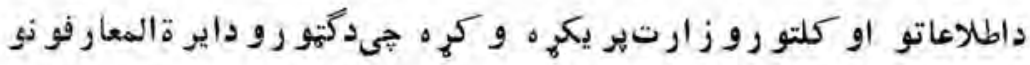

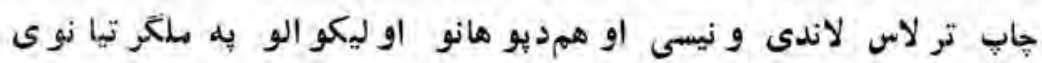

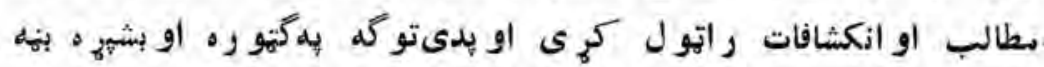

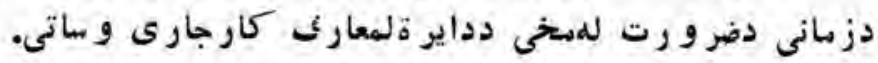

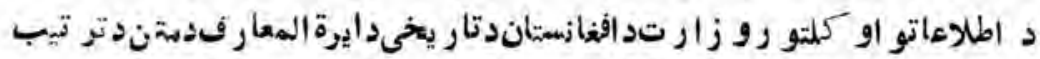

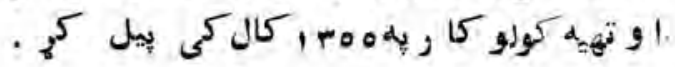




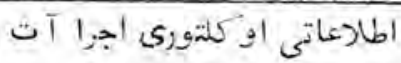

$$
: \because \text { : }
$$

ددني ادارى

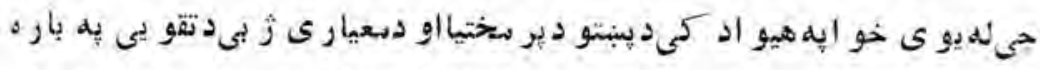

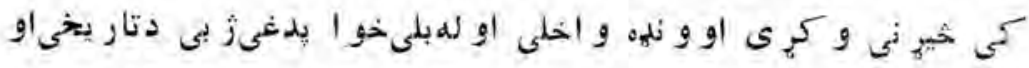

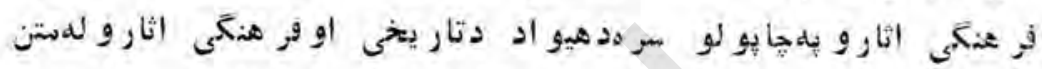

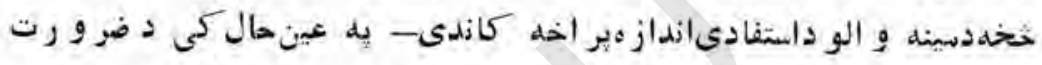

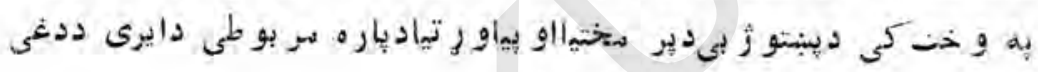

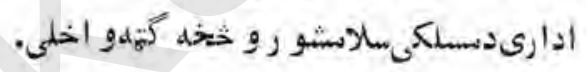

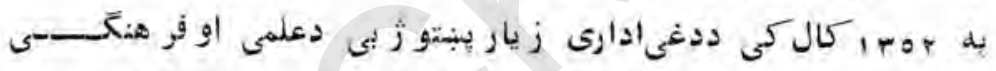

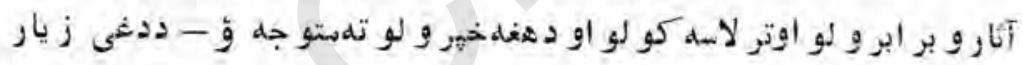

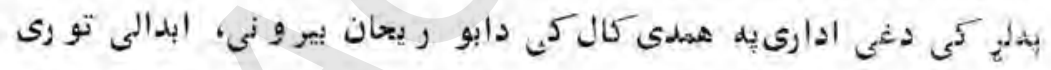

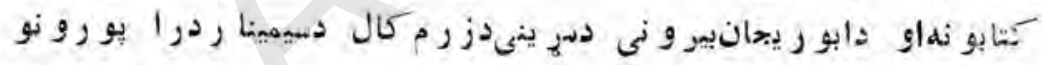

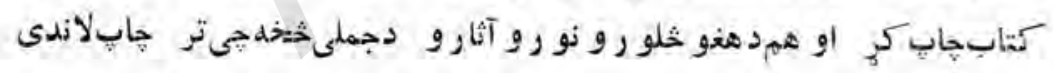

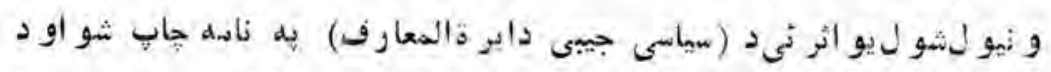

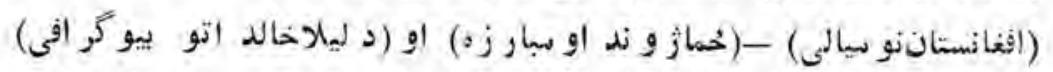

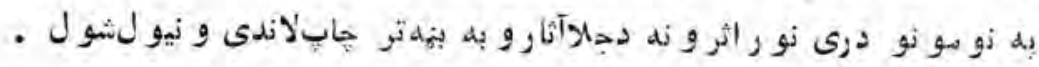

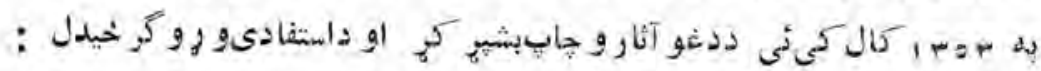

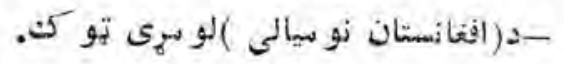
-

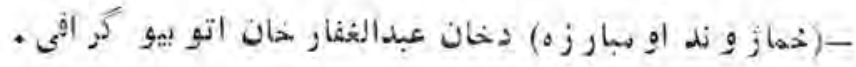




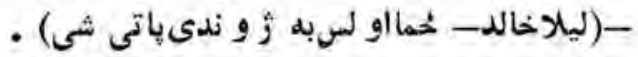

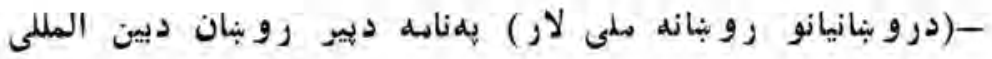
سيمينار به سناسبتيو مر ساله.

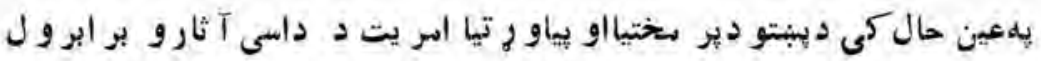

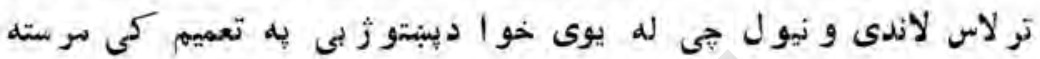

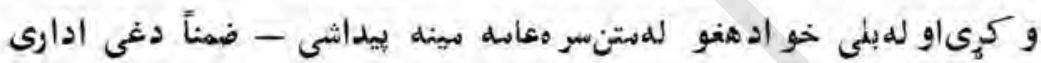

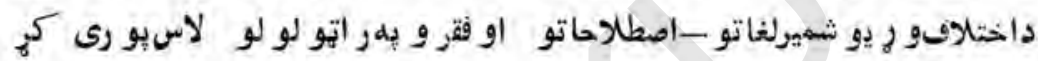

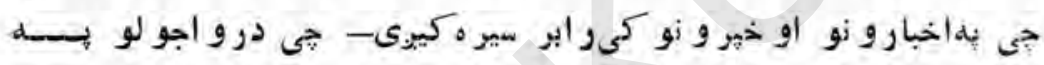

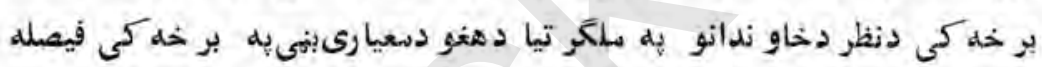

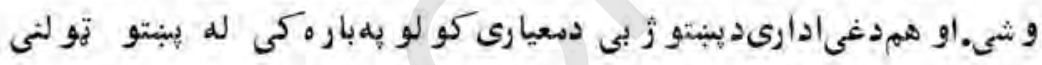

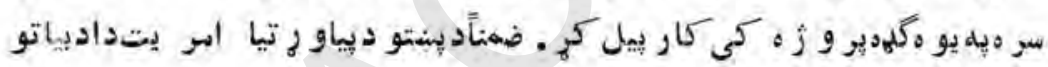

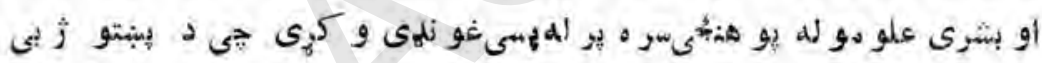

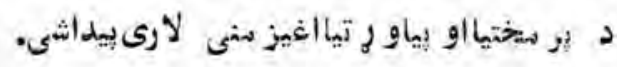

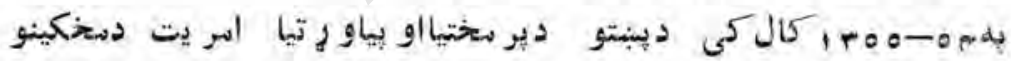

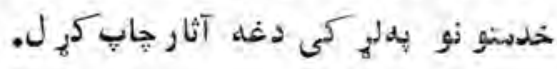

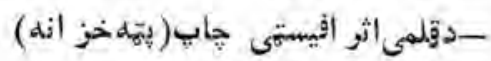

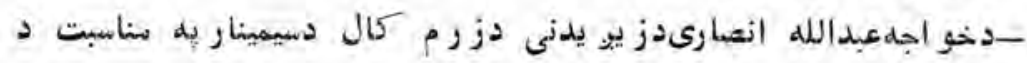
(خو اجه عبدالله انصارى او دده سناجاتو نه ) ائو جأبه.

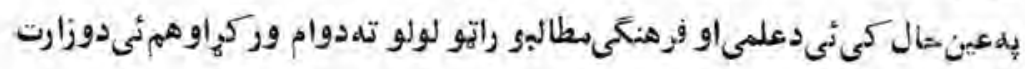

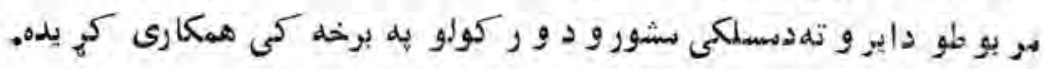




\section{: عاله}

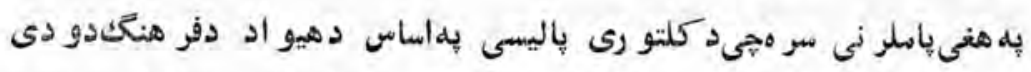

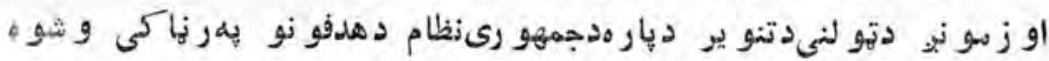

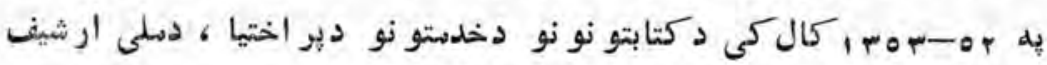

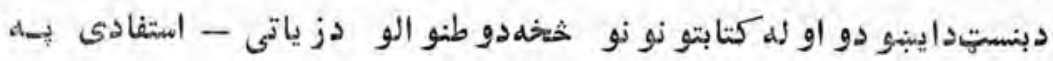

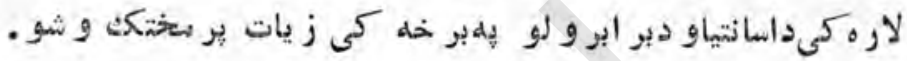

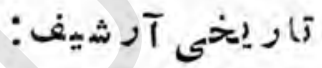

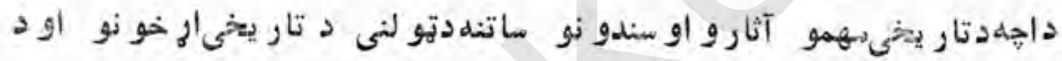

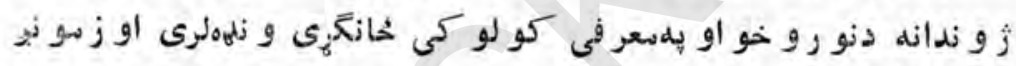
دهيو ادسترىو يأر نى بللى كيبوىنو جهو رىدو لت ددغه شان سهمو اوسترو

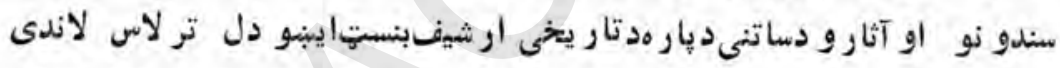

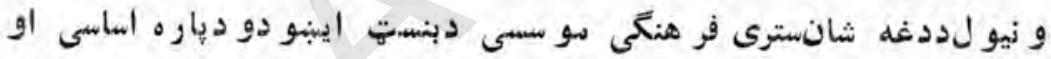

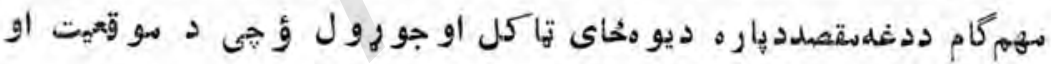

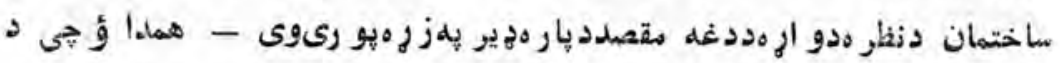

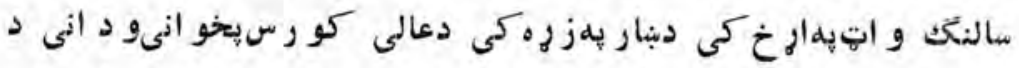

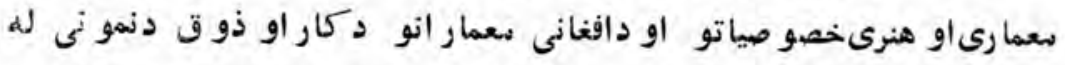

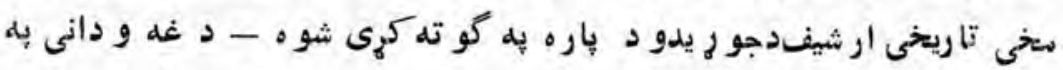

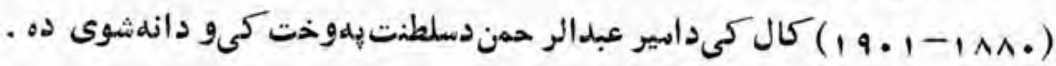

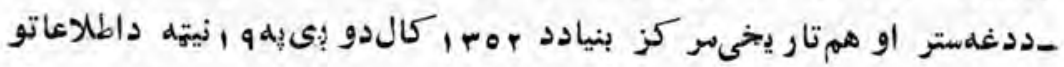

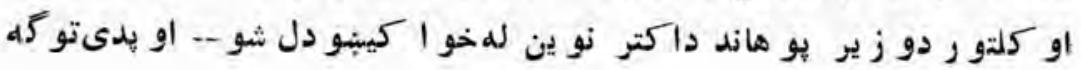


يه هيو ادكى تار يخى ارثيفمينيُ تهراغى. سملاسى ددغى و دانى تر ميم دهنى دتولوخصو صياتو هلهماتلو اودتار يخى سندو نو دياره هيه تولو ضو ورى

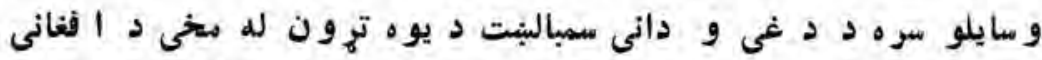
ساختمانى دستخاه لهخو اييل شو -او د يوى تار يخىى دانى يهتو كلد اسى تر ميم

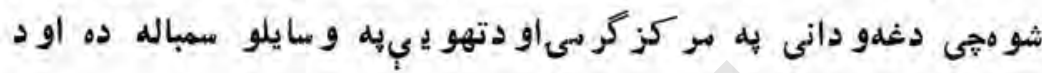
هغى دمعمارىتو لخخصو صيات هيهاصلى بنه ساتل شو يدى .

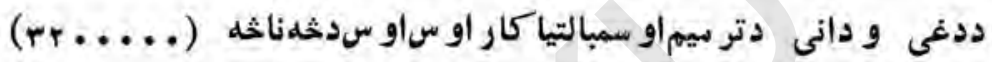

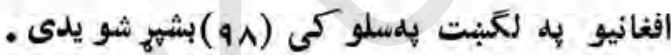
ديو نسكو دما هر انو دفيصلى لهمخحى دتاريخى ار شيف كوز نى يو هد دار شيفدمو ادو

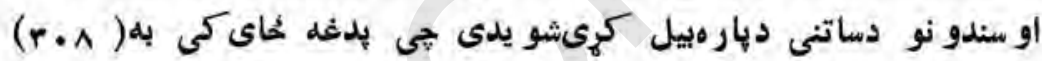
خو ز ندهالمارى كيبيو دلشى . ددغىو دانى هيه فوش كرىشوى منزل لىى دكنفر انسونو دنندارىدآثارو يه اختصاصى الماريو كى دخطى نسيخو دايبّو دلو دهيكرو فلمدلابر اتوار؛

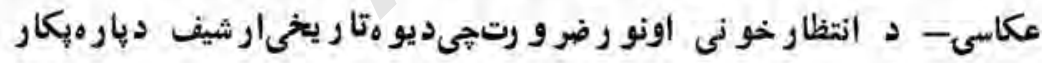
دى بلنظظ كى نيو لشو يدى .

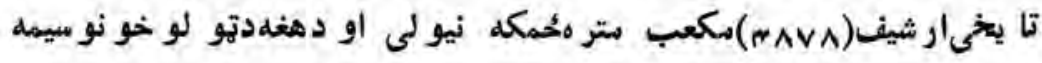

$$
\text { . (1.0v) }
$$

يه عينحالكى د اطللعاتو او كلتو روزارت د ارزبنتناكو آثارو او تار ينخى سندو نو يهر اتو لو لو او بيز ود لو بيل كَ يدى أو ددغهشان ميندونو

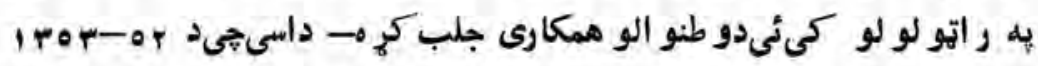


طارعاتى اوكلثو رىاجر آت

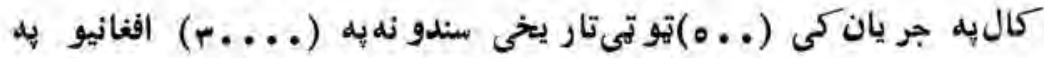

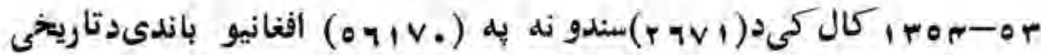

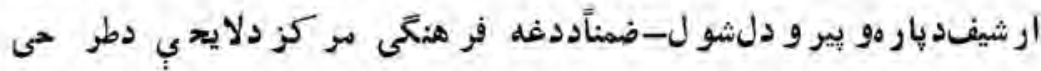

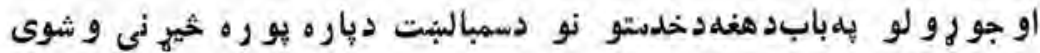

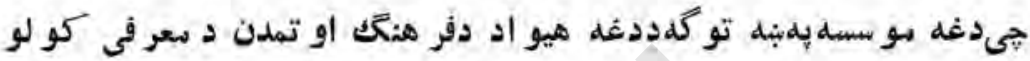

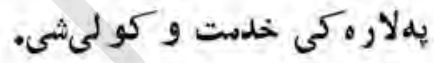
خطى نسخى

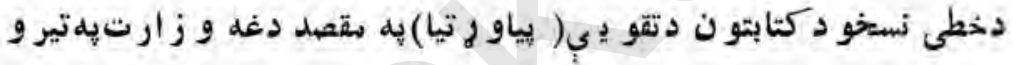
خلو رو كلو نو كى لهيوىخو از يارو و يستهي كّن شمير خطى نسيخى و بيرى او له بلى خو ائى به يو لي داسى تدبيرو نو لاسبو رى كئهى بهر تهدخطى نسخى و دو تلو مخه و نيو لشى - دغو اقداماتو به هيو ادكى دخطى نسخو

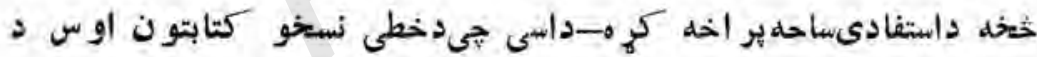

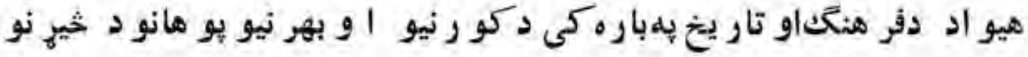
او مطالعو ستو بر كز بلل كيي.ى - دخطى نسخو د جلبو لو او راتولولو لو

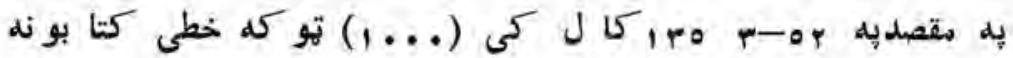

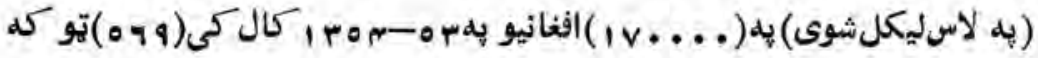

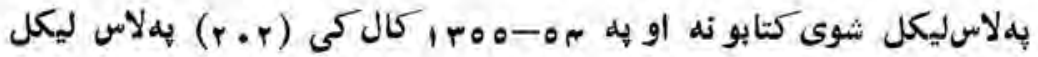

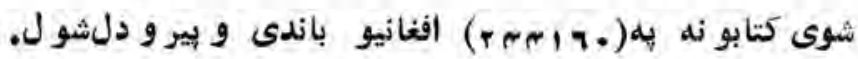



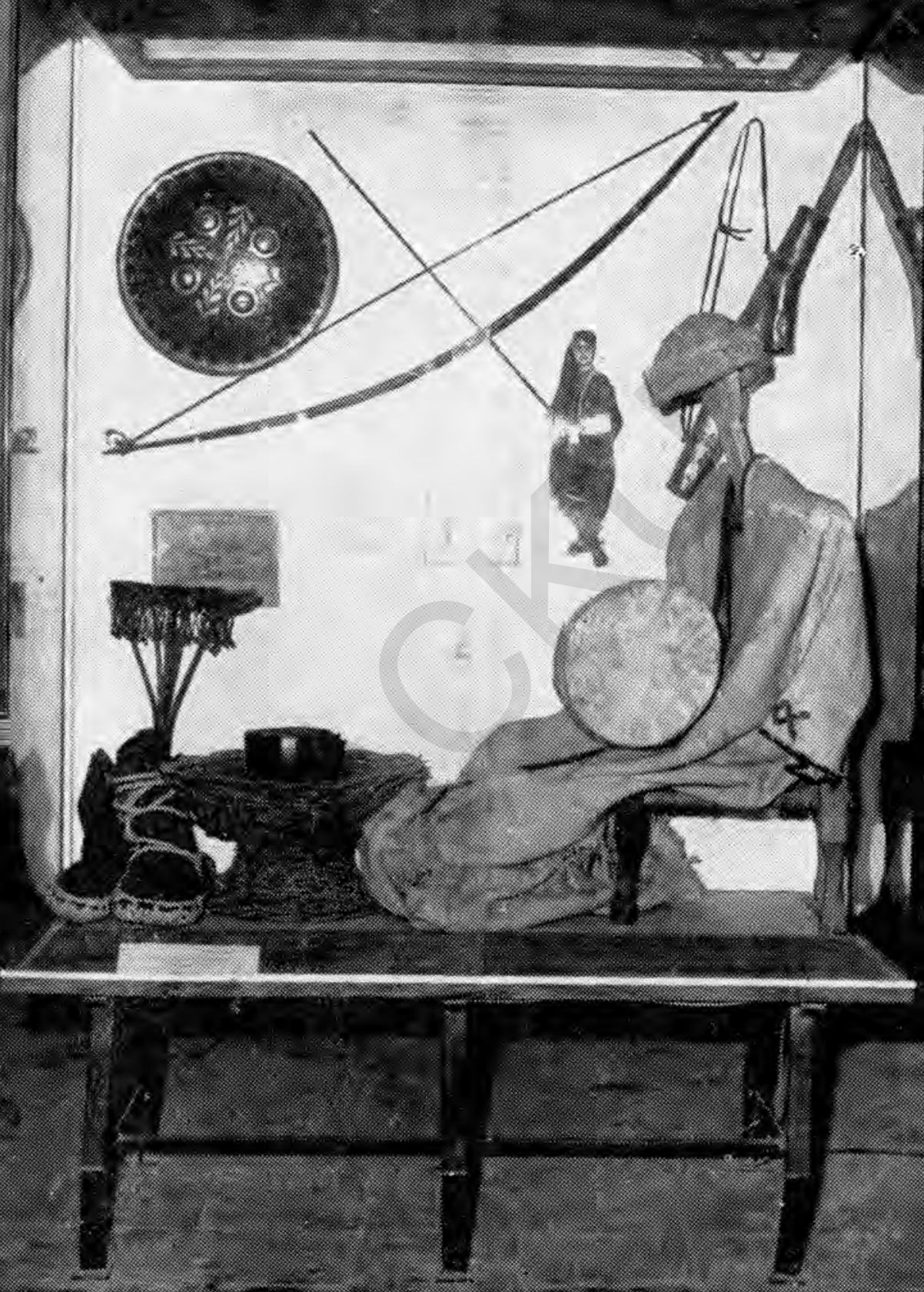


\section{:}

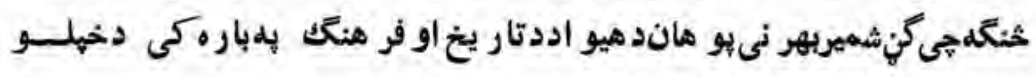

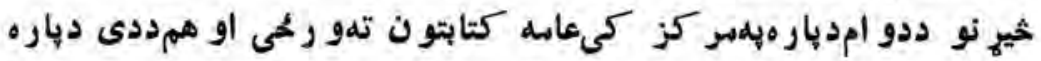
هيديو هانو او دهيو اد دئو انى بركنى (طبقى) دبار هدافغا نستان دتار يخ او جو ياناتو بلبوخه كىى دمطالعى دبارهبو ر ماسانتيا وى بو ابرى كرى شى

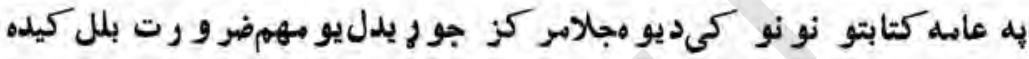

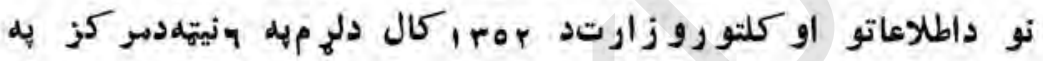

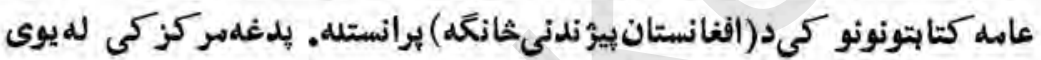

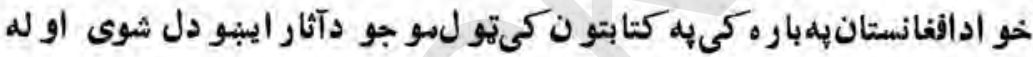

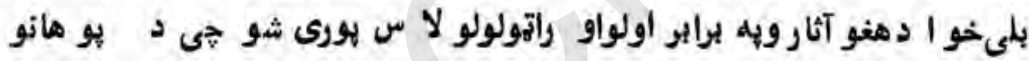
اوفو هنكىمر كز و نوله خو ازمو نيد هيو اديهبا ب خهار مشوىاو خهر يوى .

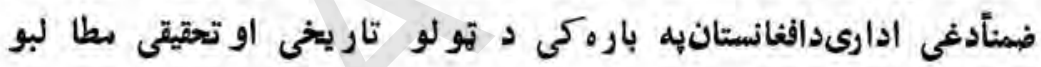

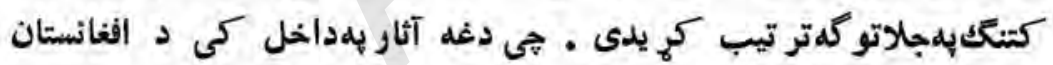

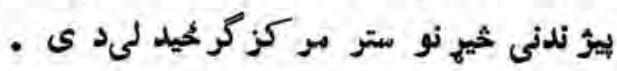

$$
\begin{aligned}
& \text { : ه: }
\end{aligned}
$$

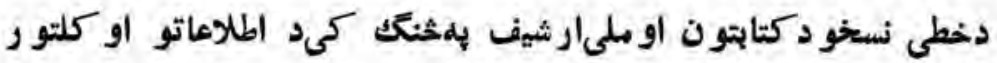

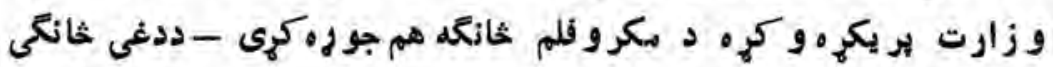

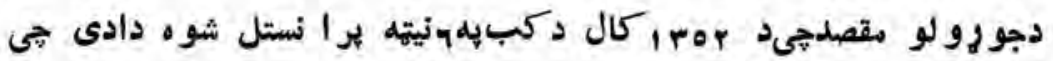

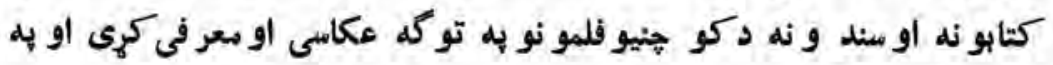

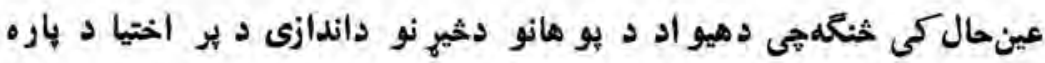




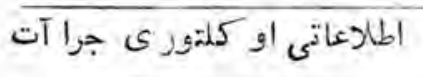

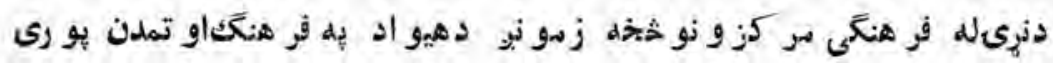

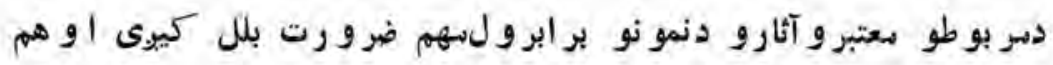

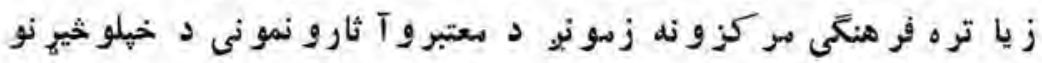

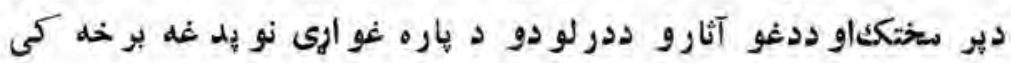

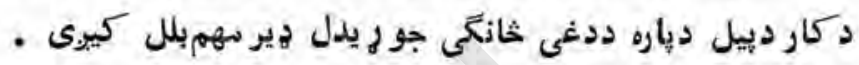

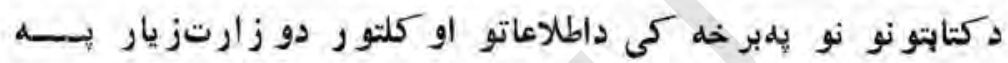

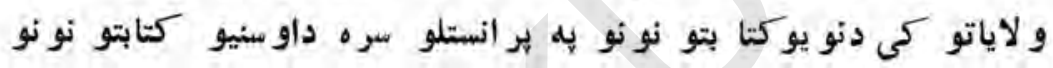

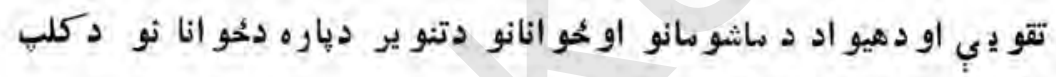

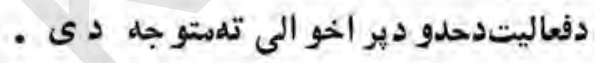

$$
\text { نو إو ك=ا بتو نو نو بر انيستل : }
$$

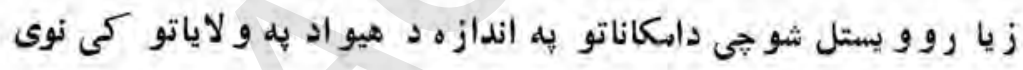

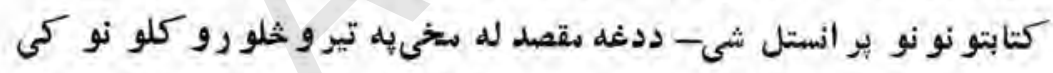

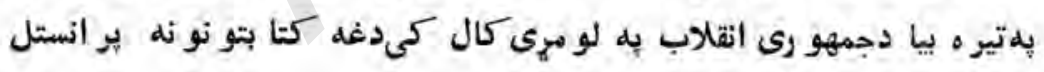
شول : بل

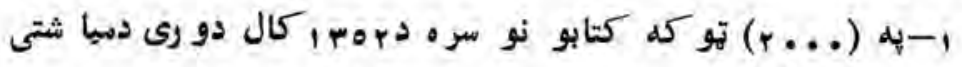

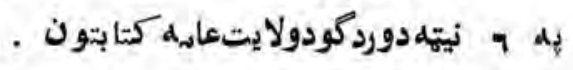

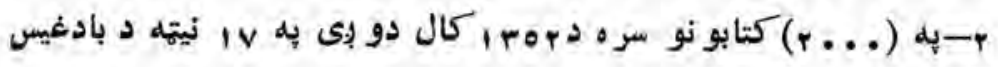

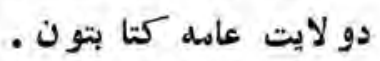

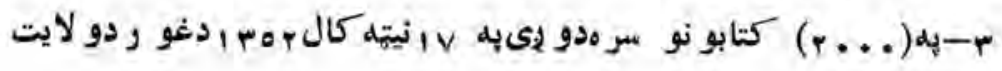
عامه كثابتون ن إنه 

(1 ro)
كتابتونوزن

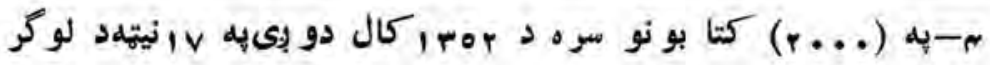

$$
\text { دو لايتعامه كتابتون. }
$$

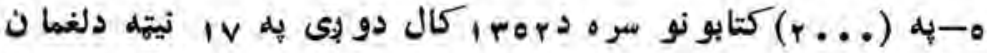
د و لايت عامه كتابتون .

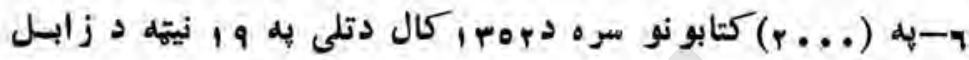

$$
\text { دولايتعامذ كتا تونون }
$$

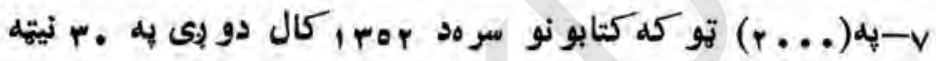
دابيا نو دولايت عامه كتابتون .

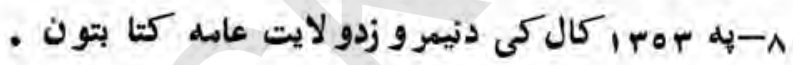

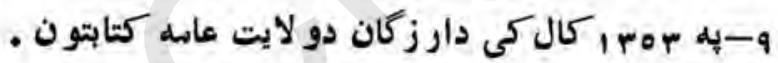

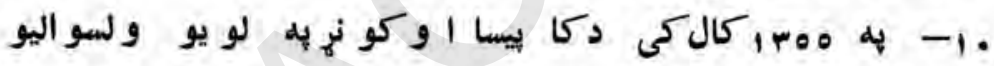

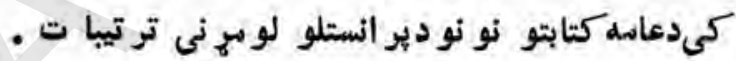

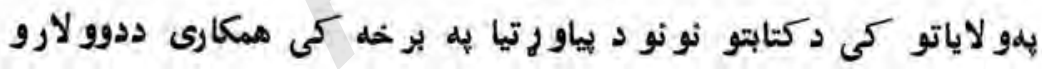

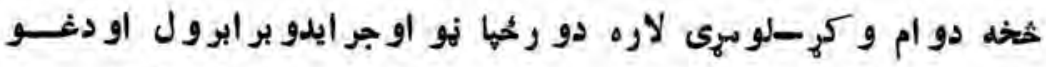

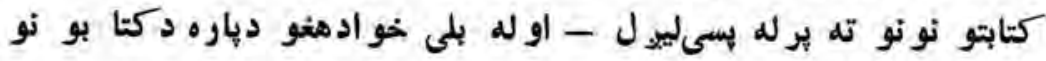

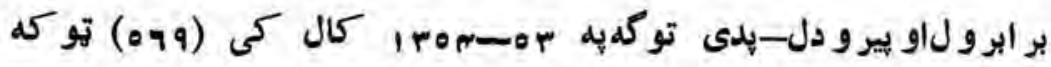

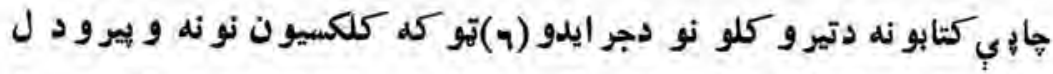

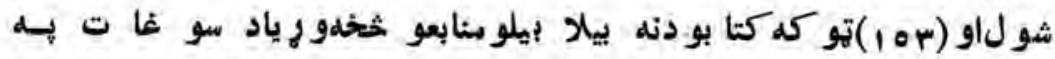

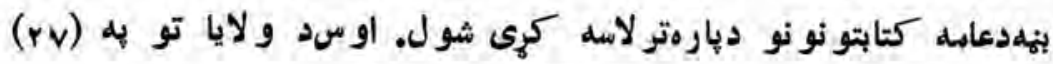

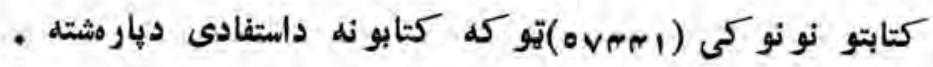




$$
\text { اطالدعاتى اوكلتو رىاجرآت }
$$

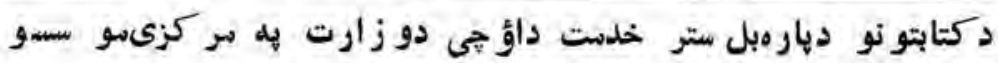

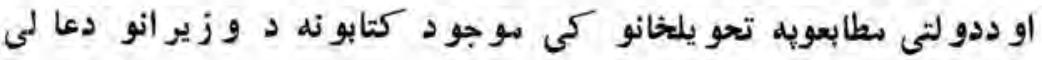

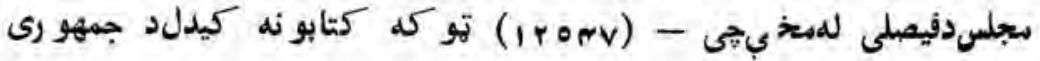

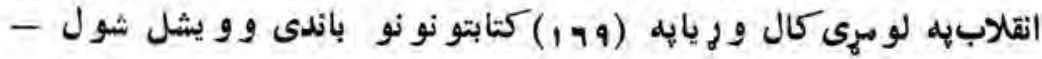

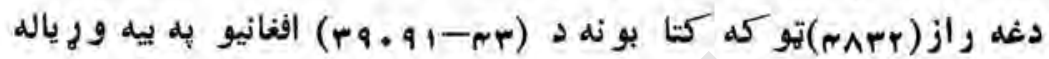

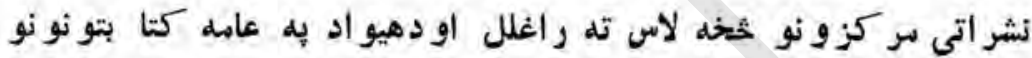

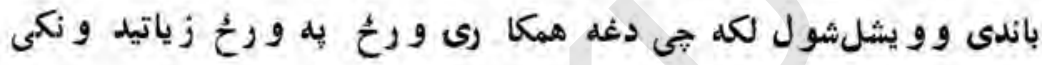

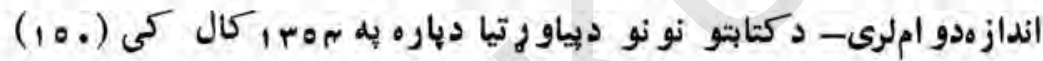

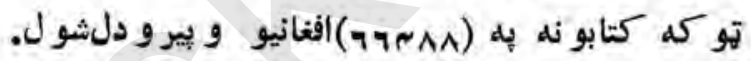

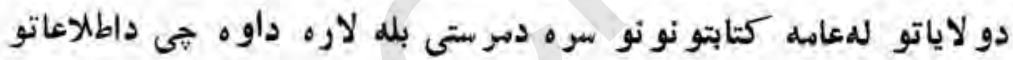

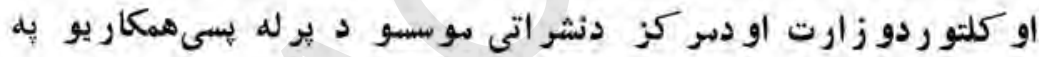

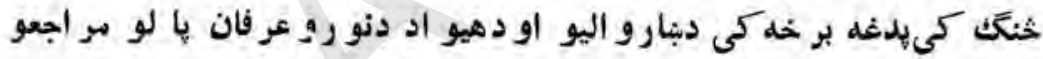

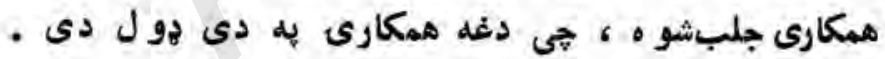

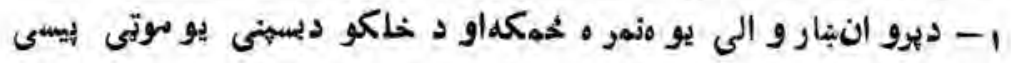

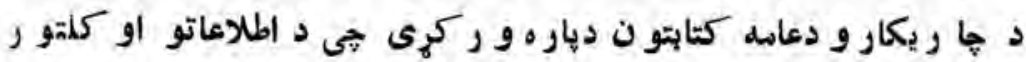

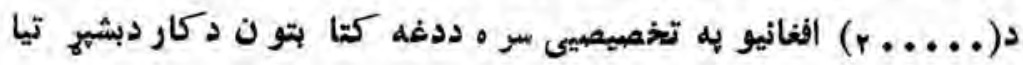

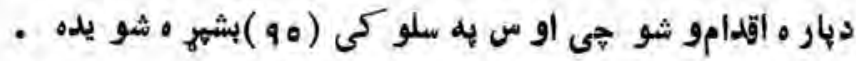

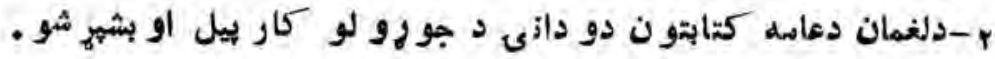

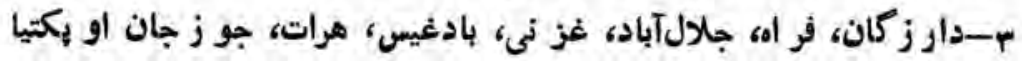

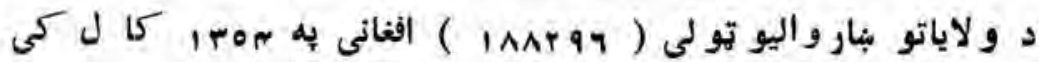




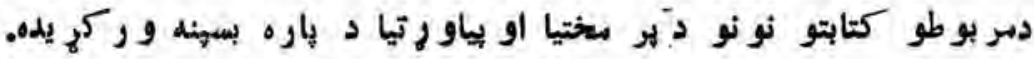

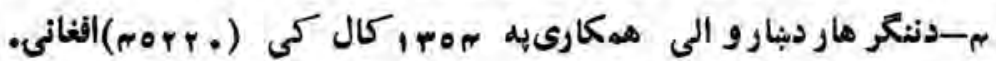

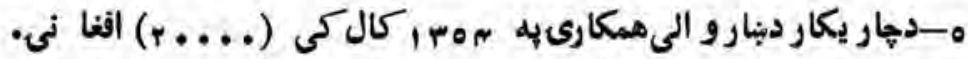

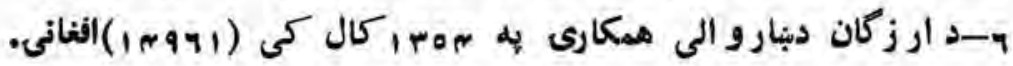

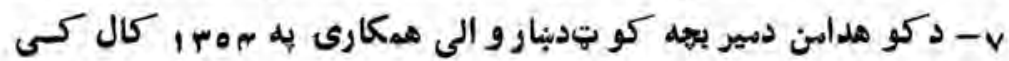
- (1....)

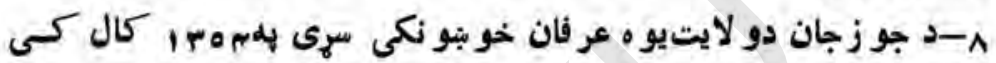

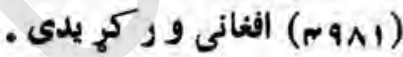
به عينحال كى به و لاياتو كى د عامه كتا بتو نو نو دو دانيو دجو وو لو

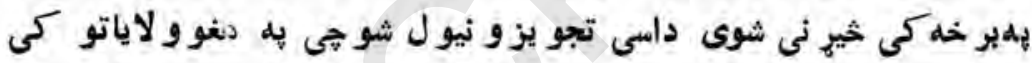

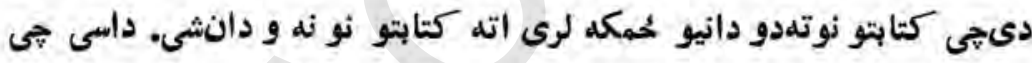

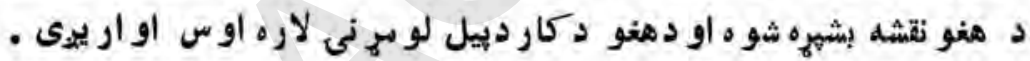

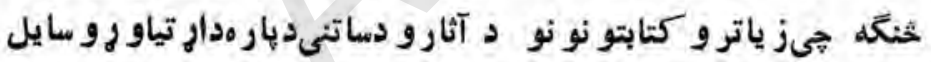

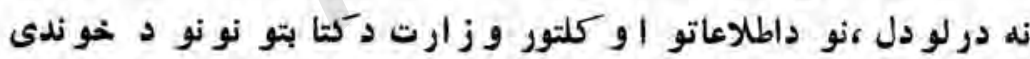

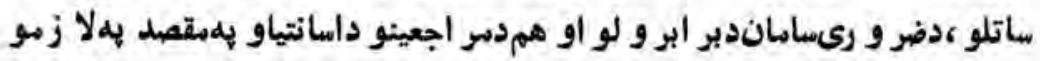

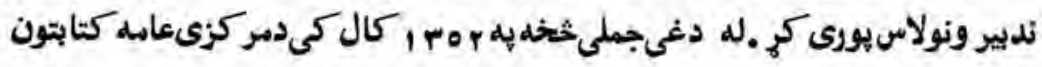

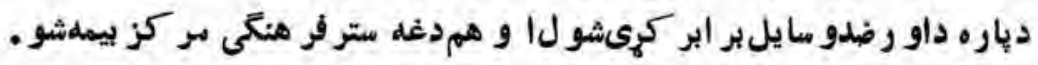
او همربه عين حال كى دجو زجان ، هلمند،بلخ ، فار ياب ،فراه، هـ ات،بادغيس

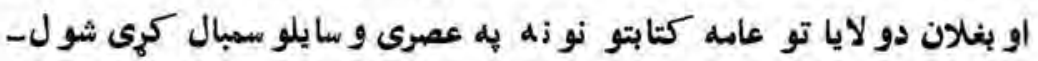

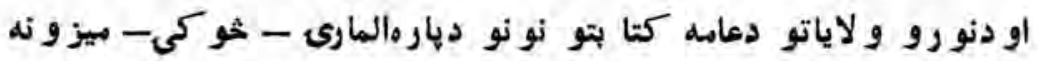




\section{الطالعاتى او كلثز زى اجرا آت}

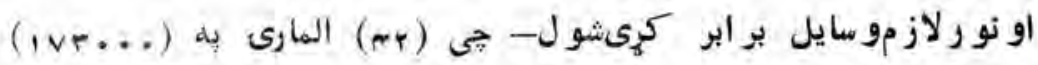

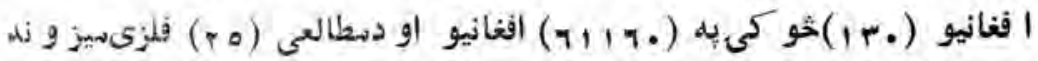

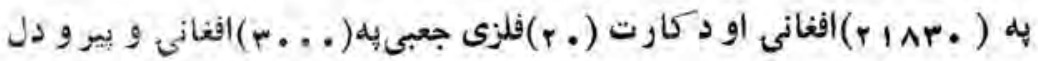

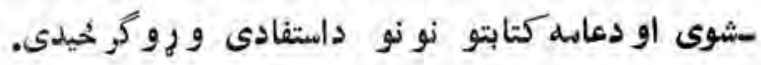

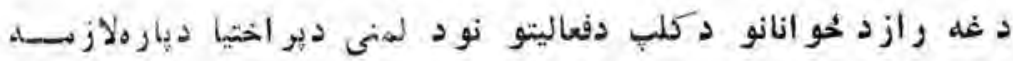

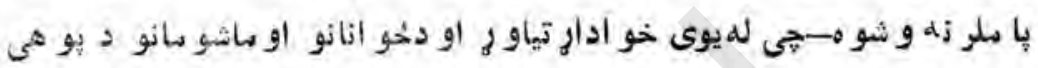

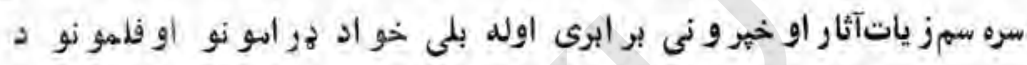

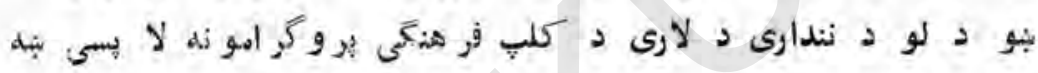

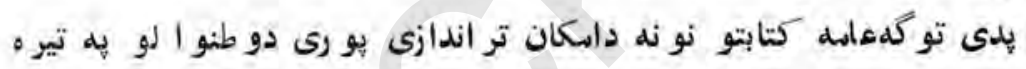

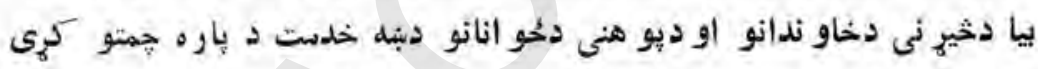

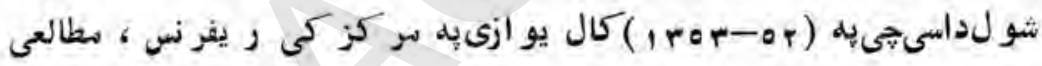

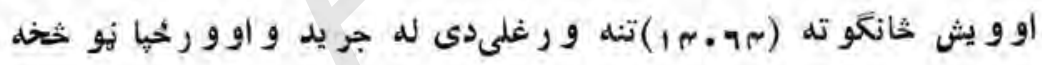

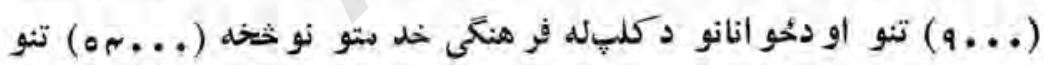

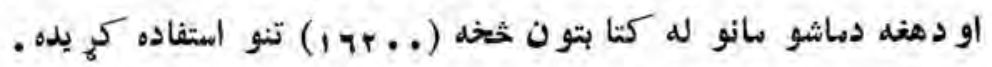

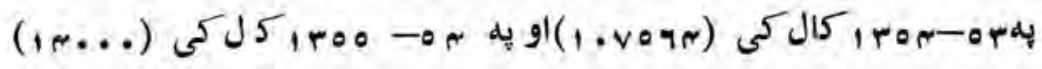

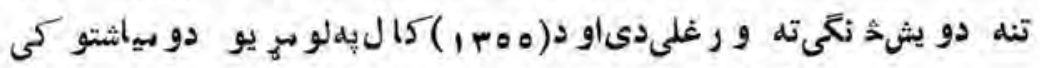

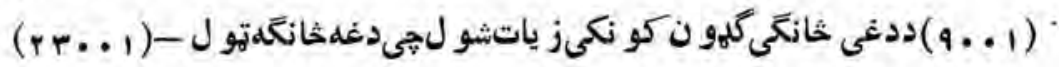

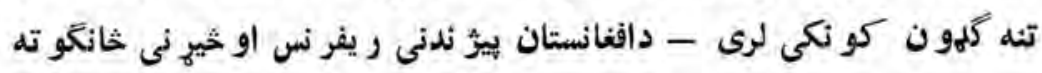

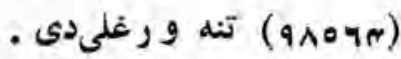




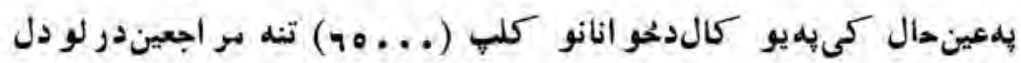

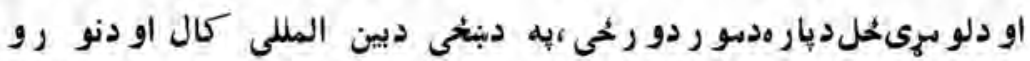

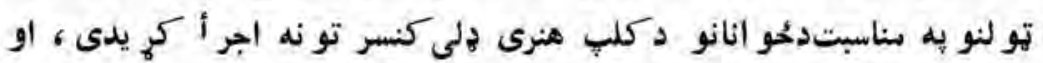

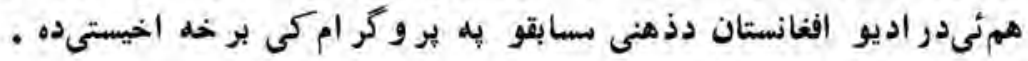

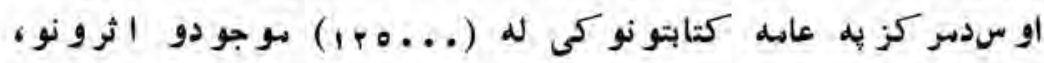

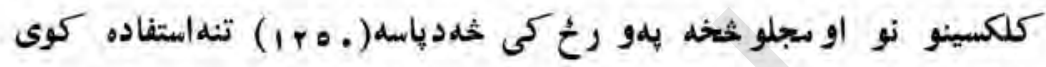

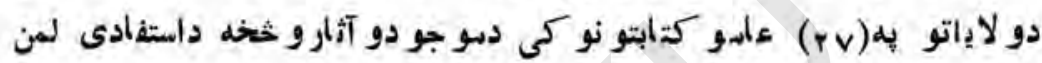
لإبسى الإير اخييزى

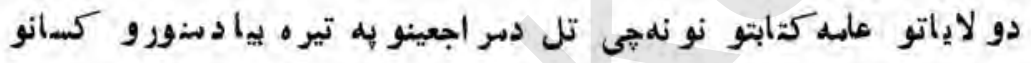

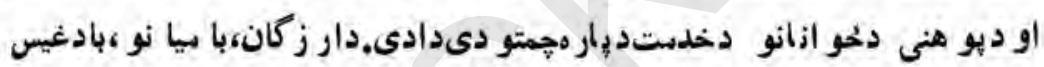

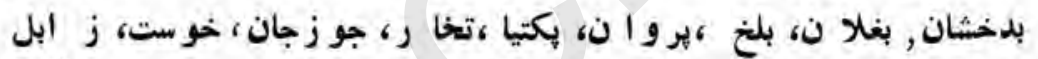

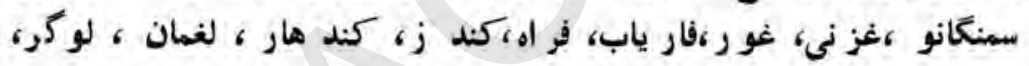

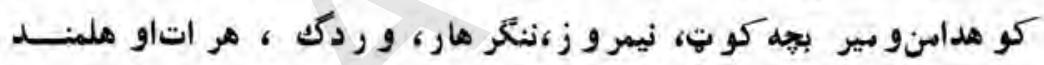

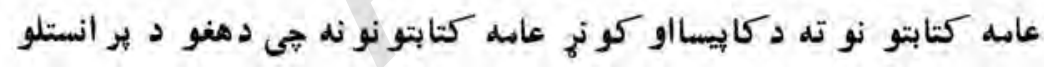

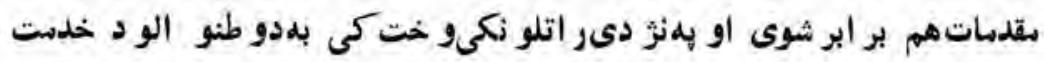

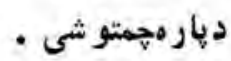

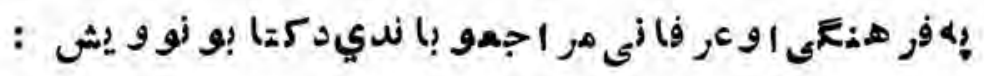

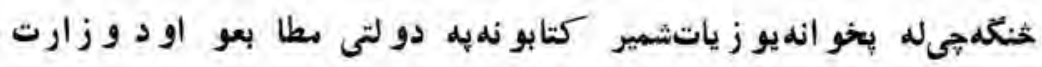

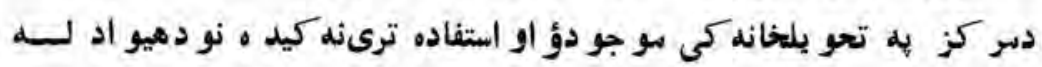

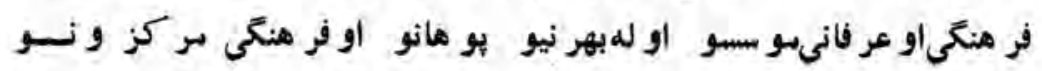


آل

سو هدهدكارى ديار مداطلاعاتو اوكلتو رو زارت دجمهو رى نظام د تيينكيدو

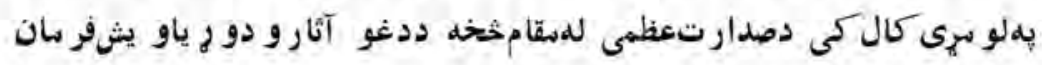
و اخيست .

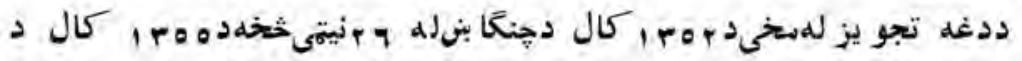

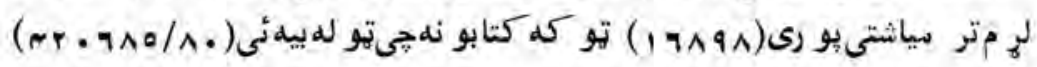

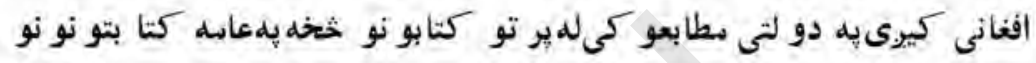

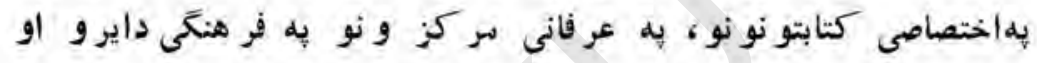

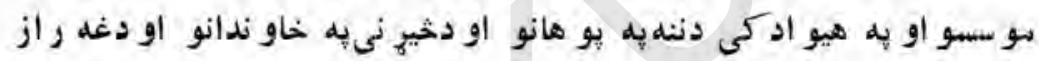

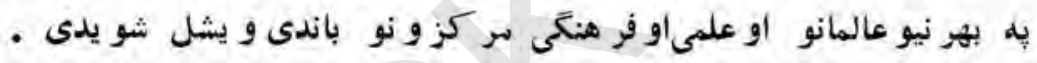

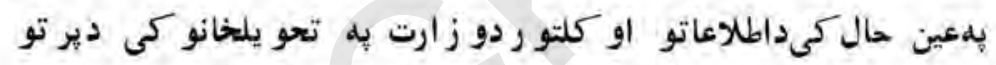

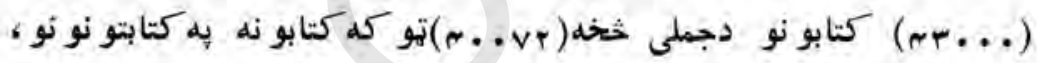

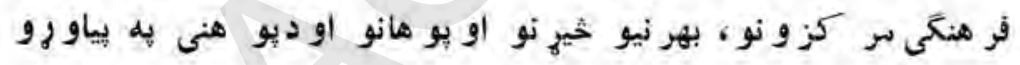

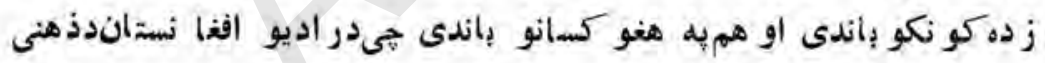

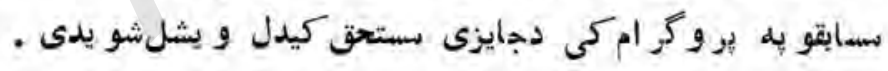

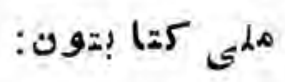

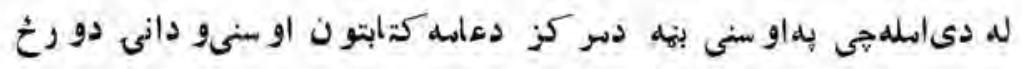

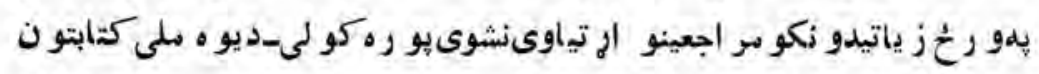

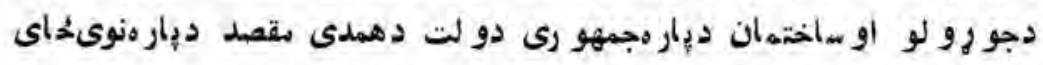

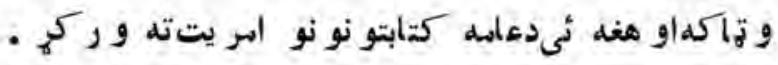

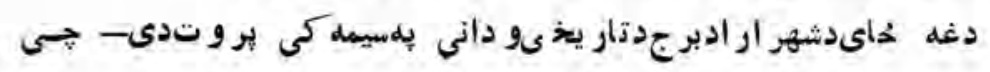



$(1+1)$

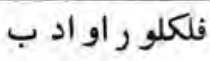

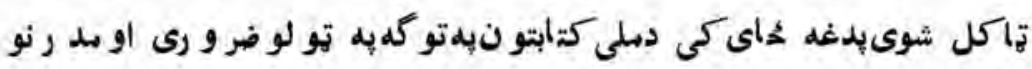
و سايلو سمباليو كتابتونو دانشى.

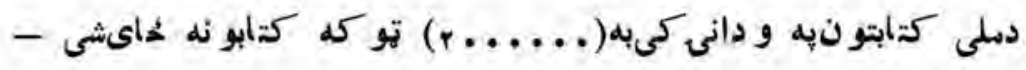
اوسددغى و دانىلومه نى سر وىيبل شو يده.

\section{فلملهورو ادب:}

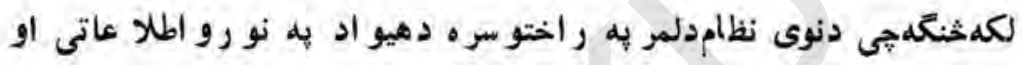

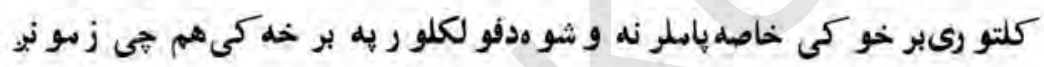
دهيو اديه رُو ندانهاو فر هنگتكى او دفو لكلو راو ادب داسو يت دلارىدخلكو داديباتو ، دو داو دمستو ريلغاتو

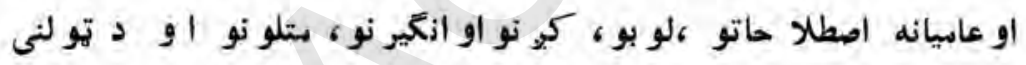

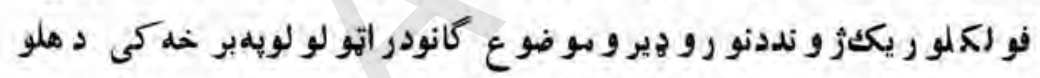

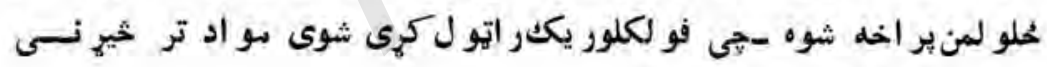
و رو ستمل يو له بسى خهار مشو يذى .

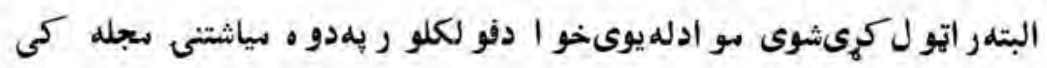

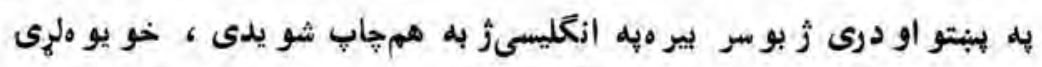

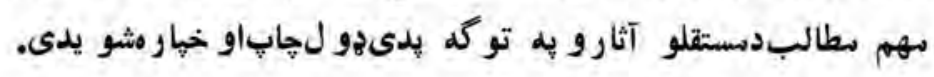

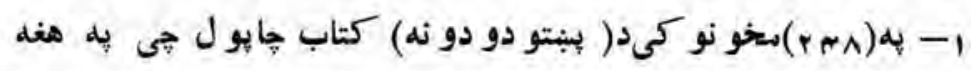
كى، دو دو نه - دستو رى او عاسيانه ادبيات او دِّبتو ثر بى هير شوىشاعي ان 


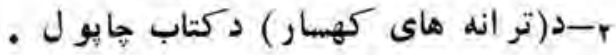

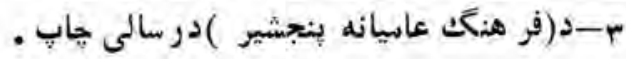
r-د( رقصهاى فو لكلو رى و معلى افغانستاندر سالى ) بر ابرو ل .

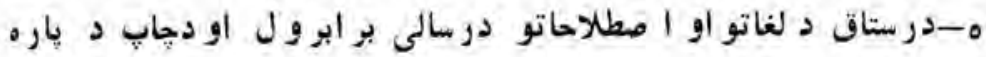
جمتو كول

ه-د هيو اد دمو سمقى او دمو سيقى دفو لكلو رى آلاتو يهل بارنكى ديوى ر مالىبر ابر ول

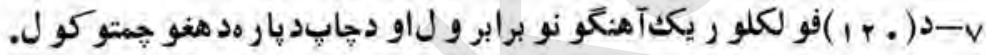
ی-ديوو ان، دفو لكلو ردر سالى او دكو هداسن درسالى بر ابر ول .

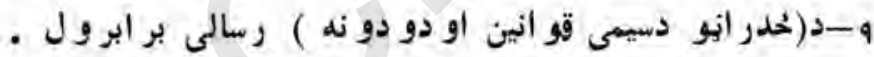
• - .

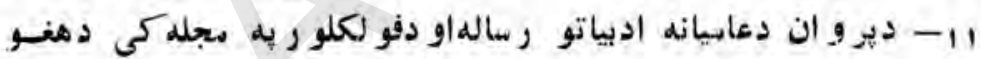
- جايول

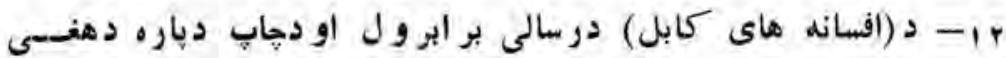
- جمتو كو ل

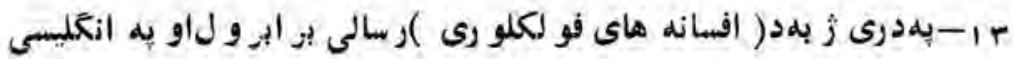

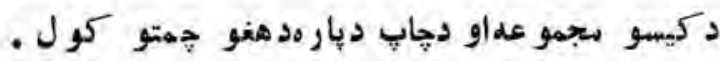

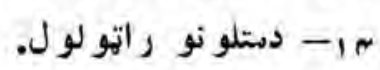

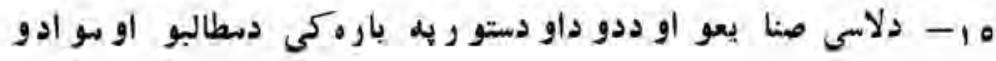




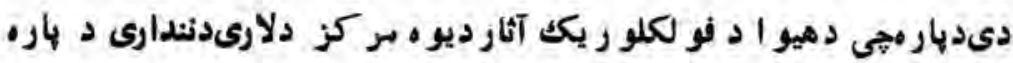
كيبنو دلشى داطلاعاتو او كلتو رو زارتددهم اكال به ودومتيو وختو كى يو هيات دفو لكلو ريكك ديبر و دنى او بو ابر و لو ديار مدهيو ادو لاياتو ته

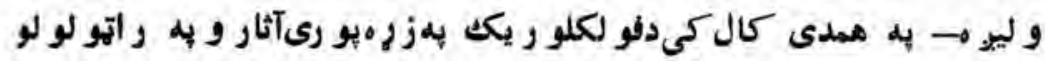

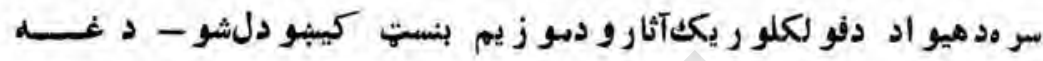

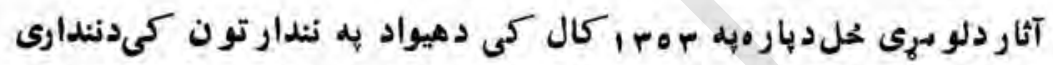

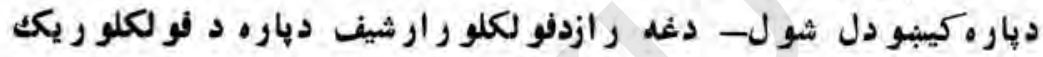
مر بوطو باحو داومو مواد و يبر ود ل اود يو شعير مضمونونو او

$$
\begin{aligned}
& \text { خهر و نو يير ودل دو ام لرى نر ن } \\
& \text { |فذانفو }
\end{aligned}
$$

داجيى فلم او سينما دسينمائى نندار و او زمو ني به هيو اد كى دخلكو دخبر تيا

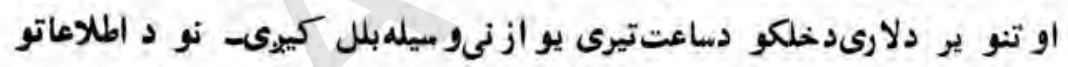

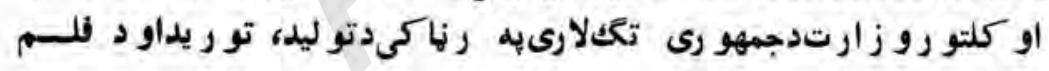
دو يشاو ثبود لو دلارىدافغان فلمحديتو نه لابسى سبال كرىل - او مغه

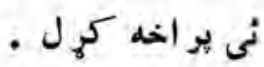

$$
\begin{aligned}
& \text { دولم جوكول: }
\end{aligned}
$$

د هغلو سايلو بهنظل كى نيو لو سو • خیى به لاسكى دى اود اوسنيو

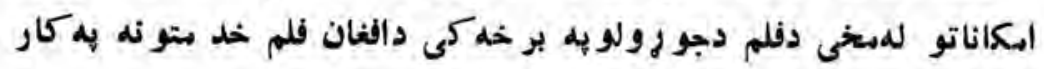
و لو يدلاو دستتندو اخبارىاو هنرى فلميه جورو لو لاس بو رى شو.

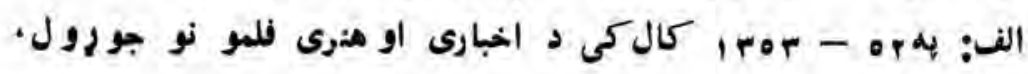




$$
\text { الطاعا تى او كلتو رى اجرا آت }
$$

- دجمهو رىنظام دجوز يدو اود هيو ا د د نو رو بر بختياوسر بوط

$$
\begin{aligned}
& \text { خبرى فلمونه (0r) كرئى }
\end{aligned}
$$

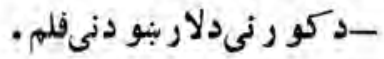

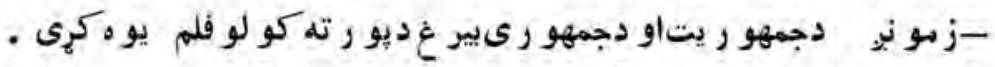

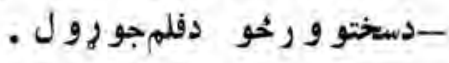

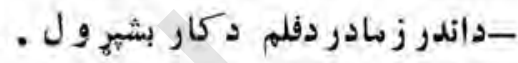

\section{: J15Iraf_ard?}

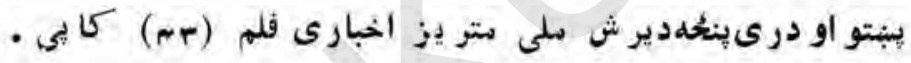

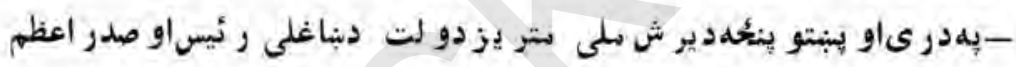

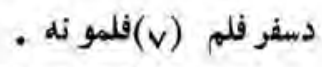

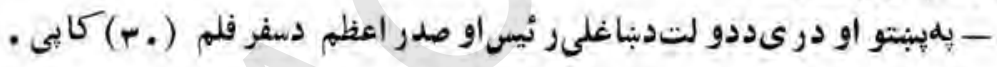

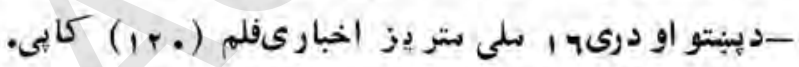

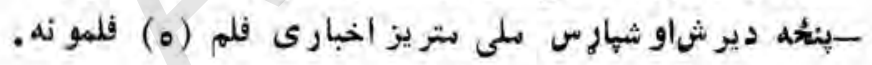

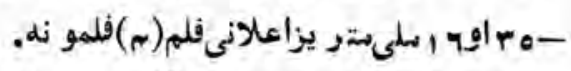

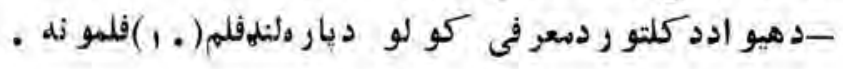

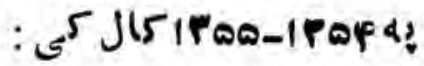

- هند-بنكلهديش-عر اق او اير ان تهددولت دبناغلىر ئيس او صدر اعظم

$$
\text { دسفر فلم (9 1 ) )فلمو ند }
$$

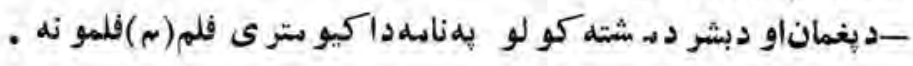

$$
\begin{aligned}
& \text { ـ د كورنى اولا رينودنىفلم. } \\
& \text { دماريادمجادلى فلمهم }
\end{aligned}
$$




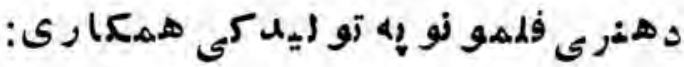

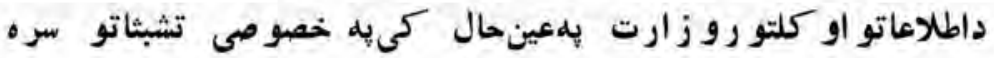

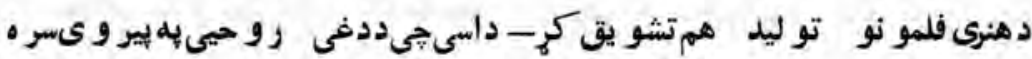

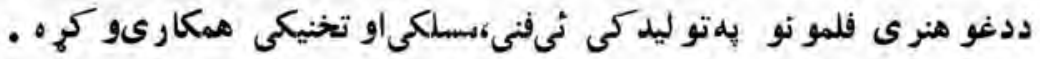
ا-_د(شعر هاناسر و دهاندند) هنر ىفلم-_در ابعه بلخى دناكام عشق د داستان

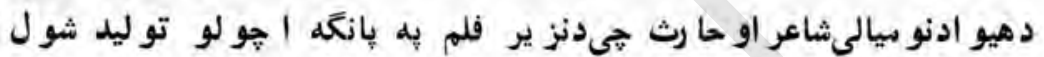

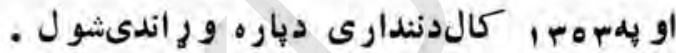

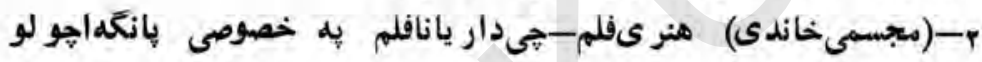
سوه بههorr

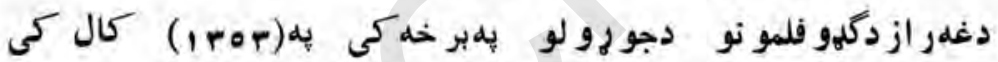

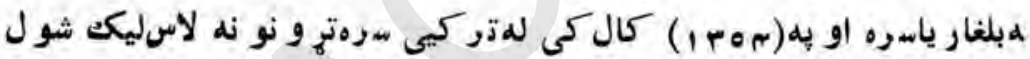

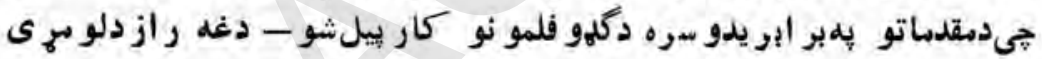

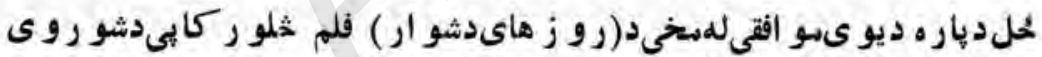
سوف اكسهو ر ات فلمهيه كمنى باندى و يلو رلثنو . : دهنرى

دخلكو دسليمى

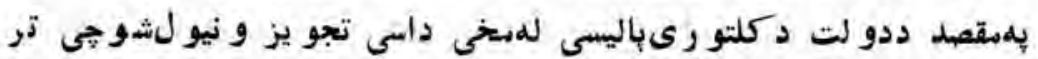
دىو رو ستهدى هنرى فلمو نه دافغان فلم دلارىر اورل شىاودهيو اد يه

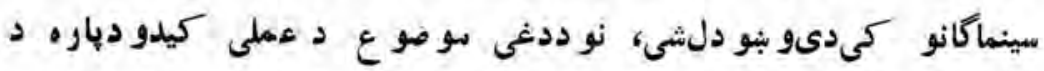




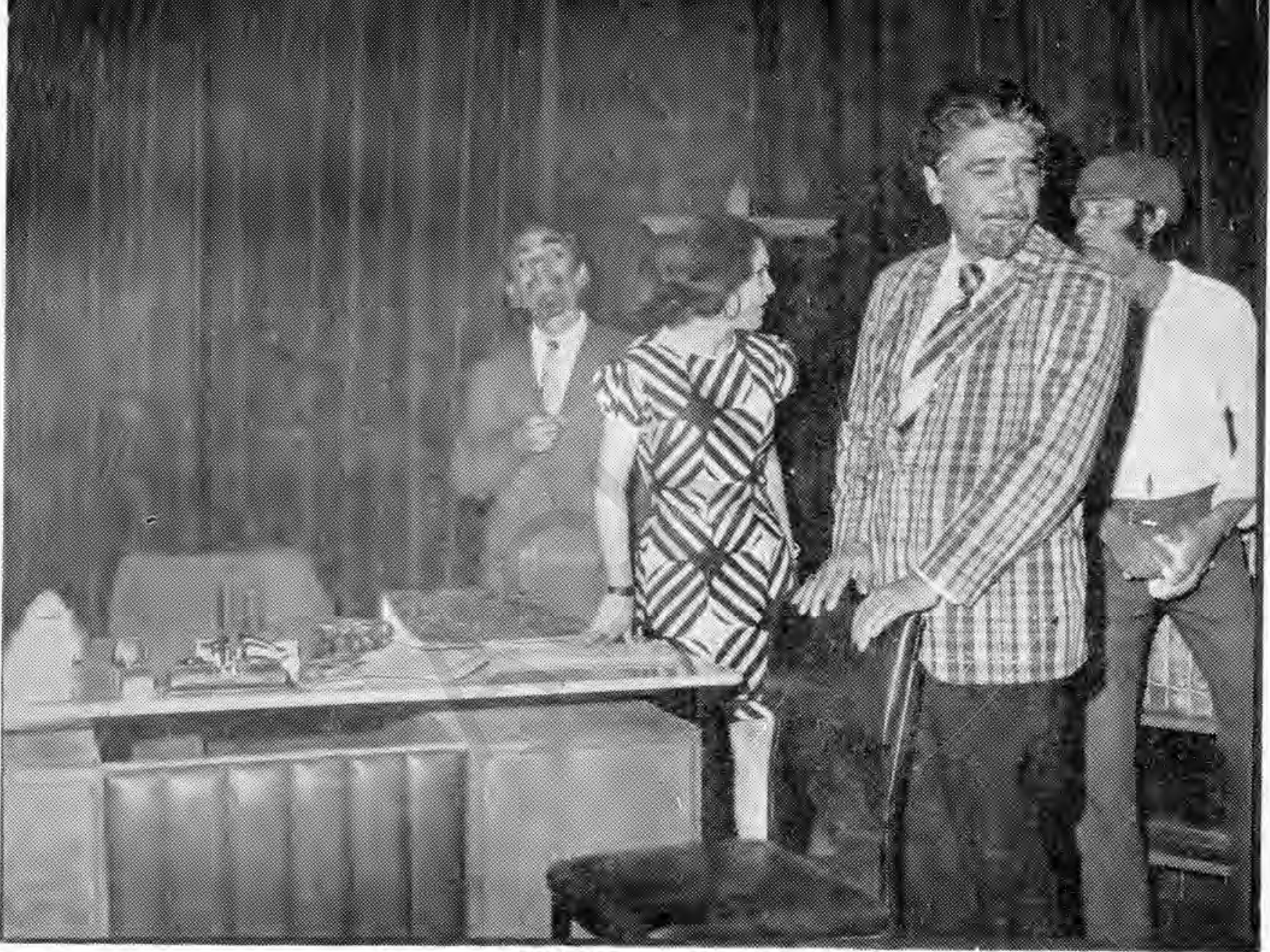

هـ كابل نندارى كى دمير زا قلمانودورام صحنه. 


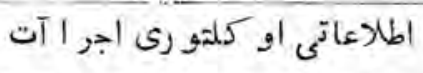

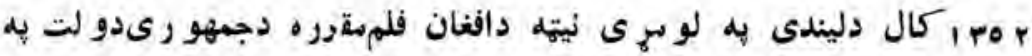

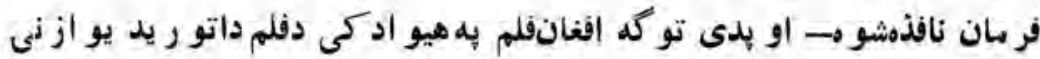

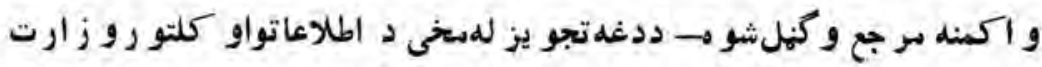

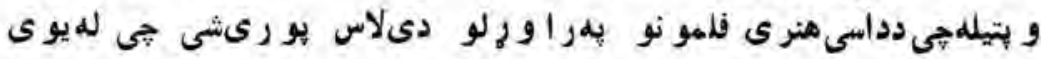

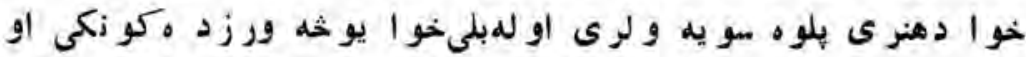

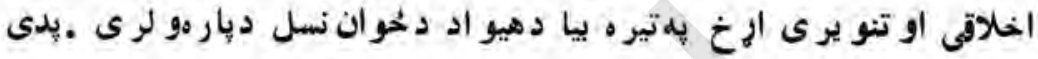

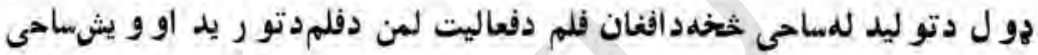

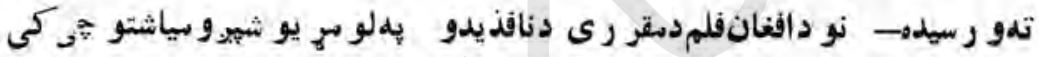

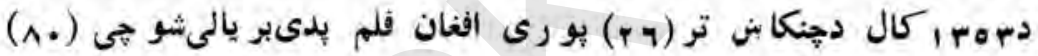

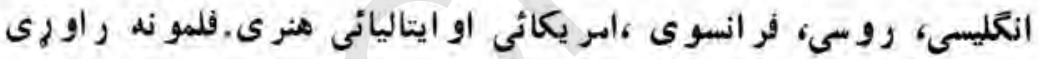

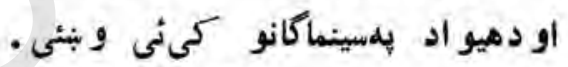

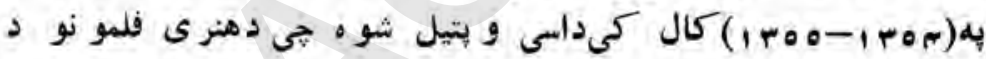

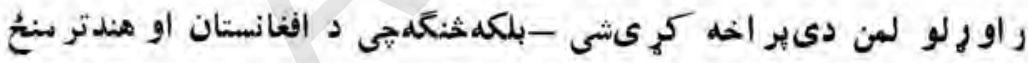

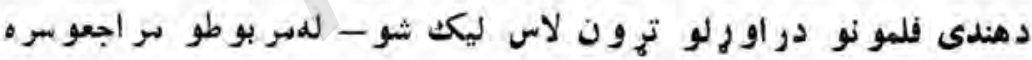

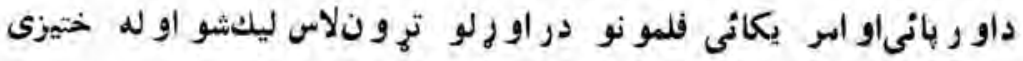

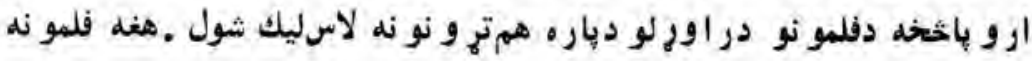

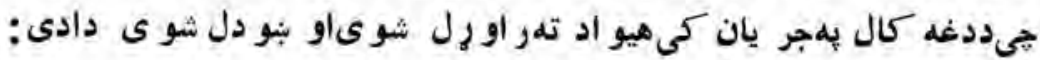

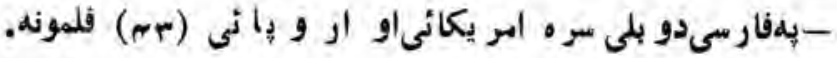

$$
\begin{aligned}
& \text { - هندى (ي) فلمونه . }
\end{aligned}
$$

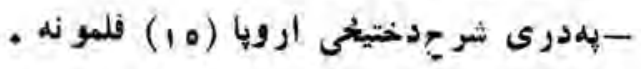




$$
\text { - اير انى (rr) فلمونه }
$$

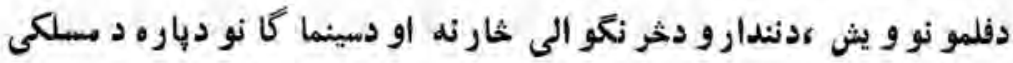

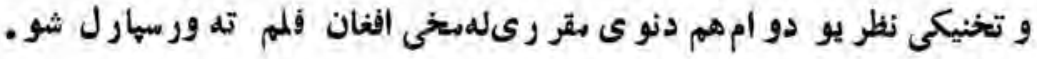

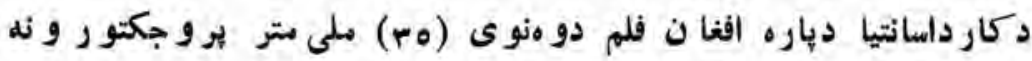
و بير ودل او در او رل شو يو فلمو نو سانسو ر دسانسو رهيات له خو اد افلغان

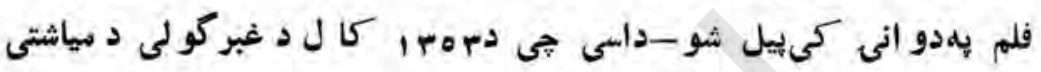

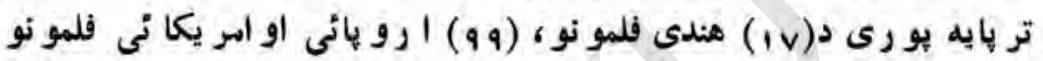

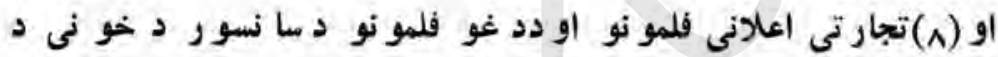

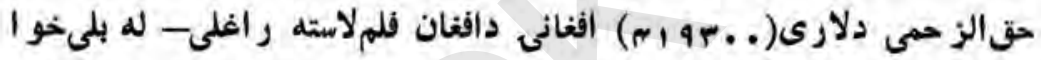

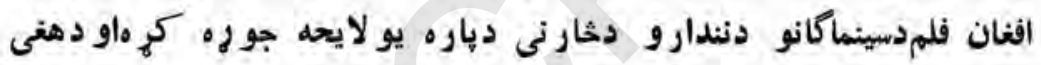

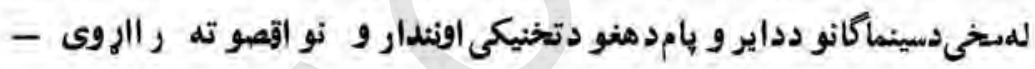

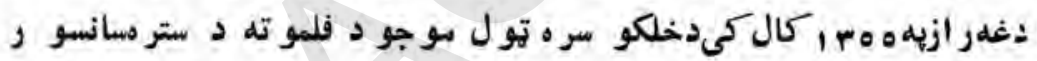

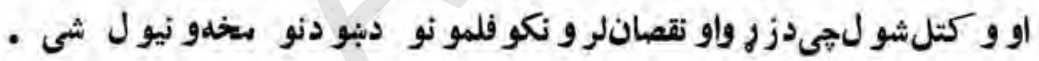

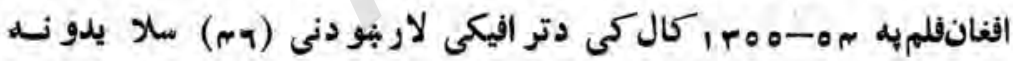

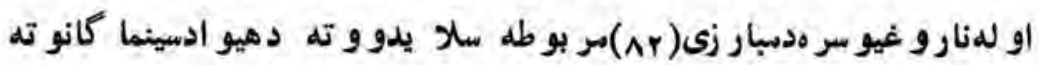

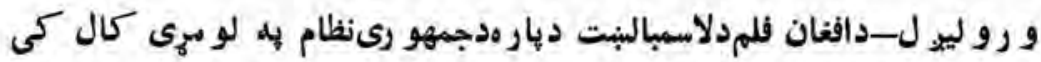

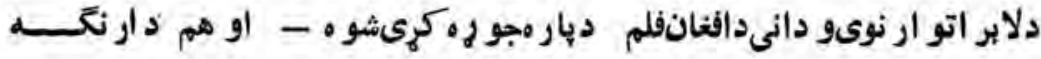
فلمو نو بهلابر اتو ار اودهغد خديتو نودير ا ختيا ديار مدنو رو مدر نسـو

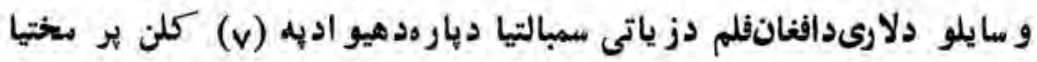

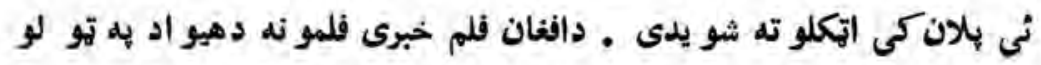


اطلاعاتى 'و كلتو رى اجر آت آت

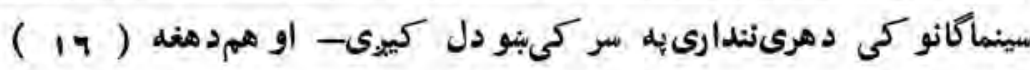
سلى ستريزفلمو نه ديو هنى دو زارتاو داطلاعاتو او كلتو ردو زارت دمهعى او بصرىيو نهو نو لهخو ابنو دل كييىى- دافغان فلم هر اخبارى قلمهىديوى

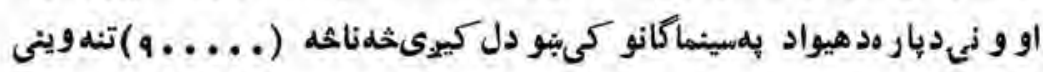
بهعين حال كى بر ابر كرئشوى خبرى فلمو نهبه تير هييا دجمهو رى نظام د

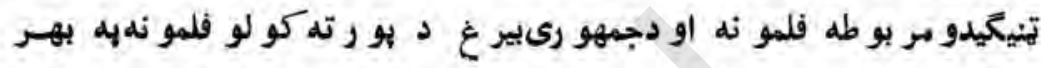
كى افغانستانسياسىنما يندكيو تهاستو لشو يدى او دحينو هيو اد و يه فرهنَّى سر كز و نو او سينماكانو كى نبو دل شو يدى.

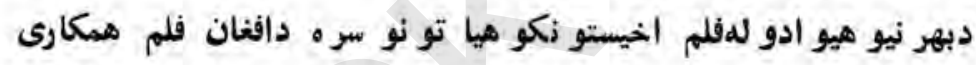

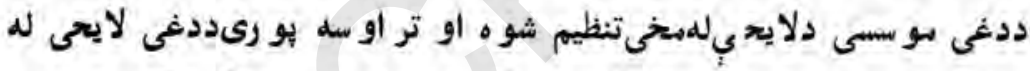

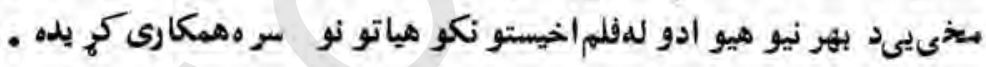
: هi

داطلاعاتو او كلتو روزارت دكلتو رى باليسى اودجمهو رىدولت دتكَ

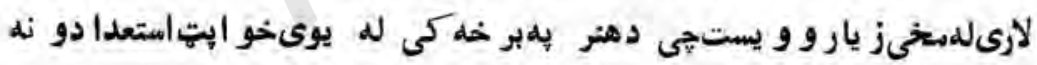

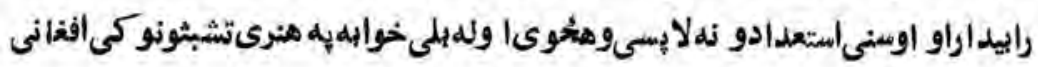

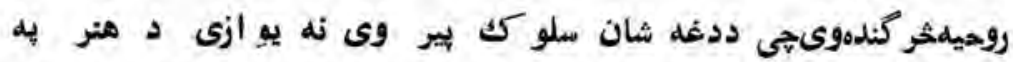
به بر خدكى دابتكارو نو مببشو ه بلكلهيه تو لو هنرى برخو كى زيا ت

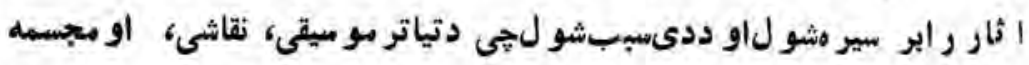
جو هو لو بلشان بيلابيلو هنرى برخو كى هنر بر مختياو كرى او هر يو ثل

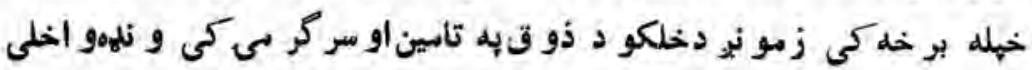


- البته ددغو خدمتو نو دير مختكث ديار مدهر بوطو بوسبو فعا ليت سمبال

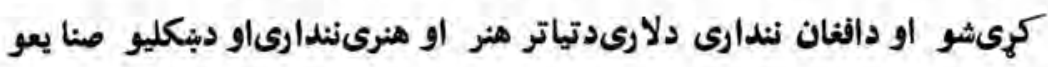

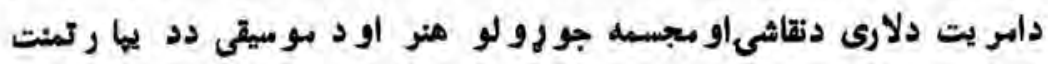

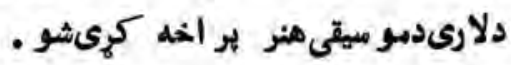

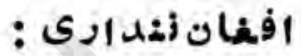

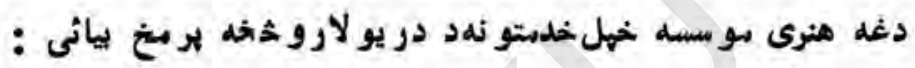

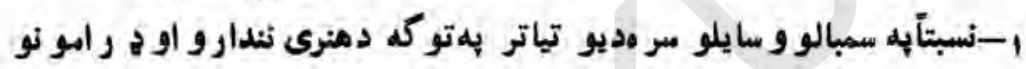

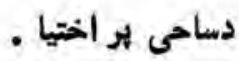

ب- دهنرى استعدادو نو هثونه اودئمو انو استعدادو نو بر الختيا ا و ود

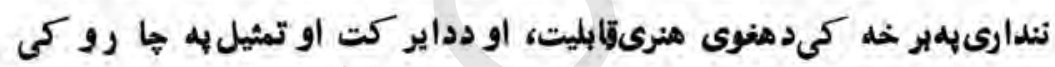
دروزنى و واستعدادو نو بالنه.

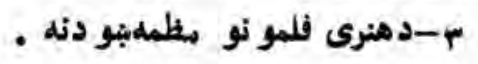

\section{نهارى اوهور امونه :}

افغان نندارى بلدغه بوخه كى خهل فعاليتو نه نهيو ازى دخلكو دهيلو سر م.

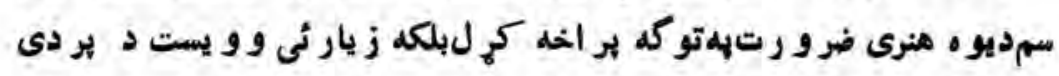

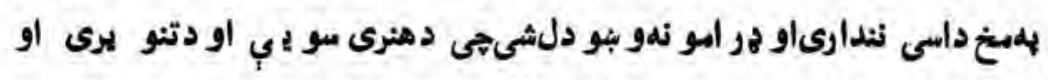

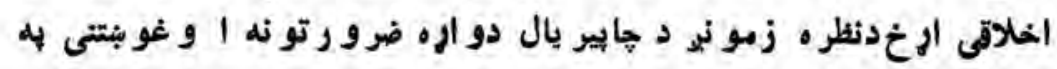

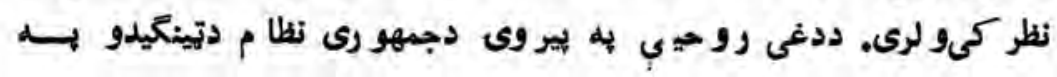

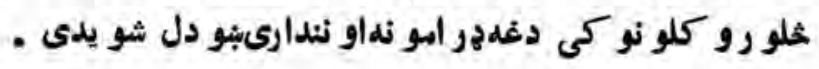




\section{: الف :}

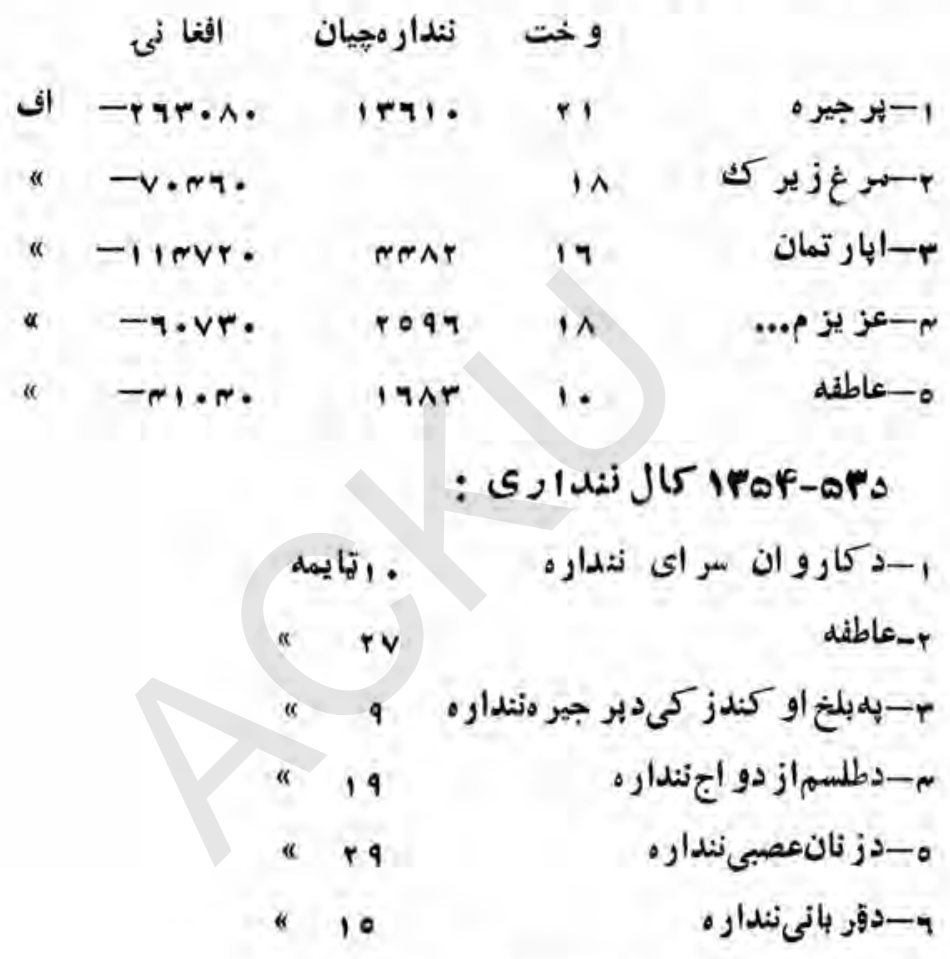

:

-

.
1) 1\%.
IV
r- بدالماد موتتى لئدارم
D Arr
$n+1$

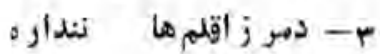




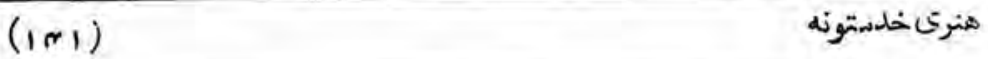

r- دطلب:خارى نثداره

" مدكو رخود بينائردم نثداره

$$
\text { 7 } 19
$$

هلعينحال كى ددغى مو سسيى هنوى هيات دنندارو دبنو دلو ديارِ

شو روىاتحادته سفر هم و كر

دبهو نيو هنرى هياتو نو نندارى :

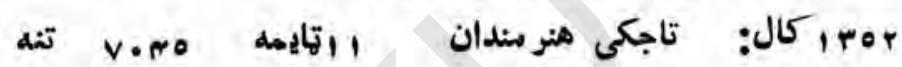

" 1110 -

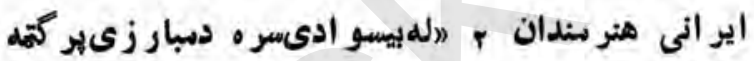

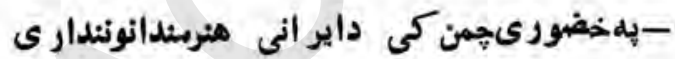

\section{هَّايمه}

- -دشو روى هنر مندانو نندارى ه

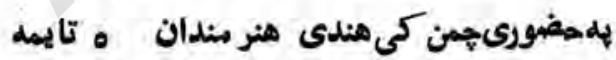

يو كو سلاو يائى هنر مندان

ror

- -دجمهو رى
ฯ

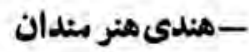

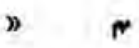
- أير انى هنر شندان
n $\wedge$
شو رو وى هنر سندان 
- دشو روى هنر مندانو نند اره . تايمهنى افر يقائى

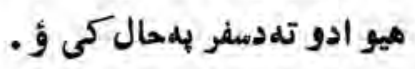

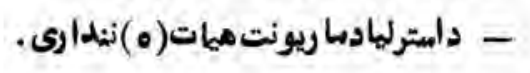

:

ديهر نيو هيو ادو دهنرى ميا تو نو كرى يندارى.

-دشو روى ـاتعاد دهنر مندانو هيات.

- داير انى هنر مندانو هيات.

- ـدمندى هنر مندانوهيات .

- كدبا كستانى هنر مندانو ميات.

- تر كيىد مترمندانو هيات .

- مديكنله يش يش هنر مندانوهيات.

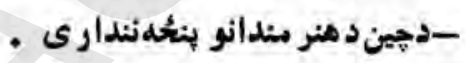

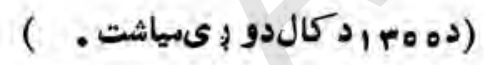

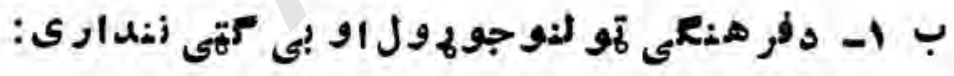

إستولنى:

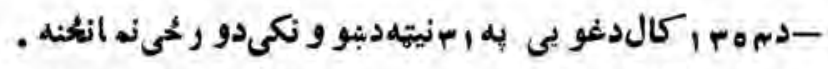

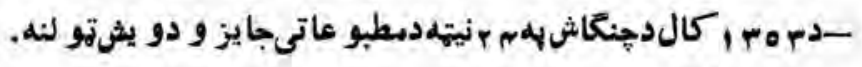

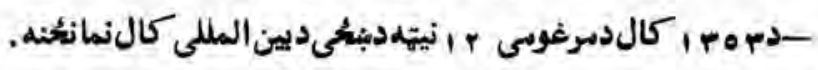

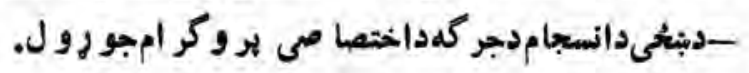

ـدبو نكىورك. 

$(1 \sim r)$
هنرىخدمتونه

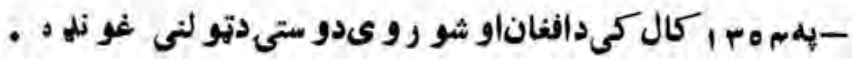

$$
\text { -ددو ردو رخحتو لنه. }
$$

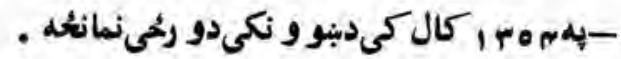

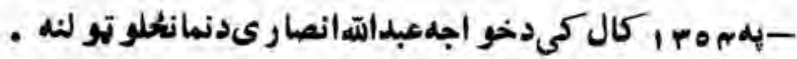

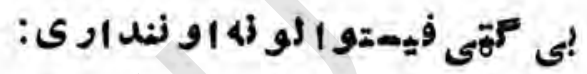

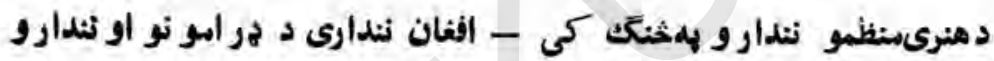

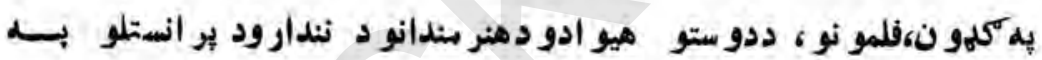
كميو نيوله بهىتى نثدا رىاو ددو ستو هيو ادو فيستو الونه او د فلمو نو ببو دنى

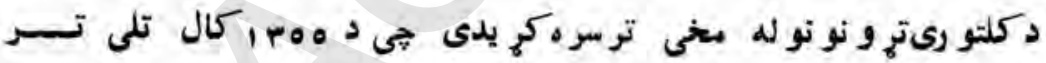

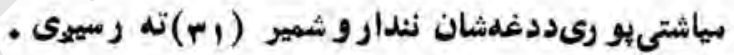
r-فر هنكى بروكر امونه اودنو رومو بسو هنرى نندارى .

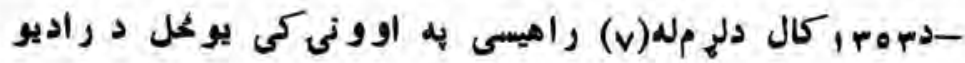
افغانستاندذ هنىمسابقى بير وكر اممثظم ريل دوراد يو د خو نو رو اختصا صى ندار روسو 0 - دمو سيقىدآمر يت به مشكارىدشام هنر ثر وكو ام( r 1) تايسه

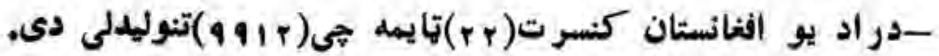




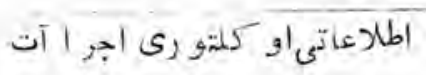

\section{: مسلمكى اوهنر ى همCارى}

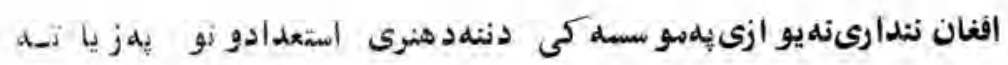

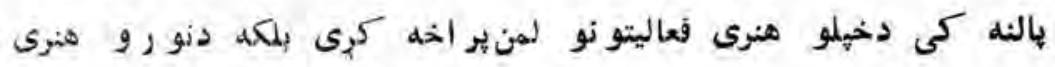

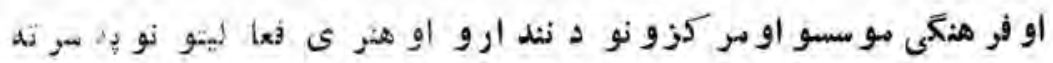

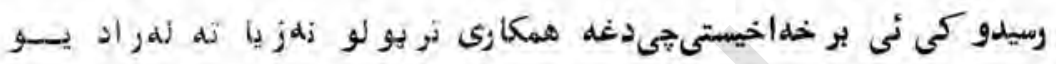

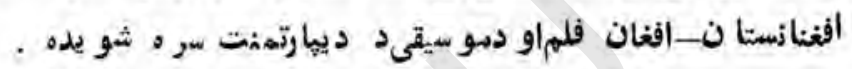

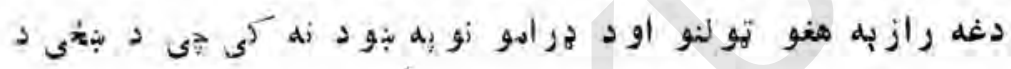

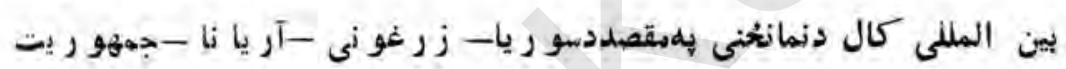

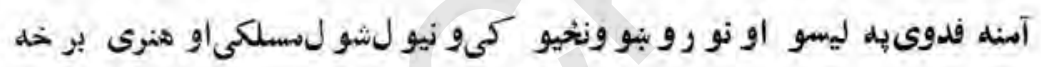
و الخيسته .

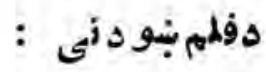

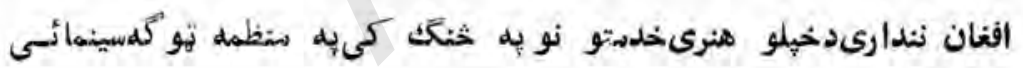
نيدارو ثلهم بدى توكه دو امو رك كريدى : -

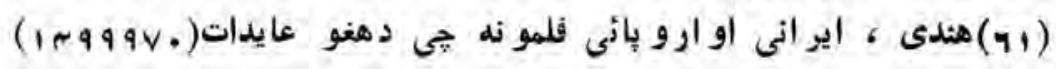

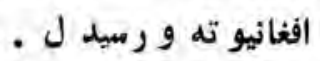

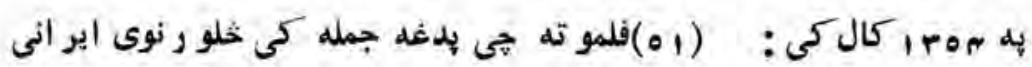

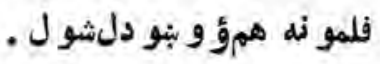




\section{بنملهوضا إع:}

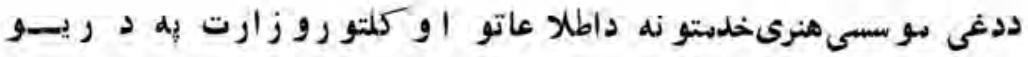

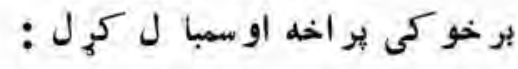

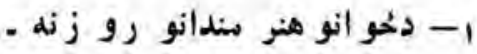

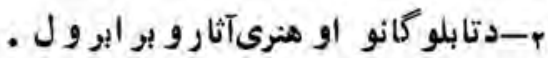

r-دهنرى

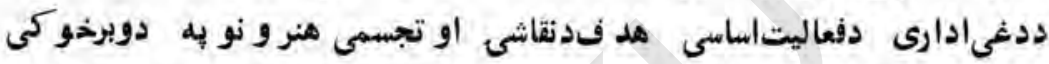

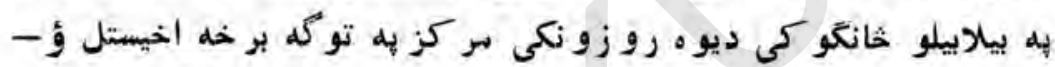

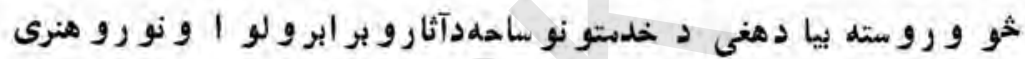

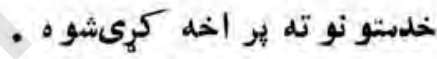

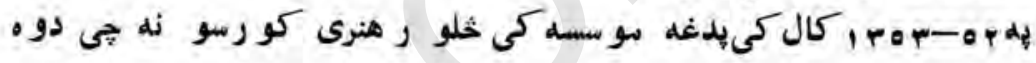

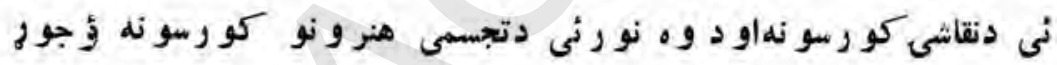

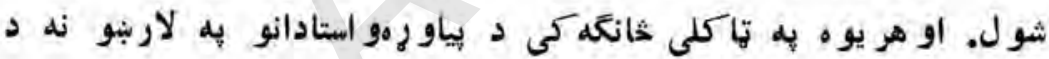

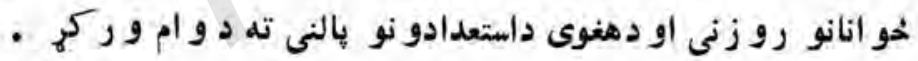

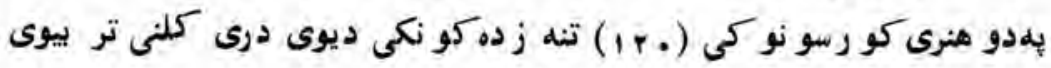

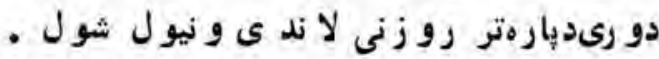

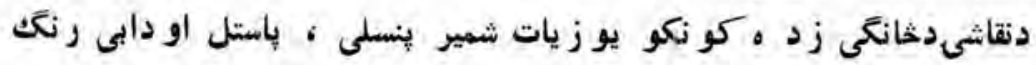

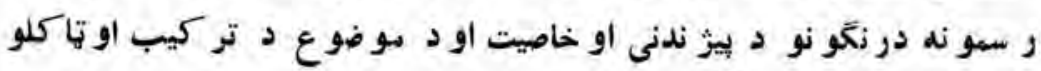

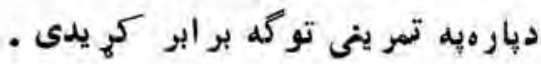

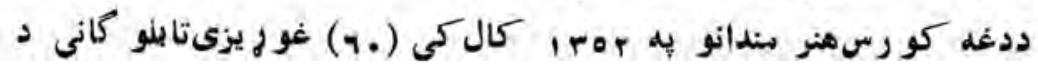




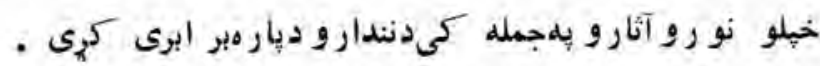

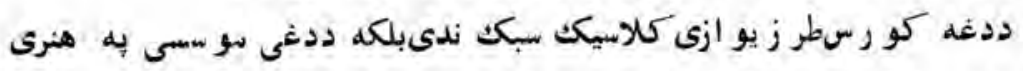

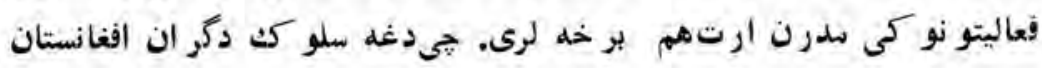

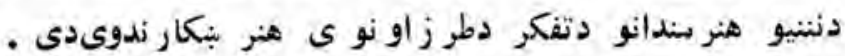

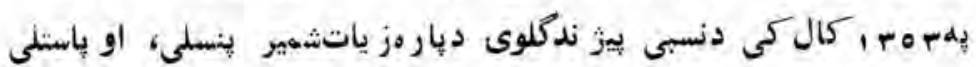

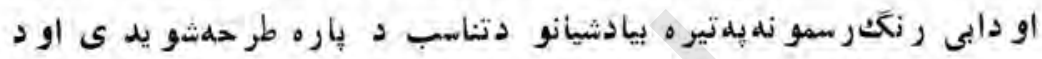

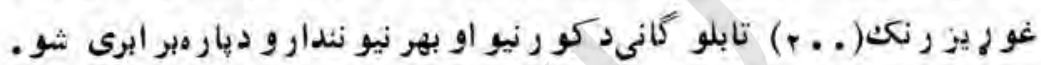

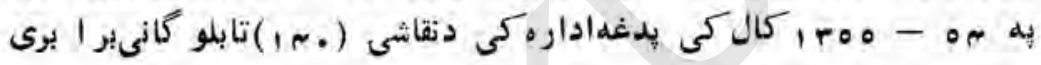

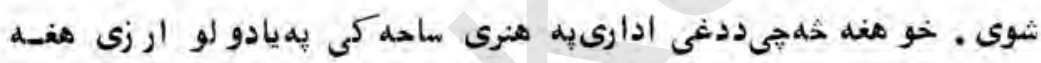

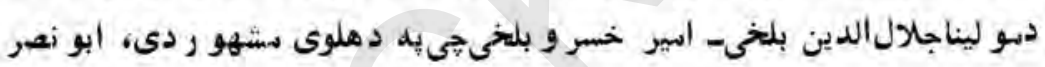

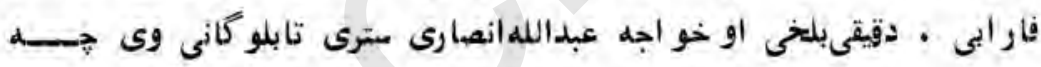

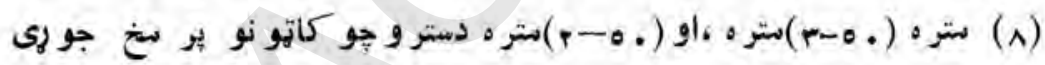

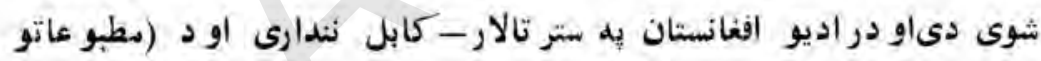
دكلو ب) دسحمو دطر ز زى بهنالار كى وخير و لشوى.

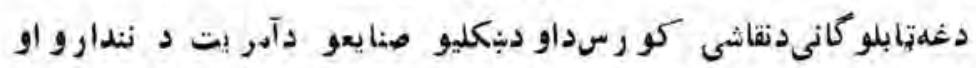

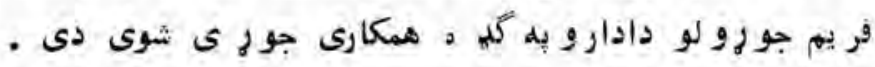

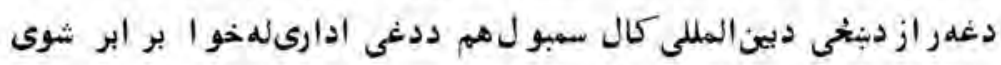

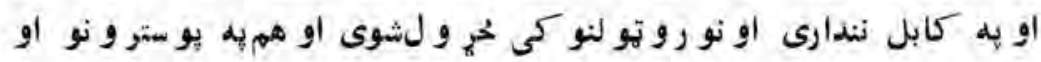

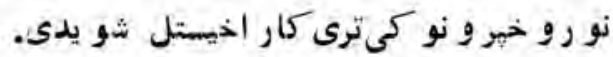

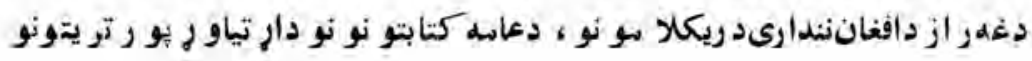



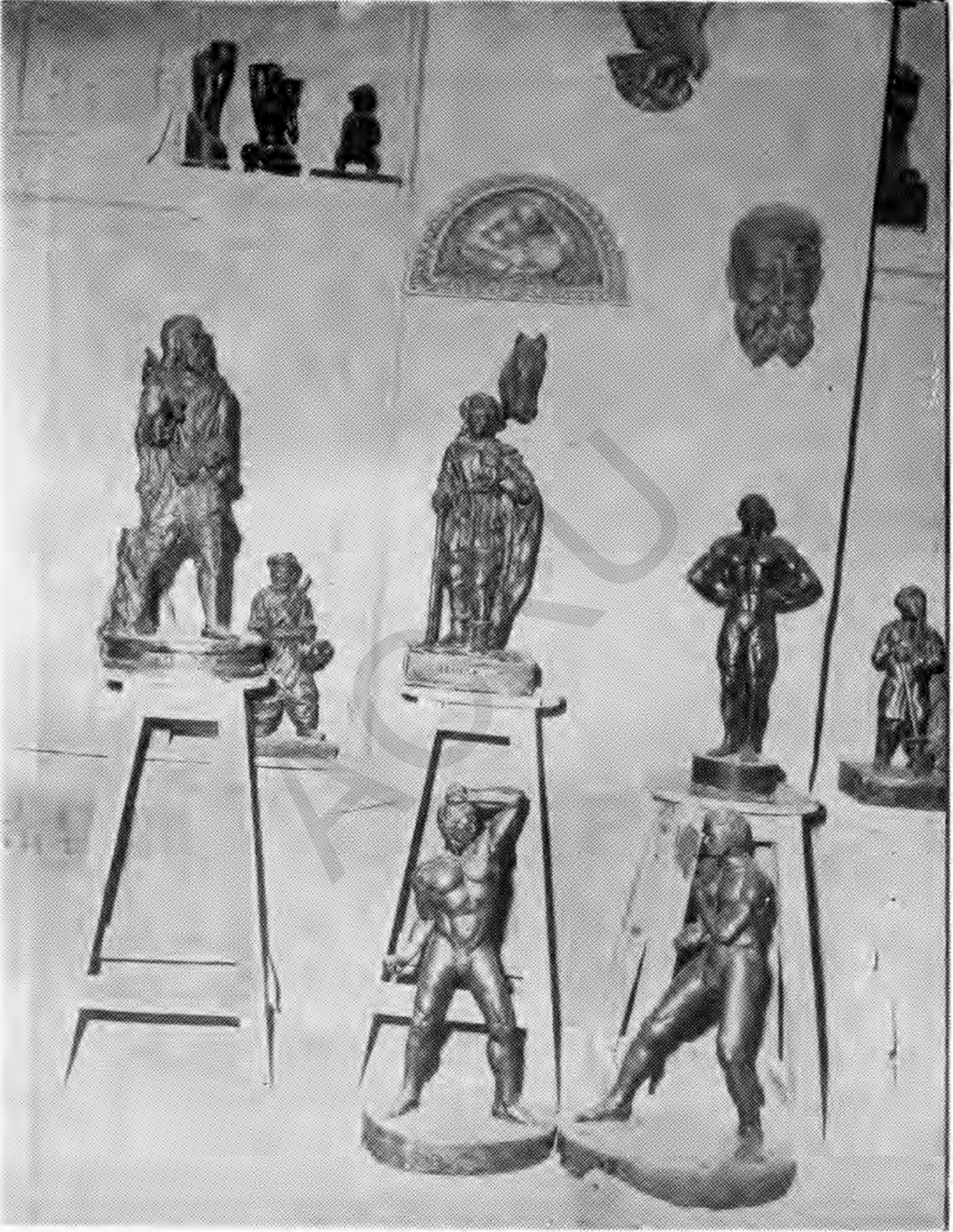

دبنكلو حنايعو دآمر يتد منرى آثارو نمونى. 
دوول يول خز ندودرسمو نو يه طرحه كولود افغان فلم دسلا يدو نو

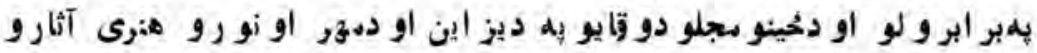

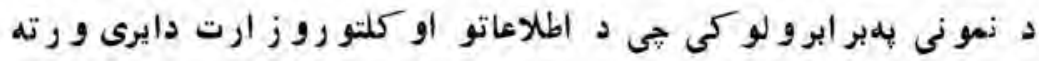
ازيىوى همكارى كي يده .

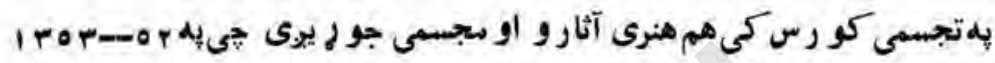

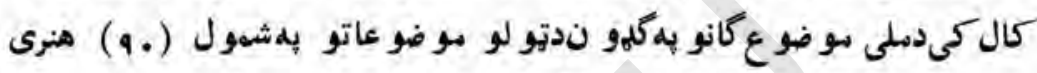

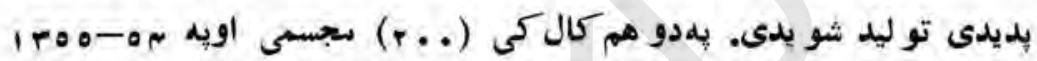

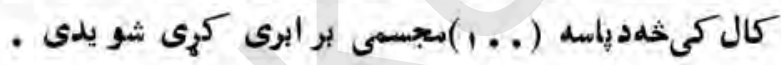

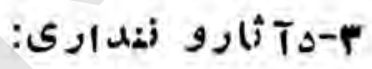

بدغهلبر خهكى هم دبنكليو صنا يعو داهر يت دخدمتو نو لهن مم دنندارىديو -

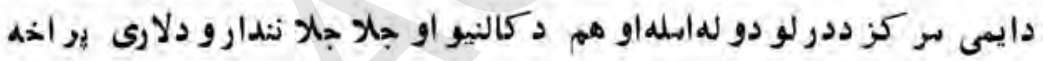

$$
\text { او سمبالد كرى شو يده . }
$$

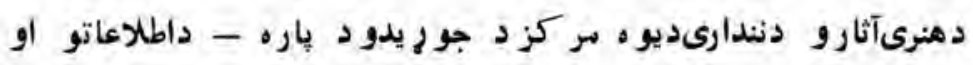

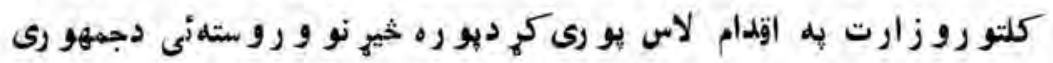

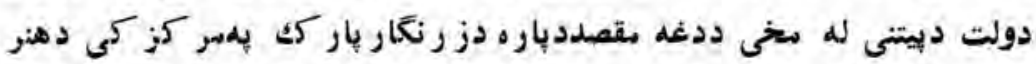

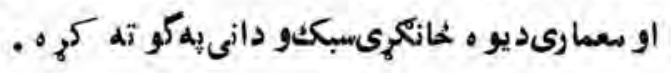

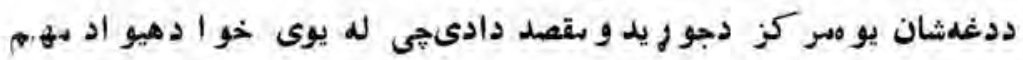

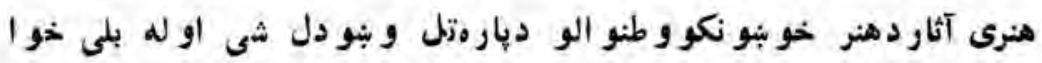




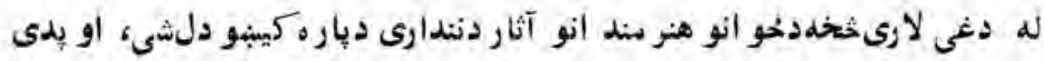

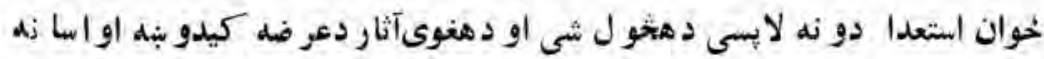

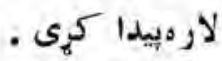

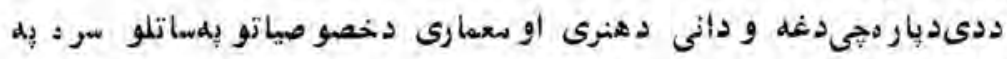

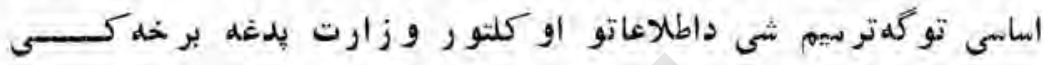

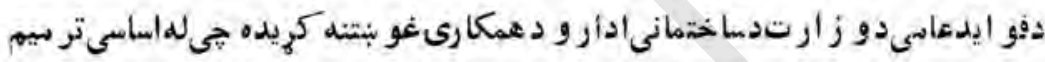

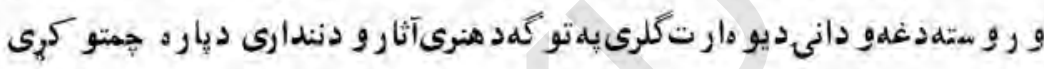

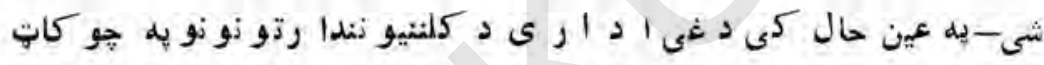

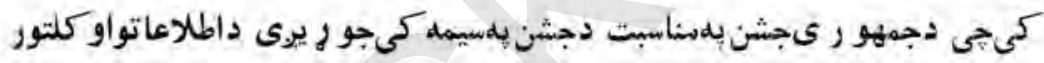

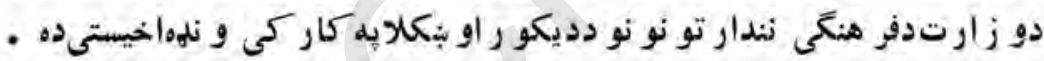

$$
\text { دفر هنكى زفل ار تو نو نو جو هيدل : }
$$

داطلاعا تو او كلتور و زارت د جمهو رى انقلا ب د تلينله كبله هو

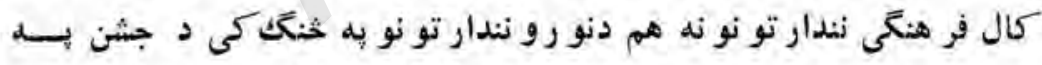

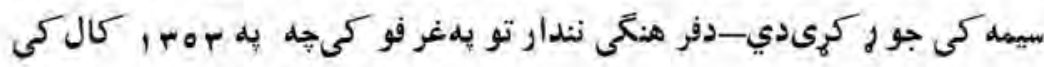

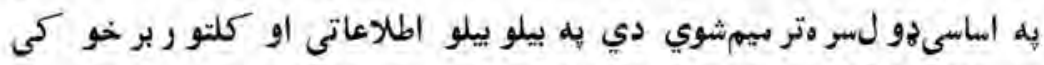

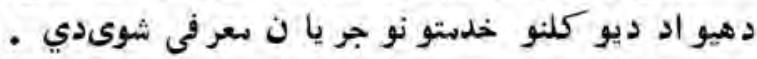

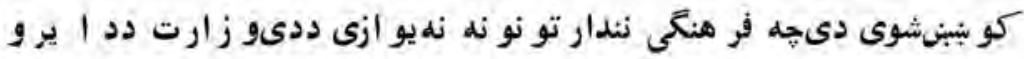

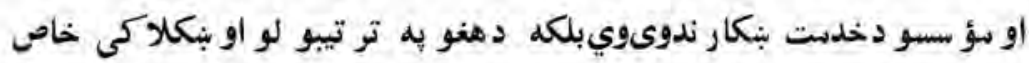

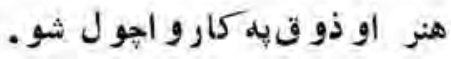

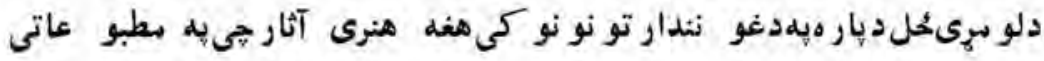


جو ايز و كىديو مبنهاو سمتاز اثر به توكمدجايزى مستخلشوى و - دنندارى ديارم كيببو دل شول .

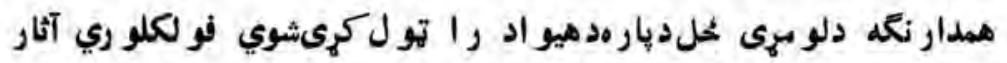

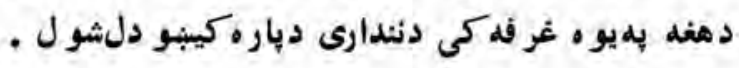

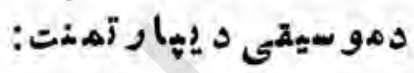

دمو سيقى ديبار تمنت به دو برخو كى خهل هنرى خدنتو نه بردخ بيائى-

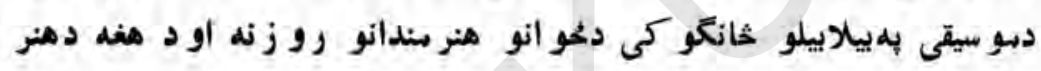

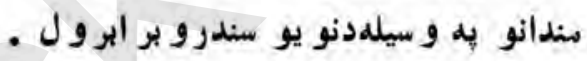

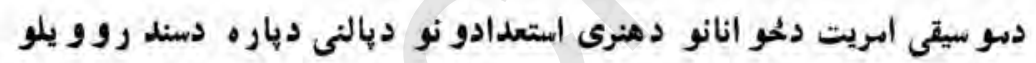

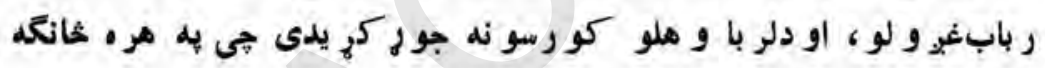

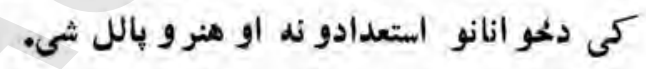

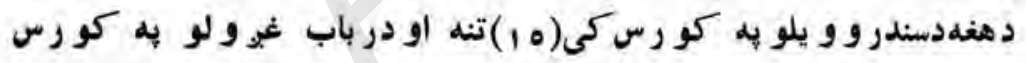

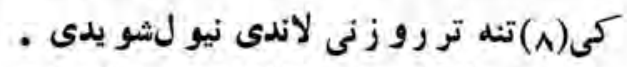

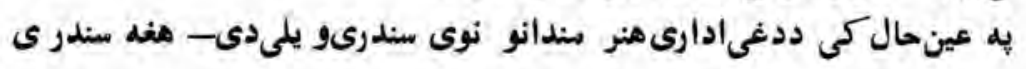

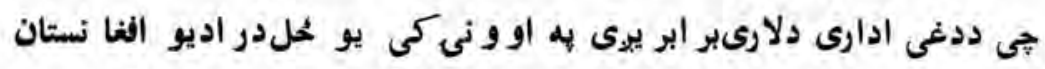

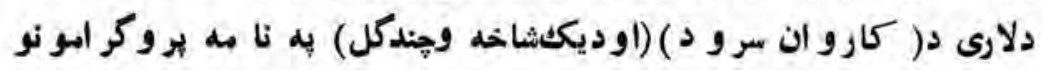

كى نشر يرى

ددغو سندرو شمير جي دهنه دختيخ اركستر او اساتو راركستر له خوا

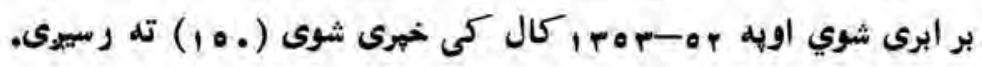

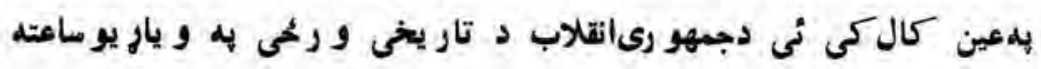




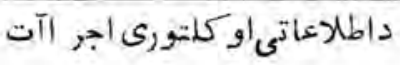

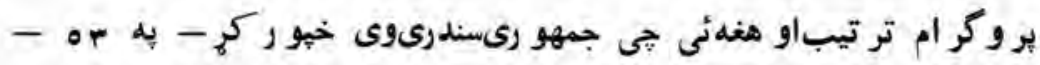

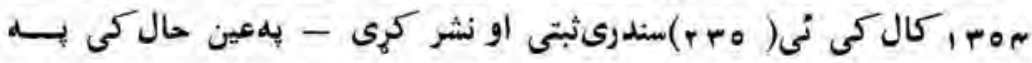

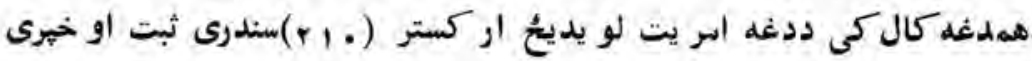

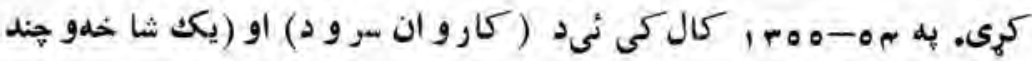

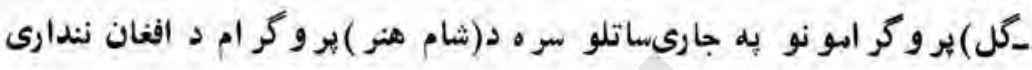

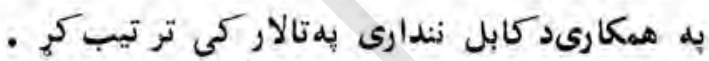
دغه اسر بت بهر نى نهى ته دافغانى مو سيقى به تير ه يبادافغائى اصيلو سندرو

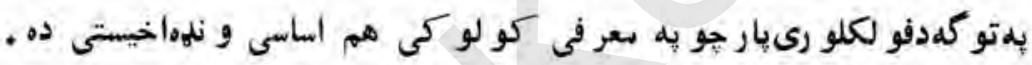

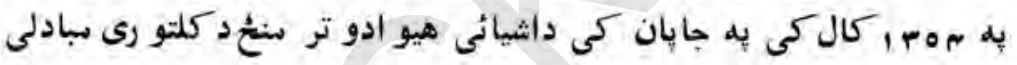

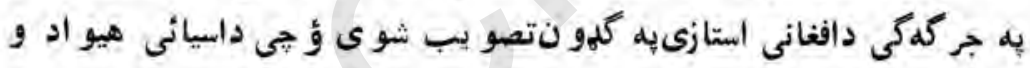

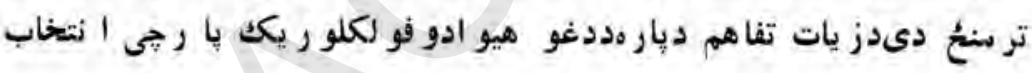

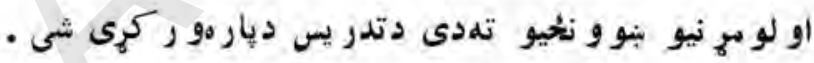

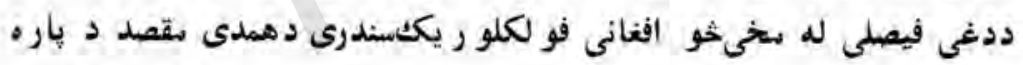

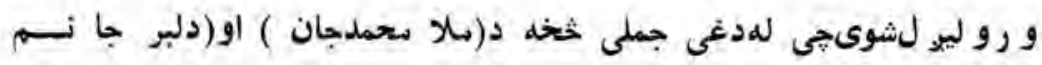

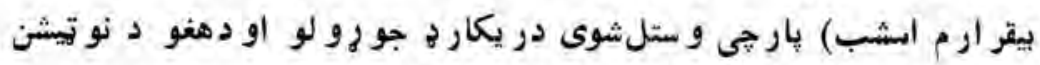

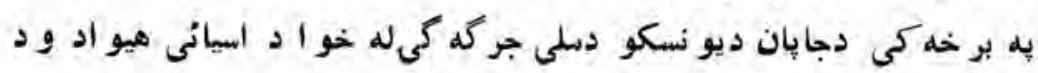

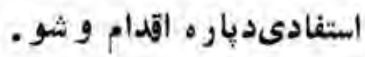

دغه رازدنرى حينو فر هنكى كر كز و نو له دغى ادارى خحخه دهيو اد د حينو

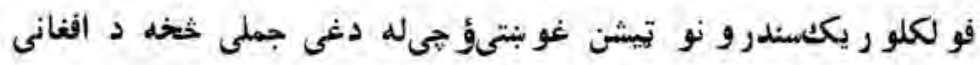

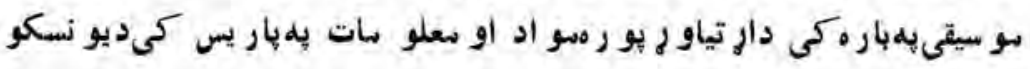


ادارىته به تو كيو كى دجايان ملى يو نسكو ته، دسصر د عر بى جمهو ريت

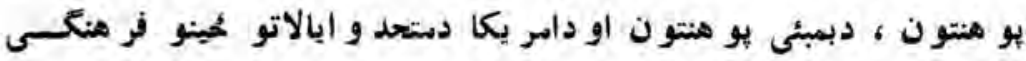

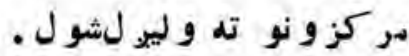

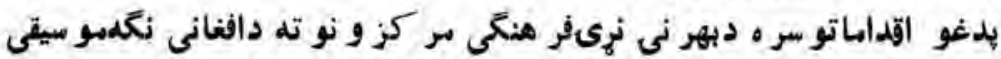

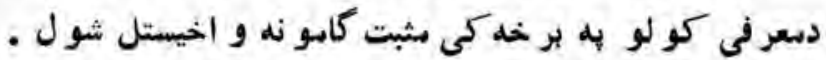
دمطبوعا تو كلموب:

دغهمر كز لهيوى خو ادنشر اتى موسسو اودو زارت دمبركزى مو سسو

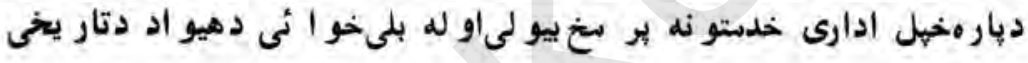

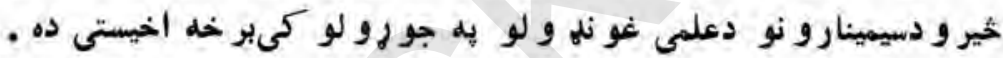

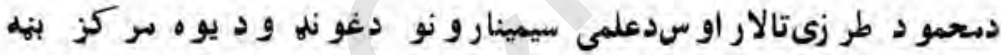

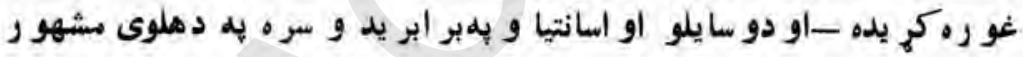

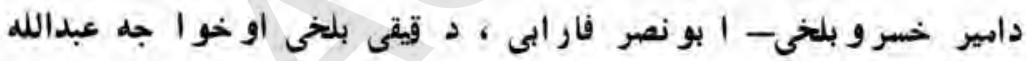

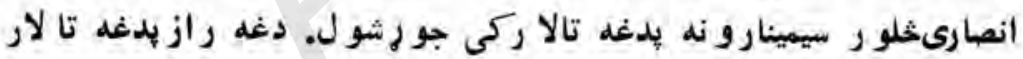

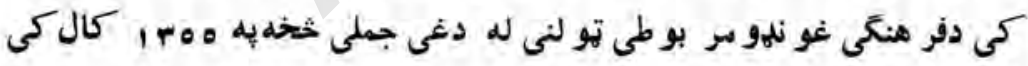
دمطبو عاتى جايز ودو يش تو لنه و شو ه

\section{ادرارىخلم:و نه:}

داطلاعاتو او كلتو رو زارت بد غه و زارت كى ادارى خدمتو نه داسسى

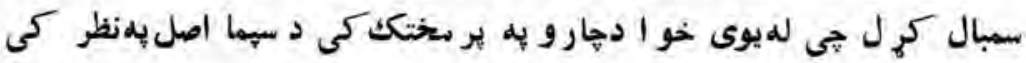

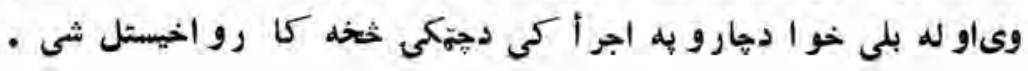


اطلاعاتى او كلمتو رى اجر اجرا آت

$(1 \circ r)$

دو زارتتحو يل خانى مهميه تير و دو كلو نوكى سو جو دى شوى او دهغو

حسابونه هم هابكت شول ل.

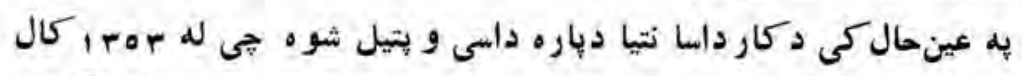

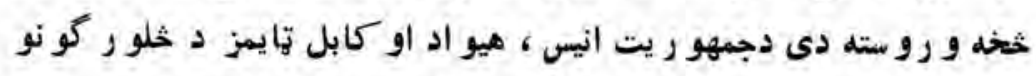

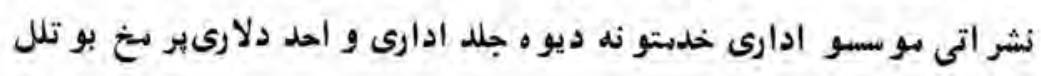




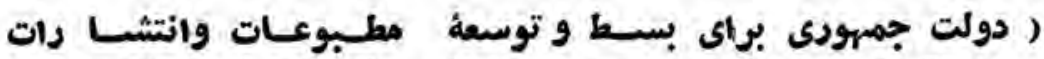

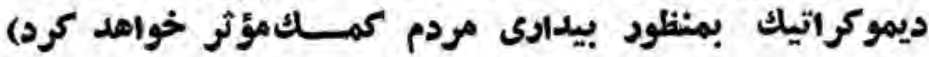
از( خطاب بمردم افغانستان)

نظلام جمهودى مهانكسونه كه بحيث يك نظاملى ومترقى شيرازة اجتهاع دالزنوتنيم بغشيد - طليعه آن در ساحة فعاليت هاى مطبوعاتى نيزتوام

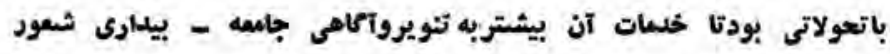

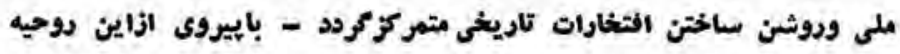

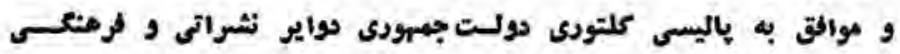

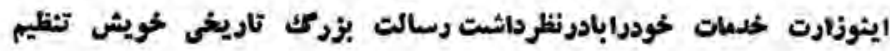
وتوسعه بغشيدند . دوينجا جبونكى سهمكيرى اين موسسات بعد از اعلام نظام نوين ددجار سال ملمشتهبصورت اختصار تقديم ميعردد . 


\section{خده سات جهار ساله وزأرتاطلاعاتو كلتور \\ IPDOIFAP}

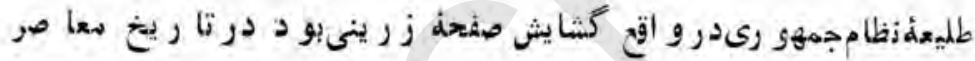

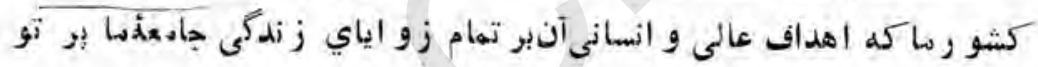

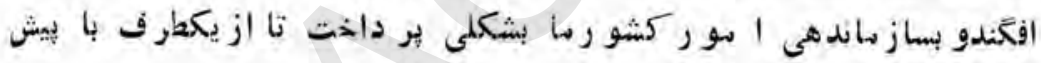

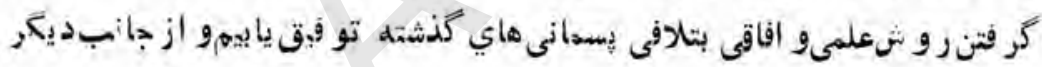

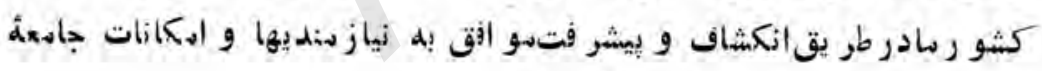

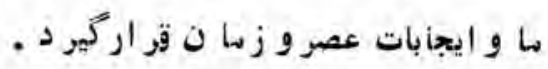

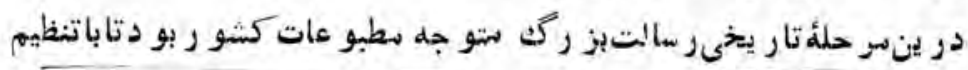

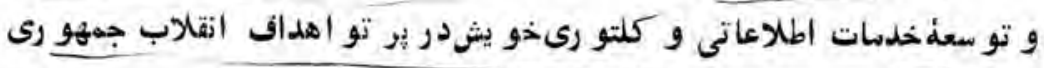

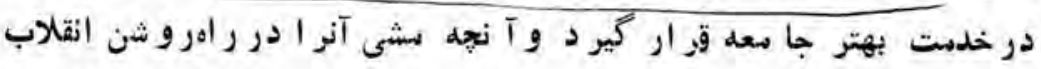

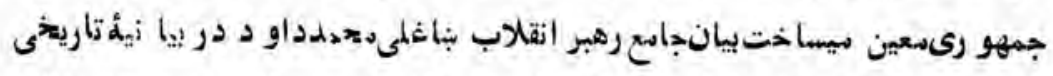

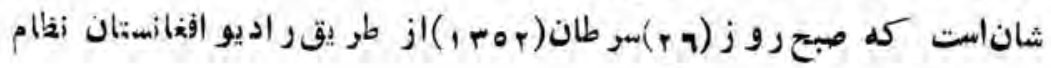
جمهورىر العلام داشته و كفتند : ماند 


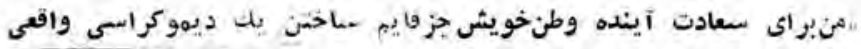

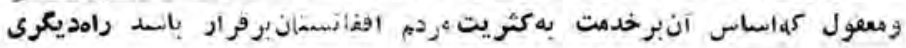

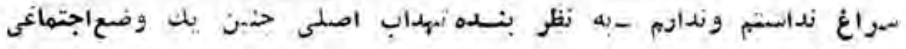

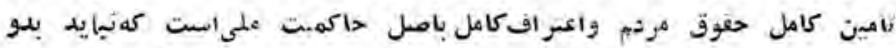

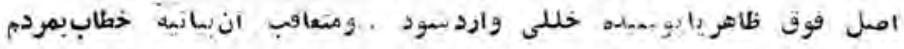

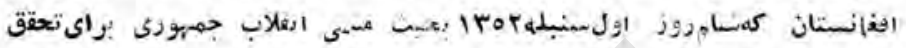

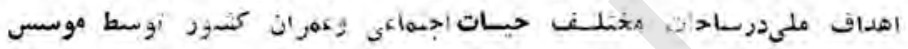

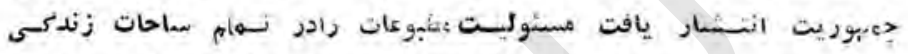

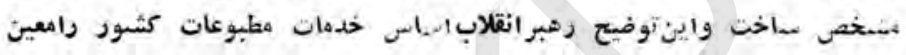

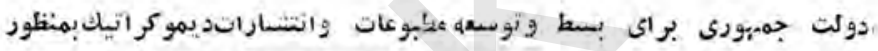

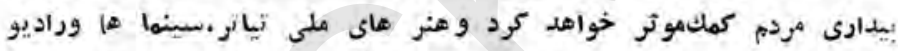

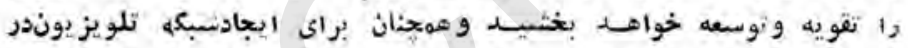

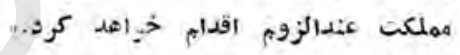

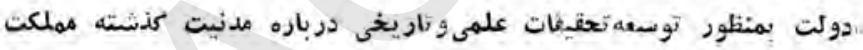

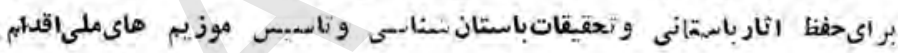

$$
\text { 11. لازم راثرعى خواهد داثنت }
$$

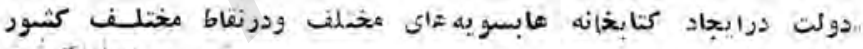

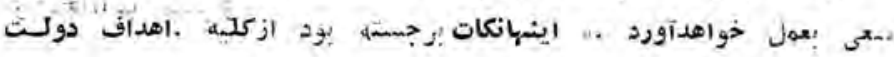

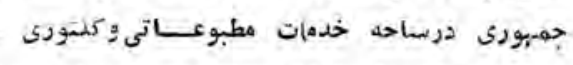

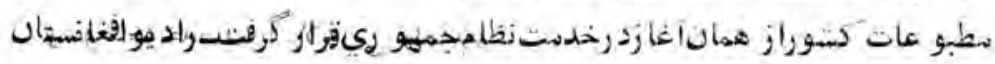

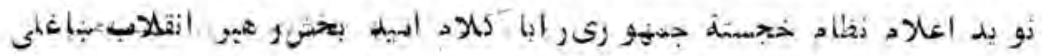

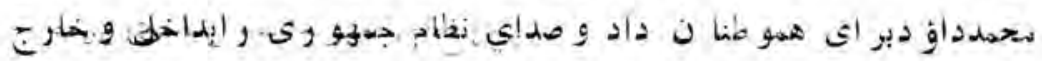

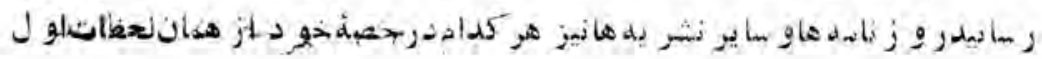

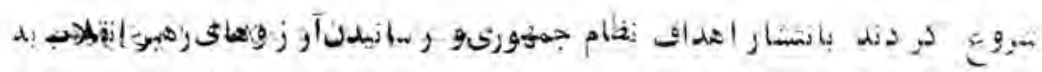




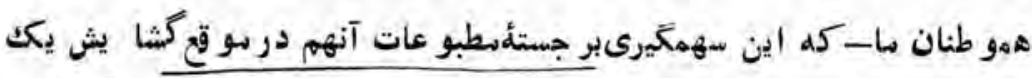

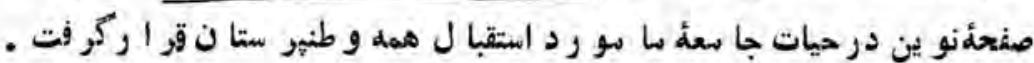
ثمعاقب انو زارت اطلاعات و كلتو ردو لت جههو رى نظر به اهداف انةلاب

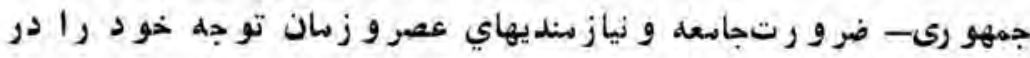
ز مينٔةتو سعه و بهبو د خدسات الطلا عاتى و كلتو رى يدو اصل عهده بجيــث ضر و رتهاي اولى سعطوف و ستور كز ساخت:

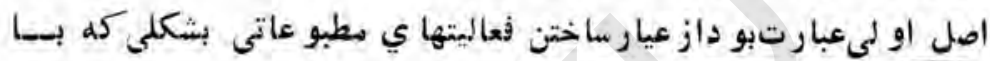

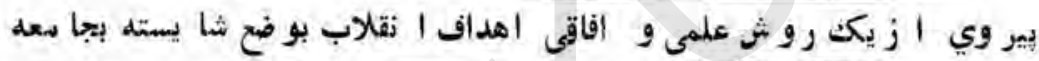

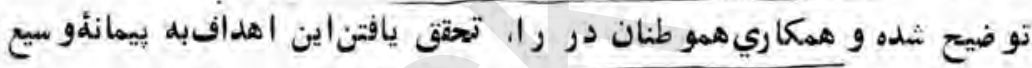

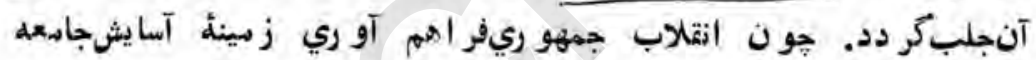

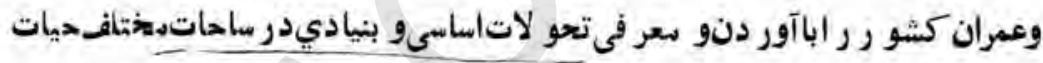

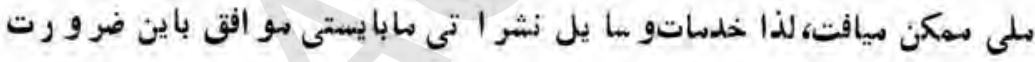

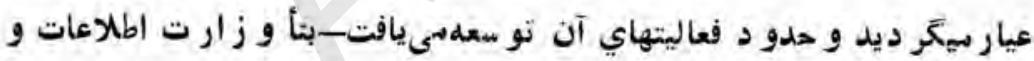

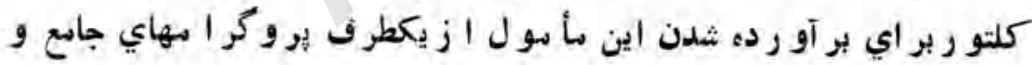

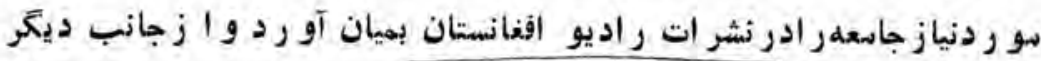

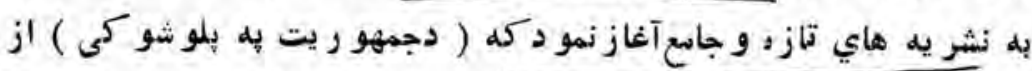

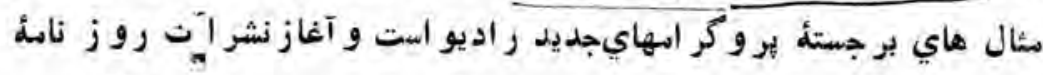

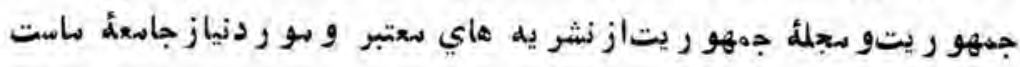

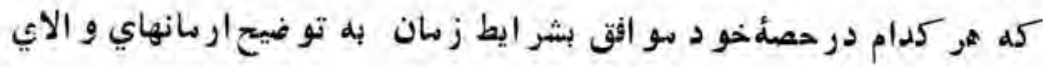

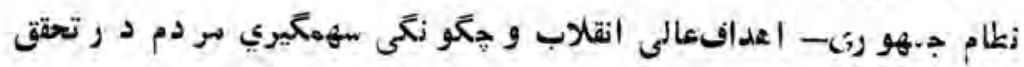


اجر آت الطانعانىو كلتيو

(109)

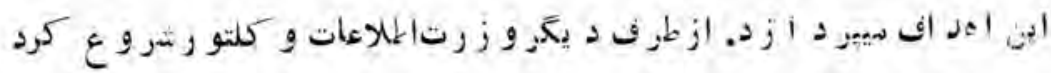

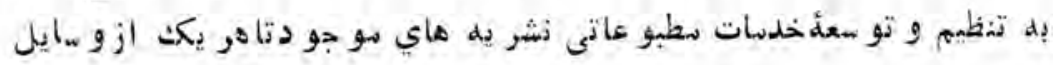

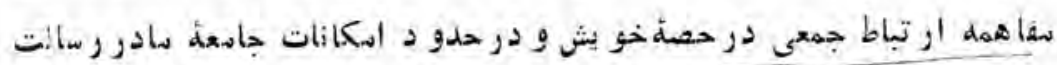

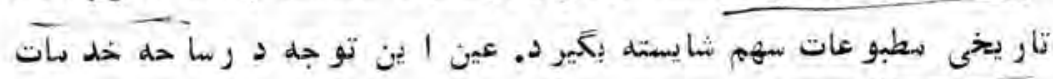

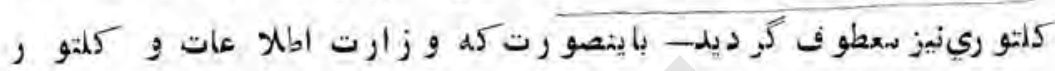

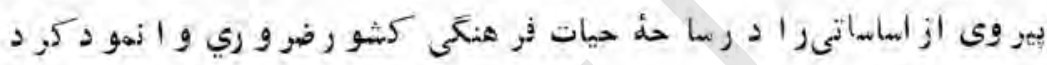

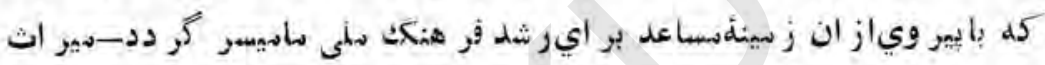

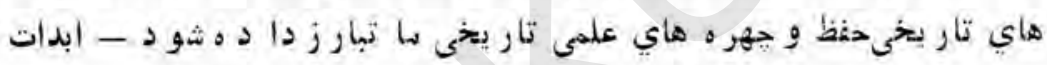

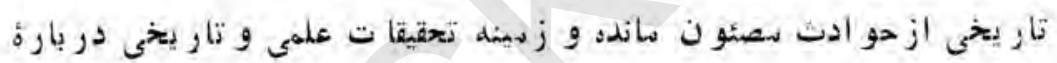

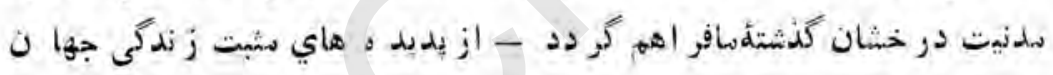

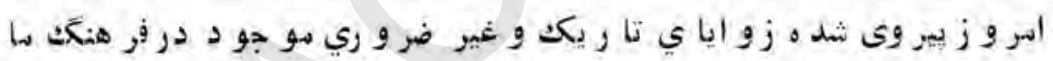

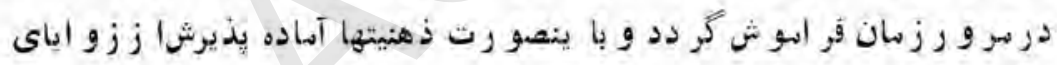

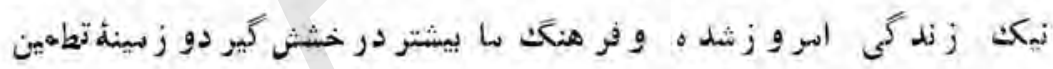

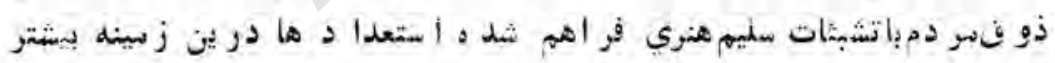
ر شد داده شو د.

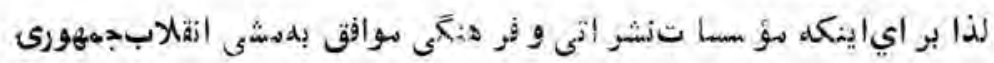

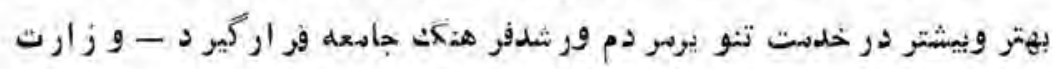

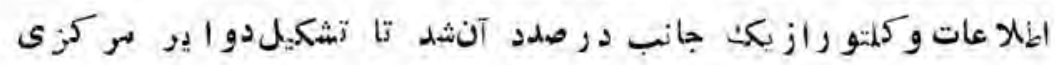

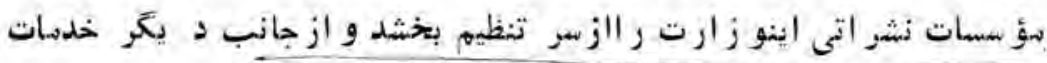

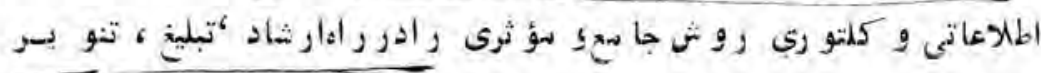


و سركز سى سلمه جامعه و غناي كلتو رملى مو ا فق بضر و رت زما ن دربيش

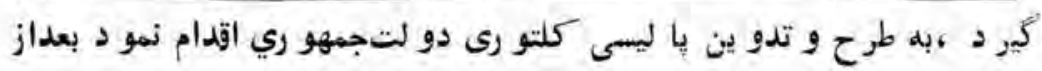

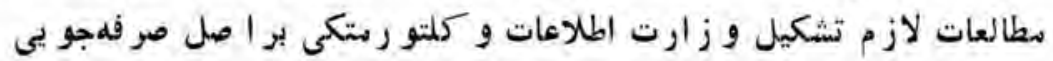

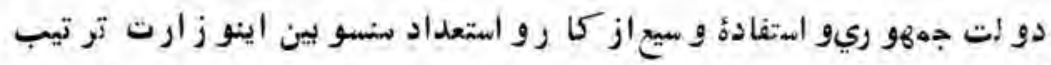

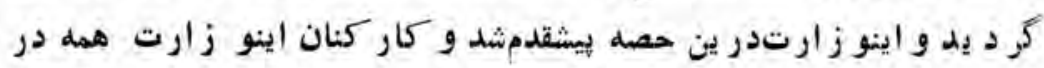

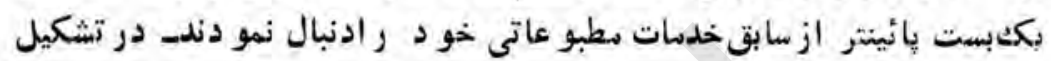

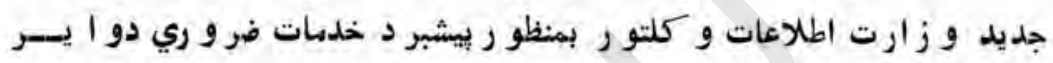

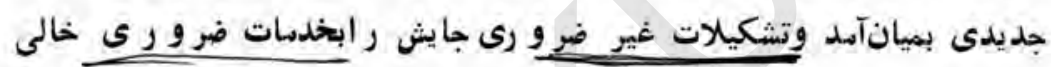

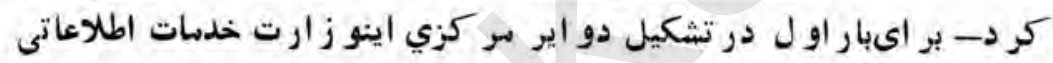

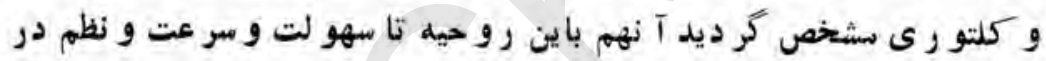

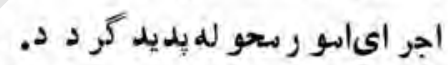

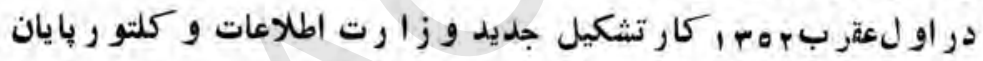

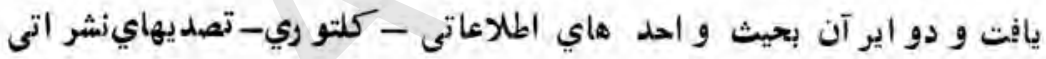

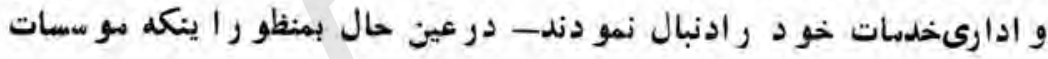

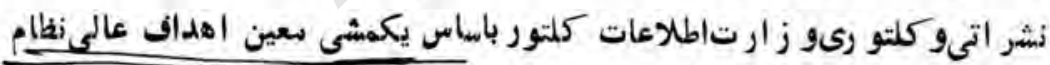

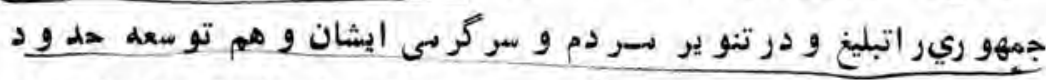

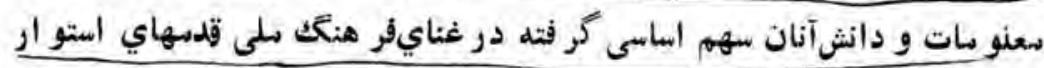

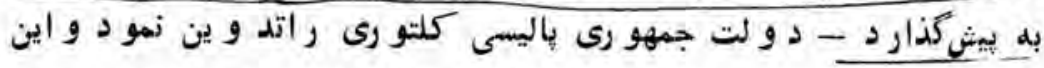

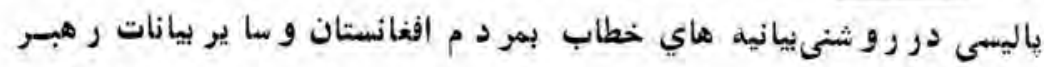

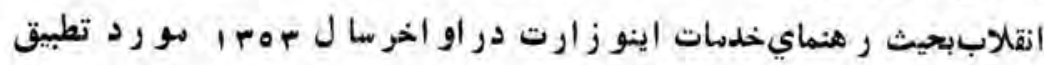

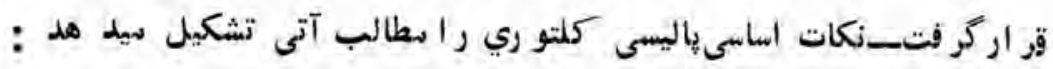




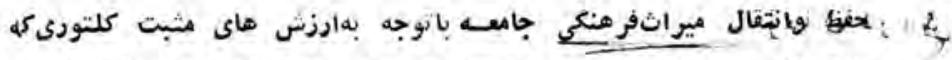

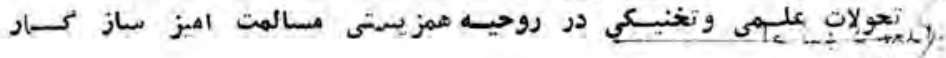

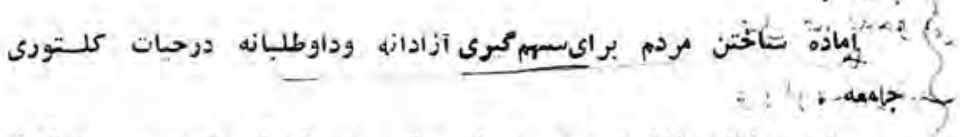

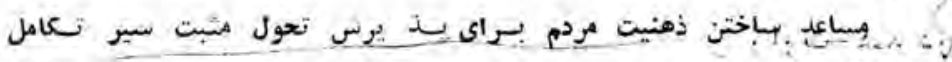

-

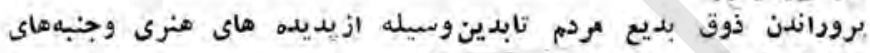

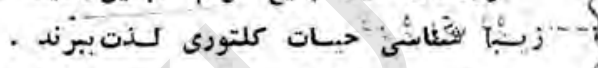

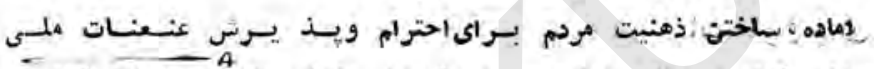

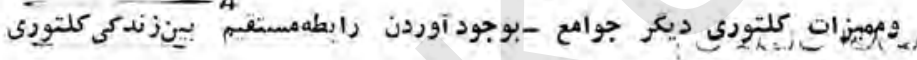

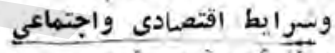

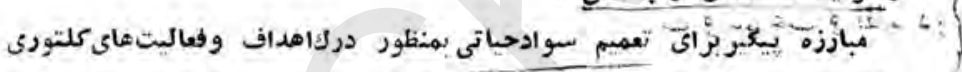
ملى

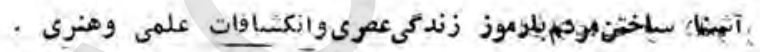

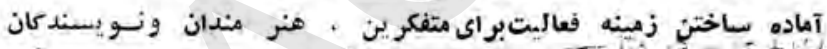

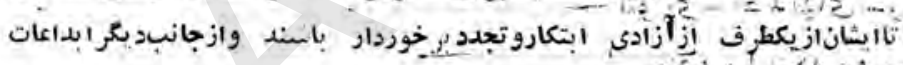

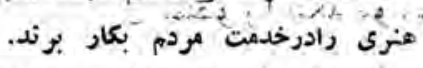

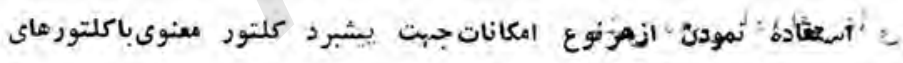

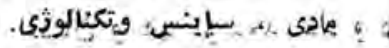

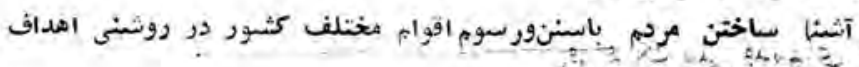

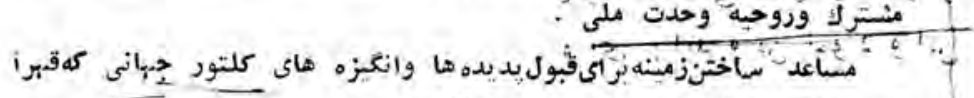

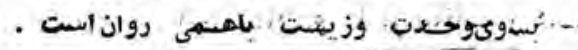

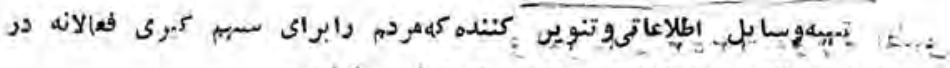

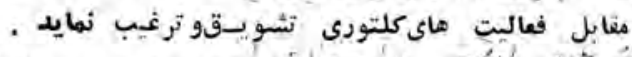

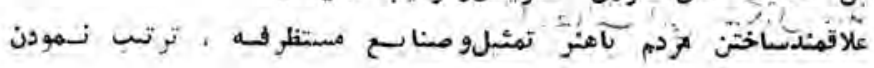




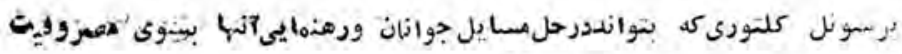

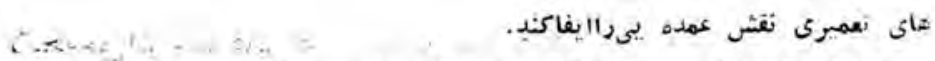

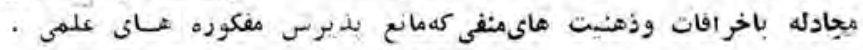

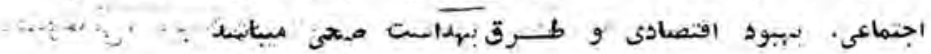

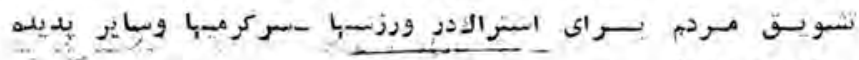

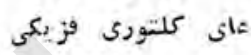

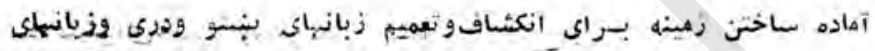

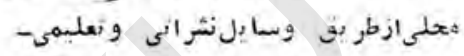

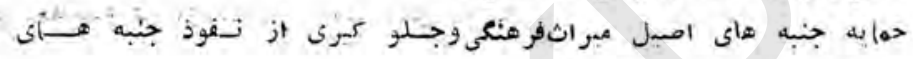

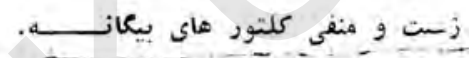

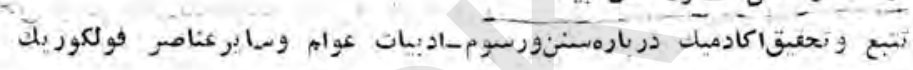

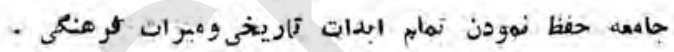

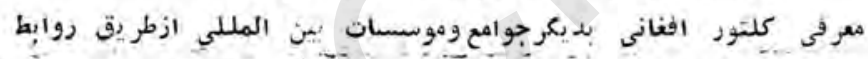

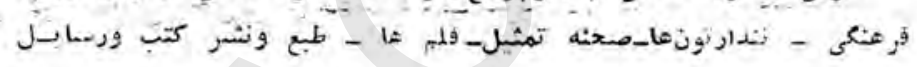

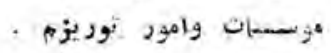

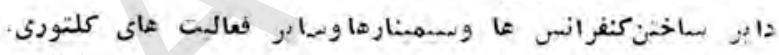

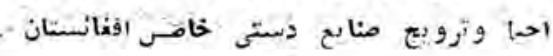

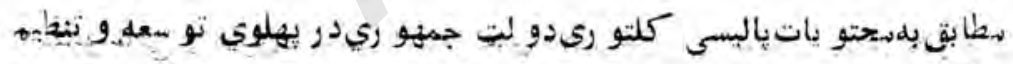

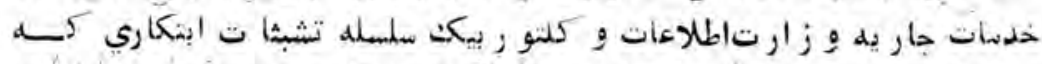

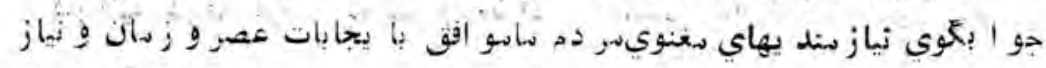

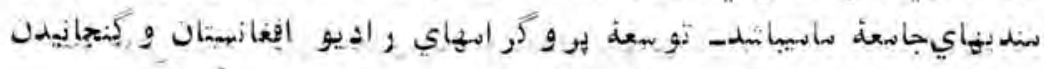

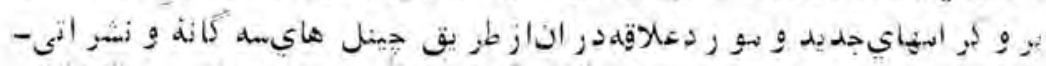

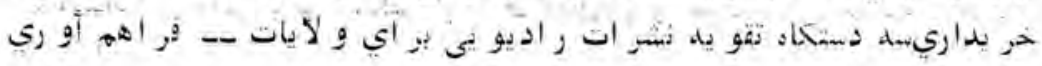

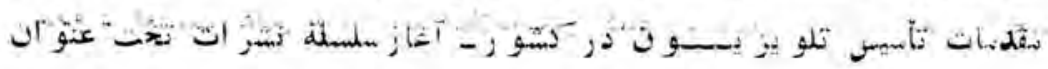

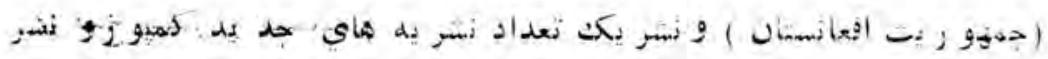




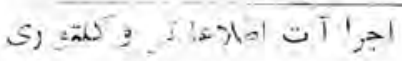

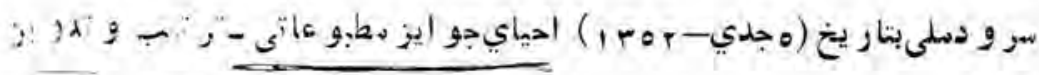

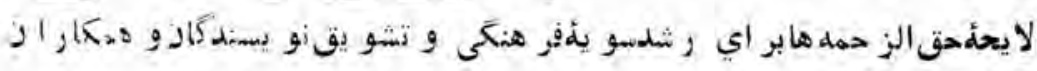

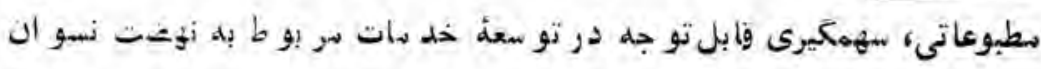

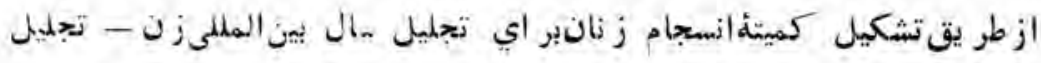

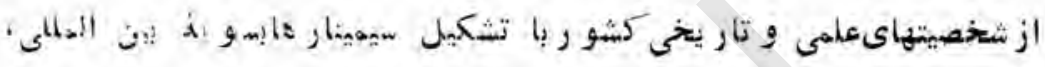

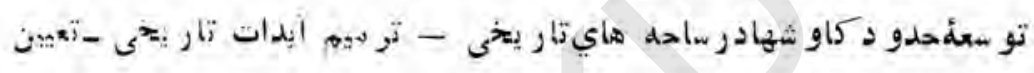

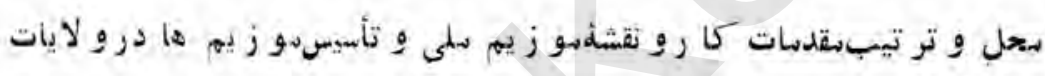

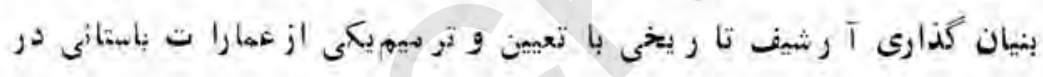

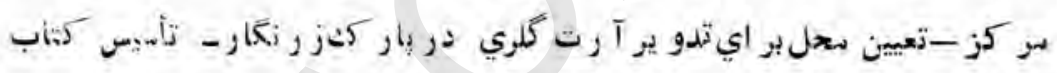

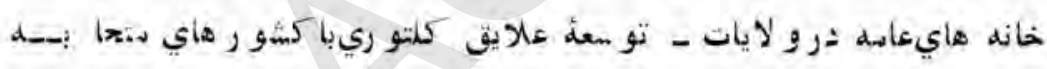
ازطر يق رفتو آسدار اكمينو هيأت هايو زازت - ز زو ر نالستأ و هيأتهاي نطبو عاتى و هنري-تأسيس آتشه هاي نطبو عانى و كلنو ر ي درخارج وآ ثاز كار آنها درقا هره ، كو يت و بغد اد - ثأسيس ادا رئ سر كري نهيئ سو اد

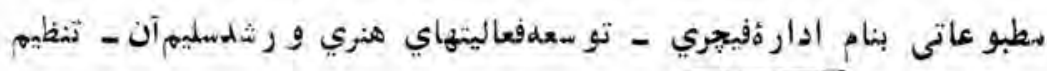

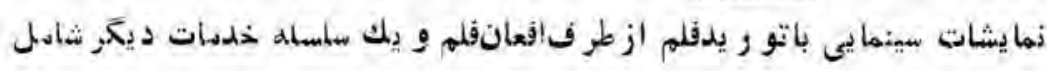
حدو دو فعاليت هاي وز اربت الطلاعات و كلتو رميباشد كلهر كدام ايجاب تو ضيت بيشتر ر السينهايد : 


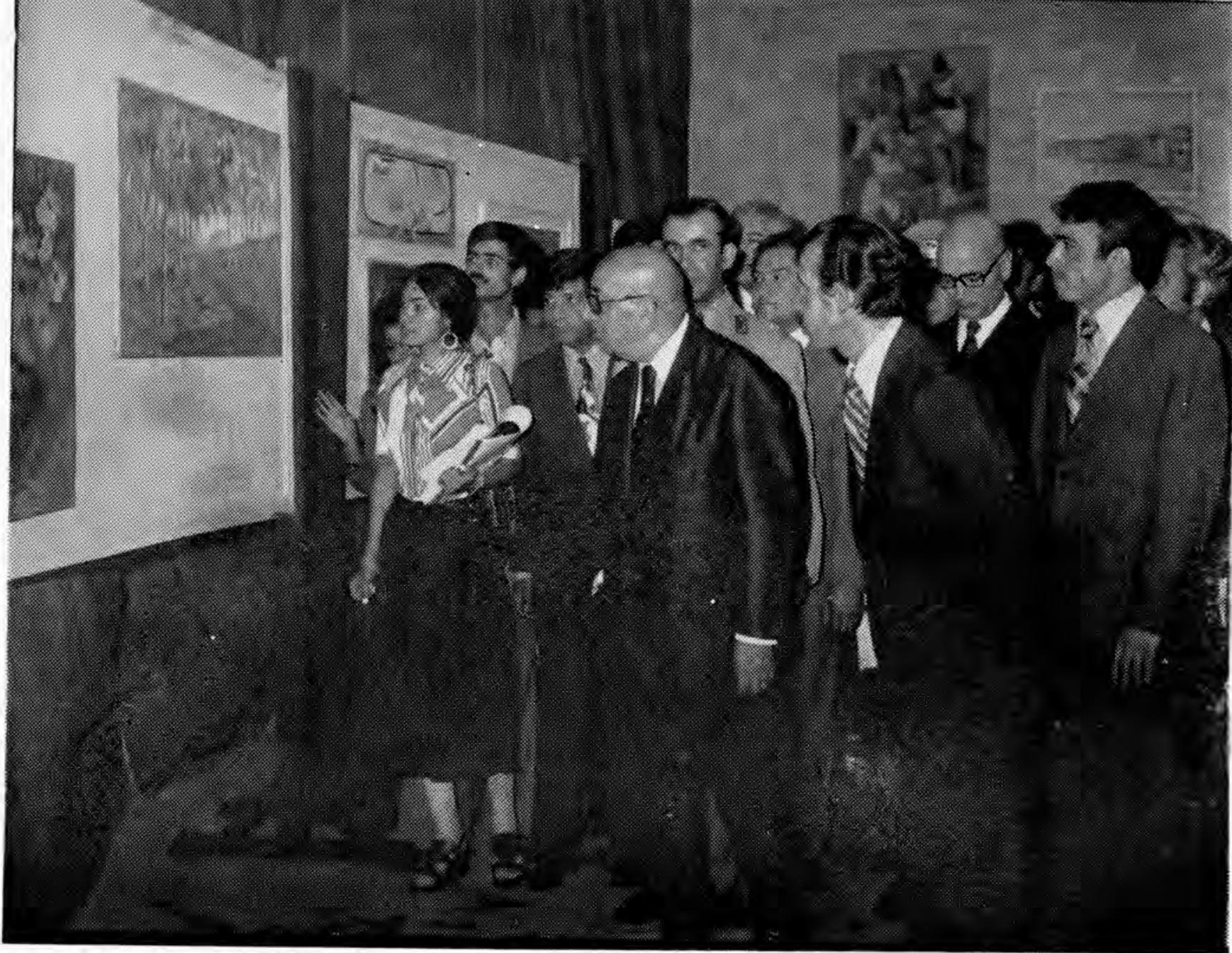

- رهبرانقلاببناغلى محهدداؤد رئيس دوكت و صدراعظمدرحال باز ديد از نندارتونفرهنعى سال Iroo $y=401$ 


\section{فعاليتهاى نشراتى:}

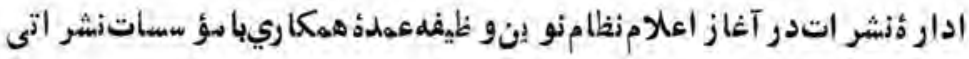

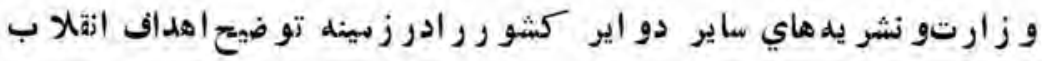

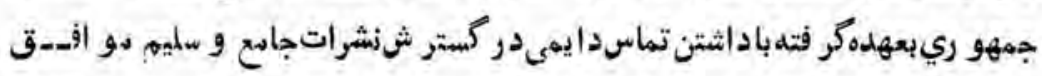

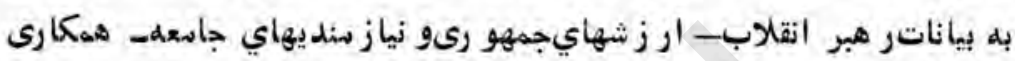
هاي خو يش رابحيثر جع مركزي ارتباط و زارت الطلاعات و كلمتور ر

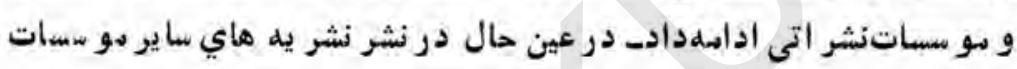

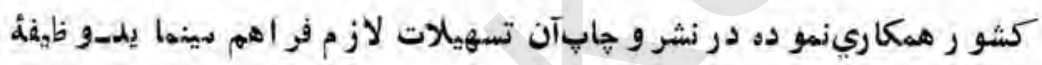

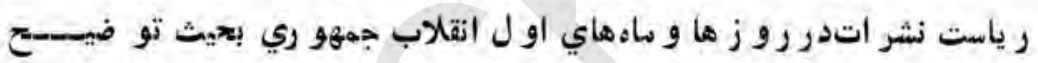

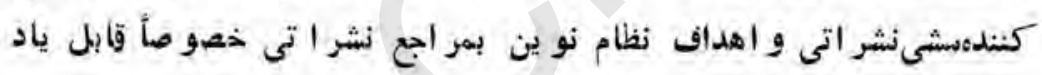

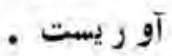

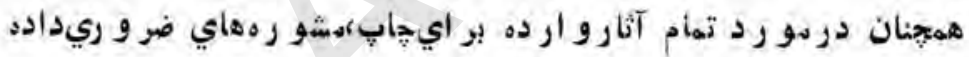

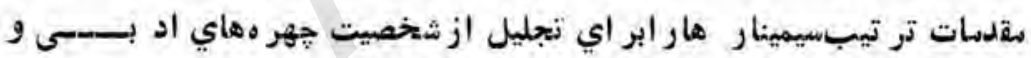

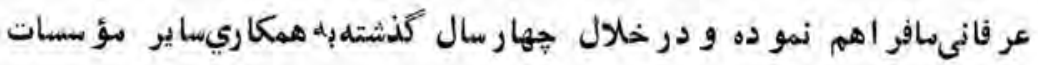

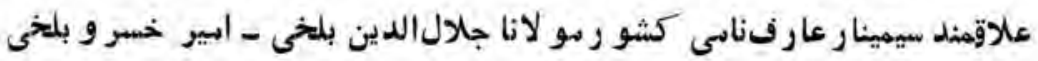

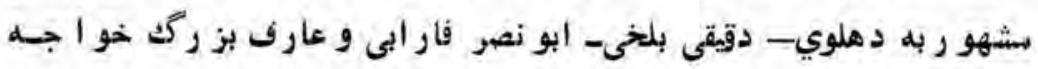

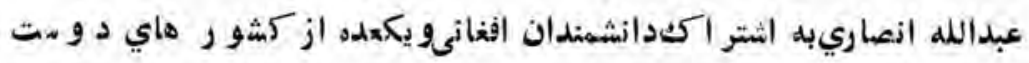

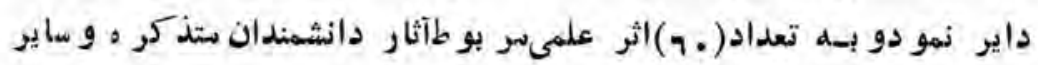

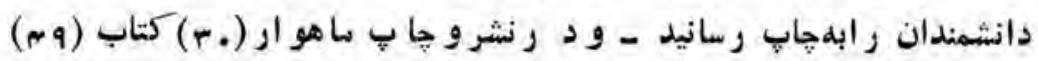

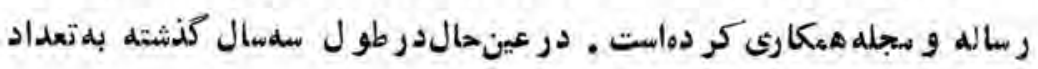




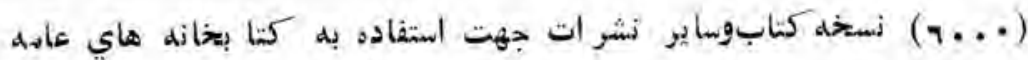

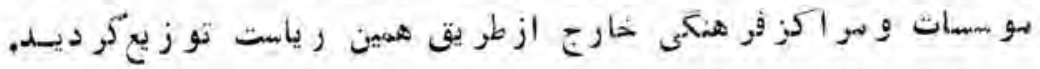

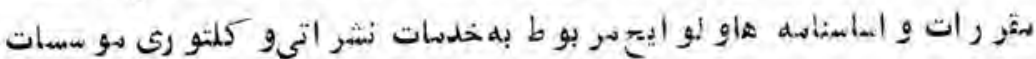

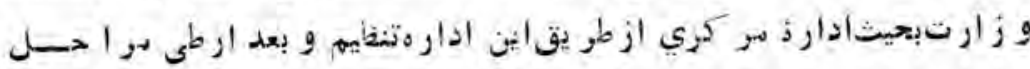

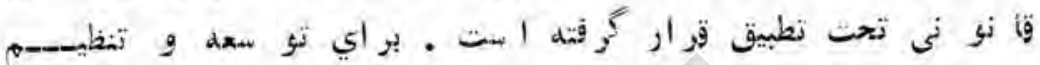

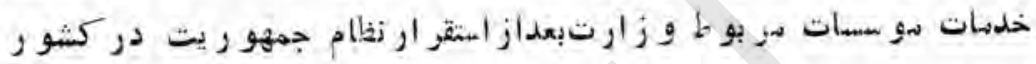

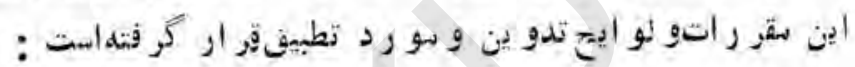

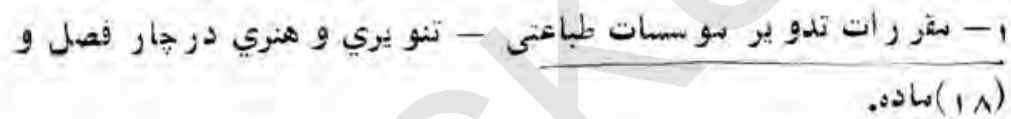

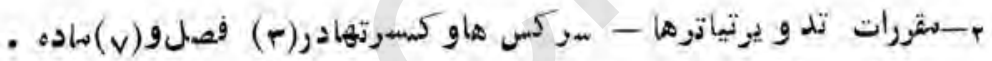

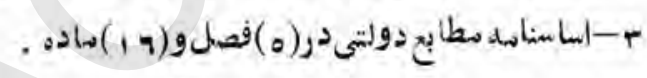

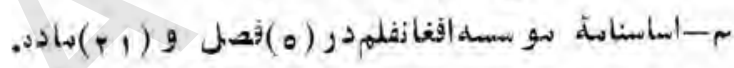

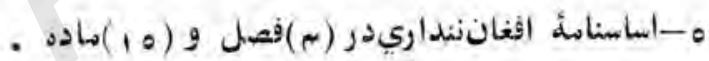

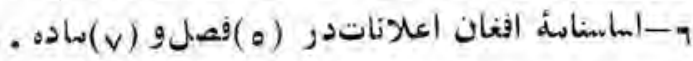

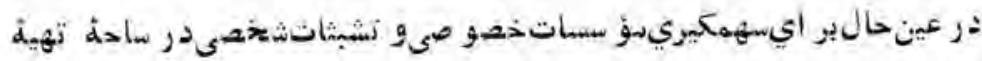
فلمهاي هنري بعداز المتقر ار زنطام جمهو ري بمؤ سسات خصو صى آتى اجاز ه فعاليت

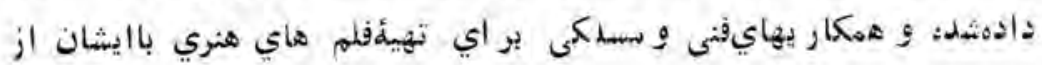
طر دق افغانفلم صو رتكر فت:

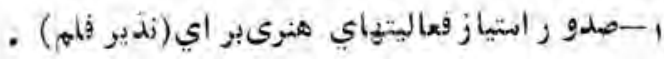
ب-حهو ر استياز فعاليت هاي هنريو تو ليدفلم بو اي( آر يانافلم ) . 


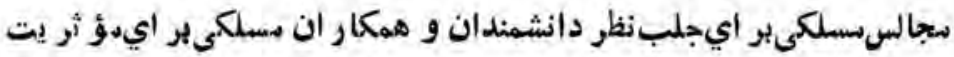
خدمات سطبو عاتى دروسو اقعضر و ريدايو نهو ده و تجاو يزيدر زبينه مسها يل نشر اتحو فر هنَّى اتخاذكر دهاست .

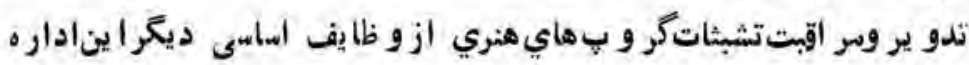
امت كم با تد و ين لايحةتدو يو نمايشات سعىنمو د فعاليت هاي هنري بشكل سليم آن انكشاف يافنه و در خدمت مر دما قو ار كير د. اين لايحه كه از آغاز

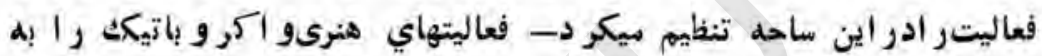

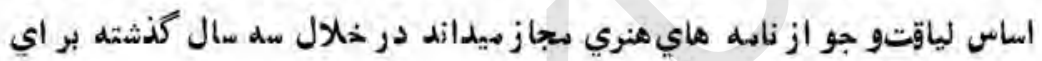

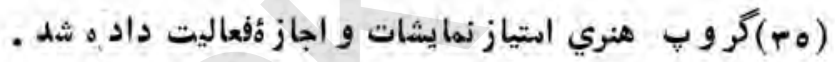

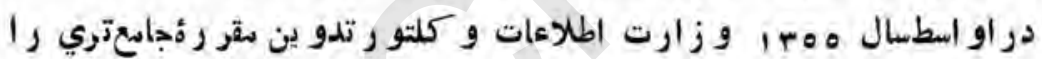
بر ايتو سعأفعاليت هاي هنري و سركر مى سليم سو دمر و يدست كر فت . درعينحال ر ياستنشراتبحيث ادارئ سر كزيبه امر يت هاي اطلاءعات و كلتمو رو لايات و فو اهممآو ري تسهيلات بر اي بهبو د (r 1) رو ز نامه و لايات ميثو روهاي لازمداده و در اسو رمسلكى و نشر اتى آنها همكاري كر ده الست و همبر اينثر ثمارههاي فوق العاده و لايات مو ادو كلميثه هاي ضر و ري فر اهم ساخته است.در طبعشماروه هاي فو ق العاده رو ز ناحهه ها ي و لايات -

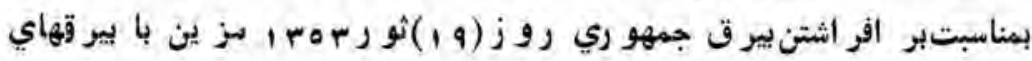

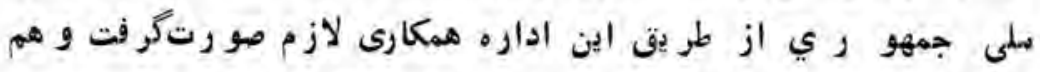

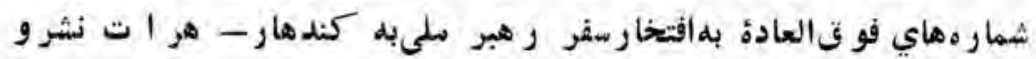




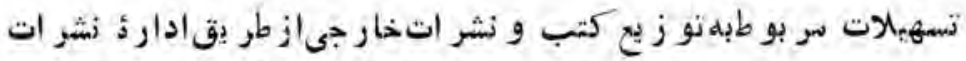

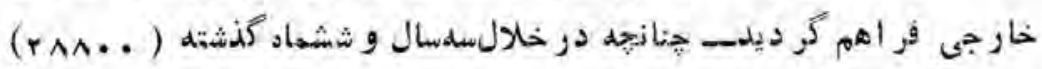

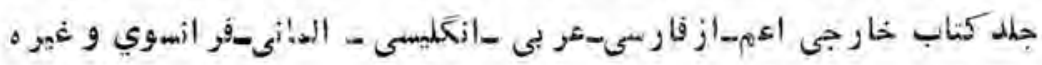

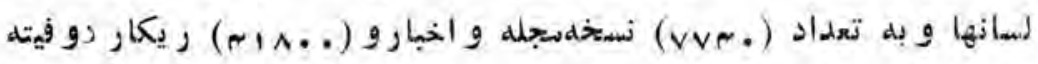

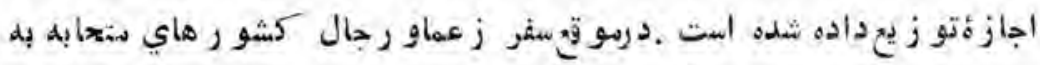

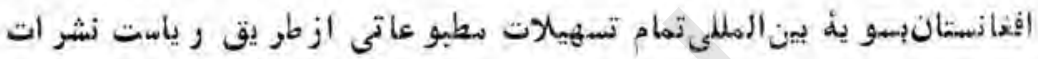

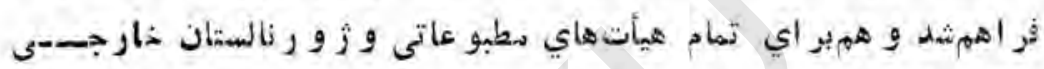

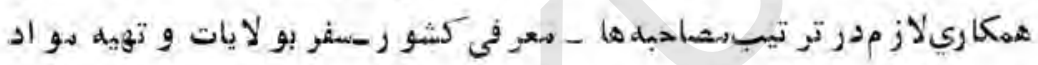

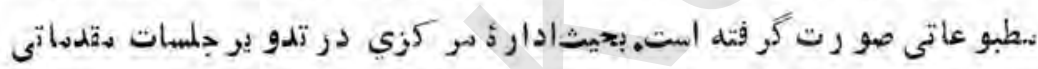

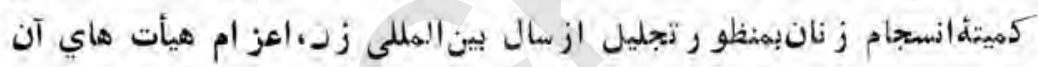
بو لايات و خابه نشر ئه هاي اختصباصى آذ نيز اين ادارد سهم كر فته است -

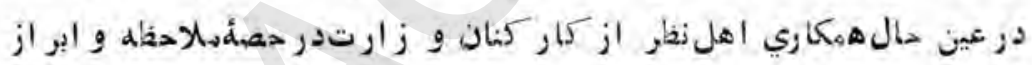

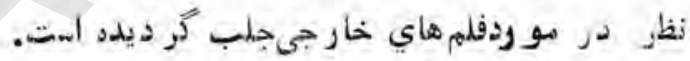

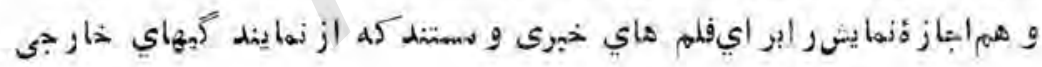

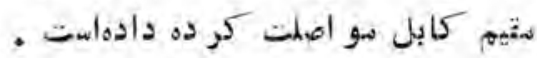

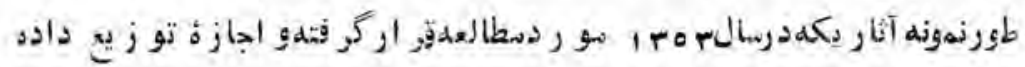
:

$$
\begin{array}{r}
\text { i }(1 .+1) \\
\text { " }(1+9) \\
\text { " (7N) }
\end{array}
$$$$
\text { | }
$$

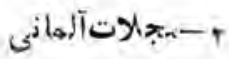$$
92 \text {, } 10 x \rightarrow-r
$$ 
فعاليت هاىنشراتى

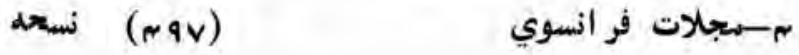

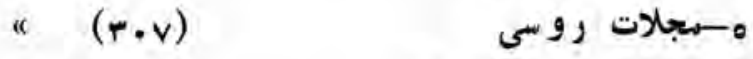

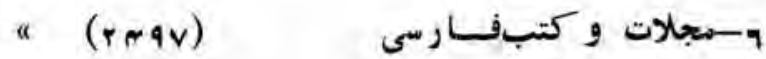

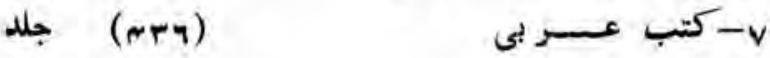

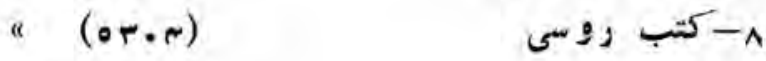

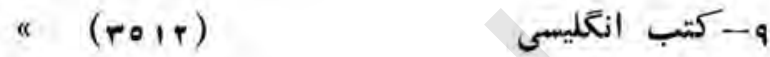

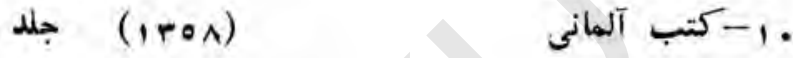

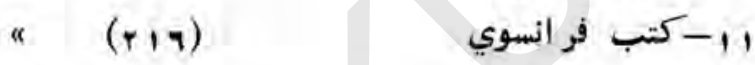

$$
\begin{aligned}
& \text { " (1r ) (1r ) } \\
& \text { " (vr) }
\end{aligned}
$$

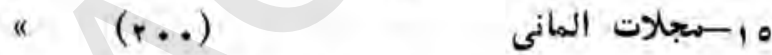

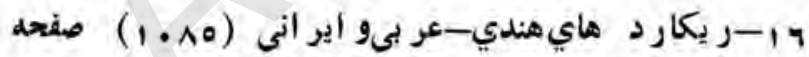

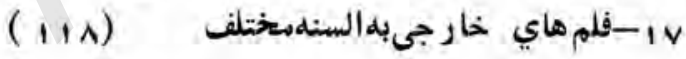

البتها زهمكا ري هيأتسلكىشامل اشتخاصو اردو و ر ز يدهبر اي ائرا ز ز نظر در سو رد آثار استفاده شده است. همجنان بر اي بار اول جهت استفا دو عاسه لو حه هاي (اطلاعات و كلتو ردورخدمت شها ) دور ز أرت خانه ها ، مر اكز بز

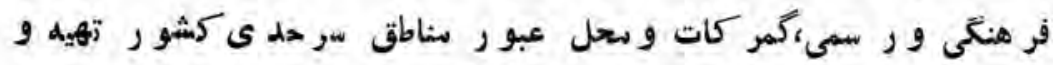
رو ز ناسئجمهو ريترووي آن نصب هيعر دد . سالنامل افغانستان بافتخار تجليل از سا لتمر د انقلاب جمهو ري بعد از استقر ا ر 


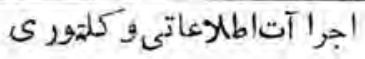

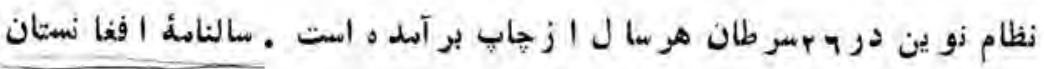
بيانات و مصاحبه هاي ر هبر انقلاب و ساير انكشافات و جر يانات عهدة كشيو ر

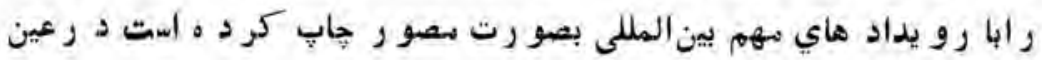
حال بحيث يكك سأخذ عمدة سطالب جاسع سر بو ط بتا ر ريخ -فر هنغك - ادب اقتعباد و ساير زو اياي حيات كثو روانشت نهو د م الست .

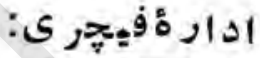

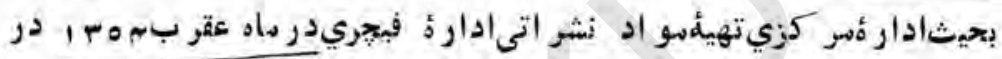

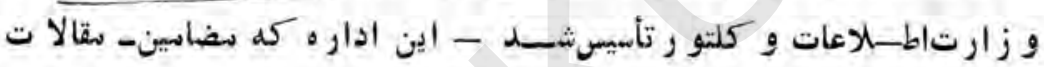

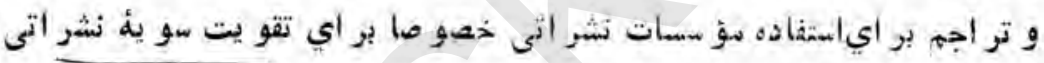

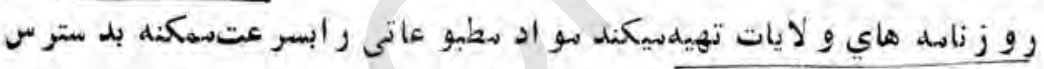

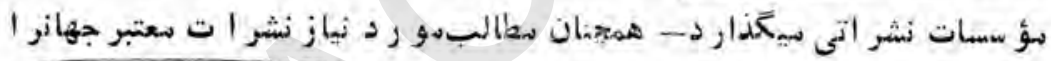

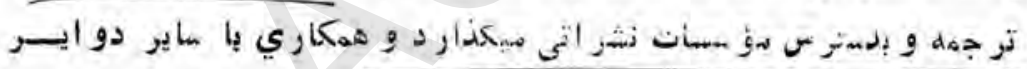

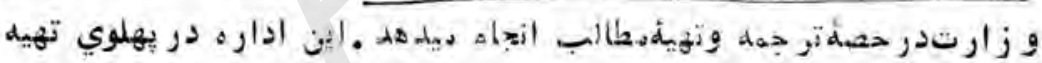

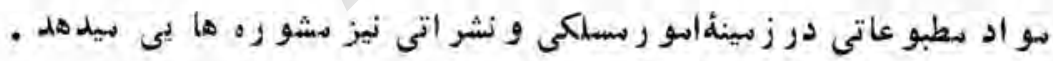

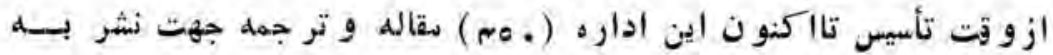

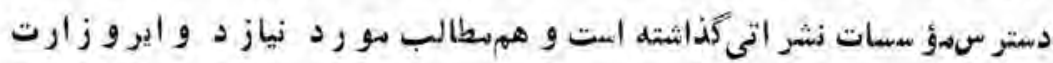

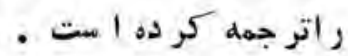

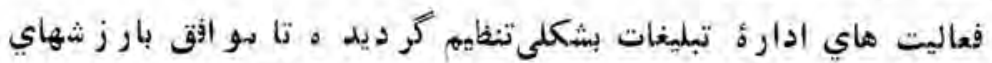

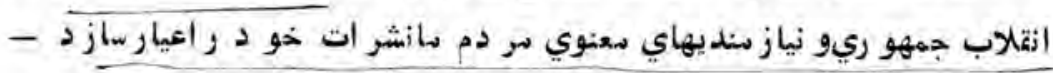

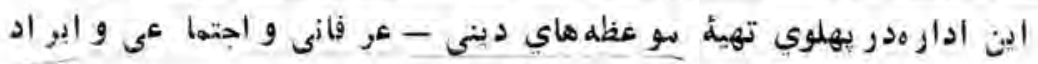


خطابه هـــــا تو سط كار كنان تبليغات آن در مر كز و و لايات ت بشعى نهو د

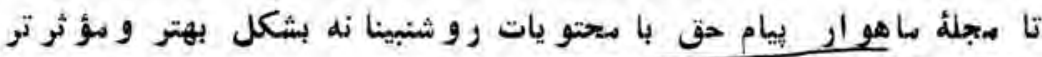

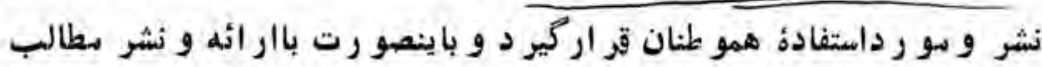
بشكلجاسع آن ارز شهاي عالى آئين الهلاسى مارا با مز اياي اجتما عى نظام جهو ري به تفصيل تو ضيح داردو اساساتآنرا كه عدالت اجتماعى - خدمت به

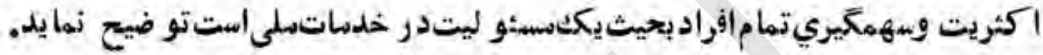
كار ارزشهندي كهم تو سطبو ردنبليغاتشأسل اشخاص و ارد د ردين اداره

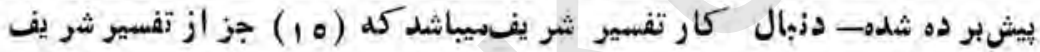

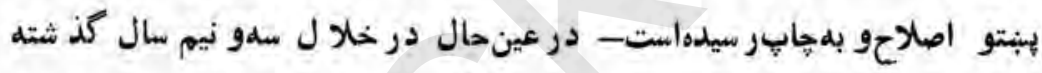

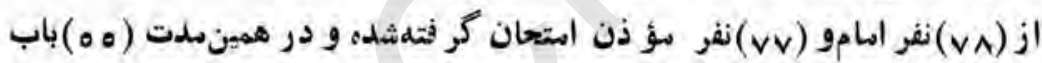

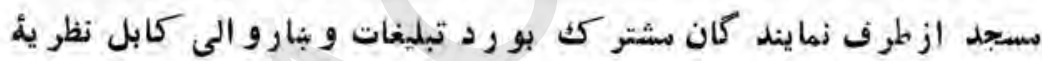
رسمىبو دن و ار تقار ادر ياوت كر دهاست.( به 1 1) جلد كتب دينى و تنو يري نهز در ين ادارهبر اي در يافت اجازئنو زيع ملاحظةه شهه است .

$$
\text { روز زالمه ها - جر ا يل }
$$

سماعىو ز ارتاطلاعاتو كلتو ردر نشر نشر اتبطبو عتو جلسهاصل بو د : 1آـآغاز نشر ات جديد. ب-بهبو دنشر ات بو جو د.

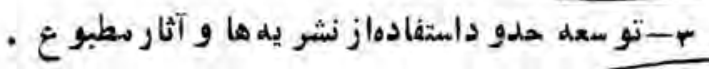

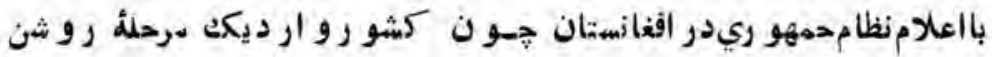


اجرا آت اطالاءاتى كلتو

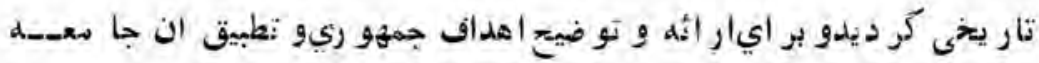

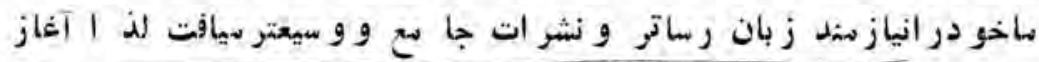
نشر نشر يه هاي تازمبر اياين هدف سلى و الللاع و تنو يو هر دم و معر فـى

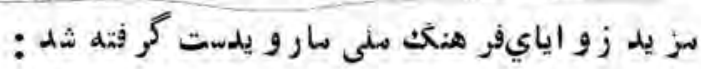

$$
\text { : روز }
$$

بهنظو ر تو ضيح اهداف و ار سانهايو الايانةللب جمهوري-بر اي تحليل و بو رسى عهيق اصل هاي كلى اين نظام - - بهنظو ر روشن سا ختن بز اياي

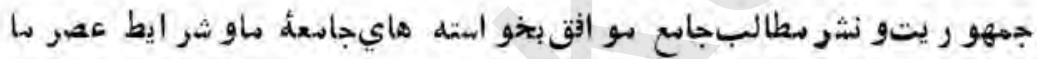

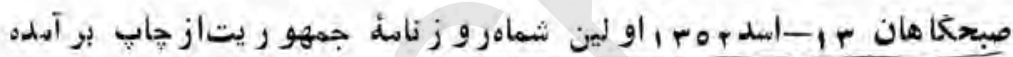

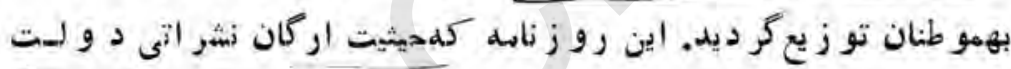
جمهو رير ادارد ازيكطرف بهنشر مقالات عميق و تحليلم بر د اخته أهـــداف

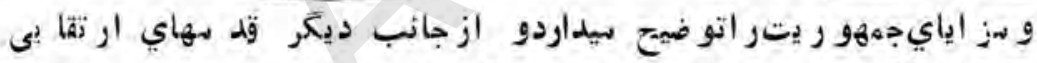

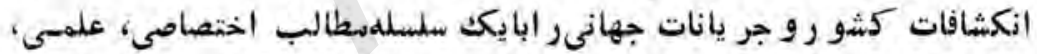
تحليلىو تنو يزىبه نشر سىر ساند.سطالبعمده ازقيهل قو انين و رائو رثاز

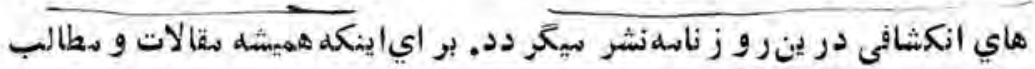
جاسع در رو ز نامئه جمهو ريتجاب شو د همكاري تعداد زياد د انشه:دان و نو يسندكان و ر ز يدهر امو سمه نشر اتى جههو ريتجلب كر ده است .

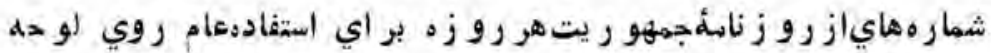

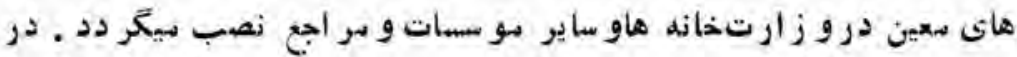

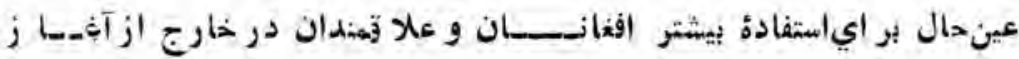




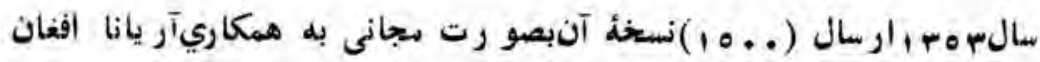
هو ايى شر كت بخار ج رو يدست كر فته شده.

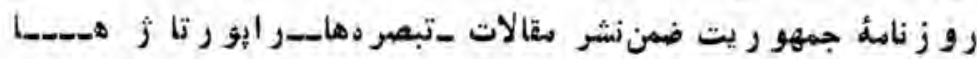
مصاحبه ها و اخبار داخلى و خارجى صفحات اختصاصىنيز دارد كلعبار تاست از صفحات جو انان- سو ضو عات علمى تعليم و نر بيه-ز نو ز ندكى نو و صجت.

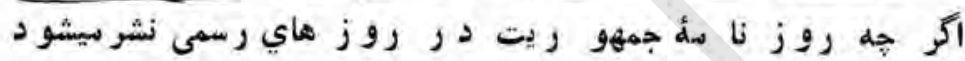

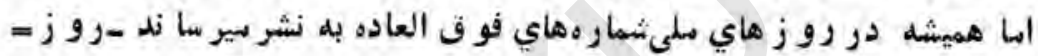

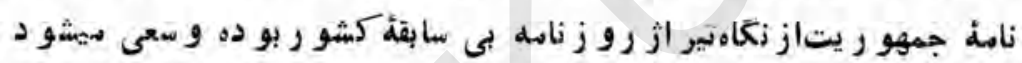

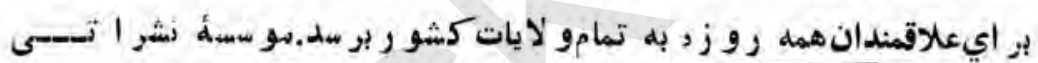

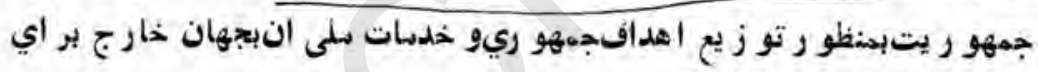
بار اول لدر سالمه م ابله نشرشمار مهاي اختصاصى اخبار جهو ريت به زبان

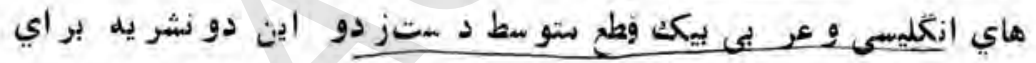
معر فيى يدز يد كثو رو جر يان انكشاف آندر بو تو اهداف عالى انقلاب جههو ري

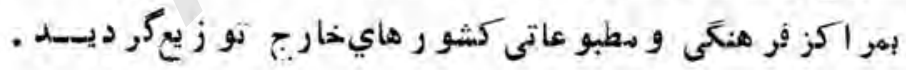

$$
\text { : }
$$

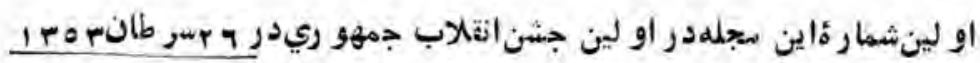

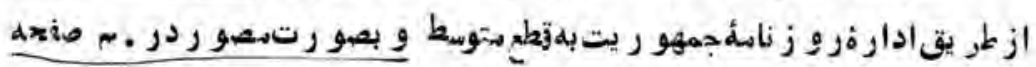

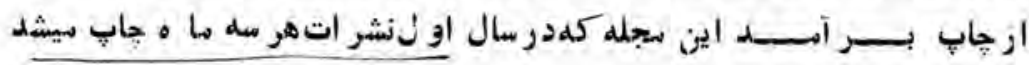

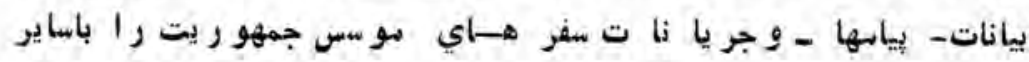

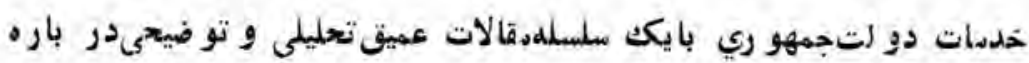


اجزا آت اطلح عاتى ف كميورى

$(1 \vee \cdot)$

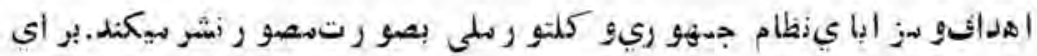

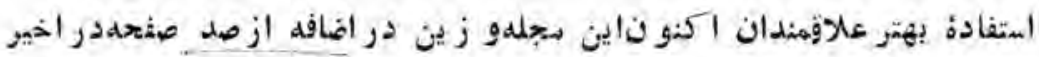

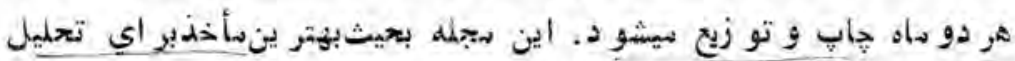

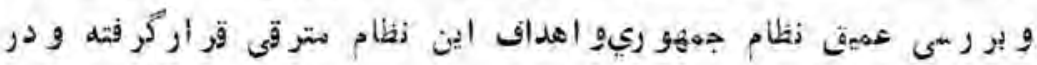

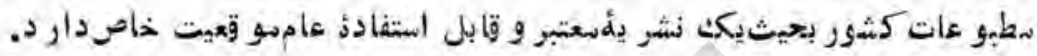

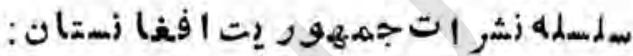

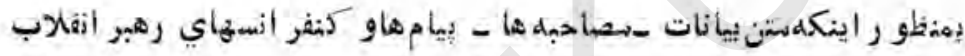

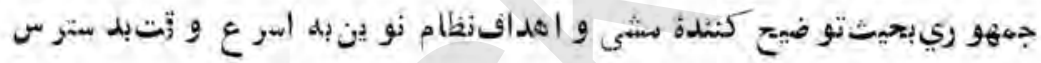

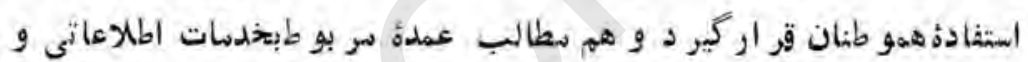

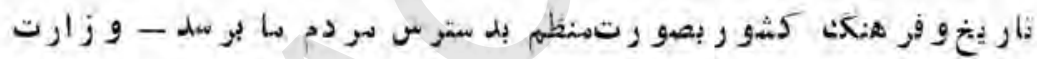

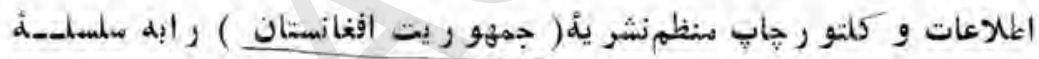

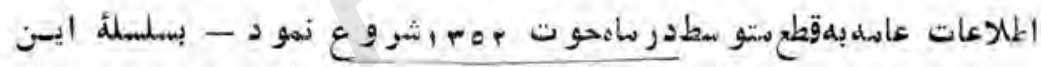

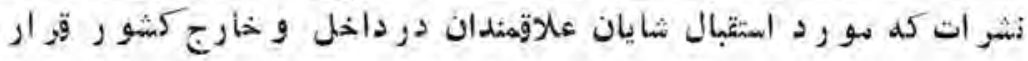

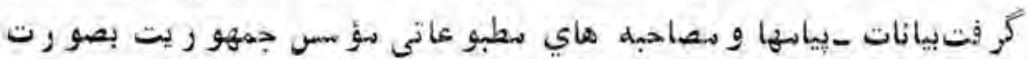

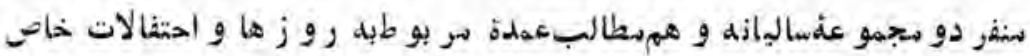
از فبيل رو ز جهانى سو اد و سطبو عات ـتجلميل سال بين الململى زنسسيمينار هاي

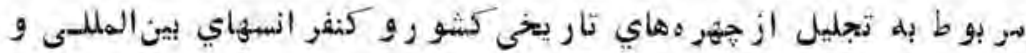

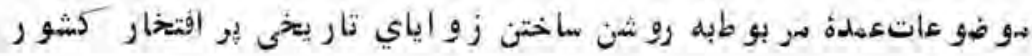

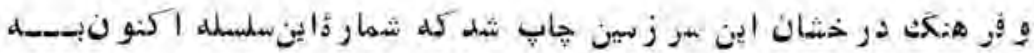




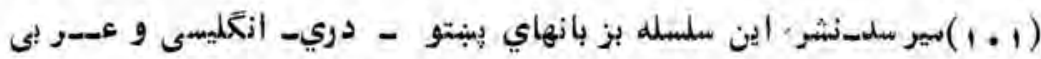

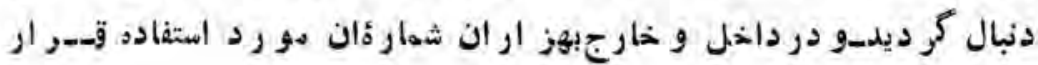
.

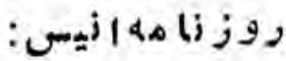

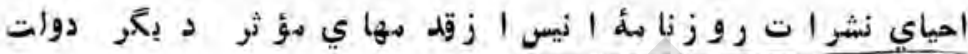
حمهو ري بو د كله در انكشاف ساحة خد سات مطبو عا تى د ر ركشو ر بو

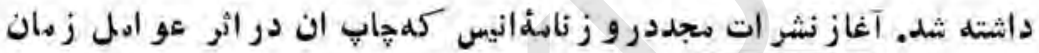

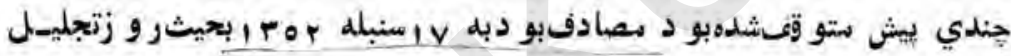
سو ادو بطبو عات. اين روز ناسه درم صفته باقطع بز ركف نشر ات خو د روا

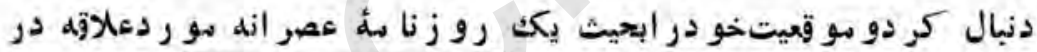
إششتيبانى و تحليل ار زشهاي انقلاب جمهو ريو ار ائه دطا اب خبري- تنو يوى

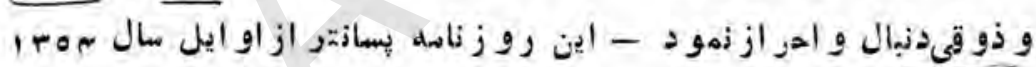

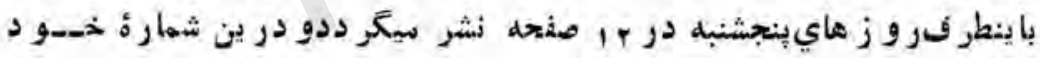
ميطالب ذوقى رابه نشر برساند.

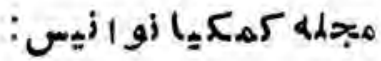

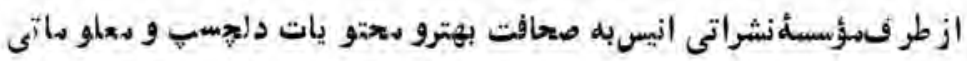

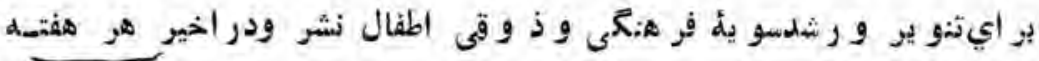
توزيمنميمر 2 


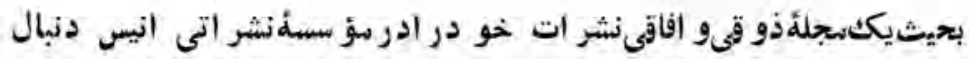

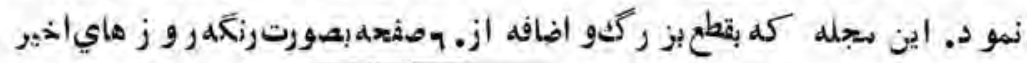

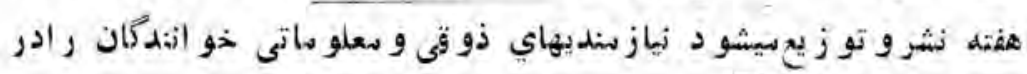

$$
\begin{aligned}
& \text { نظو سيكير د . } \\
& : l_{4}=\int, 4 \geqslant 0
\end{aligned}
$$

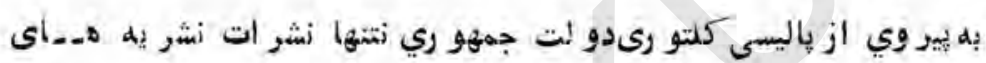

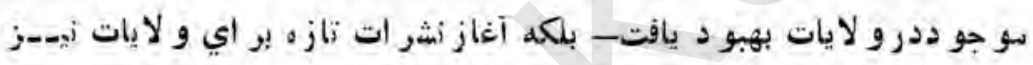

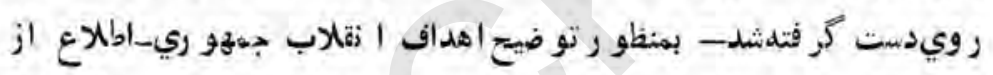
انكثافات كثو رو معرفى زو اي-أي هيختلف حيات فر هنكى و سايو انكشافات

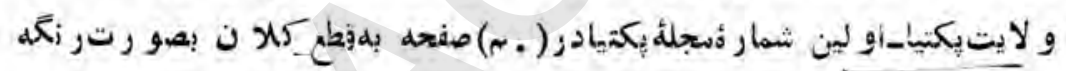
2ر ساد سنبله

\section{:}

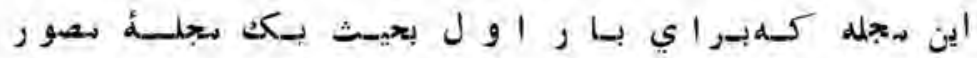

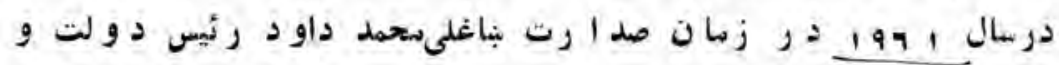

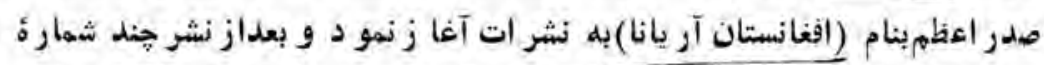

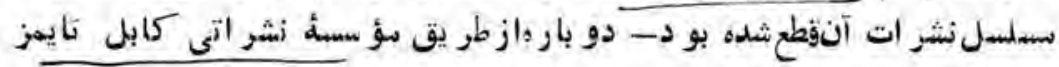

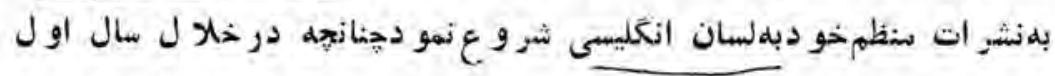

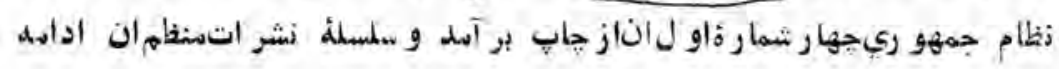


يافت.نشز و توز يجاين سجلهبر اييمر فى جر يان انكشاف كشو روخدمات

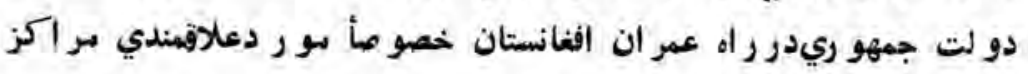

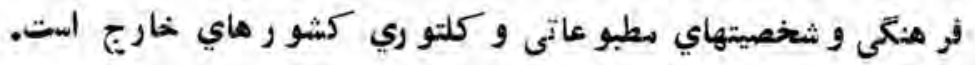

$$
\text { مجاجه }
$$

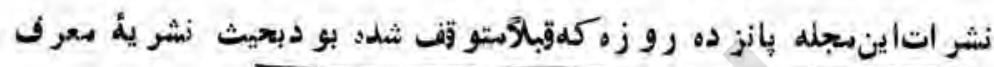

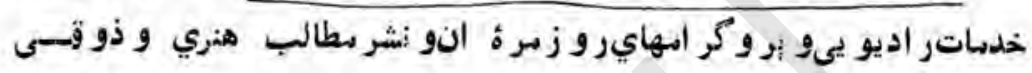

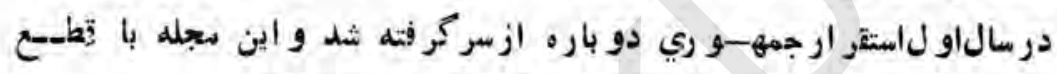

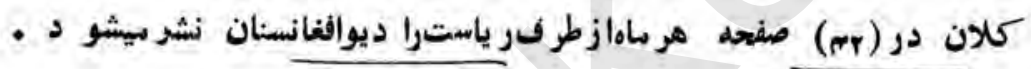

\section{جهودى إلمو شها :}

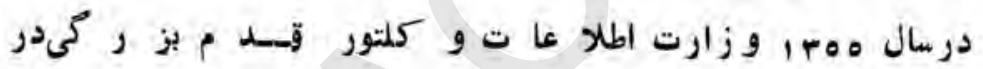

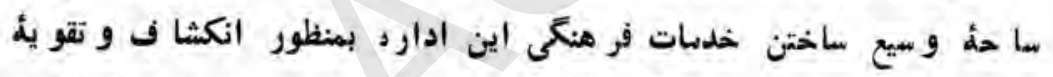

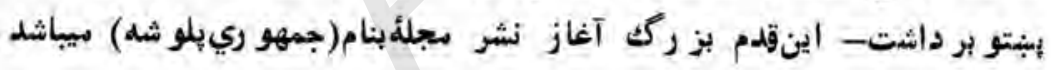

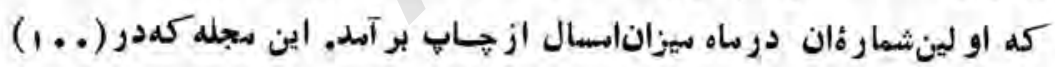

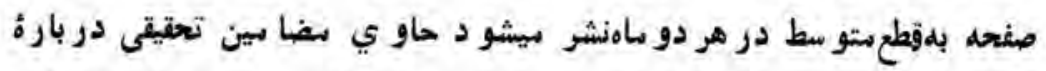

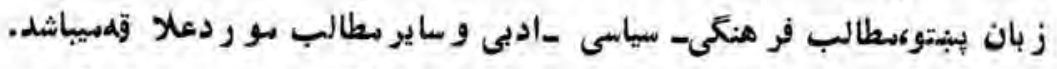

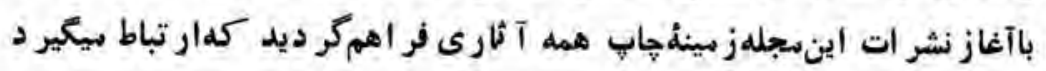

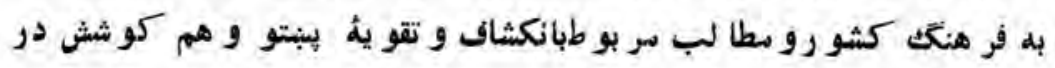

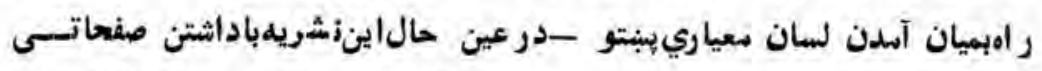

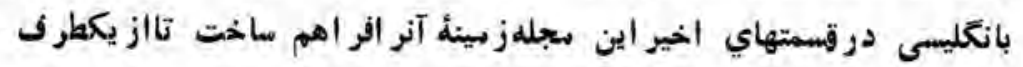




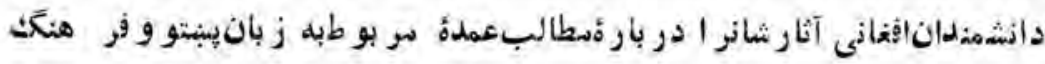

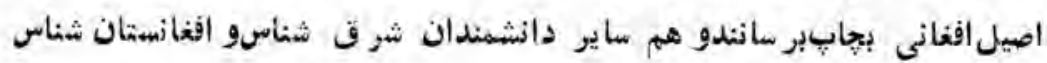

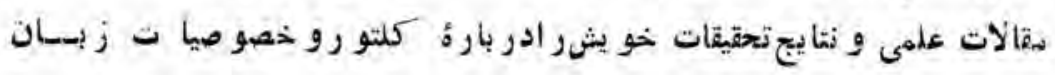

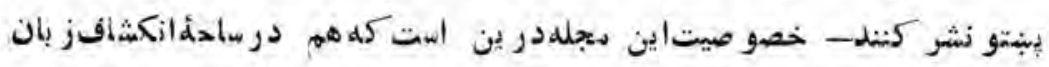

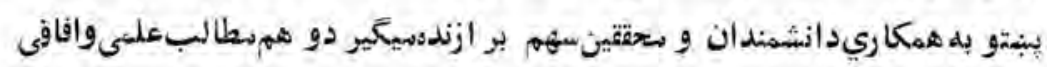

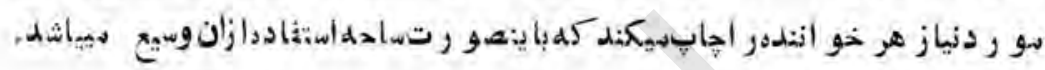

\section{$: \int 9254 d x_{0}$}

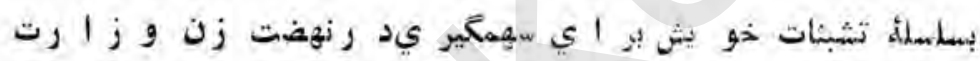
الماءعات \&

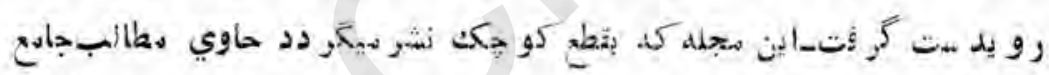

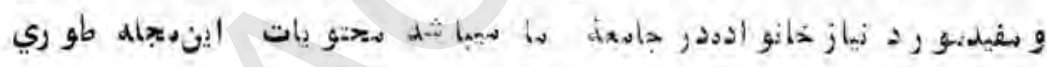

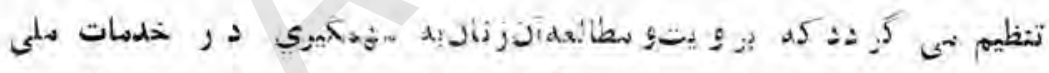

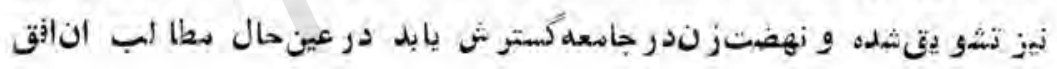

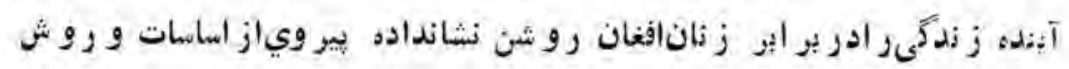

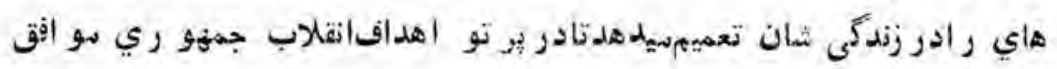

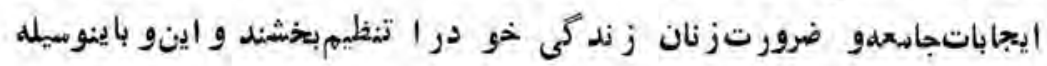

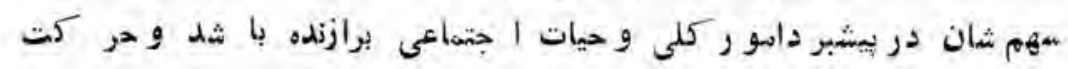

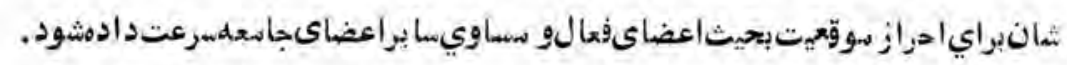

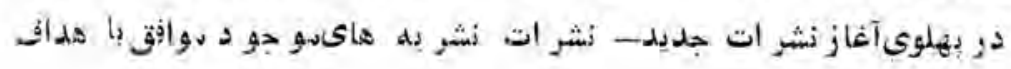




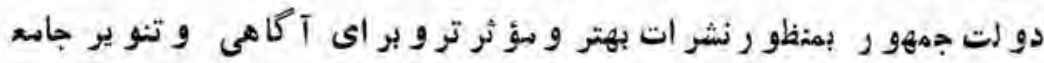

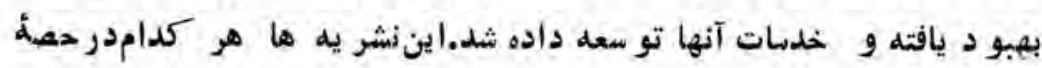

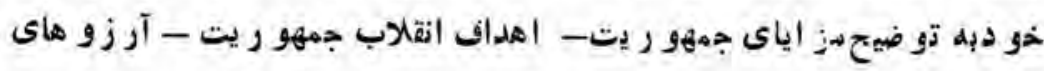

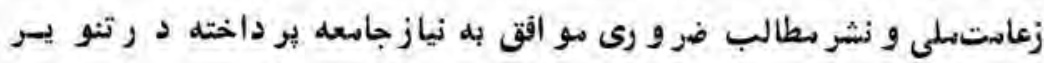

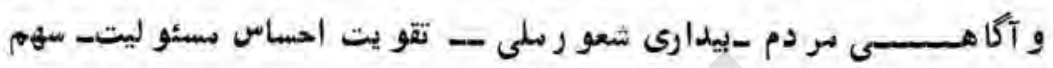

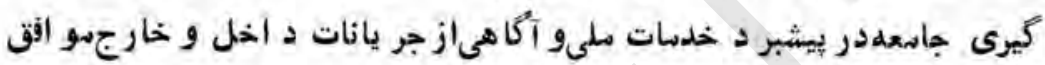

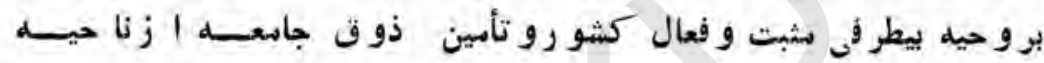
نياز سنديهاي ذو قى و وفر هنكئ بر دواختئد.

$$
\text { روز }
$$

اين رو ز ناسله هو اقق باساساتز و رناليز م از يكطر ف بهنشر سطالبجامع و مفيد بمنظو ر روشنساختن واياي مختلففر هنكت ملى بر داخته و باينصور ت

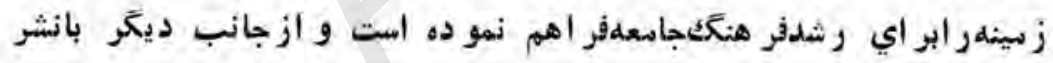

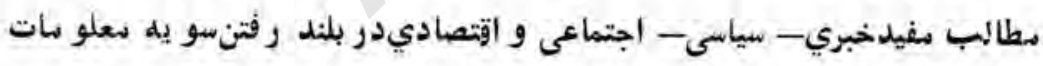

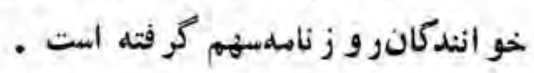

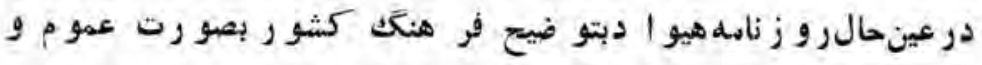

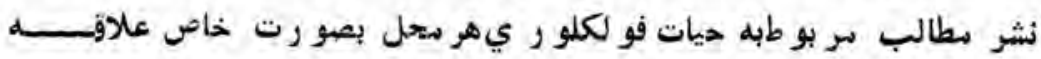

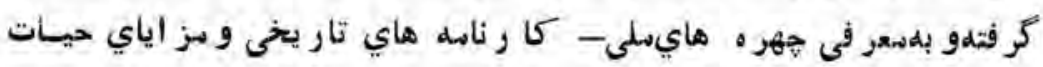

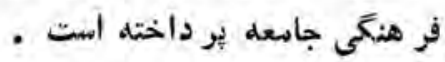

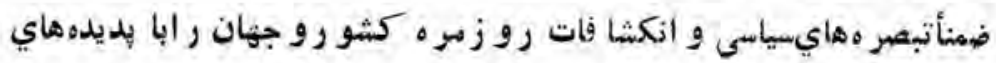


اجرا آ ت اطلاعاتى وكلتورى

$(1 \vee 7)$

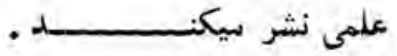

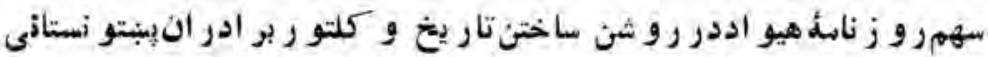

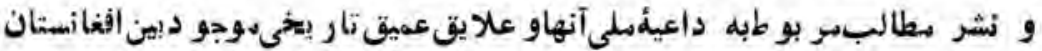
و هبنتو نستان دربطبو عات كثو رخيلى بر از نده بو ده أست .

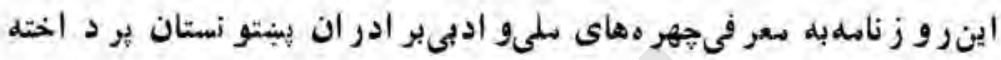
و باينصو رتدر رو شن ساختن خصو صيات كلمتو ري و حهاسه هاي تار يتى آنها

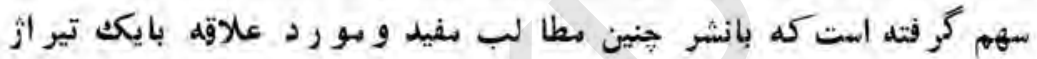

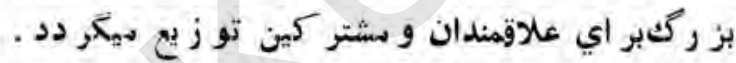

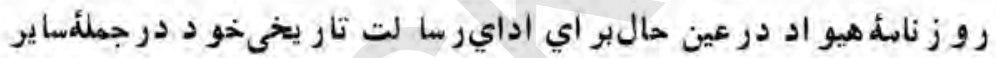

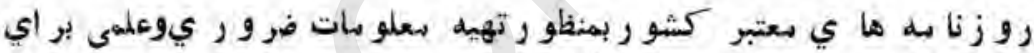

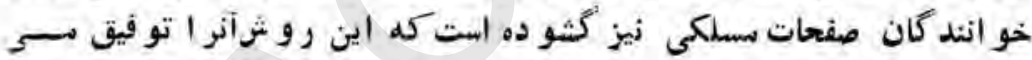

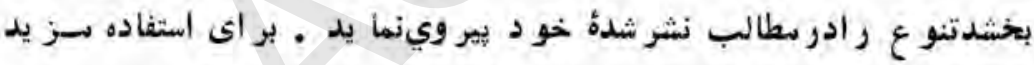
علاقهمدان نير اثر روز نامه هيو ادئيز باطلميعه نظام نو يث بلنذ بر ده شد . $:$ : بر ائاينكه مجلات و لايات باسطالب جامع و سفيد و صفحاتز يبانشر و مو رد استفاده همو طنان سخصو صأخو انثدكان آن در و لايات مر بو ط و سائ همو طنان و علاقومندانقو اركيرد، و ز ارتاطلاعات و كلتو رجنين تجو يز نمو د كــــه

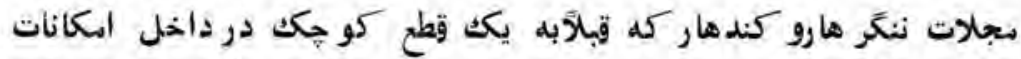

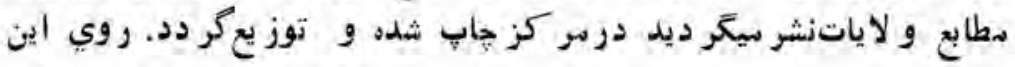

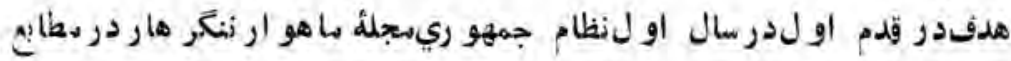


(Ivv) روز نامه هاو جرائد

دو الثي كابل باقطع بز ركث بصو رت مصو ر و با مطالب سفيد وحياتى و به

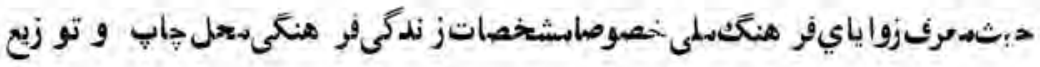
كر د يد ـالبته دربر كز تسهيلات اداري آن ازطار يق هؤسسئه نشر اتـــى

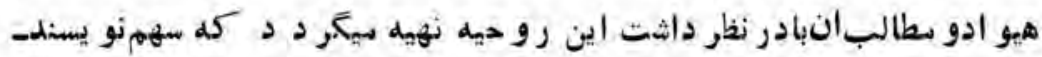

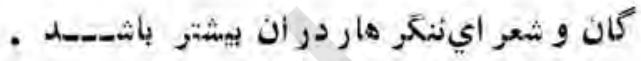

\section{هيجله ك:دهار :}

مجلة كندهار نيز بو اياينكه با بحتو يات و صحافت بهتر در خددت خو اندكان

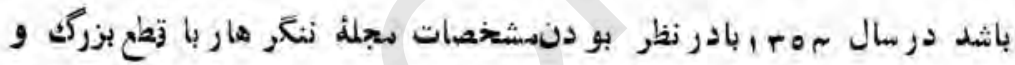
بشكل تصو رو ر نكمدربر كز عبع وبر اي علاقهندان اندر كندهاروسايو

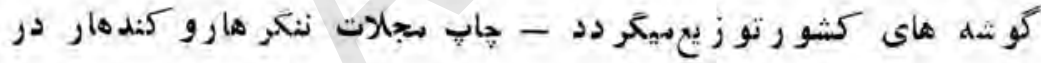
مر كز و همثروع نشر ات مجلة بكنيا باين شكل الداهئ نشر مجنه أدبى هر ات

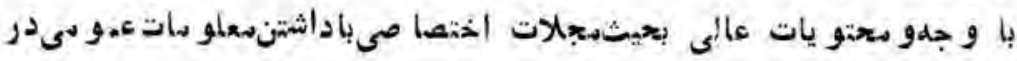

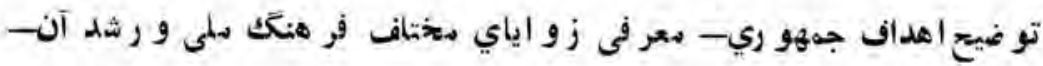

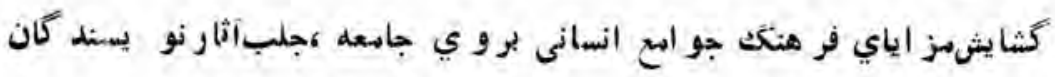

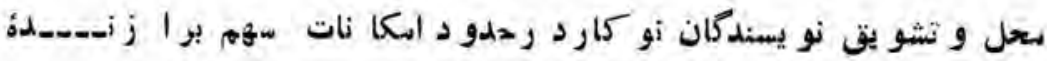

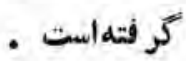


اجرآ آت اطلنغاتىو كلمتو رى

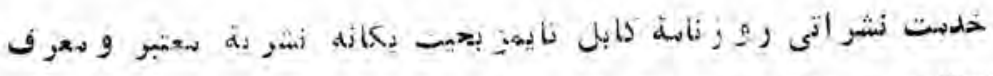

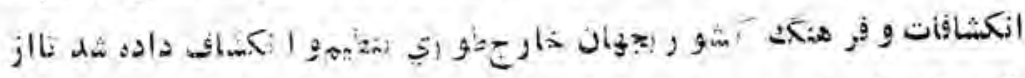

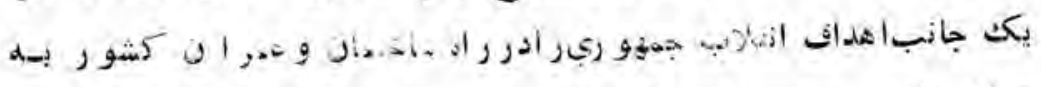

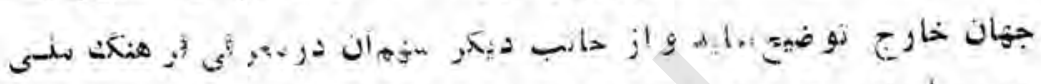

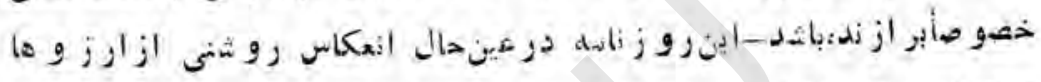

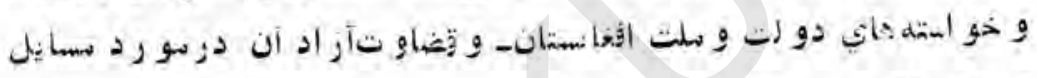

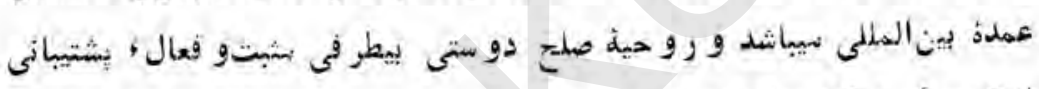

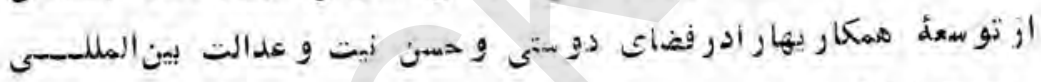

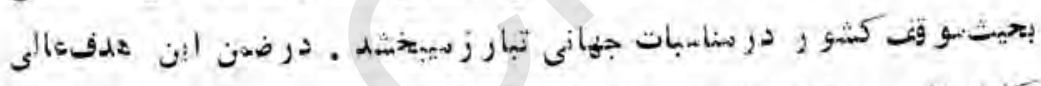

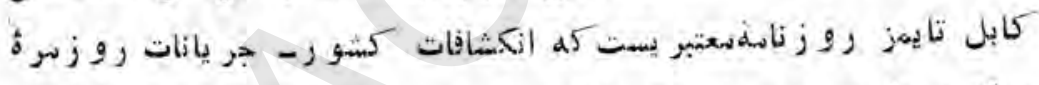

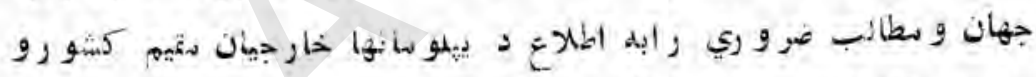

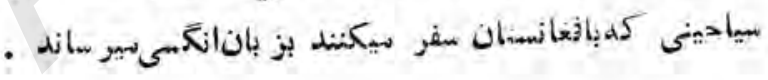

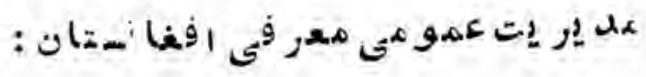

باساس يالبسىى كلثو ري دو لت جمهو ري در تشكيل لهؤ سمةنسر انتى كابل

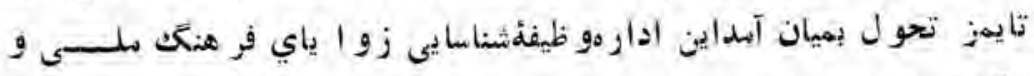

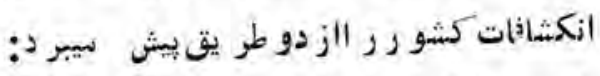
طر يقاو لآغاز سشر ات موقوف وغيرسوقو ته ازطرف اين اداره سبباشد - وراهدوم

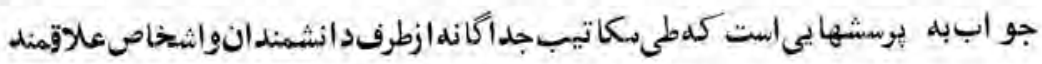



$(1 \vee 9)$
روزناده هاوجرايل

خارج سير سدنشر ات مجلةُافغانستان (آريانا) ر ييبليكك از طر يق اين اداره مجددأ

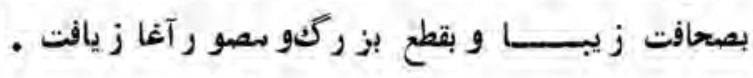

\section{:}

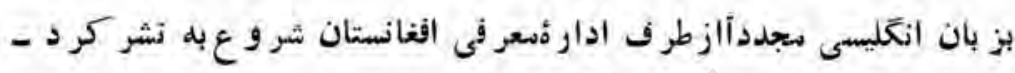

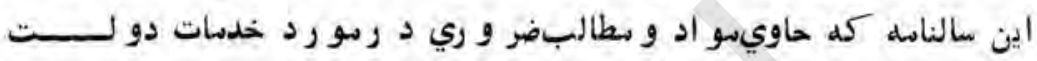
جمهو ري · معرفى كشور و علايق سيا سى - اقتصا دي و فر هنكى

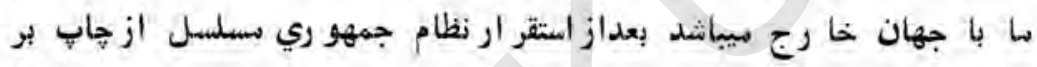

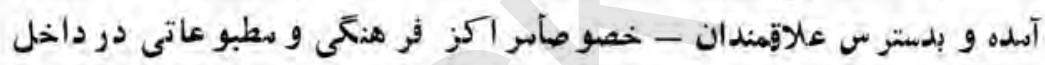

$$
\text { و خارجقر ارگُ فته است . }
$$

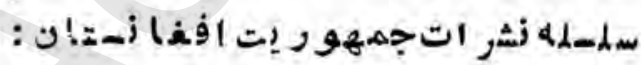

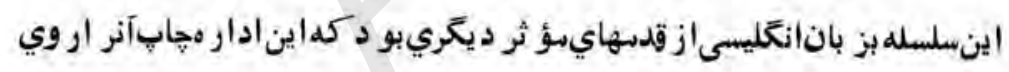

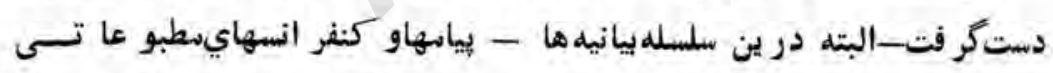

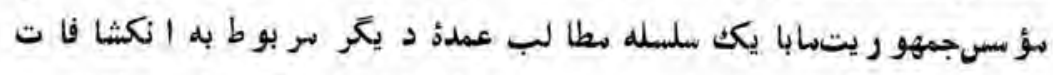

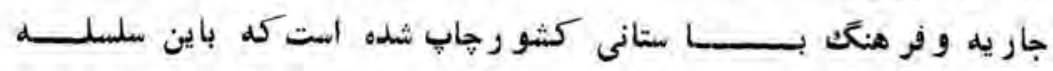

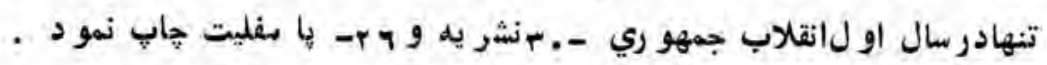

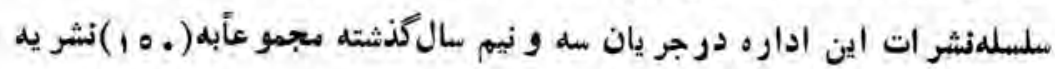
بالعزر ديده و بدستز ساستفادهخار جيان سقيه كابل ، كياحينو علاقهنداندر خارج

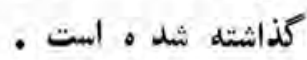




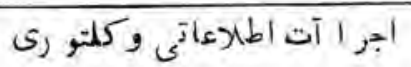

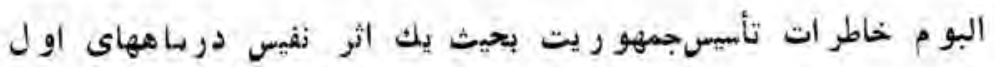

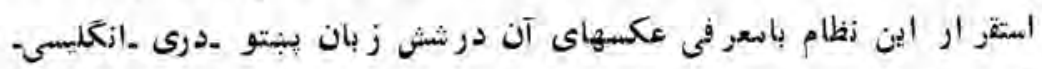

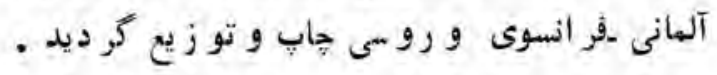
در بهلوى نشر ات رو ز ناسهما و مجلات سركز - آسر يت هاى الطلاعات

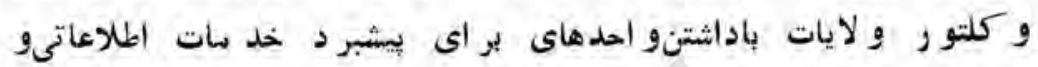

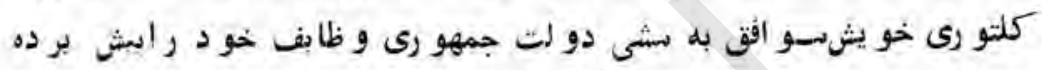

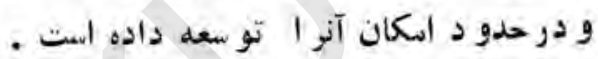

إمنظو ر اينكه ادارئ اطلاعات و كلتو ر و لايات با ا لهام كرفتن از

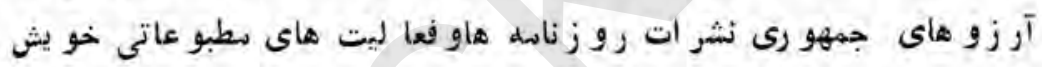

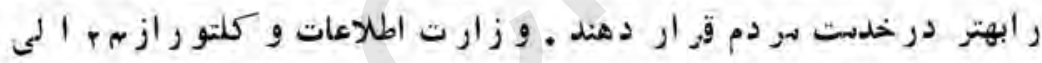

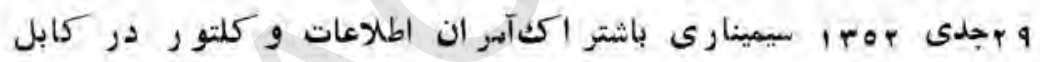

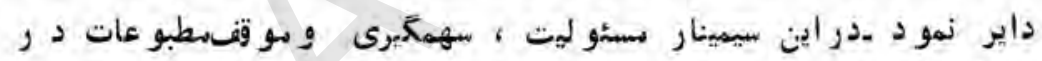

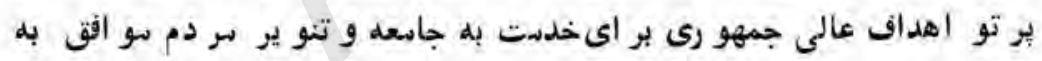

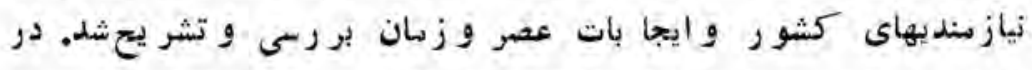

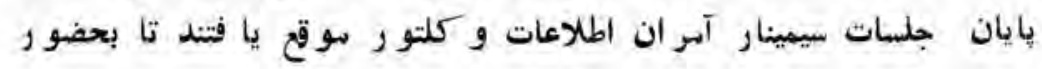

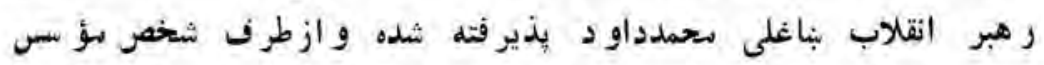

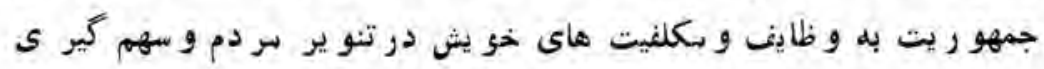

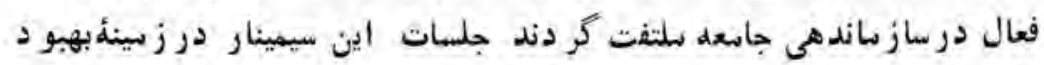

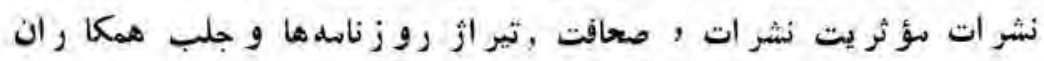

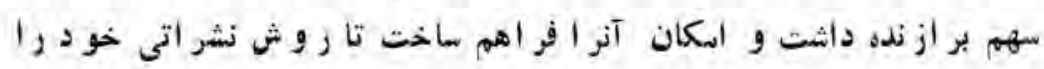



$(1 \wedge 1)$

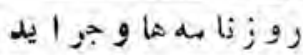

درولايات سوا فق بايبانات رهبر ملى - باليسى كلتو رى دولت جمهو رى

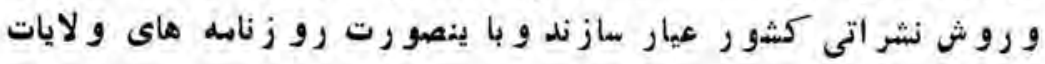

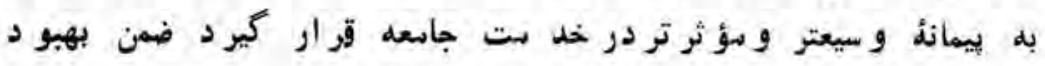
نشر ا ت و فر الهم آو رى زمينه بهتر نشر ات د رو لايات تير اث تمام روز نامه هاى ولايات باساس ضرو رت و تقا ضاى روز ا فز ون علاقهندان

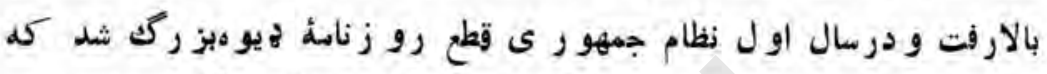

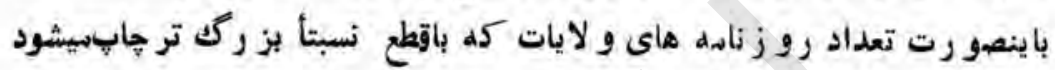

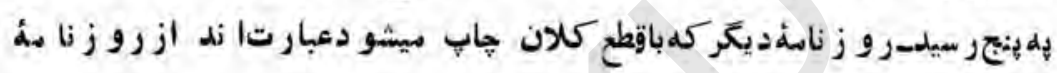
انفاق اسلامدر هر ات-يهدار درو لايتبلغ ،طلوع افغاندز كند هار و ننكر هار

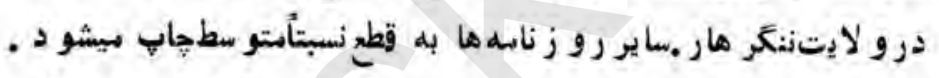
ازطرف آسر يتهاى اطلاعات و كلتو رو لايات ات روز نامه هاي آتى به نشر : مير سد :

ا-رو ز ناسئاتفاق اسلامازطرف آسر يت اطلاعات و كلتو رهــر ات.

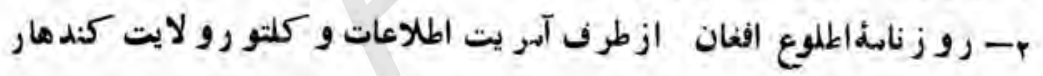
r-رو ز نامه بعدار ازطرف آسو يت اطلا عات و كلتو ربلخ.

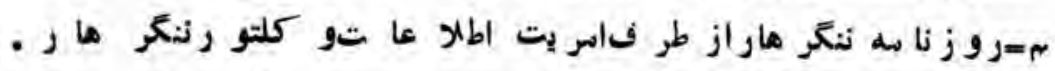

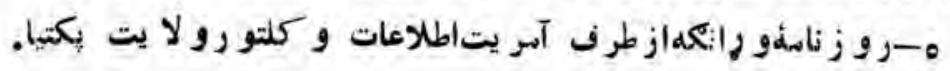
ب-روز زناسئاتحاد ازطر فآسر يت اطلاعات و كلتو ر بغلان. V-روز نامهٔسنايى ازطرفآسر يت اطلاعات و كلتو رغزنى.

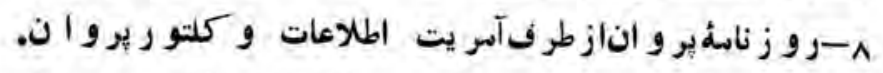

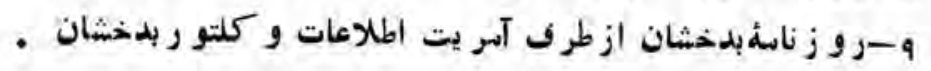




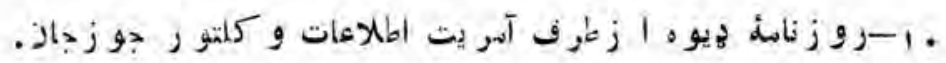

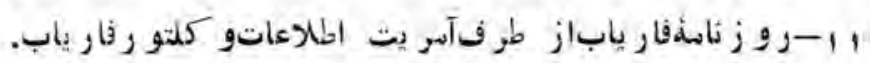

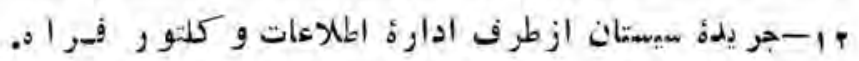
rا

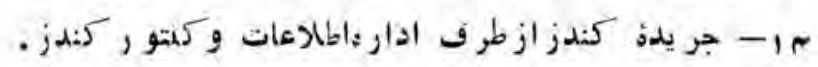

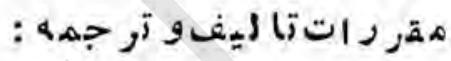

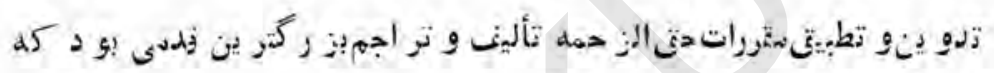

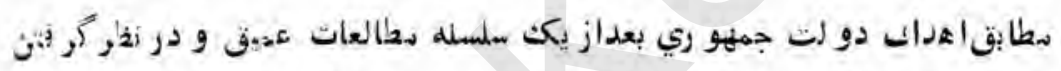

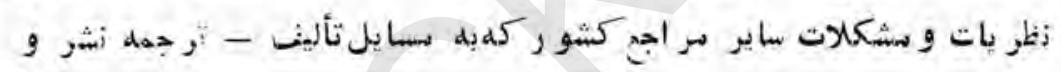

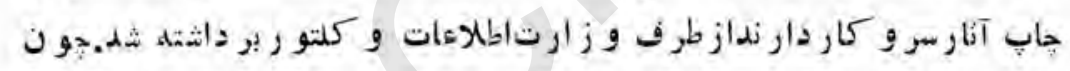

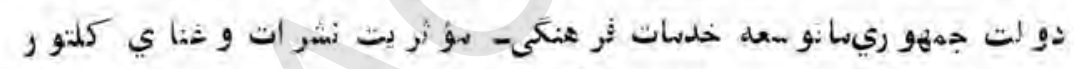

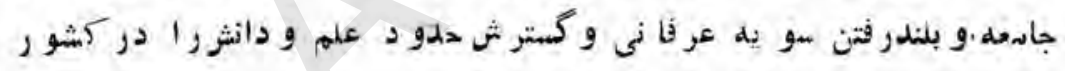

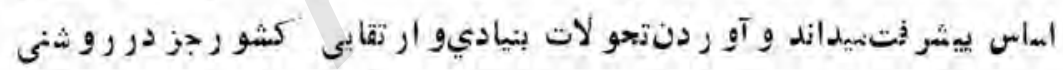

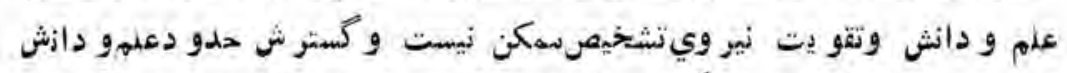

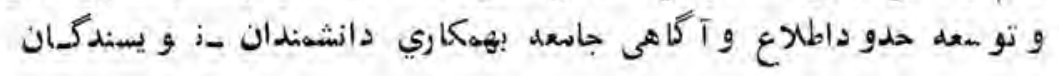

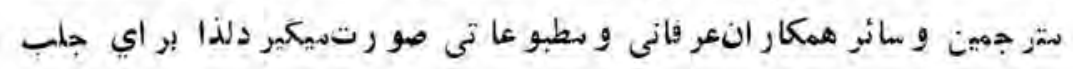

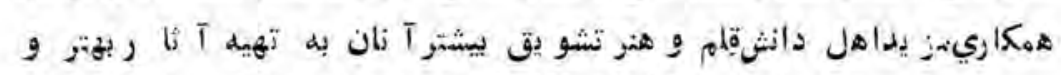

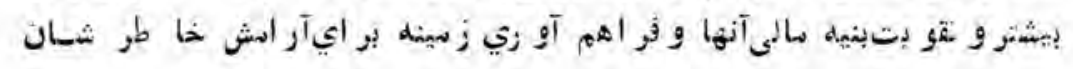

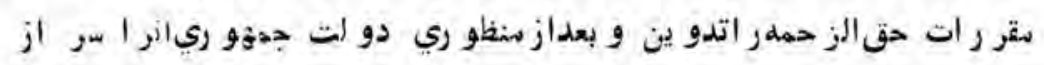

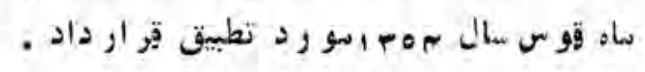


اين حتز رددار اي خار خصو صيت بر از ندهيباشد:-اواليكله معيار حق الز حهه ها د رحل و ود الهكا نات ما لي كئو رو ايجابات عصر و زمان بشكل خياسى

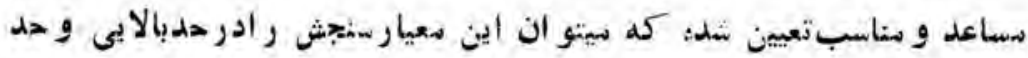

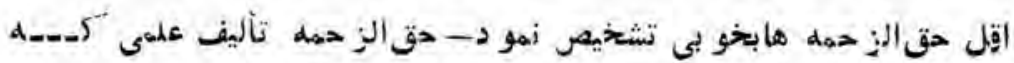

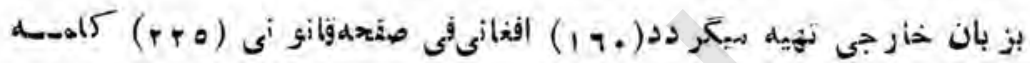

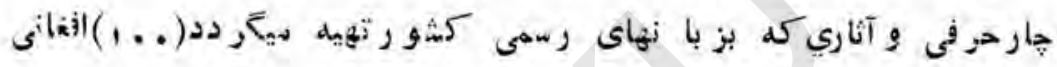

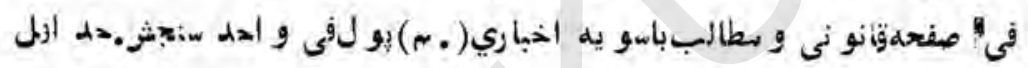

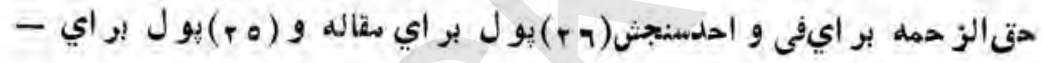

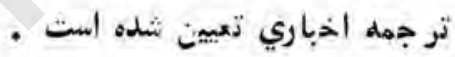

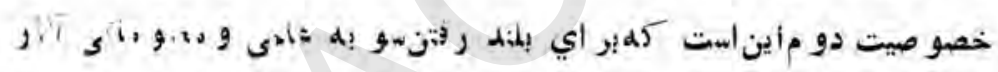

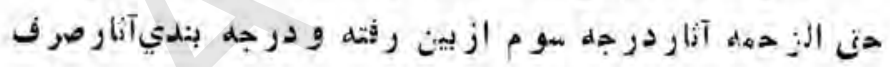

$$
\text { بدو در جة او لنو دو م صور رت سيكير د. }
$$

خصو عيتسو ماين سقر رنعبارتاست ازعهوبيبو دن آن - اين هقر رن

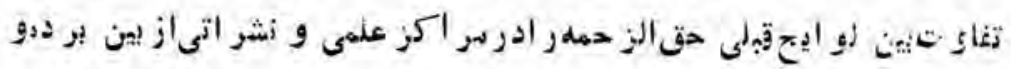

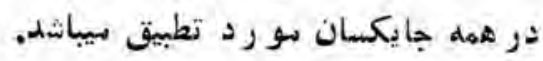

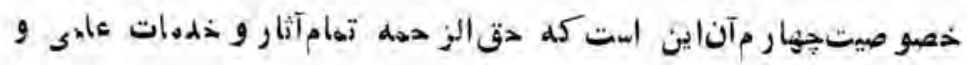

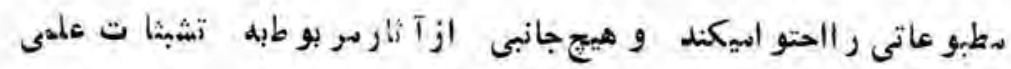

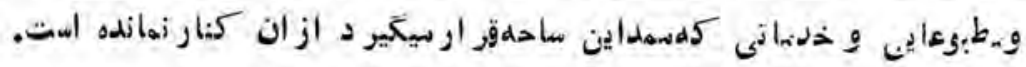




\section{كهية النسجامزن :}

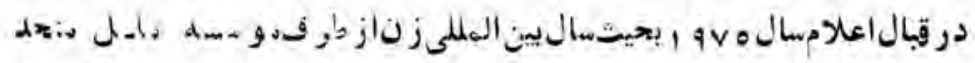

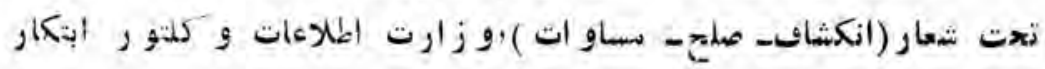

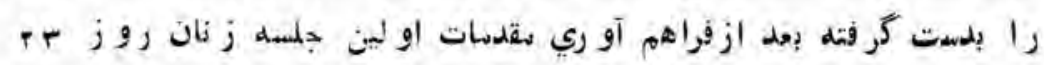

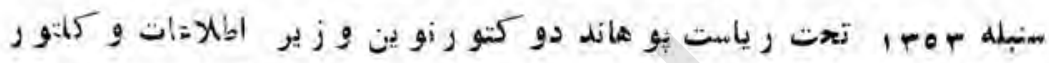

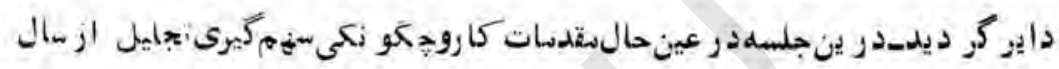

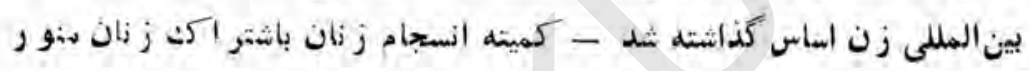

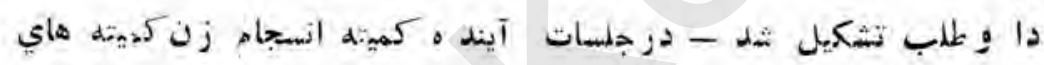

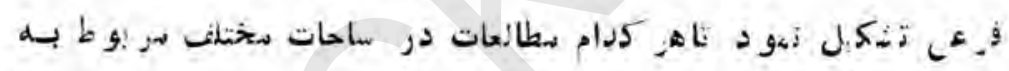

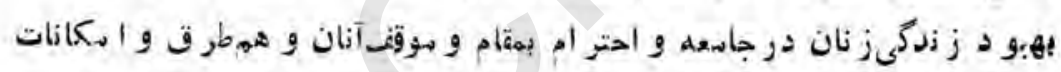

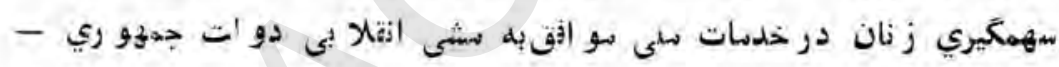

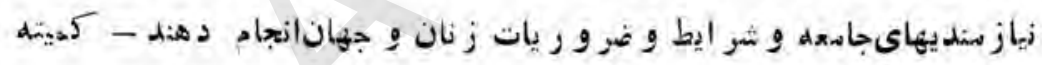

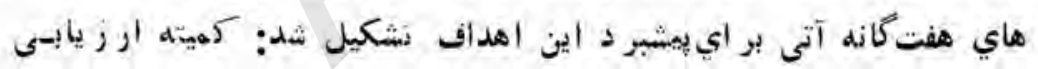

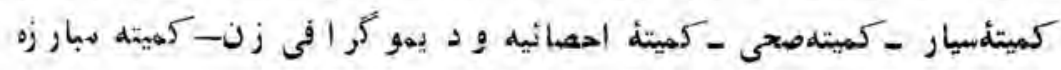

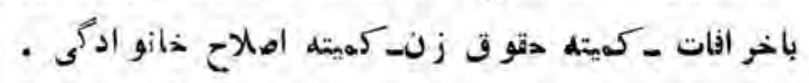

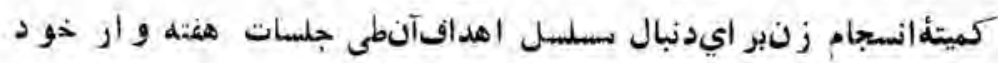

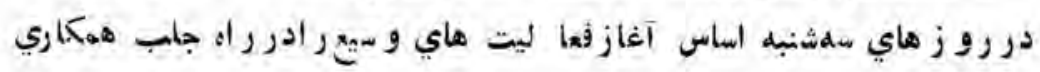

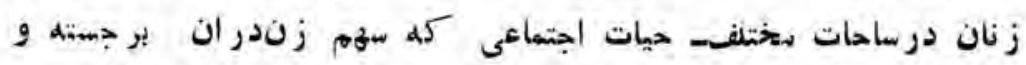

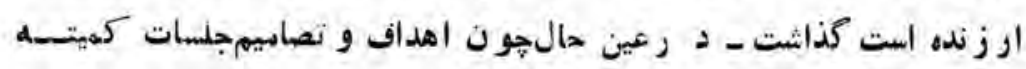

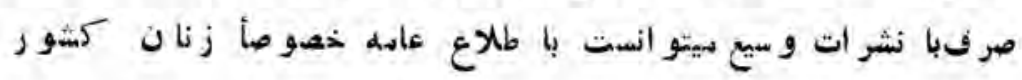



$(1 \wedge 0)$
5

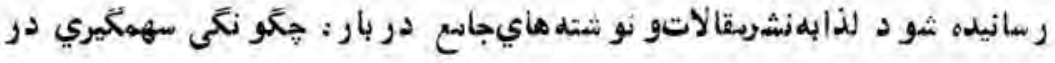

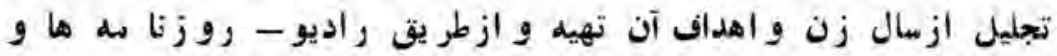
سجات بلهنشر آن آغاز نمو د. بالهميت خاص الين موضوع كله بلنصف جا معل ما ارتباطهيكير د - در روز ناهه ها صفهات اختصا صى بازودروراديسيو هو و كر ام يكث ساعته هفته و ار آغاز يافت ـ عدجنان فعاليتاين كميته دربو كز

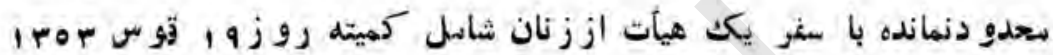
كميته انسجام زنباثتر اككز نانهنو ر و داو طلب در هر ات تشثكيل و شر و ع

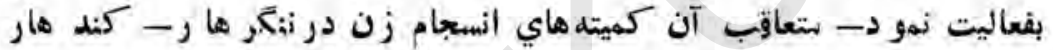
ثزنى - هلمند -ووزابلداير شد ودر هر يكت ازين ولايات نزدار تو نهاي ازعكس هاي معرف نهضت زث در كثو ردايركر ديد .

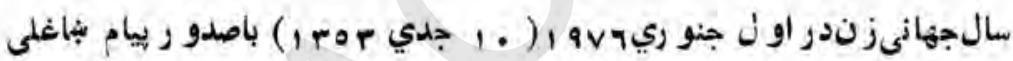
رئيس دو لت و صدر اعظم ضمن انعقا د مهفل بز ركى در سالو ن كابل ننداري

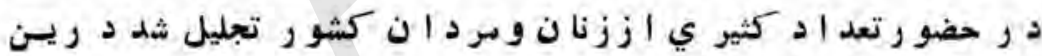
روز يوستر اختصاصى كميثلانسجام زنكله باديزاين دششغص تو سط يو هاند

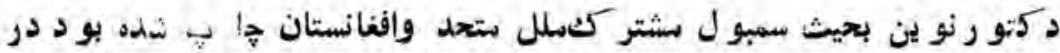

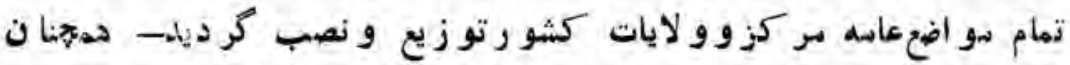

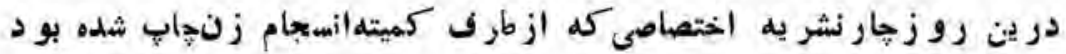

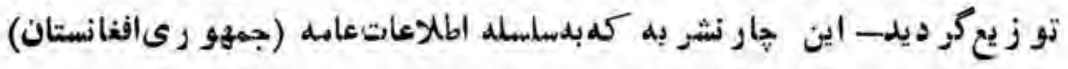
خابشدعبارت بو دازحاوى ييامنياغلى رئيسدو لتو صدر اعظم بلمنأسبت تجمليل

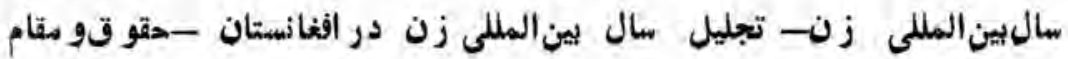


اجرا آت اطلا عاتى و كلثو رى

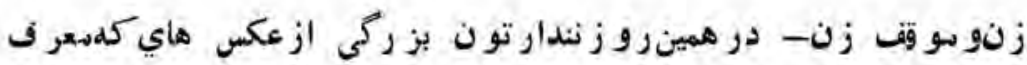

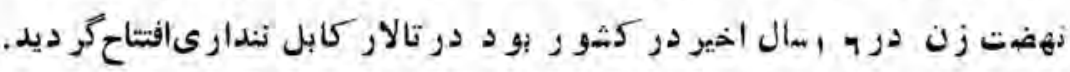

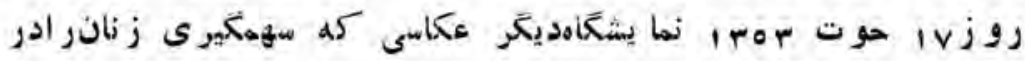

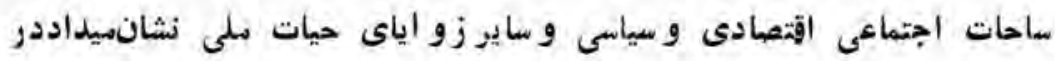

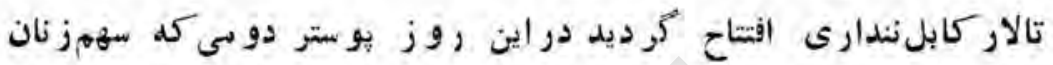

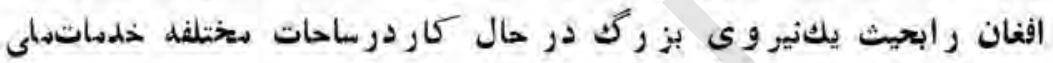

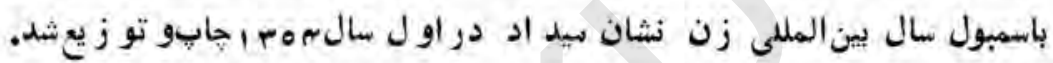

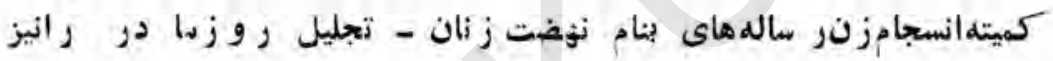

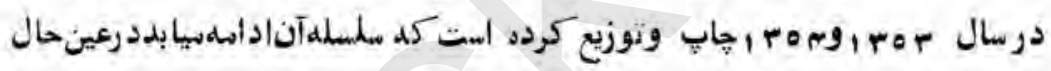

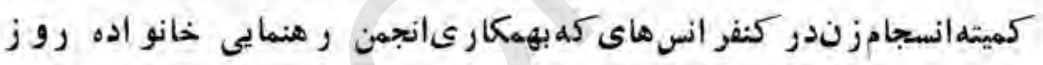

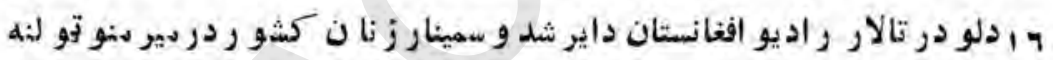

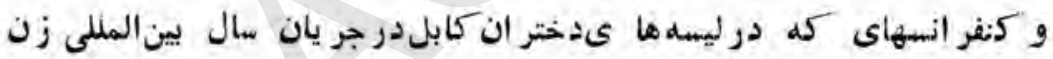

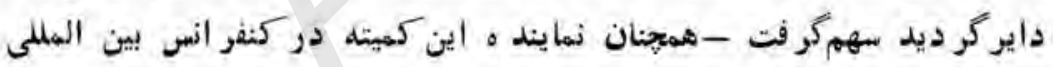
زنان جهان كهدر (مكسيكو )داير ثداشتر اكت أهو د.

\section{تجلميل ازشخصيتهاع}

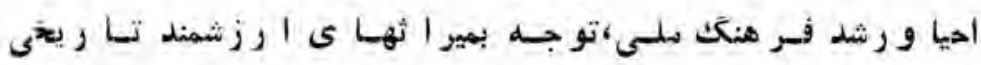

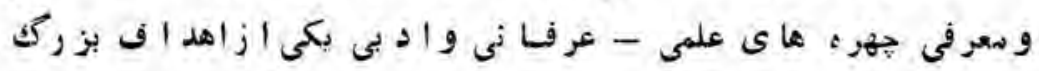
باليسى كلتو رى دولت جمهو رى استكه ازآغاز كار بان توجه لبذول

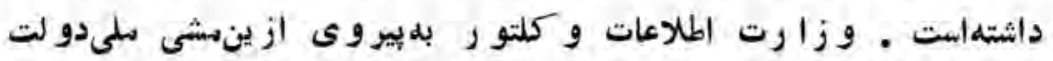



$(1 \wedge v)$
سيمينار سو لينا جلال الدين بلخى

جمهو رى تد و ير سي:ما رهاى را باشتراكتدانشهندان افغانى و كثو رهاى

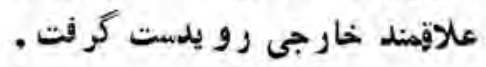

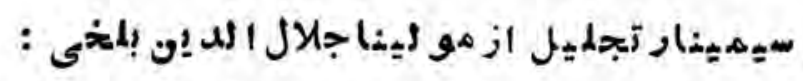

بو ای تجليل شخصيت كرانها يهوعار فبزرك كشور مو ليناجلال الدين بلخىى

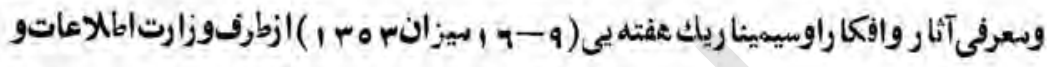

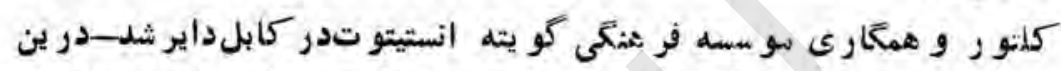

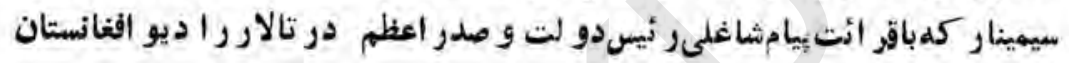

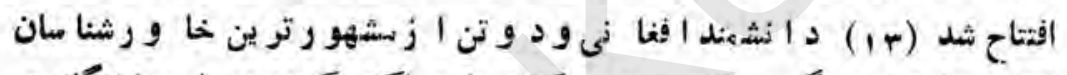

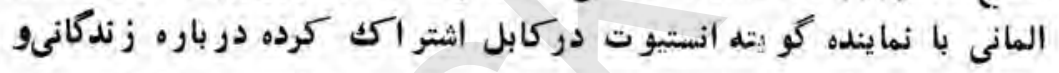
افكار وآثار جالحل الدين بلفخى يبانيه ها - سقالات ونتا بجنحقيقات خودر اقوائتنمودند

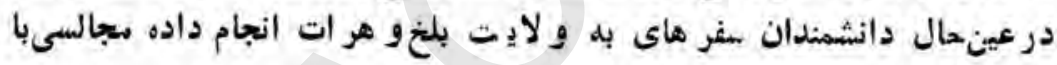
باشتر اككعوفا - ادباو دانشهندان آنجا تشكيل دادند و ازآثار تار بخخى ديدن

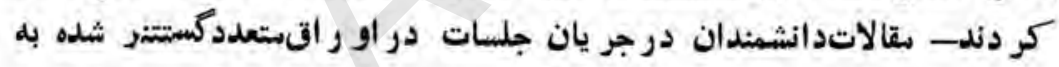

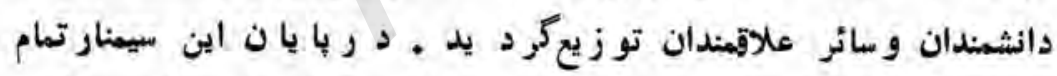

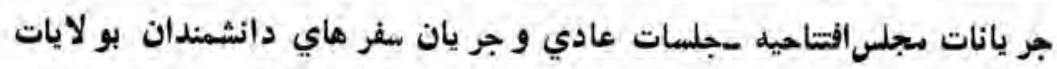

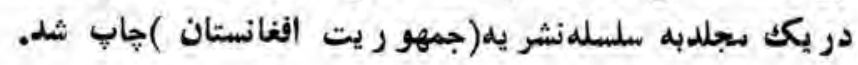

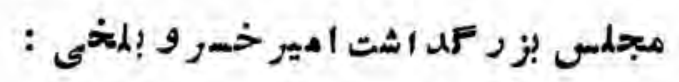

بمناسبتمر ورهفتقرن از آثاز شاعري/مير خسر و بلنخىشهو ر بهد هلو ي سيمينازيبو اي بز ركداشتاز مقامعلمىو ادبىاين ستئسر ا وهنر بند نابى افغانستان

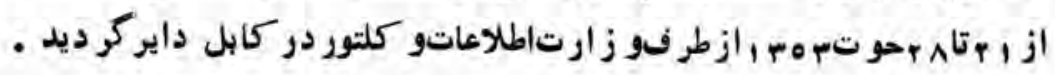


مجلسافتتاحيه تجليل ازشخصيتيمين الديناسير خسروفر زند سيف الدين

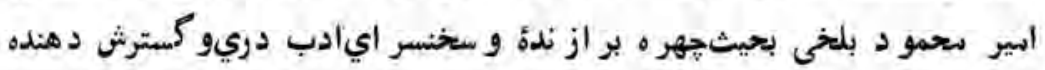

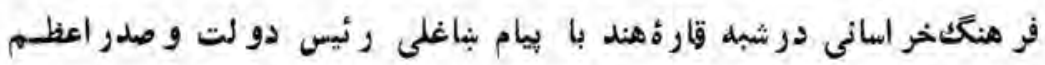

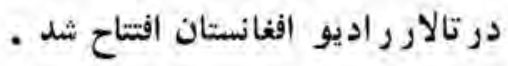

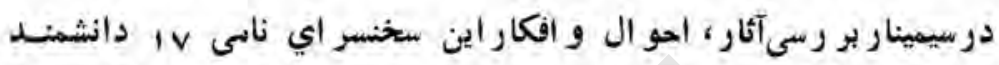

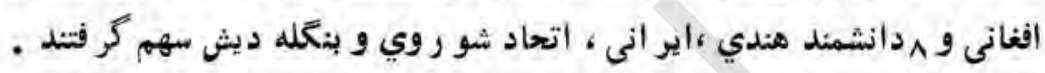

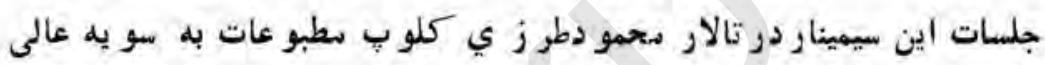

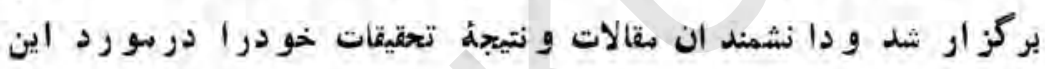

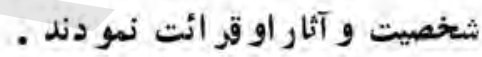

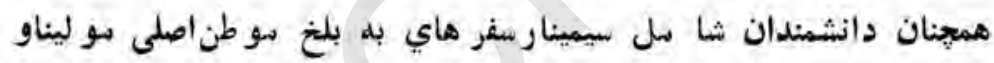

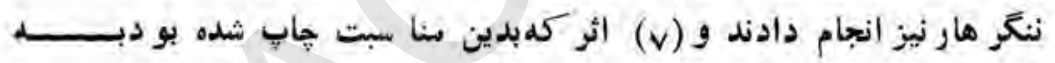

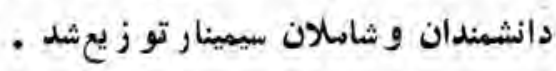

$$
\text { مجلمس بزو تمد اثشتفار ابى : }
$$

بمنظو ر تجليل ازشخصيت دانشمند بز ركثر اسا ن ابو نصر محمدفار ابى

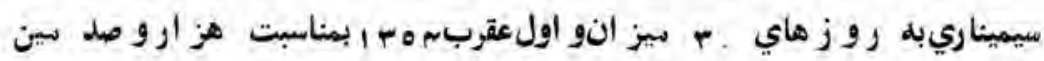

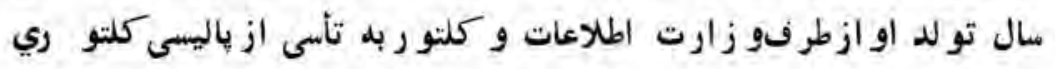

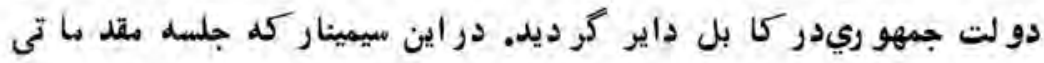

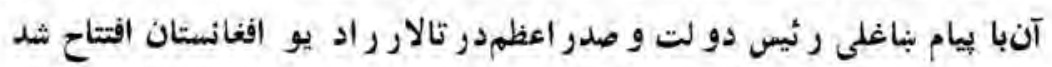

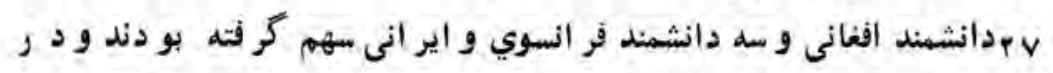








$(1 \wedge 9)$
هيجلس بز ركداشت دقيقى بلخى

لو ر دآثار و سهمعلمى ايندانشمند كر انمايه مقالات خو يش را قر ائت نهوده. و نظر يات خو در ادر سو رد تاثير افكار شابو از داشتند. درجو ياناينسيمينا رو

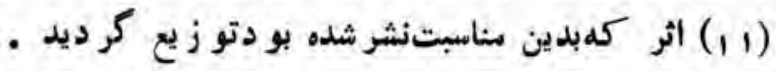

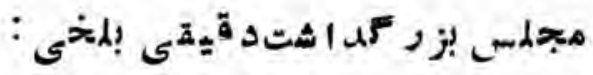

سيمينار هز ارميين سال و فات دوقيقى بلخخى با يبام بباغلى ر ئيس دولت و صدر اعظمروزاول جدي مهمر ازطرفوزارت اطللاعات وكلتوردر تالار ر اديو افغانستان افتتاح شد • و سلسله سباحثات دانشهندان سيمينار تا

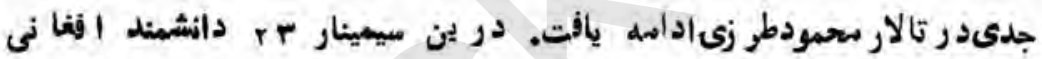
و "م دانشهندازكثو رهاىفر انسهـايران - اتحادشو روى وهندسهم كرفتثل. درجر يانجلسات اينسينينار دانثمندان د رمو رد زو اياى زندكى، آثارو

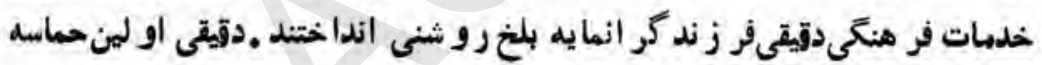

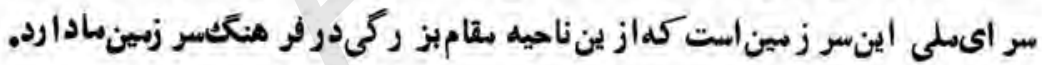

\section{: :}

هز اربينسالتو لد ليم هر اتخو اجهعبداتهانصارىطىسيميناره رو زم باشتر اك

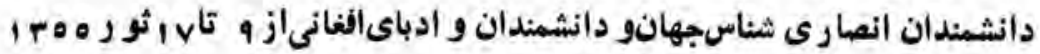
از طرف وزارت اطلنعات وكلتور در كابل و هرات داير كرديد .

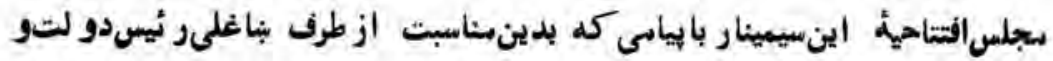

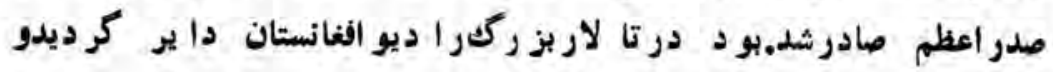




$$
\text { اجرا آت اطلاعاتى و كلتورى }
$$

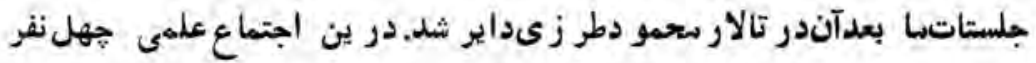

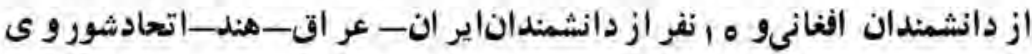

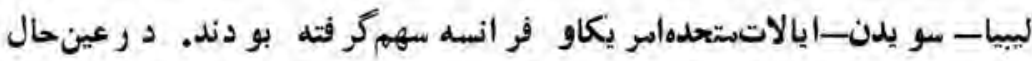
بمناسبت اينسيمينار نمايشكاه اثارخطى خو اجه عبداته انصارى در كتابخانه

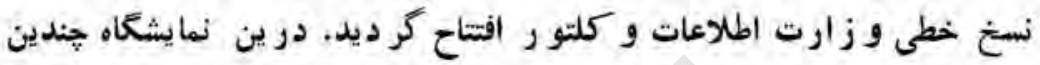

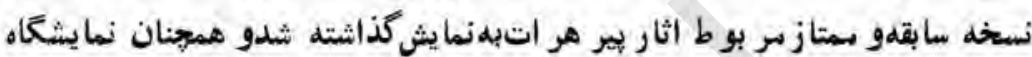

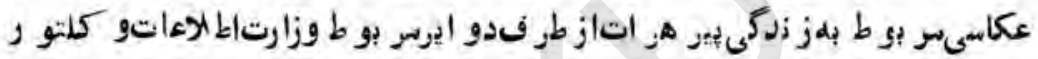

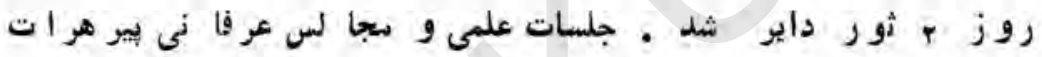

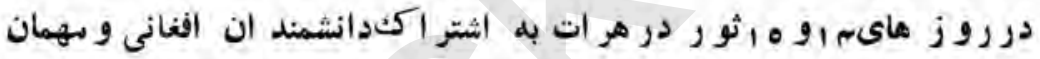

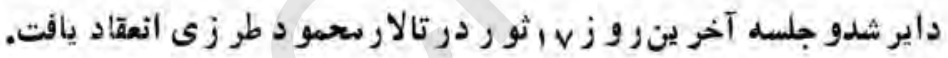
تشكيل اينسيمينار ها بر الى تجليل از شخصيتها ىعلمى افغانستان درعين حالى

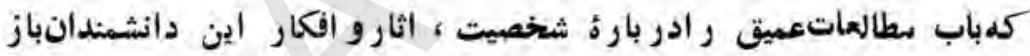

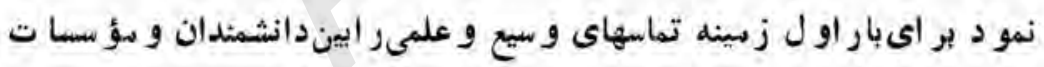

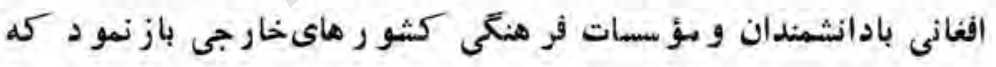

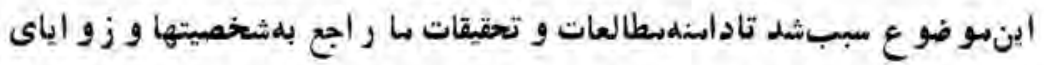

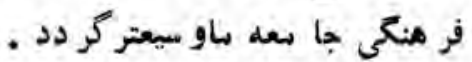

درعين حالاين سيمينار هاتو أم باكار طرحتابلو هاى بز ركك إز جهر مهاى

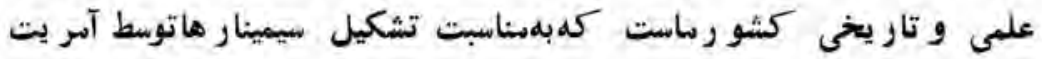
صنايع مستظر فه و زارت اطلاعات و كلتو ر طرح كر ديده استو آثار بر ازنده

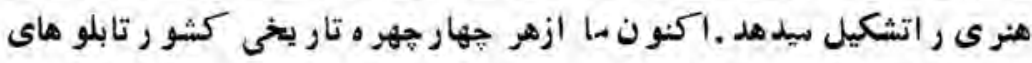


ممتا زى بد ست دار يم ـ درعين حا ل براى محا فل افتتا حيه اين

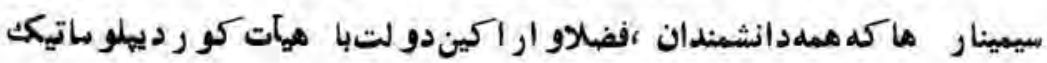

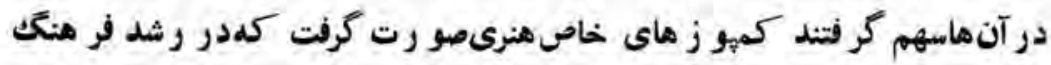

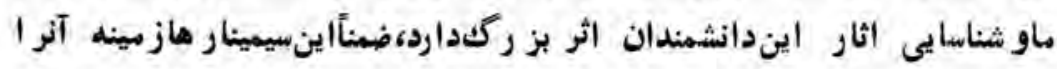

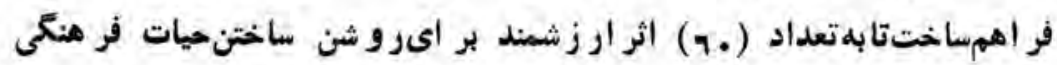

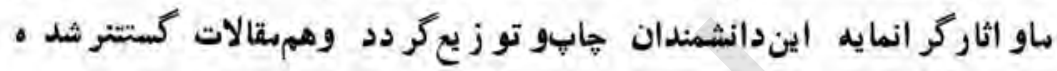

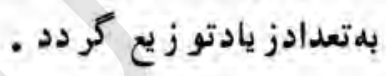

مجلمس علمدى سيل

باساسباليسى كلتو رى دو لتجمهو رى ، و زارت اطلاعات و كلتور

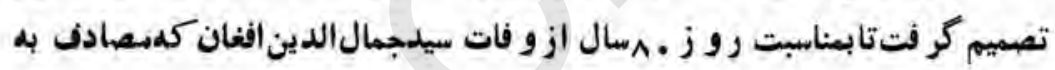

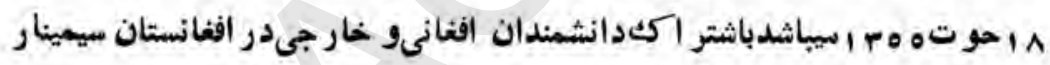
و مجلسعلمىتشكيل شو د.در ينسيمينار كمدجلسمقداتى آناز ماه سنبله السال

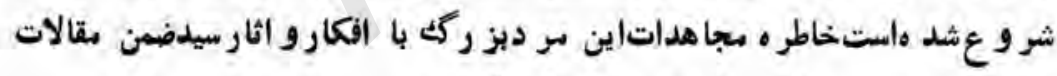

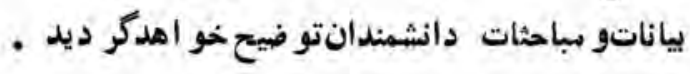
در عينحال افغانستان در بيمينار يكه بمناسبتصدبينسالو رو دسيدجمال الدئن

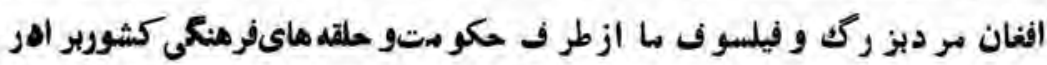

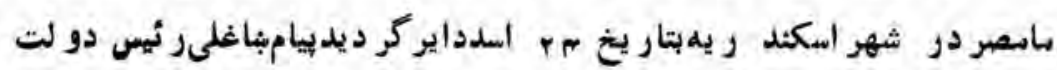

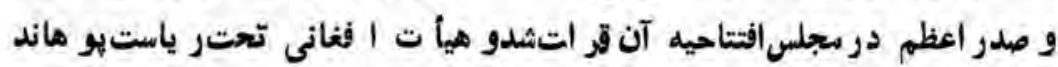

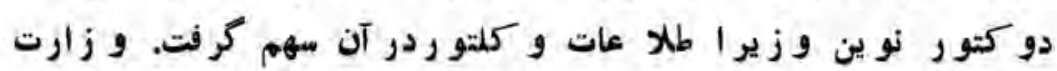


اطلاعات و كلتو ردر عينحال نشير يه فو قالعادة بمناسبتاينسيمينار بز بان-

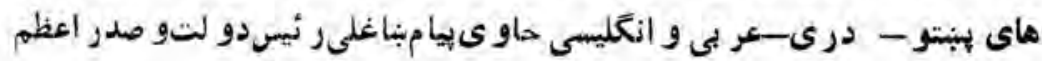
بيانية بو هاندد كتورنو ين وزير اطلاعات و كلتو ر وونطالبى دربورد

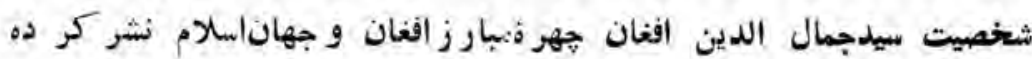

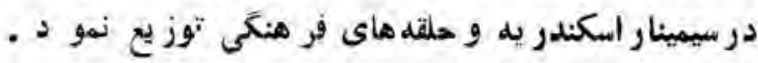

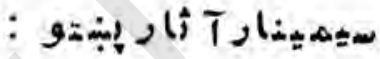

باساسباليسى كلتو رىدولتجههو رى، و ز ارتاطلاعاتو كلتو رتصنيم

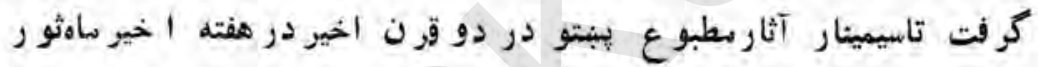

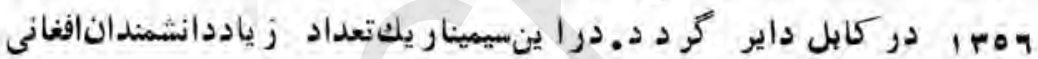

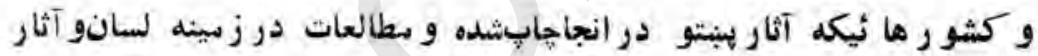
بهيتو در ين كثو ر ما ادامه دارد الشتراكث مينما يند در عينحال يكتعدادآثار ارزشمندكماكنو نشماردهاى آن بكلى ناياب شده و ثكل نست خطىر الز

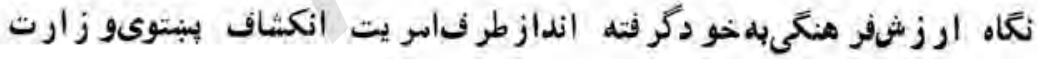
اطلز عات و كلتو رجابِميشو د'.

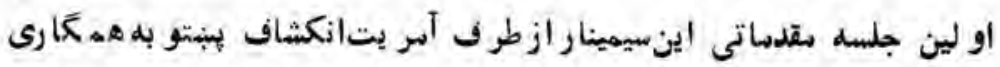
دانشمندا ن ودوا يو مر بوط وز ارت اطلاعات و كلتو روسايو مر اكز

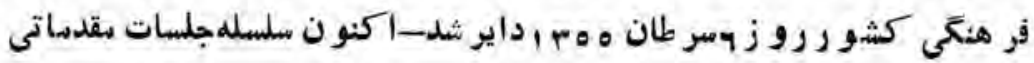
انادامهداردو تر تيباتاينسيميناركر فته ديشو د.

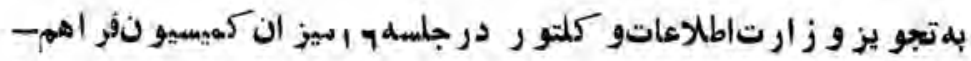




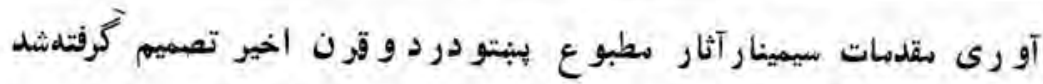

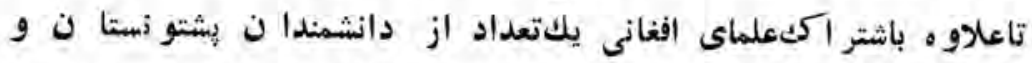

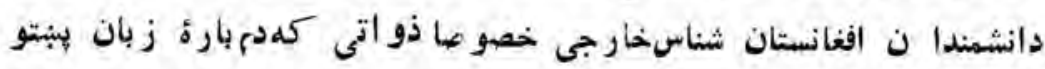
سابقه و مطالبات عميقدارند ازطر يق دو ايو ومقامات سو بوط د عوت شود

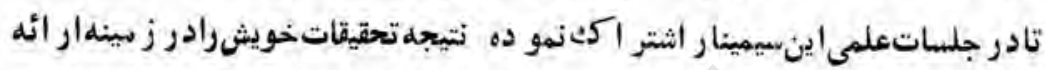

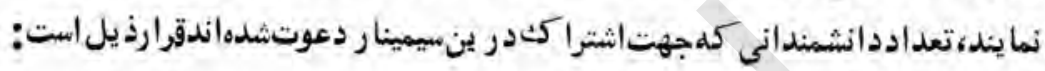

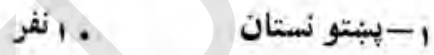

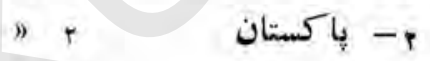

$$
\begin{aligned}
& \text { r- ب اير ان } \\
& \text { "re } \\
& \text { no - اتحادئسوروى - } \\
& \text { " } \\
& \text { " جكو سلو اكيا } \\
& \text { n } 1 \text { ف انسه }
\end{aligned}
$$

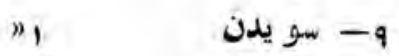

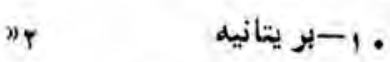

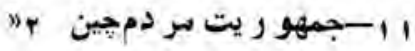

$$
\begin{aligned}
& \text { ne peortit }
\end{aligned}
$$

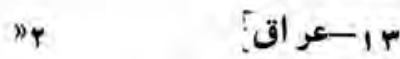

$$
\begin{aligned}
& \text { م ا-هآمر ادارةيو نسكو در بار يس }
\end{aligned}
$$




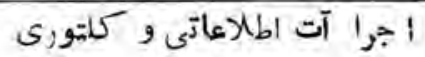

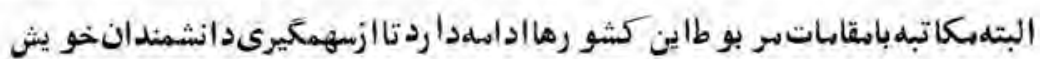
ورقالات و آثار أيشان كمدر جلساتاينسيمينار ارائد مبدارند الطميناندهند.

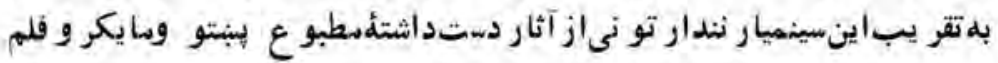

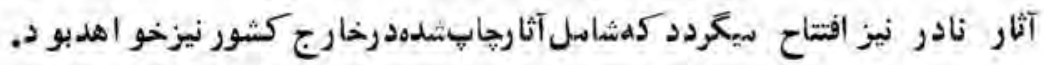

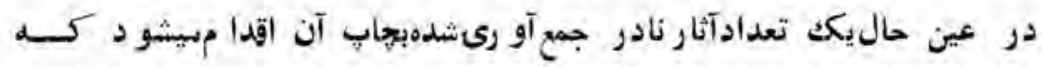
درجملهُآثار آتى ثاسل سيباثد :

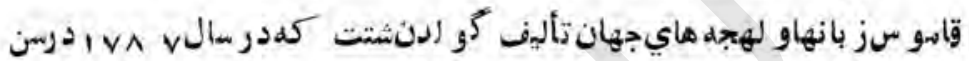

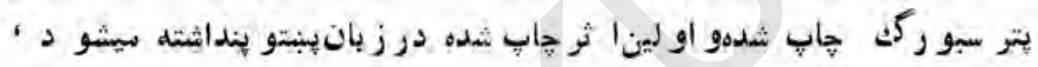

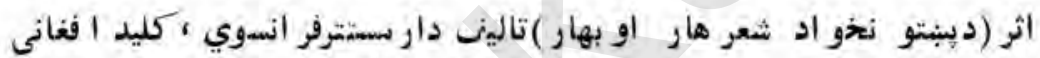

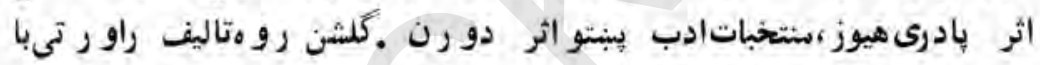

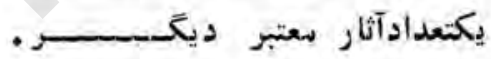
همجناندو اير وار راكين وزارتاطلاعات و كلتو ر درسيمينار سو اجالدين بايز يد رو بنان كلبناسبتجار صدمين سال و فات اين شاعر نابى

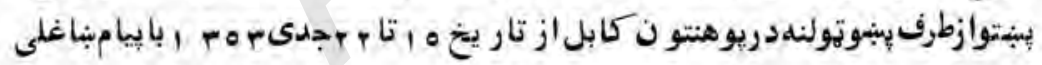

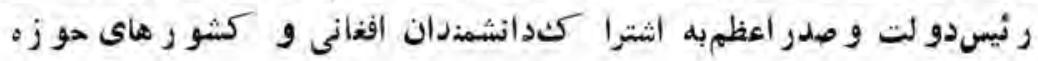

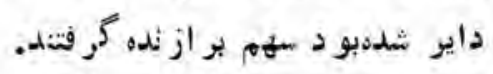

و زارتاطلاعات و كلتو ردر سيمينار سر كز تحقيقات ينبتو كلبهسفار ش

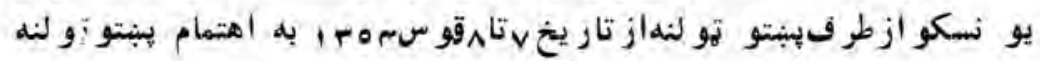

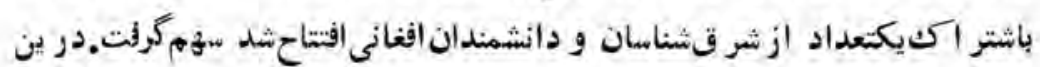

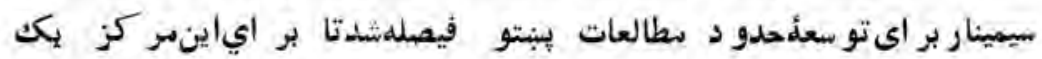
هيأت ر ئيسه عالى و يكك كميتة. .vعضوى علمى تشكيل شو د. 

$(190)$
راد يوافغانستان

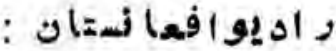

بحيثبز ركتر ينو سيلة|طاطع ، تنو ير و سركربى، ر اديو افغانستان در بيشبر دخدمات سطبو عاتى سهم بر از ندهدار د-نسبت عام نبو دن سو اددركشور

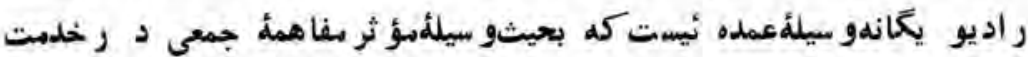

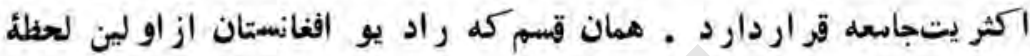
سبيده دمجمهو ريت درخدمت نشر اهداف عالى اين نظام فرخند ه بو ده است

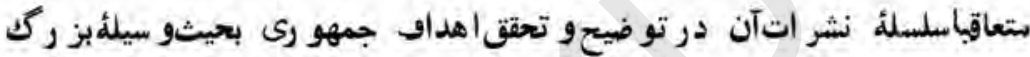

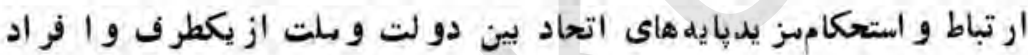

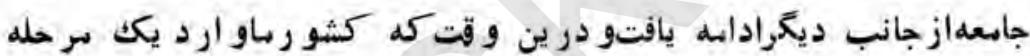
تار يخىدر سسير انكشاف و بيشر فتخو د بيشو د،سهم شايسته و بر از ند مداشته استبر ائ بهتر شد ن ومؤثريت مزيد نشر ات راديو افغانستان وزارت

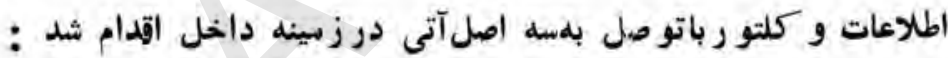

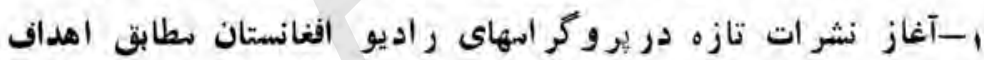
انقلاب جمهو رىو نياز مندي هاي جامعه .

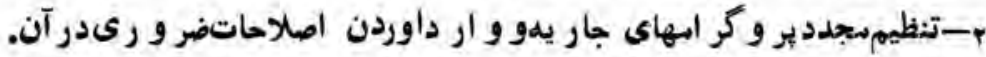
r-تو جلبه تسهيلات تخ:يكى آن تا نشر اتر اديو بر اعساعات بيشتر در

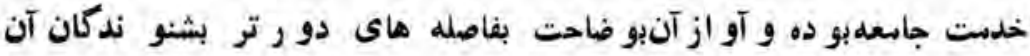
درداخل وخارج سيده بتو اند .

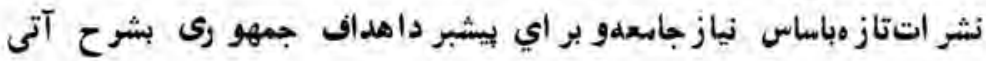

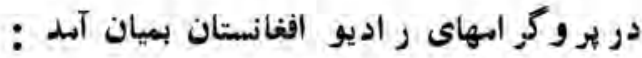


اجر ا آتاطلاعاتى و كلمتو رى التي

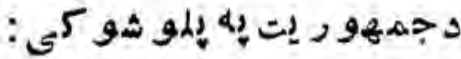

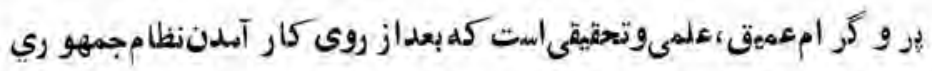

در كثو ر ساعت(ه)ثب هايشنبه در هينل اول ل ر اد يو افغانستان بر ائ نيم

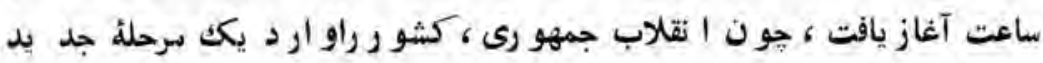

تار بذخى كز د و اين انقلاب تحو لاتعميقى رادر زو اياتع مختلفحمات سلى سا

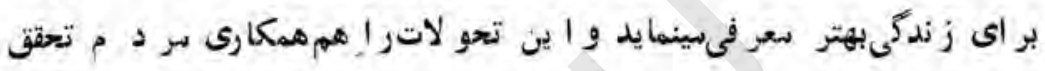
سيبخشدلذا آشنايى سر دمها بهز اياي زظطام جمهو ري ، اساسا ت كلى اين نظا م

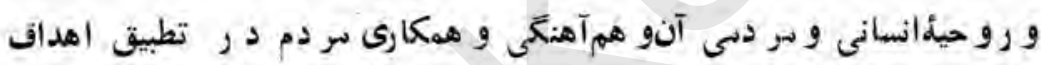
بنيادي|نقلاب در ين مرحلهخصو صاً از ضر و ر بات او ليست كد تصام و سابل

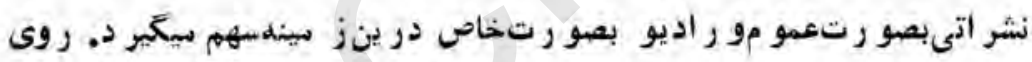

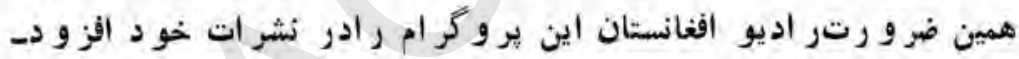

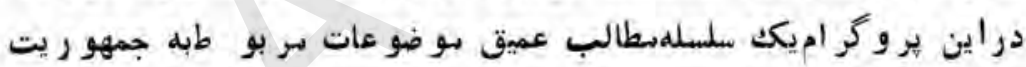

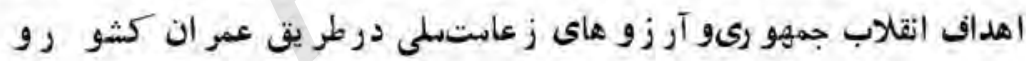
آر السى سردم نشر سيشو دو هم قدمهاى اصلاحى كلبتدر يج بر الى خدست بله

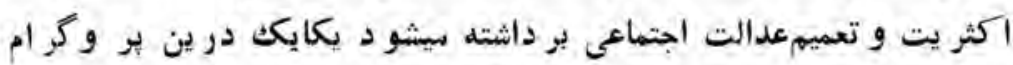

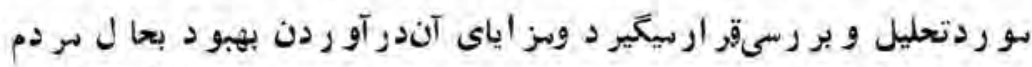

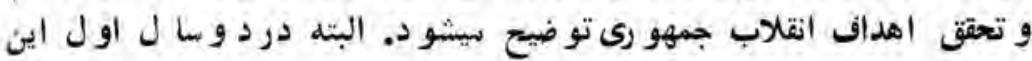

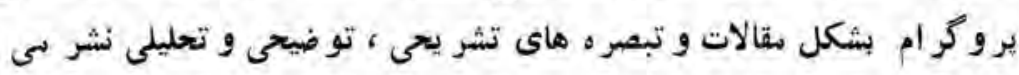

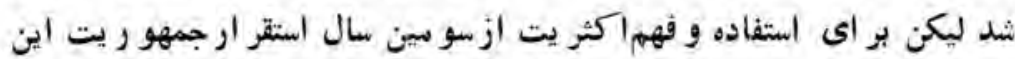

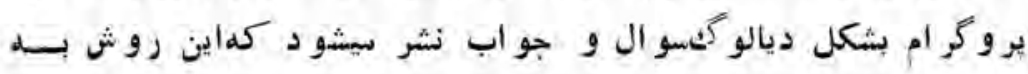



(१ १ง)
راديوافغانستان

شنو ندكان اين بي وكر ام بصو رت قابل ملاحطه افزو دهاست. ضمنا بر ایى اينكه

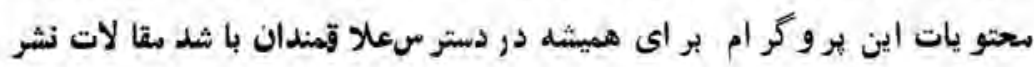

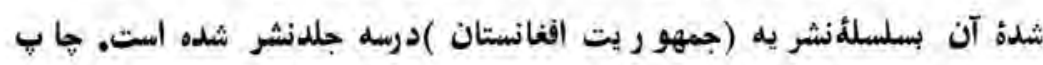

$$
\begin{aligned}
& \text { هطالباين ثرو كر امدر آيثهنه اداده خو اهديافت } \\
& \text { | }
\end{aligned}
$$

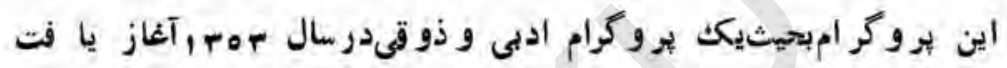

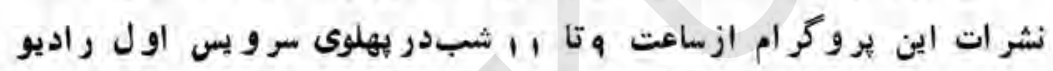

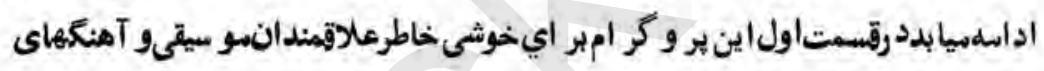
هنر هندان كشوراز ساعت ه تا. اشب نشر هيكر دد ودر آنسوسيقــى كللسيكت - يابٍ - جو انان و سو سيقى لايت طرف علا قمندي آهنك هاي بين المللى بر و دكاميت ميكر دد .

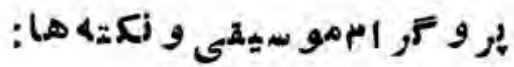

اين ير وكر امذو قىىو معلو ماتى در او اسط سال بمه إبخاطر خوشى مز يد

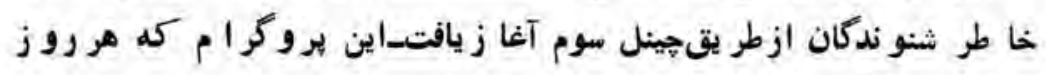

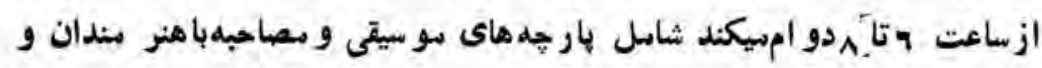

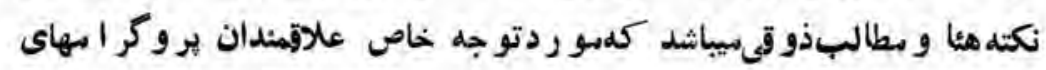
ذو قى راديو افغانستان قر اركرفته است اين بروكر ام ازنكاه شنو نده د ر رجمله يرو كر امهاى بر ازنده و سو ردعلاقه قر ار ميكير د. 


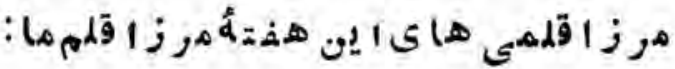

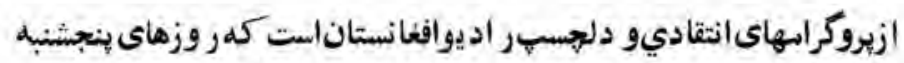

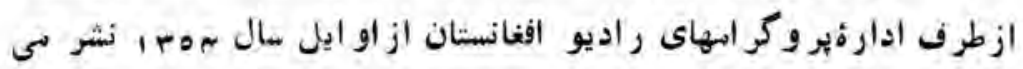

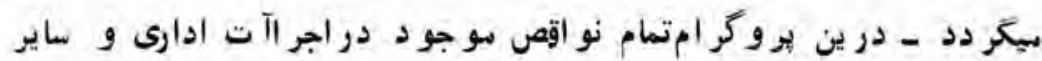

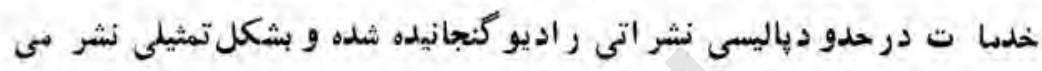

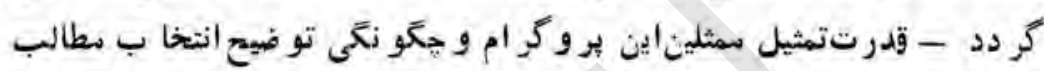

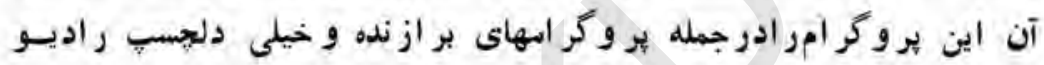
قر ارداده است .

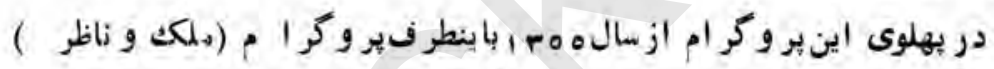

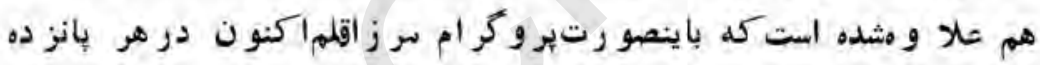

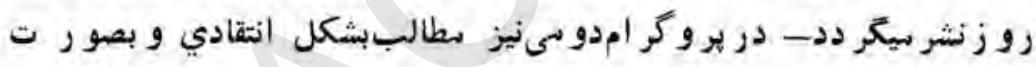

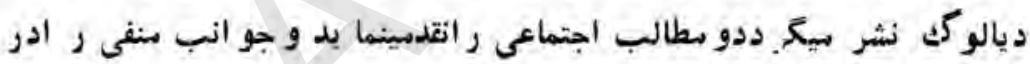
ز ندكى رو زمره نشان ميد هد.

$:$ :

اين خر وكر ام از نشر اتجديد و عمدئديخر ر اديو افغانستاناست كهاز سال

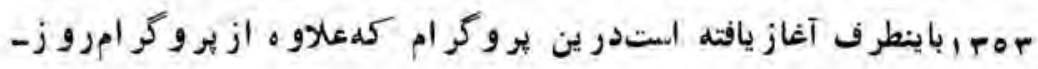

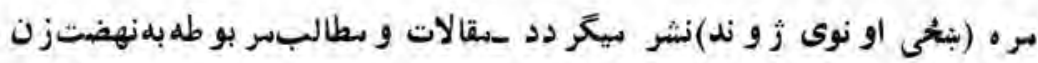

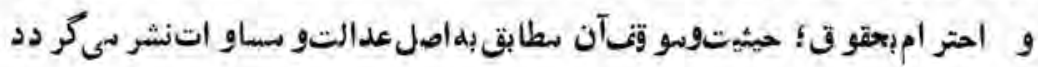
اكر خهاين ير وكر ام بحيثانعكاسخو استه هاو نياز هنديهاى اجتماعىز نا ن بر اي 


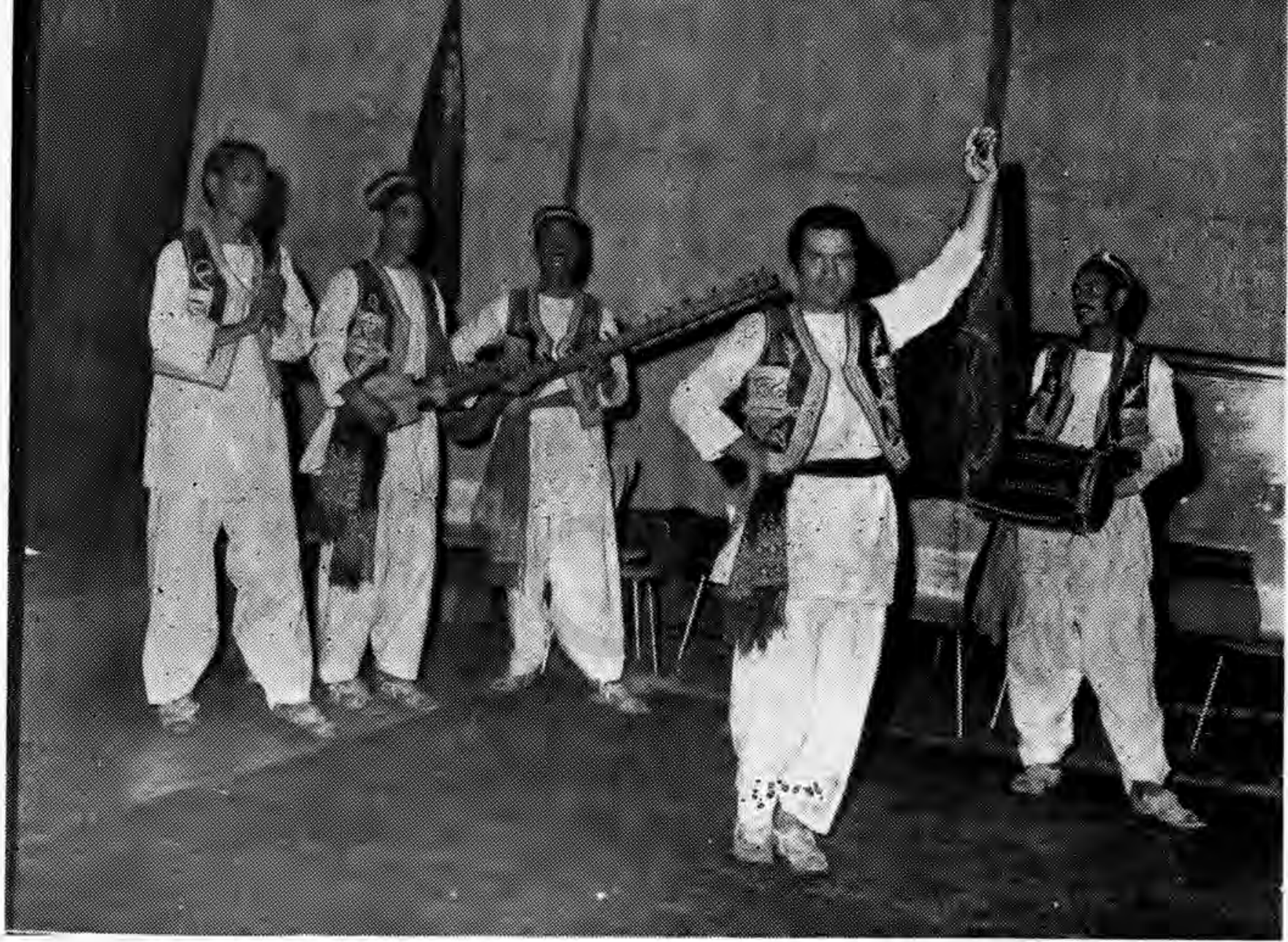

- اجراى كنسرت از طــــرفهنر مندان داديو افغانستان بهلباسملى - 


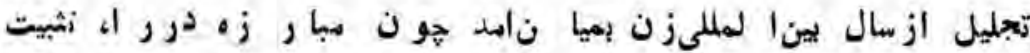
حقو قو مو قعيتز ناندر جاسعةما در رو شنى هداف انقلاب جمهو ري و ز عامت

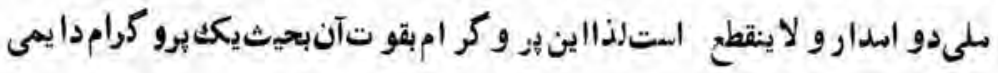

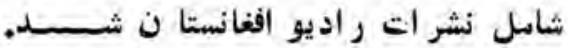

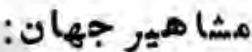

نشر اين بر وكر امبر ائمر فىنو ابغ و بز ركان و جهرههاي جاودان جهان

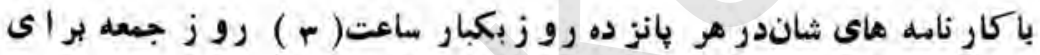

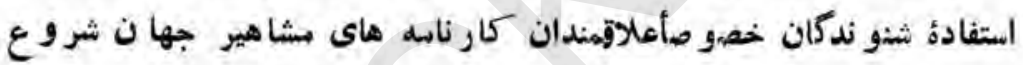

\section{داستان كود كان :}

بر ائسركر سى و تفر يح كو دكان تاسن هو همتنو يوشانبه ارز شهانى

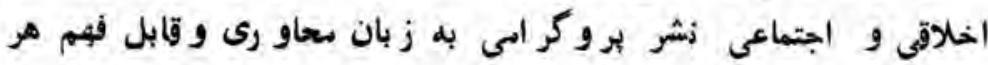

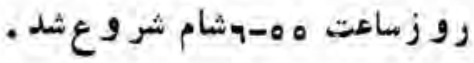

$$
\text { باز بار بار }
$$

اين بروكر امتفر يحى و هنرىهر رو زجعله بشكل ديالوكنشر ميشو د و شاسل بارجه هاى تمثيلى مطالب ذو قىو بار خه هاي مو سيقى ميباثد. 
اجرا آت الطان عاتى و كلمتورى

$(r \cdot$.

\section{:}

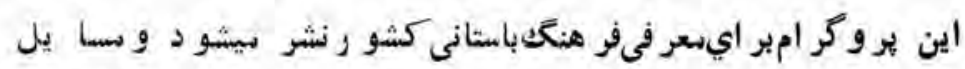

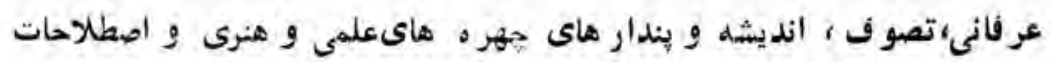

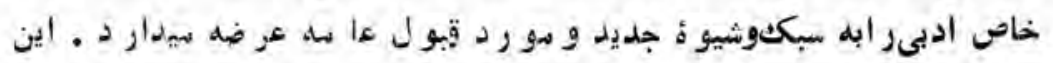

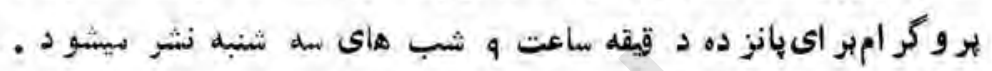

$$
\text { : }
$$

اين ير وكر ام درو اقع يكت نمايشر اديو يىاستو تهيهو تثظيم آنبشكلى

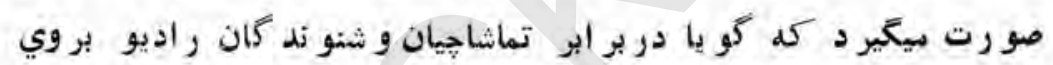

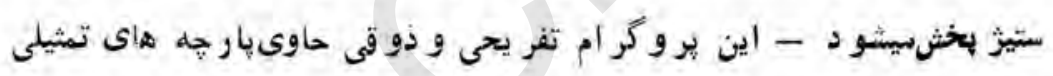
و نمايشناسه هاى كو تاه كميدي و بار خهلهاي سو سيقى سببأشد و بر اى خو نثى

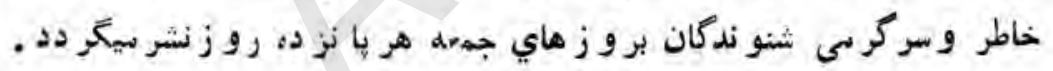

$$
\text { : }
$$

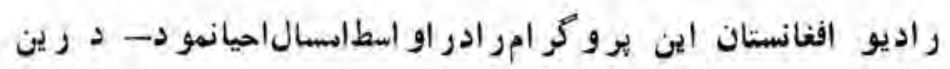

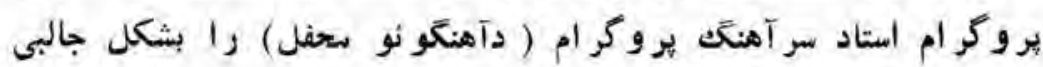

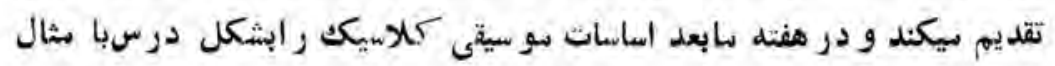

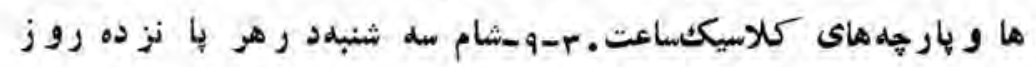

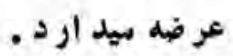




\section{درلابلاى نشر اتر اديو :}

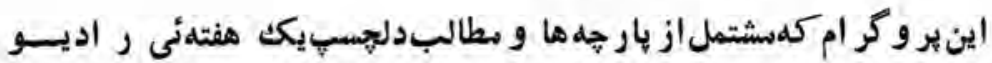

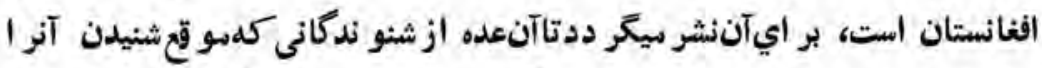

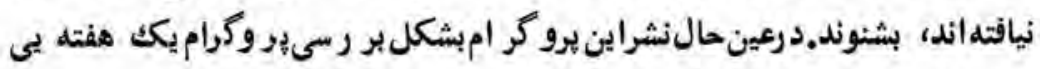

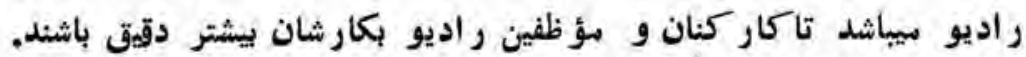

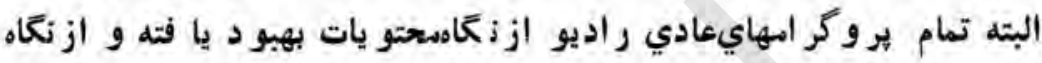

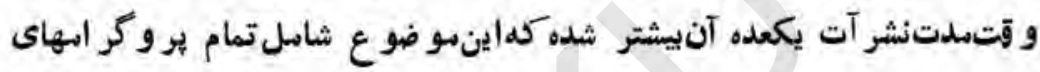

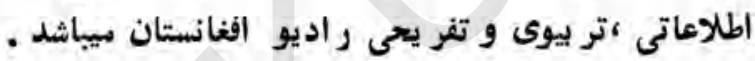

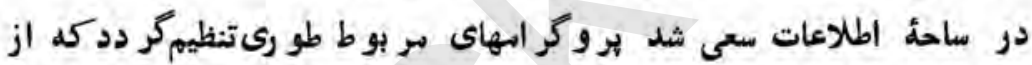

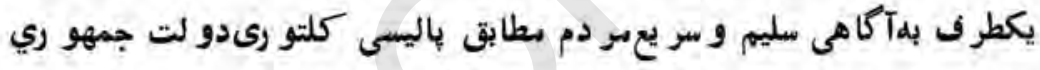

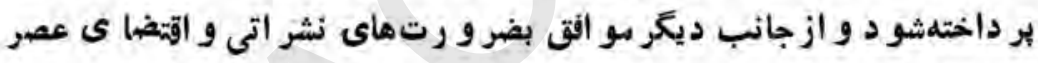

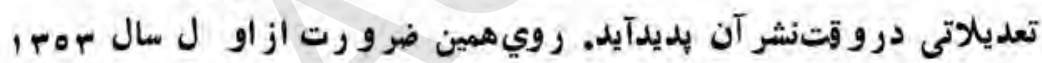

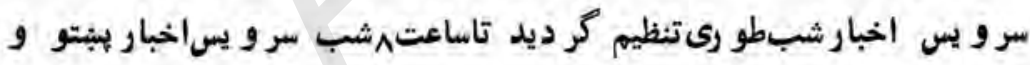

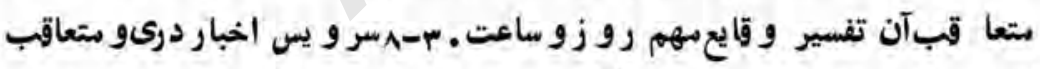

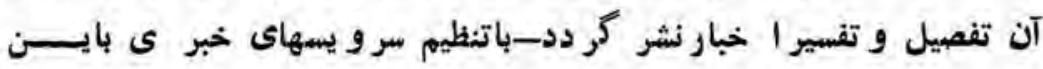

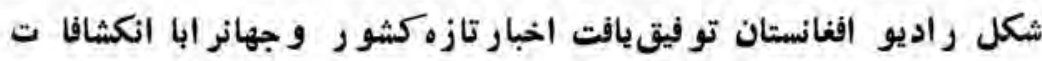

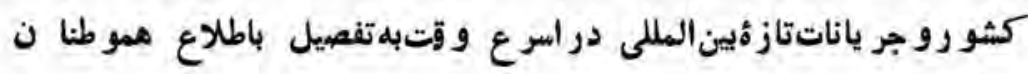
بر سا نـــــــــــ ضمنا بروكر ام اقتصادي بشكل تازهنشر كرديدباينصو رت كمدر يسـن

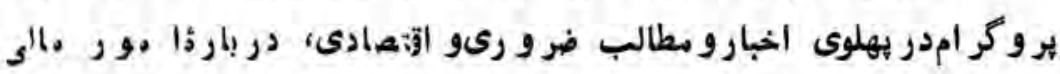




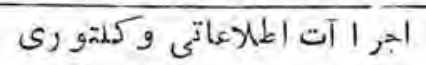

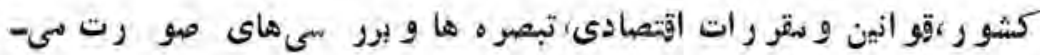

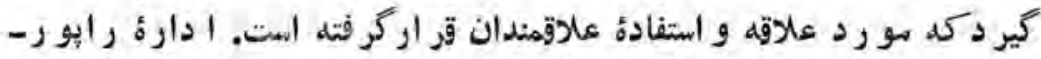

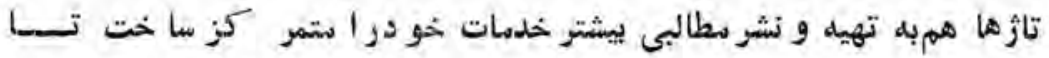
خدنات مؤ سساتو دو ايررادربهلوى سايو جر يانات و انكثماف كشثو ر بشكل

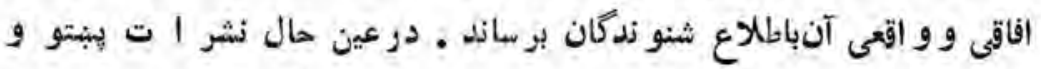

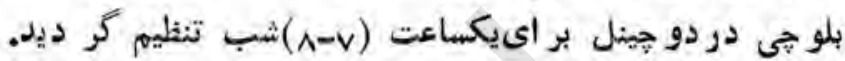

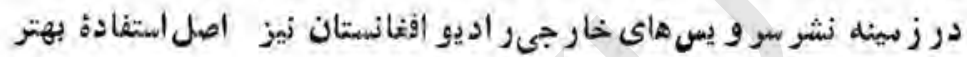

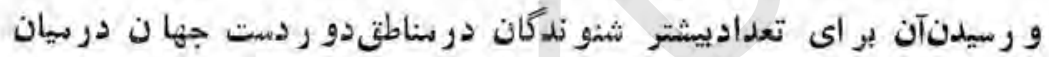
بو ده است .

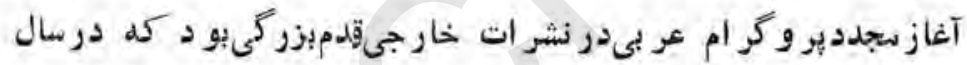

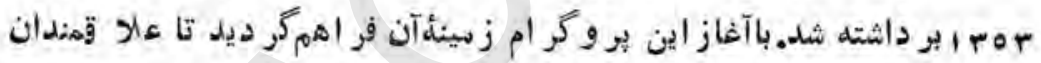

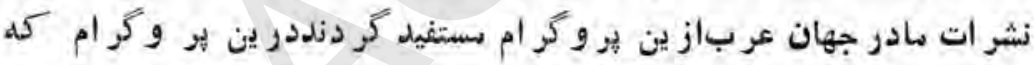

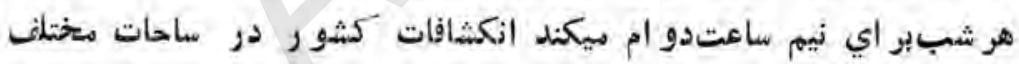

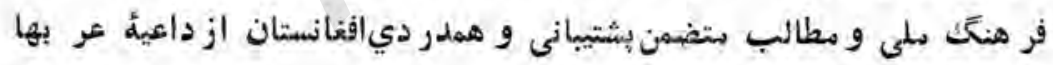
در بحر ان شرق هيانه نشر سيكر دد.

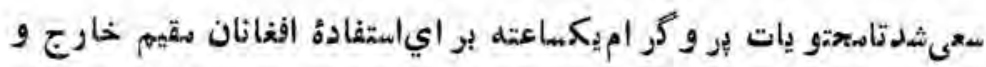

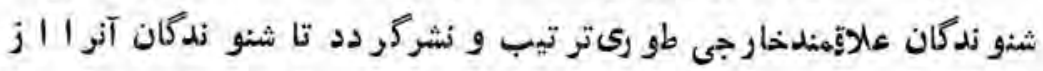

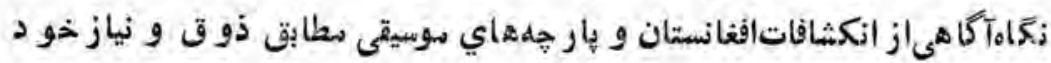

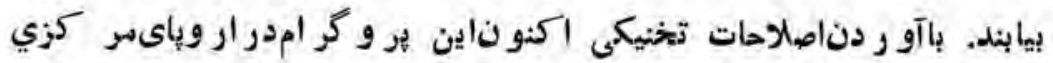
تعداد ز ياد شنو ندكان ر ابخو د جلب كر ده است سل 

$(r \cdot r)$
رانيوافغانستان

هم:جنان بافر اهمماختن تسهيلات تخنيكى بر وكر اسهاي السنه خا رجسيى راديو افغانستان ازسالبهمبرابا ينطر ف بيثتر مو ردعلاقه شنوند كا ن ير و گر امهاى سر بوط قر اركز فته است. افز ايش در تعداد شنو ندكان سرو يس هاي انگلينى، المانى و رو سىر اميتو ان بمقايسة نامهلهاى د د ريافت كه در

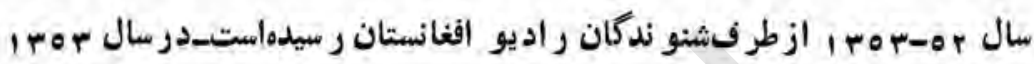

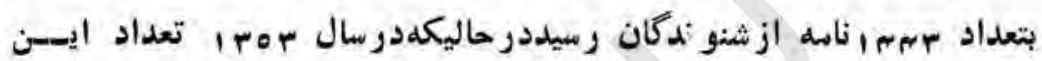
ناسه هاجهار جند شد. البته سعى شدهاست تااين بو وكر اسها منبع مؤثق اطلح ع ازجر يانات و انكشافات كثو و و معرف فر هنك ملى باشد و همذو قشنو ندكان

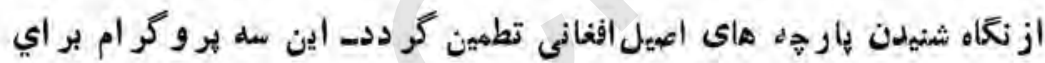
استفادة شئو ندكان ارو حايحى آن ميباشد م سو و يساردو و يو وكر ام دو مانكليسى بو اي كشو ر هايحوز منشربى كر دد- ايندو بر وكر ام نيز دراثر اصلاح و بهبو دو سايل تنغيكى تعدادز ياد شنو ندكان رابخو د جلب كر دهاست. افز ايشدر تعداد شنو ند كان اين بر وكر ام

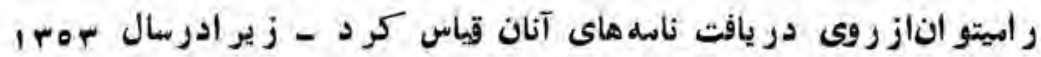
تعدادناهd هاى و اصلفسلجيند نامه هاى سال قبل بو د. البته و قتيكعده از بر وكر امهاي راديو افغانستان بمنظور استفاده زيادتر مر دم بيشتر كر ديدكه بر وكر امهاي عمدة آنقر ارآتى ميباشد : 


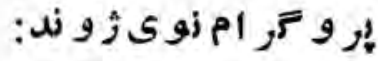

بمنظور تنو يوزنان و كُشايشدر بهاى ازز زندكىنو ين بروى آنها و آشنايى ثانبه زو ايايجديد زئدكى مطابق ضر و رت زمان بروكرام نوى ثو ثو ند

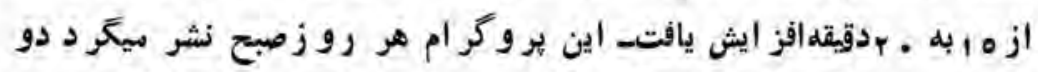

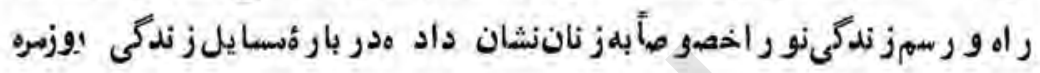
بايشان سشيو ره ميدهد.

\section{:}

يكى از ابتكار اتبز رككدر نشر اتر اديو افغانستانتر تيبسسابقات ذهنى

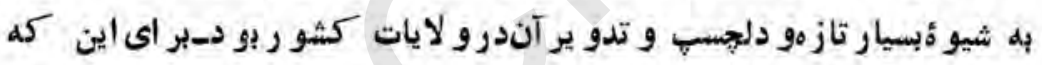
لمو افق با صل عدالت اجتماعى تدو يو اين بيروكر امصرف منحصر به مر كز

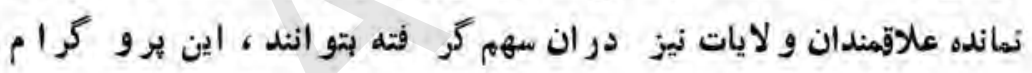
درحدو د الكانات راديو افغانستان دربر اكز و لايات كندها ر- هر ات

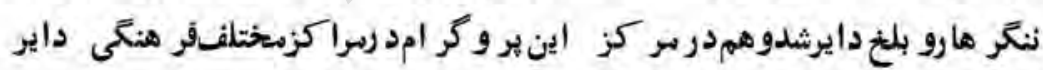
كر ديد.در عينحال درين بروكرام نه تنها بلشا كرودانسعارفو بو هنتون

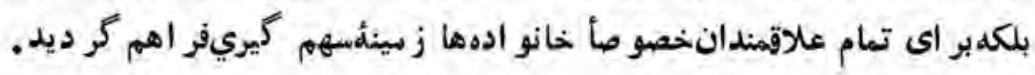
اين ابتكار بروكر ام مسابقات ذهنىر ادر جمله ير وكر الهاى بسيار دلجسب راديو قر ارداد و و قت نشر اناز نيم ساعت بيكك ساءت بالا بو دهثد البتــهـ در شب هائيكهاين نو وكر امبرو زهاى ملى و شناسبت ها ى خا ص تصادف 
ميكند ،بر اى دو ساعتنيز نشر شده است .در رشد استعداد جو انانو بالابر دن حدو د جرئت شان سهم اين برو كر ام خصو حابر ازنده بو ده المت.

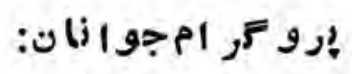

باتوجهبايناحل كهجوانان بحيث يكنير وى بزرك درسازماند هىو ليشر فت جامعه مسئوليت آيندهر ا بهعهدددار ند،بروكر ام اختصاصى جو انان بر ائشر مطالب ضرو رى وحياتى از نيمباعتييك سباعت ار تعايافت د رين بروكر ام نيز مطا لبى نشر ميكر دد كماز يككطرف معلو ماتجو انان ر ادر باره مجيط و جهانشان و سيعاز دو ازجانبديعر باار ائه سسايلتنو يرى نسلجو ان خصو صاً بلمسئوليت هانىلمىان كمانقلاب جمهو رى كشو ر بلعهده آنها بعيث نسل نسئول فرداىجامعه كذاشته،متوجه كر دند.

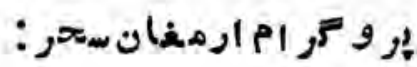

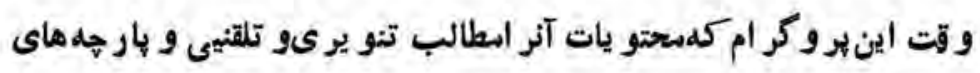

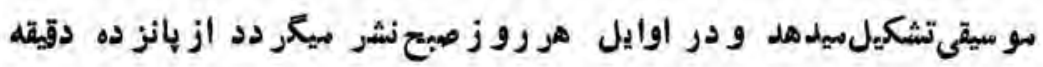

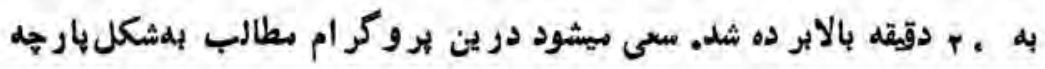
هاى تنو يرى و ادبى نشركر دد كديكانسان درآغازرو زبايد بايك ابيد و نير وى اراده به زندكى شروع كند. 


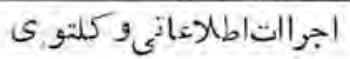

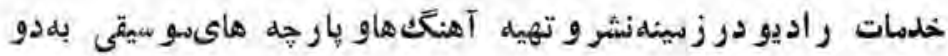

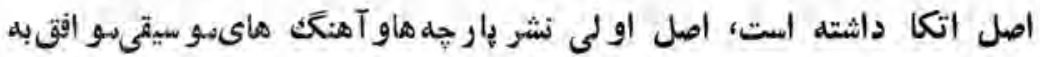

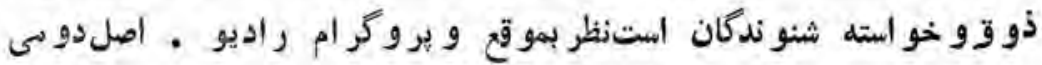

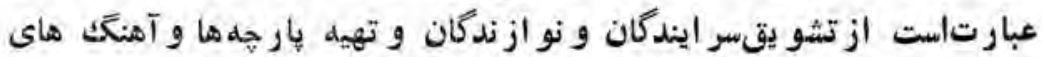

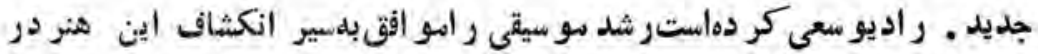
جهان و خو استه و ذوق مودم تشو يق نمايد . بميان آمدن كر ومهاي متعدد

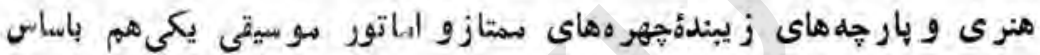
اين موجبه بوده است كلر اديو افغانستان به بارجهاوهاو آهنكهاى برازنده بيشتر التفات نشانداده است - اين تشو يق راديوو تهايلذو ق علاقهمندان

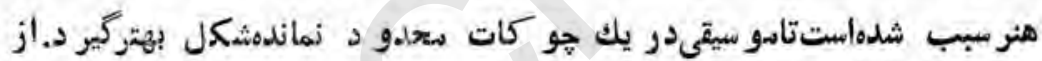

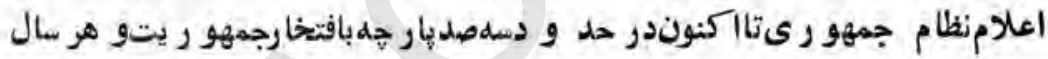

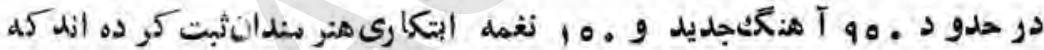

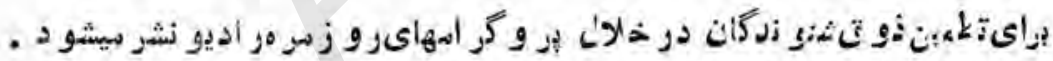

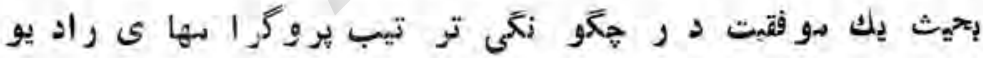

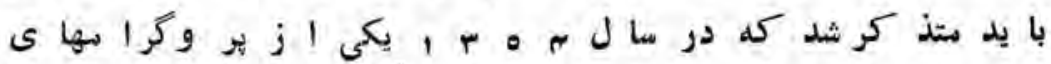

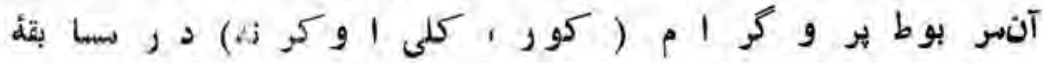

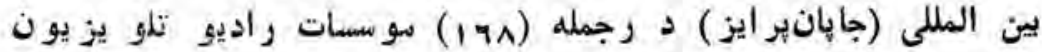

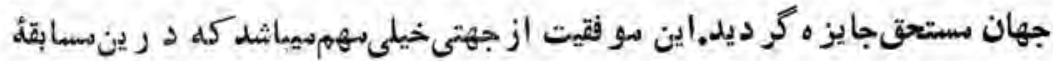
بين الملمى متخصصين و ثرو رنالستان و درزيده سهم داثته و ازطرف د يكر جهره هاى مهم مطبو عات درمور رد آنغو رو حكميت نمو دهاند.اين موضو ع 

$(r \cdot v)$
راديوافغانستان

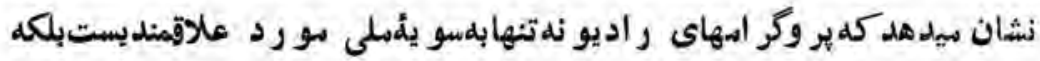

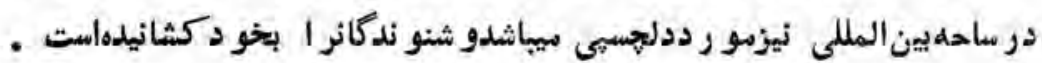

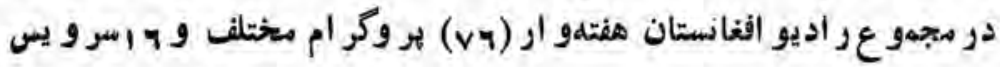

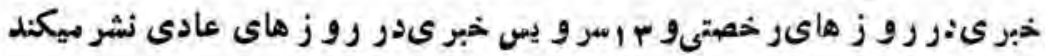

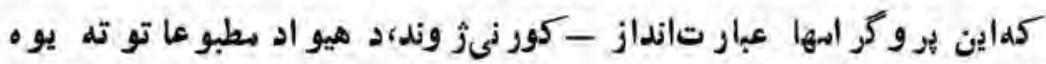

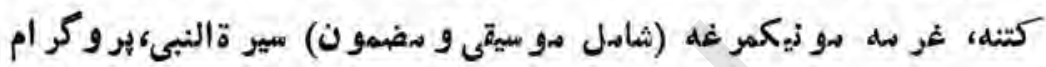

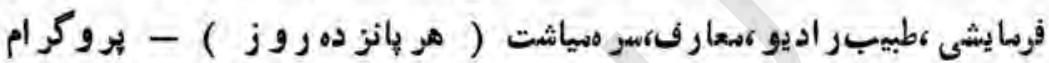

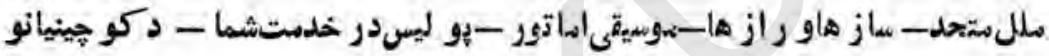
بو وكر ام-ينيتو لوست-انغليسى لو ست-فو انسوىلو ست- روسى لوست

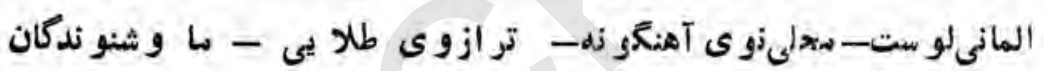

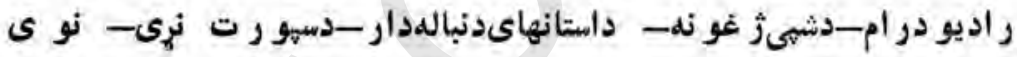
ثبتشوي آهنخو نله-ددو ستانو سر كله - راديو يهى مجله - اجمالسياسى هفته مو عظلو مر دانحق - از هر همن مهمنى - ما و كشو ر ما - دانه ها ى

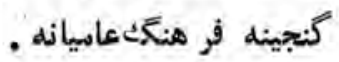

\section{:}

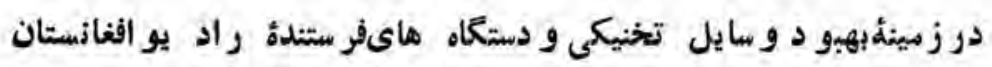
عين أهتمامى كم در ساحه نشر اتى آن صو رت كر فته بو دبلهعمل آمد، آنهمباتو جه

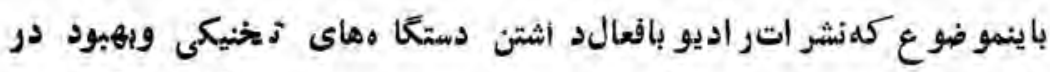
كار و تقو يتمز يدان بهتر ميتو اند در خدنت همو طنان و ثنو ندكانير وكر امهاى 
الجر ا آت اطلاعاتىو كلثو رى

آندرداخل وخارجقو اركير د.لذاوزارتاطلاعاتو كلتور باساس مشى نشر اتىدولتجمهو رىبهيو د در كار تسهيلات تخنيكى رابااهتمام باين سه

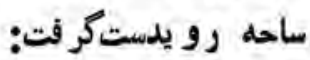

1-تهيهو سا يل ضر و رى بر ايقعالن نكاهداشتن بهتر و سايلمو جو دتخنيكى

$$
\text { و دستعاههاى فر ستنله و ستديو ها. }
$$

r-بكار انداختن دستامهاىجديدتيلىثر انسميتر براى رسانيدناو ازر. اديو بلمسر اسر كثور و جهان خارج. ب-طرحبلانهان انكشافى و تحت تطبيقكر فتئن

دراولين سالتأسيس نظامجمهو رى سعىشدتاوسايل سوجود دون باترميم و تكيلو سايل ضر و رى بشكل بهترى در خدمت نشر ياتر اديو قر اركير دلذابعد

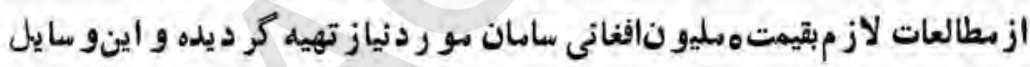

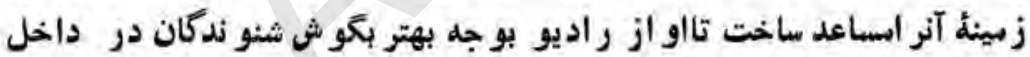
وخارج بو سد.

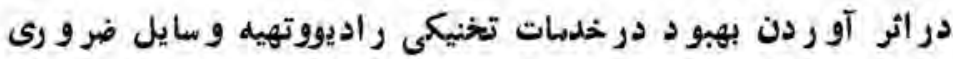

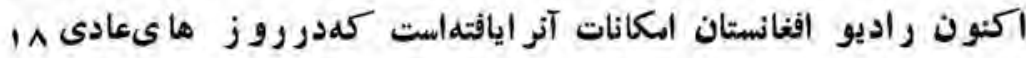

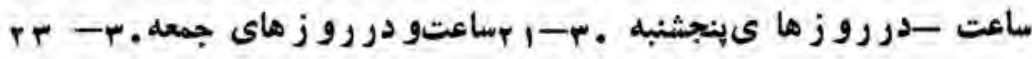

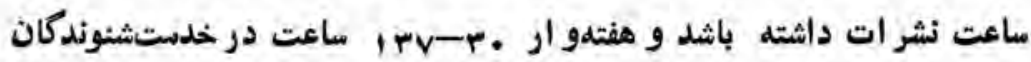
خو ددرداخل وخارجباشد.

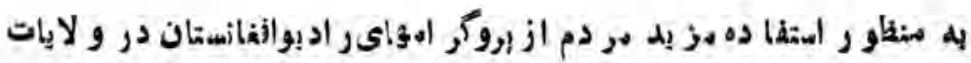



$(r \cdot 9)$
راديوافغانستان

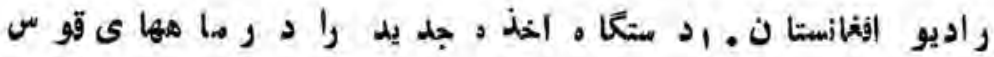
و جدى

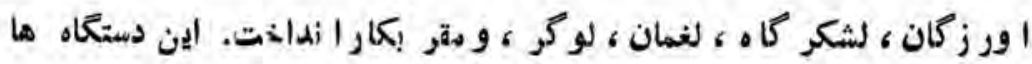

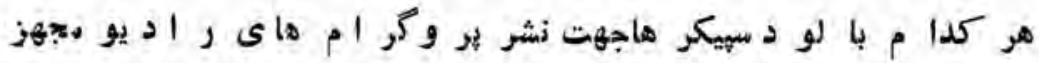

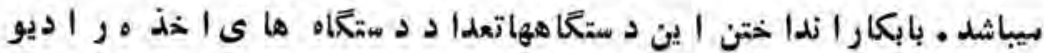

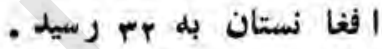
اكنونامواجراديوافغانستلنسر اسو كشور رالحتوأ ميكنداما ازطر فروزهنو زامواج آن در بعضىمناطقدو ردستنسبتشر ايطفز يكى بامز احمت هايىتو أم ميباشد كمفعال

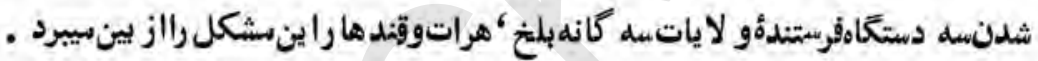
زنشر ات خارجى ر اديو افغا نستانسو السر او ر با، كشيو ر هاى حو زمو شرق

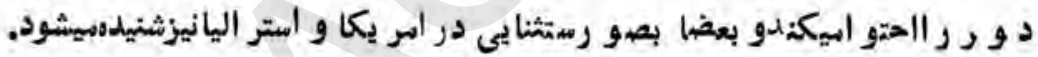

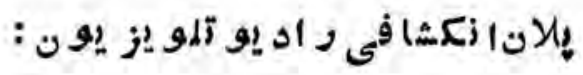

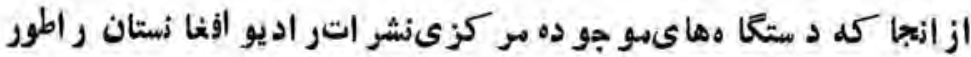
و اضع د رمراكز كثور رسانيده نميتو اند و همايندستغاههابر ائ ربايدن

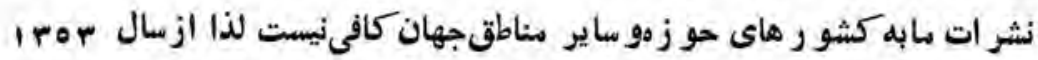
با ينطرف طرح يكنانان جامع بر ایىانكشاف راد يو رو يدستكر فتهشدهو قو ارشد

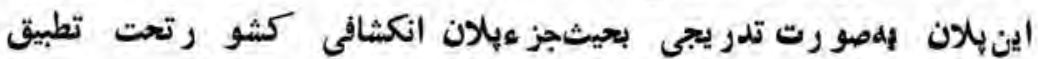
كر فتهشو د د 
اجرآتاطلاعاتى, كلتو رى

ا-دستكاههاى تقو يه: بر الىاينكه نشر ات ر اديو درسر اسر كثو ر بهمه

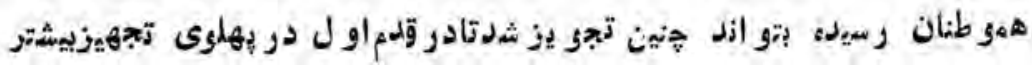

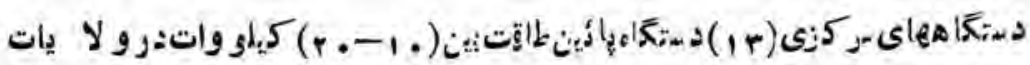

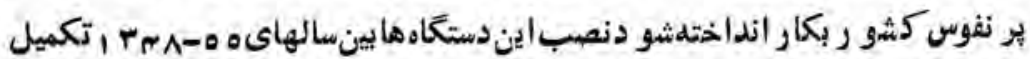

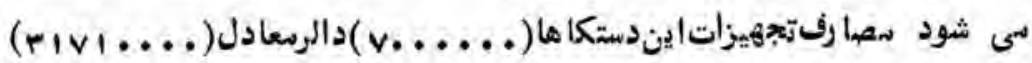

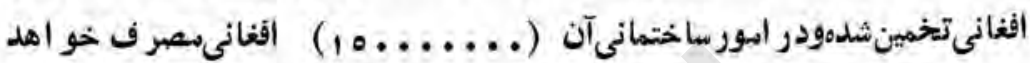

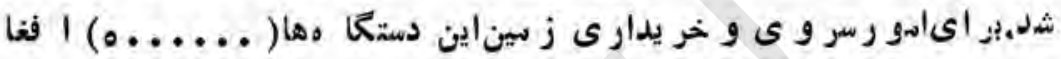

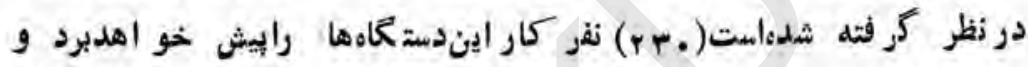

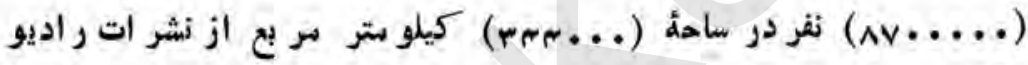

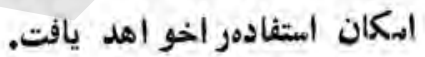

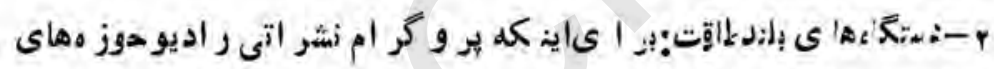

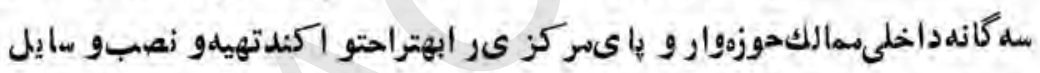

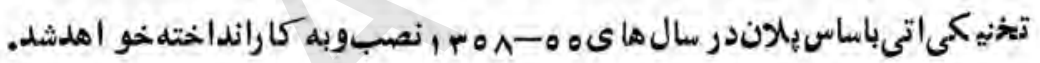

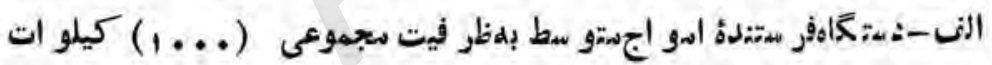

$$
\text { (r) (ب) احدهر و احد(. . م) كيلووات. }
$$

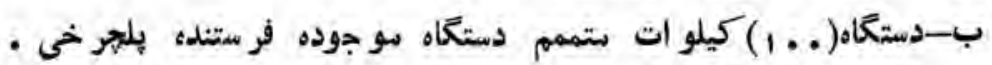
ج-دستغاهفوستندة الو اج كو تاه(†) و احد هر و احد (. . ه) كيلووات.

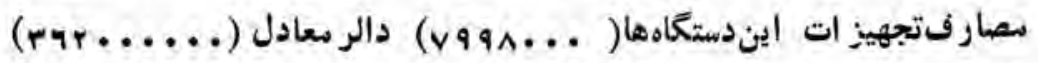

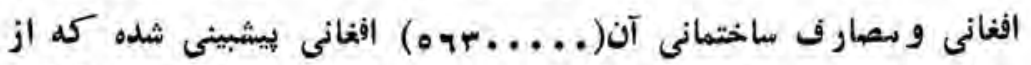

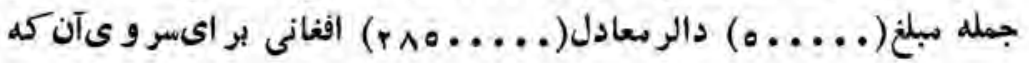

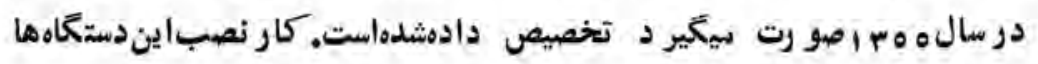






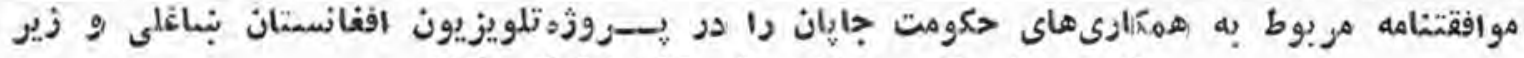

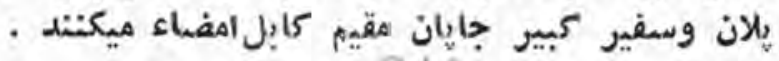
210 वा 
تا سال)

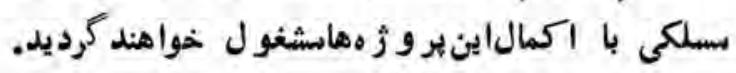
بـأستديو ها: براىاينكه خدنات ثبت و نشر خو د راراد يو افغانستان تو أم بانياز هنديهاو تحو لاتنو ين إيشبو دهيتو اند_لذادر ساحه جو ارعمار ت

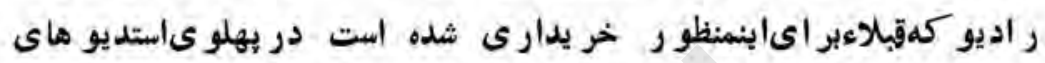
تلو يز يو ن- عمار تستديو هاى جديدر اديو افغانستان بر ایى بيث بردا مهو رو

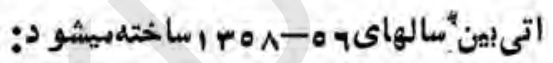

\begin{tabular}{|c|c|c|}
\hline و احد & YA & ستد يو هاىثبت او از \\
\hline و احلد & $r$ & ستديو هاىدر الههاىر اديو يى \\
\hline و احد & $r$ & ستديو هاى كابى \\
\hline و احد & & ستديو هاىىو ز يك \\
\hline و الحd & 1 & دفاتو -تحو يلخانهو \\
\hline
\end{tabular}

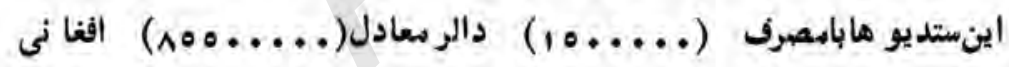

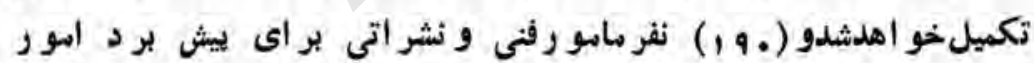
انمؤ ظفخو اهندكر ديد.

\section{تلمو إز يون}

نطابق بيانئة تار يخى(خطاب بمردم افغانستان) از همانآغاز استقر ا رجمهو ر يت وز ارتاطلاعاتو كلتو ردرحصةتا سيس و بكار انداختنتلويز يونبمطالعاتلازم آغاز نمود - كمه بعدازمطالعات عميقو كر فتن نظو يا ت متخصيصين و 


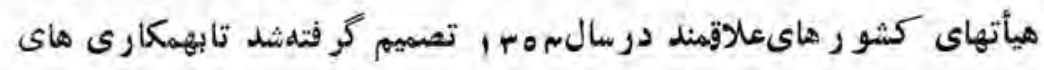

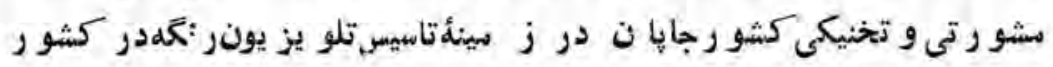

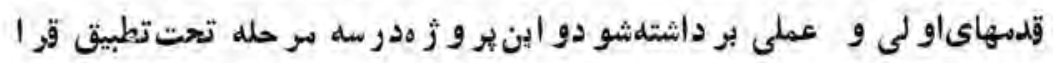
خو اهدكر فت . تهائ

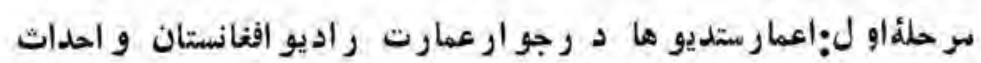

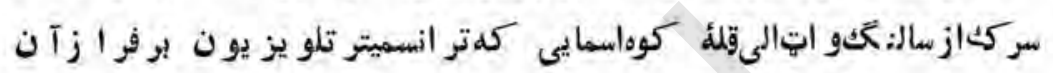

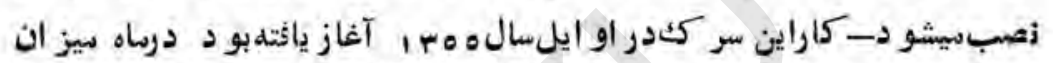

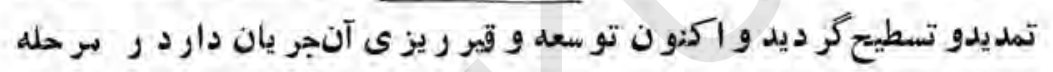

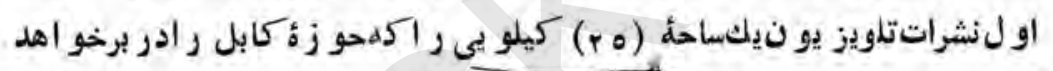

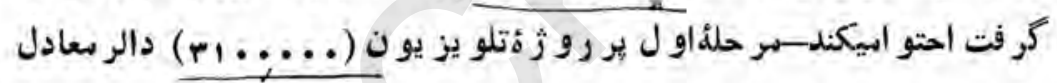
أفغانى سصر فخو اهدداشت -بر اي تمو يل سر كث تلو يز يون

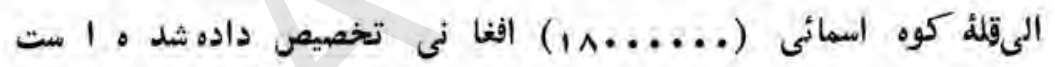

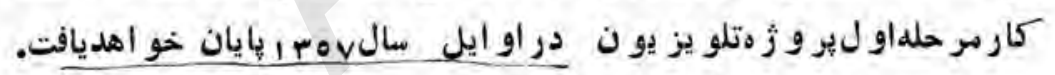

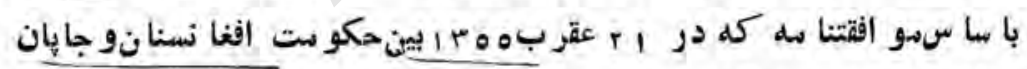

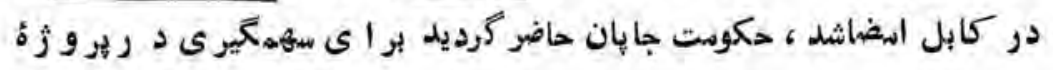

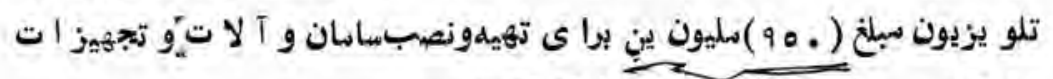

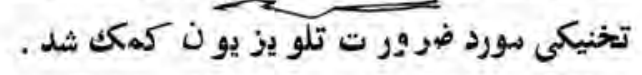

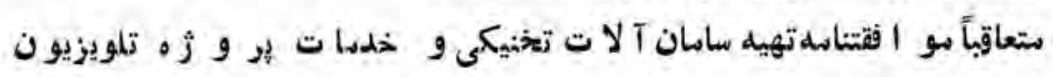

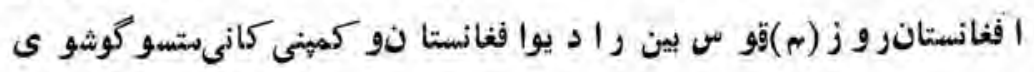

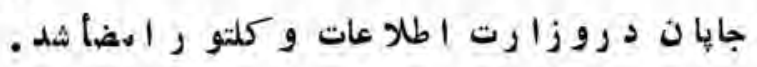


مرحلةدو م: شامل آنا زكار بر اى نشر اتتلو يز يون درو لايات نز ديك كابل (ير و ان-لوكر و رد ركتو و لاياتبلخ) ميباشد.

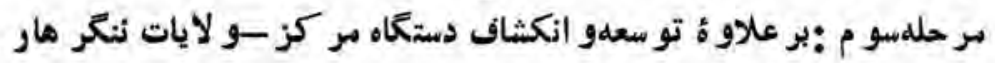

$$
\text { كندهار و هر ات ر انيز احتو اخو اهدمكر د. }
$$

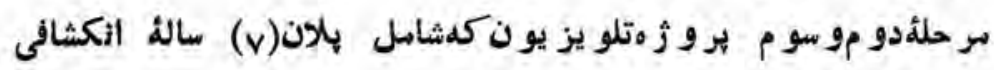

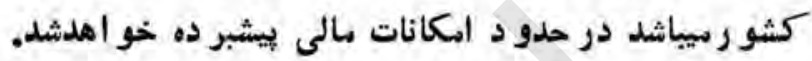
نصار فتجهيز ات تخنيكى آن بالغ بر ( . . . . 1 ع 1 ) دالر و مصار فساختمانى آن

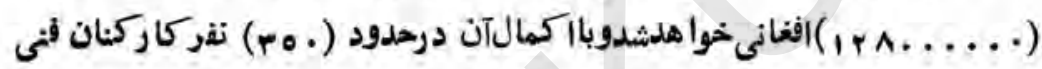

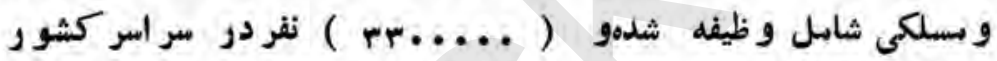

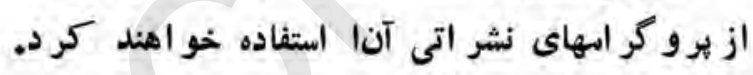

$$
\text { : باختر آز انس }
$$

باختر آز انس فعاليتهاىخو در اباساس سشى كلتورى دو لتجمهو رى رئ

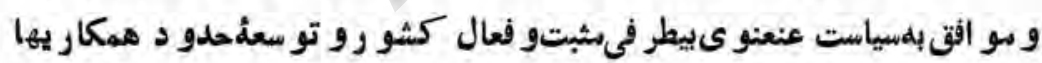

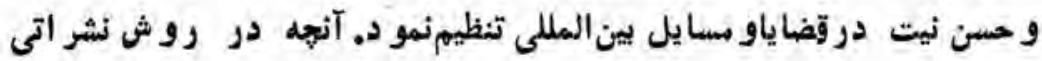

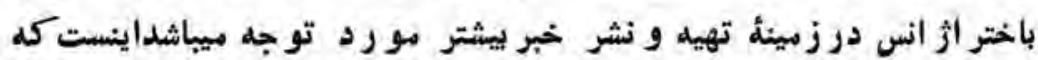

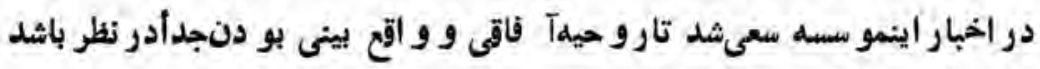

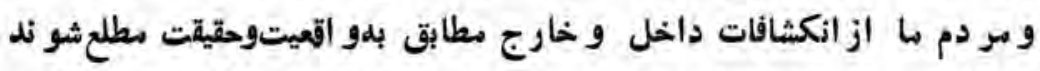

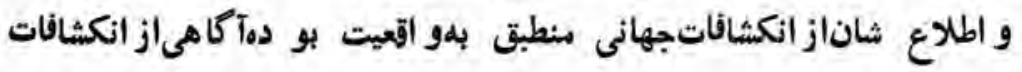
كثو ر بلدر هبرى ز عانت جمهو رى مو جب تشو يق و سهمكيرى مز يدشان 
اجرا آتاطلاعاتىوكليتورى

$(r, n)$

درخدمات و تشثبثات ملى گرده .

اخبار آر انساز سه هينل تهيه ميكر دد-انكشافو اقعات كشورا زمر كزو

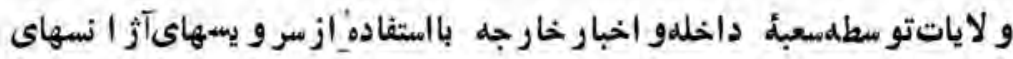
عمدة بين المللى و ر اديو هاى معتبر جهان توسط تيلى تايِو رادئ.

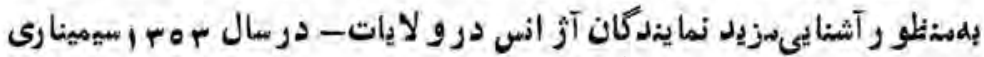
باشتر اكك آثهادربو كز دايركر ديد و ايشانبوهوزخبر نكارى بيشتر اشناشدند. همرجنان بو ا اينكه خدمات باختر آز انس در تهية عكسها ازجر ياناتو ازكشافا ت كثو رو همز و اياى ميختلف فر هنك جامعه تو سعه و تنظيم يابد فو تو رايوتر ان مؤ سسات نشر اتى در باختر اثز انسفعاليت خو دو الزطر يق يكادار همر كزى دنبال نمو دند.

باتنظيمخدمات باحتر آز انس و تو سعله حدو د فعاليتهاى آناكنون اين

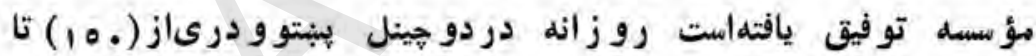

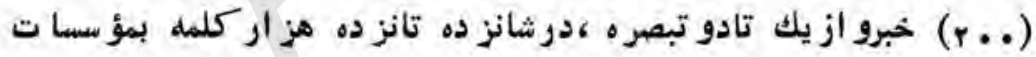
نشر اتى دخابر ه كندو تمام عكسهاى سر بو ط بلانكشافات كشو ر را بلدسترس آنهابگذار د. در عينحال البو مجر يان سسافرتمهمانان عاليقدرخارجى راتهيه

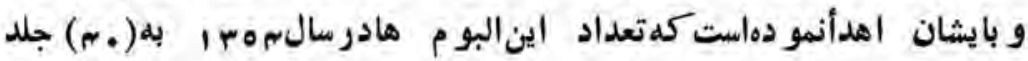
رميد. ضمناً بر أىسؤسسات و مر اجعات انفر ادى نيز عكسهاى مو رد نيا ز تهيه نمو ده الستو يك و تو ين بر اینمايث عكسهاى مو بوط با نكشافات رو زمرء

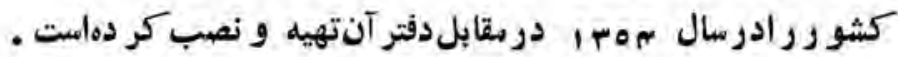
درعينحال باخترآ آنس بمنظو رتو سعة حدود همكا رى ها. علاوه 
بر آث انسهاىفر انس ير س-رو يتر -تاس-سينهو ا-ه هيتكا-تانيوكثـانتا رااثانس

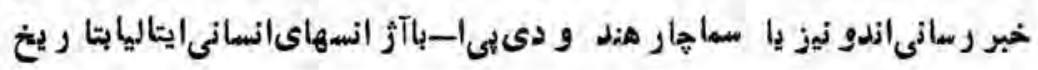

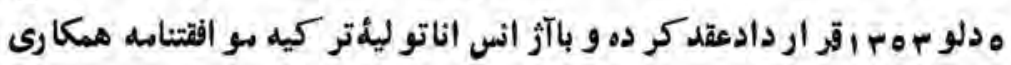

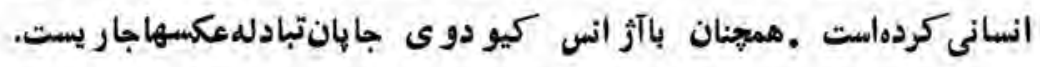

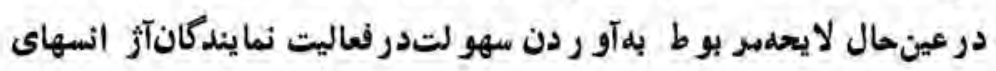

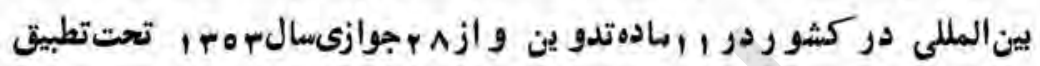

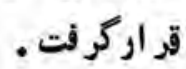

\section{سم:معى او بصرى :}

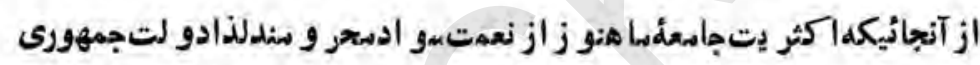

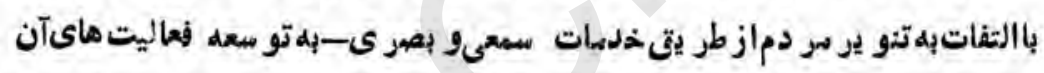
توجهخاص داشته الت ،روى همين ضوورت وز وزارت الطلاعات وكلتور

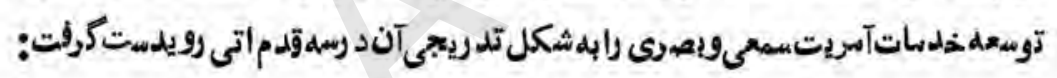

$$
\begin{aligned}
& \text { ا-سمر امو حدو دفعاليتو احدسمعىوبصر ى. }
\end{aligned}
$$

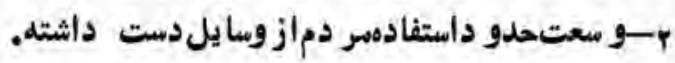

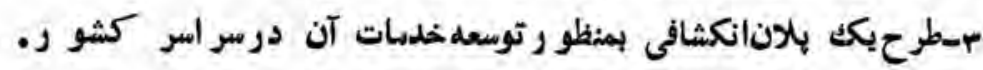

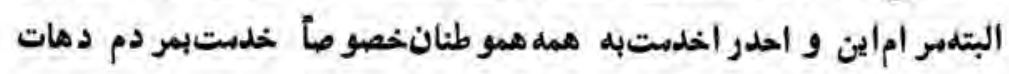

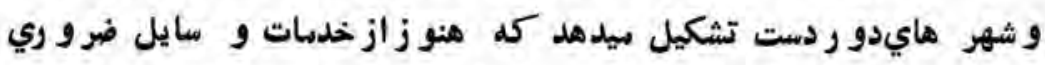

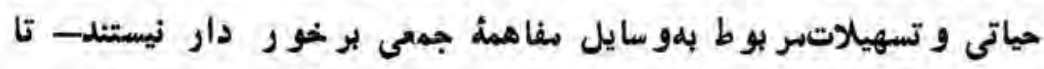

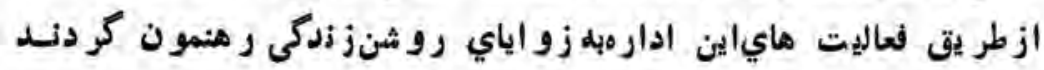


داسنففاليت هاي اينمؤ سسهراكه توسطو احدهاي مجهز سيار آنصو رت بى

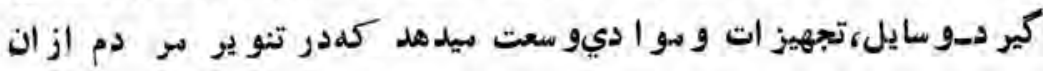

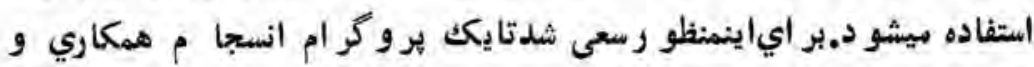
مساعى مشتر كثبا شعبنشر اتى سمعى و بصريو ز ارت ها و مؤ سمات ذيعلكقئ

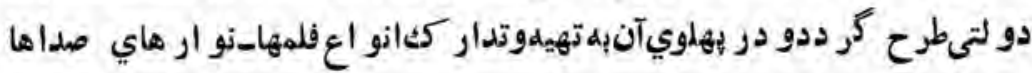
و ديو تيهو نشر ات مطبوع آغاز كرد يد اين تشبثاتساحل خدمات ايســن

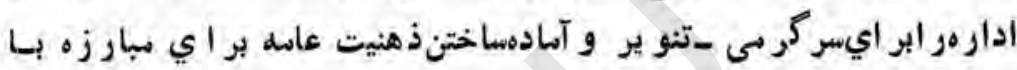
خر افاتو قرار كر فتن بيكتسيير روثن ز ندكى تاحدو د ادكان و سعتبخشيد. خدماتسمعى و بصريدر هار سالاو لطليعل نظام جمهو ريقر ارآتى خلاصه :ميثرو

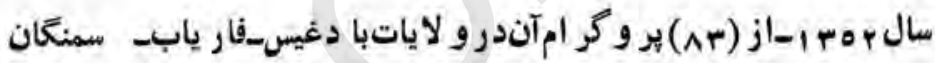

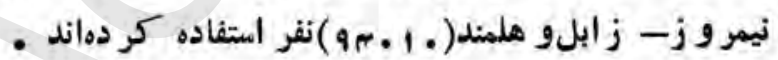

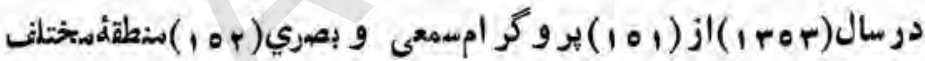
كشو ردورو لايات كابل - إكتيا- بر و ان-بغلانه نو ر-نيمر وز - و سمنكان (irriv.)

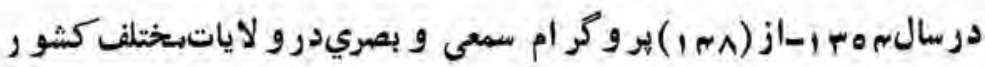

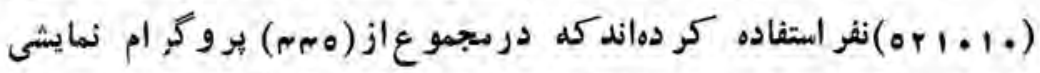

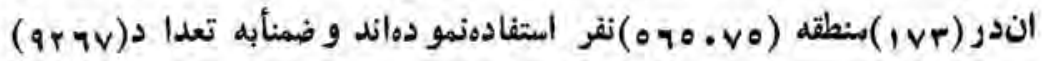

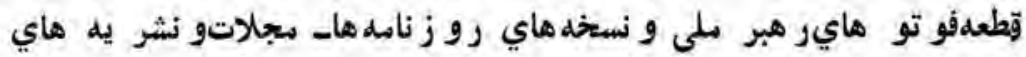
مو بوط وز ارتاطلذعات و كلتو رر اتوزيع نهود. 
خدمات سمعى و إحريدرو لايات كشو ر

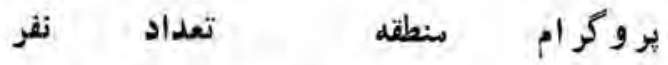

نف vro

1.11.

" $\% q$.

n erre

" พั0.

1) Р9q.

") VAr.

نte ror

$$
\text { بو وكر ام }
$$

。

17

و لايت بادغيس

17

ولايتفار ياب

10

و لايتجو زجان

9

و لايتبلخ

7

و لايتسهنغان

。

و لايت كندز

$\wedge$

ir

و لايتبغلنان

rمير وكرام

هجموع vو لايت

ولايتنيمروز
1190.
(1.
* 19
و لاليتفو لاهئ
$n \quad 1 . .$.
" ir
" r.
و لايت هلمند
n $\mathrm{rV}$.
" $\wedge$
i) T+F.
* r
a 17
و لايتز ابل
n $\wedge \vee \ldots$
a $v$
9
و لاليتسمنغان
n) $1 \mathrm{re}$
* ir
10

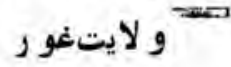
D. F.
* $1 \wedge$
9
و لايتير و ان

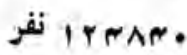

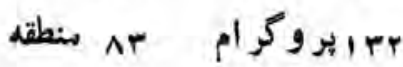 و لايت بغلان هجموع ^و لايت 

اجر آت الطلاعاتىو كلمقو
$(r, \Lambda)$

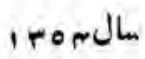

\begin{tabular}{|c|c|c|c|c|}
\hline نفر & تعداد & הنطفd & يو وكر ام & \\
\hline$"$ & $\wedge \cdots$ & 1 & 1 & و لايتنيكر هار \\
\hline$n$ & rerd. & 19 & $r$. & و لايت دِكتيا \\
\hline$n$ & 0018. & 9 & Tr & و لايتغو ر \\
\hline$n$ & rono. & $r$ & 17 & و لايت كابل \\
\hline$"$ & oro.. & + & $\wedge$ & و لإيتسمن:خان \\
\hline$n$ & ror.. & $\kappa$ & $1 \pi$ & و لايت نيمر وز \\
\hline$n$ & $1.1 \ldots$ & $r$ & 11 & و لايتبدخشان \\
\hline " & $10 \% \ldots$ & $v$ & 17 & و لايت تخار \\
\hline
\end{tabular}

شجهوع ولايت

\section{1 rood}

\begin{tabular}{|c|c|c|c|c|c|c|}
\hline نفر & ror... & مقن & $r$ & ير وكر ام & $1 \pi$ & و لايت كابل \\
\hline$n$ & va.. & " & - & $"$ & 11 & و لاليت \\
\hline$"$ & $1 \cdot v+$. & " & $\wedge$ & $"$ & 9 & لايتز ابل \\
\hline n & $97 .$. & " & 15 & " & 15 & لايتغزنى \\
\hline$"$ & $\wedge \cdots$ & " & 1 & " & $r$ & لا يتسمنغان \\
\hline N & rVR... & $"$ & T & " & 11 & لايتغو ر \\
\hline$n$ & $90 .$. & " & $r$ & " & $r$ & لايت نيمر و ز \\
\hline
\end{tabular}




و ولايتارزكان

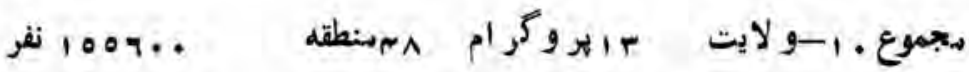
درعينحالبر اي تو سعة خدسات سمعى و بصريبهان انكشافى آن ترتيب شد تادر خلال يالان هفتساله انكشافى كشو ر درحدو د انكانات مالى د و لت

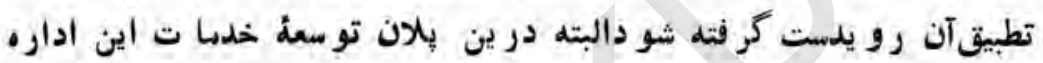
ازطر يقتهيه و احدهاي سجهز سيارو تأسيسمر اكز كلتو ريدر يكث عده از

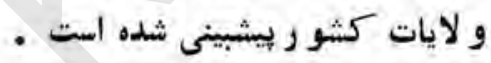
:

اينمؤسسه خدمات خو د ر ادرطبع رو ز نا مه ها ـمعلات و تمام نشر ات مر كز و هم حاب آثار و كتبـو ز ار تهاهـ دو ايو، بؤ سسات و اشخاص ا نفر ادي تنظيم كر ده و باستقر ار نظام جمهو ري - فعاليت هايخو د ر اسو افق بـه نيازجامعه بيشتر تو سعل بخشيد. اينمؤسسه حد و د فعاليت هاي خو د ر ادر

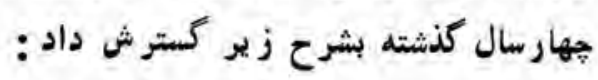
- ror ror

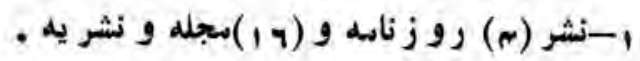
r-هاب تذكرة جديدجمهو ر يت. 
اجرا' آ تاطلاوعا تى وكلقو رى

$(r+)$

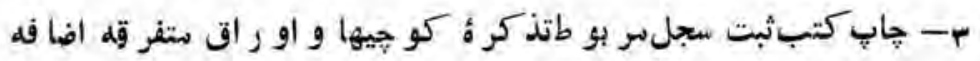
dr..... j)

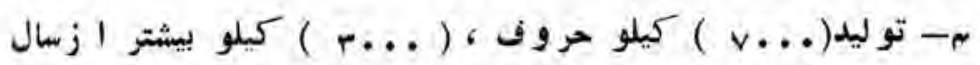
1001

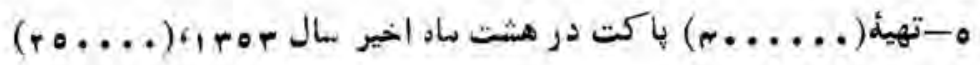

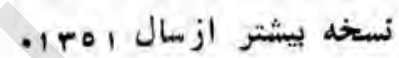

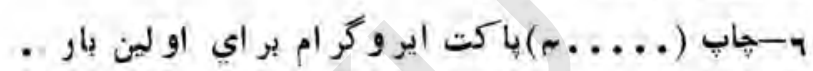

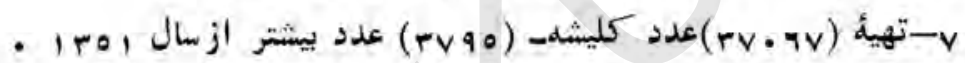

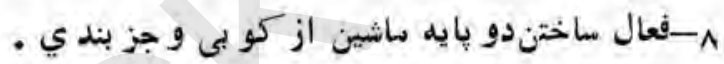

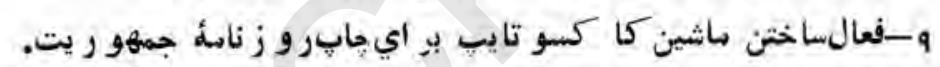
•

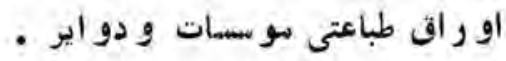

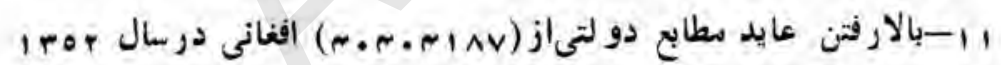

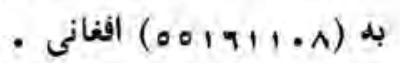

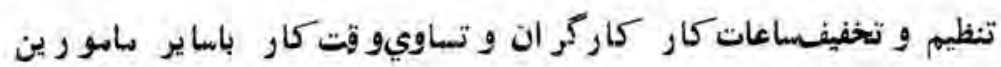

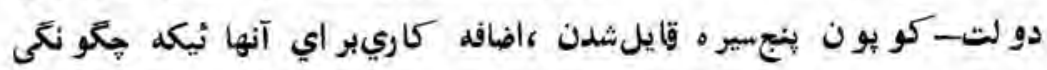

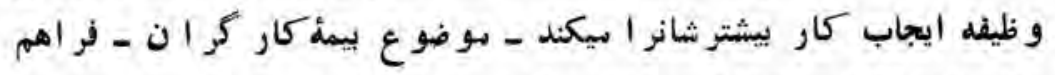
ساختنز مينهُتداوي ايشاندر داخل سطبعه و آغاز نما يشات هنظم- هفته و ار دروسينماي مطابع دو لتىمائة دلخو شى و تشو يقسز يد كاركر ان شده باءث بالارفتي بيمانه كار و فعاليت بيثتر آنان كر ديد. 

$(r+1)$
مؤسسلطب كتب بيتهق

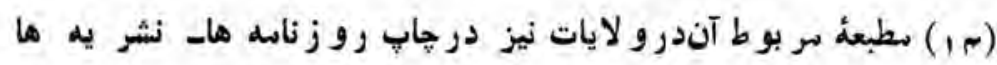

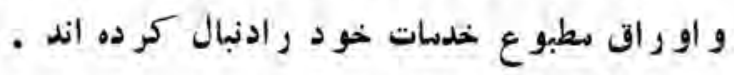
در سالنهبr

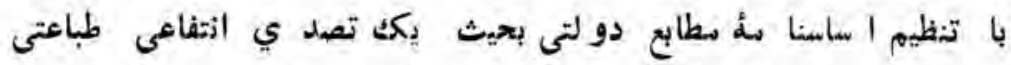

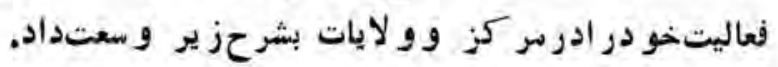

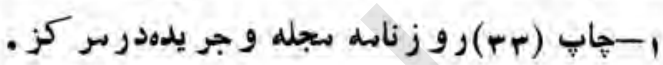

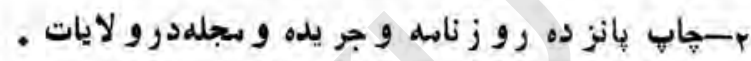

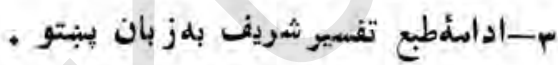

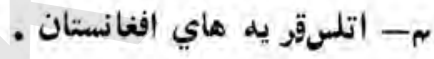
م-ر هنماي تيلفو ن.

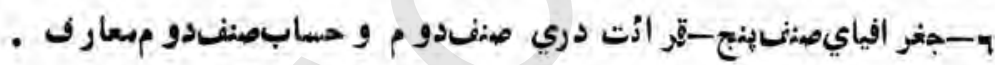

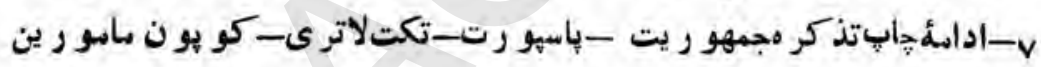

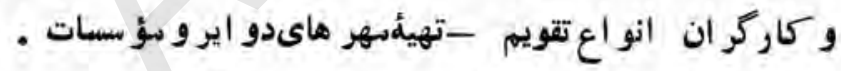

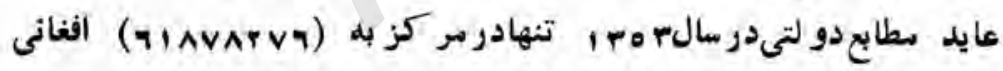

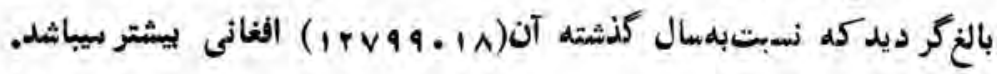

\section{مو سسه طبع كتب إ:هقيى:}

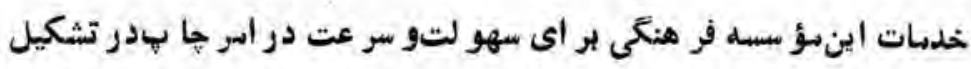

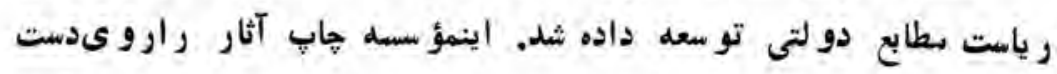

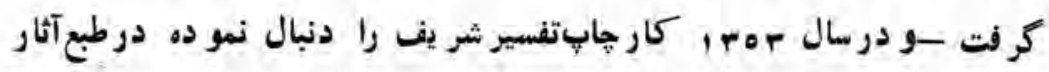


بياناتر هبر ملى جمهو ريت بصورتشفف دو مجمو عه،جلددو م كتابفارو ق

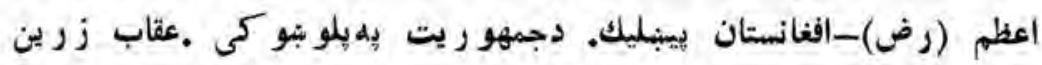

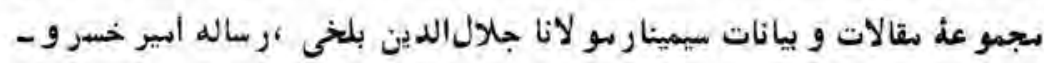

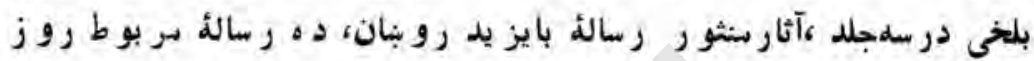
سو اد و نطبو عات، جار ر سالة تجليل سال بين المللى زن، زيانات بناغلمى اجمل ختهك

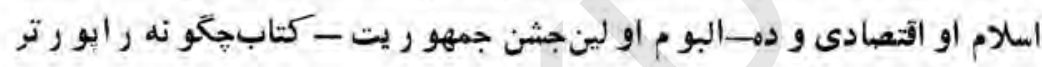
خوبسيشو يم-اثر آىخانم- جر احى اوعيه -طبى يو دو لو زٔى .و هم بر ائ

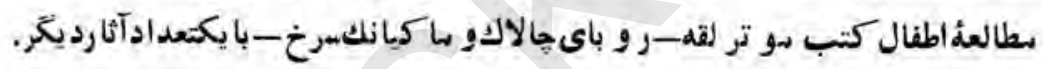

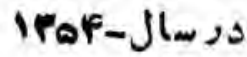

|-نشر رو ز نامه ها-_جرايدو آثار .

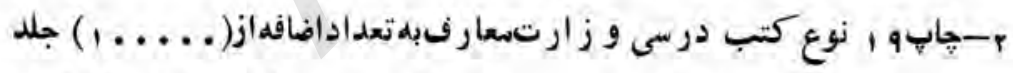

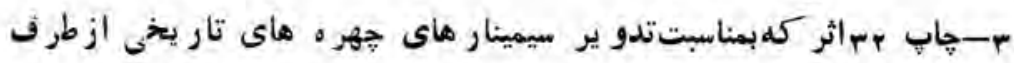

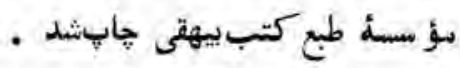

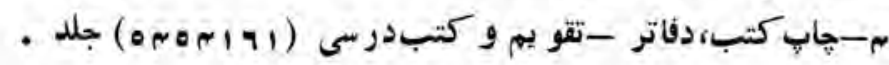

ه-او راقبطبو ع (qverororv) نسخd.

$$
\text { ح- كليشه (rrvs }
$$

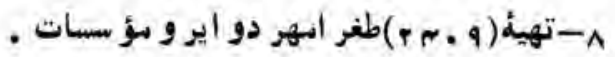




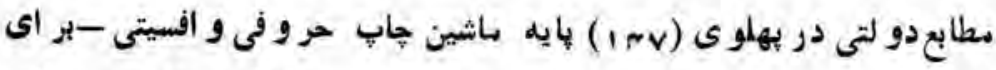

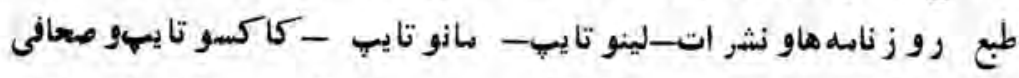

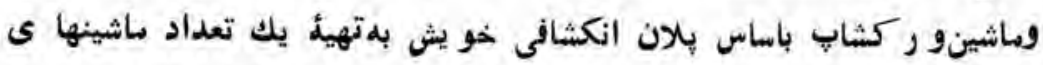

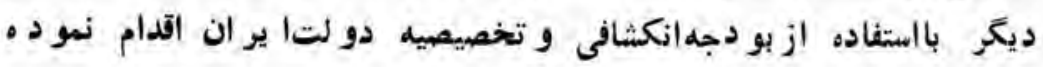
كمبر و يت افر هاى و اصله در زمينهاجر التبعمل سى آيد- ممرجنان يك ماشين

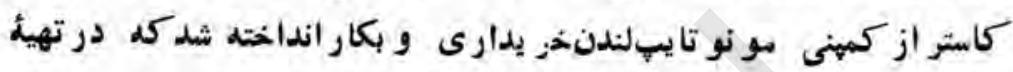

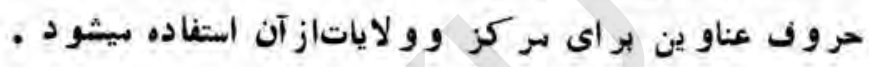

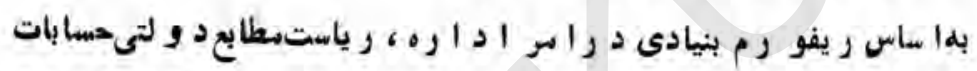

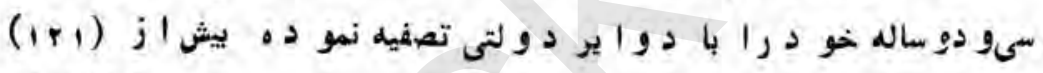

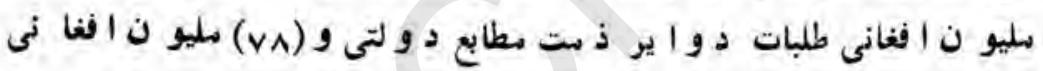

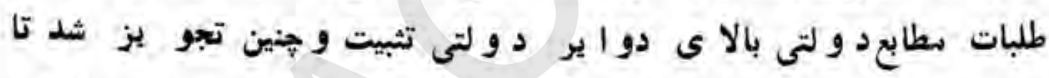

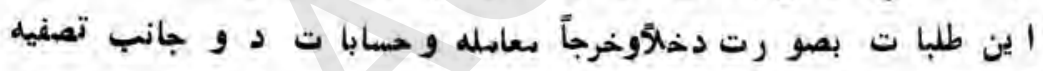

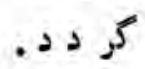

\section{افغذان اعلا نات:}

اينمؤسته كار خو در ادر ز بينه جمع آو رى و نشر اعلا نات ا زطر يق

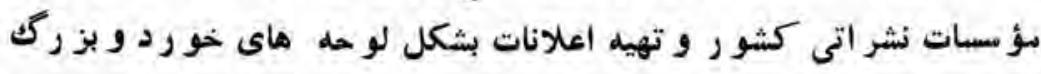

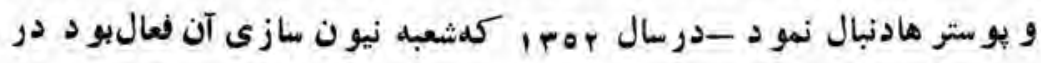

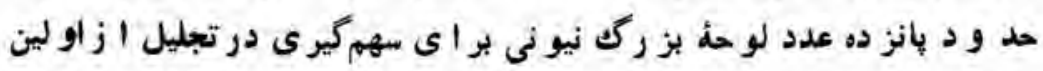

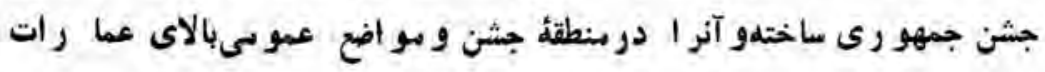




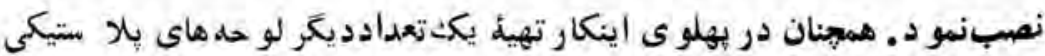

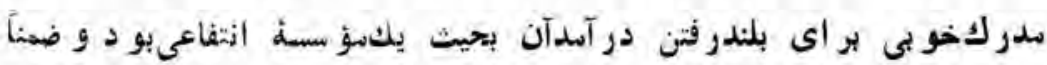

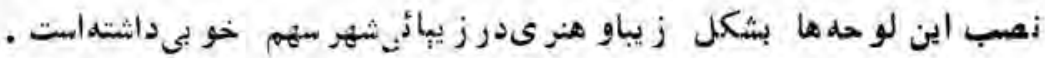
در آمد اينمو سبهاز ناحيهتهيهو نشر اعلانات د داخلىوخارجى ازطريق رو زنامه هاو ر اديو افغانستان و همزنصبلوحلها و بو ستر هادر كنا ربار كها

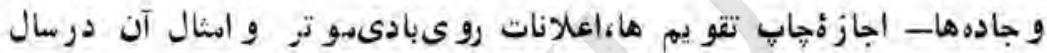

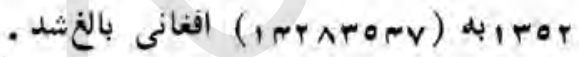

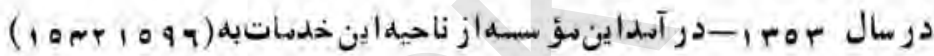

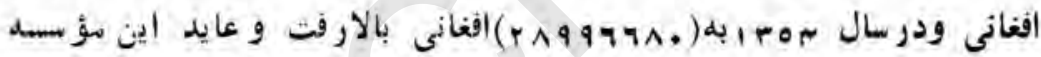

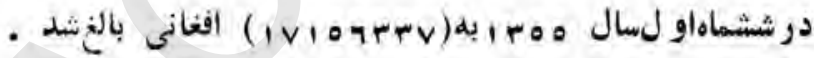

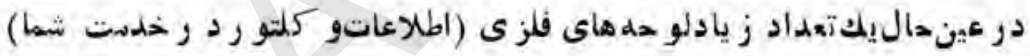
از طرف اين مؤسه تهيه ودروزارتهاومؤسسات"جهت نصب شماره هاىر و زناهذ جمهو ريت بر ایىاستفاده علاقمندان ساختهشد. افغان اعلانات باساسلايحهخو د اعلانات رالزمر اجي داخلىو خارجىكر فته و باساس اخذ

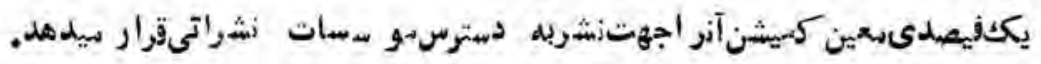
البتهدرلايحةٔمؤسسه|فغاناءلانات حق النشر اعلا ن مو اد وخد ما ت روحيه تشو يق صنايعو متحصو لات كشو ردر نظر ميباشد. 


$$
\text { : خ }
$$

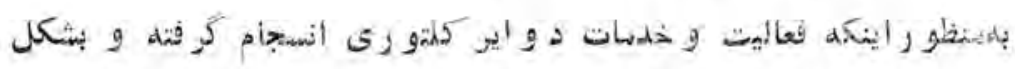

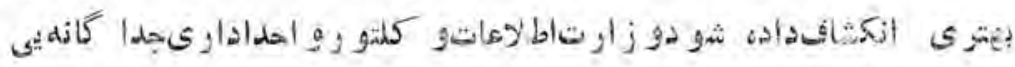
ئ

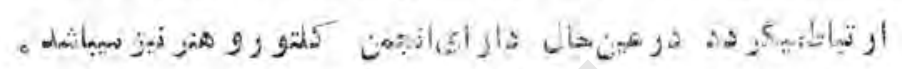

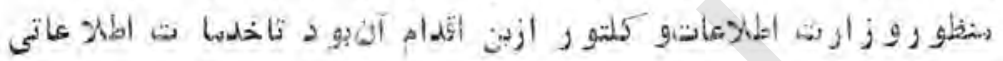
e

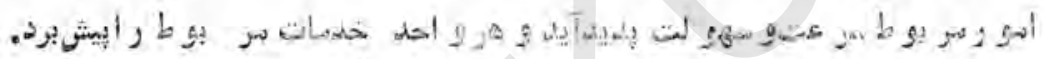

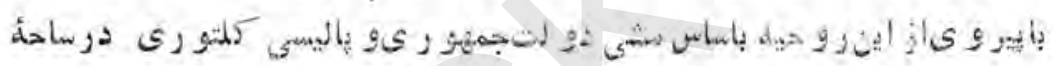

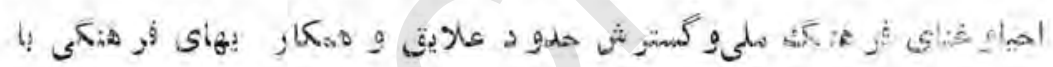

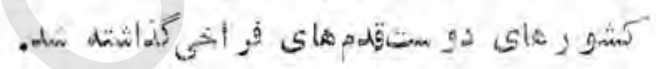

$$
\text { : E:D, }
$$

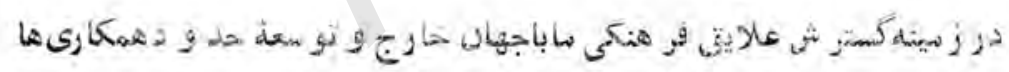

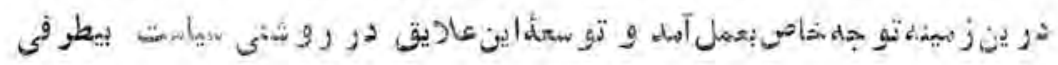

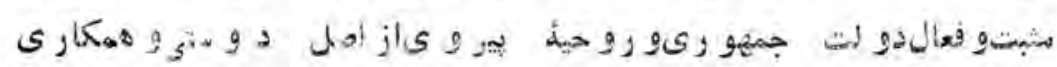

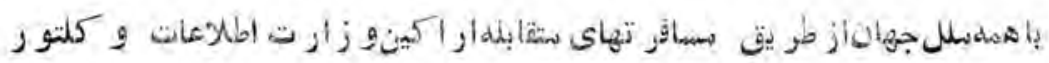

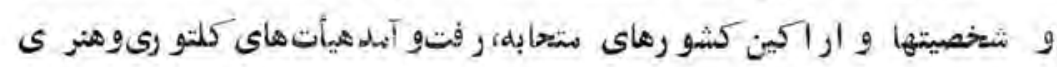

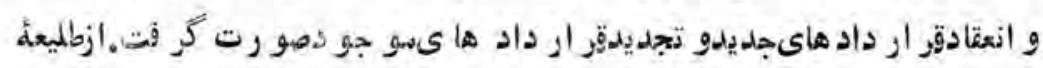

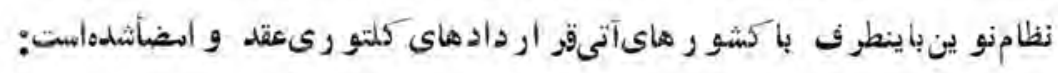


ا-قر ار دادكلتو رىييندو لتجمهو رى افغانسئان و يوكو سلا و يا. جامقر ار دادفر هنكى بيندو لتجمهو ر ى افغانستانو اتحادشو روىى.

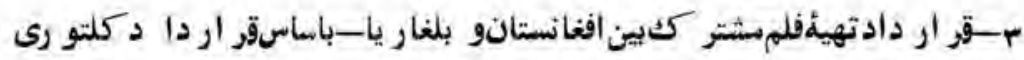
r- مو افقتناسه كلتو رى بينجمهو ريتافغانستان و دولت كويت.

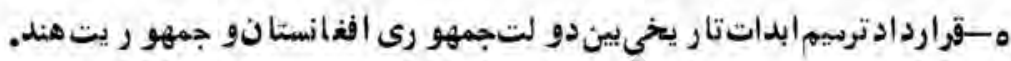
ه-قر اردادتر ميمابدات تار يخىيين دو لتجمهو رى افغانستانو حكو ستايتاليا

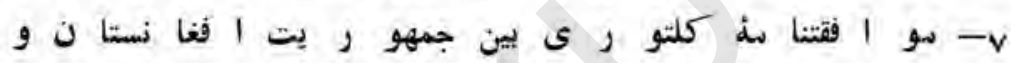
جمهو ريت عربى سعر - مبر ا.

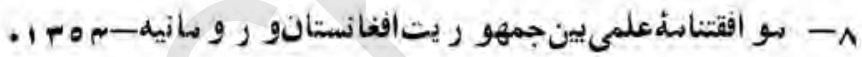

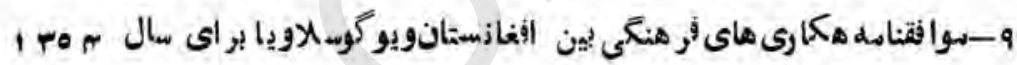

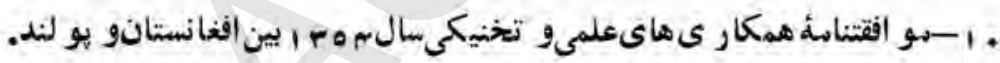
1 1 1 بر ائسال ( م م م ا )بين افعانستان و تر كيه .

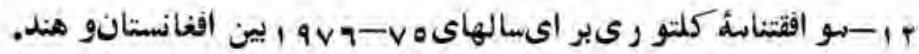

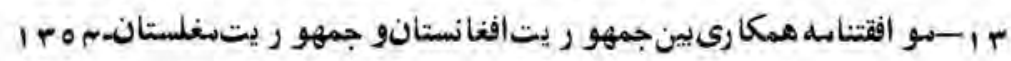
م ا -تجديدمو افقتناسلة كلتو رى بين افغانستانو بلغار يا-سم هب 1.

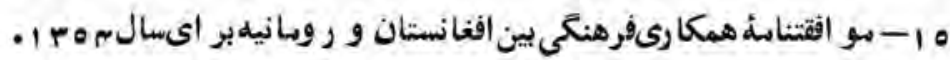

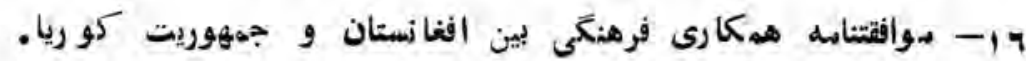




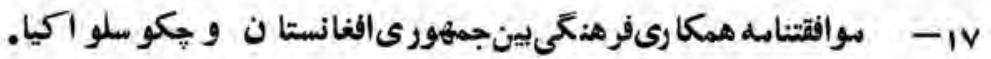

- و مجا ربيتان

$\begin{array}{lll}/ / & / 1 & -11 \\ / 1 & / 1 & -19\end{array}$

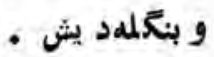

- وجانان

و جمهو ر يتمبردمجين

وفر انسه

- وجمهو ريت كور ريا -

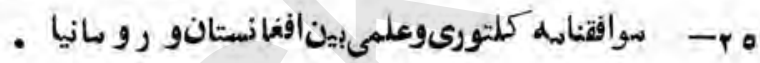

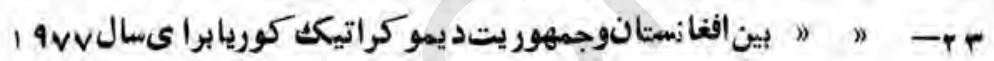
درعينحالاسو رانجمندو ستى افغانستانر ا باسلل شتحد- اتحاد شوروى

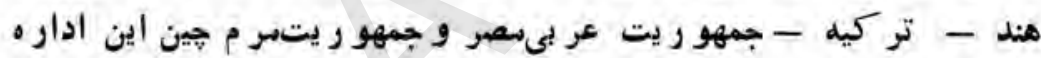

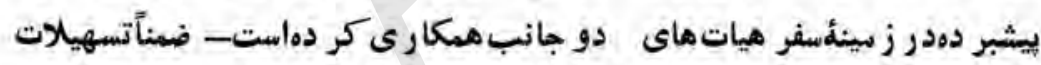
سسافرت هيأتهاى مطبوعاتى - ز و ر نالستان -خبر نغار ان و عكاسانرا فر اهمباخته و خدماتيو نسكو ازطر يق ارتباط فو هنكى باسايو مؤ سسات

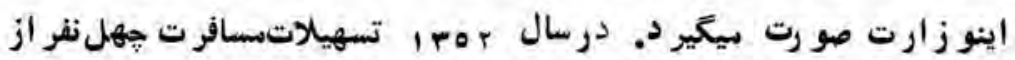

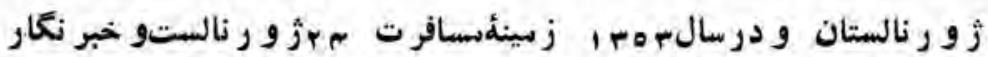
به ممكارى دو اير نشر اتىى تهيئ رايو رو سصاحبه فر اهمكر ديد. در بهلو ىطر حو تطبيق باليسى كلتو رى دو لتجمهوى در داخل كثور و ز ارت اطلاعات و كلتو ردر ز مينهتو سعdعلايق كلتو رى و سعر فىار زشهاى 


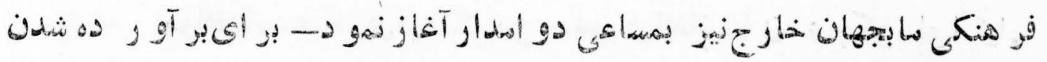

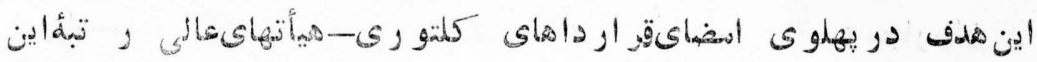

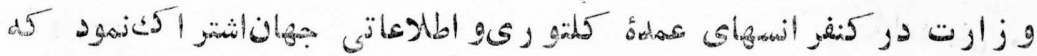

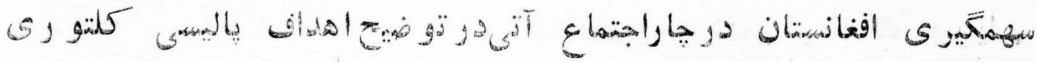

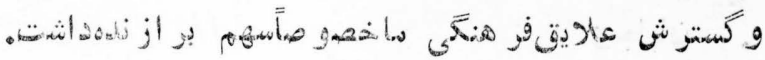

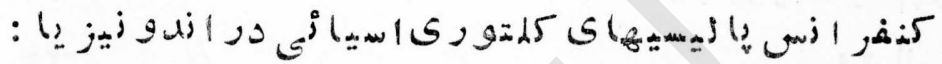

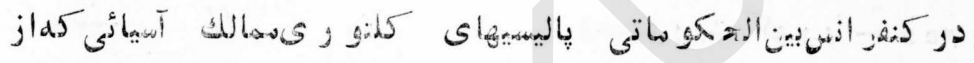

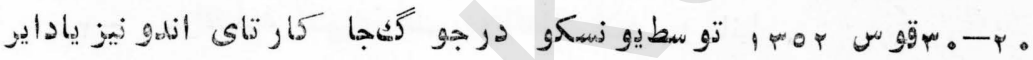

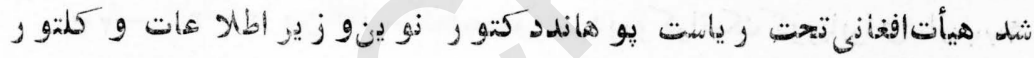

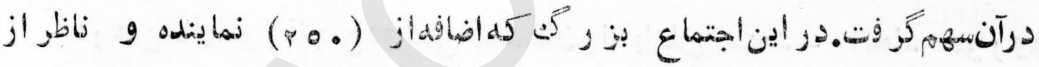

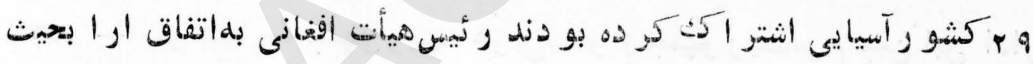

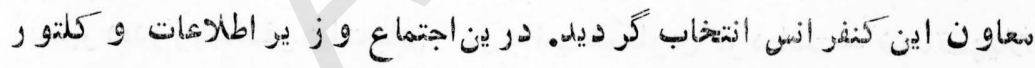

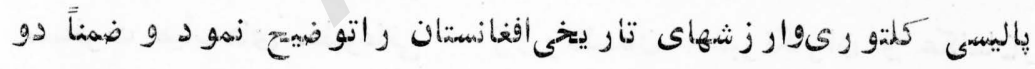

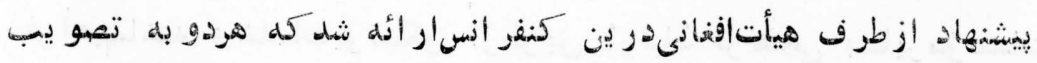

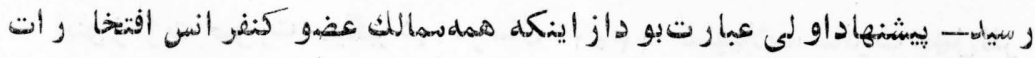

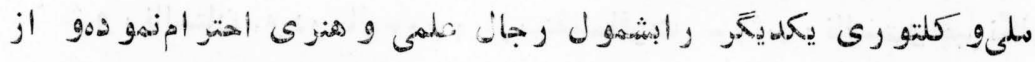

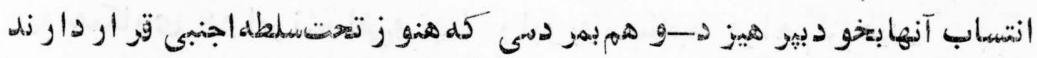

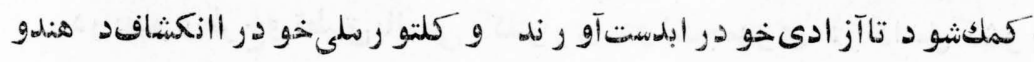

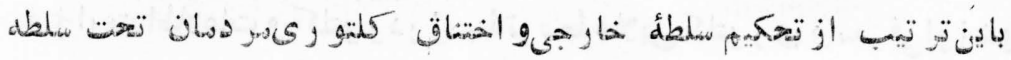




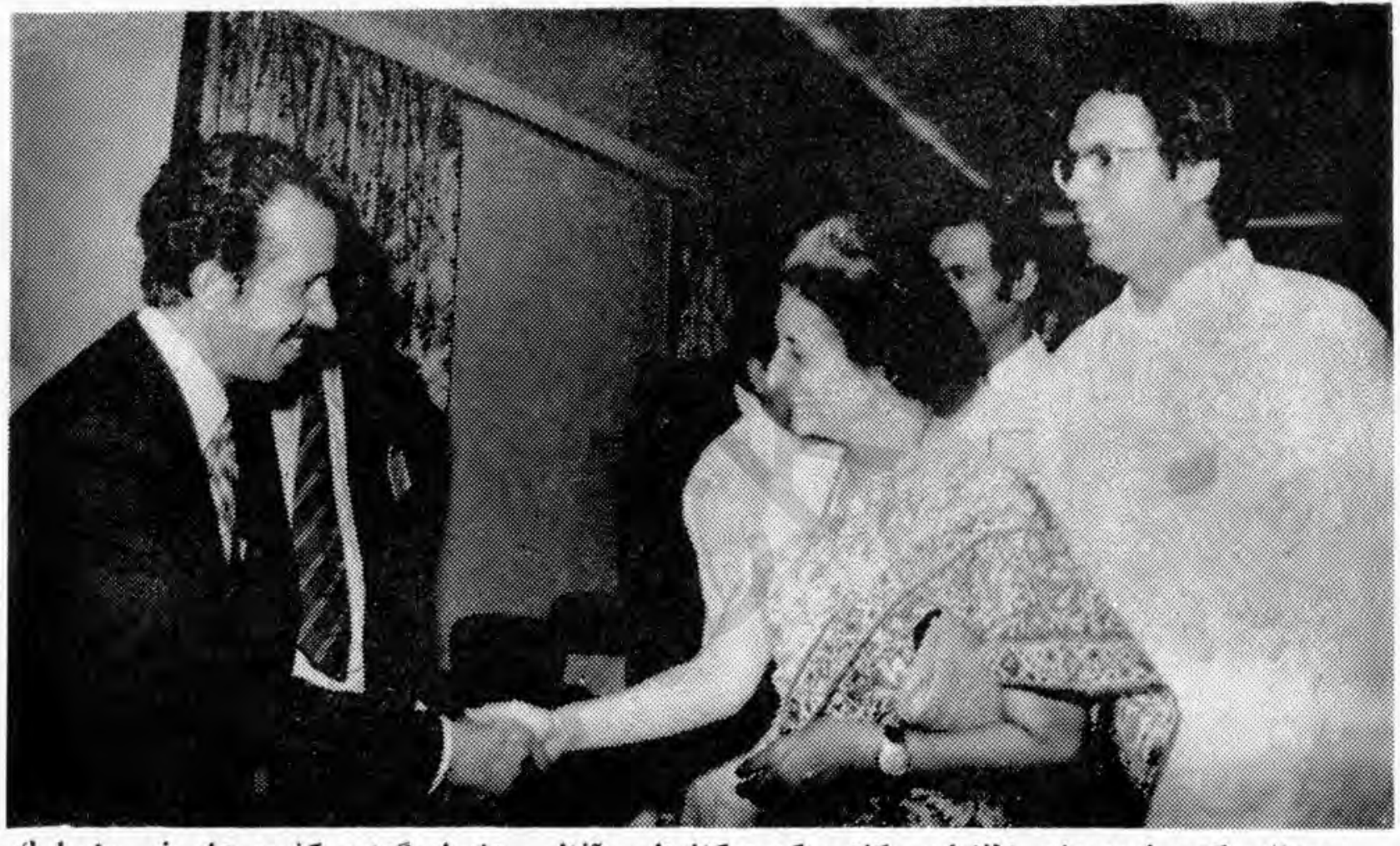

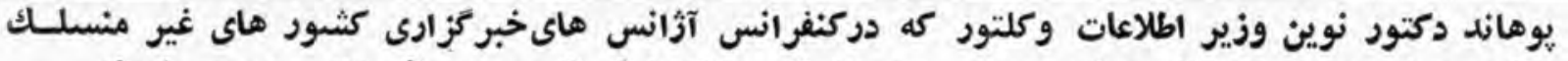

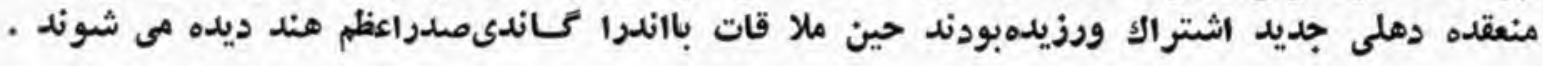




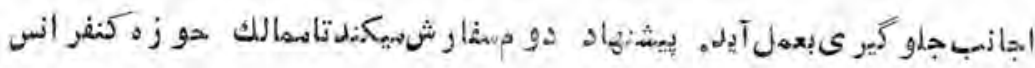

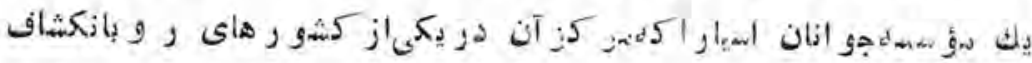

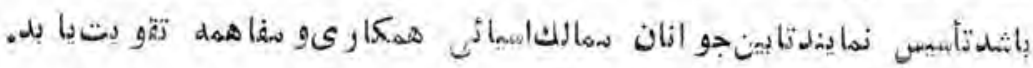

$$
\begin{aligned}
& \text { ك:خر انس } \\
& \text { : كشور }
\end{aligned}
$$

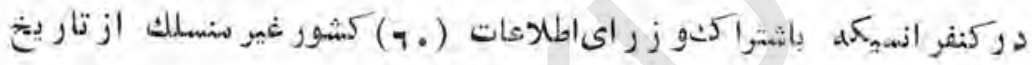

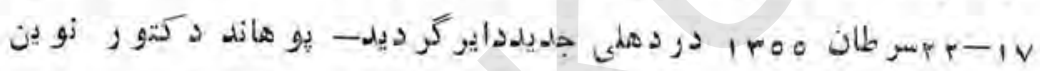

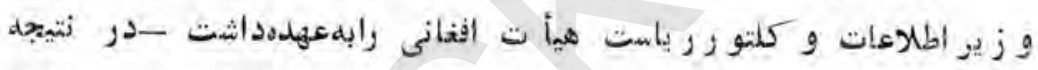

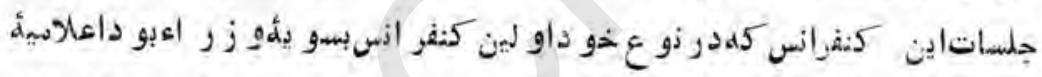

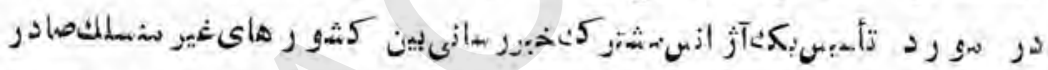

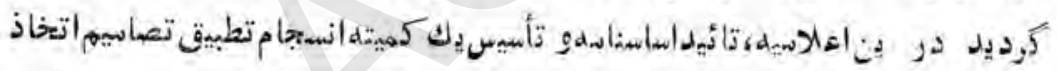

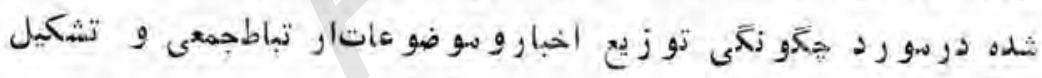

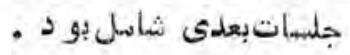
بو هاند دو كتو رنو ين رئيس هيأتافغانى درجر يان جلسات اين كنفر انس

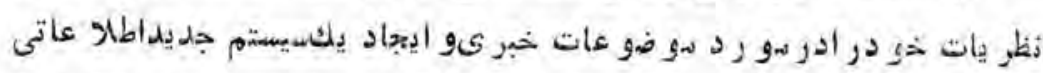

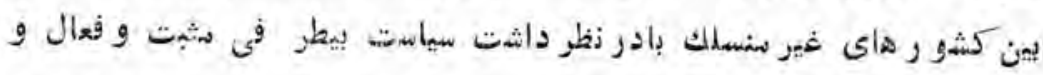

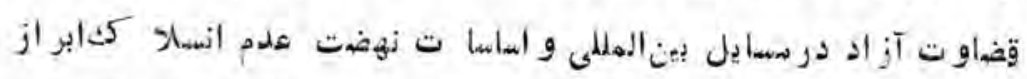

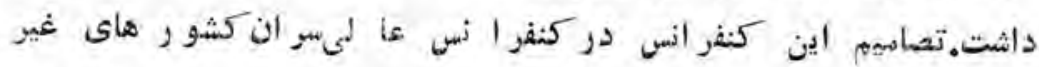

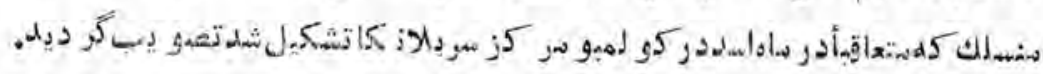




\section{كنفر انس عمو مي يو نسكو در نا يرو بى :}

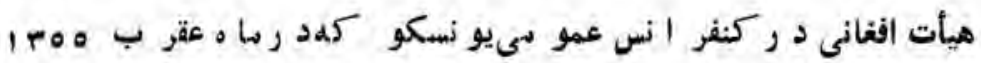

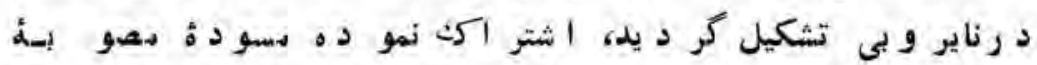

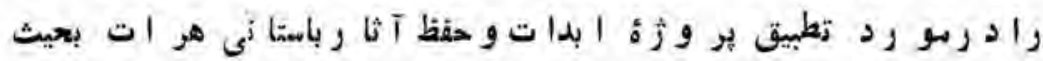

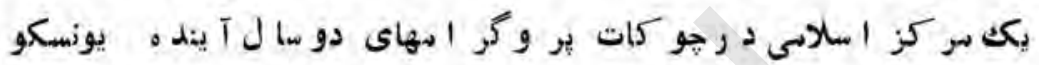

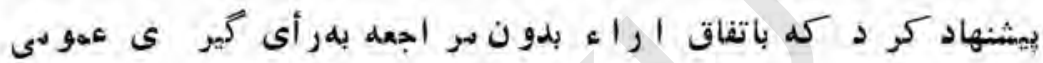

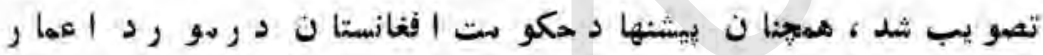

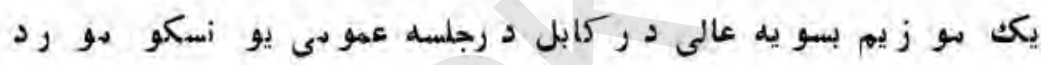

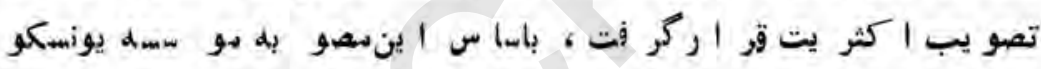

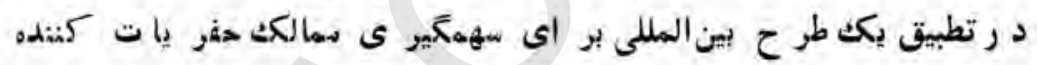

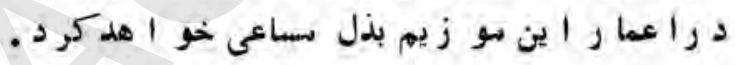

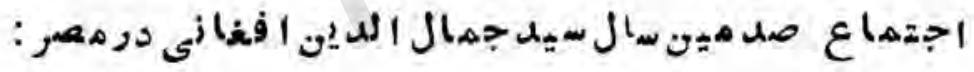

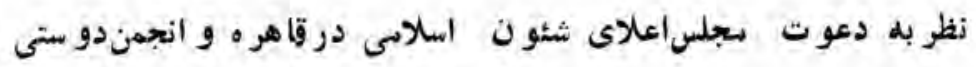

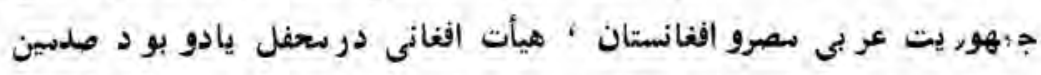

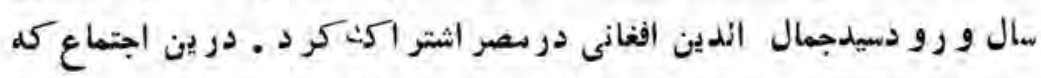

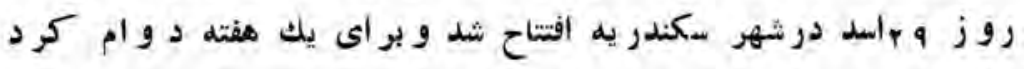

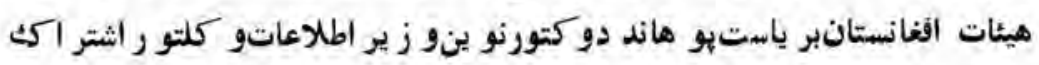

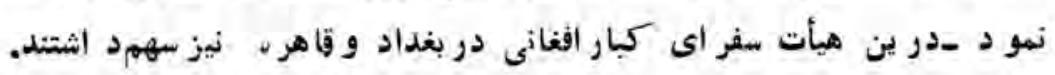




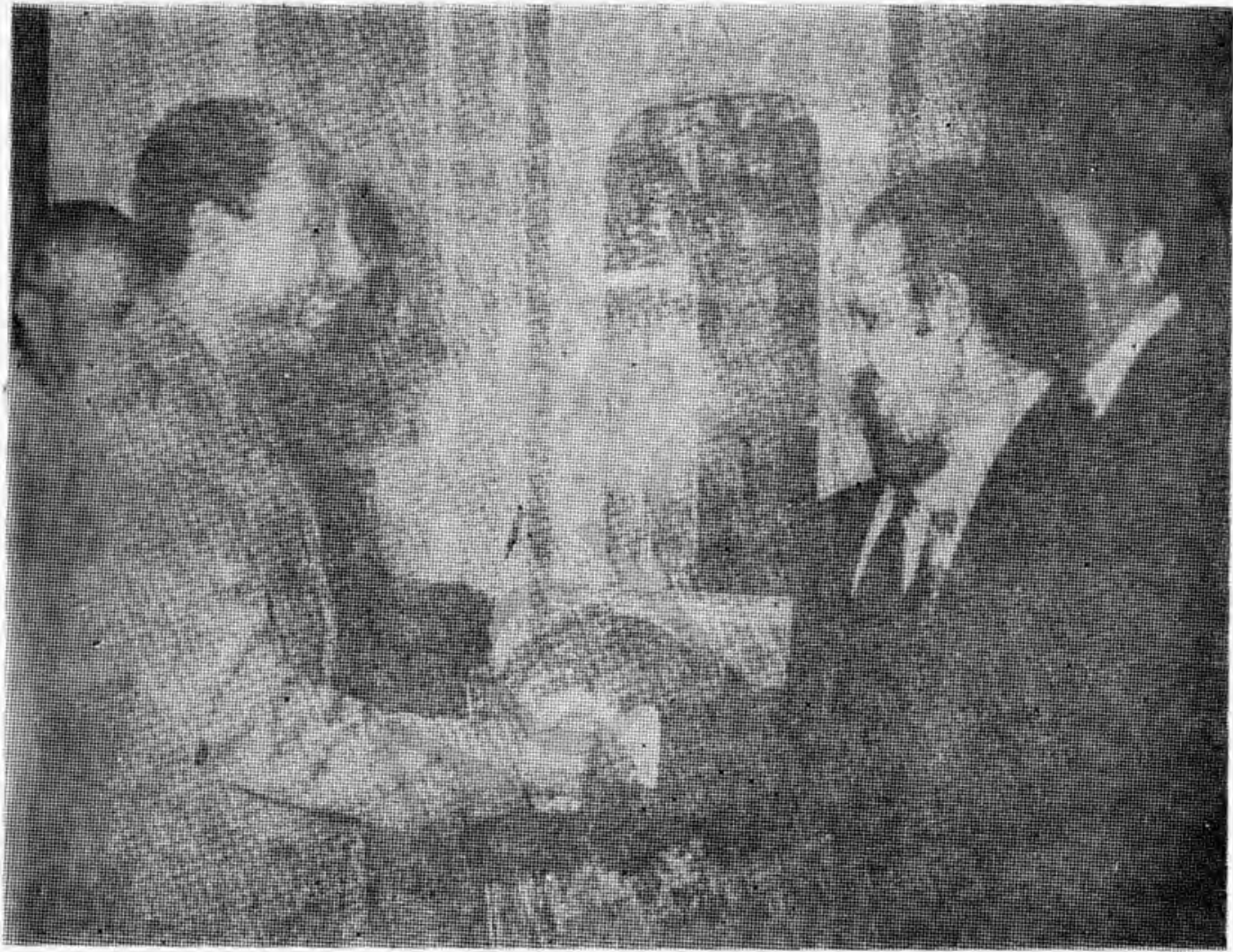

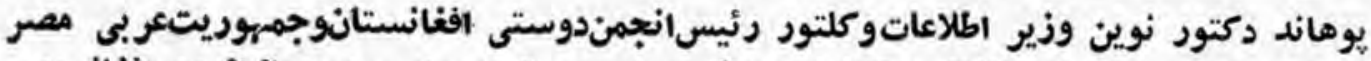

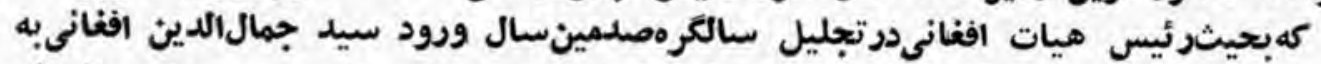

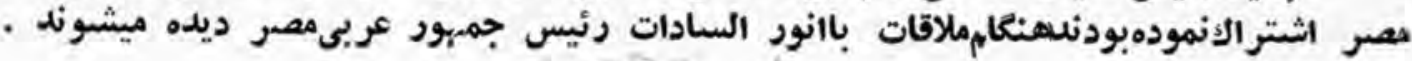
230 al 

$(r+1)$
كنفوازي 10

در احتفال سكندر يه ييام بناغلى رئيس دو لت وصدر اعظم كه بمناسبت صدنين سال وورودسيد جمال الدين الغانى به بصر صادرشده بود توسط يو هاند دكتو رنو ين قوائت كرديد. در ين يبام بناغلى رأيس د و لت و صدر اعظم تو ضيعداشته اندكه (مائه امتنان زياد است كه دولت د و وست و برا درمصز صدمين سال ورود سجاهد وفيلسوف بز ركت سيد جمال الدين افغانى ر ا به آن كشو ر تجليل مينمايد و بنياد عميق بو ادر انله د و سلت

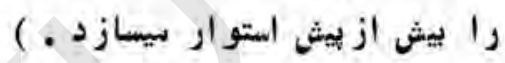

همجنان يو هاند دكتو ر نو ين ضمن بيانية ازين اقدام سقا مات فر هنَّى كشور برادر بصر اظهارتنشكر نمو ده سهمكيرى تاريخى فوزند نابى افغانستان سيدجمال الدين افغانى رادر راه بيدارى جهان الها م توضيح نهود ـ. درين احتفال كه مقارن به ايام اجتماع جو انان كشور هاى اسلانى

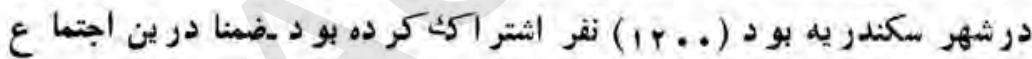
رسالل كله بد ين هناسبت ازطرف وز ارت ا طلاعات و كلتور به بيتتو

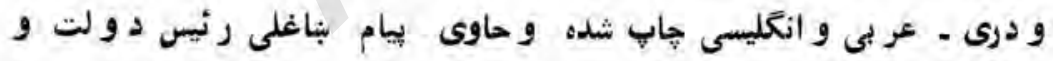
صدر اعظم، يبانية وز يو اطللاعات و كلتور و وعلايق عميق فر هنَى بين دو و كشور بر ادر افغانستان و سصر سيباشدتو زيع كرديد .

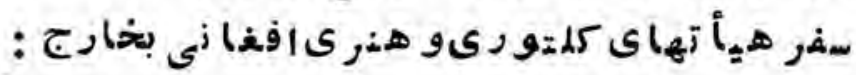

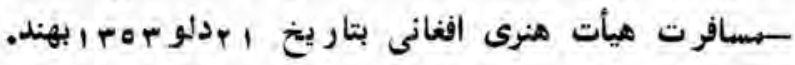

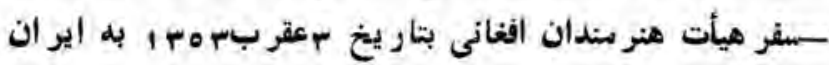

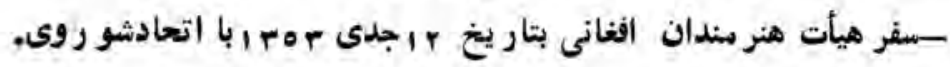




\section{إج آث}

$(r+r)$

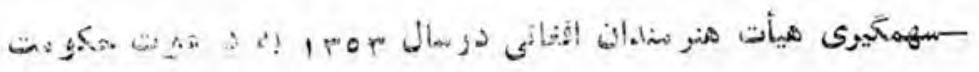

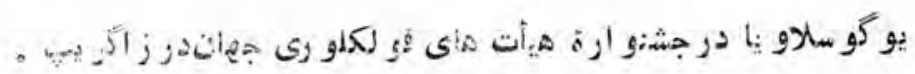

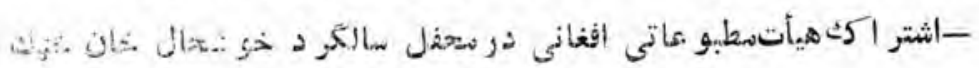

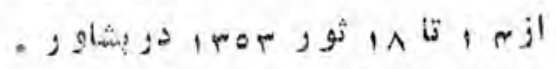

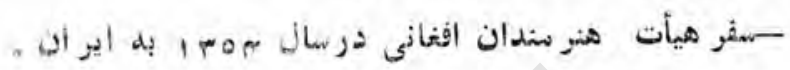

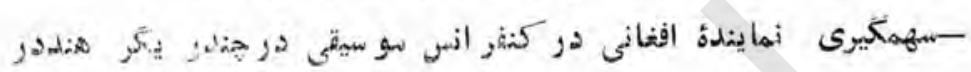

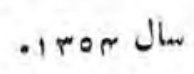

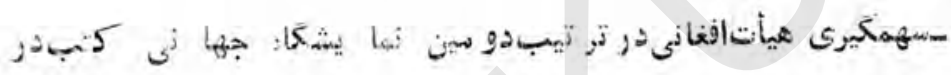

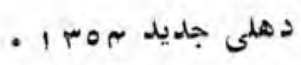

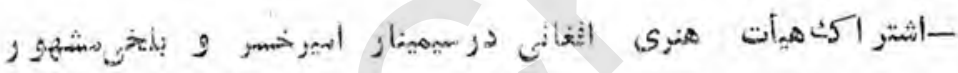

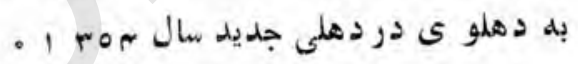

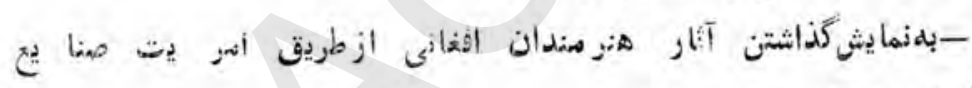

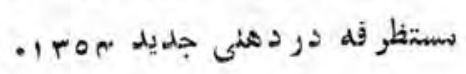

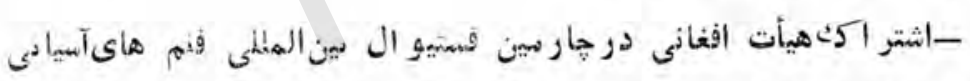

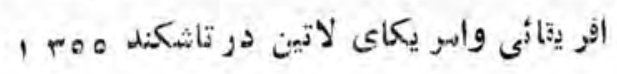

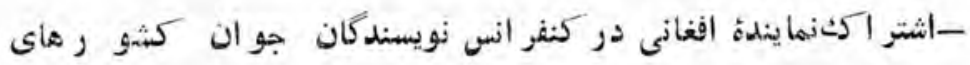

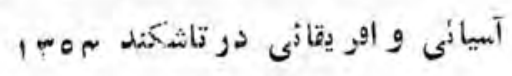

-اشتر اكثهيأت الفغانى در كنفر انس كشو رهاتى اسلاسى در استانبون 


\section{كتاب باليسيى كلتو ر ى}

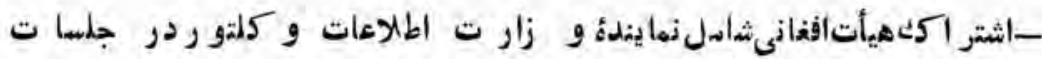

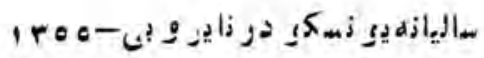

-

$$
\text { : }
$$

بلهمنظو راينكه ياليسى كلتو رىدو لت جمهو رىدر زمينهآ أهاهى -تنو ير

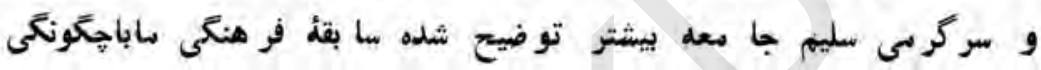
خdنات و زار تاطلاءات و كلزو ر از طر يقدو اير نشر اتى و فرهنَى خصو صا

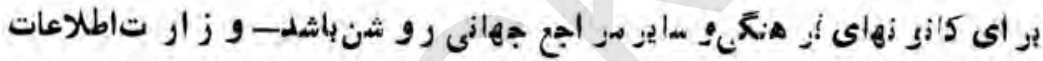

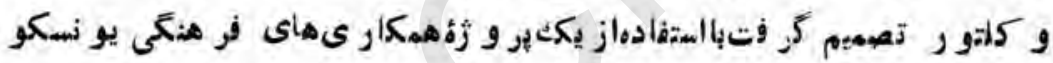

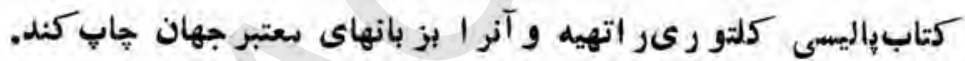
لذا رإليسى كلتورى كهازطرفاينوزارت بز بان انگليسى تهيه شده بو د دراوايل سالهوه ابهاداره يو نسكو درويار يس تسليهم دادهشدو

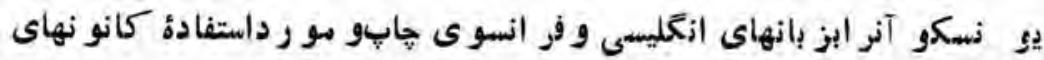

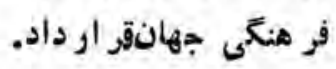

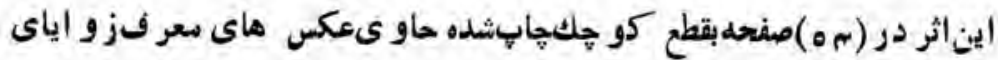
فر هنكى ماو خار تهاى در بارة فعاليت هایىمبو عاتى كثو ر ميباثد.

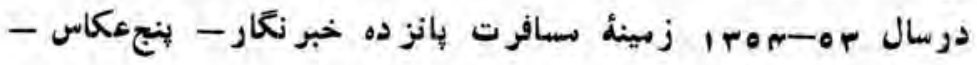
هجده هيأت فلم بر دا رىدر كثو ر فو اهمشدهو تسهيل ت جهت تهيئ سطا لب 


\section{اجرا آت اطلاعاتى و كلتورى}

$(r+\mu)$

و سعلو سات در باره انكشاف و زو اياى فر هنكى كثو ر بر اى شان فر اهم كر ديد.

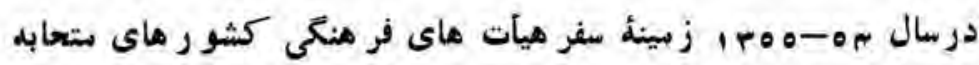

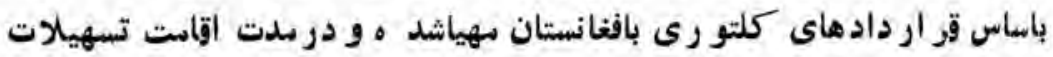

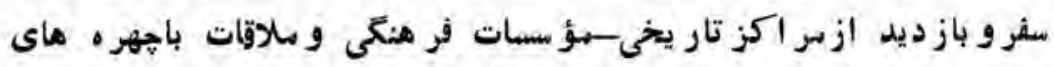

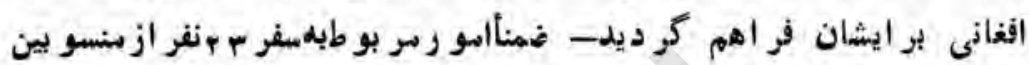

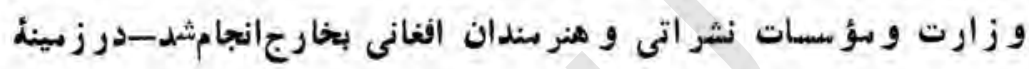
تدو يو نندار تو نها بهناسبت رو ز هاى ملى كشو ر هاىمتحابه و نشايش فلههاى

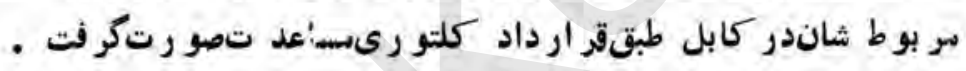

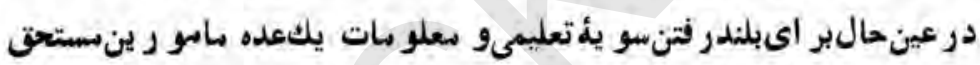

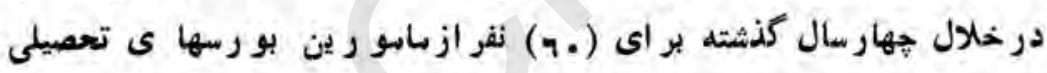

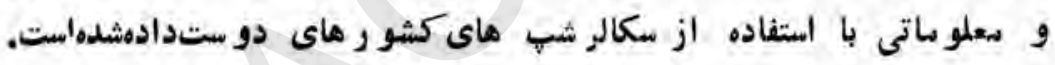

\section{جو ايزمطبو عانى :}

بمنظو رتشو يقدانشمندان نو يسندكان و هنر مندان كشو رو سهمكيرى در رشدسو ئعلمى- فر هنكى و هنرى جانعه و بر ايى بميان آندن آثار بكر و سمتاز

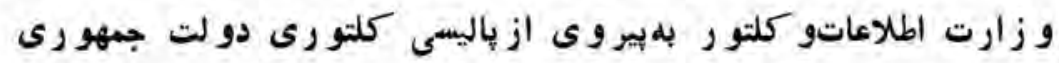

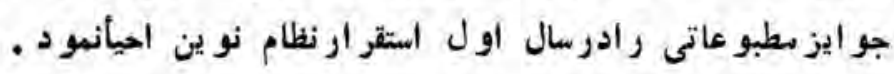

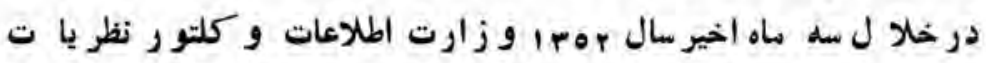

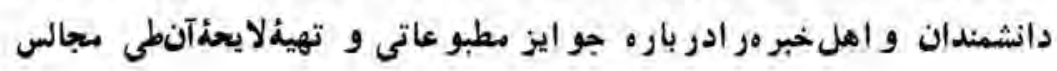




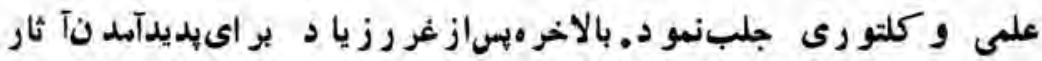
ارز شعنددر لسانهاى بنبتو ودرى لايحلجو ايز مطبوعاتى وكلتو رى ادر

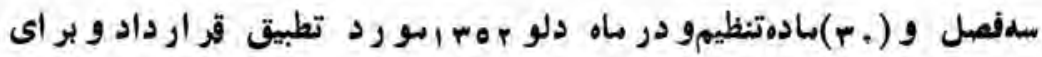
يبشبرد امو رآنادارؤجديدى رادرتشكيل وزارت بميان آور د.انتشار اينخبر وجلب علاقمندانـدر خلالسلهاه اول يكتعدا د زياد اثار خود را د انشمندانونو يستدكان براى كاند يدد رجمله جو ايز مطبوعا تى باين

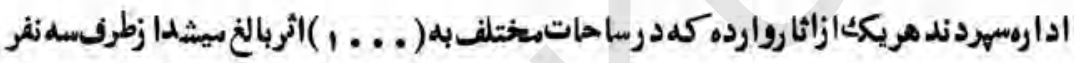
اشخاص صا حب نظرملاحظهشدو نظر شاندر ز مينهاخذكر ديد_البته تمام آثـار رسيده از لحاظ مهتو ا به ينج رشتهعلو م طبيعى -علو م اجتماعى- ا دبي-هنري و و سايل اطلاعات و آثار كلتو ريتقسيم شد. كميسيو نها ي باصلاحيتى بر اي

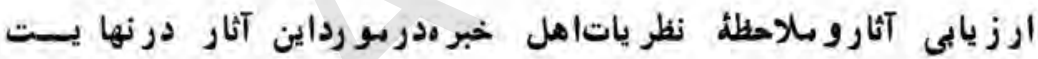
تشكيلو آثار بر ازندهو سمتاز وارده ر اسستحق جو ايز سطبو عاتى وجو ايز تشو يقى شناختد كمرو ز مب سرطان rorrاين جوا يز از طرف بوهاند

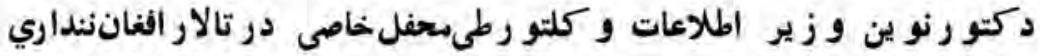

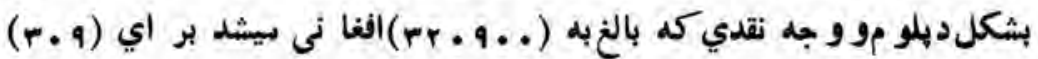

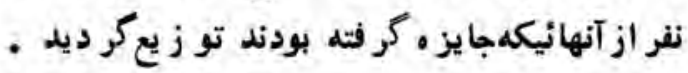

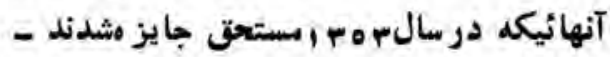
10
ا-هدر ر شتهعلو مطبيعى
" $\%$
ب-در رثتهز و رناليز م 


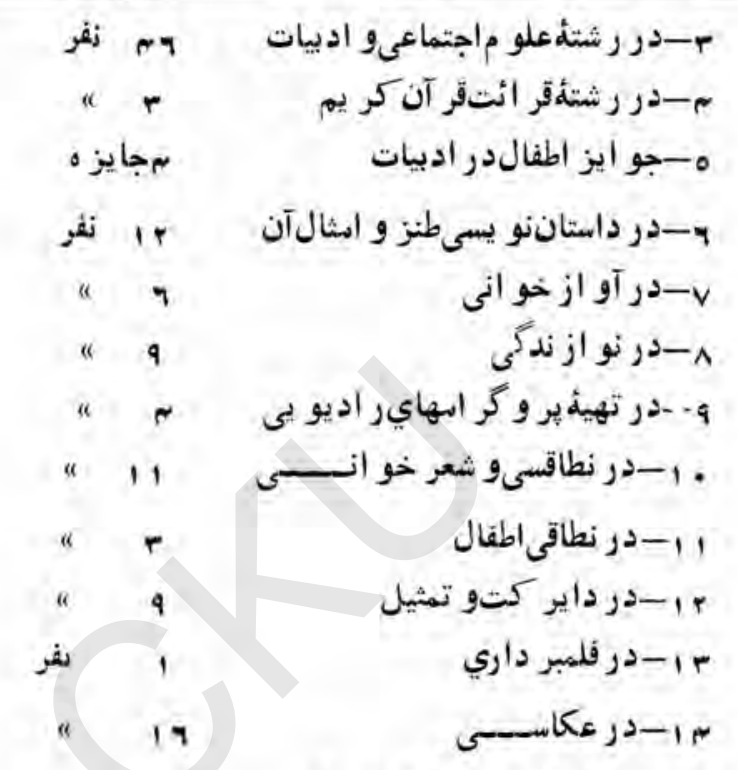$$
\text { (10 }
$$

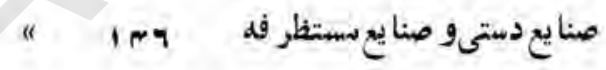$$
\text { " is }
$$

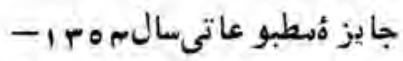

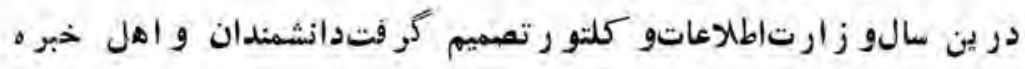

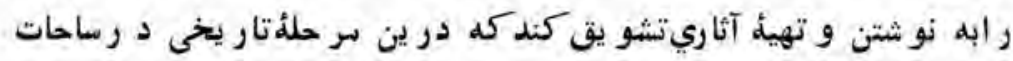
ازكثاف كشو رو آو ردن نتولاتاساسى مهد اهد اف انقلاب جمهو ري و تحقق آنو اقعثو د. لذابلهمكاري دانشمنداندر نتيجة تثكيل يكث كميسيون

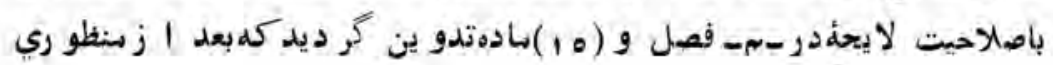



(rrv)
جوايز بمبو عانى

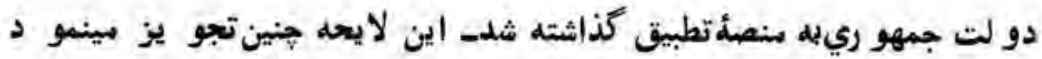
تا فهر ستى ازعناو ينمتخلفدرز مينه هايمر بوطبمسا يل رشد اجتهاعى اقتصادي-مو ضو عات اداري-صنى -بلدير ششد فر هنَى و سياسى - مطالعات تار يخى- جغر افيا و فر هنكَ سر دم افغانستان ،تحو لتار يخحى و معا صر ا دب افغانستان و هنر هاي ز يبادر هفت فصل تر تيب و از طر يق منابع نشر أتسى

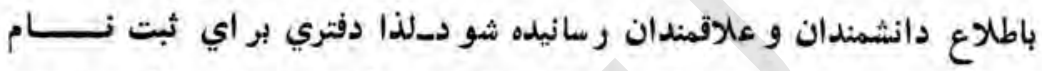

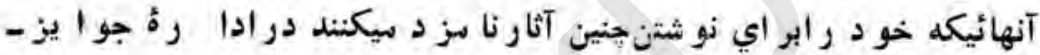
كُشو دمشد. همجينان بر ايسهو لت كارو تشخيص آثار ( كميسيو ن تشخيص قبلى )ازطرف و زارت اطلاعات و كلتو رتشكيل كُ ديد تآ ثار ر ر ايبث از

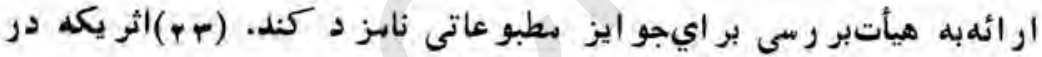
رشته هاي فر هنكى اجتماعى اقتصادي-تار يخحى -ز ر اعتى و غيو ه بر ايجو ايز مطبو عاتى ازطرف كميسيون ناسز دشده بو د بملاحظئ هيأت هاى سه نفري رسانيده شدو (. . ب) اثر هنري در نمايشكاه سو رد نمايش و قضاوت همو طنان

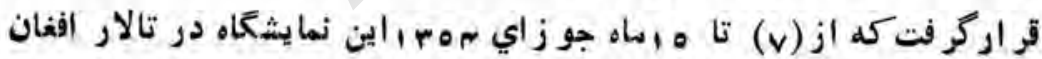

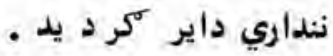

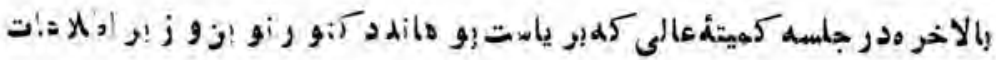

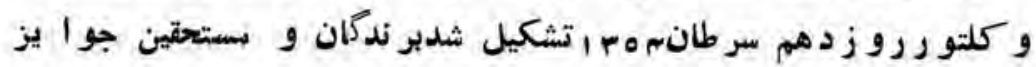

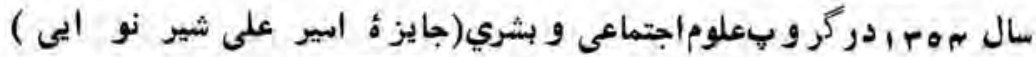

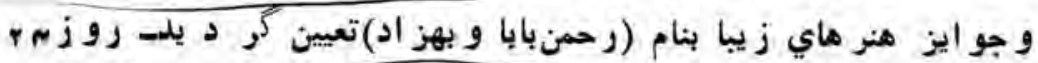

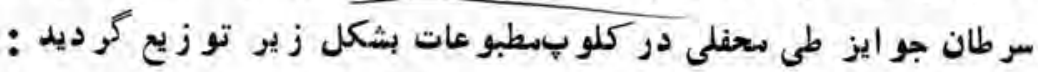


اجرا آ تاطلاعاتى و كلتورى

ا-سجايزة ابير على شير نو ايى بر إى كتاب تحتعنو ان(تالين افغانى )

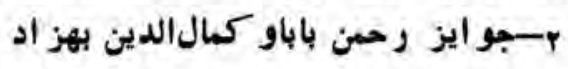

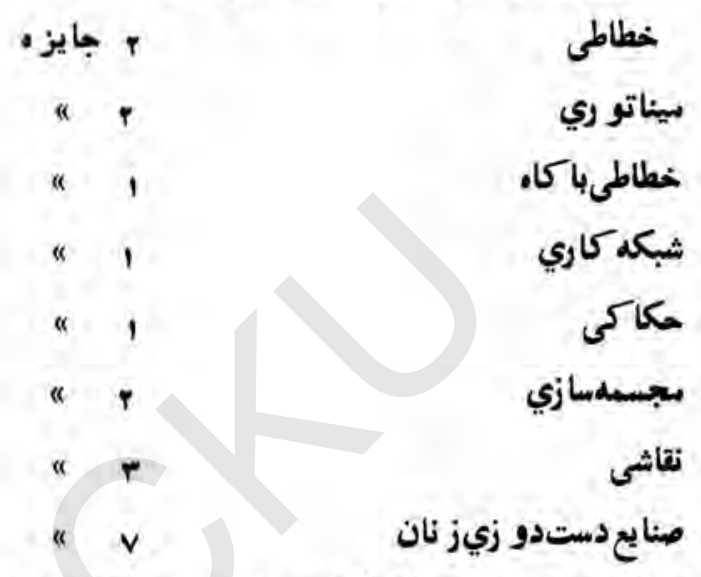

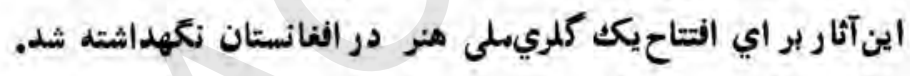

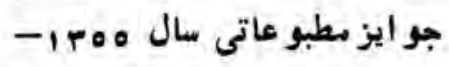

بر ايا ينكه آثار بكرو مفيد بمنظو رتنو ير و تر بيئطفل بحيث نسل بسئول

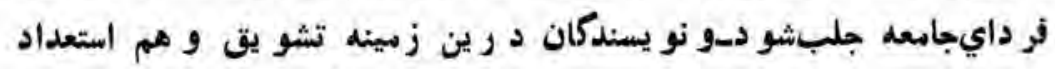

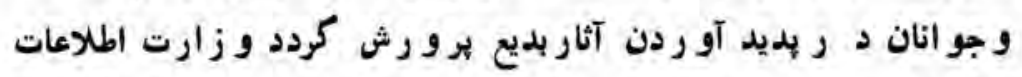

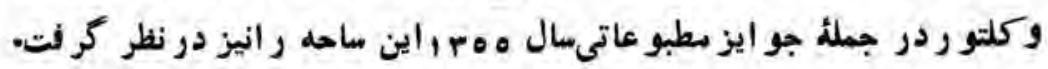

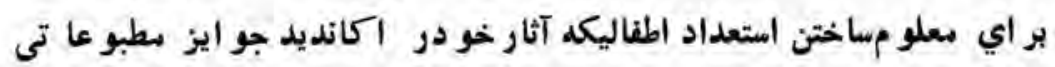

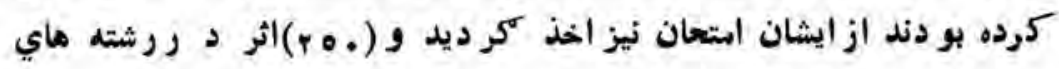

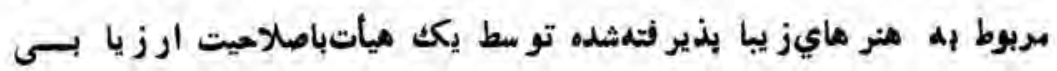

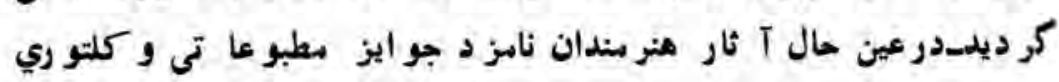




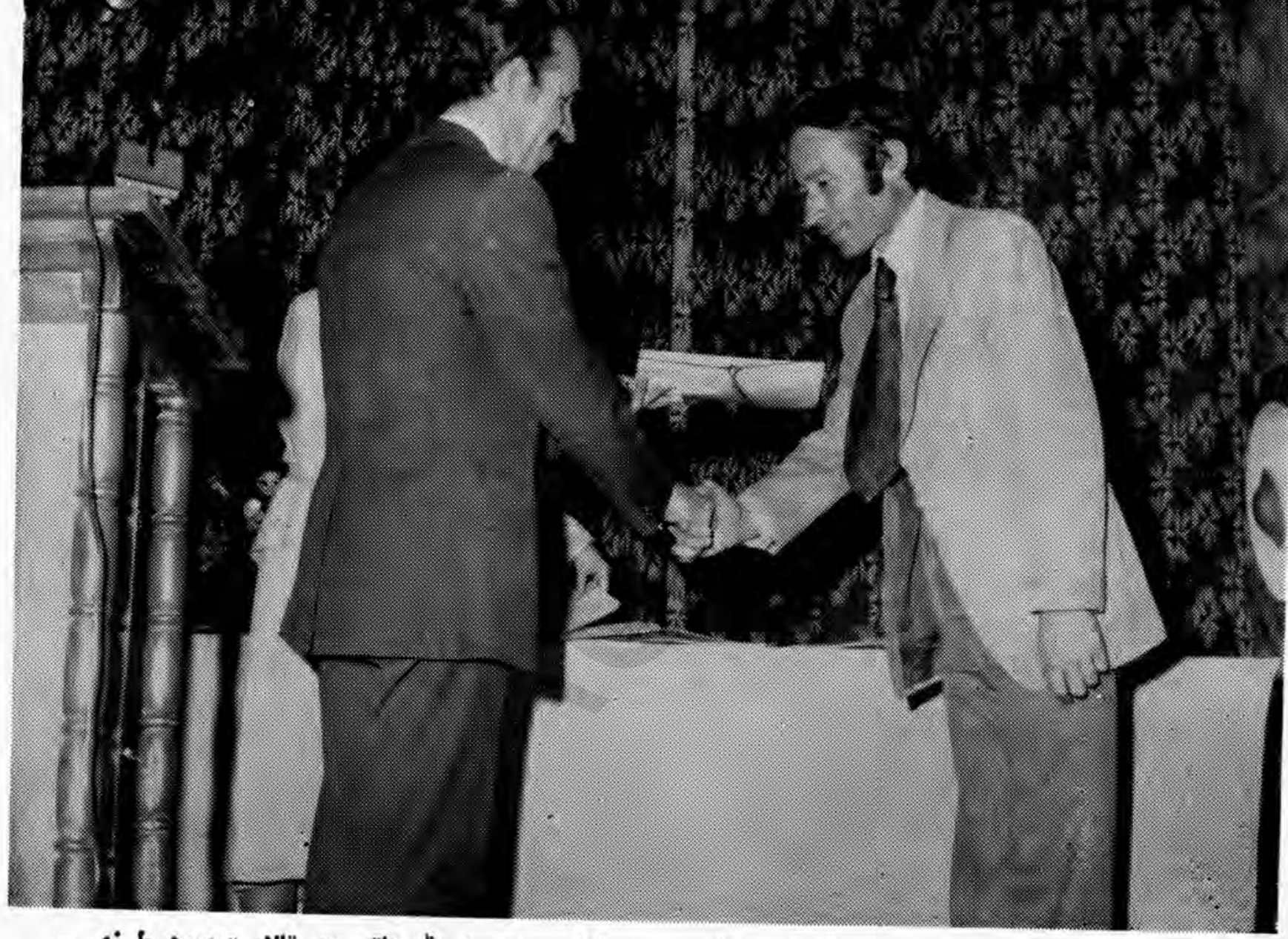

ـ يوهاند دوكتود نوين وزيـــر اطلاعات وكلتود حين توزيع جوايـزمطبوعاتى در تالار امحمود طرزى - كلئ

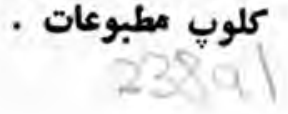




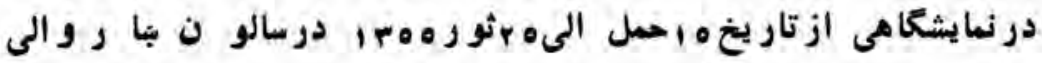

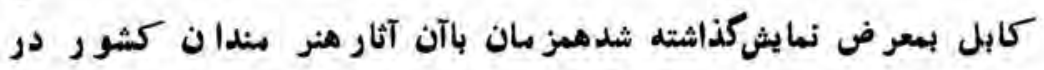

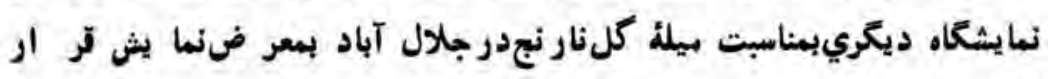

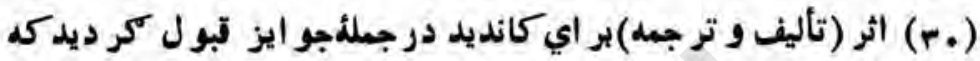

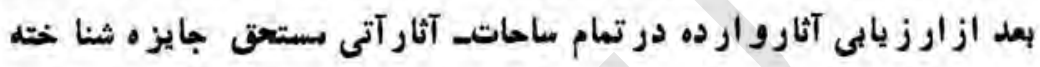

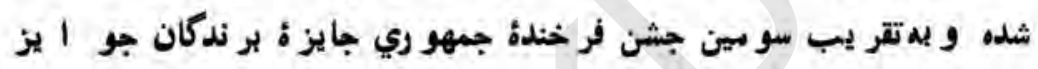
طى منفلى توزيع كر خيد :

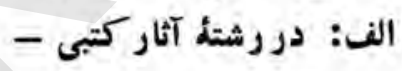

ا 1- إركرو بخو شحالخان " $r$ " 1 " $r$

• a $r$ " $r$ " 1 a 1

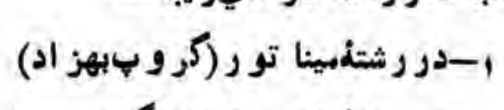
r-دركر و بسيدجمال الدين افغان r-دركر و بامير علىشير نو ا يى ب-دركر و باينسينا ي بلخى r-در رشتdنقاشىرو غنى(كر و بجساسى ) r-r م-در ر شتهيسمهسازي(كر و بجسابى) م-در رشئشبكه كاري(كر و بجسابس) ب :در رشتله هنر هايز يبا - بائ 


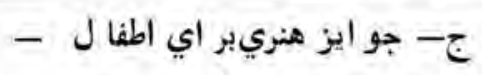

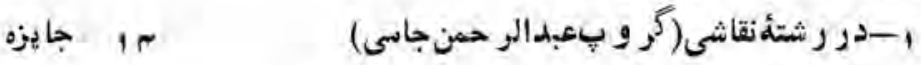

r- rدر رشته خطاطى (كر و بر حمن جانى)

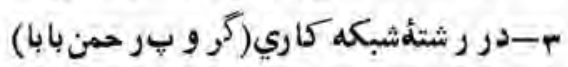

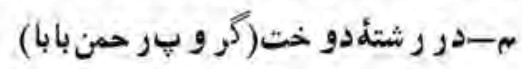

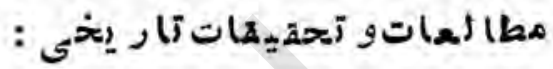

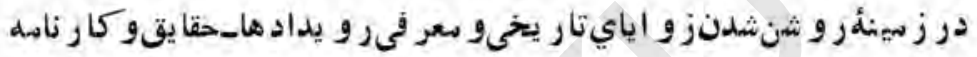

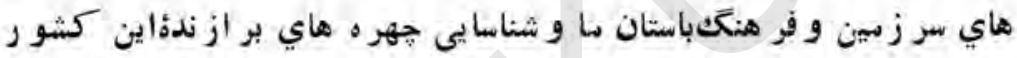

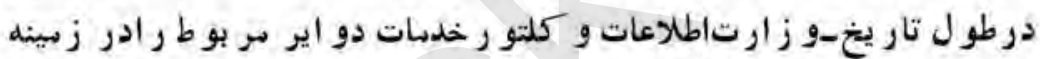

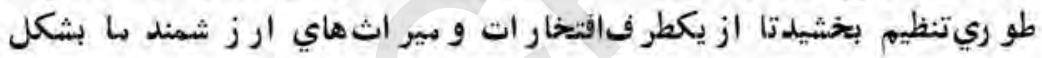

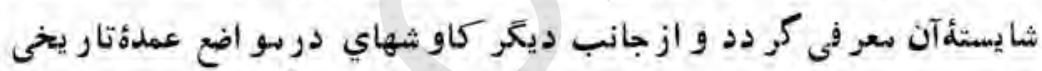

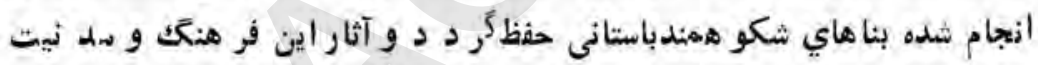

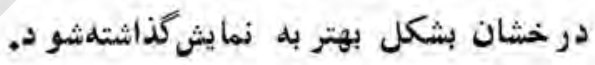

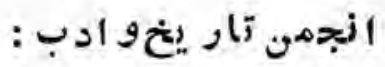

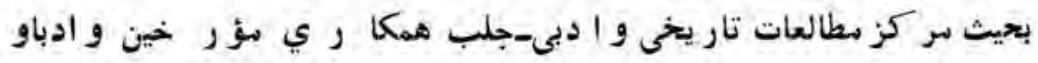

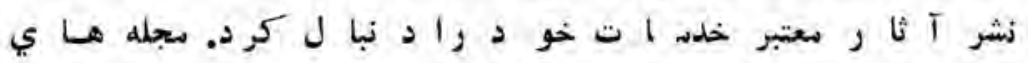

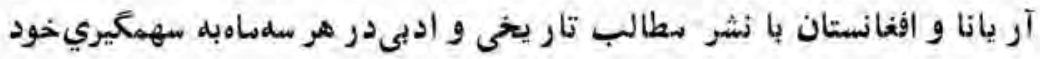

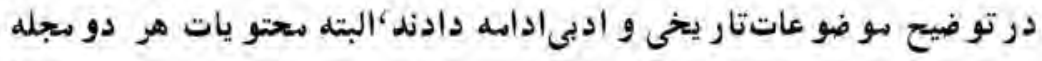

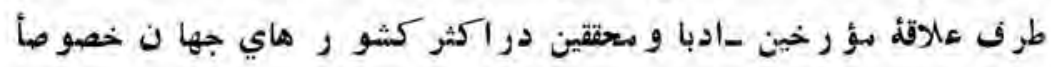

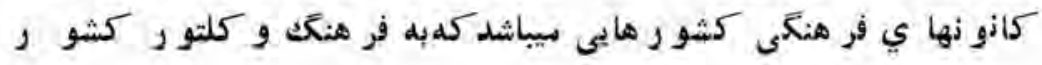



$(r \pi 1)$
ازيجن تانز

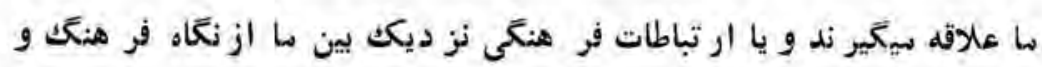

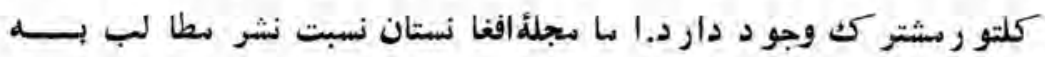
ز بانهاي انكليسى و فر انسوي بيشتر درحلقه هاي فر هنكى خارج راه دارد زير ا اينمجله سستقيماً طرف مطالعه و استفا دهُ شر ق شنا سان و افغانستا ن

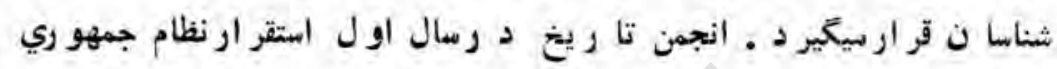
1, 1ror-or

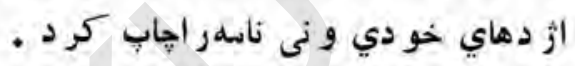

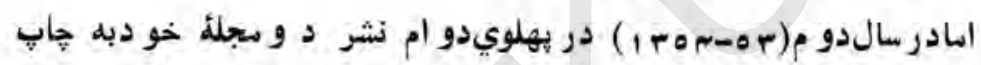

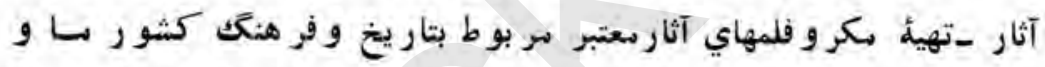

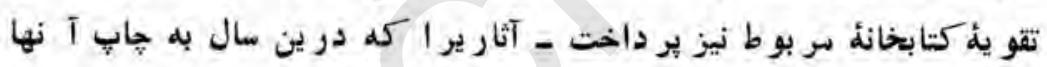

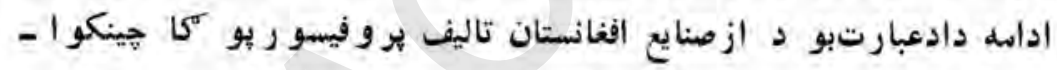

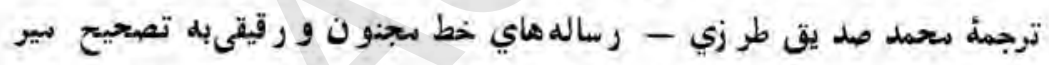

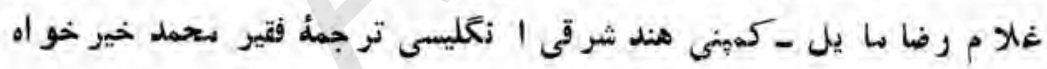

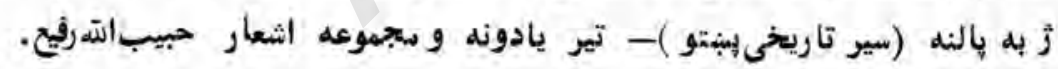

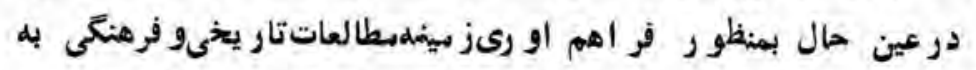
تهيه مكروفلموفوتو كائى كتب واثار معتبو معر ف كلتور كشوربهشرح اتى اقدامشد:

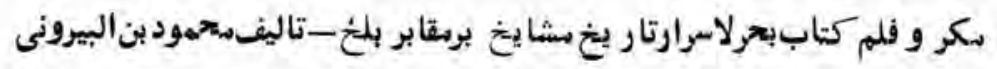

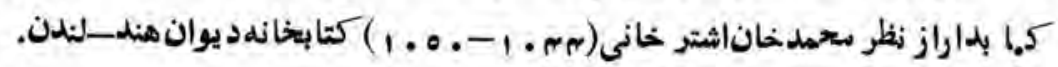

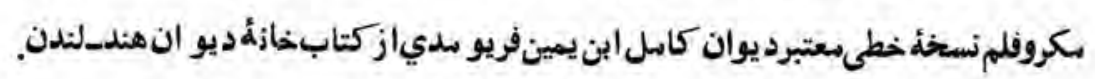

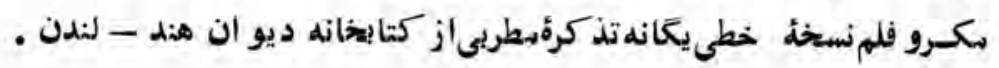


جرا آ ت اطلاعاتى و كلتورى

$(r<r)$

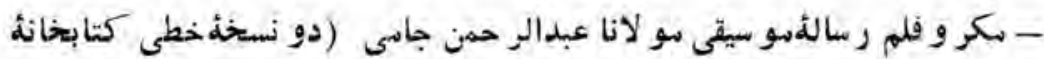
تو به سعابر سو ائى الستانبول لـتر كيه ) .

ـفو تو كانيى ديو ان خطى تيمو رشاه در انى( بز بانها ي ينجتو و د ري)

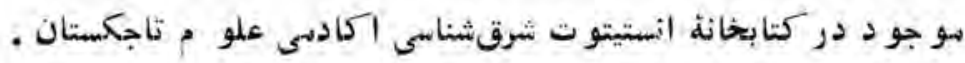
درعين حال انجهن تار بيخ و ادببه افز ايشمبادلة آثار با سر اكز فر هنكى

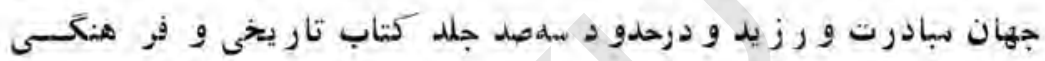
بر اي كتابخانه اختصاصى آنتهيه شدسأين ادار مدر سيهينار بو لاناجلكل الدين

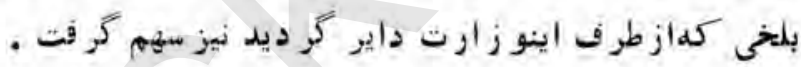

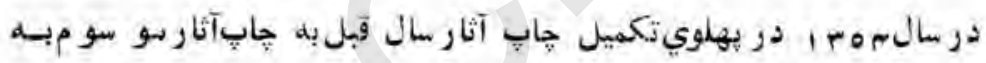

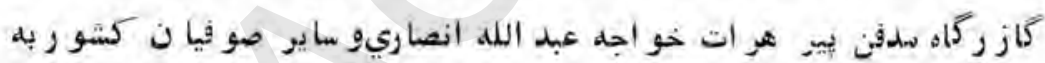

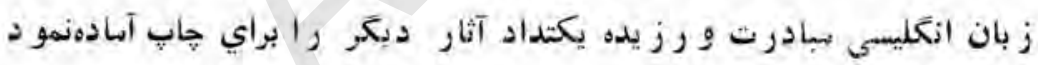

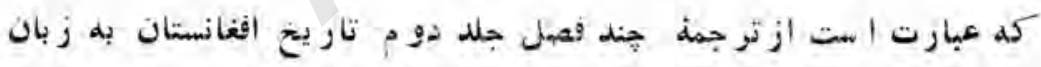

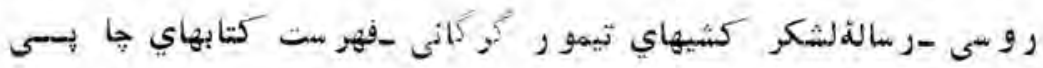

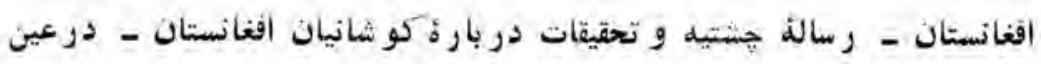

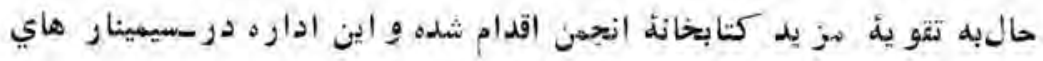
تجليل ا ز زثخصيتهاي ابو نصرقار ابعىدقيقى بلخى و خواجه عبدالله أنصاري هو وينيز درحصنخو دسهم كر فت. 


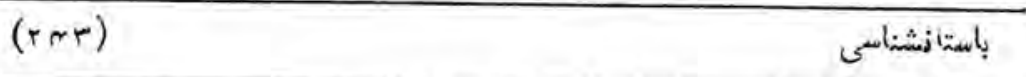

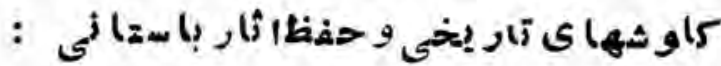

هو ن رو شن ساختن زو اياو افتخا رات تار يخى كشو ر با تو سعه حدو د كاو شها و حفظابدات باستانى يكى از اهدافبز رك دو لت جمهو ري رابر اي رو شن شدن زو اياي تار يدخى اين سر زبين بحيث كهو اره تمدن آسياي سو كزي

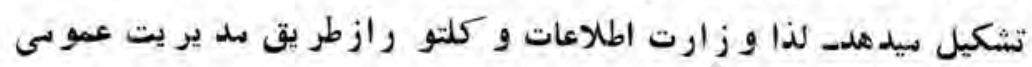
باستان شناعى و حفظابدات تار يخى خدهات در ين زمينه رابا تو جلهبه جهار ساحئَآتى توسعd داد : ا-ماو شهاي تار يخى دروساحه هاي بز رك باستانى .

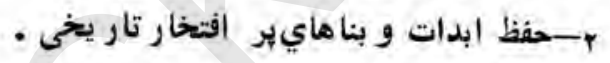
م دستر سى به تعدادز ياد آثارقيمتى و لير و رش كار كنان و جو انان افغانى در ماحله حفر يات ، تر بيم و حفظ ابدات . م-طرح يكك بلان جاسع بر ايتر ميمرابدات مهمتارئخى درسر ا سر كشور

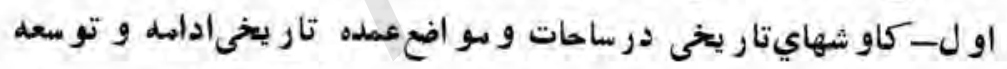
داده شده و بادر نظر داشتاصل ارجحيت و درحدو دادكاناتمالى و بر سونل باستان شناسىاين فعاليت دنبال كر ديــ در سال اولاستقر ار نظام جمهو ري دو حفر يات د ردو سا حه مختلف

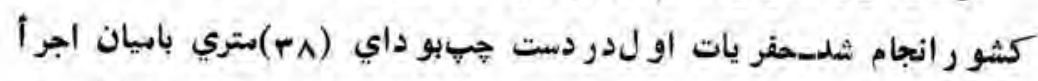

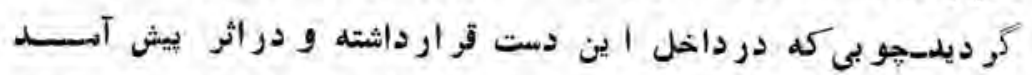

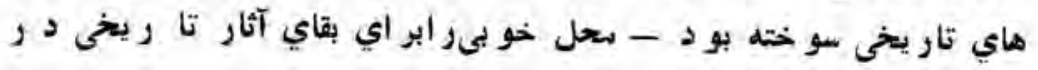




\section{ا جرا آت اطاط عاتى و كلتور}

$(+\% \mu)$

هو و رقو و ن و اعصار تشكيل ميداده است- درجوفاين بازو تير هاي جنكى

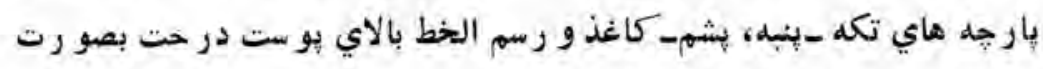

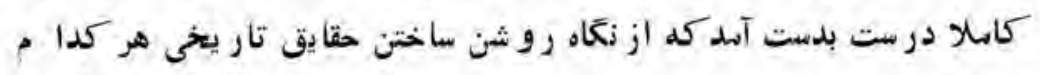
ار زش خاص دارد. - مار.

ساحلدو م كاو شها دو رؤ شيثم حفر يات تبلشتر هده در زمستا ن سال

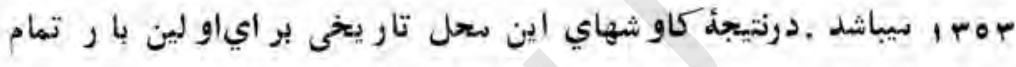

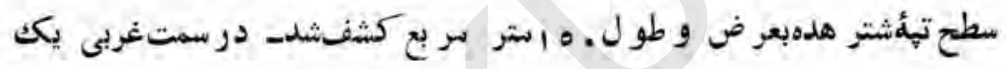

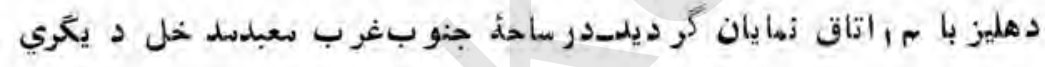

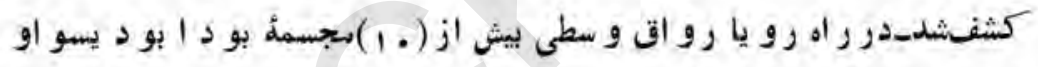

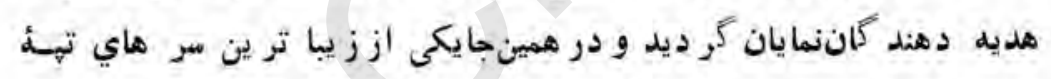

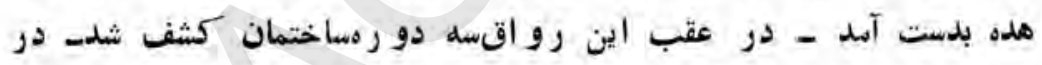

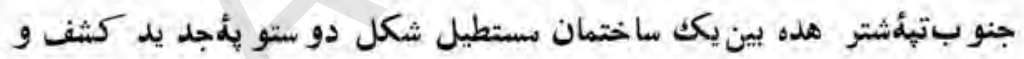

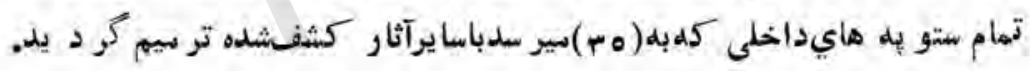

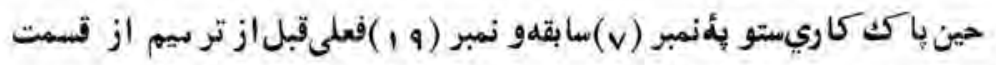

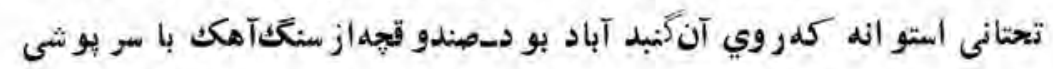

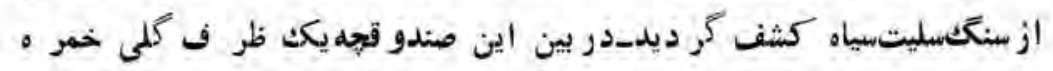

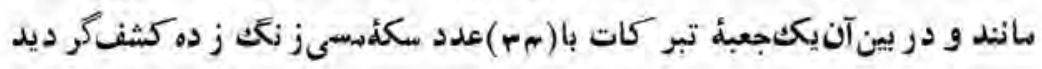

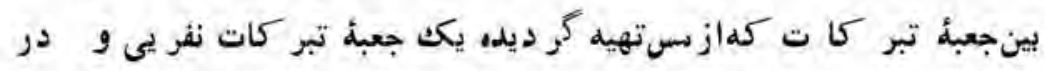

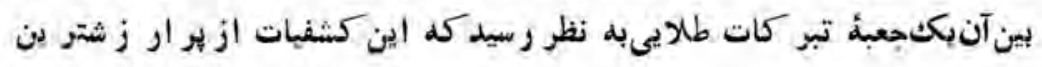



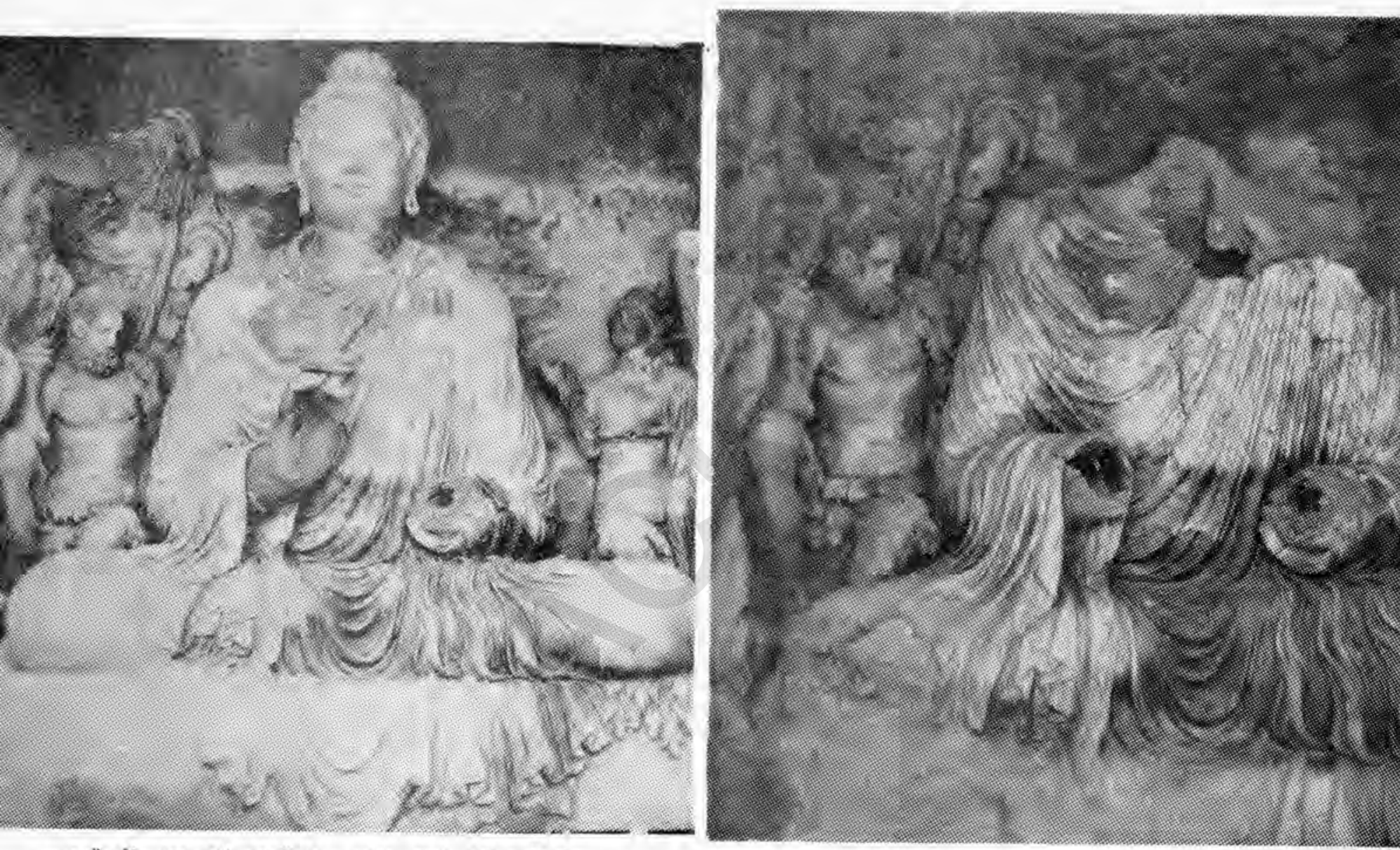

ـ حفريات تيه شتر هلده دوا ق (و-r)، بعد از ترميه.

- حفريات تهه ثتر هـده رواق (و-r) ييثل از حفر يات.

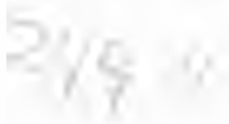


كثفيا ت تا ر يخ با بدتان شيا سى افغا نستان ينداشته ميشو د ـدرعين حا ل كا و شهاي در سمتشمال معبد در حجر مٔر اهنين صو رتكر فتس درجناح شمال غرب معبد نيز كاو ثنها يیى صو رت كرفت كه در آنجا در بهلوي د و رو رو اقى كله مابق كشف شده بو ديكك رو اق جديد كثف شد كه نه تنها ازمهمل تر ين رو اقهاي اقغانستان ينداشته نيشو د بلكه از كاملتمر ين رو اقدر آسيا بشما ر سير و دمدجسمه ها همهتر بيم و جابجاشدنداين سه رو اقدر غرفه ها ي آهنى هنو ظانكهداثته شده است. دو رؤ نهماين حفو ياتدر زمستان همبرادنبال كرديد - د ردو رؤ دهم

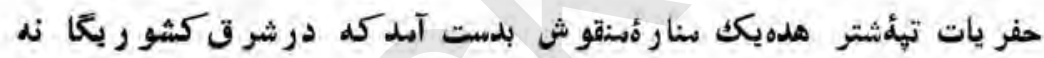
منارة منقو ش بنداثته سيشو د. درعينحال در بعضىساحات ديخر تار يخىى حفر يات ازطرف هيأت هاي باستان

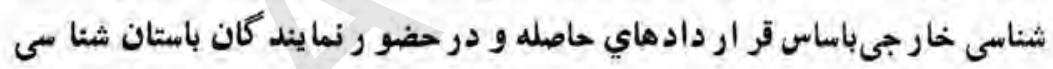
كشور ادامه وتوسيه يافت كهحفريات اع خانمتوسط هيأتباستانشنابسى فوانسهـ

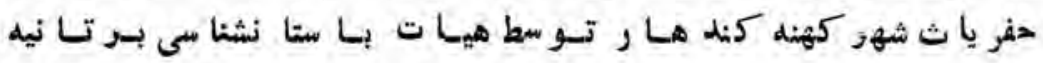
حفر يات تهئه سو دار غز نىتو سط هيأت باستانشناسىايتاليا و حفر يات شهر هاى تاروسار و شهر غلغلئ نيمر وز توسط هيأت باستانشناسى سمنت سو نين

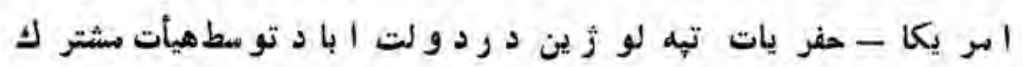
ا فغا نستان و ا تعاد شو روى وحفويات تية سكندر بـكر ام به همكارى هيات باستانشفاسى جابان صو رت كر فت . 


$$
\text { دو م - حفظ و تر سيم ا بدات تا ويخى : }
$$

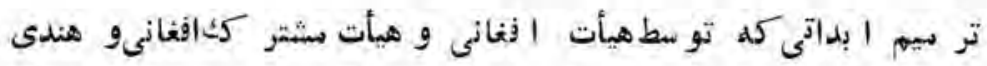

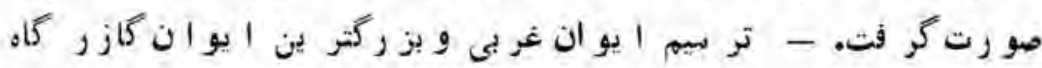

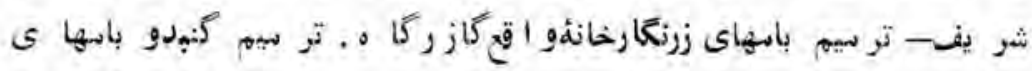

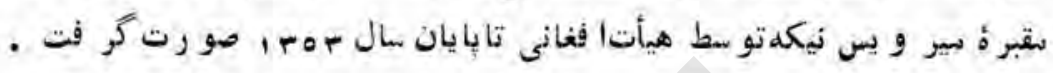

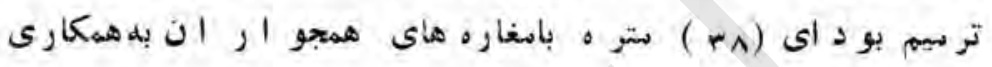

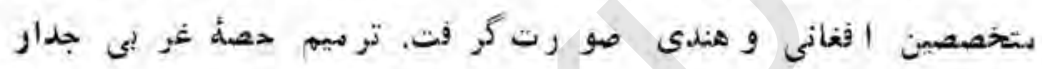

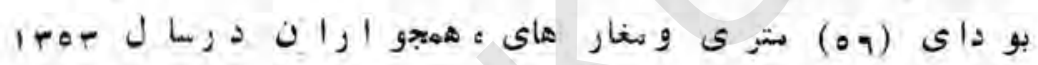

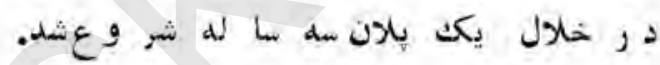

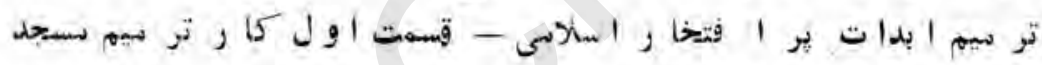

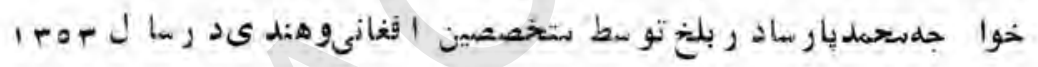

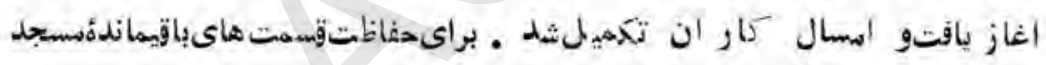

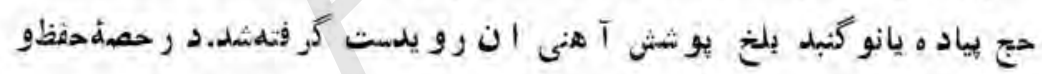

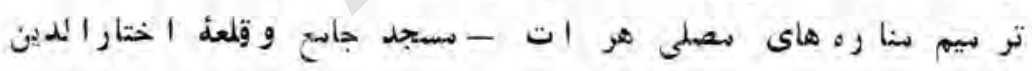

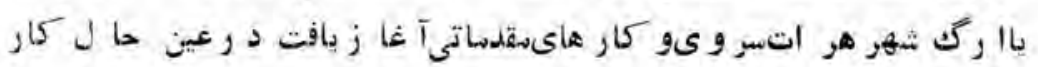

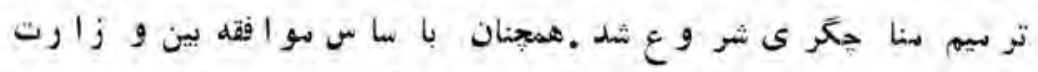

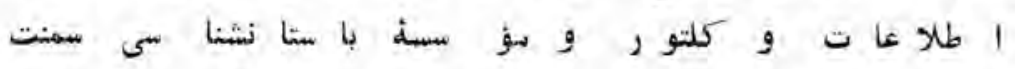

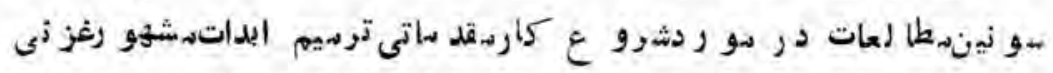

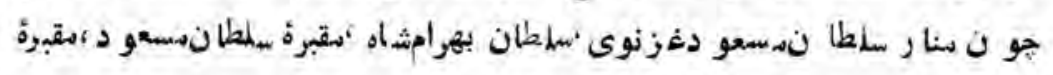

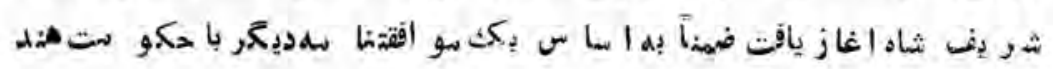




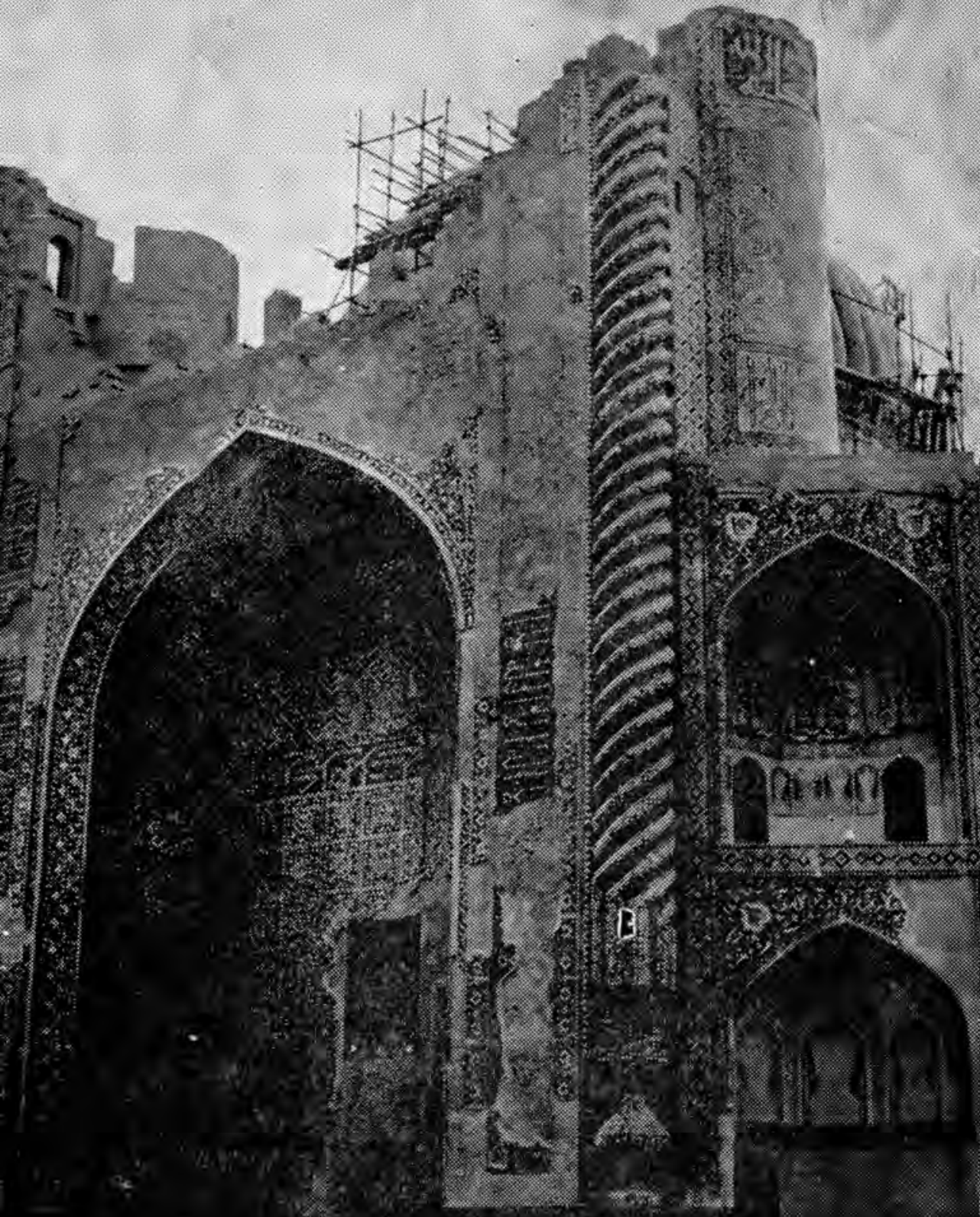

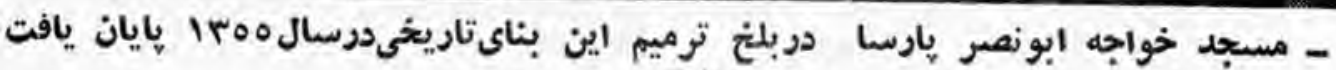
24691 
باستمانشناسى v

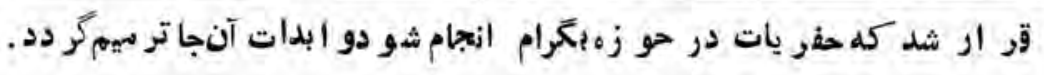

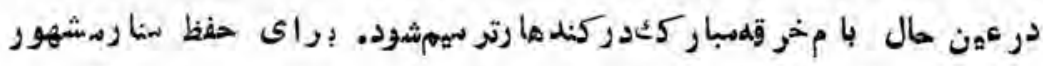

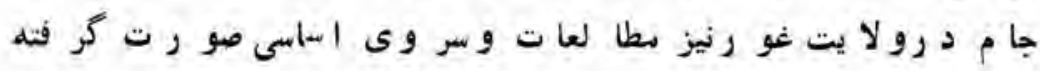
ا ست . با اين اقد ا مات وزار رتاطلح عات و كلتو ر ابد ات

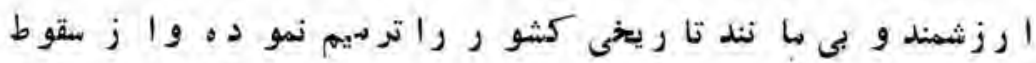

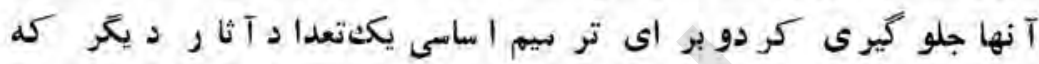

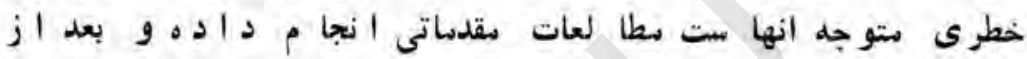

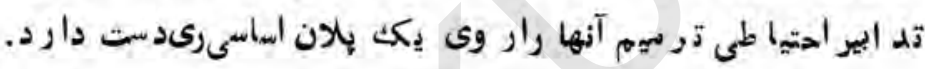

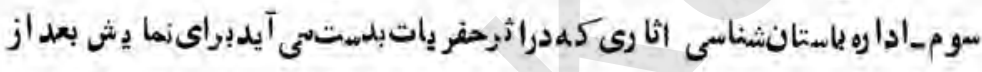

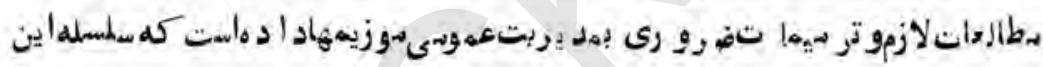

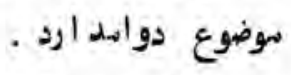

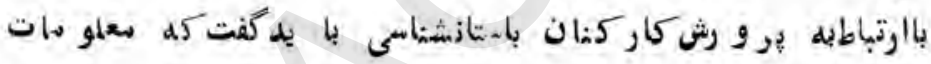

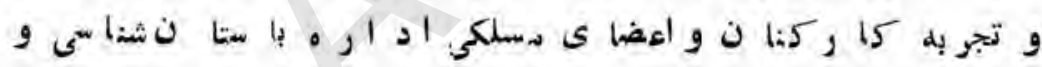

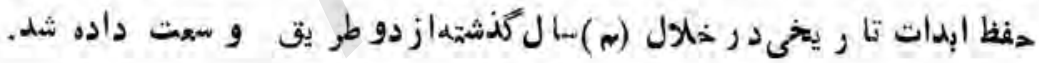

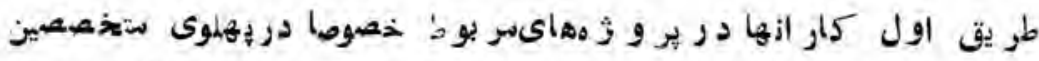

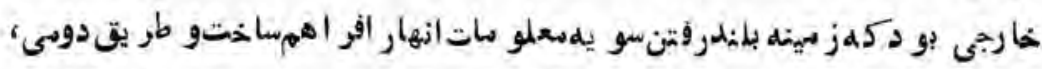

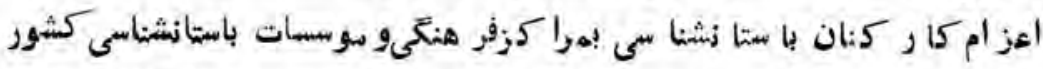

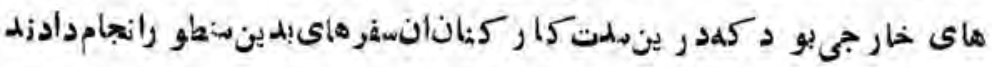

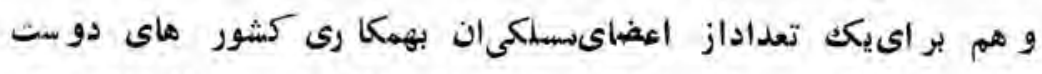

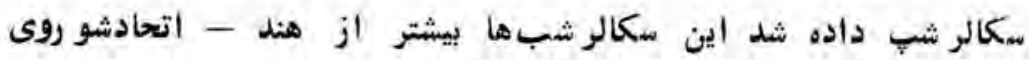

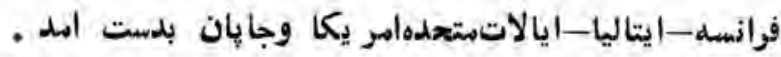




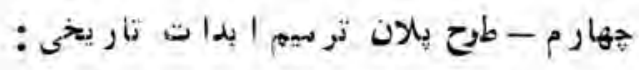

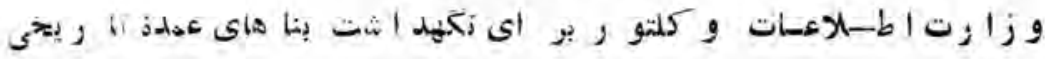

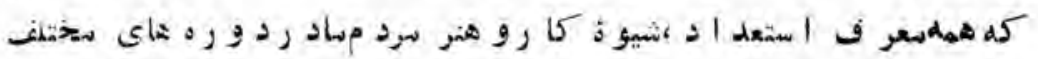

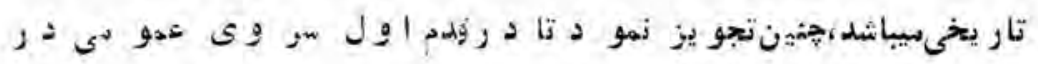

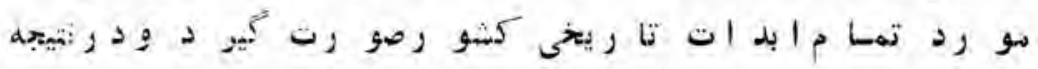

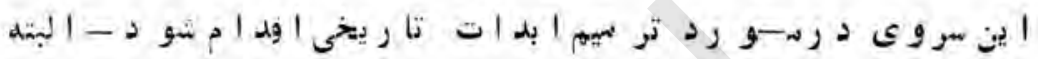

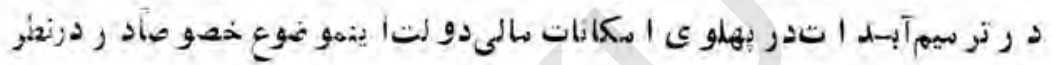

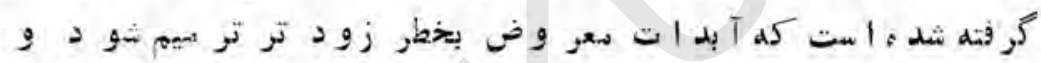

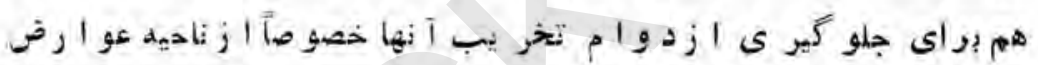

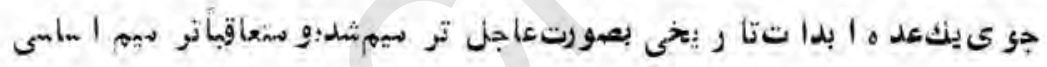

$$
\text { آنها صر رتكير }
$$

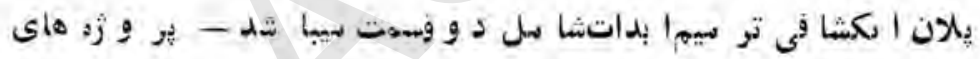

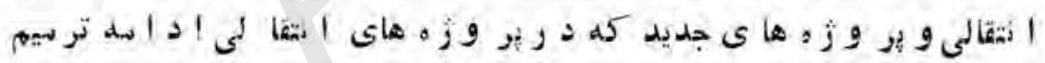

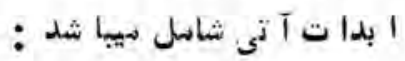

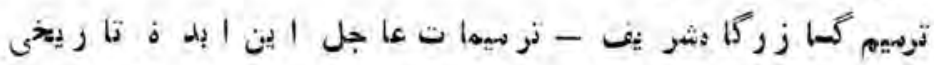

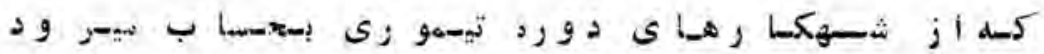

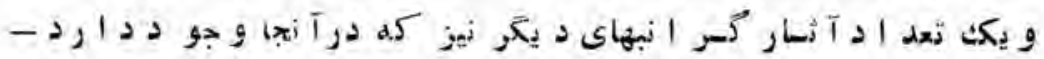

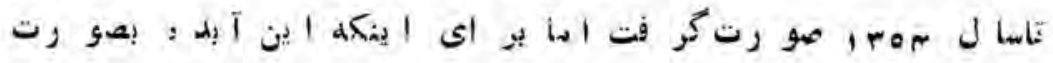

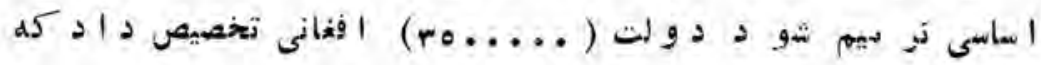
يين سالهساى هم-هوه 


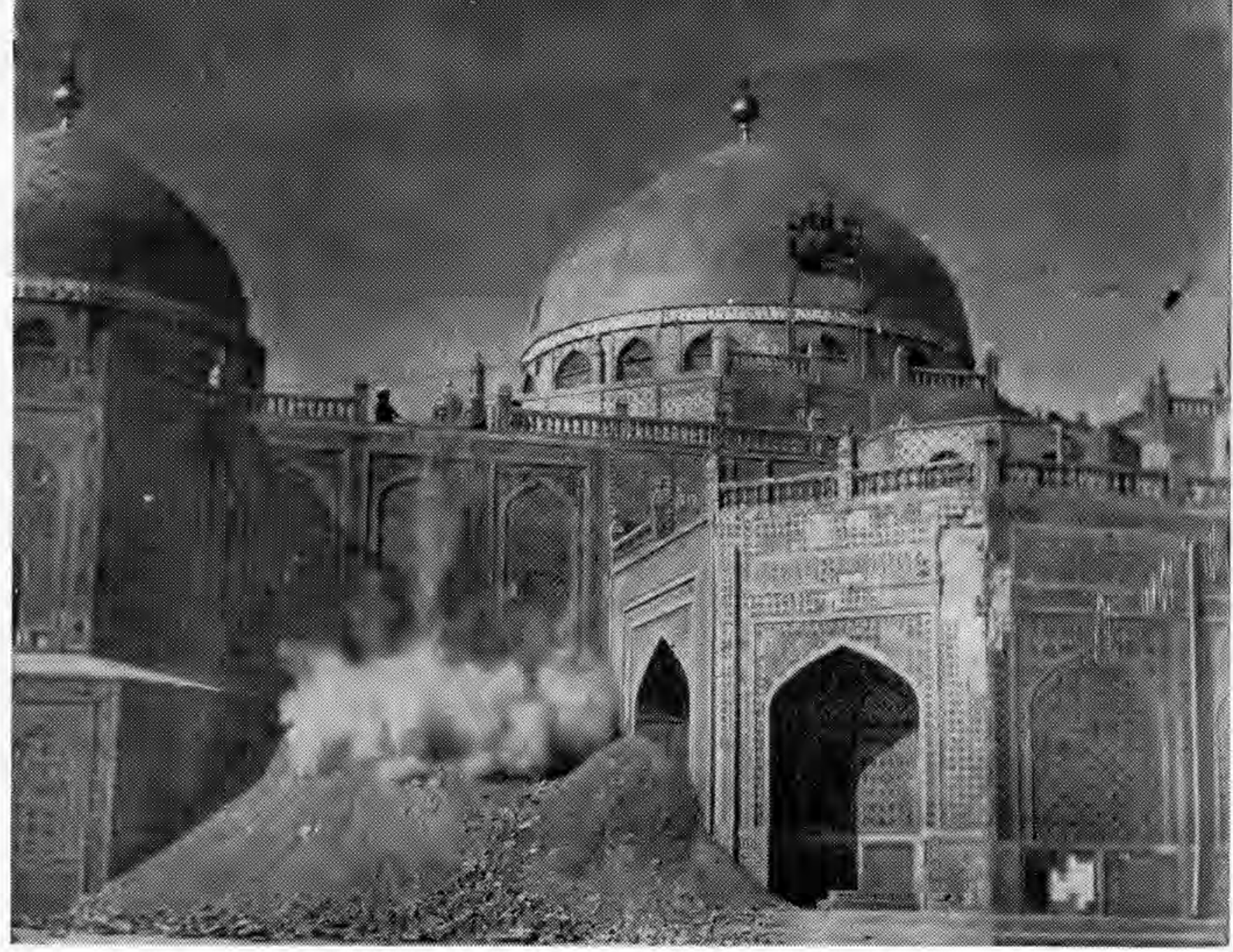

- عمارت دوضه شاه ولايتمـآ. ردر مزار شريف در حالت تتميه . 248.4 


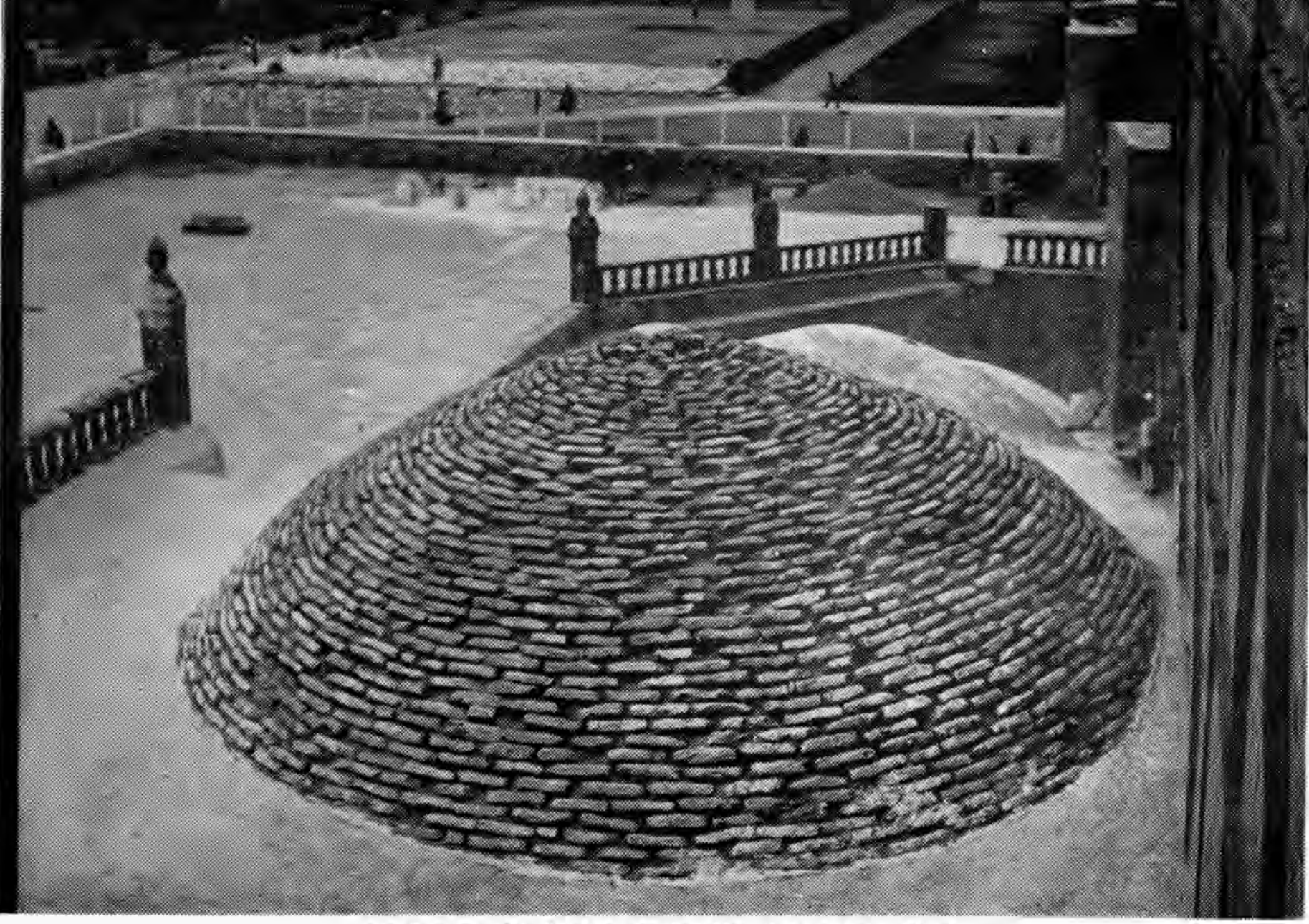

- باهباى روضه شاه ولايتمآبدد مزار شريف حين ترميه यदि a 

$(+\circ 9)$
$v^{m i n i s t i m l}$

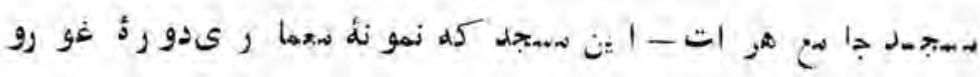

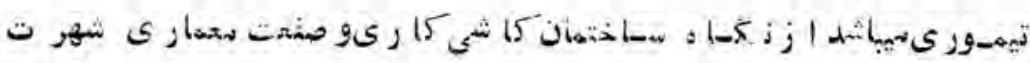

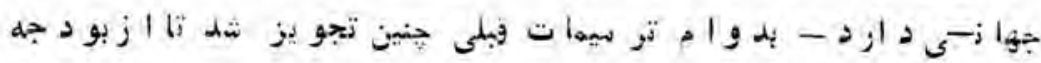

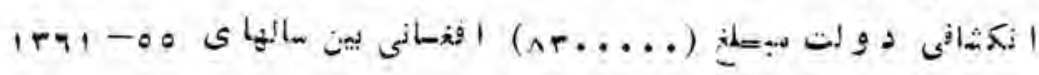

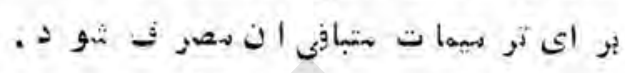

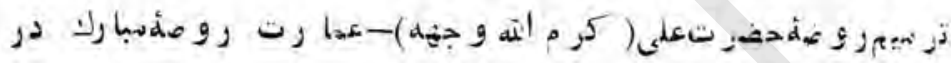

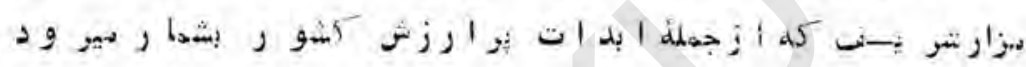

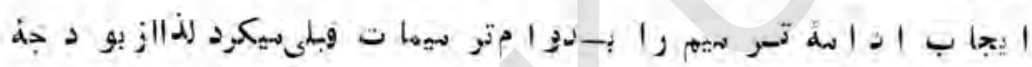

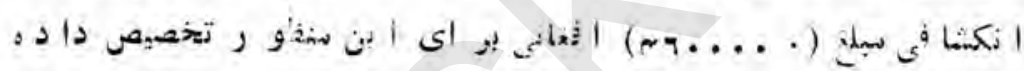

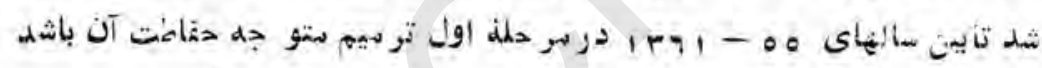

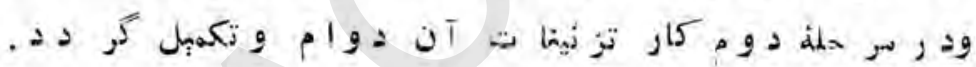

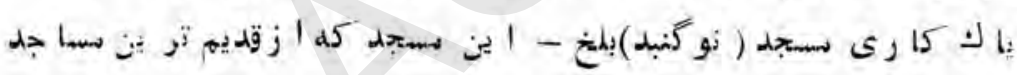

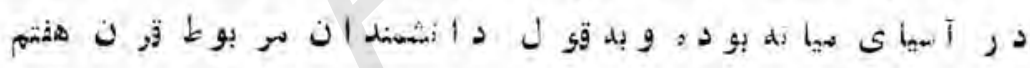

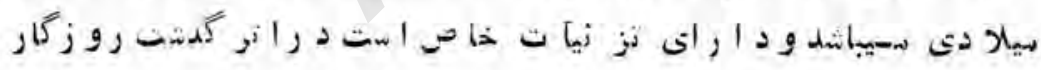

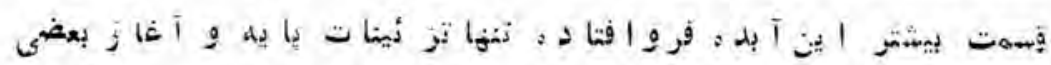

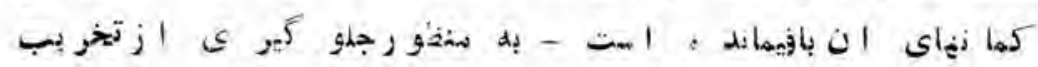

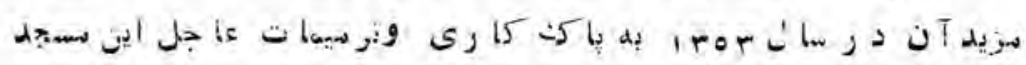

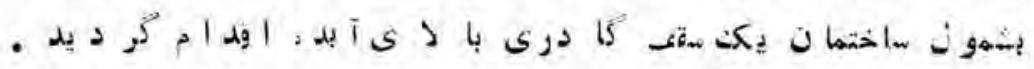

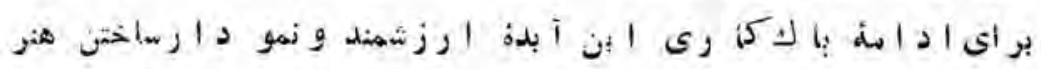

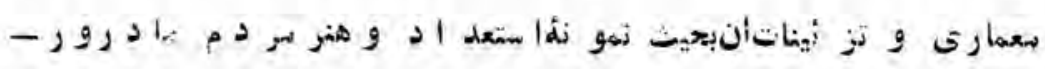




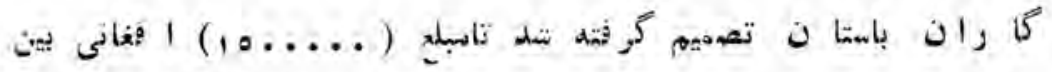
سالهأ

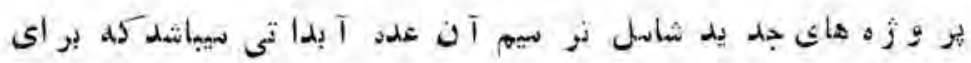

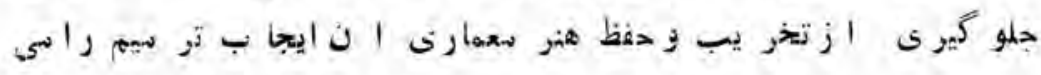
- نها بـ

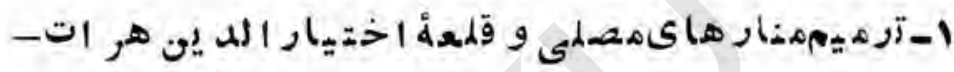

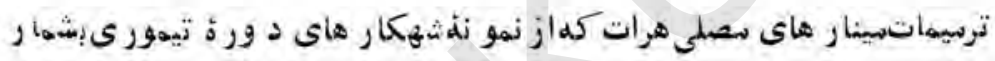

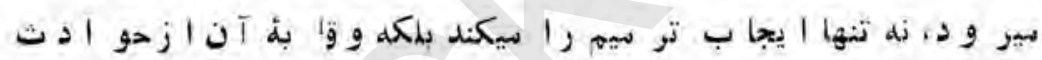

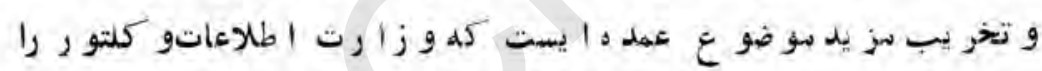

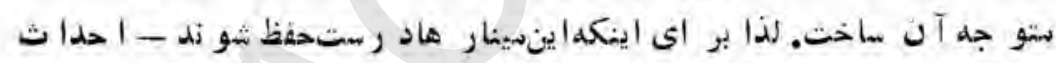

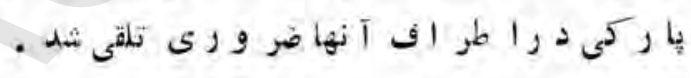

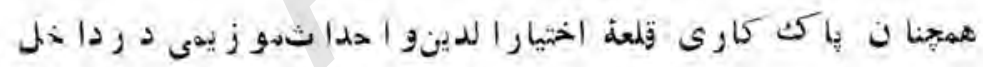

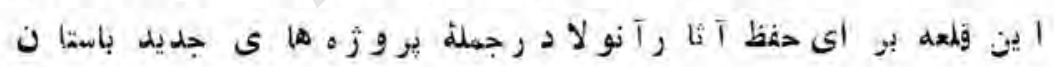

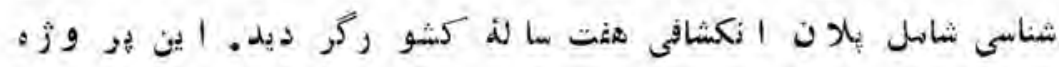

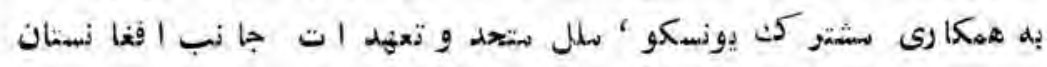

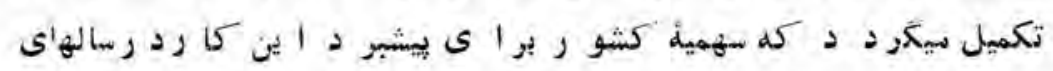

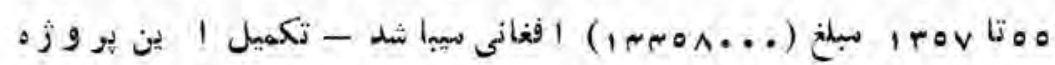

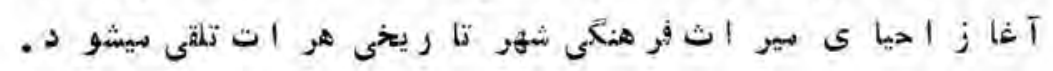

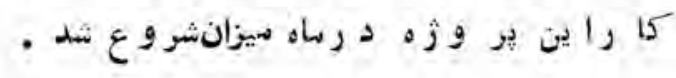




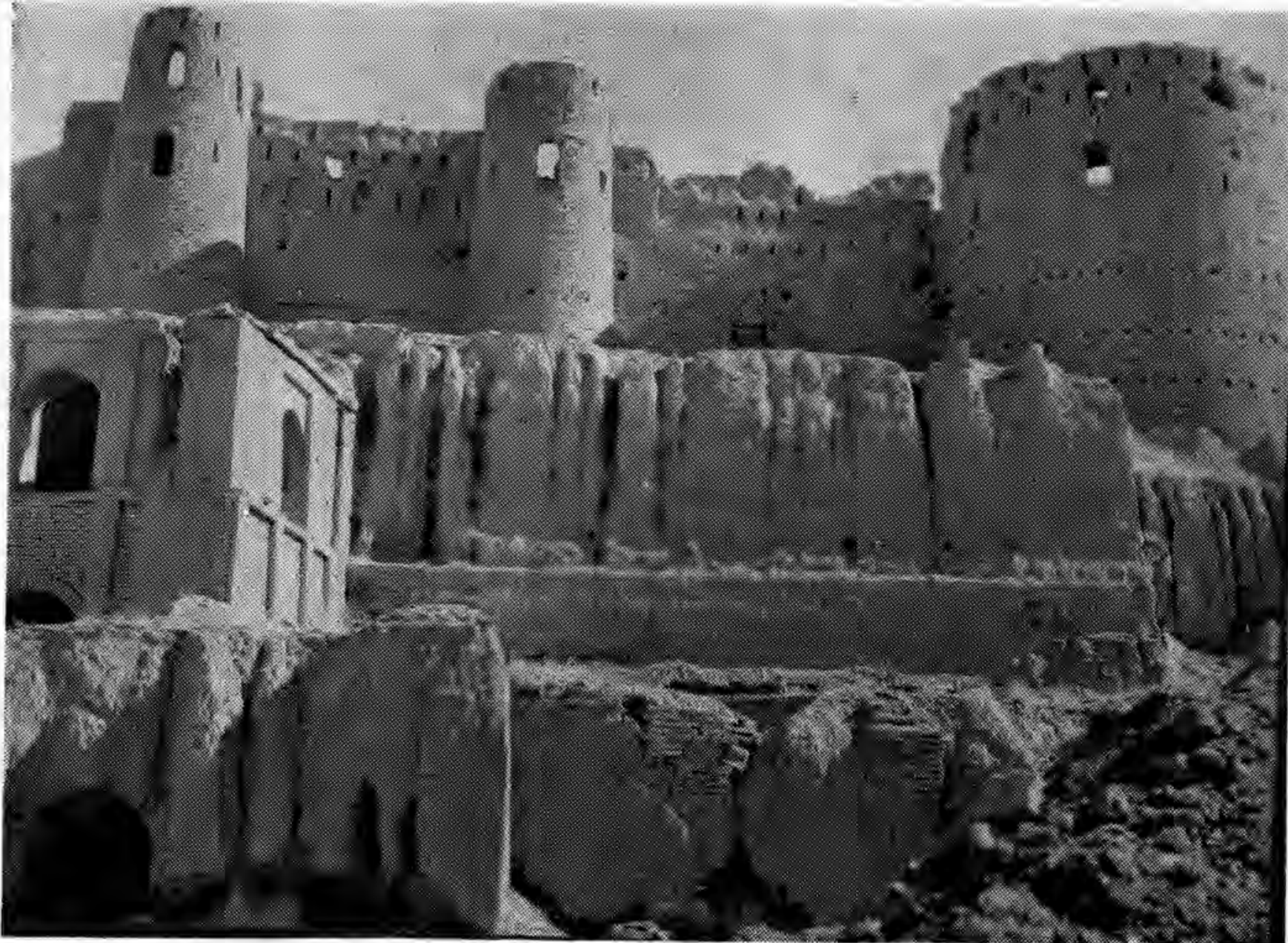

ـ قلعه اختيار الدين هرات كسـه ترميرآذ ددسال مهبا آغلاز يا فت. 2दर्श का 


$$
\text { (r०1) }-r
$$

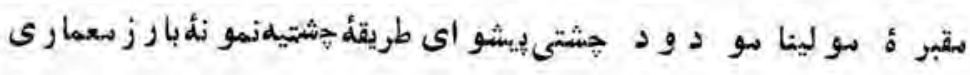

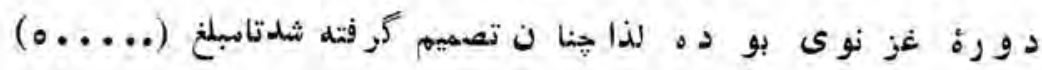

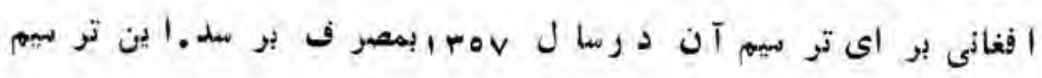

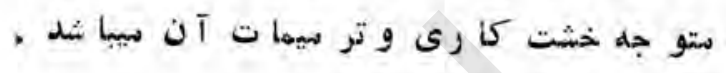

$$
\text { r- ترميم حوض ح- }
$$

اين حو ض كلبصورتبو شيده ازدو رؤ تيمو رىتاحال بر اى التمفادهاب آن ازلطر ف شهر يا ن هر ات بجا ساند ه، بر اع آغاز كا رتر بيه

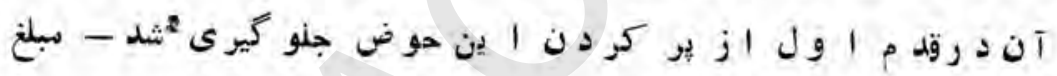
( ا.....)

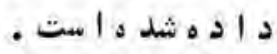

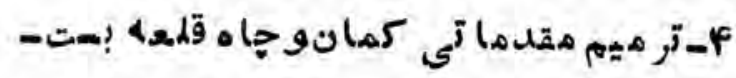

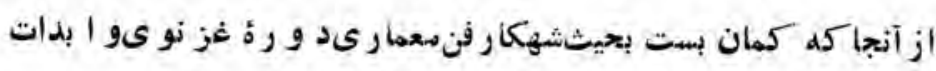

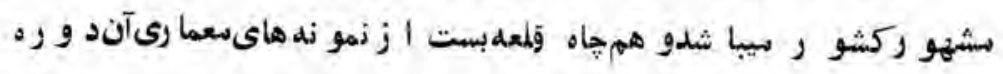

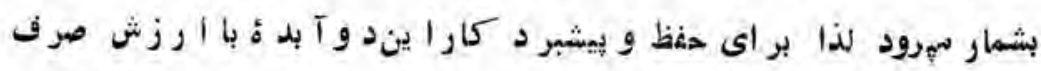

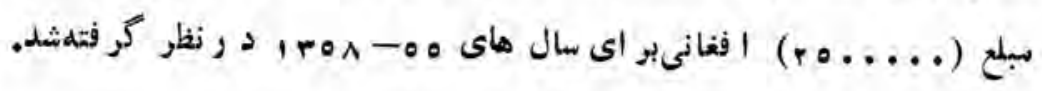




$$
\text { - زئى }
$$

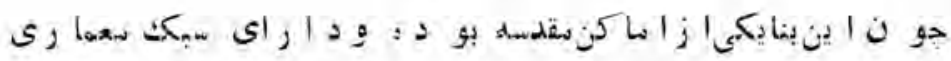

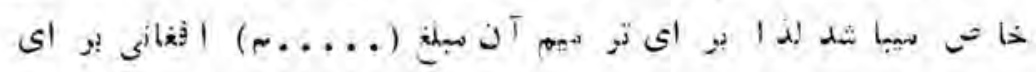

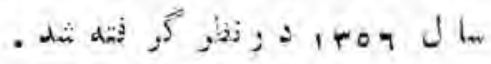

$$
\text { - }
$$

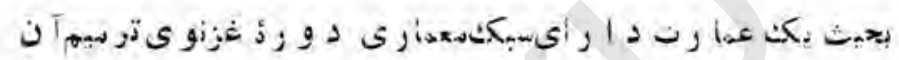

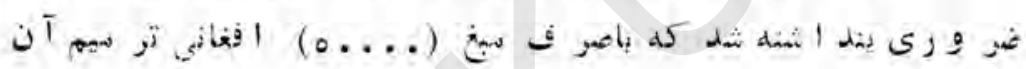

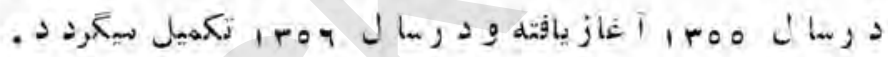

$$
\text { - }
$$

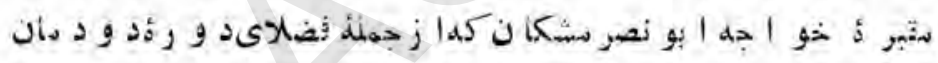

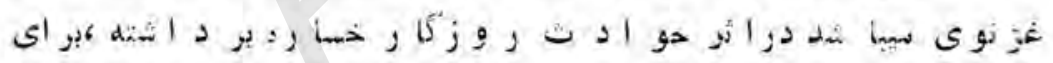
ros - or -

$$
-4
$$

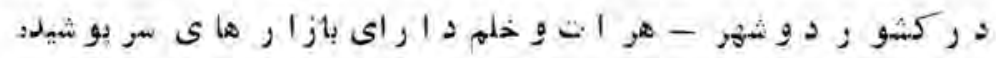

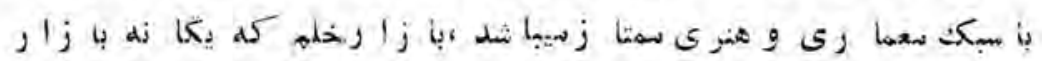

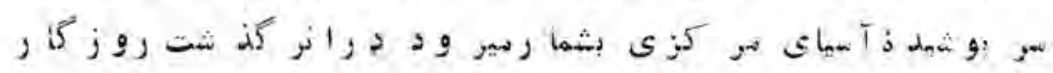




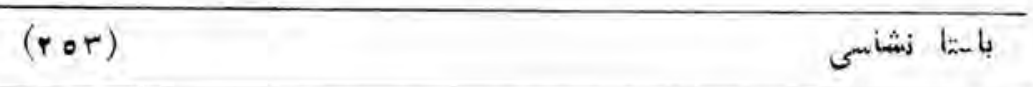

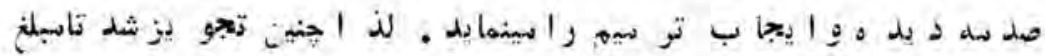

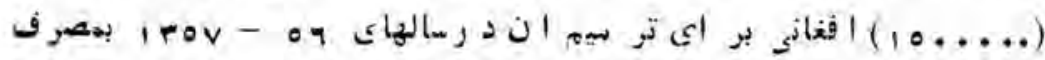

بو مدل .

- a

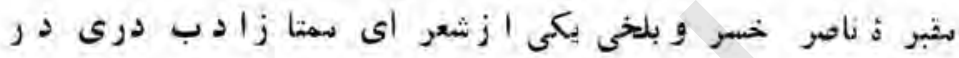

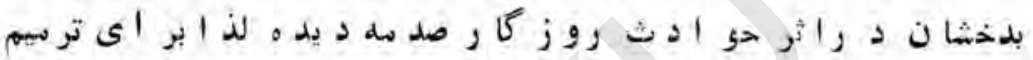

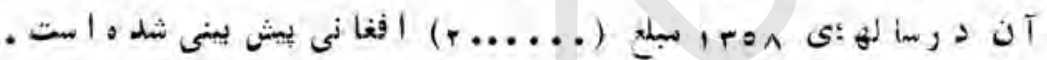

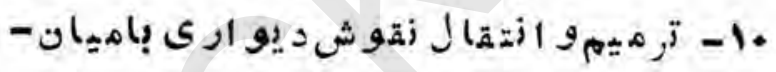

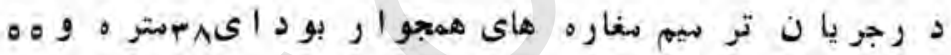

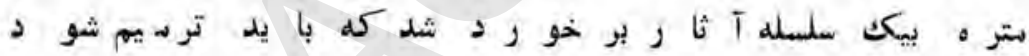

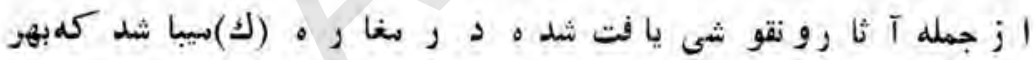

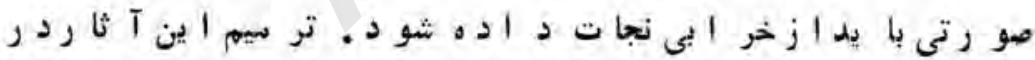

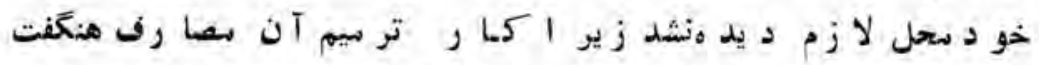

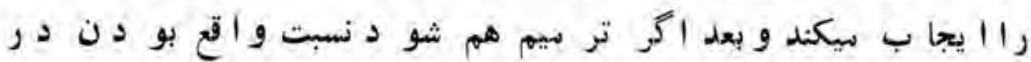

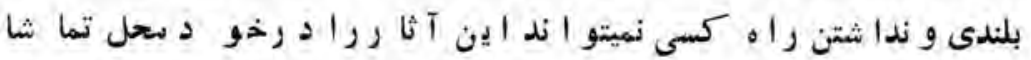
كند جو ن ا ين سغاره د رمحل بلندى و اقع است لذا بر ايى تر سيم و

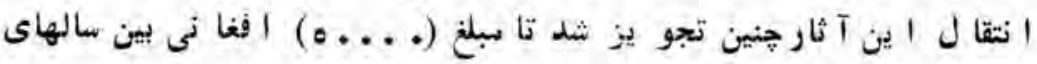

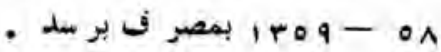




\section{- ك-}

بوداىد رؤككرلكاكل در جنوبشرقدو بو داىبز ركى باسيانو اقع است در

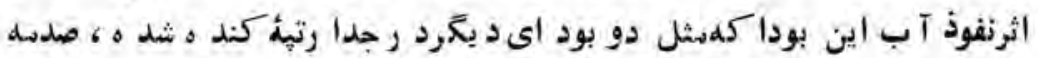

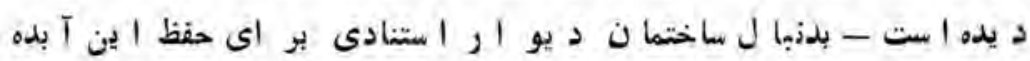

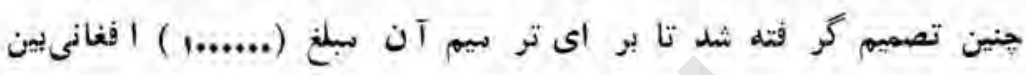

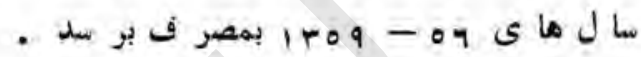

$$
\text { 每 }
$$

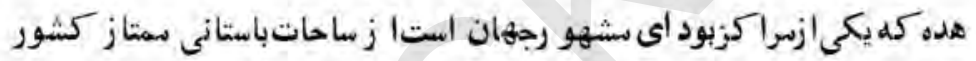

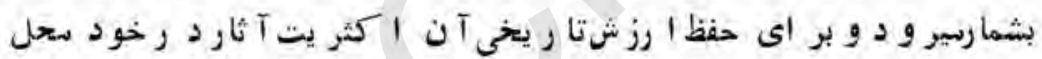

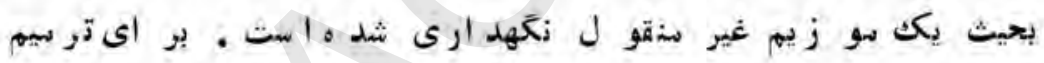

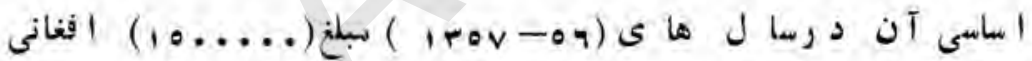

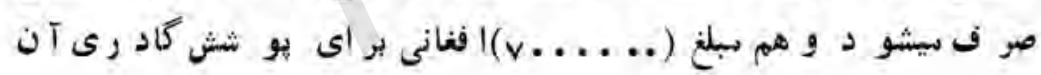

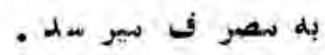
-

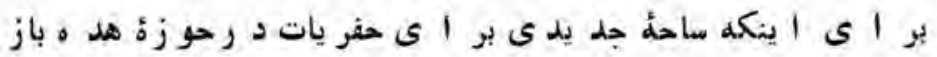

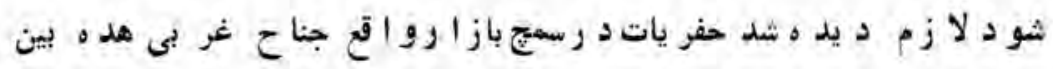
ما لهاى ( 
ل ا If تخار

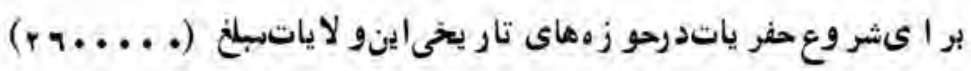

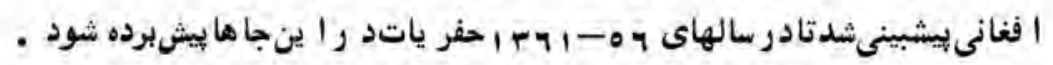

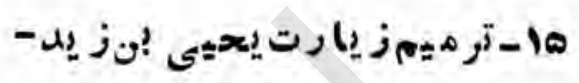

مقبرة يحيى بنزيدو اقع سريل سزا رشر يف يكى از ماكنمقدسه بشمار مير و د

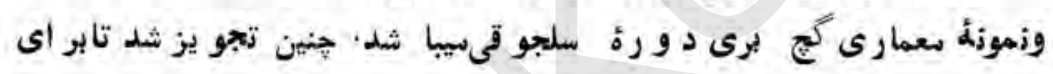

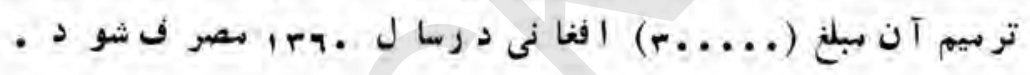

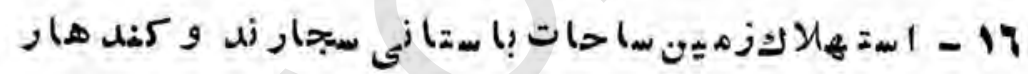
بر ايى احياى معبدسو نا د ر سجاو ند لوكر و كتيبها ثمو كا در سريو زة

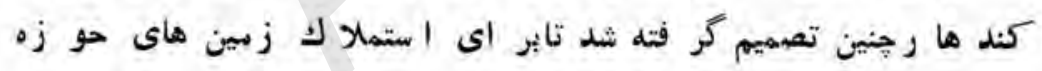

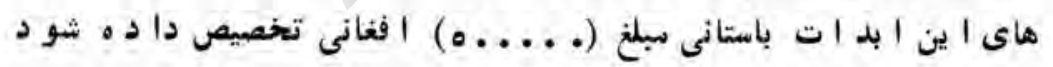

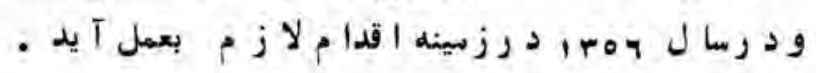

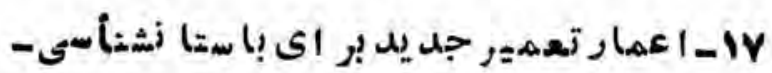

بر إيى اينكه ادارة باستانشناسى در يكت تعمير سجهز خدنات خود ر ادنبال

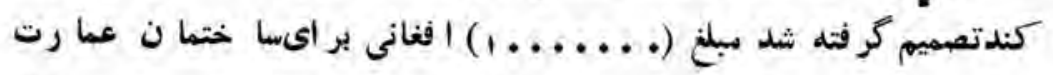

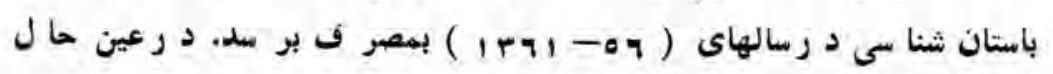




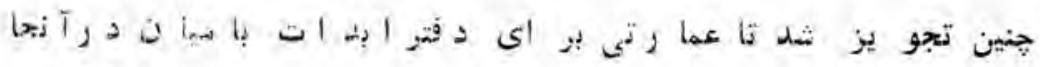

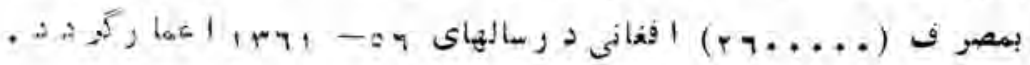

\section{- I}

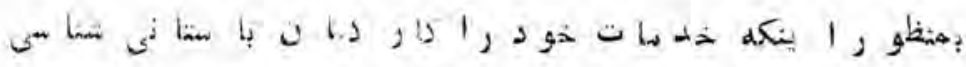

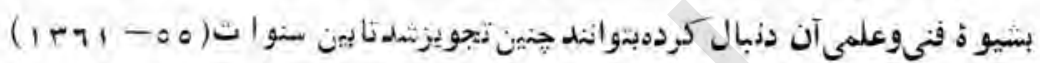

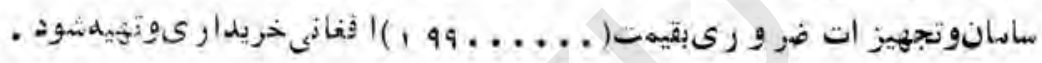

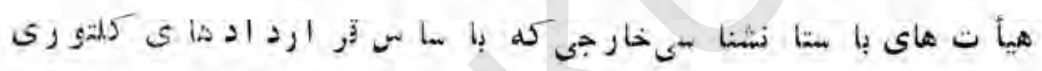
و همكارى هاى فر هنكى

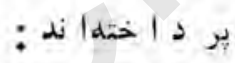

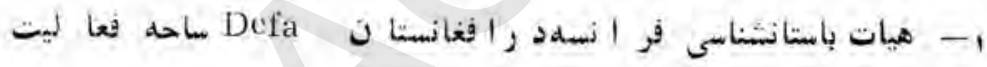
- آى خا نم

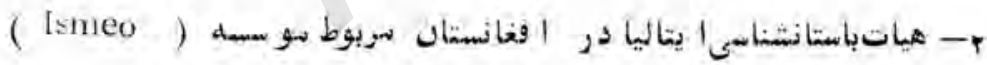

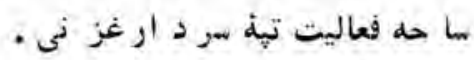

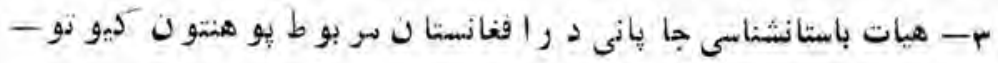

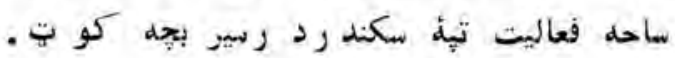
r- هيأت باستأ نشناسى بو تانوى د ر الفغانسةا ن - سا حه فعاليت شهر

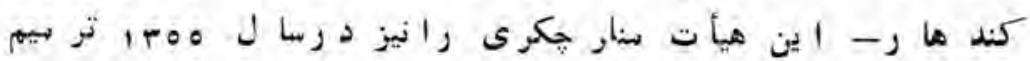




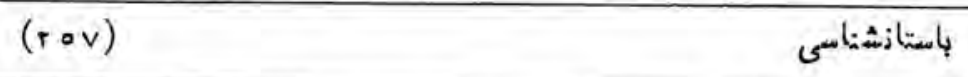

0- هيأت با ستا نشنا سى المر يكا د ر الفغانستا ن سر بو ط مو سسه سمنت سو نين و اشنغتن ك،احه فعاليت شهر غلغلة تا و و ساياسارو تا رمر بو ط ولا يت نيمر و ز .كارا ين هيأ ت د رسا ل همرا با سا سق اردد اد با با ن يافت

ه- هيأ ت باستا نشينا سى الما نى د ر الفغانستان مر بو ط بو هنتون بناين هيأ ت سروى نقشه هاى با ستانشناسى راد رولايت نيمر وز

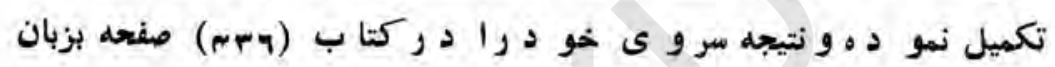

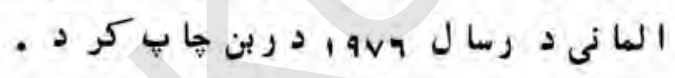

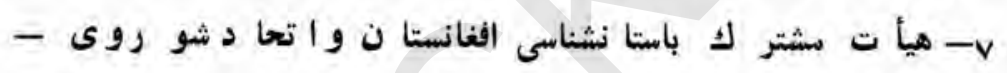
ساحه فعاليت د لورز ين تيه و جغه تهه بر بوط د و لت آ با د بلغ..

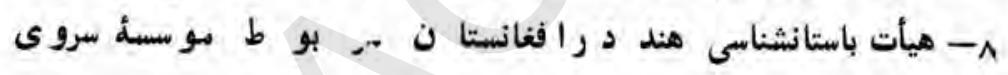
باستا نشناسى هند • سا حه فعا ليت ساحه باستانى بابيا ن و سر و ى هناطق

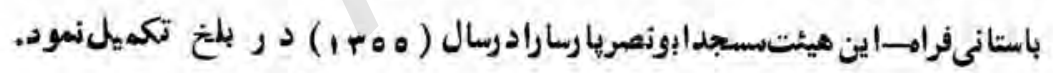

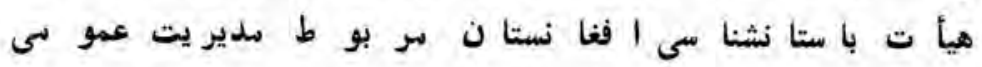

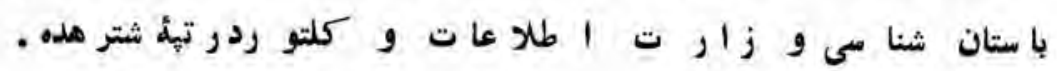
د رعين حال نما يند ه هاى بأ صلا حيت مد يو يت عمو سى با ستا نشناسى در ركا و ش هاى تا ر يخخى باتما م هيأ تهاى بأستانشناسى كشو رهاى خار جى

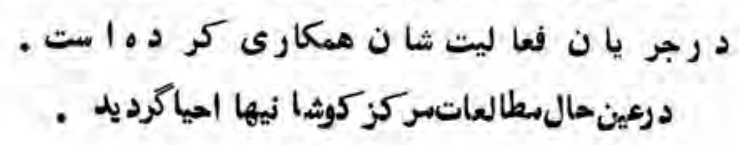




\section{هوز ניم}

ازآنجاكه الفغانستان د ارواى تاريخ دورخشان و فو هنكباستانى

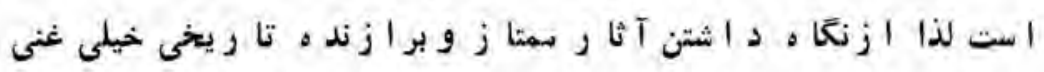

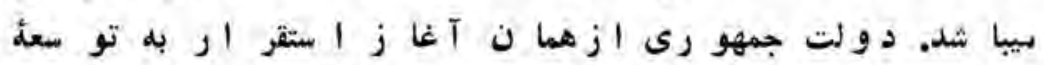

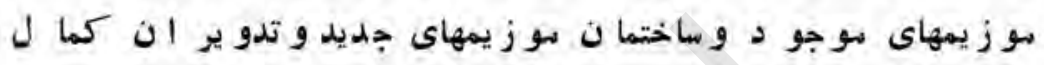

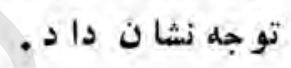

د رسوز يمهاى لموجو د كثو ر كل عبا رتاستازموزيم كابل

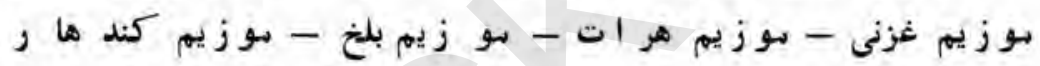

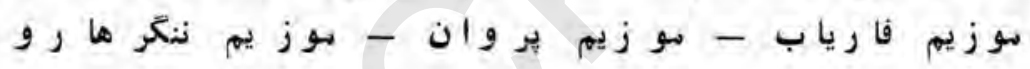

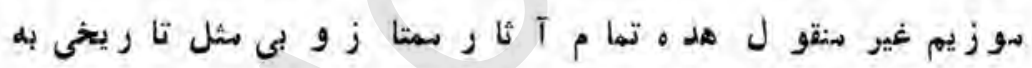

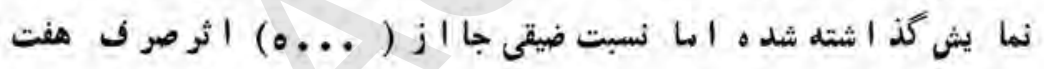
فيصد آن د رمعر ض نما يش قر اركر فته ستيواند بر اي نمايث بهتر

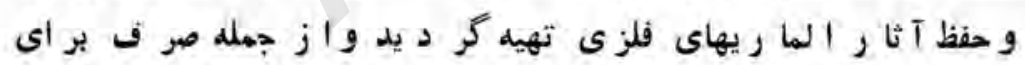

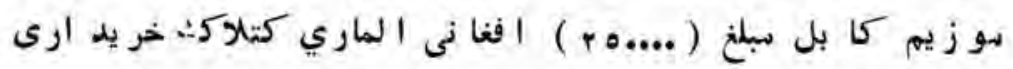

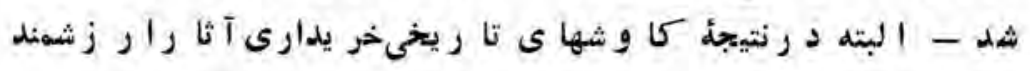
رو ز بو و زا ين سو ز يمها غنى سا خته بىشدد - منا نجه آثا ر سكثيو ف

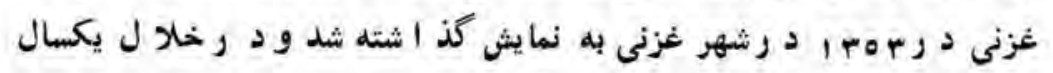

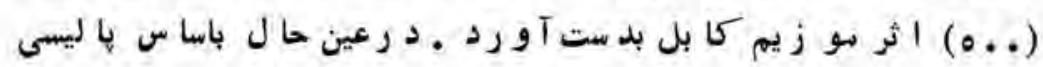

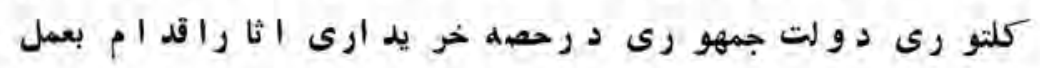




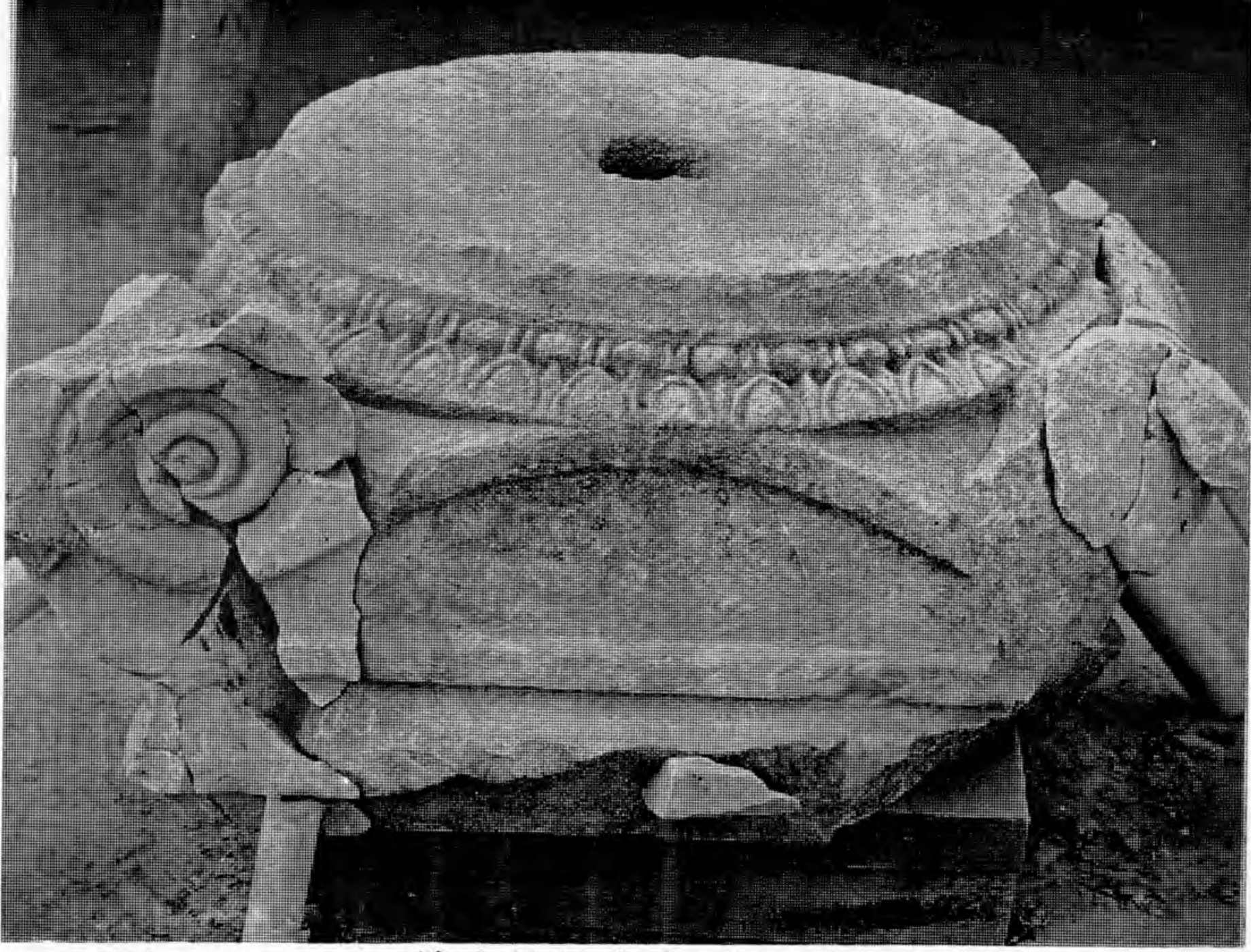

-يكى ازسر ستونى سنكى شهر باستانى آى خانم. 


\section{(r०q) (rزيمها )}

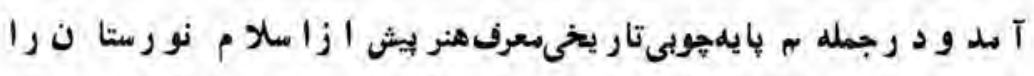

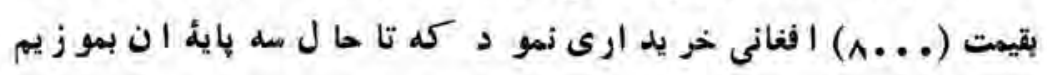

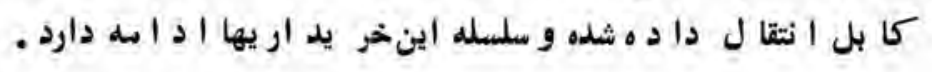

$$
\text { هوز إم ملى }
$$

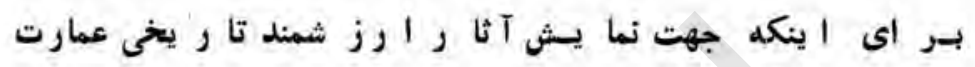

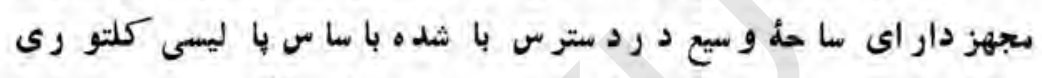

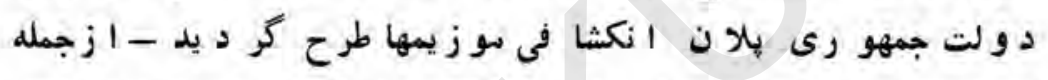

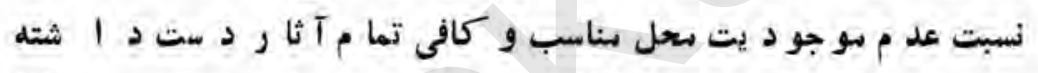

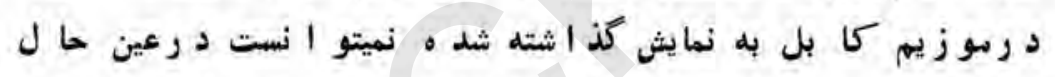

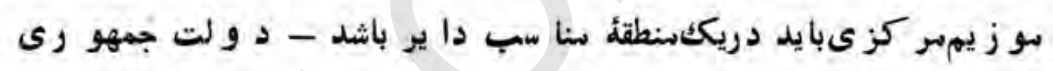

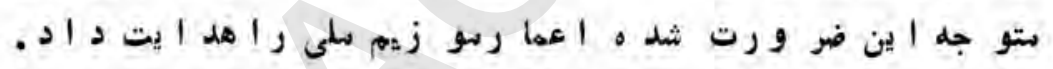

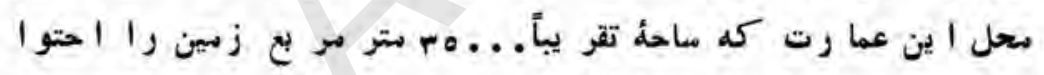

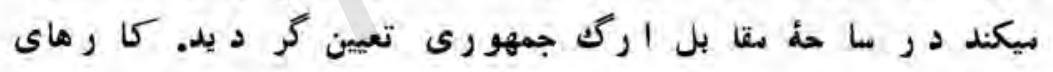

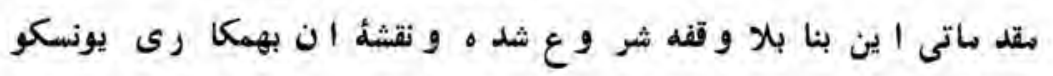

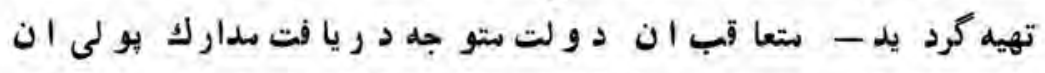

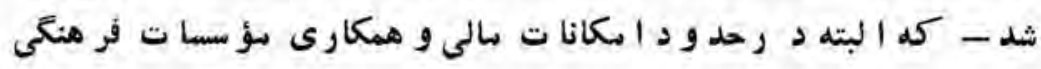

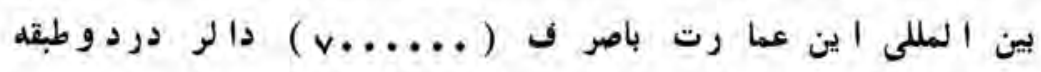

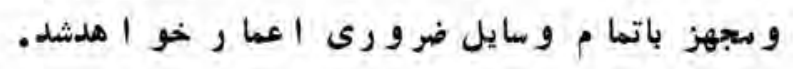
تا آغا زكا رعما ر ت بو ز زيم سلى بر اي ا ينكه آثاردستد ا شته 
اجرا ات اطال عاتى وكلتورى

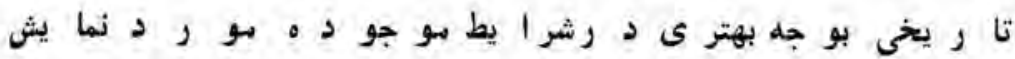

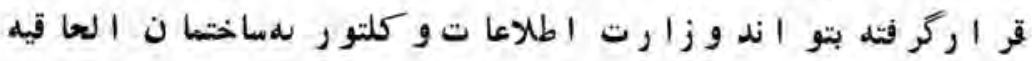

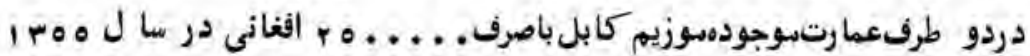

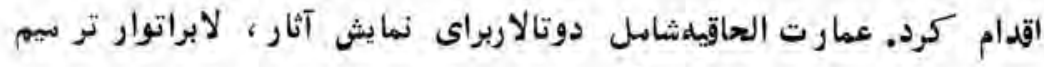

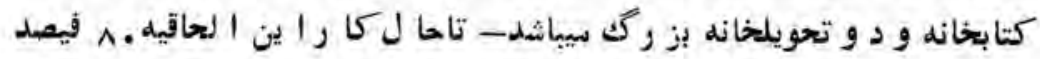

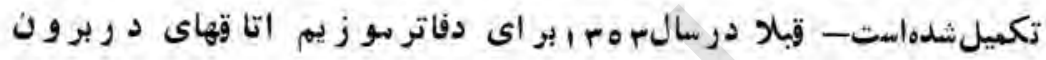

عمارت اصلىمو ز يمنيز ساخته شده بود . .

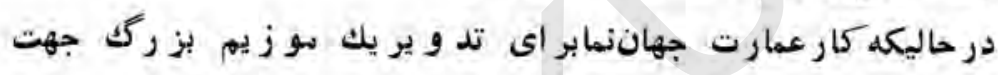

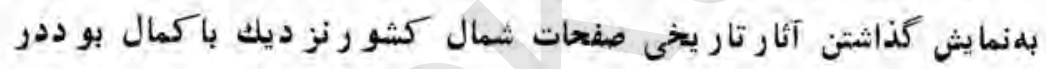

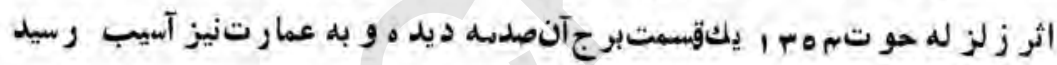

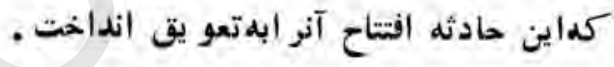

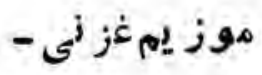

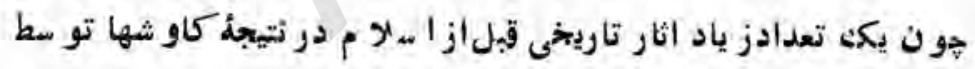

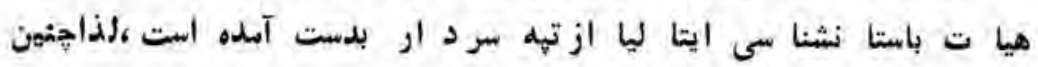

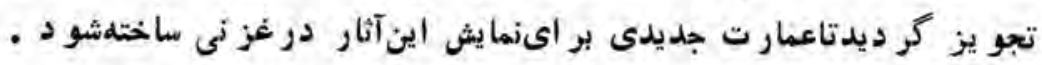

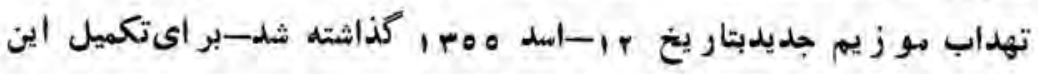

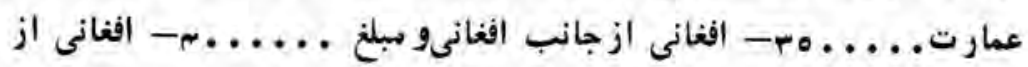

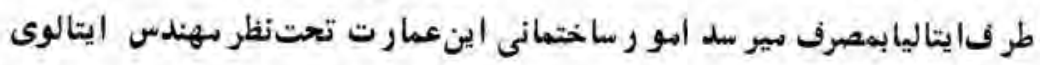

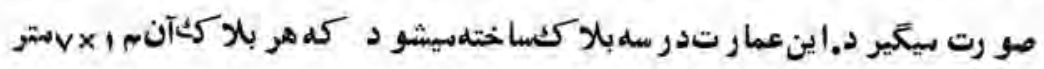




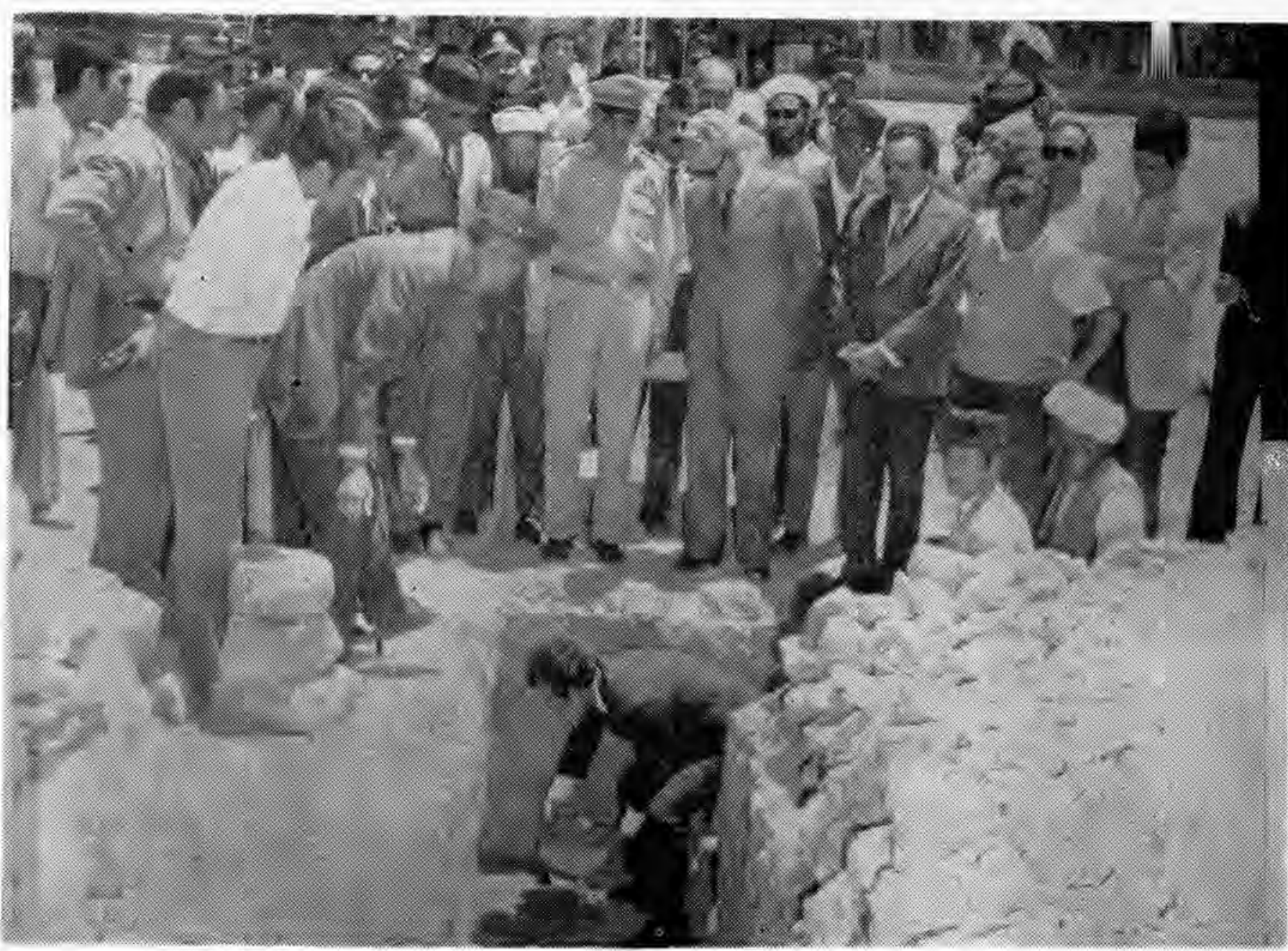

- يوهاند دوكتور نوين وزيـــراطلاعات وكلتور هنعام تهدابكدارى موزيم جديد ثزنى · 
بو ده و شامل دو وسمتاست - در ين بلاكها علاوه بر سالونهاى نمايش-

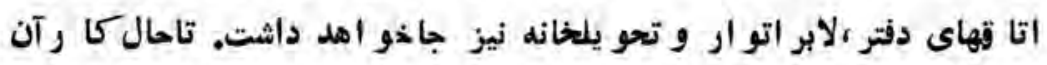

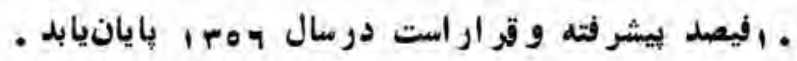

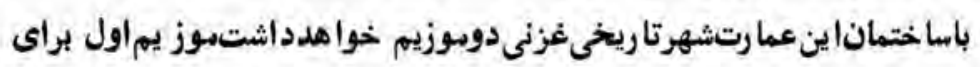

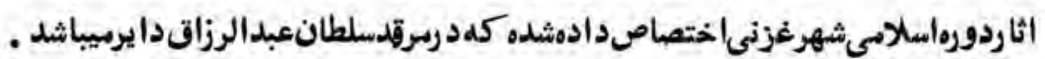

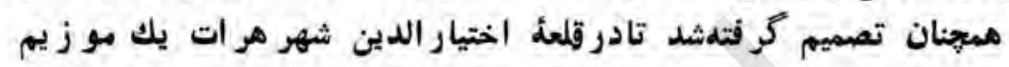

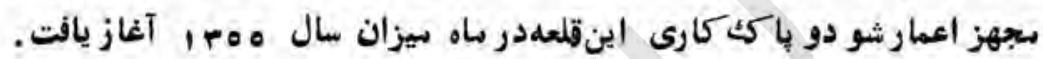

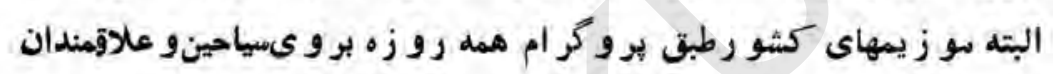

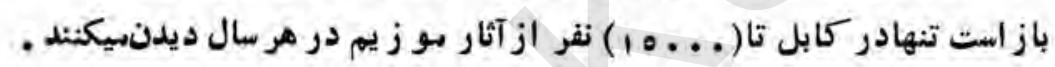

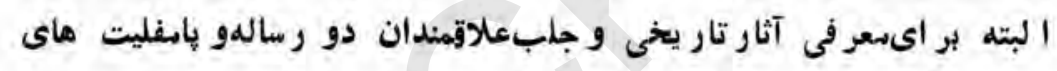
بز بان انكليسى نشر و تو ز يع شدهاست.

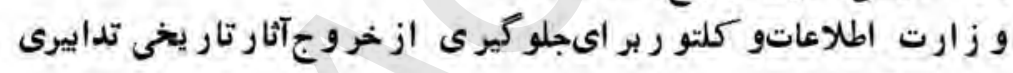

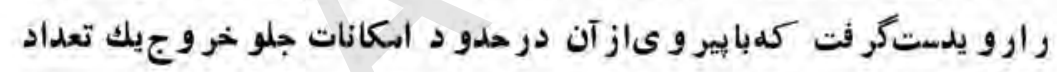

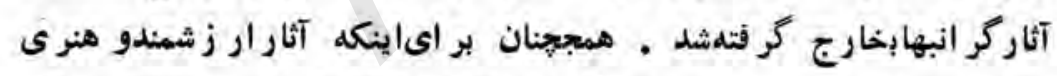

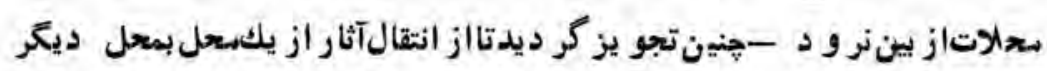
جلو كير ى شو دو ممازكندنآثار و بارجهساختن آنجلوكير ى به به عمل آيد.

\section{آر ياناد ايرة المعادف}

فعاليتهاى انجمندايره المعارف بحيثيكث كانون فر هنكى بهاساس مشى

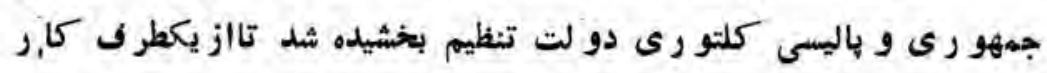

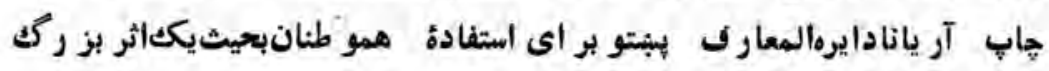


اجرا آت اطلادعاتىوك كلتورى

فر هنگ

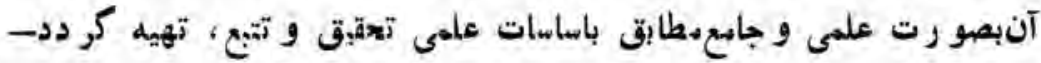

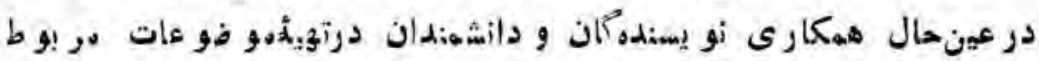

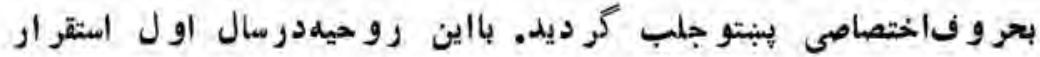

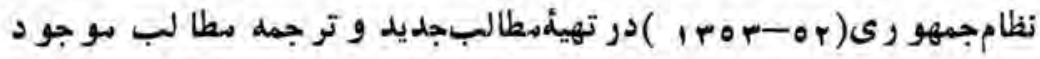

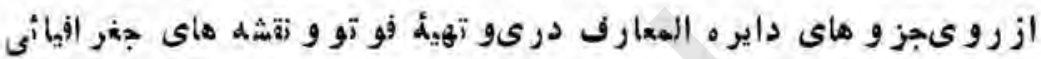
آغاز نمو د. در ينسال فعاليتهاى اين ادار ه مسدود بو دبهتهيئ سفابين باقيهانده

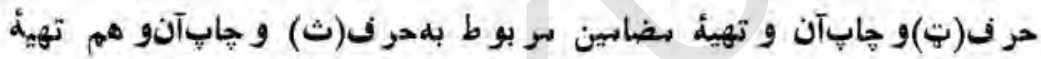
مطالب سر بو ط بلهرف (ج) و اثازخاتِان.

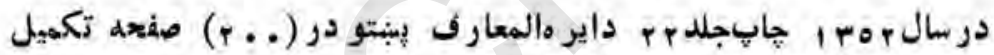

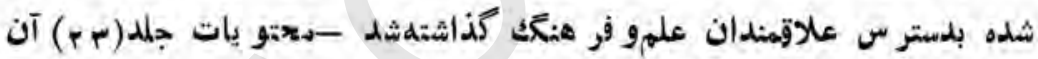

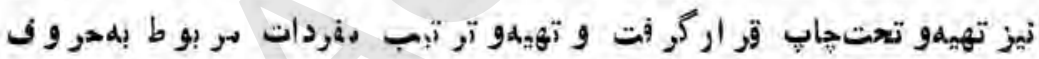

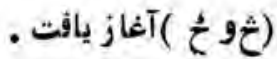

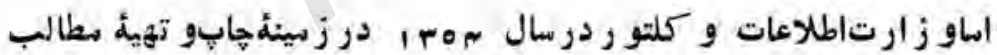
قبهمتباقىمانده دائره الهعارف بيك سلسله تدابير مهم و عاجل دست زد،

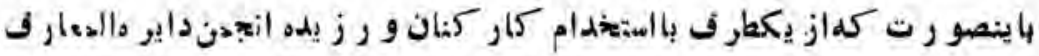

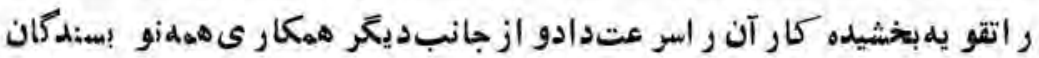
و دانشمندان ر ادر زمينه تهيذو تر جهه نفر دات آن بشكل وسيع جلب نهود. درعين حالباتدو ين و تطبيق مقر رات جديد حت الزحهله تأليف و تر اجم زبينه آنرافراهمساخت تا هدكار يهاىوسيع دانشهندان و اهل قولم ر ادر تهام ساحات 
مطبو عاتى و ازجمله تهيه مفر داتدايو هالمعارف جلبنمايد. همان بو دكه

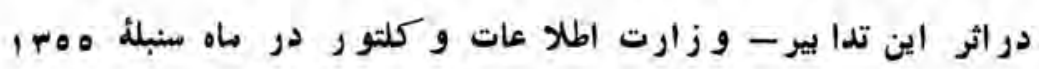
بهتكميل متتو يات و حاب آر يانا دايو هالمعارف ينبتو تو فيق بيافت و بإعاشه

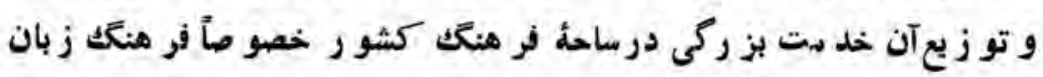

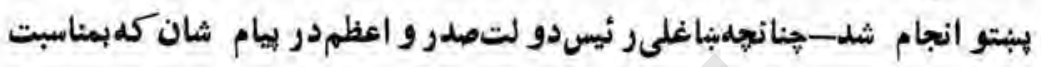
اكمال ايناثر ارزشهند صادرفوبود ند، تكميل هاب ار ياناداير مالمعارف

$$
\text { بنبتو ر اخدنتبز ركى دروفر هنكك كشو ر خو اندا ند . }
$$

بايايان كارياب ار يانا داير ه المعارق هبنتو ،و زارت الطلاعاتو كلتور

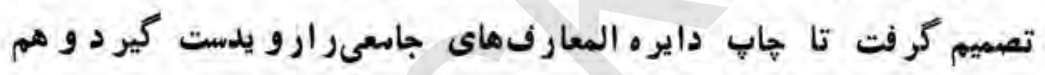
به همكارى دانشهندان و نو يسندكان مطالبجديد و انكشافاتتازه راتهيه كندو باينصو رت سلسله كار داير ه المعارف وابشكل جامعو كاملتو آن نطار بضرو رت زمان دنبال نمايد .

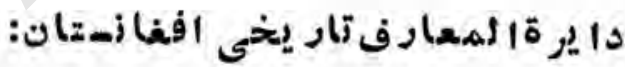

بهنظو راستفاده عامه و هم روشن ساختن ييشتر زوا يا ى تا ريخى

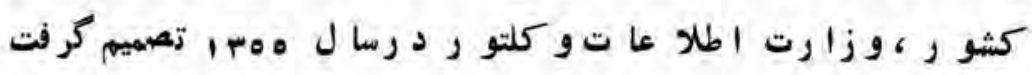

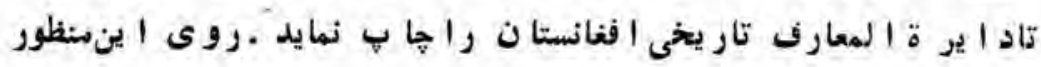
د ر زمينه تهيه مطالب و معتو يا ت د ا ير ق المسارف تار يتخى الفانستان

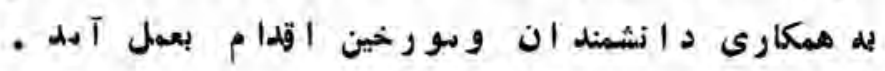




\section{آمر يت الكشاف ينبتو}

خدسات اينادار ه را و زارت اطلاعات و كلمتور طورى تنظيم بخشيدتاز يكطر ف بطالعاتى در بار ؤ انكشاف بينتو و سههكير ى در تقو يت لسان سعيا رى ري

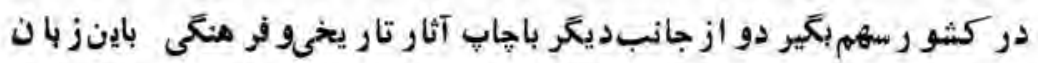

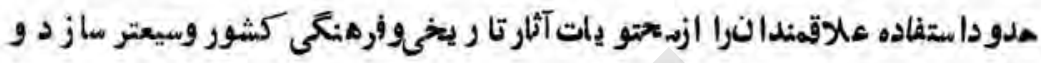

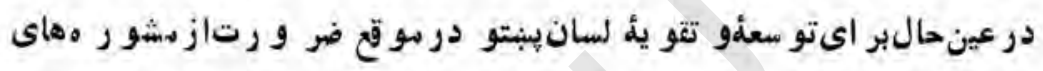
مسلكى اين اداره دو اير بر بوط اسبيفاده نمايد.

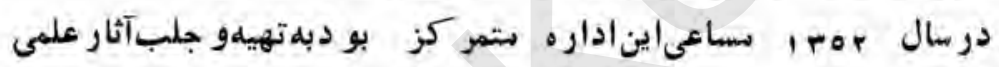

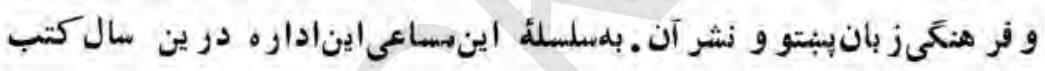

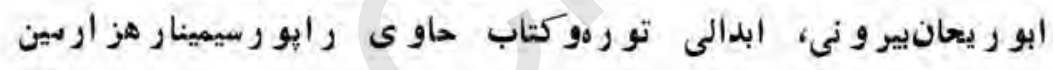

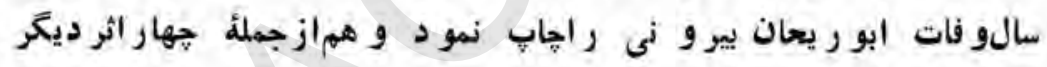

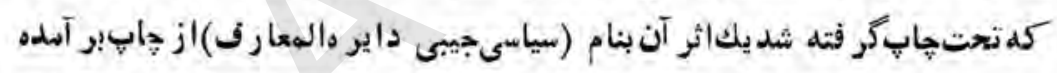

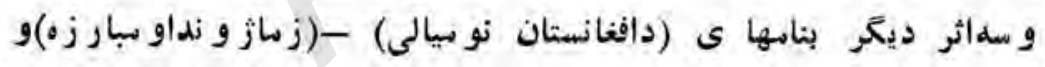

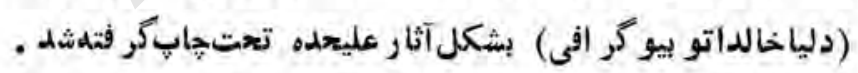

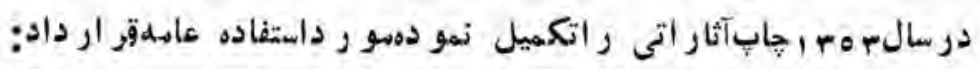
- (دافغانستان نو نيالى) جلداو ل. -

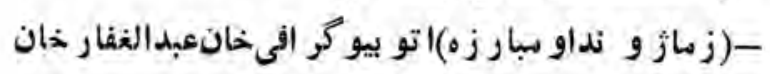

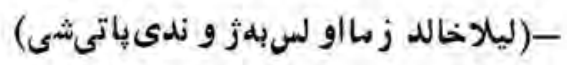

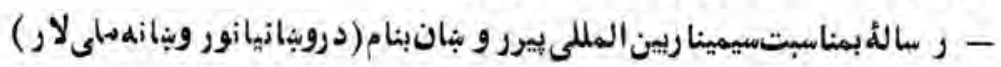


درعينحالآسو يتانكشافو تقو يئهبنتو تويلهآننو ع آثارى رأ رو رو إيدست

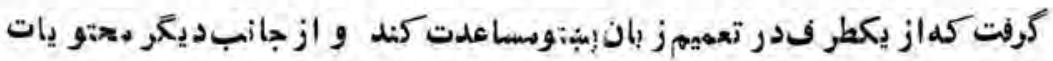

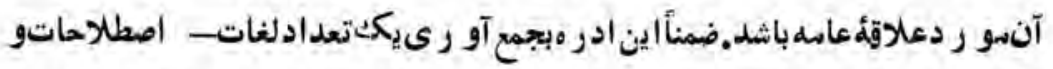

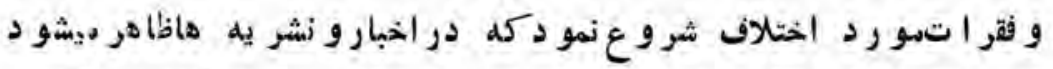

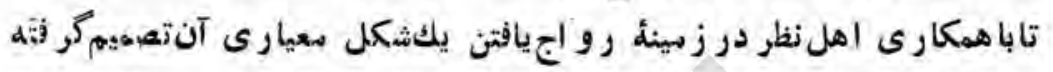

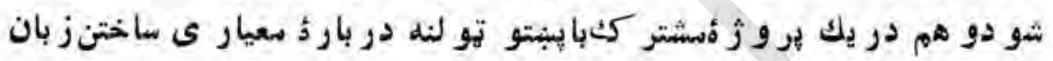

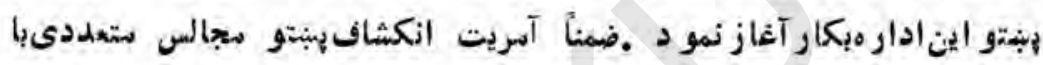

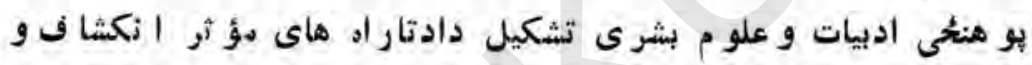

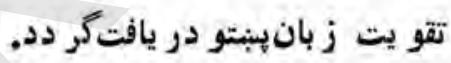

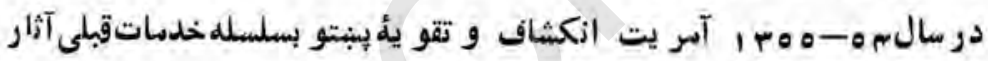

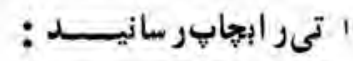

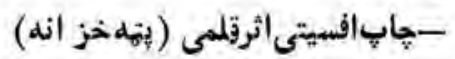

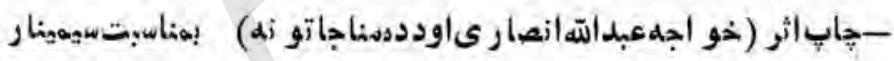
هز ارمينسال تو لدخو اجلهبداته انصارى.

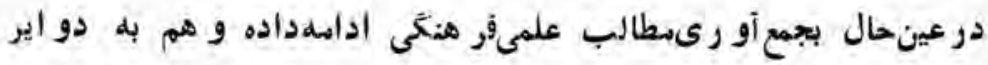
سر بوطو زارتدر زبينٔ ار انلهشو ره. هاىسيسلكى همكارى كر ده است.

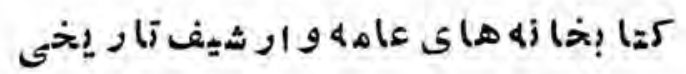
با تو جهايكهدر رو شنىاهدافعالىنظامجمهو رى بر ايىرشدفر هنكث كشو ر

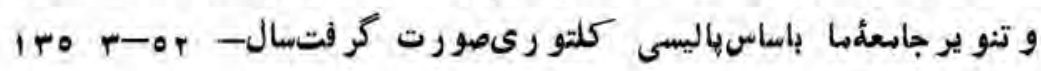


اجرا Tا ت الطالجاتى و كلمورى

$(r \neg 7)$

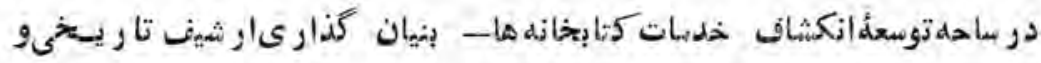

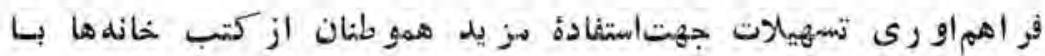
سو فقتيتهاى ثايانى تو أمبو دم.

$$
\text { ارشيف تارف إنى }
$$

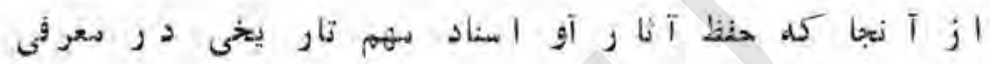

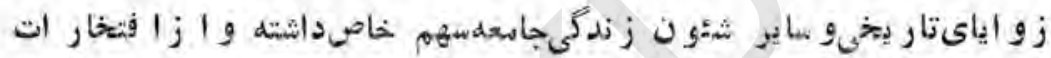

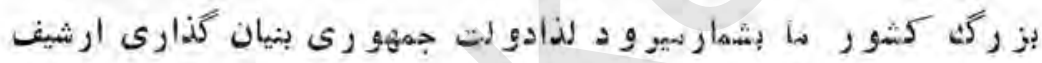

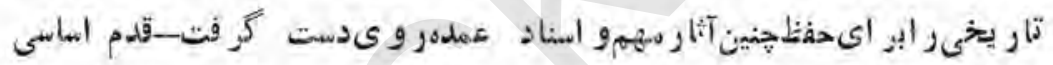

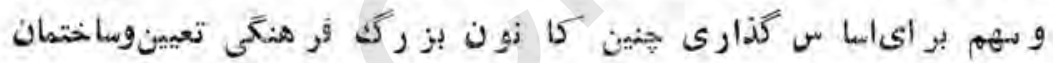

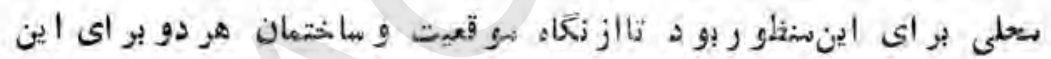

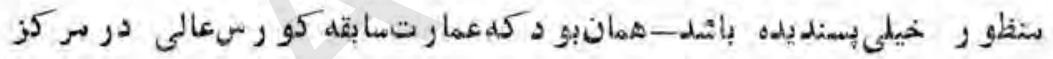

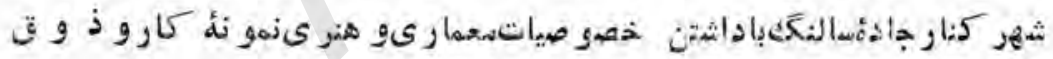

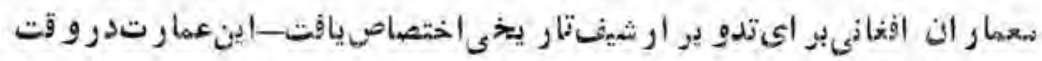

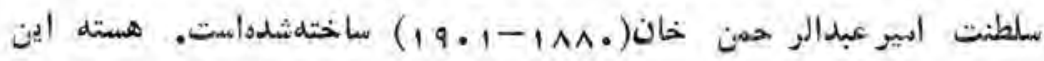

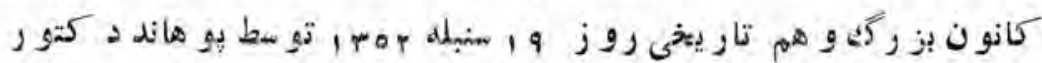

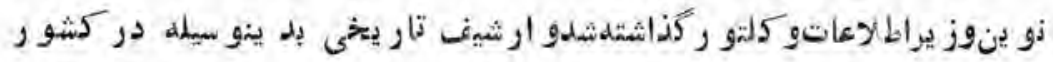

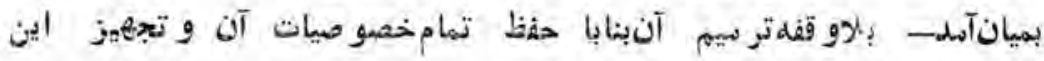

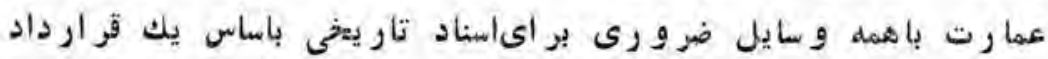

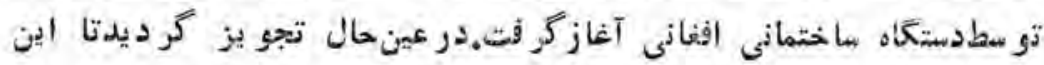




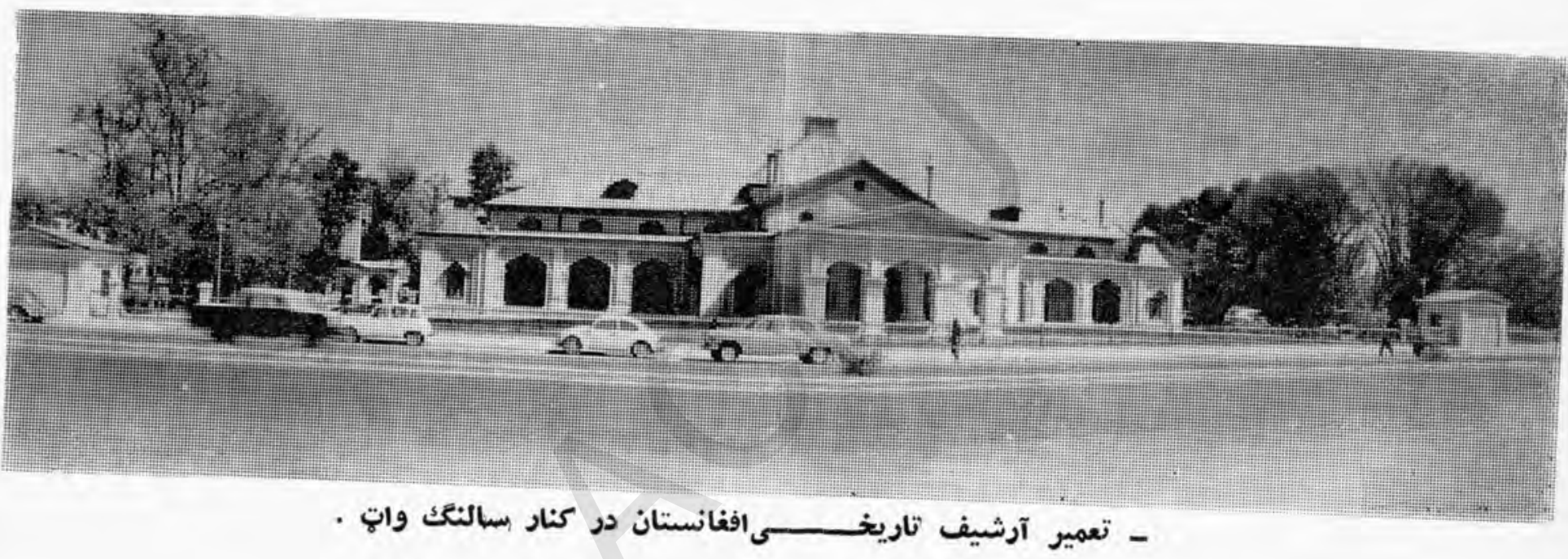


بنابانو كز كر بسى و و سايل تهو يه مجهز بو ده و بحيث يك بناى تار يخى طو رى تر ميهم ديد ما تمام خصو صيات معمار ى آنبهمان شكل اصلى حفظشو د.

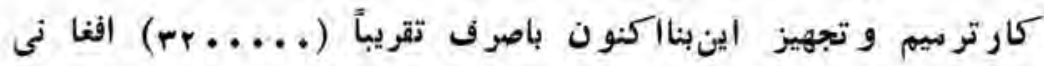
(9^) باساس فيصله ستخصصين يو زسكو طبقل تحتانىارثيفتار يخىبراى حفظ

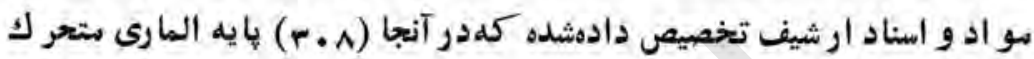
جاداده خو اهدشل- درمنزل فر شاين بناى بز ركث اتقاقهاى بر ايى كنفر انس

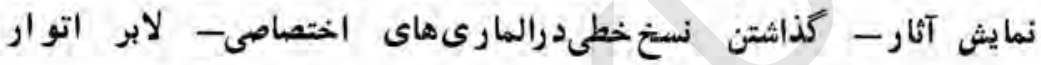
مكر و فلم -عكاسى - اتاق انتظلار و غير • ضر و ر ياتيكار شيفتار يخى در نظر

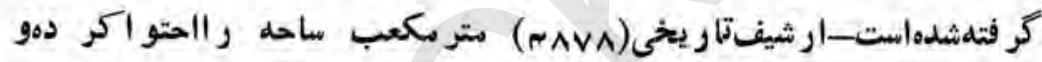

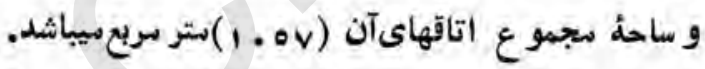
درعينحال وز ارت اطلاعات و كلتو ر بلجمع آو رى وخر يدارى آثا ر ارزشمندو اسنادتار يخى شر و ع نمودو همكارىى هموطنان رادرجمعآو ر رى هنينا سنا د جلب كر د. باينصو رت كارتو بيم و تجهيز عمارت ا رشيف

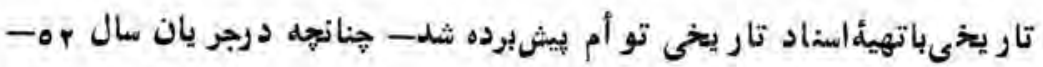

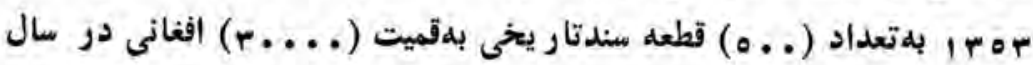

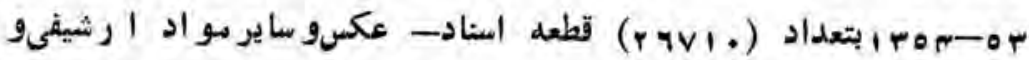

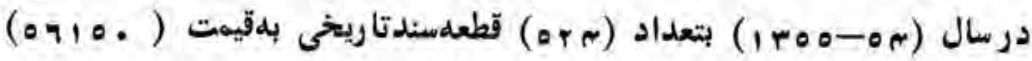

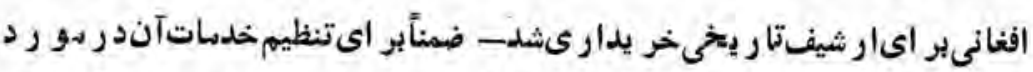

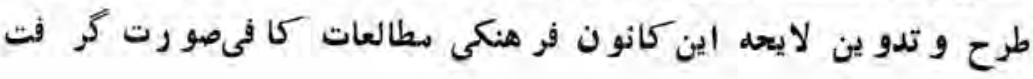




$$
\text { اجرا آت النا عاتى وكلتور ى }
$$

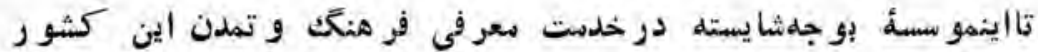

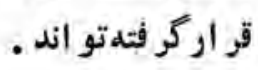

\section{ز ز}

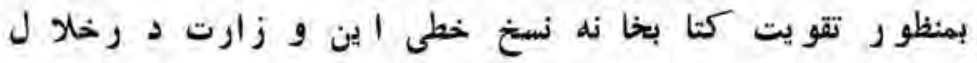

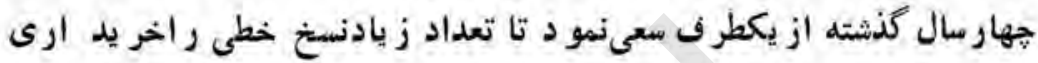

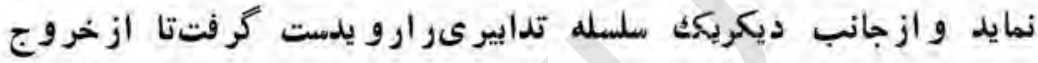

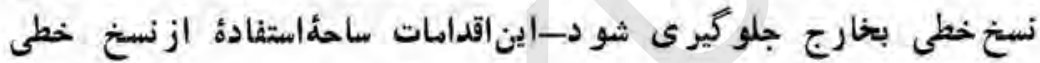

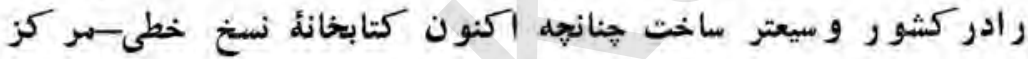

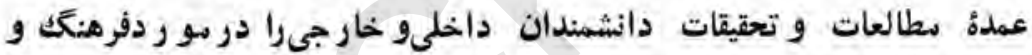

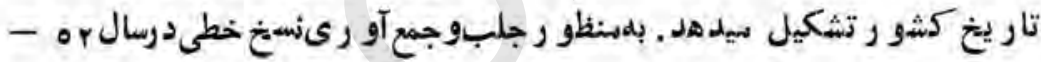

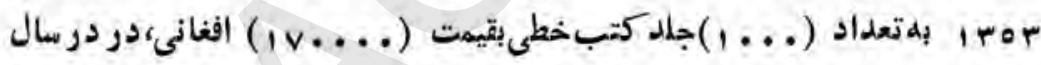

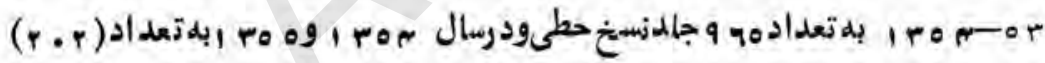

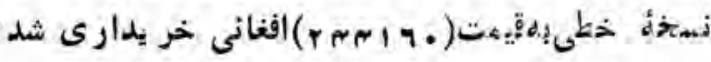

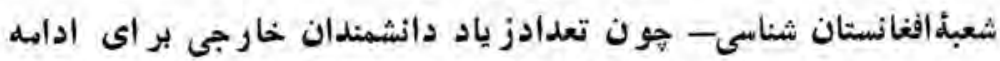

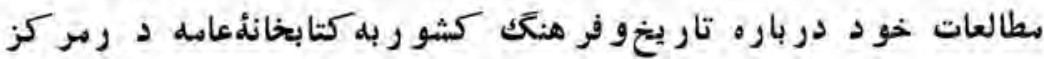

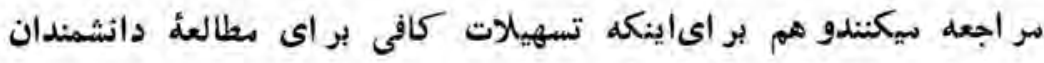

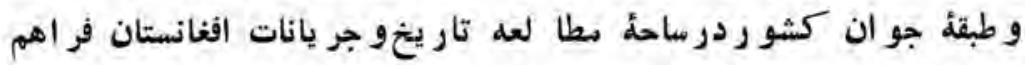

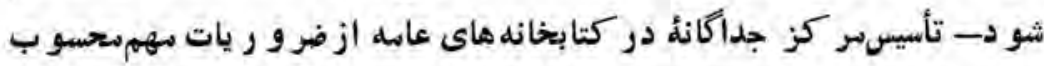

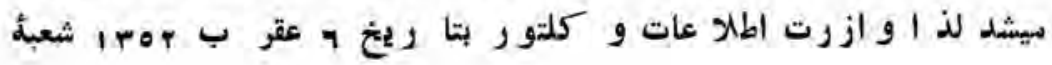






- كوشه از كتابخانه عامه كابل. 


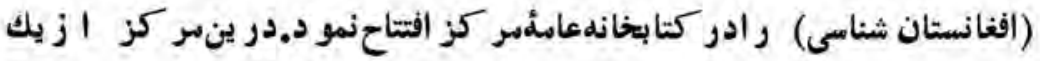
طرف تما مآثاروسوجود كتابخانه دربارة افغانستان كذاشته شد و ازجانب ديكو بجهع آو رى و تهيل آثارى اقدام بعمل آهدكل ازطرفدانشهند ان و

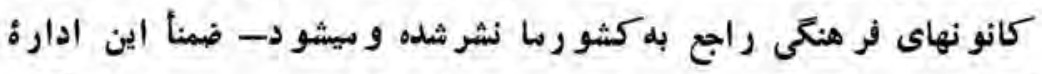
كتنغ تمامدطالب تار يخى و تحقيقى رادر باره افغانستان بصو ر ت جد آثانه تر تيب كر دهاست كله اين آثاردورمجموع مر كزعمده مطالعات افغا نستان شناسى رادرداخل تشكيلدادهاست

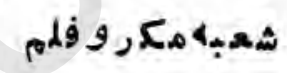

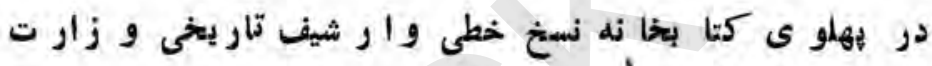

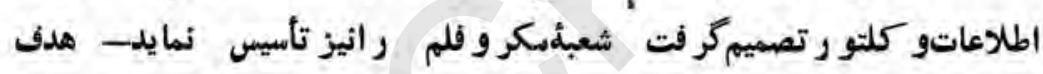

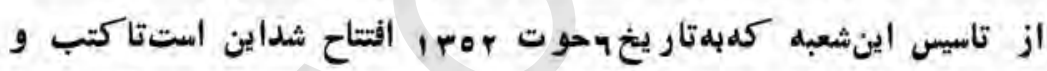

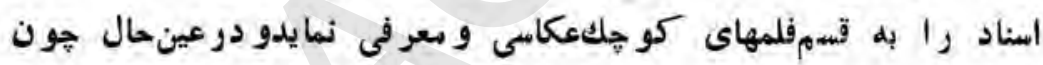
تهيئة نمو نه هاى از آثار معتبر مر بو ط بهفر هنگك و تمدن كشو وما از كانو نهاى فر هنكى جهان براىتو سعل حدو دمطالعات دانشمندان كشيو ر ازضر و ر ريات عمده شمو ده ميشو د و هما كثر كانو نهاى فر هنكى نعونه هاى از آ ثار معتبر مار اجهت بيشبر د مطالعات خو يش و داشتنايناثاربطالبه مينمايند ، لذاتأسيس

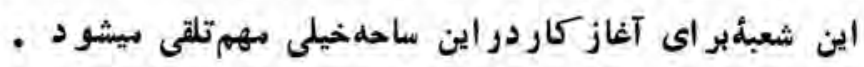

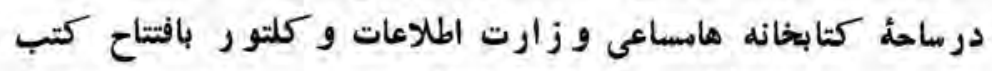
خانه هاى جديد درو لايات- تقو ئه كتابخائه هاىمو جو د و تو سعل حد ود فعاليت كلب جو انان بر ایىتنو يو اطفال و جو انان كثو رمتثر كز بوده است. 


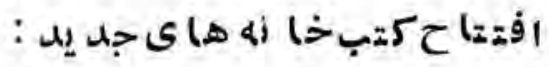

سعىشدرّتادر حدو دامكانات كتابخانه هاىجديد درو لايات كثو ر افتساح

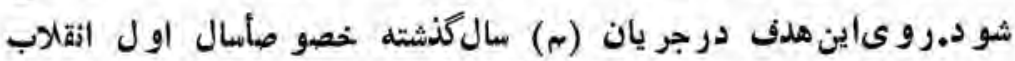

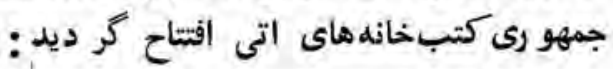

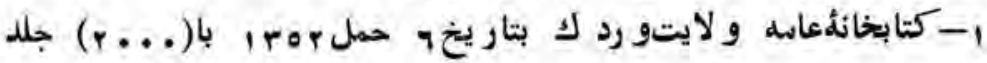

كتاب

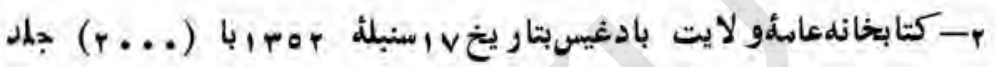

$$
\text { كتاب }
$$

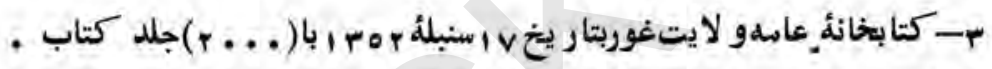

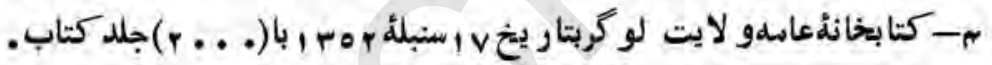

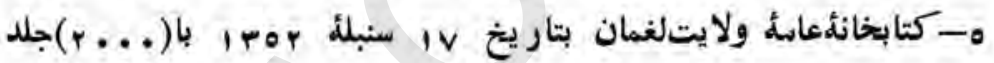

$$
\text { كتا ب }
$$

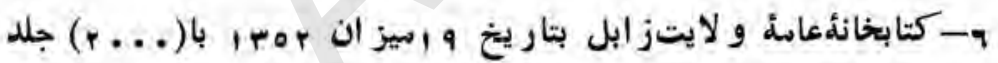

كتاب .

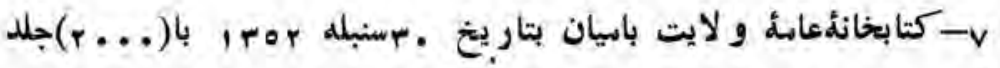

$$
\text { كتاب . }
$$

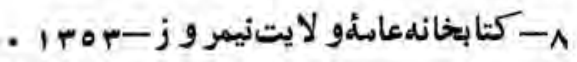

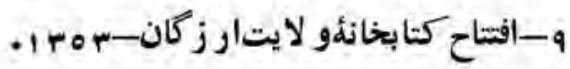

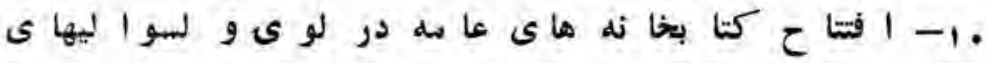

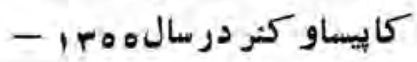


(rvi)

د رحصهُ تقو يل كتابخانهماى ولا يات همكارى به د وطر يق اد اله اله

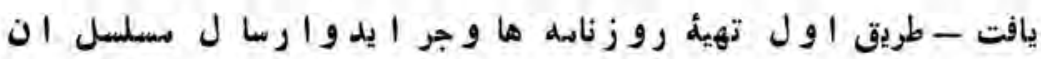

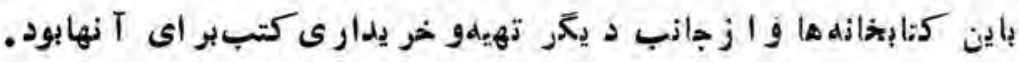

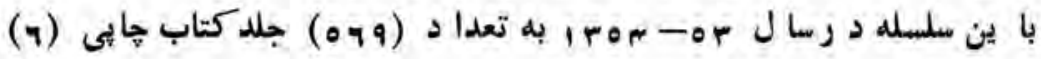

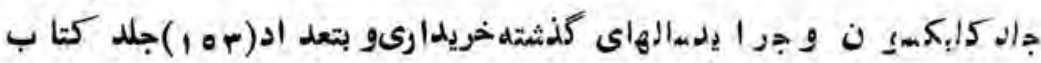

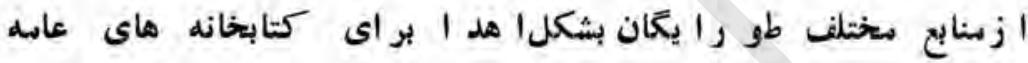

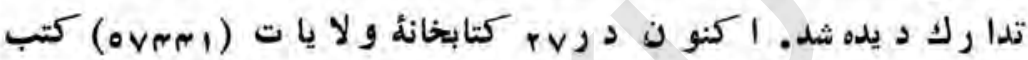

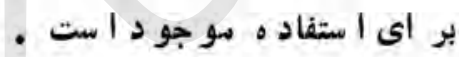

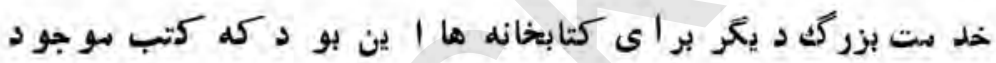

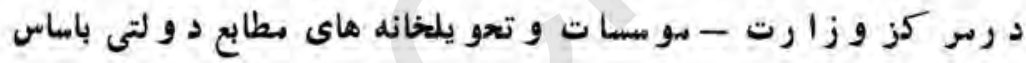

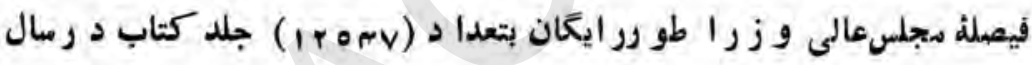

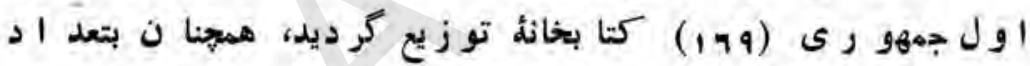
(كل) (rArr)

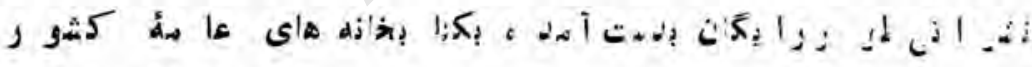

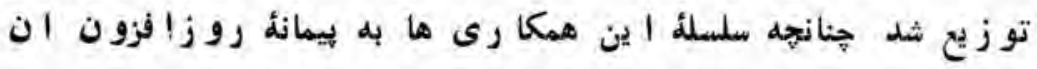

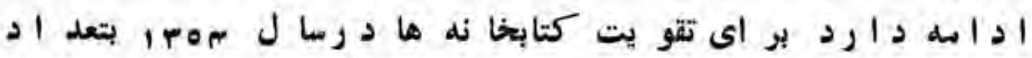

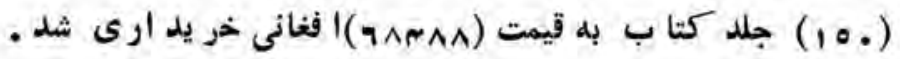

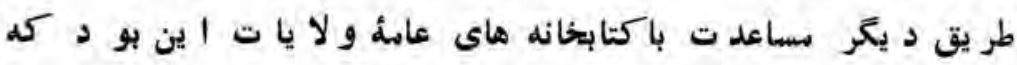

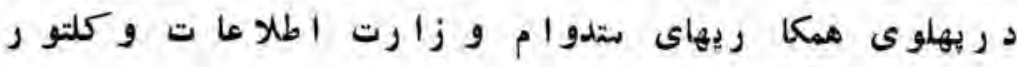

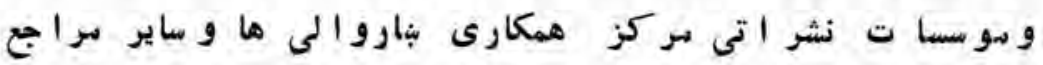




\section{v,}

عر فا ن د و ست كشو ر د ر ين زمينه جلب شد كمه ا ين همكار يهاقرا ر آتى ميبا شد :

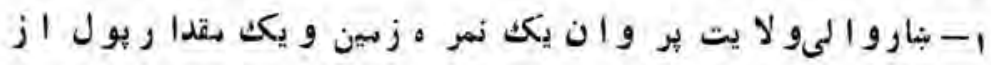

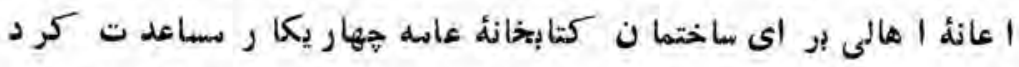

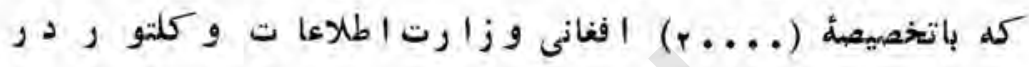

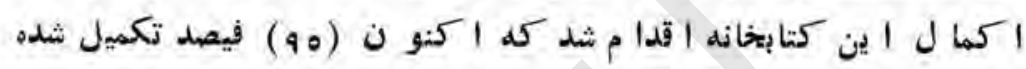

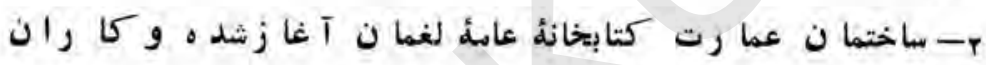

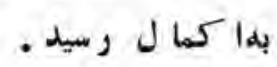

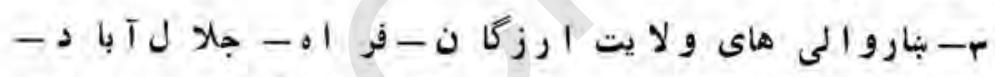

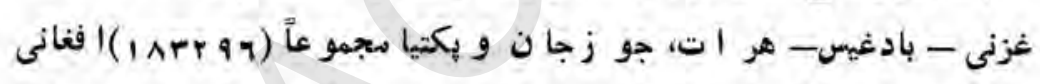

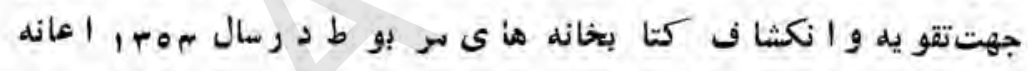
دا جادماند.

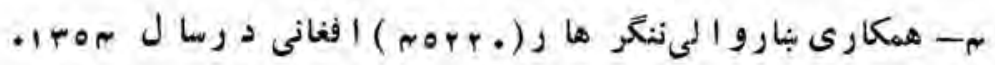

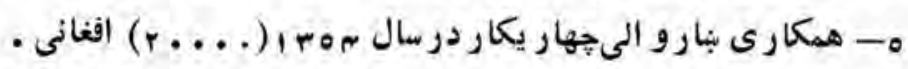

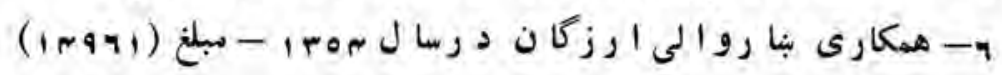
ا فغانى

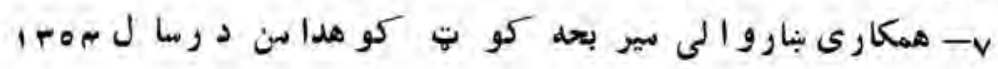
- انغانى (1...)

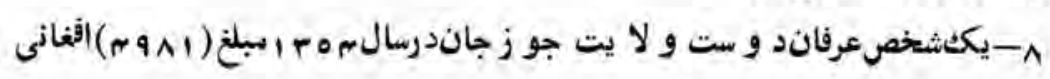




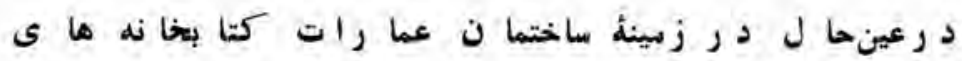

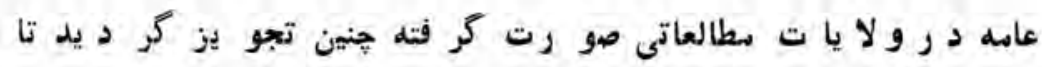

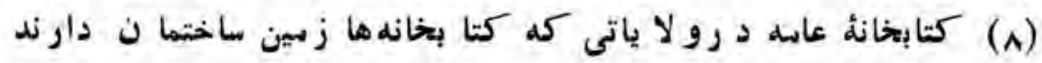

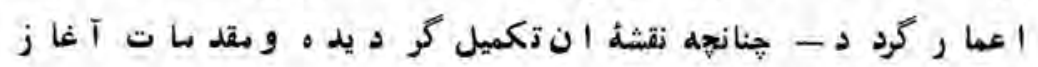

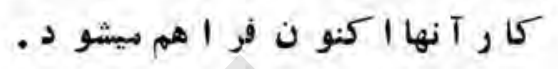

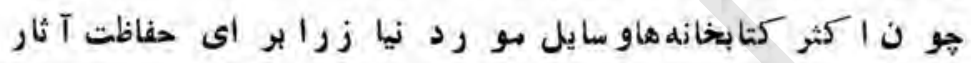

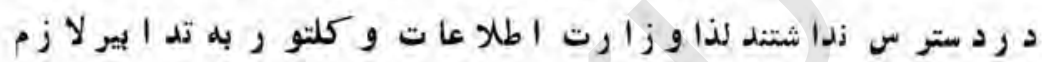
جهت وقائه كتابخانه ها و تهيه و سا لا ن ضو و رى و فو ا هم آو رىى

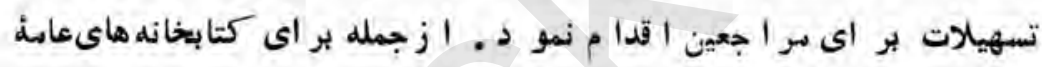

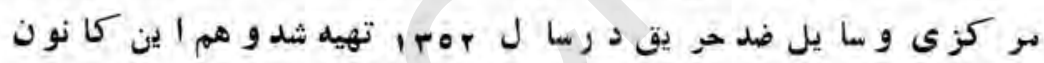

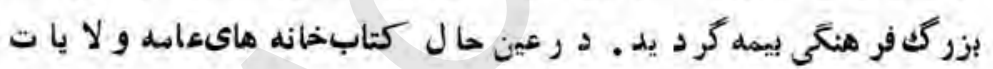

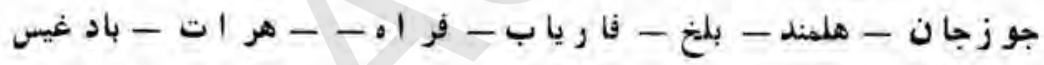

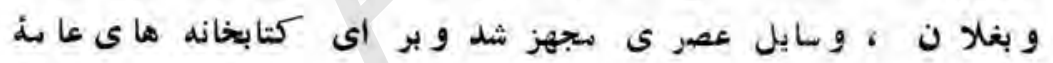

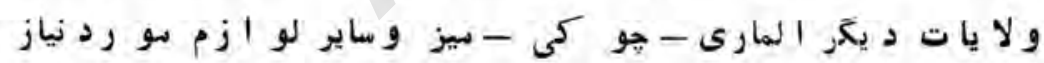

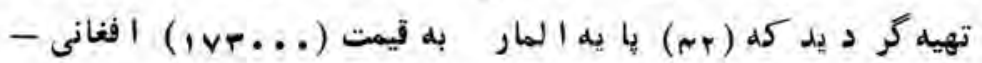

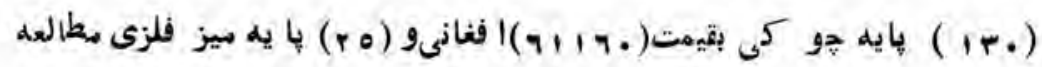

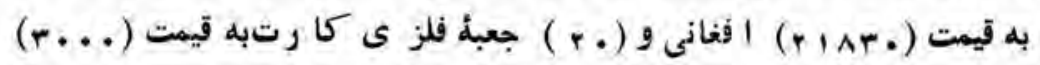

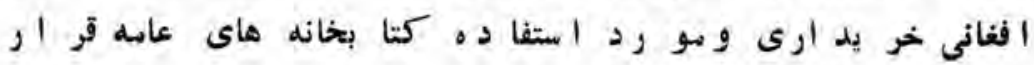
.

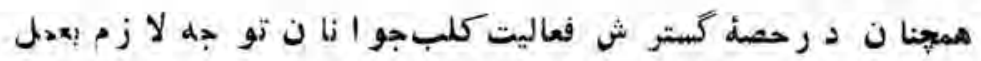


اجرا آ ت اطلاعاتى و كلمبورى

$(r \vee r)$

آسد تا ازيكطر ف تعد اد زيا دآثار و ثشر ا ت مو ر دنياز

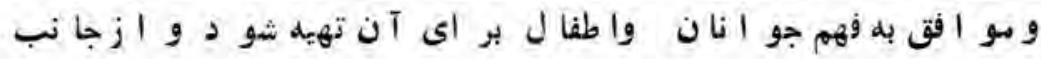

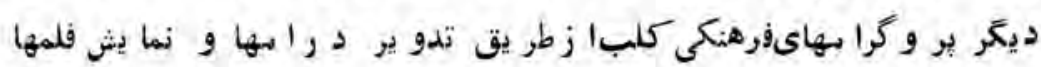

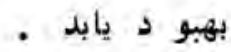

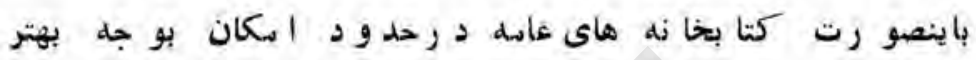

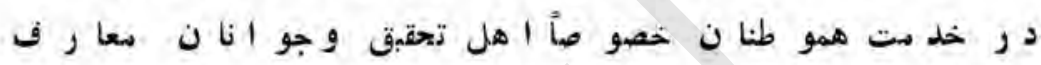

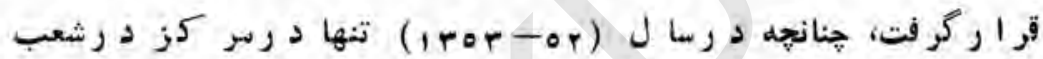

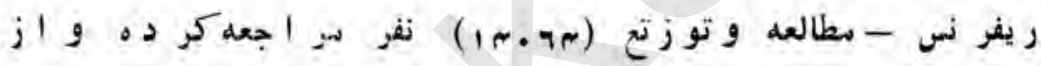

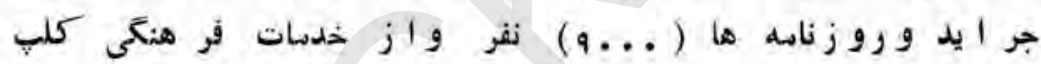

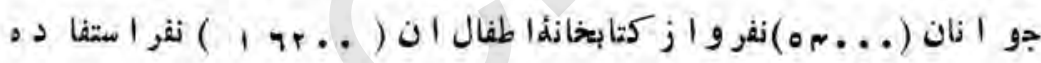

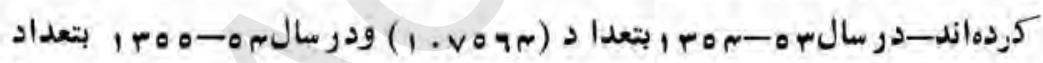

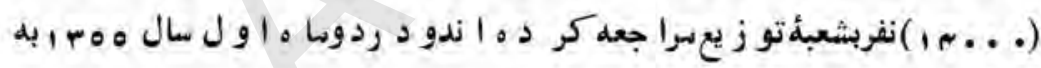

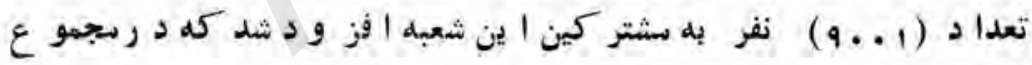

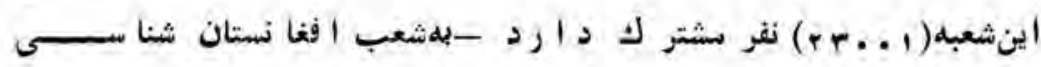

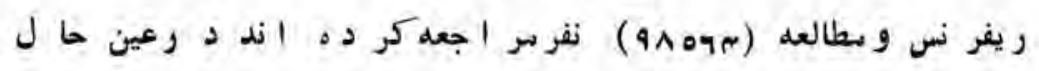

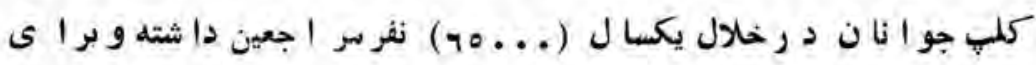
باراول بمنا سبت رو مادد ر ـ سا ل بين المللى زن و سا ير احتفالات كنسرتهاى از طر ف كروه هنرى كلب جو انان ان جزئ أه شيده الهت

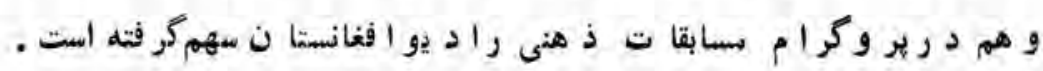


(rvo)

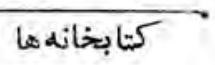

اكنو ن از(....

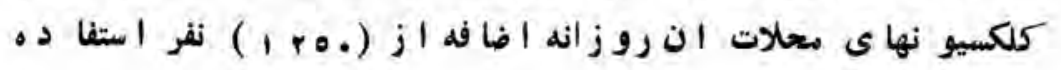

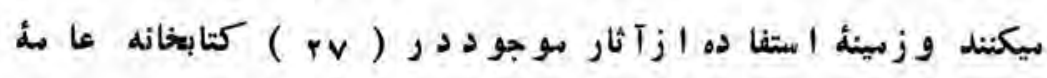
ولا يات

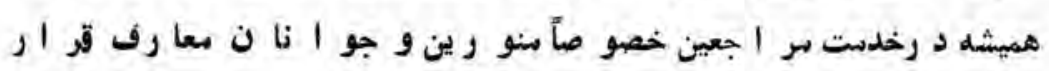

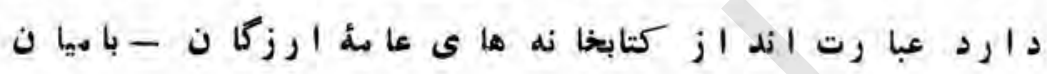

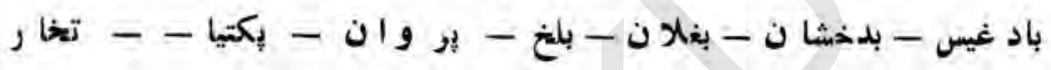

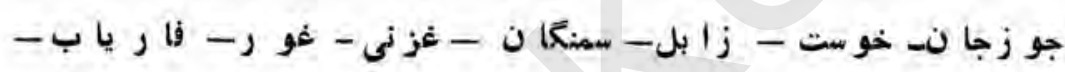

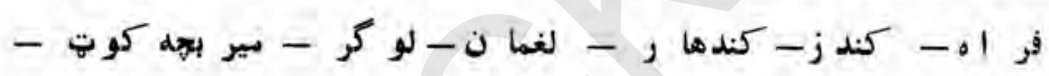

كهدا سن -نيموو ز-ننكر هار - و روك - هرات - ملمند- كاييسا و كنر.

$$
\text { تو ز إع كتب بمر احع فر هذعى و عر فانى : }
$$

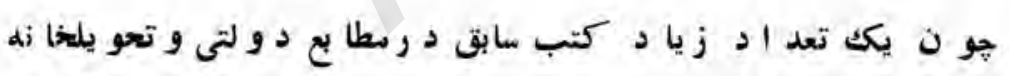

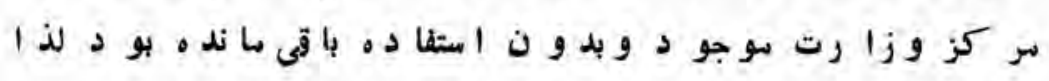
بو اي همكارى بامؤ مسيا ت فوهنكى و عر فانى كشو رو هم د ا نشمند ان

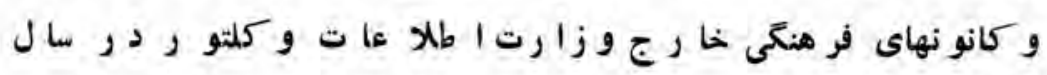

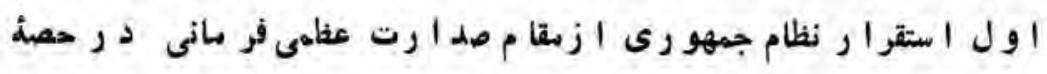

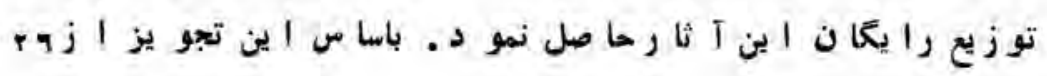




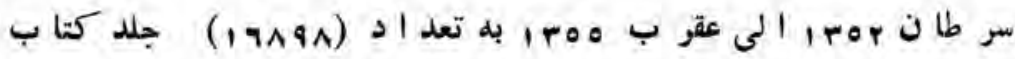

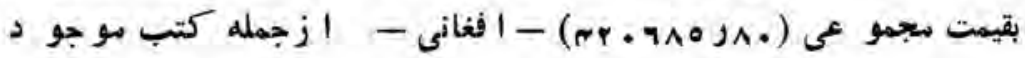

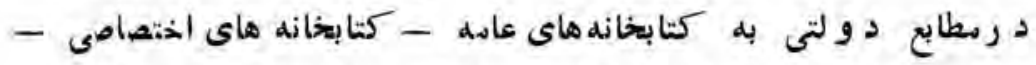

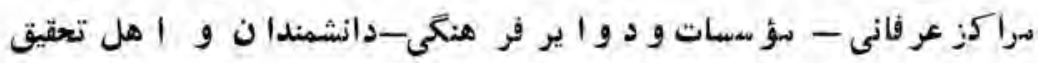

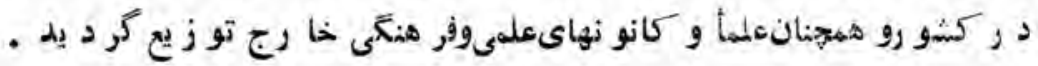

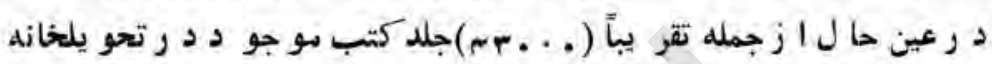

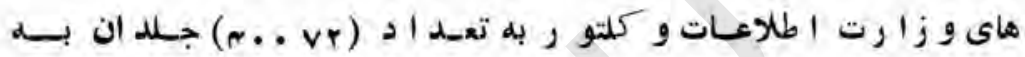

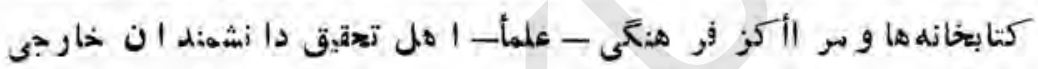

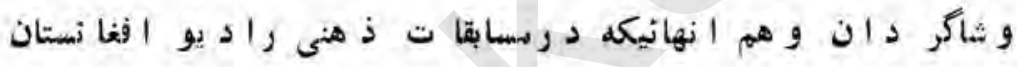

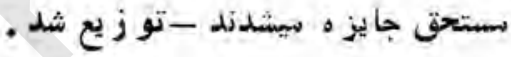

$$
\mathrm{s}^{\alpha \Delta \Delta i l>-1=5}
$$

از آنجا كه عمارت سو جو ده كثابخانئ عامه سر كز بشكل بو جو ده

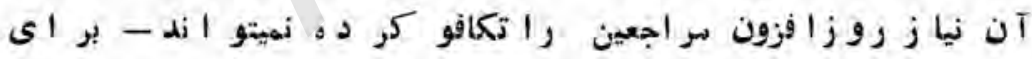

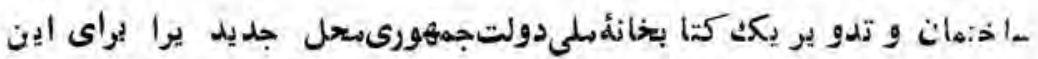

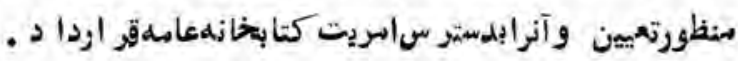

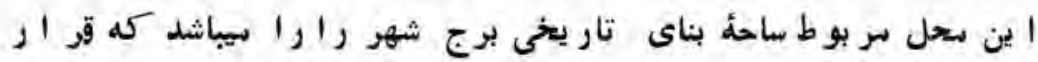

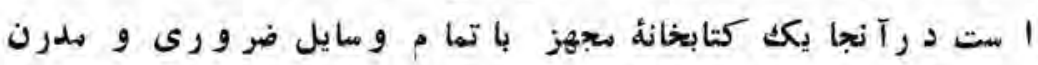

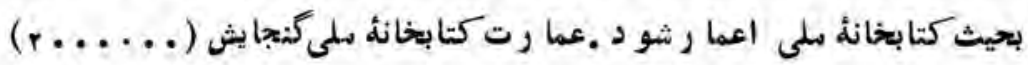
جلد كتابرا خو اهد دا شت.اكنو نسروى سقد ماتى اينعمار ت آ آثازيافتهاست. 


\section{فلمعلمورو ادب}

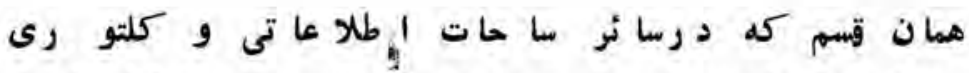

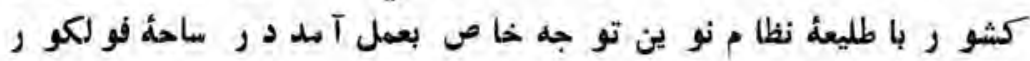

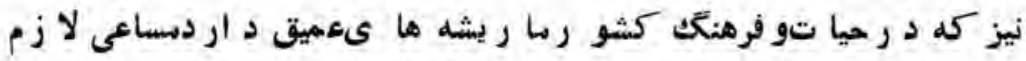

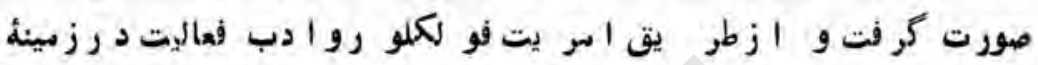

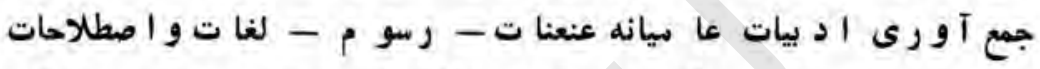

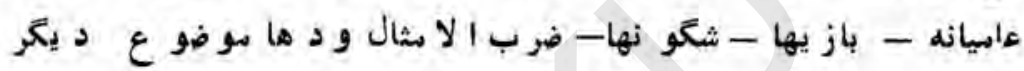

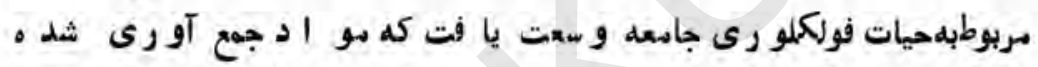

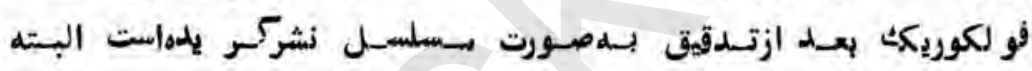

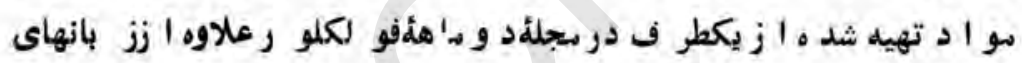

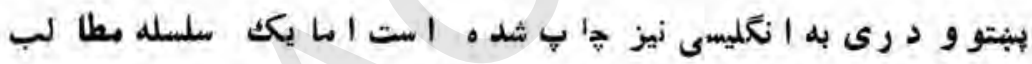

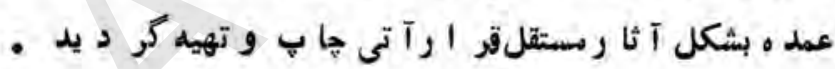

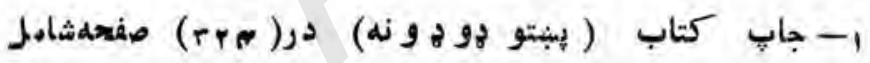

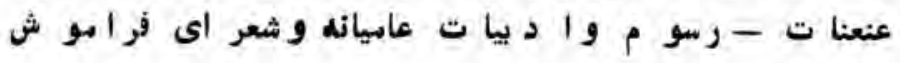

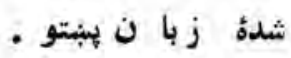

$$
\begin{aligned}
& \text { r- جاب كتاب ( تر ا نه هاى كوسار ) }
\end{aligned}
$$

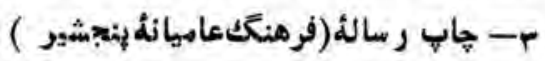

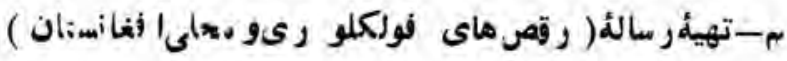

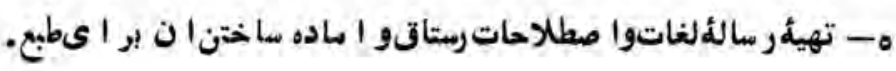




\section{اجرا آتاطلاغاتى كليورى}

و- تهيئر سالله د ربا رؤ مو ميقى و الات فو لكلو رى مو سيقى

$$
\text { كشو ر }
$$

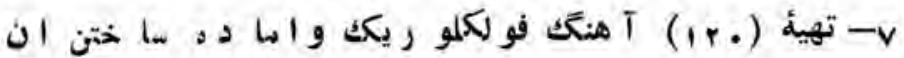

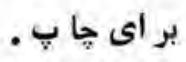

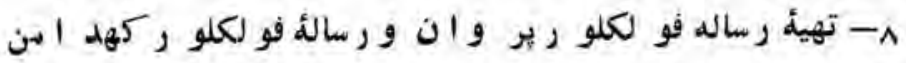

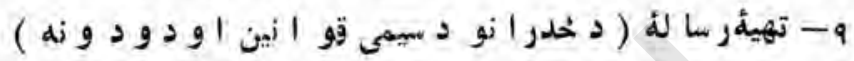

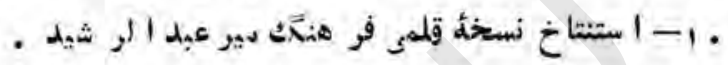

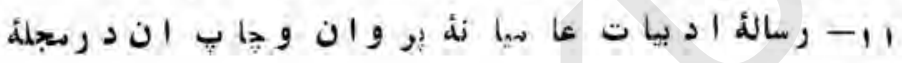

$$
\text { فولكلو ر }
$$

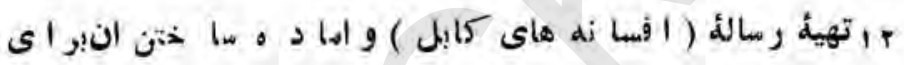
جابٍ

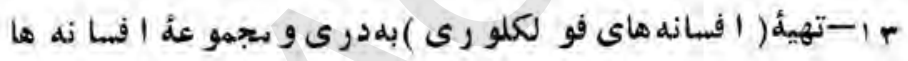

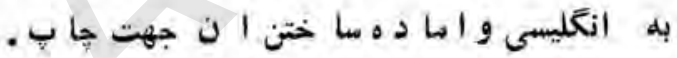

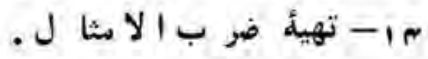

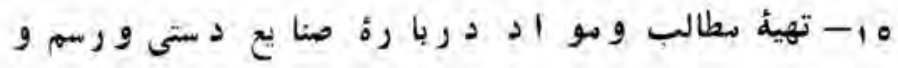

$$
\text { - lo }
$$

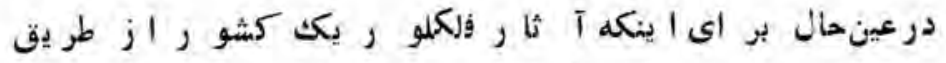

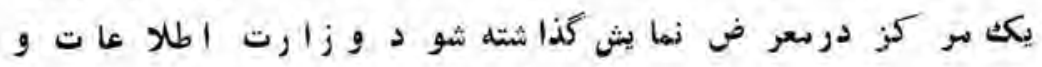

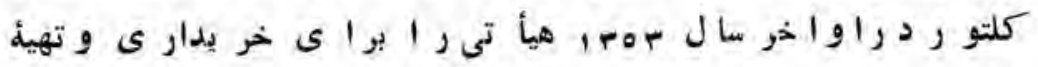

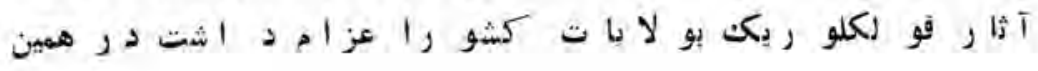


سا ل با جمع آورى آثا رد لجهب فو لكلو ريكن بو زيم فول لمو ر ريكث

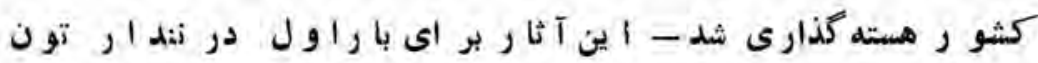

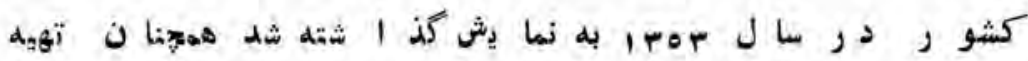

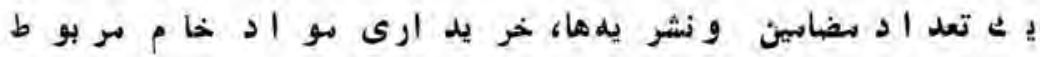

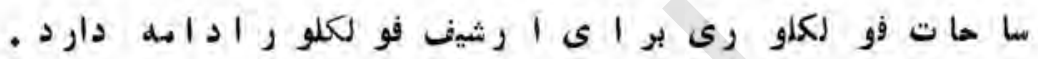

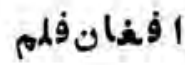

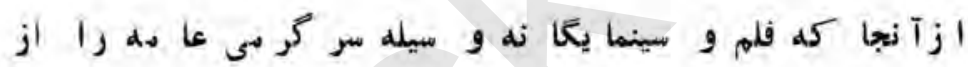

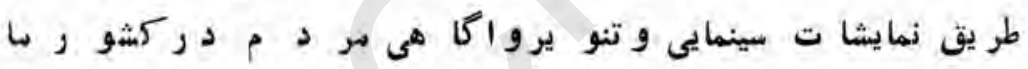

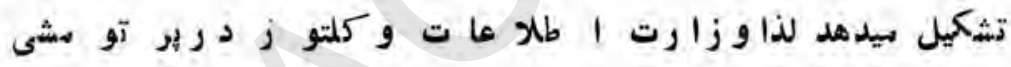

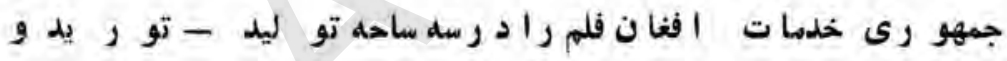

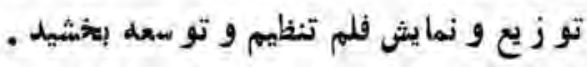
تو ليدؤمم

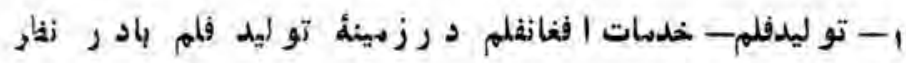

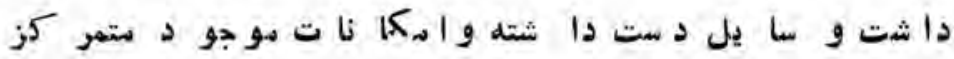
كرد يد به تهئ فلمهاى مستند اخبارى وفلمها ى هنر ى . الف : تو ليدفلمهاى اخبارى و هنر ى . 
ـفلم هاى خبرى لمر بو ط تاسيس نظام جمهو رى و سا ير

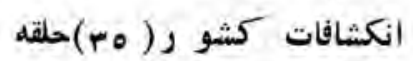

ـفلم جمهو ريتو مر اسه بر افر اشتن بير ق جهوورى (1)حلقه.

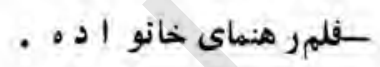

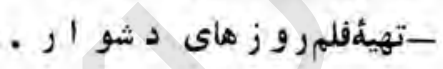

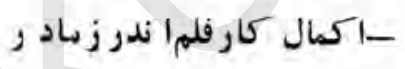

-

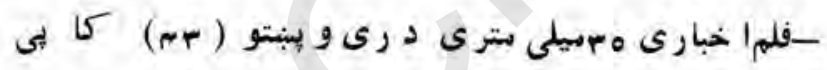

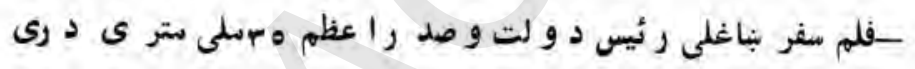
و ينبتو (v) فلم -

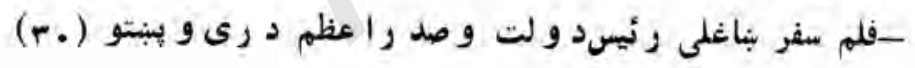

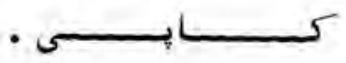

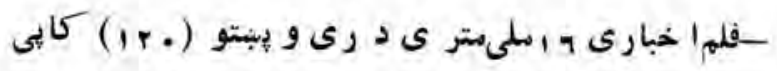

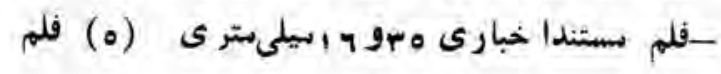

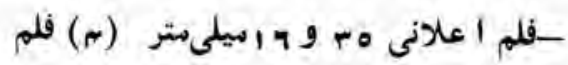

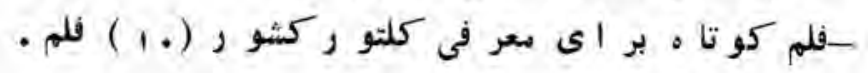

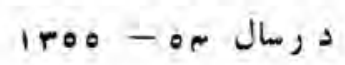


- فلم هاى سفر بناغلى رئيس د و لت و صد را عظم

$$
\text { بdهند- بنغلهد يش-عر اق ق وا ير ان (و 1)فلم }
$$

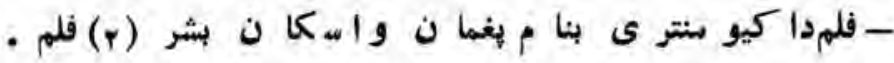

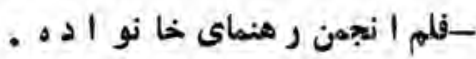

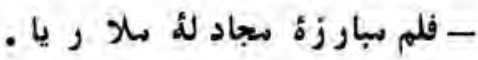
همكارى د ر تو ليدفلمهاى هنر ى : و زا رت اطلاعا ت و كلتو ر

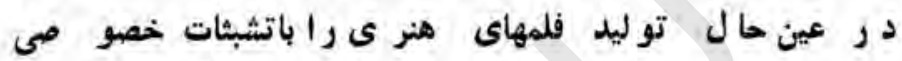
نيز تششو يقنمود جنانهل بإيير و ى ازين رو حيه د ر تو ليد

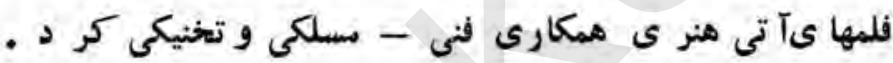
ا- فلمهنر ى ( و شعر هاناسو وده ماندند) - داستا ن عشق ناكام را بعلة بلخى شاعرة نامى كشو رو حارث - كله بأسر مايه

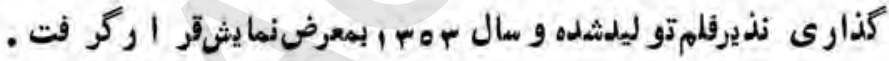
r- فلمهنر ى ( مجسمه ها ميخدند ) كه باسر مايه كذارى خصو صى (آر يانافلم) د رسال همبر توليد و بمعرض نمايش

$$
\text { - قر اركرفت }
$$

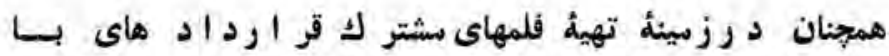

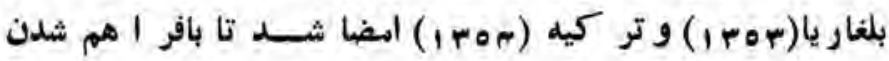

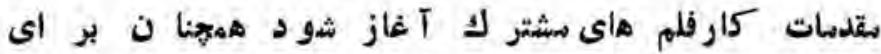

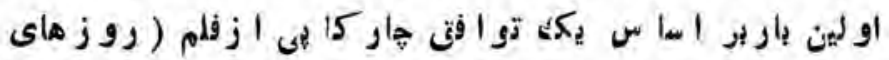

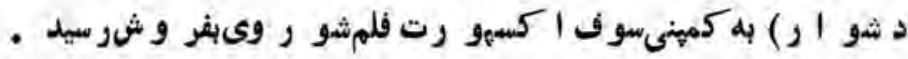




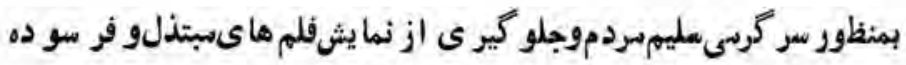
باسا س ياليسى كلتو رى د و لت هنين تجو يز شد كله فلمها ى هنر ى بعد ا زا ينازطر يق ا فغا ن فلم و ا رد شد م به سينما هاى

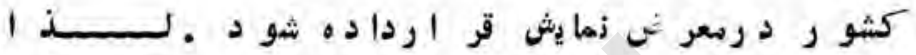
بر اي عملى شد ن أينمو ضو ع مقر رة أفغان فلم بتا ريخ ا و ول

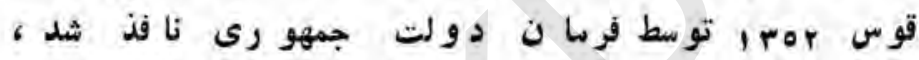
و با ينصو رت افغان فلم يكانه سر جع با صلاحيت توريد فلم د ركشو ركز د يد . باسا س اين تجو يز وزا رت اطلا عات و كلتور تصميم كر فت به تو ريد آن نو ع قلم ها ى هنر ى

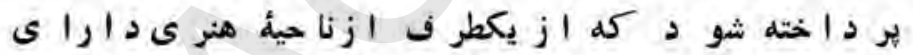
سو يه باشد وازجانب د يكر امو زنده ودواراى جنه اخلاقى و تنويرى خصو صاً بر اى تسل جو ان كثو ر باثلد .

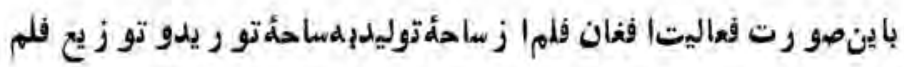

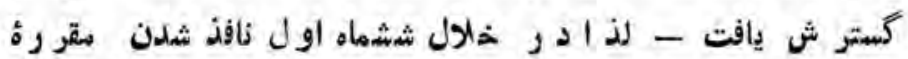

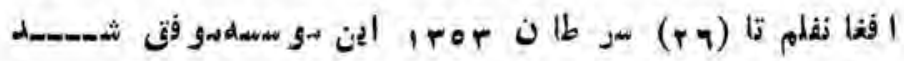

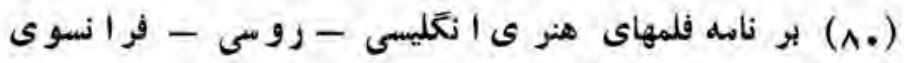

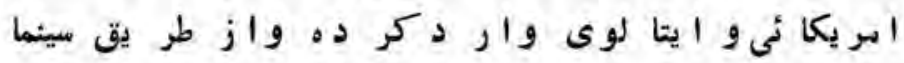
هاى كثو ر د رمعر ض نمايش قر ارد هد . 


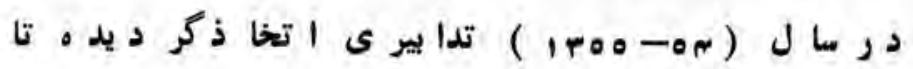

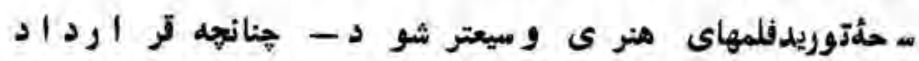

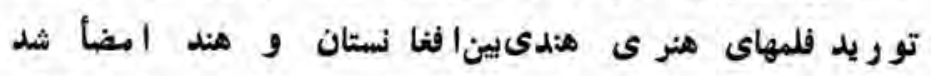

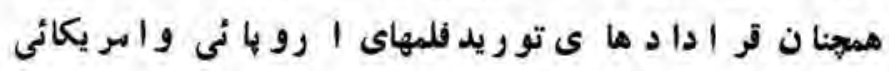
با هر اجع مر بوطه بامضا شدوقو ارد ا د هاى بر اي تو ريد

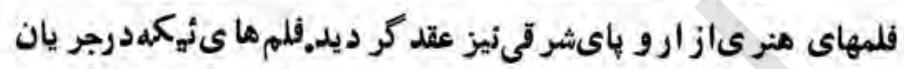

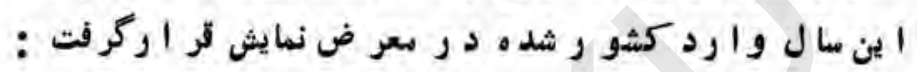

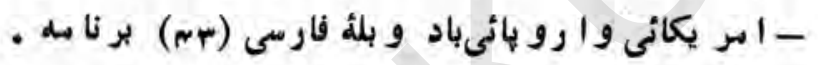

$$
\text { - }
$$

- ارو هاى شر قى باشر ح د ري (10 ) بر نامه .

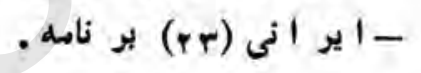

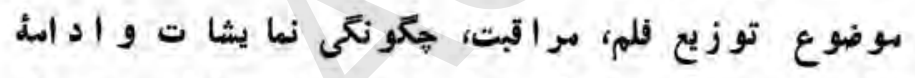

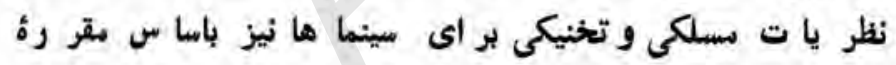

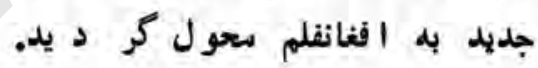
بو اي سهو لت كا ر افغانفلمدو با يه بر وجكتو رد جديد(ب) ملىمتر ى مخر يد ارى و سا نسو رفلمهاى وا رده تو سط هياً ت سانسو ر

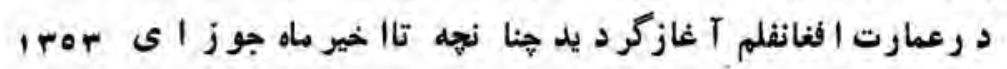

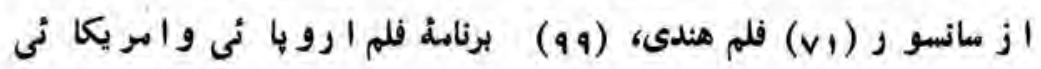

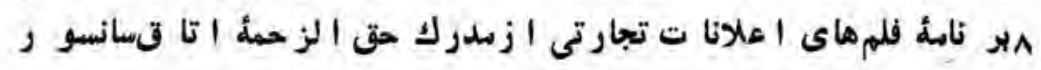

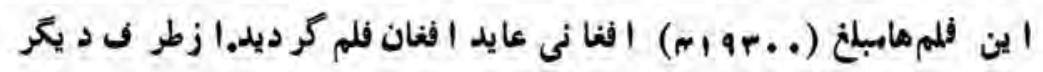


اجرا آتاطل عاتى كلثو رى

$(r \wedge r)$

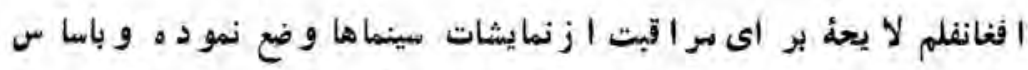

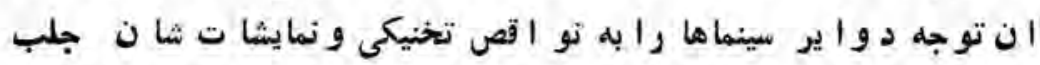

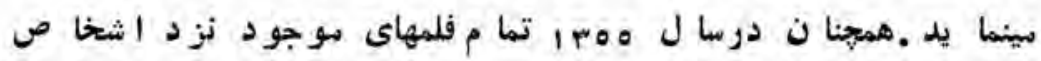

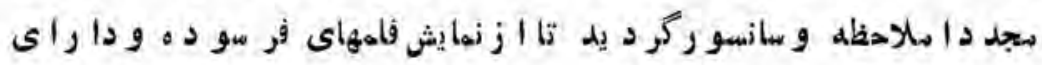

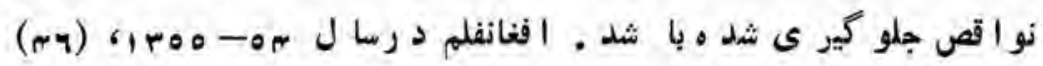

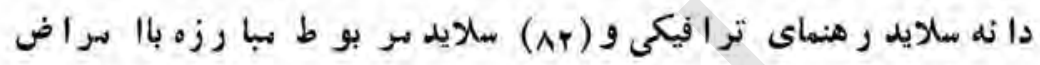

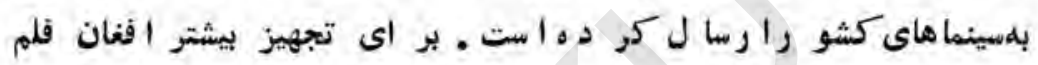

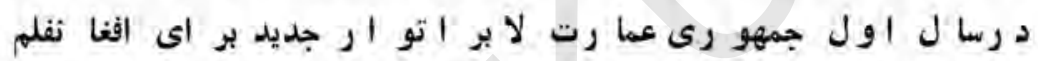

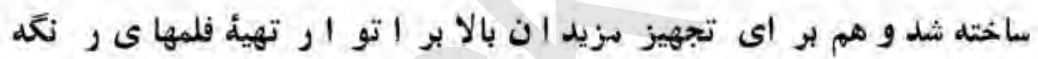

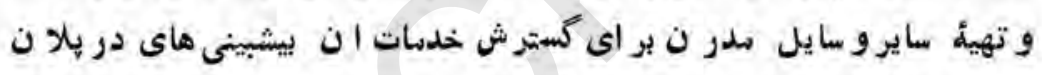

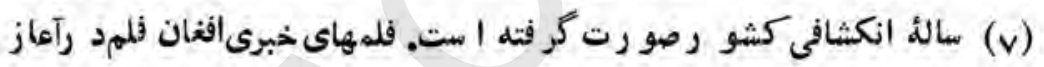

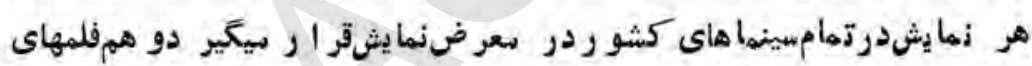

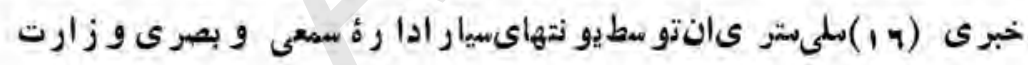

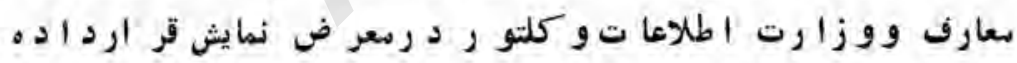

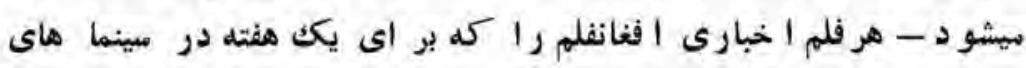

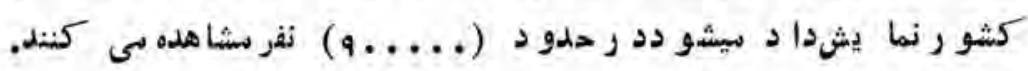

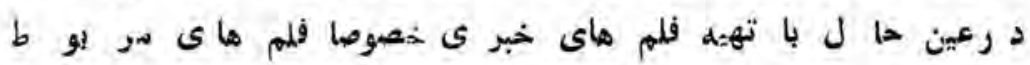

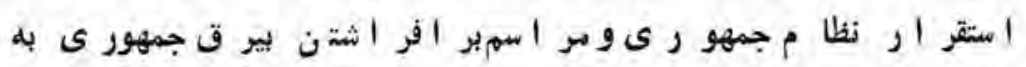

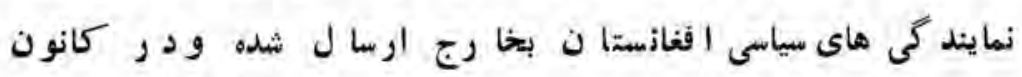

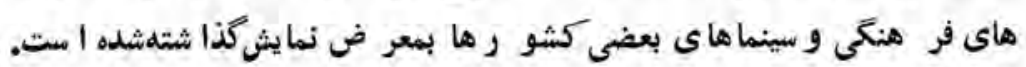




\begin{tabular}{ll}
\hline$(r \wedge 0)$ & خدمات هنرى \\
\hline
\end{tabular}

همكارى الفغانفلم باهيأت هاى فلمبر دارى كشو رهاى خارجى باماس لا يحهُ الفانفلم تنظيم كر د يدو تاكثون باسا س ا ين لا يحه باهيات ها ع

فلبر دارى كثو ر هاى خا رجى همكارى كر ده است .

خد مات هذرى

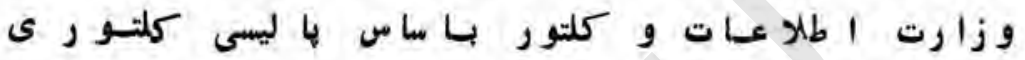

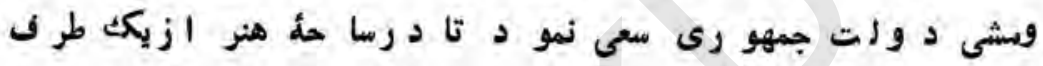

استعد اد ها ى نهفته را بيد ار واستعد اد ها ع موجو د را بيشتر تشو يق نما يدو ازجا نب د يكر روحيه افنانى د رتبارزو تشبثا ت هنرى نمو د ار باشد كه بير وى ازينين روش نه تنها باعث ابتكا رات د روساحلة هنر شد بلكه آثار زيا دى د رتمام ساحا ت هنر ى هد يد آمد و با عث شد تا انكشا فاتى د ر سما حات هخخالن هنز ى ازقبيل تيا تر - مو سيقى

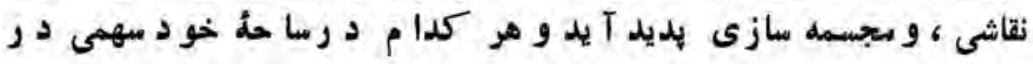

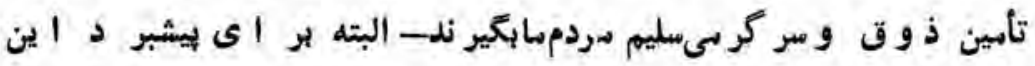
خدمات فعاليت مو سمات مر بو ط تنظيم كر د يدو منر تياتو و نما يشات هنر ى ازطريق الفنان نندارى - نقاشى و مجسمه سازى ازطر يق آ مر يتصنا يع مستظر فه و هنر موسيقى ازطرف د بيار تمنت مو سيقى انكشاف

و تو سعd داد ادمد مان. 


$$
\text { اجرا آت اطلا عاتى وكلتورى }
$$

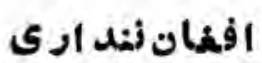

ا ينهو مسله هنرى خد با ت خود را از سه طر يق أمض مير دج

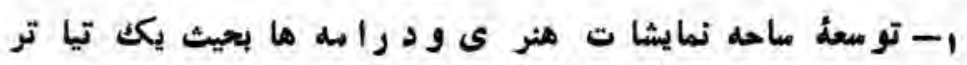
باو سا يل نسبتاً مجهز .

ه-تشو يق امتعد اد هاى هنر ى و ا نكشاق ا ستعد اد هاى جو ان

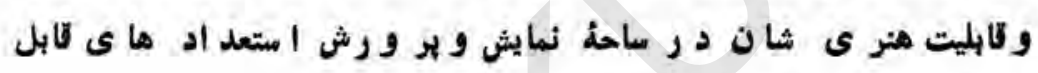
تر يه د رامو ردا يركت و تمثيل.

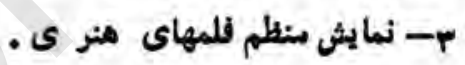
تمايش نامه هاو د را مها : ا فلا ن نند ا رى فعا ليت ها ى خود ر راد رين سا حه نه

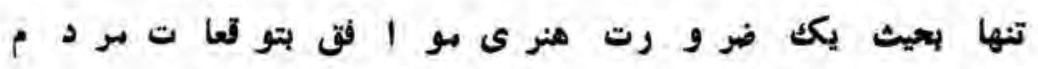

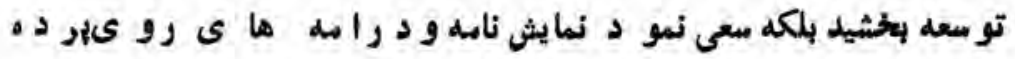

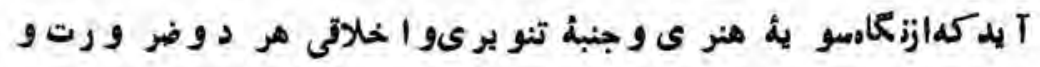

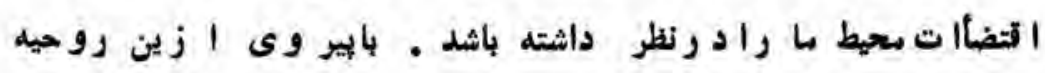
د رحها رسا ل ا ستقر ار نظام جمهو رى درا بهاونها يش ناهه هاى آتى

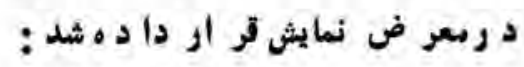




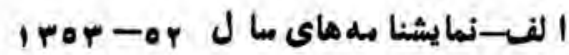

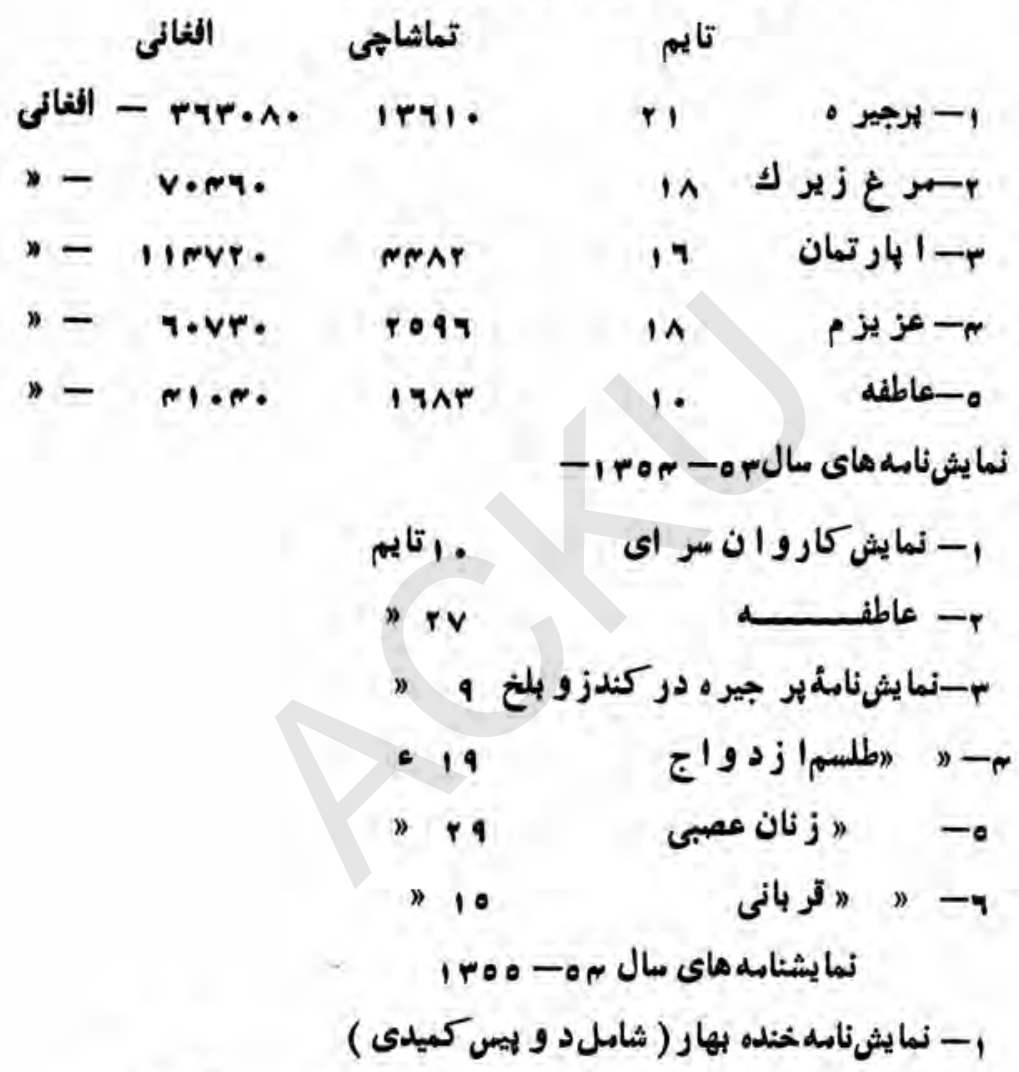

• تايم ...
nirg. mir

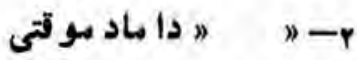
natre mel
r- " "مر زاقلمها
" rean "I
r- " " " " " ملبكارى 


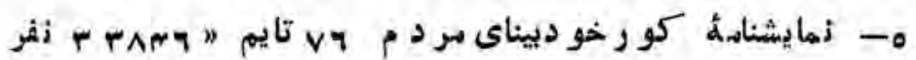

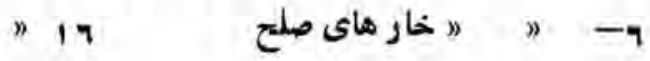

$$
\begin{aligned}
& \text { دوامباق }
\end{aligned}
$$

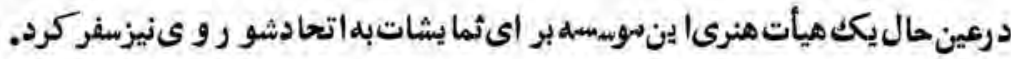

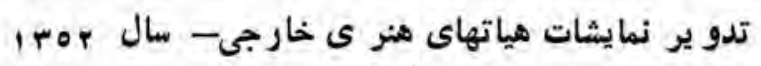

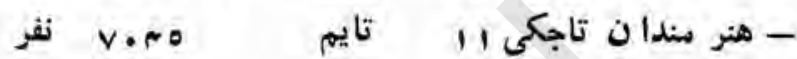

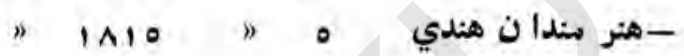

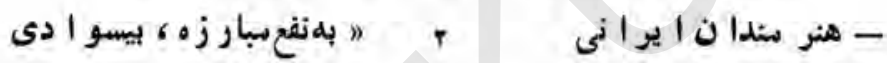

$$
\text { سال - ror }
$$

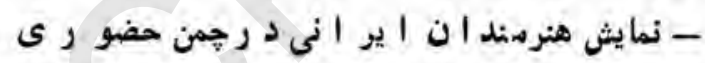
0

$$
\begin{aligned}
& \text { - ه نمايشهنر سندا ن شو روى }
\end{aligned}
$$

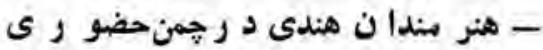

$$
\begin{aligned}
& \text { • } \\
& \text { - Tهنر هندا ن يوكوسلاوى }
\end{aligned}
$$

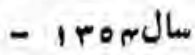

ونمايشد رسالكر د جشنجمهو رى

$$
n \text { " } " \text { ल }
$$

mmm" " " $" \wedge$

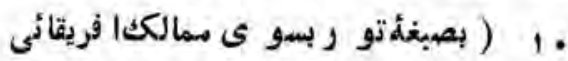

$$
\text { در حال سما فوت بو د د ند ) }
$$


$(r \wedge q)$

إفغان نندارىى

- هيأت مار يو نتا ستر اليا م نمايش سا لood

- نمايشات سشتر لـ هيأتهاى هنر ى كشو ر هاى خار جى - هيات هنر هندا ن ا تحاد شو روى ته ته

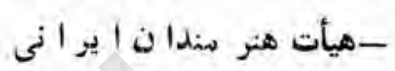
Lـ " ن - - क

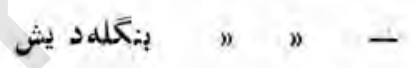
- تمايشات هنر سندان هين منمايش

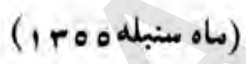

ب : تدو ير نحافل فر هنكىو نها يشات غير ا نتفاعى.

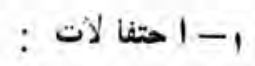

- تجليل روزمعلم آثو ر مهبر .

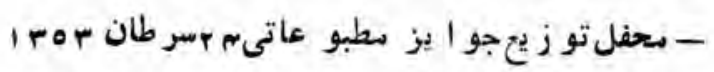

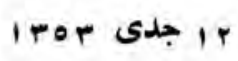
- تجليلسال بين المللىزن -تدو يو ثرو وكر ام ا ختصاصى كميتها نسجام زن - تدو يو روز دملمج 


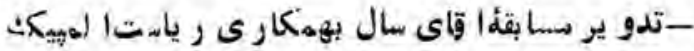

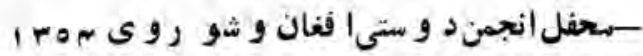
-

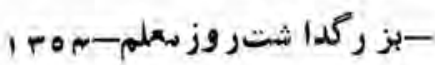

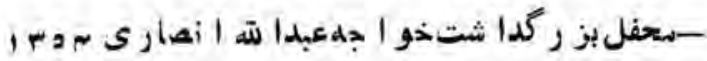
r-فستيو الهاو نمايشات غير انتفاءى:

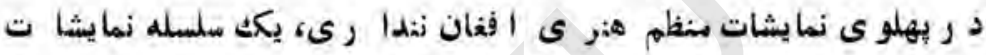

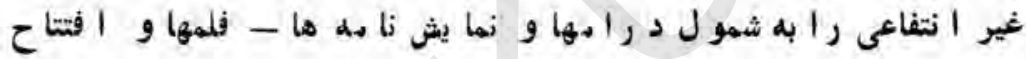

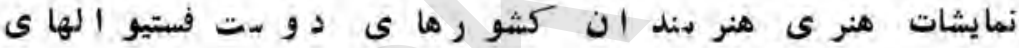

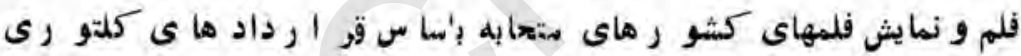

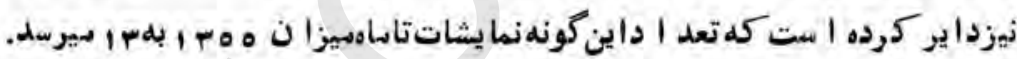

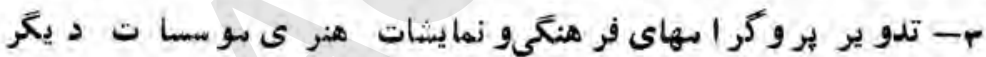

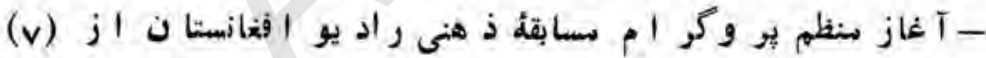

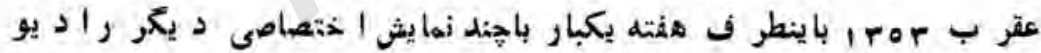

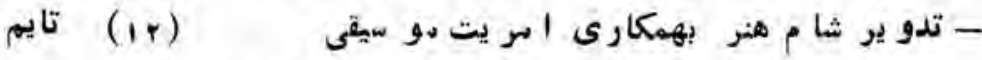

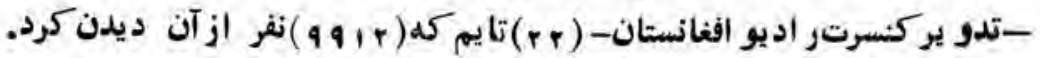

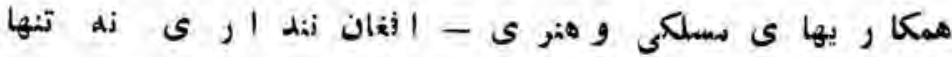

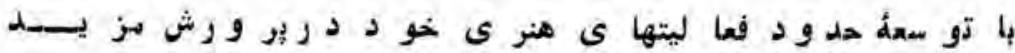

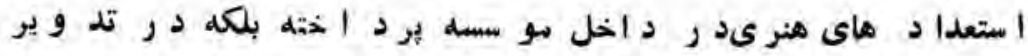

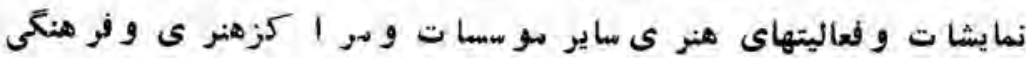


سهم كر فته كل بيشتر ا ين هدكا ريها بار الد يو ا فغانستا ن - ا فغا ن فلم

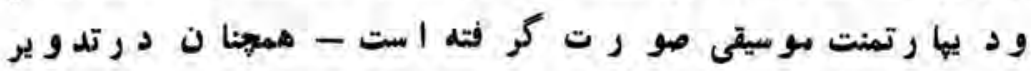

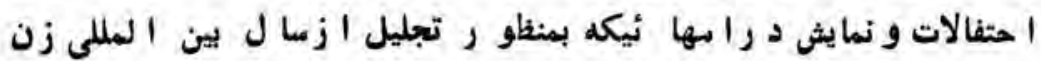

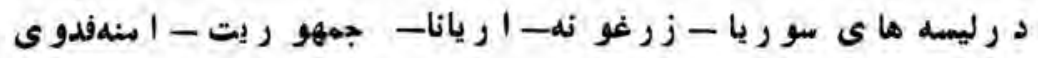

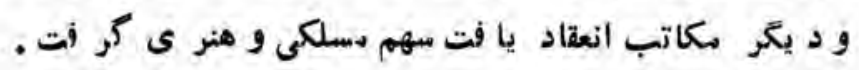

$$
\text { زما يشات فلم- }
$$

د ربهلو ى خدمات هنو ىخو يش الفان نندا رى بصو رت هنظم به

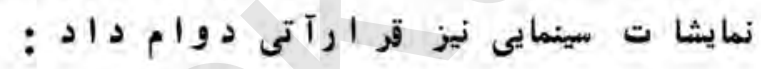

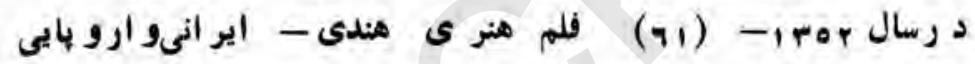

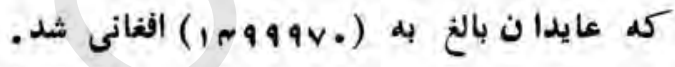

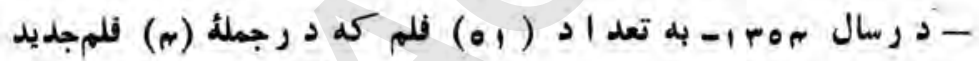

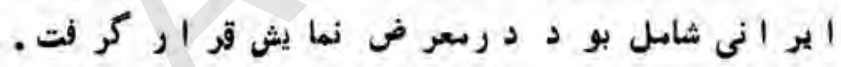

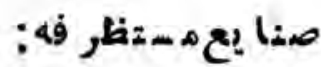

خدمات هنرى اينسوسسه راوزارتاطلاعاتو كلتورد رسه مساحه تنطيموتوسعهبيشيد

$$
\begin{aligned}
& \text { |- تر بئ هنر هندانجو ان }
\end{aligned}
$$

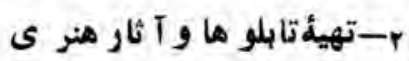

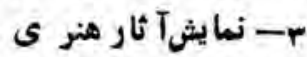

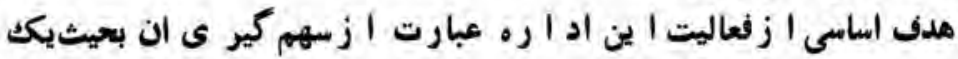

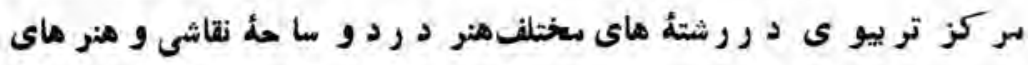


اجرا' أ اطلx عاتى وكلتور ى

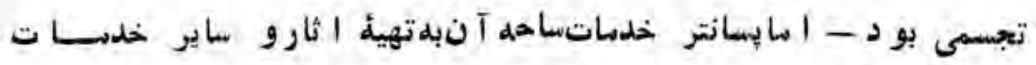

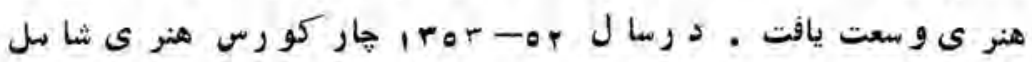

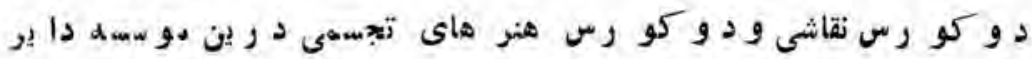

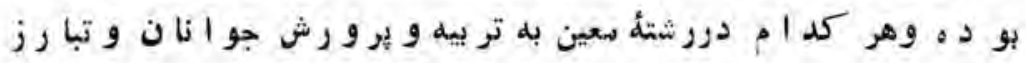

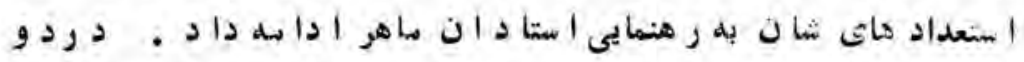

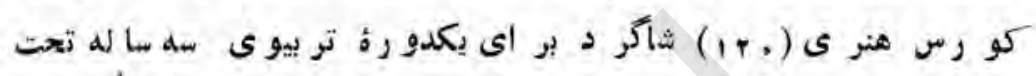

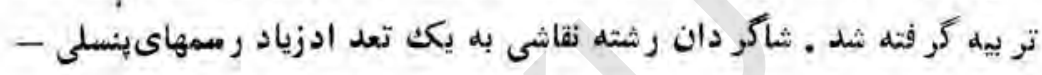

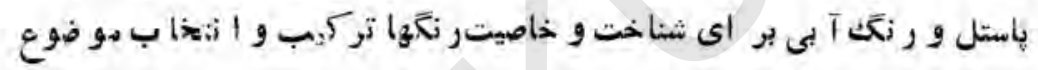

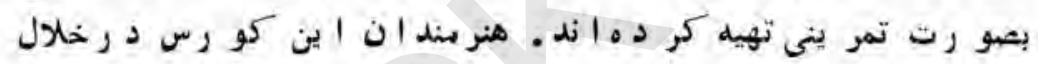

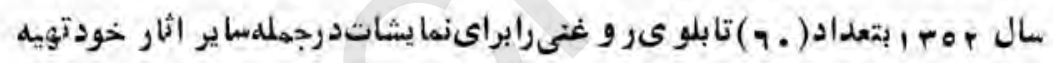

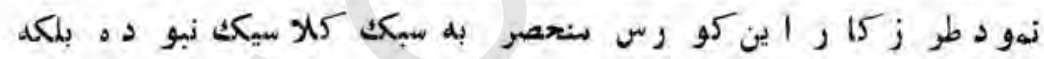

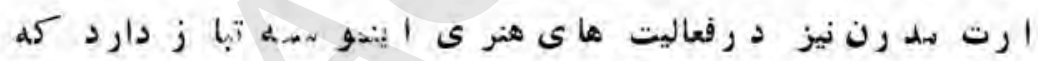

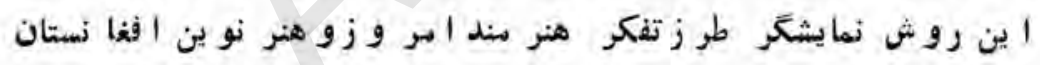

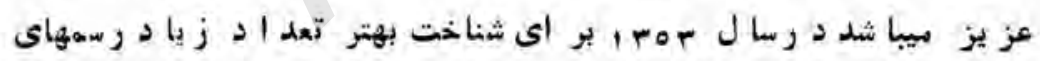

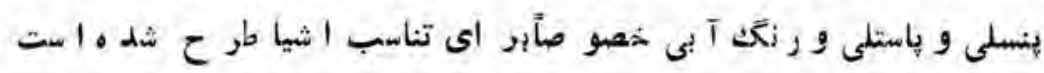

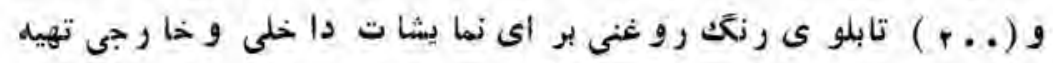

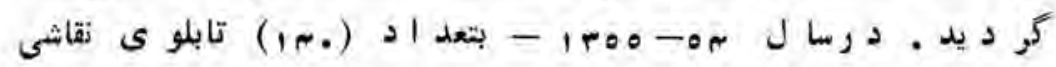
درين أد الد أره تهيه شهد.

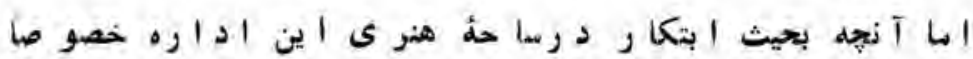

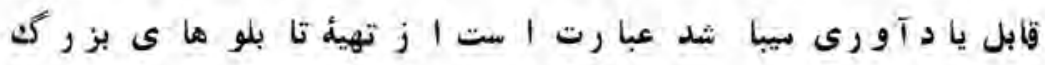



$(r q r)$
صنا في

موليناجلالالدين بلخى - انير خسو و بلخى مشهو ر به د هلو ى- ابو نصر

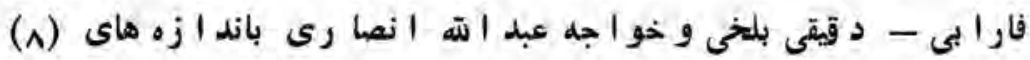

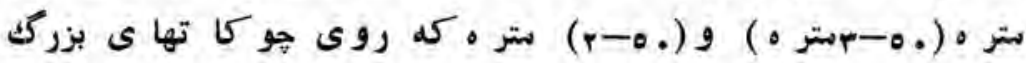

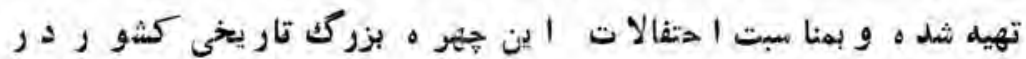

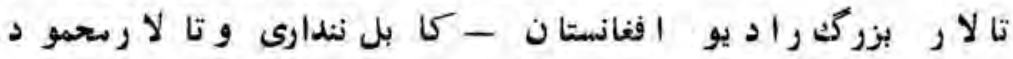

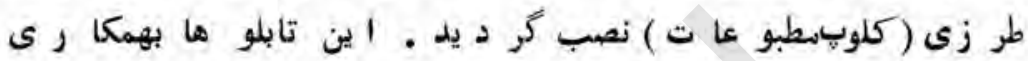

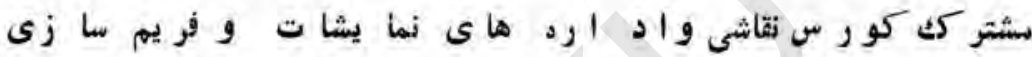

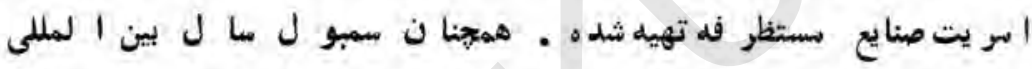
زن نيز ازطر ف الين الداروه تهيه ود ركا بل نندا رى ومعا فل د يكر

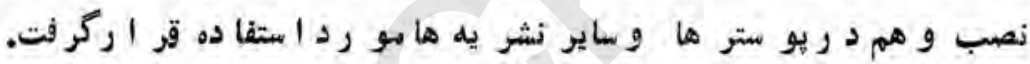

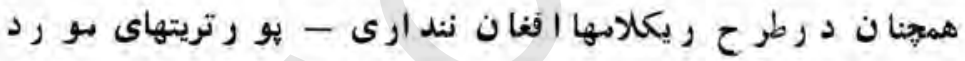
نيا ز كتا بخانه هاى عا مله رسمهاى انو اع حشر ا ت ت بر ائ تهيئ

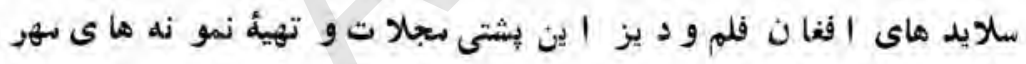

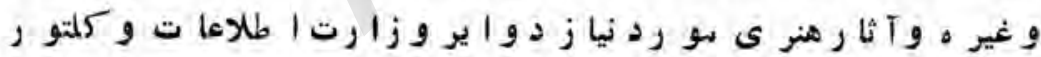

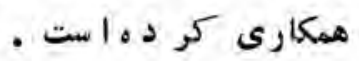

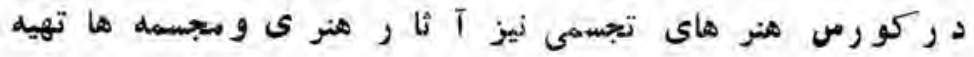

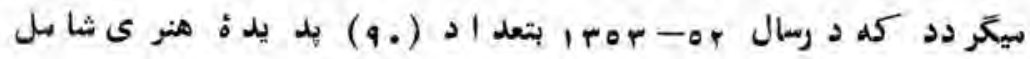

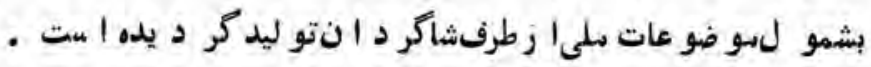

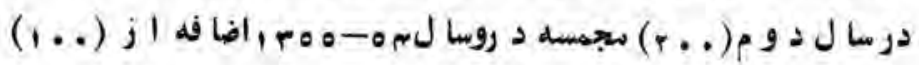


اجراتاطالعاتىوكلتو رى

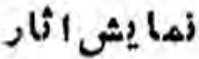

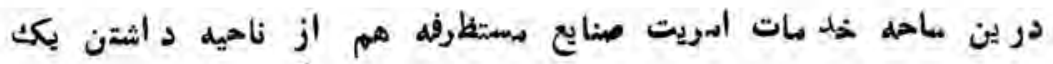
مركزدايهىنهايشوهمتدو يرنهايشاتساليا نهوستفرقه تنطيمو تو سغهدادهشد.

$$
\text { تدو ير نثلدار تونهأى فرهنَّى }
$$

وزارت اطلاعات و كلتو ربهناسبتسالكر د ازئلاب جمهو رى هر سال نند ارتو نها في فو هنكى را نيز د ر بهلو ى ساير نندارتونهاى

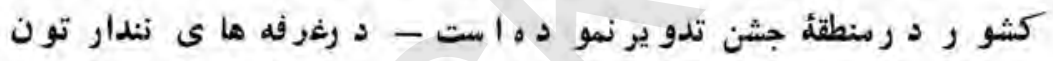

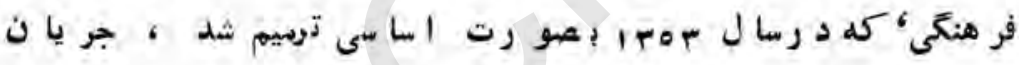

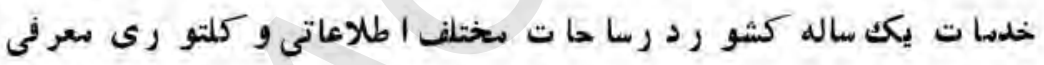
ثمد ماست

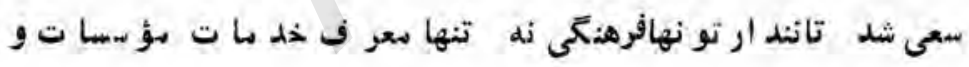
دوا ير اين وزا رت با شد بلكه د رتوتيب و تزئين انذ وق و هنر

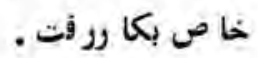

بو اي اولين با رد رين نند ارتو نها آثا رهنر عى كه درجو اليز

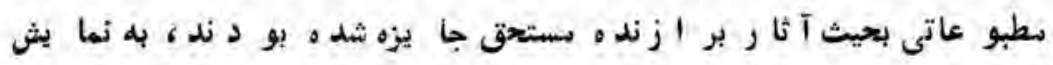

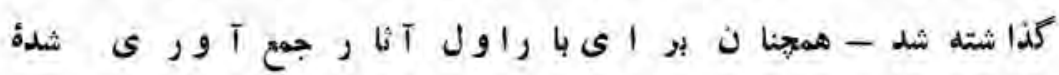

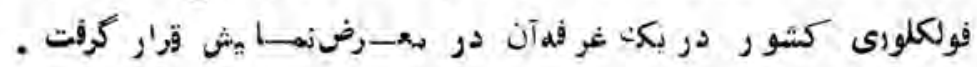




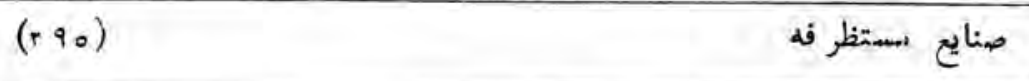

$$
\text { الف: ارت Fملمرى }
$$

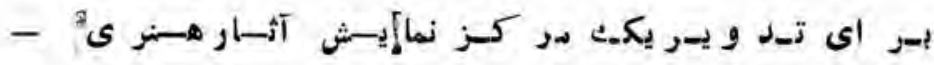

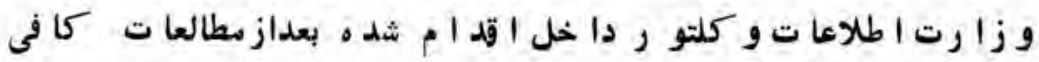
باسا س تجو يز دولت جمهو رى يكى عمارت دار اي سبكك خاص هنر ى

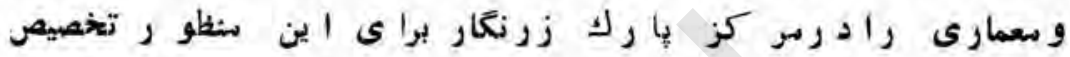
د الد. سنظو راز إسيس هنين سر كز اين است تا از يك-ططر ف

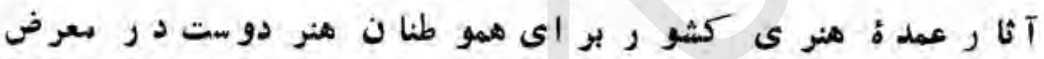

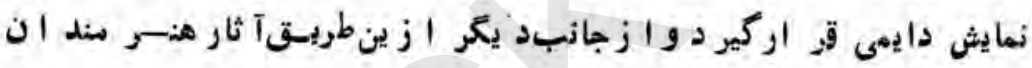
جو ان به نمايش كذا شته شد مباينصو رت أستعد اد هاى جو الن انيشتي تشو يق شو ند و آثا رشا ن زمينه بهتو وسهلتر عر ضه ثلد ن را إيد اكتند.

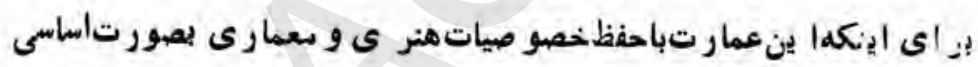

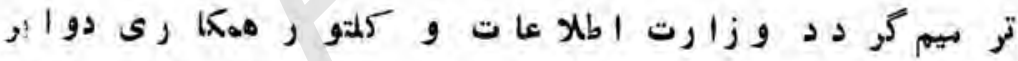
ساختما نى وزا رت فو ائد عامه راد ر ز زينه مطا لبه كر دما ست

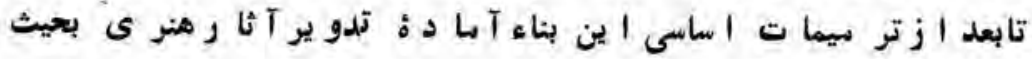

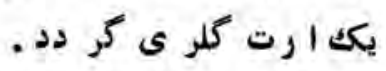

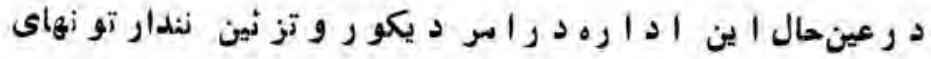
فر هنكى وزارت اطلاعا ت و كلتو ر د رجو 15 ت تندارتونهاى ساليانة كل بمناسبت جشن جمهو رى د ر رنطقله جشن تر تيب ميشو د سهم كر فته 1 ست 


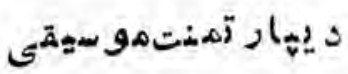

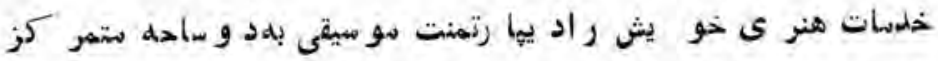

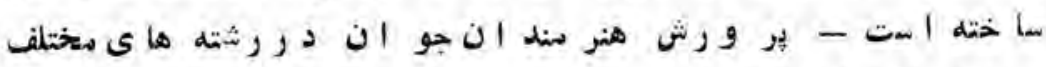

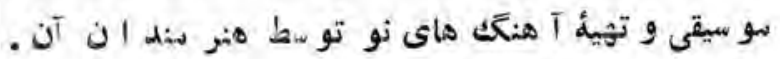

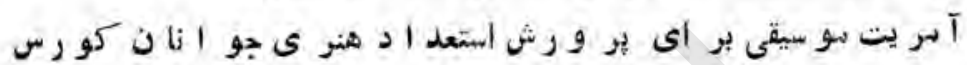

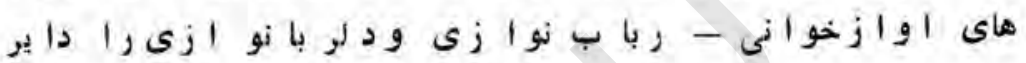

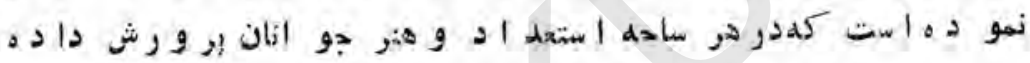

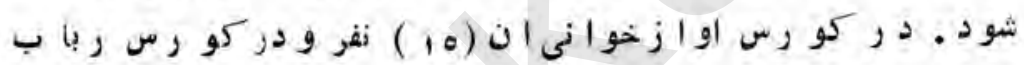

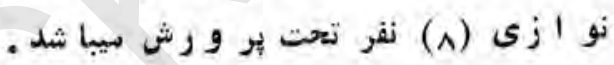

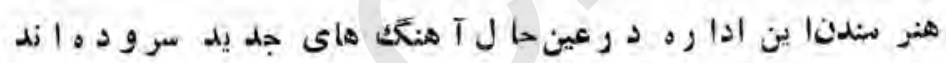

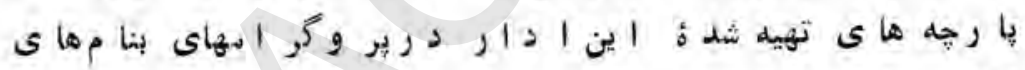

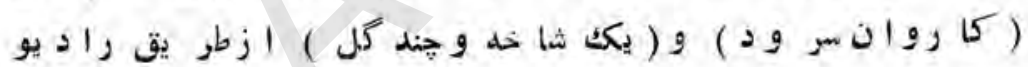

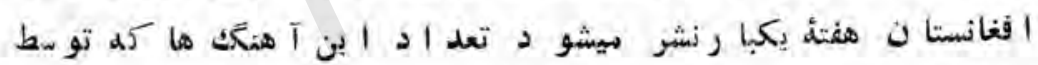

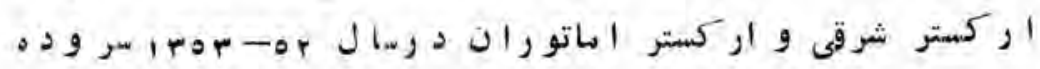

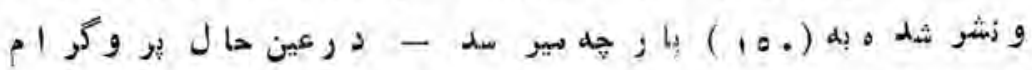

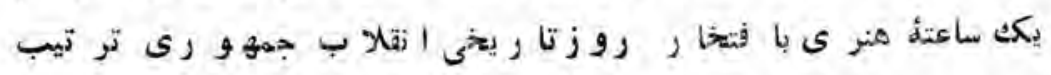

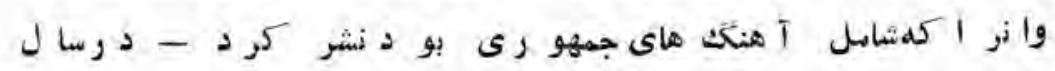

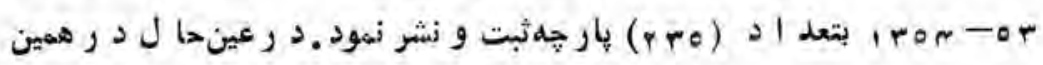

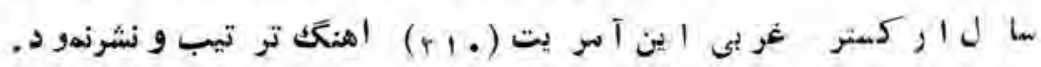




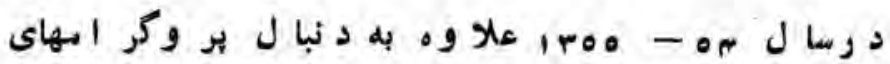

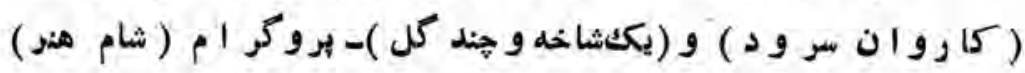

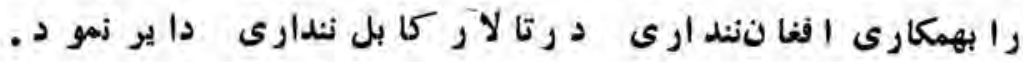

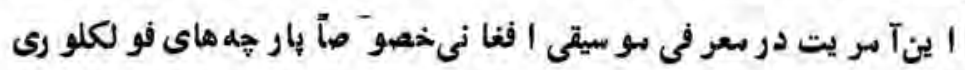

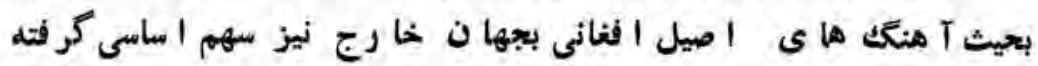

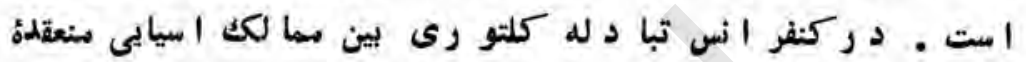

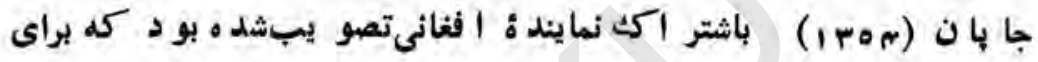

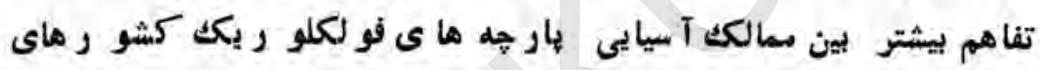

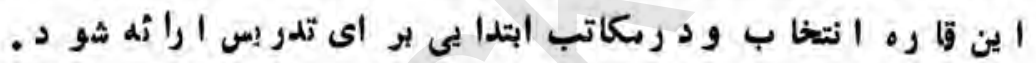

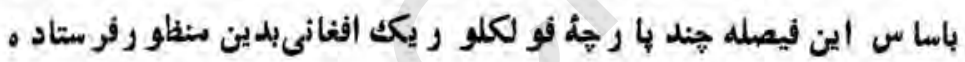

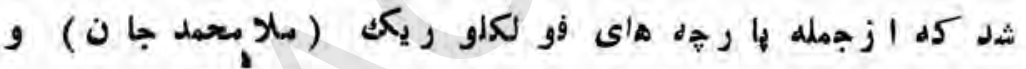

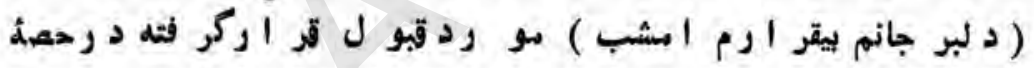

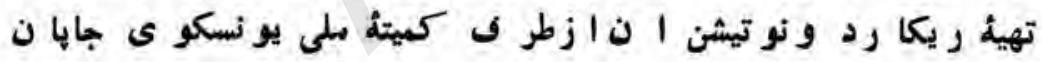

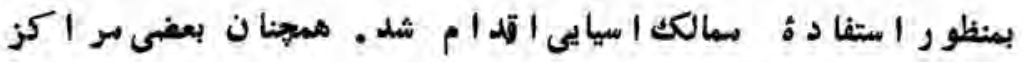

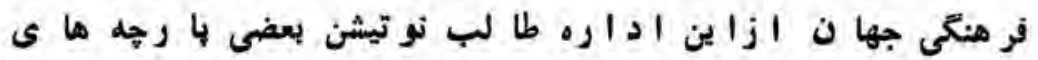

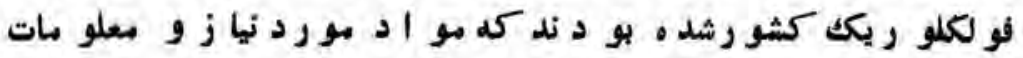

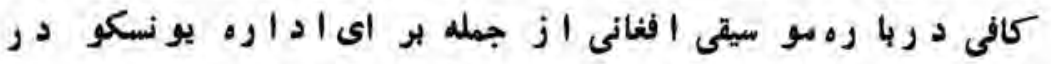

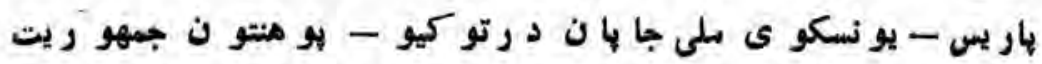

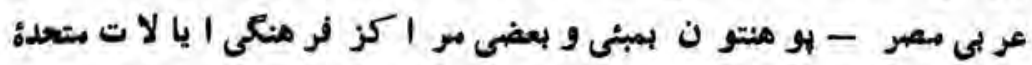

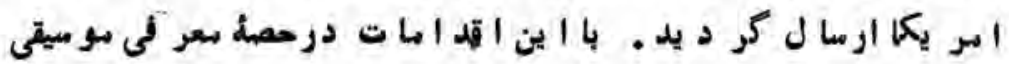


ا صيل افغانى به كانونهاى فرهنكى جها نخا رج قدهـائشثبتى بر داشته شهد.

$$
\text { كلمو ي مطبو عا }
$$

ا ين سركز از يكطرف خدمات اد ا رى خو يش را بو أى مو سسات نشر اتىو

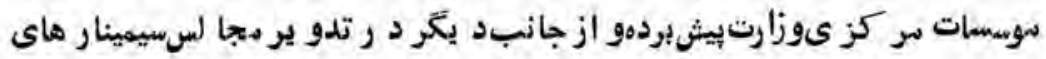

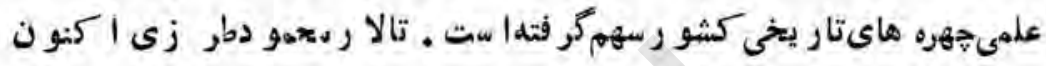

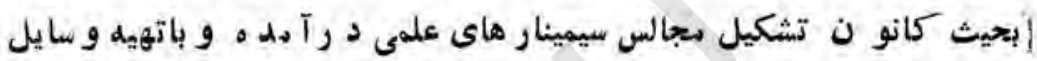

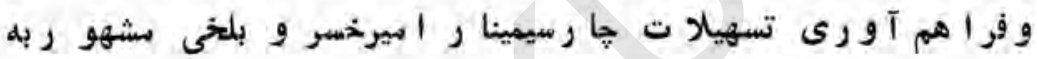

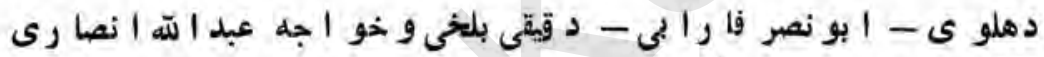

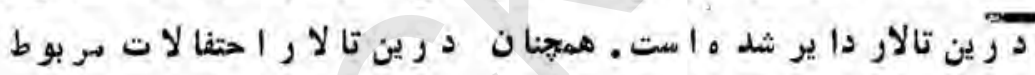

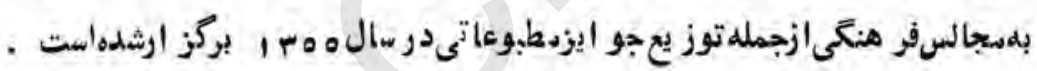

\section{خدماتاد ارى-}

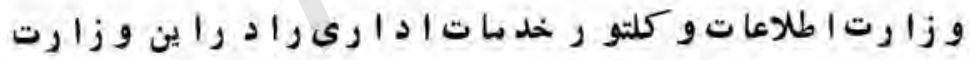

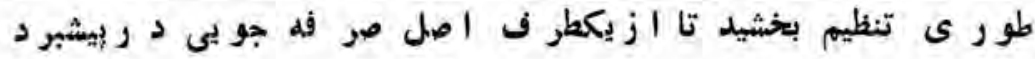

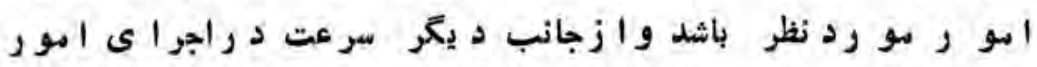

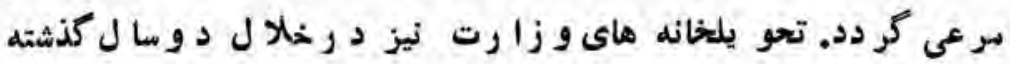

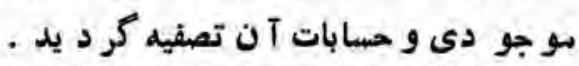

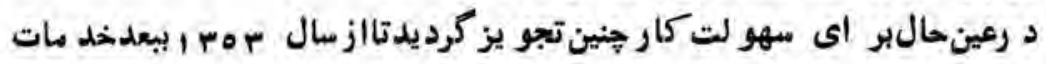

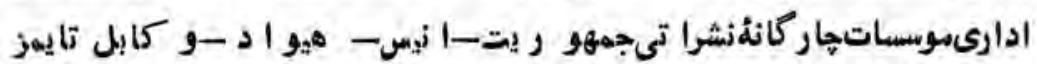

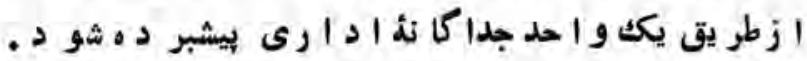




\section{تثكيـــــلـل وز1 رت اطلا عات وكلتــو ر}

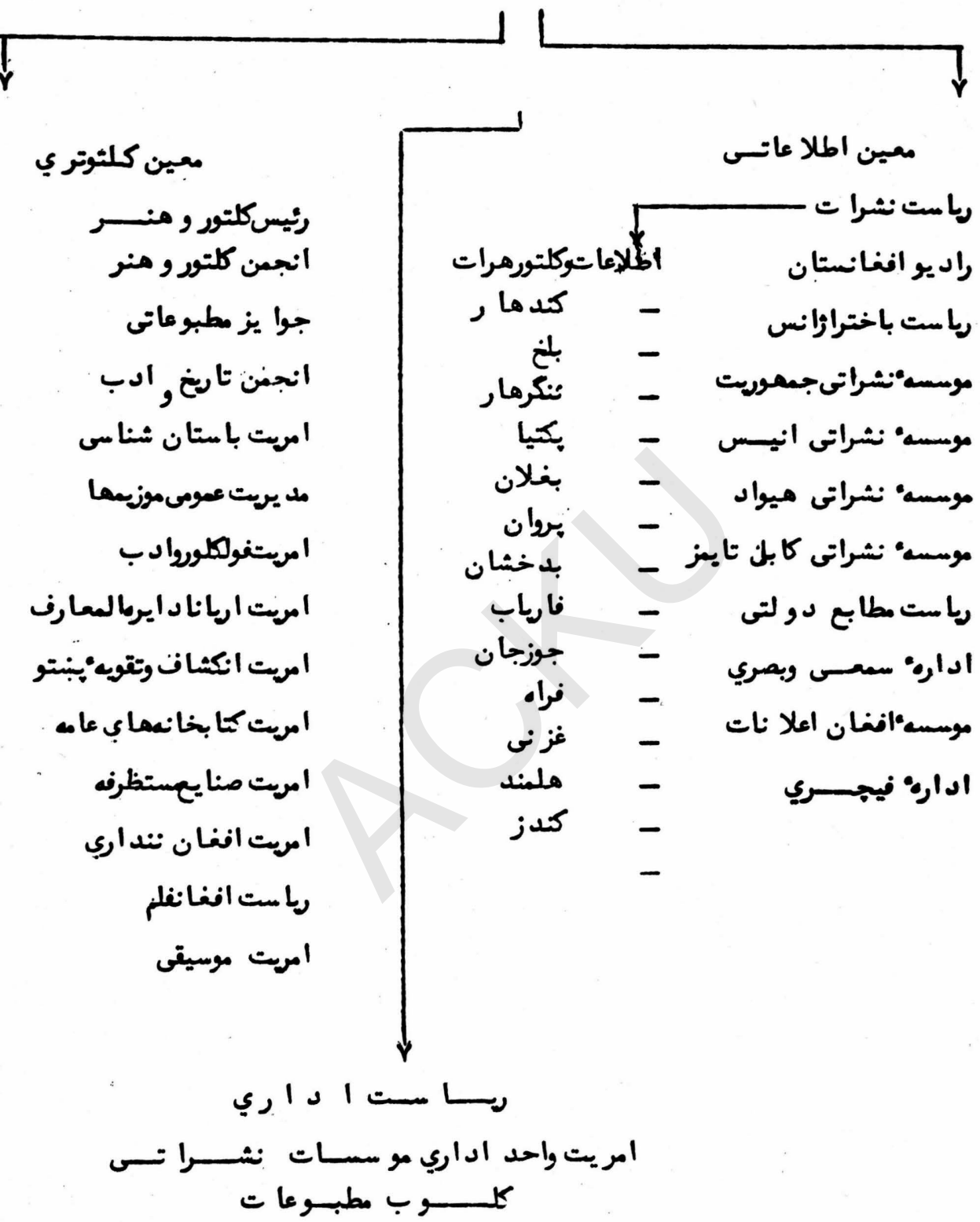




\section{ضميمه :}

$$
\text { جإl }
$$

وزارت اطلا عات وكلتو ر بلهير وى از

باليسى كلتو رى د ولت جمهو رى وحا بآثار را

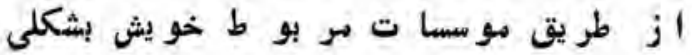
تنظيم بخشيد تامو ا فق به مشى ا نقلا ب جمهو رى الى

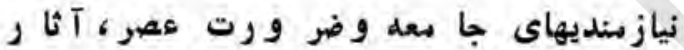

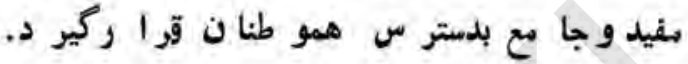

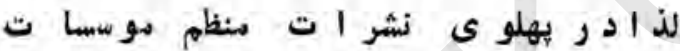
نشر ا تى بحيث يكك ابتكا ر سلسله نشر ا ت ت

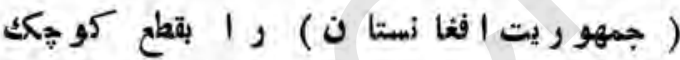

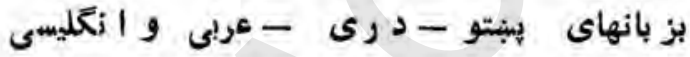

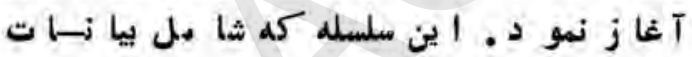

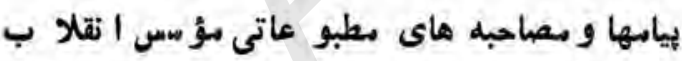

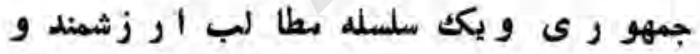

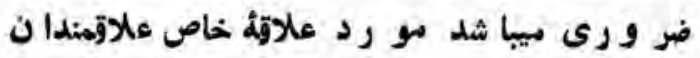

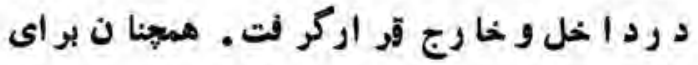

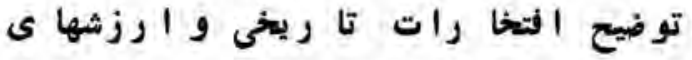

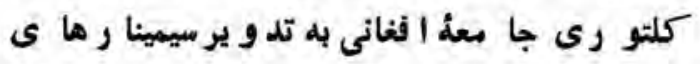

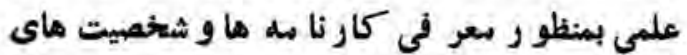




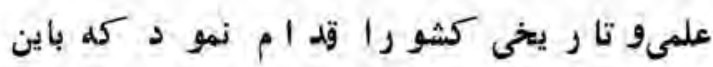

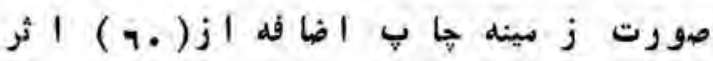

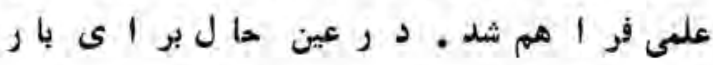

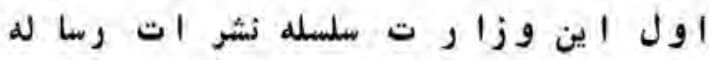

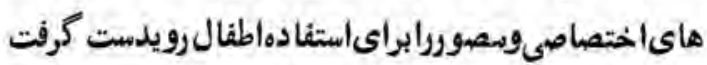

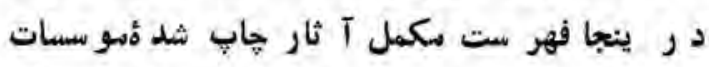
ا ين و زارت كهمو اد ا ناز طريق دقيتزو زارت-دواير نشراتى، سديو يت عمو سى سعر فى ا فغا نستان تهيهو

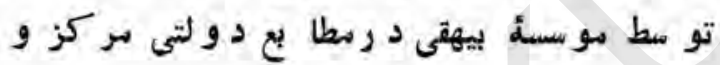

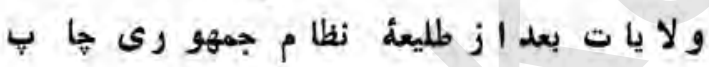
شد م ا ست بصو رو ت ضميمه إرانه ميكر دد. 


$$
\text { رو زنامه ها_ستجالاتو جر ايد }
$$

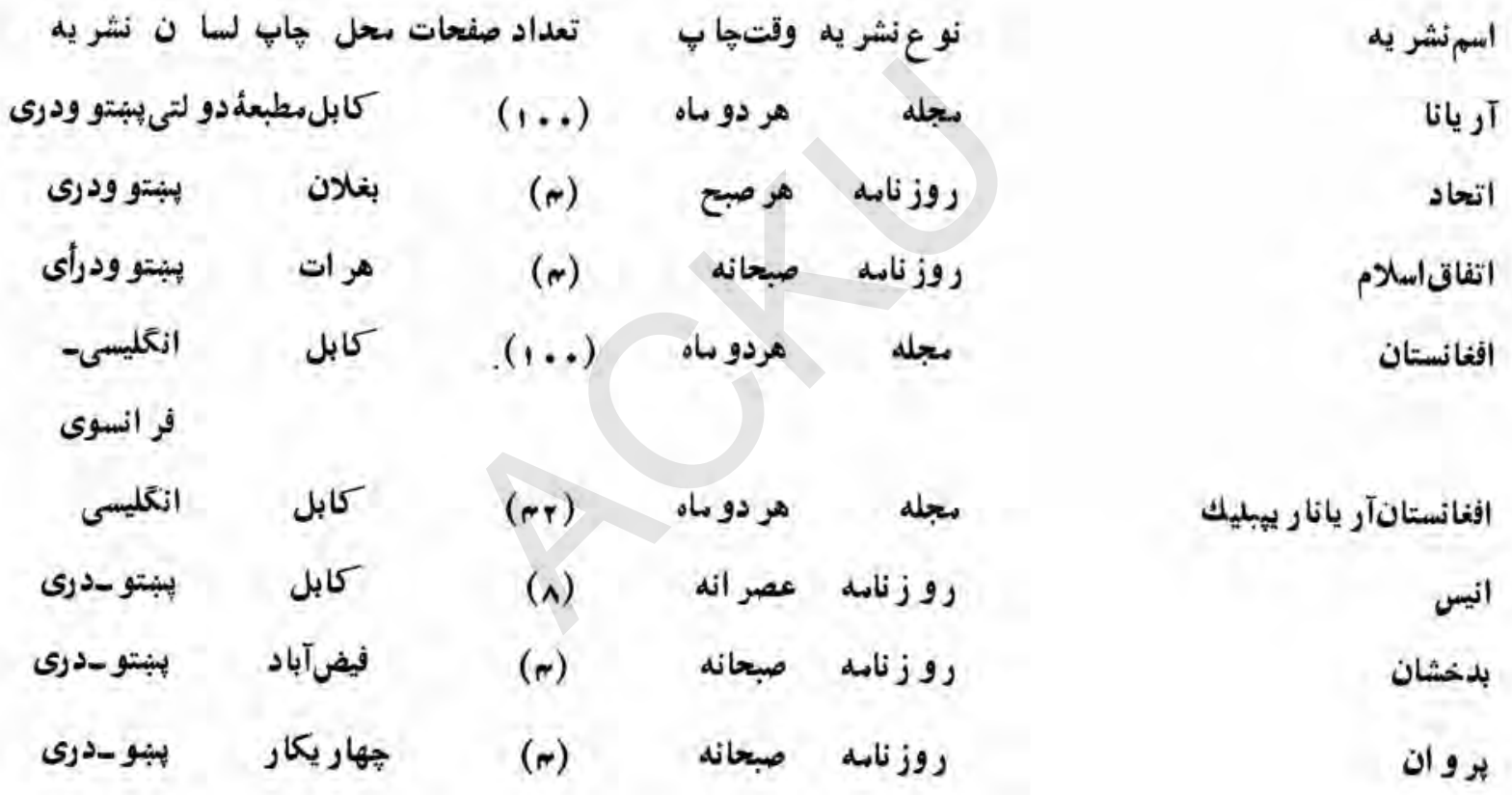




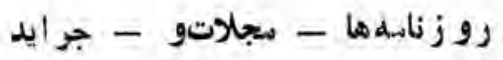

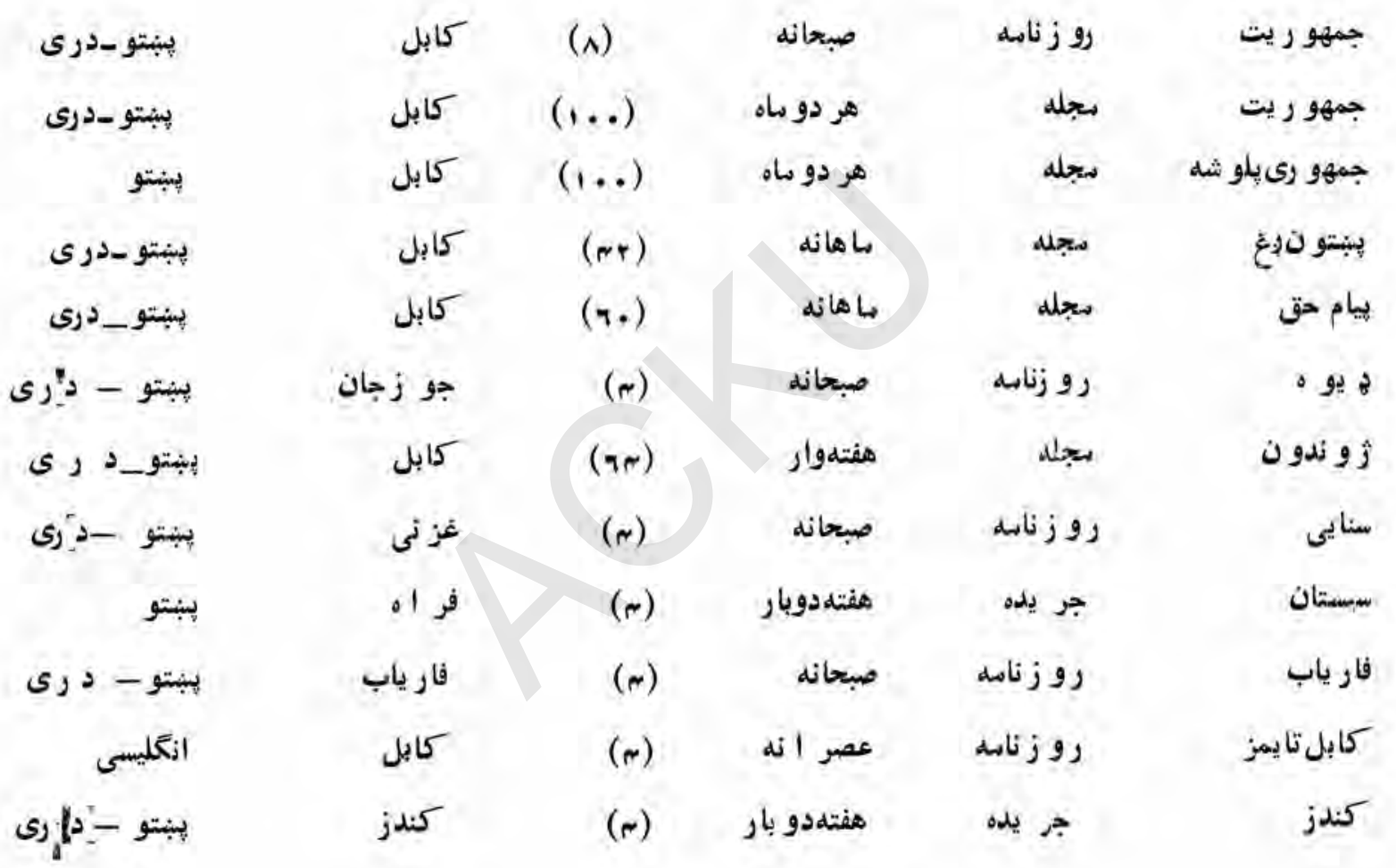




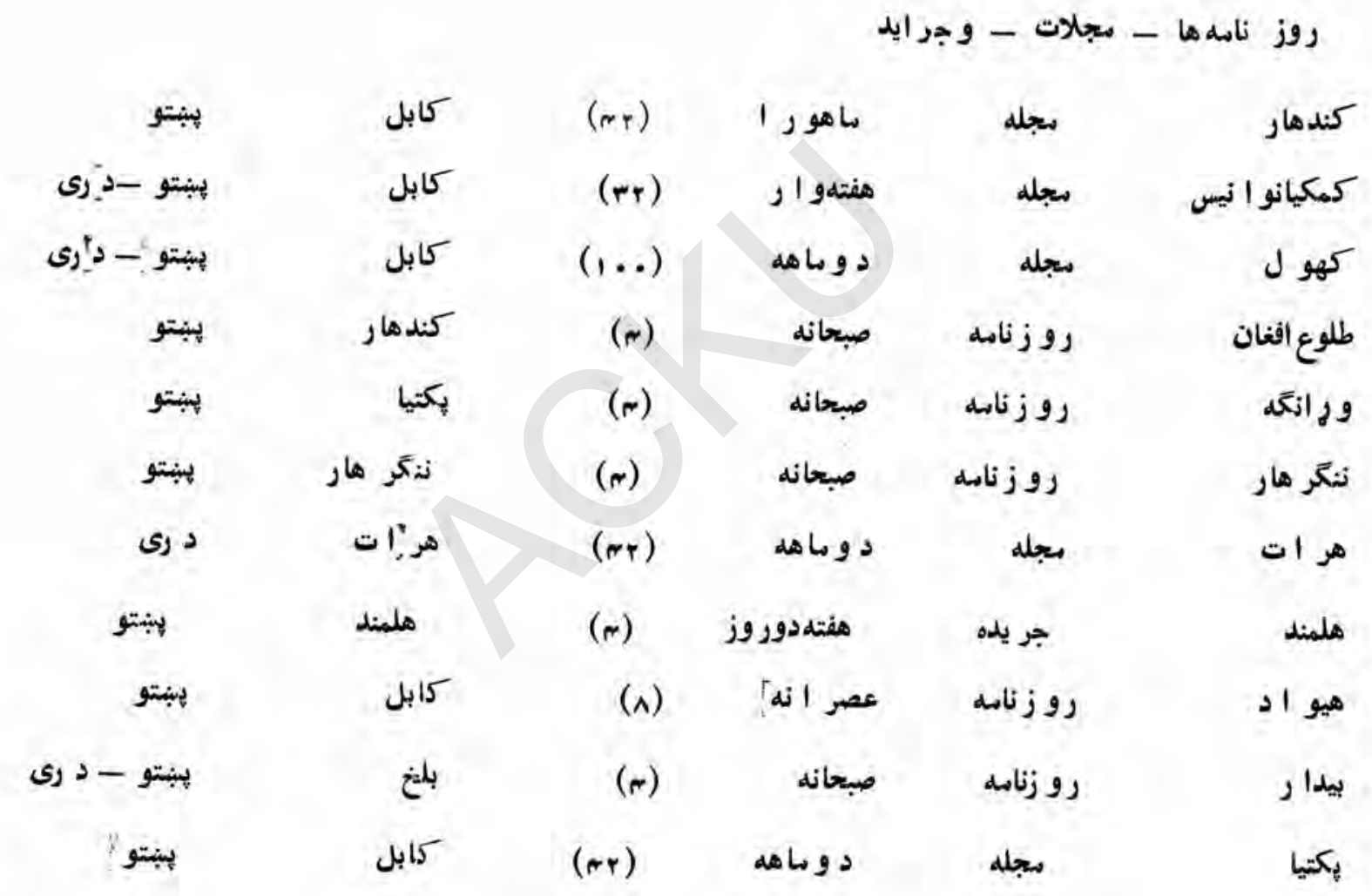




اسم نشر يلياكتاب

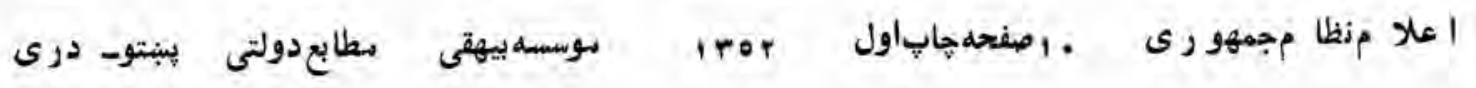
مو" " I "

1ropdintor

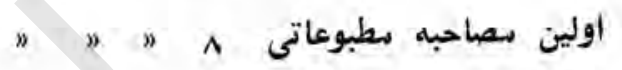
ناغلى رئيس دولتوصدراعظم

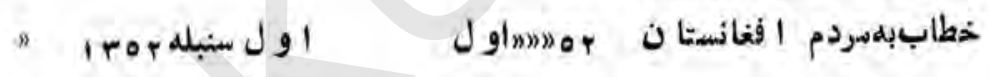

$$
\begin{aligned}
& \text { مد" " } \\
& \text { م" " " }
\end{aligned}
$$

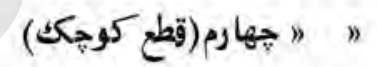

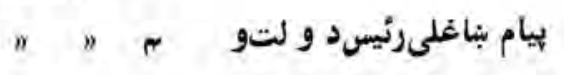
صدرا عظم عنو انى رنيس كنفرانس كشورهاى خيرنسيلك الف 
"

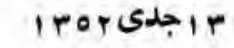

"

4

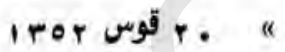

$\sim$

*

《

《)

ملى

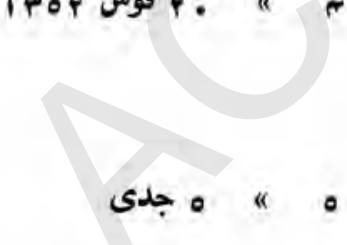

\author{
يَيام بناغلى رئيسدولتوصدر اعظم بمناسبت \\ هفتلمنيخصوص \\ عيلهعيد فطر \\ وعيدسعيداضحى \\ بيامبناشلى رئيسد لت وصدر اعظم بمناسبت \\ (ro) سالكره حقو ق بشر \\ بيانية بناغلى رئيس دو لت و صدراعظم \\ دورسفل توزيع ديبلوأمهاىفارغانحريى يوهنتون
}


$\alpha$

《

«

《

u

"

\section{" \\ 《 \\ a \\ 《}

《

,
(

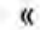

fror sda r 9 "

A حوت A U V

. " اول حمل ب0 1.

«

4

is

a

《

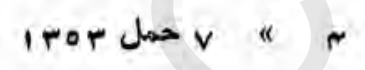

itor a IV

$$
\text { "rorg " }
$$

بيام هاى بناغلى وئيس دولتو صدر اعظم عنوانى زعما ى اتحاد شو روى -صدر اعظم هند وئيس جمهور تركيه خطاب بلهآنران اطال عات و كلتو ر ركاب خطاب بلهفار غا ن إولى تخغيكي يبيأم بdمناسبت سال تو

خطاب بلهأحبمنصبا ن قو ايى مر كز مصاحبه بناغلى رئبس دولتو صدر اعظم

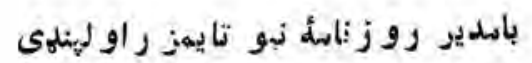
بصاحبئ بناغلى رئيس دولت و صدر اعظمم

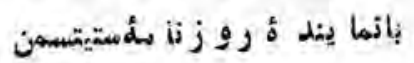


《

$\ll$

《

|veror و اثور

u

《

$\alpha$

«

"

1rorg . " v

" 11

《

$$
\text { N }
$$

$\ll$

*
بيانيئه بناغلى رئيس دولتو صدر اعظم درمر اسمبر افر اشتن بير قل ملى جمهو رى r " Vوزا "

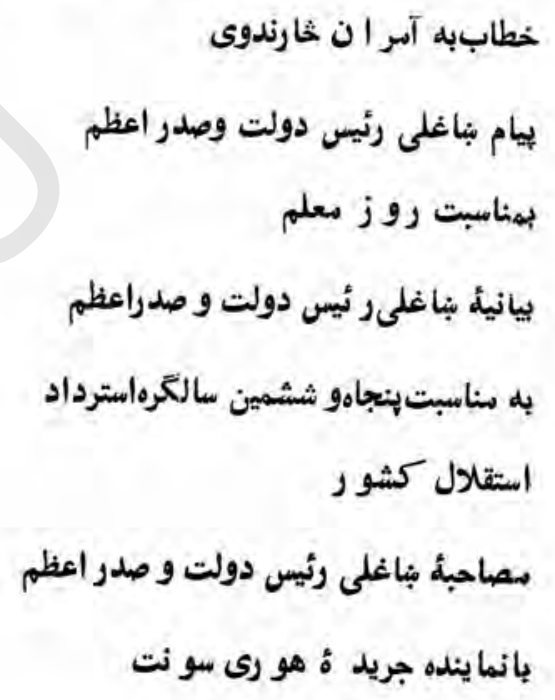


n
)

n

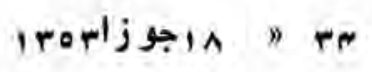

b)

)

s |

V

n

》)

n

$n$
" irorible

"

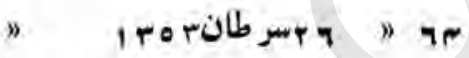

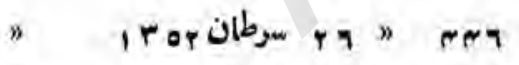

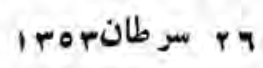

جيانيهو اعلانيهمثتر كسفر

باغلى رئيسدو لتو صدراعظم بdاتحادشو روى يهام يهنساسبترو زمادر خطاب بدفار غان يو هنتون نئكر هار يبامبلهناسبت نو زيع جو ايز مطبو عاتىو كلتو رى ييانيهنباغلى رئيسدو لتو صدر اعظم بلهناسبت تجليل او لين سالغر دجشنجمهو رى نجمو علهيانات، ييامهاو كنفر انسهاىنسبو عاتى رهبر ملىو مؤ سسجمهو رنى 
") 1Fordinian " 11

b)
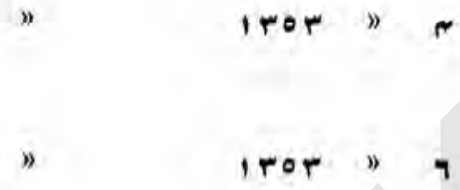

Iror
يبامبلمناسبتسالكر درو ز نامئ جمهو ريت بيامعنو انى منشى عمو بىملل هتخددر بار ببلو حستان ييام بلميناسبتر و زمطبو عات و نهو اد بيامبناخلى رئيسدو لتو صدر اعظم بهمناسبت هفته مخصو صسنز ثمياشت بيانيهنباغلى رئيس دو لتو صده ر اعظم بهناسبتعيد معيدفطر

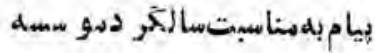
ملل متنحد 


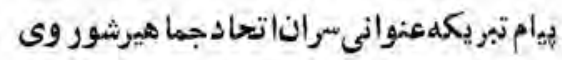
هصاحبهلباندا ينده ثايمزا ف -

$\begin{array}{ll}n & n \\ n & n\end{array}$

tror
roor

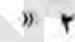

11) 7

m

》)

)

$\begin{array}{lll}n & n \\ n & n\end{array}$

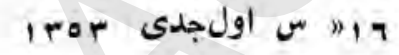

I rop shap

$n 0$

Iror

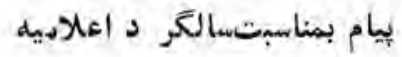

يقو ق بشر

\section{انديا}

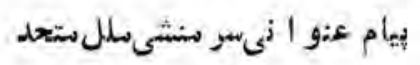

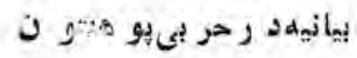
مصاحبهنباغلمى رئيسد و لتو

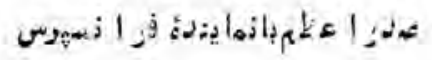
يمام بمنأسبتعيدسعيدا ضتحى

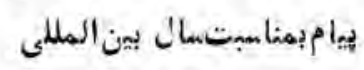
jز 


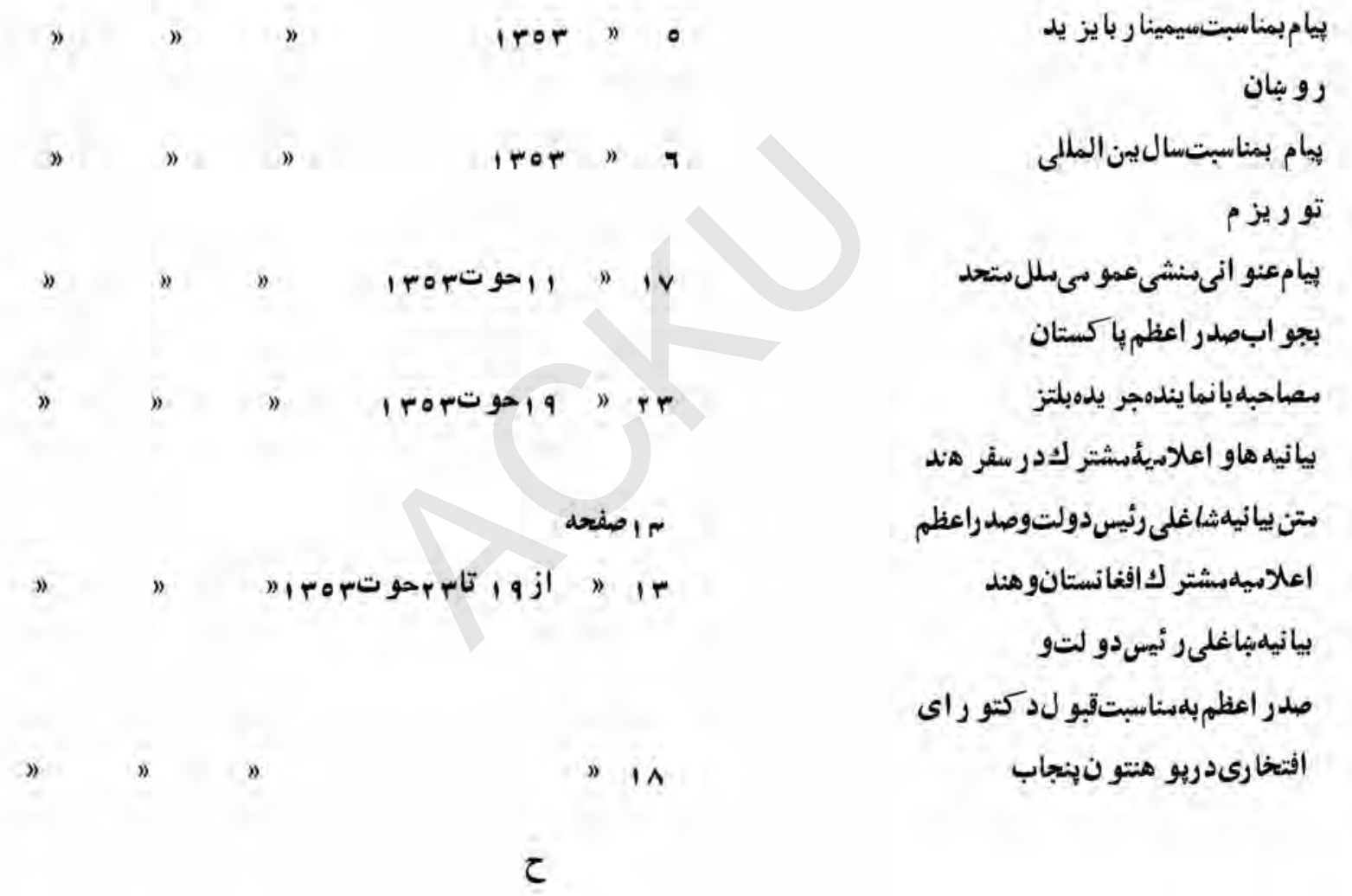




4

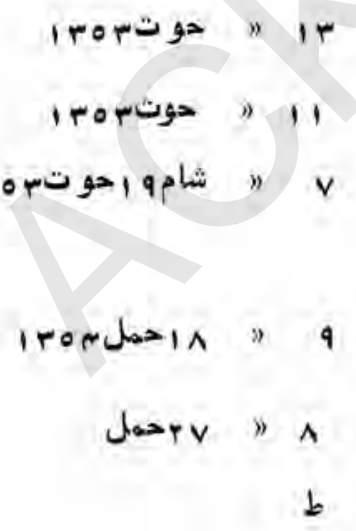

بهام بمناسبتدبلس تحقيق احو الو

$$
\text { تحليل آثار المير خسو و }
$$

ستن بيانيهنباغلى رئيسد و لتو

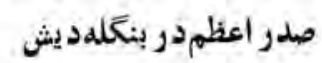
اعلانيئمشتر ككافغا بستانو بذغلهديش بيانيلدر اجتماع شهو يان كندهار اعلانيهمشثتر كافوغانستانو عر اق بيانيلنيانلمى نبيسدو اتبلهنئاس:ت حلو لسالنو مصاحبهباز و ر نا ليست فنليندى مصاحبا، بانما يندد:ثنو يز يو نايران 


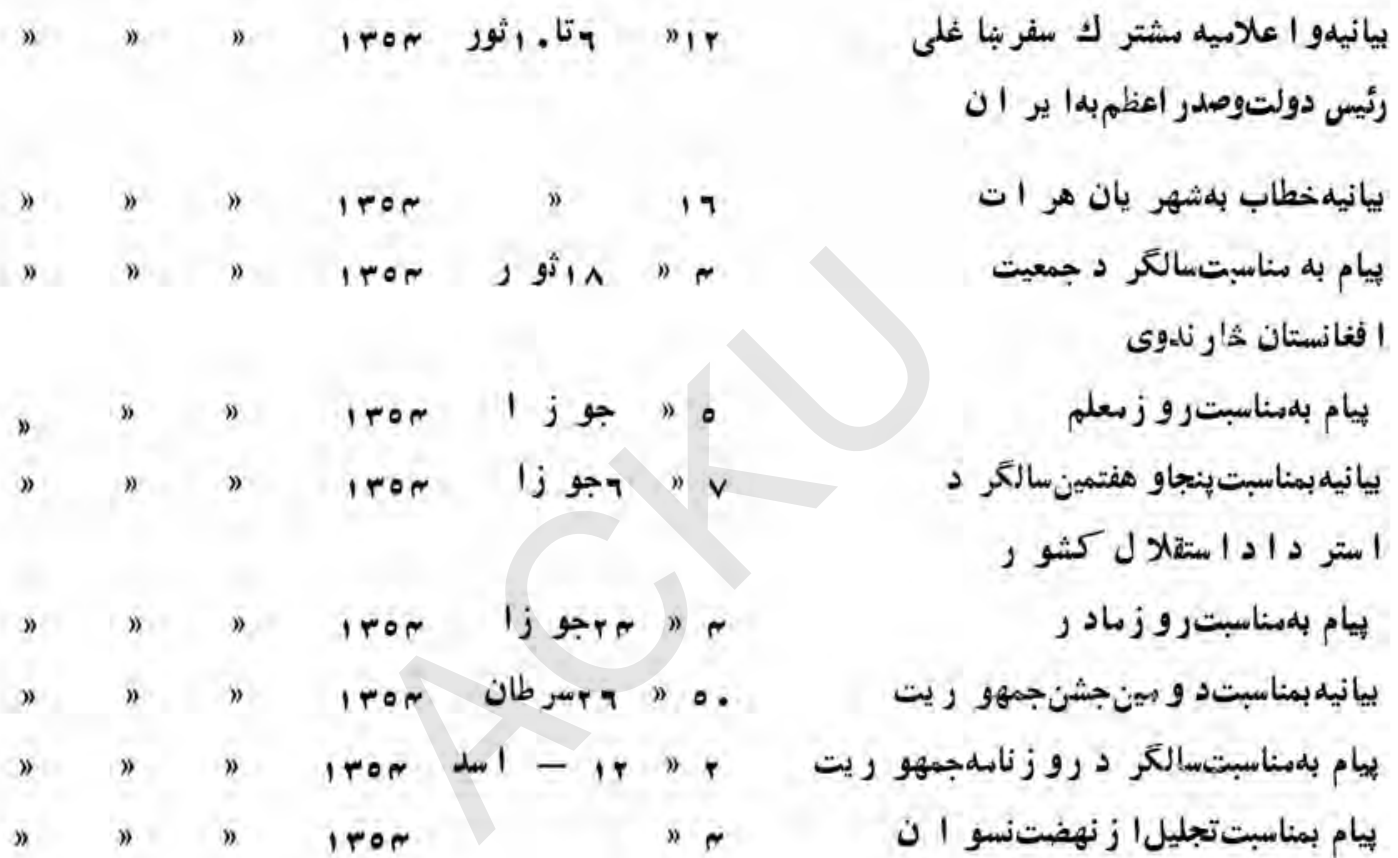




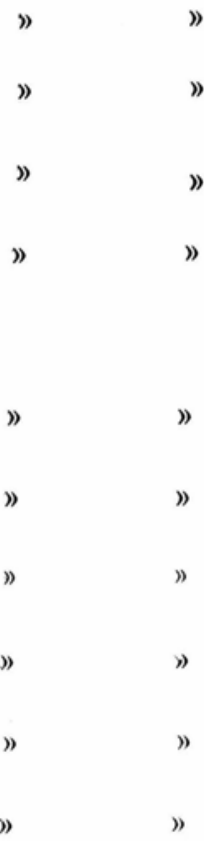

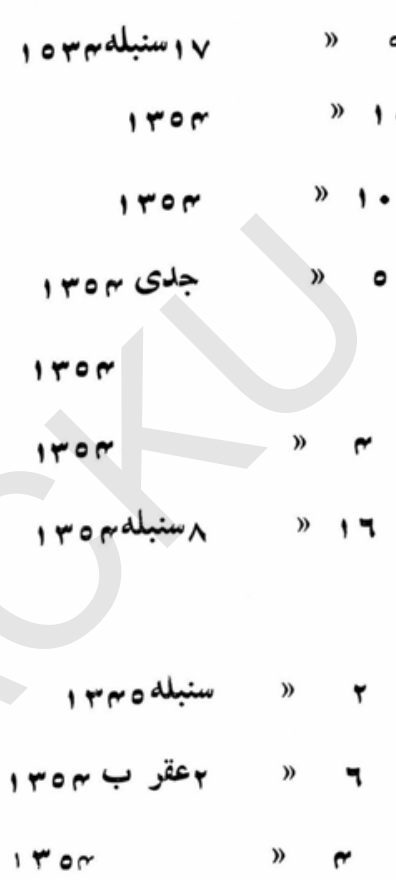

ييام بلمناسبتسو ا د مطبو عات مصاحبلبار و ز ناهdنكًار جايانى نصاحبه بار و ز زاههنكًار تر كى بيام بمنا سبت عيد سعيد فطر بيام بلمناسبت هفتلهر ه مياشت بيام بمناسبت يادو بودابونصرفارابى

)

ناسهعنو انىد كتو ركو رت -

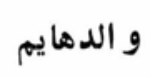$$
\text { يبام عنو انىد كتو ركو رت }
$$$$
\text { و الدهايم بمناسبتر و ز مللل ستحد }
$$$$
\text { هناسبتسيهينارور كز ى }
$$

تحقيقات هنبتو 
(1)

a

《)

(

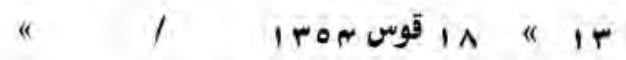

$*$
$*$
$*$

* $\quad$ *

$"$

"

\&

"

《

«

«

«

*

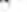

\section{\&}

a

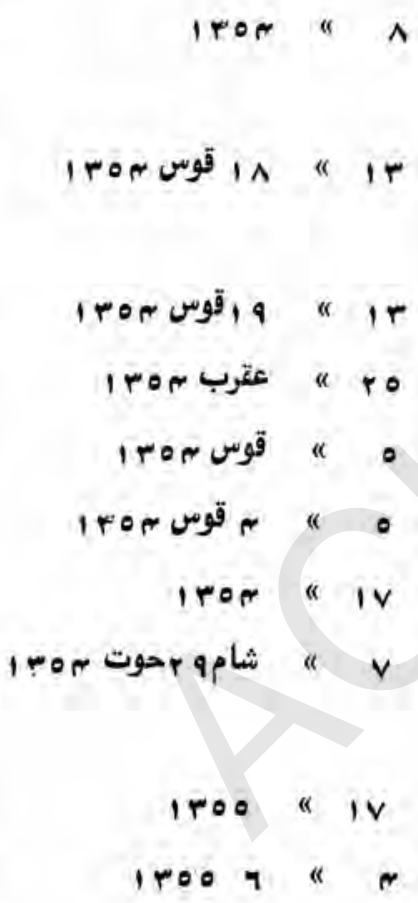

مصاحبئأبناغلىر ئيس دولت بانما ينده. روز نا مهلو سو ند بيانيه واعلاميه سثتر كافغانستا ن واتحا د شو روى اعلاميه دشتر كك افغانستا ن و اتحا د شور وىى بيام بمناسبت رو زحقو ق بشر

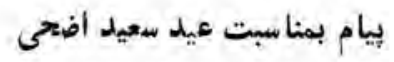
بيام بمناسبت سيمنار دوقيقى بلخى بئل

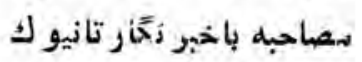

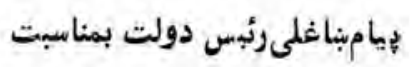
آغاز سال نو نو مصاحبه بانما ينده رو يتر

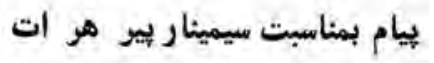




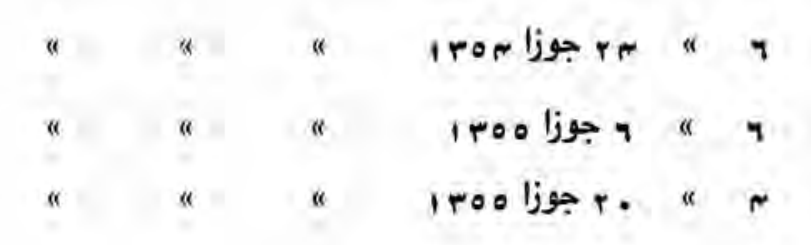

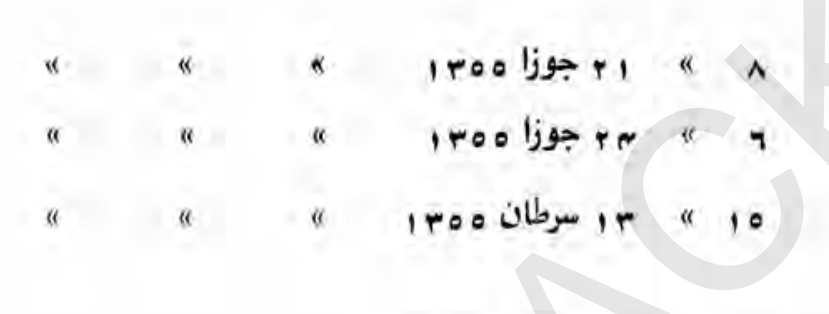

"
" 1roo

" irooulbert " rV

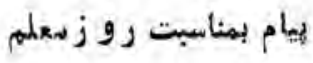

ييانيه بمناسبت استر داد استقلال كثثو ر

بيانيه بناغلى رئيس ودلت وصدر اعظم

دوضيافتى كمازطرفبناغلىذو الفقار على بوتو

تو تيب شده ه بو د

اعلاسيه نشثتر افغانستا ن وبإكستا ن |ز أم بنائلى رئس دولت بلهناسبت رو ز سادر

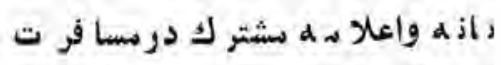

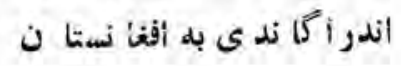

اعلاده لمثتر كل اوغانستانووهند

ب إن لبناغلى رئسدو لت بمناسمت

سو من نجشنجمهو رى 


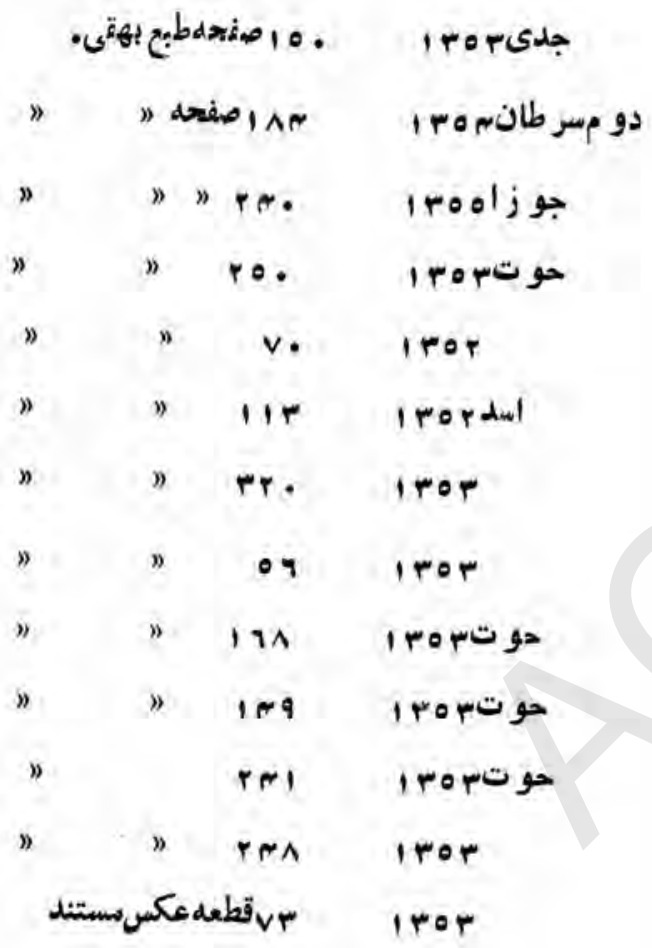

كتابدر بو تو جمهو ر بتجلداو ل تهيه ر اديو افغانستان كتابدر بر تو جمهو ريتجلددو م تهيه ر اديو افغاستان كتابدر ير تو جههو ر ريتجلدسو متهيه ر اديو افغانستان

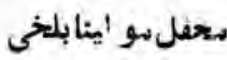

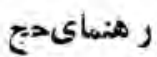
نطلام اجتماعى-غلامرعلى آنيز

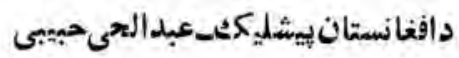
مبر و ويسبابا

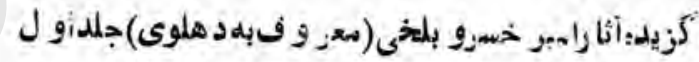

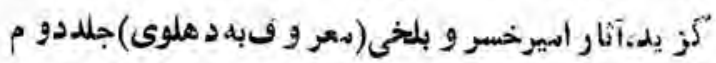
مز يدهآثاز اسير خسر و بلنخى(معر و فبهد هلوى) جلدسو م

مدجمسمو ليناى بالخىى البو منخستبنجشن جمهو رى 


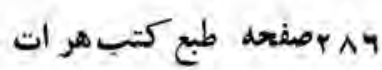

)

بيقى

n

$\hat{\Lambda}+$

ก人

vV

07

n

)

y)

n

ov
1 rors

1 rop

ثو ربه تون

جدى

قوسمهمبر

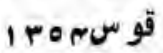

قوسبم بr
خطاطانو نقاشانهر اتـعلى احمدنعيغى بخشاول ت تتبع وكر دآو رىيمير عبدالعلىشايقي نقاشانو خطاطانسعاصر هر اتسبيرأعبدالعلى تشايق در اممنظو مصبح سعادتو تجلى جمهو رىدر كشيور

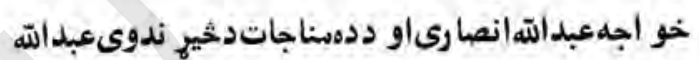
خديتًار او حبيبالشهر فيع يلهو يازي

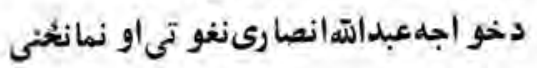
تر جمه حبيب السه رفيع ز زندانىو آثار ابير خسر و بلخى (بينتو و درى)

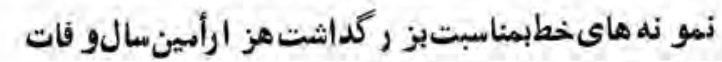
دقيقى بلخى- اثر بحمدعلىعطار

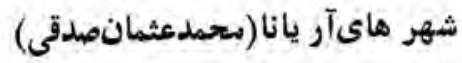

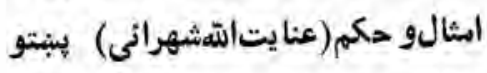

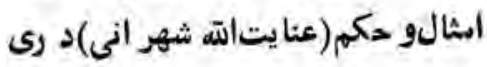




\begin{tabular}{|c|c|c|c|}
\hline صفحهd & $r$ & D & در فثملىجمهو رى(احمدعلى كهز اد) \\
\hline$n$ & 09 & $n$ & ر هنماى مر غدارى(د كتو رثر يفى) درى \\
\hline 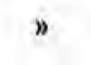 & 1. & 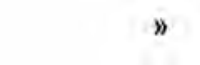 & ز مو ني. و طن (و طن ما) \\
\hline$x$ & & لوصفحd & درى-بنبتو \\
\hline$n$ & 17. & او لجدى & بامقد مهو تعليقاتد كتو ر سيلمتخدو م ر هين \\
\hline " & & 1ror & خسو و \\
\hline ) & & iron & كتاب|سلامو رشداقتصادى \\
\hline$n$ & & سالبمهبr & مجمو علسيمينار امير خسر و بلخحتهيه رياستنشر ات \\
\hline » & & Iror & تقاسير شر يفتابارأهُ( م ) \\
\hline$\Rightarrow$ & & iron & ابو بكر صديق(رض)جلداول \\
\hline$n$ & & trom & مقامات شيخ الاسلام \\
\hline
\end{tabular}




$$
\begin{aligned}
& \text { troer } \\
& \text { iroer } \\
& \text { troe }
\end{aligned}
$$$$
\text { iror }
$$$$
\text { ror }
$$$$
\text { tror }
$$$$
\text { tror }
$$$$
\text { roor }
$$$$
\text { ror }
$$$$
\text { iror }
$$

$$
\text { اندر كنشتي يير هر ات هاي يبير هر ات }
$$$$
\text { بوخىاز كتيبه هاو سنكنتبثته هاي هر ات }
$$

جلداو لاحاد يثنبوي(تجديدجاب)

يار هماي تفسير شر يف(إششتو بار هشانز دهو هفدهم ) كتابز ندكانىفار و قاعظم (جلددو م)تر جمه بر هانى رسالهسهمو سا يلسمعىو بصريدر سو اد آسو زي

، مطبو عات و جمهو ر يتو اثر آندر بسطو تو سعلسو ا د مقتشمطبو عاتدر اجتماع سوهمبطبعهدر انكشافسو وسالهنقش كتابو كتابخانه درسو اداموزي مطبو عاتو سو ادآسو زي رساله راديو و سو ادآمو زي 


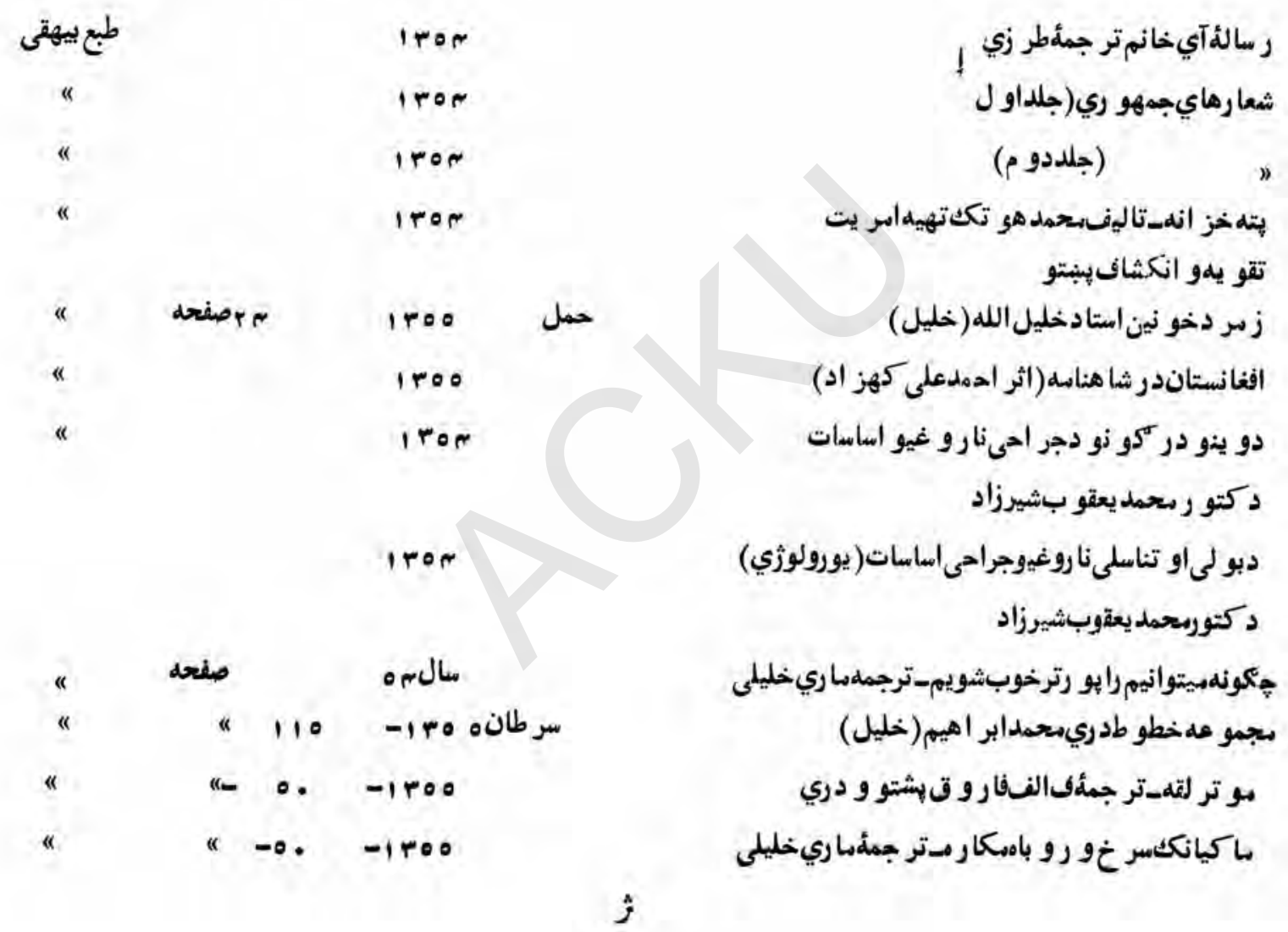




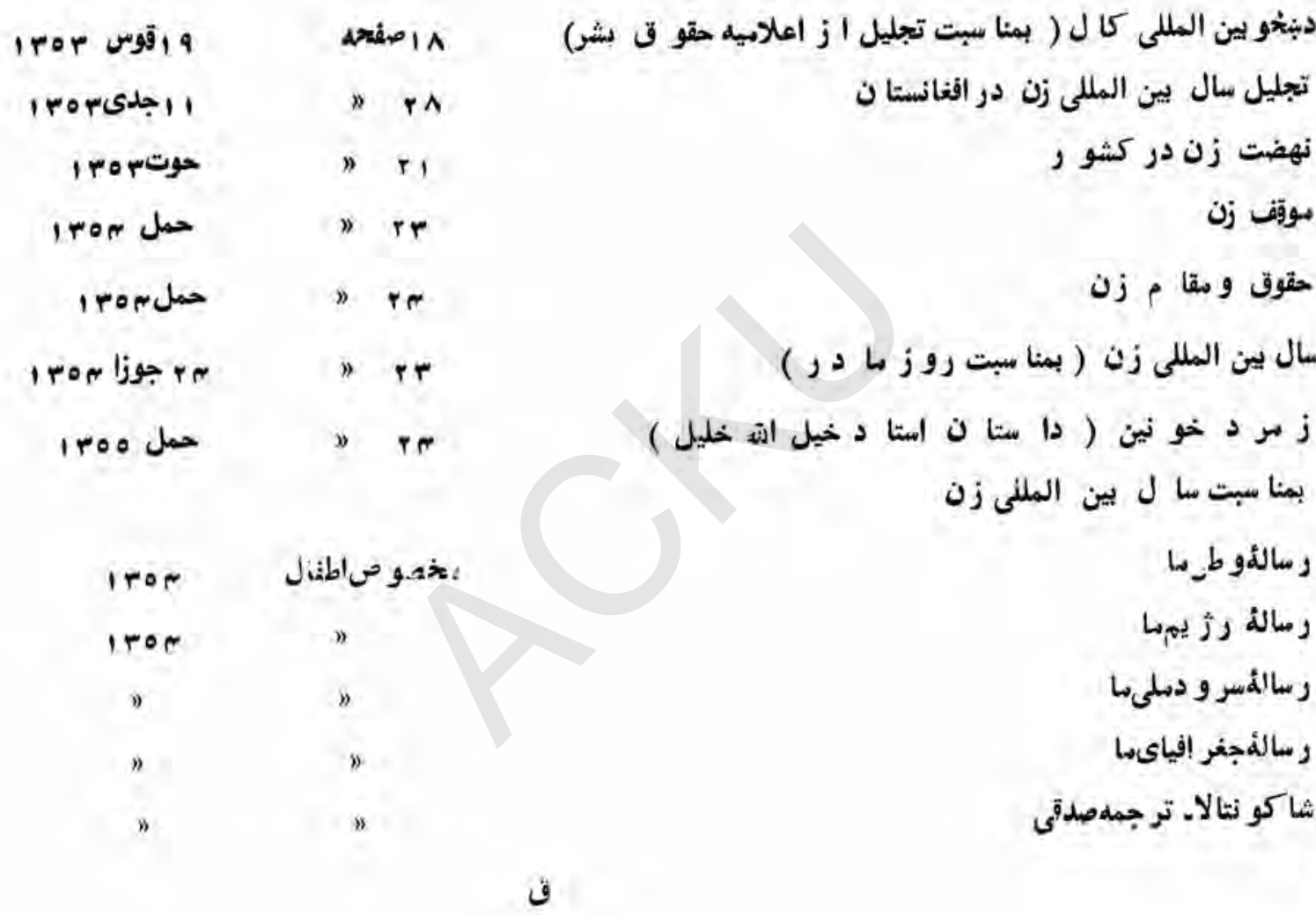




\section{PUBLICATIONS IN ENGLISH}

Afghanistan Prociaimed a Republic

\section{July 171972 \\ January 28 197\%}

Publicity Department of Afghanistan, Kabul Times, Government Printing House. July 17, 1973, 8 pages.

Afghanistan becomes a Republic, July 1973, Album, 20 pp.

President Mohammad Daoud's first Three Decrees, July 26, 1973, 12pp.

The Information and Culture Ministry in the first six months of the Republic Regime of Afghanistan, 1973, $8 \mathrm{pp}$.

Cultural Policy-Republic of Afghanistan, October 20, 1973, 6pp.

Bandi Amir, Afghanistan's first National Park, 1973, 7pp.

President Mohammad Daoud's First Press Conference, July 24, 1973, 8pp.

Address to the Nation, August 23, 1973, 27pp.

President Mohammad Daoud's UN Day message 28th anniversary October $24.1973,6 \mathrm{pp}$.

President Mohammad Daoud's Humans' Rights Day message, December, 10, 1973 2pp.

Red Crescent Week Miessage, 1973, 2pp.

$$
\text { (a) }
$$

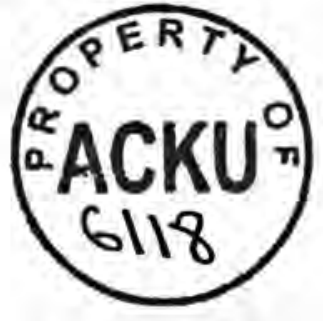


President and Prime Minister Mohammad Daoud's Speeches of July 17 and August 23, 1973, 17pp.

President's messages to leaders of Friendly Countries, 1973, 5 pp.

Address to the Graduates of Military Academy, Dec, 26, 1973, 2pp.

President and Prime Minister Mohammad Daoud's Address to Provincial Directors of Information and Culture, Jan. 19. 1974, 2pp.

President and Prime Minister Mohammad Daoud's Address to the Chiefs of Scouts, Jan. 1974, 3pp.

President and Prime Minister Mohammad Daoud's Address to the Graduates of Polytechnics, Feb. 24, 1974, 3pp.

President and Prime Minister Mohammad Daoud's New Year Message, March 22, 1974. 4pp.

President and Prime Minister Mohammad Daoud's Interview with the Editor of the Daily New Times of Rawalpindi, Pakistan, April 7, 1794, 6 pp.

President and Prime Minister Mohammad Daoud's Interview with the Correspondent of Horizont, May 28, 1974, 4pp.

President and Prime Minister Mohammad Daoud's Interview with the Correspondent of the Daily Statesman of New Delhi-India April, 29, 1974, 9pp.

\section{(b)}


President and Prime Minister Mohammad Doaud's Address on the Occasion of hoisting the National Flag of Republic of Afghanistan, May 9, 1974 13pp.

President and Prime Minister Mohammad Daoud's Interview with France Press, Dec. 21, 1974, 4pp.

President and Prime Minister Mohammad Daoud's Teachers Message, May 21, 1974, 6pp.

President and Prime Minister Mohammad Daoud's Message on Eid-e-Fiter, 1974, 2pp.

President and Prime Minister Mohammad Daoud's Speech of the Independence Anniversary of Afghanistan, May 27, 1974, 2pp.

State visit of President and Prime Minister Mohammad Daoud's to USSR, June 4, 1974, 3pp.

President and Prime Minister Mohammad Daoud's Message on Mother's Day, June 14, 1974, 4pp.

Trade Development Programme, June 2, 1974.

Foreign Trade in Afghanistan, June 2, 1974, 6 pp.

President and Prime Minister Mohammad Daoud's Address to the Nangarhar Medical College Graduates, June 26, 1974, 3pp.

President and Prime Minister Mohammad Daoud's Message on Awarding Press and Cultural Prizes, July 15, 1974, 4pp.

\section{(c)}


President Daoud's Speech on 1st Anniversary of the Republic July 16, 1974, 37pp.

President and Prime Minister Mohammad Daoud's Address to the Provincial Education Directors August 18, 1974, 4pp.

President and Prime Minister Mohammad Daoud's Message on Press and Literacy Day, Sept., 8, 1974, 2pp.

President and Prime Minister Mohammad Daoud's message on 30th anniversary UN Day. Oct. 24, 1974, 3pp.

President and Prime Minister Mohammad Daoud's Message on Human Rights Day, Dec., 10, 1974, 2pp.

President's Message on 50th anniversary of Amani School, Nov., 9 1974, 5pp.

President Daoud's Interview with Correspondent of Times of India, Nov. 16, 1974, 7pp.

Message on Military Academy Graduation, Dec, 16, 1974, 2pp.

President and Prime Minister Mohammad Daoud's Message on the International Women's Year. Jan. 1, 1975, 4pp.

President and Prime Minister Mohammad Daoud's Message on the Work and Life of Peer-i-Roashan, Jan. 5, 1975. 4pp.

President and Prime Minister Mohammad Daoud's Interview with the Editor of Bombay Weekly Blitz, March 7, 1975, 8pp.

\section{(d)}


President and Prime Minister Mohammad Daoud's State Visit to India, March 10, 1975, 22pp.

President and Prime Prime Minister Mohammad Daoud's Message on the International Seminar of Amir Khusrau Balkhi. March 15, 1975, 4pp.

State Visit of President and Prime Minister to Bangladesh, March 16, 1975, 14pp.

President Daoud's visits to Kandahar. March 17, 1975, 10pp.

State Visit of President and Prime Minister to Iraq, March 17, 1975, 9pp.

President and Prime Minister Mohammad Daoud's Address to Goyernors, April 2, 1975, 3pp.

President and Prime Minister Mohammad Daoud's New Year Message April 2, 1975, 3pp.

President and Prime Minister Mohammad Daoud's Interview with correspondent of a Finnish Publishing Agency, April 7, 1975, 6pp.

President and Prime Minister's Interview with correspondent of Indian Weekly Blitz, 7pp.

President and Prime Minister Mohammad Daoud's Interview with correspondent of Iranian National Radio and Television, April 23, 1975 3pp. 
President and Prime Minister Mohammad Daoud's Official Visit to Iran, April 26, 1975, 19pp.

President and Prime Minister Mohammad Daoud's Visit to Herat, April 30, 1975 14pp.

President and Prime Minister Mohammad Daoud's Message on Teacher's Day. May 22, 1975, 6pp.

President and Prime Minister Mohammad Daoud's Message Mother's Day, June 14, 1975 2pp.

President Daoud's Speeches, Messages, Interviews And Official Visits, July $17-1973$, to July $15-1975422$ pp.

President and Prime Minister Mohammad Daoud's Address on 57th Independence Anniversary, May 26, 1975. 3pp.

Herat, 1975, 12pp.

The Monument of Herat, Sept., 1975. 38pp.

Cultural Policy in Afghanistan, The UNESCO Press, Paris 1975, 49pp.

Afghan Women Today, March 1976, 24 pp.

Pamphlet on "Afghan Handicrafts" 1976.

Pamphlet on "Afghan Costumes". 1976

Pamphlet on "Education in Afghanistan" 1976.

Pamphlet, "Industrial Afghanistan" 1977. 


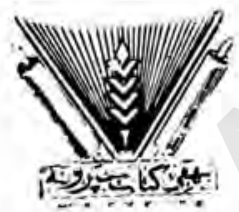

بيهقى كتاب خيرولو موسسمه

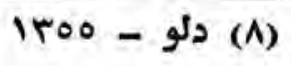

تعداد طبع (1... باهتمام

$-$

دوكتور محمد ظاهر صديق دولتى مطبعه

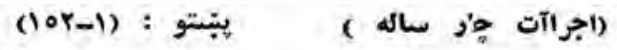

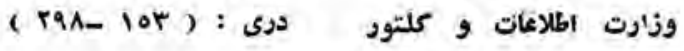

$$
\begin{aligned}
& \text { - تشكيل وزارت اطلاعات وكلتود } \\
& \text { ضميهـ : }
\end{aligned}
$$

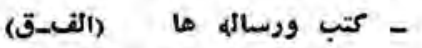

$$
\begin{aligned}
& \text { ـ نشر يه ها ورساله ما بزبان انعليسى (a-f) }
\end{aligned}
$$


irdr

ITAQ d A

إم

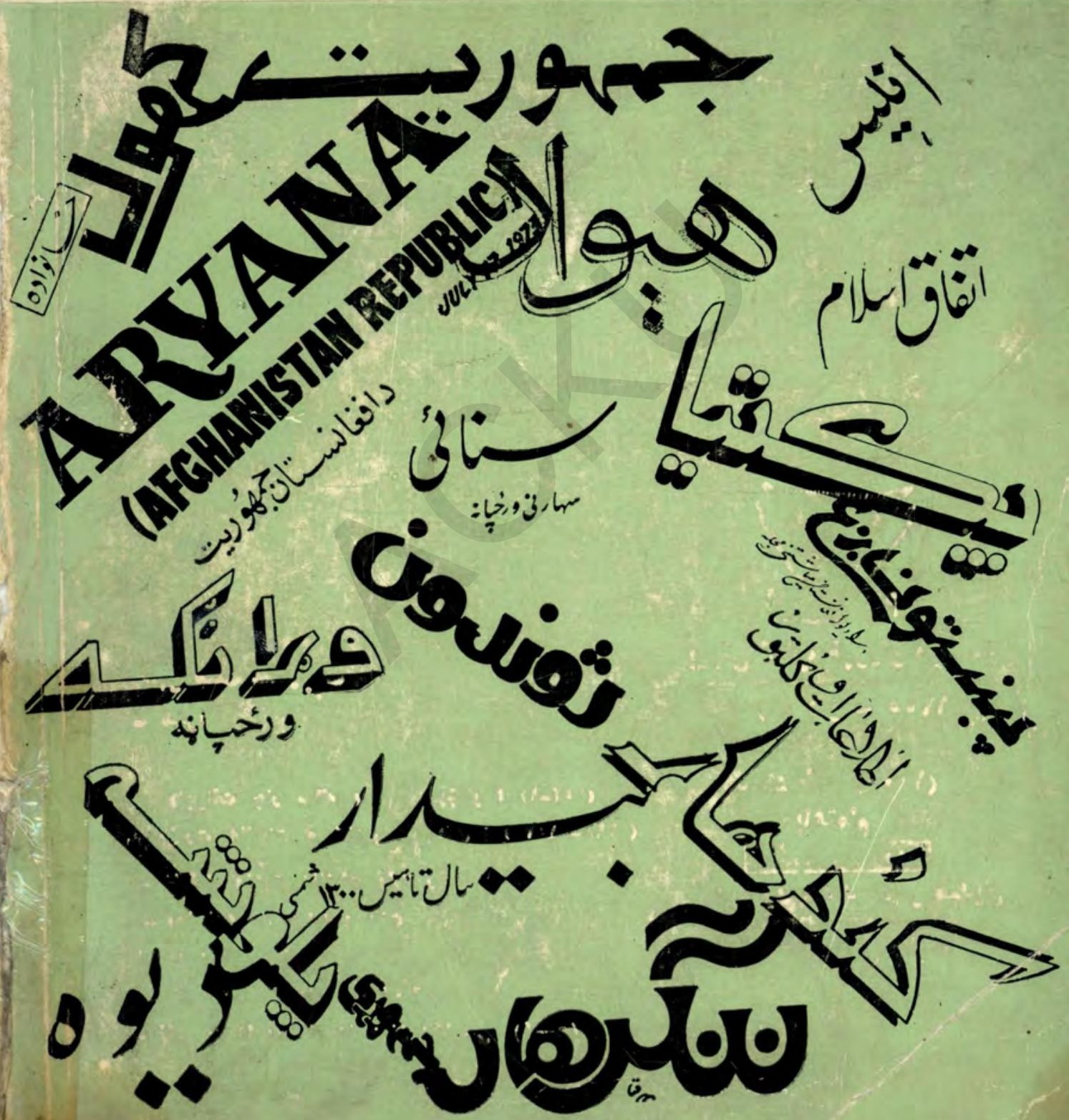

